$+2$

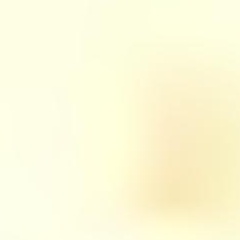

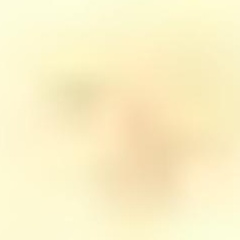

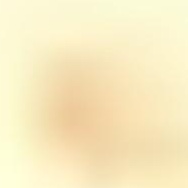

(n) 


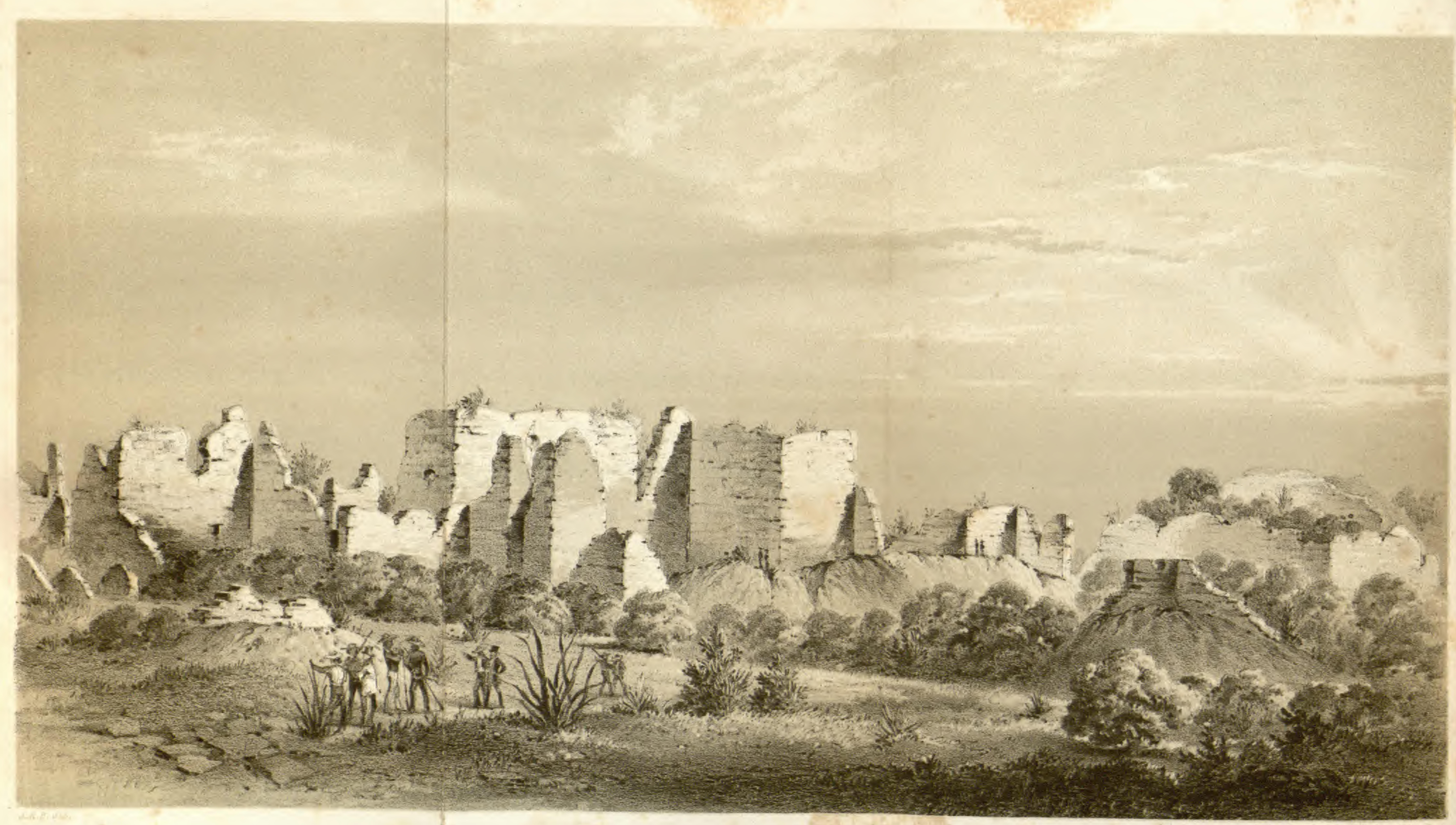




\title{
PERSONAL NARRATIVE
}

\section{oF \\ EXPLORATIONS AND INCIDENTS \\ IN}

\section{TEXAS, NEW MEXICO, CALIFORNIA, SONORA, AND CHIHUAHUA,}

\author{
CONNEOTED WITH
}

THE UNITED STATES AND MIEXICAN BOUNDARY COMMISSION, DURING THE YEARS 1850, 51, '52, AND '58.

\section{BY}

JOHN RUSSELL BARTLETT,

UNITED STATES COMMISSIONER DURING THAT PERIOD.

IN TWO VOLUMES, WITH MAP AND ILLUSTRATIONS.

VOL. II.

MISSOURI

BOTANICAL

GARDEN.

NEW YORK :

D. APPLETON \& COMPANY, 346 \& 348 BROADWAY, AND 16 LITTLE BRITATN, LONDON.

M.DCCC.LIV. 
ENTERED, according to Act of Congress, in the year 1854, by

D. APPLETON \& COMPANY,

In the Clerk's Office of the District Court of the United States for the Southern District of New York. 


\section{CONTENTS OF SECOND VOLUME.}

FOURTH DIVISION.

JOURNEYS AND INCIDENTS IN CALIFORNIA.

CHAPTER XXII.

SAN DIEGO TO NAPA VALLEY.

Arrival of Dr. Webb and his party-Dr. Webb's report of his journeyState of the Survey-Reduction of the Commission-Advance of wages -Diegeno Indians-H'hana Indians-Leave for San Francisco-Its fine harbor-Extensive commerce-Great activity and enterprise of its people-Origin of its name-Contrast between the wants of the Californians in 1770 and 1850-Trip to the Geysers-Benicia-Application to Gen. Hitchcock for an escort to the Commission on its journey back-Vallejo-Napa village-Napa valley-Its beauty and fertility-Mr. Yaunt -His history-Red-wood trees-Their great height-Enormous yield of vegetables-Thermal springs. . . . . . . . . . . .

\section{CHAPTER XXIII.}

THE GEYSERS OF PLUTON RIVER, AND RETURN TO SAN FRANOISCO.

Mount Helena-Russian inscription-Digger Indians-Dwellings-Mode of fishing-Dress-Pass the mountains-Meet bear hunters-Mode of cooking without utensils-Pluton River-The Geysers-Deseription of 
these phenomena-Effect of the water on wood-Extent of volcanic action-Return to camp-Abundance of grizzly bears-Recross the mountains-Return through Napa valley-Visit to the Obsidian hills -Extensive use of this material by the Indians-Return to San Franeisco.

\section{CHAPTER XXIV.}

THE QUICKSILVER MINES OF NEW ALMADEN.

Leave San Francisco-San Jose valley-Fertility of the soil-Mission of Santa Clara-San Jose-New Almaden-Quicksilver mine-Mode of extracting the ore-Large tanks of quicksilver-Account of the quicksilver mines of Spain-Production of this metal in all parts of the world-Situation of the New Almaden mine-Descent into it-How worked-Laborers-Extent of the mine-Effect of the mereury on laborers--History of the mine-Return to San Franciseo-Captain Sutter-His history. . . . . . . . . . . . . . . . . . . .

\section{CHAPTER XXV.}

RETURN FROM SAN FRANOISCO TO SAN DIEGO.

Leave San Francisco-Monterey-Its harbor-Society-Californian ladies - Father Juniper Serro's account of Monterey in 1770-Visit to the Mission of San Carlos at Carmel-Father Garces visit in 1777-Leave Monterey-Point Conception-San Pedro-Visit to Los Angeles-Rich prairies-Large herds of cattle-Vineyards and wines-Indians of the Missions-Mission of San Gabriel-Return to San Pedro-Craw fishArrival at San Diego-Preparations for return to El Paso-Engage Mr. Leroux as guide-Trip to Los Coronados-Description of these islands -Sea lions-Climate of San Diego-Visit to the Mission of San Luis Rey-Extensive buildings-Fine valley-Kechi Indians-History of Father Peyri-Description of the harbor of San Diego-Viscaino's account of San Diego in 1602-Father Juniper Serro's account in 1769Mission of San Diego-Picturesque situation-Fine lands-Olive trees Society of San Diego-Initial Point and monument on the Pacific. . . 


\title{
FIFTH DIVISION.
}

\author{
SAN DIEGO TO EL PASO, ALONG THE GILA.
}

\section{CHAPTER XXVI.}

SAN DIEGO TO ALAMO MUCHO.

Preparations for the journey to El Paso-Leave San Diego-Accident to wagon-Snook's rancho-San Pasqual-Gen. Kearney's battle at this place-Indian village-San Pasqual mountain-Difficult ascent-Reach camp at Santa Isabel-Deficiency of transportation-Leroux despatched for another wagon-Indians of Santa Isabel-A Mormon arrives with a wagon-List of return party - Journey resumed-Luxuriant valleySan Felipe-Indians-Their mode of life-Narrow mountain passVallecita-Desert appearance-Carrizo creek-Increased barrennessIntense heat-Mules run away-Skeletons and carcasses of animalsImmense destruction of sheep-Utter desolation-Wagon upset-Sacket's well-Dig for water-Meet Lieut. Sweeney in pursuit of deserters from Fort Yuma-Arrival of bearer of despatches-Alamo Mucho. . . 109

\section{CHAPTER XXVII.}

ALAMO MUCHO TO FORT YUMA.

The Desert-Dry basin- "New River"-Alarming news from the TrainColonel Craig's encounter with the deserters from Fort Yuma-Report of Sergeant Quin-Dr. Webb returns in search of Colonel Craig and Sergeant Bale-Loss of wagons on the desert-Great heat-Return of party with the body of Colonel Craig-Sergeant Bale's return-Further particulars of the encounter with the deserters-Burial of Colonel Craig Word sent to San Diego-Prompt action of Colonel Magruder-Arrest of the murderers by Indians, and their execution-Colonel Craig's character and services-March resumed-Cooke's well-Colorado riverBanks washed away-A passage eut through the woods-Arrival at Fort Yuma-Depredations by the Yuma Indians on the camp at night -Unsuceessful pursuit-Lieut. Whipple commences crossing the Colorado. 


\section{CHAPTER XXVIII.}

FORT YUMA AND THE ADJACENT COUNTRY.

Crossing of the Colorado continued-Description of Fort Yuma-The Colorado and Gila rivers-The adjacent country-Rich alluvial bottomsFacility of irrigation-Ruins of the old Spanish Missions-Difficulty of supplying Fort Yuma-Plan for surveying the head waters of the Gulf of California-Frustrated by Colonel Graham-Discovery of the Colorado in 1540 by Alarchon-Later voyages-Difficulties in navigating the Colorado-Attempt of a steamer to ascend the river-Its velocity and height-Fort Defiance-Massacre of Dr. Langdon and his party by the Yumas-Indians of the Colorado-Early tribes not identified-The Yumas-Cocopas-Mohavis-Extent of Alarchon's voyage in 1542Fathers Kino, Font, and Garces. . . . . . . . . . . . . . . 156

\section{CHAPTER XXIX.}

FORT YUMA TO THE COCO-MARICOPA VILLAGES.

Leave Fort Yuma-Absence of grass along the Gila-Petahaya or Giant Cereus-Gila trout-Meet the surveying party-Inscribed rocks-Excessive heat-Night marches-Wagons found-How caches are madeParticulars of the murder of Mr. Oatman and his wife-Basin of the Gila-More sculptured rocks-Cross the Jornada-Great bend of the river-Another desert-Toilsome march-Reach the Coco-Maricopa villages. . . . . . . . . . . . . . . . . 185

\section{CHAPTER XXX.}

THE COCO-MARICOPA AND THE PIMO INDIANS.

Visit from the Coco-Maricopa Indians-Camp removed to the banks of the Gila-The river dry, and no grass-War party-Return to our first camp-Traffic with these Indians-Farther accounts of the Oatman family-Francisco, the Maricopa interpreter-Feeding the tribe-Visit from the Pimos-Religious notions of these tribes-Their manners and customs-Agrieulture-Art of spinning and weaving-Manufactures of cotton-Pottery-Basket-work-Dress-Their attempts at collecting zoologieal specimens-Villages-Houses and mode of building-Store houses-Horses and cattle. . . . . . . . . . . . . . 213 


\section{CHAPTER XXXI.}

AT THE COCO-MARICOPA AND PIMO VILLAGES.

Journey to the river Salinas-Its rich bottom-lands-Large stream--Pimo Indians-Ruined buildings-Mounds-Broken pottery-Traces of irrigating canals-Ancient population probably large-Return towards the Pimo villages-Are taken for Apaches-Arrival at camp-Arrival of Lieutenant Whipple-Survey of the Gila completed-Trade reopened with the Coco-Maricopas-Presents-Tribe of Cawenas-Remove to the Pimo villages-Cola Azul and the Pimos-Traffic with them-Conference-Giving presents-Arrival of Mexican tradersReturn of Lieutenant Paige with the escort-Leave the villages. . . 239

\section{CHAPTER XXXII.}

INDIANS OF THE GILA, AND THE CASAS GRANDES.

History of the Coco-Maricopas and Pimos-Origin of their semi-civilization -Difference of languages-Their number-Physical peculiaritiesDeserving the attention of Christians and philanthropists-Early accounts of these Indians-First described by Father Kino in 1697Sedelmayer's visit to them in 1744-Father Font's in 1775-Visit to the Casas Grandes of the Gila-Description of these ruins-Evidences of a former large population-Irrigating canals-Broken pottery-Father Font's description of these buildings-Singular error in relation to their dimensions-Kino and Mangi's visit to them in 1694-Notion of the Aztec origin of these buildings not well founded-Excessive heat. . . 261

\section{CHAPTER XXXIII.}

\section{CASAS GRANDES TO SANTA ORUZ.}

Leave the Gila-Terrifie storm on the desert-Encounter a party of Americans at midnight-Stopped by the darkness-Unpleasant situationPack mules and cattle missing-Picacho mountain-Vegetation of the desert-Second night's march-Arrival at Tucson-General BlancoArrival of Mexican troops-Campaign against the Apaches-Meet Mr. Coons with 14,000 sheep-His disasters-Visit from General Blanco 
and his officers-Repairs on wagons-Tucson and its valley-Meteorite San Xavier del Bac-Beautiful church-Spanish and Anglo-Saxon colonization-Incessant rains-Presidio of Tubac-Meet Inez Gonzales the captive girl-Her sad fate-Uneertainty of irrigated lands-California emigrants-Calabasa-Picturesque valley-Tumacacori-San Lazaro -More emigrants-Reach Santa Cruz. . . . . . . . . . . 285

\section{CHAPTER XXXIV.}

SANTA CRUZ TO THE PRESIDIO OF JANOS.

Shoeing mules and repairing wagons at Santa Cruz-Standing guard-Sad fate of Inez Gonzales-Sickness of the town-Boldness of the Apaches and their constant inroads-Wretched state of the people-Leave Santa Cruz-Country assumes a new aspect-Rio San Pedro-Enter the mountains-Agua Prieta-Prepare for a fight-False alarm-Meet Colonel Garcia with Mexican troops--Enter Guadalupe Pass-Wagon upset-Description of the country-A better route suggested-Take the Janos road-More emigrants and their encounter with a bear-Two human bodies found-Open country-Reach Janos. . . . . . . 314

\section{CHAPTER XXXV.}

JANOS TO CORRELITOS, AND VISIT TO OASAS GRANDES.

Janos, an old military post-Its decline-Aid a party of American emigrants-A Thomsonian doctor-Difficulty in fording the Casas Grandes river-Arrival at Correlitos-Smelting works-Unhealthiness of the people-Barranca Colorado-Visit to the town of Casas Grandes-Extensive ruins-Resemblance to those on the Gila-Fertile valley-The river and its tributaries-Modern town-Return to Correlitos. . . . 339

\section{CHAPTER XXXVI.}

CORRELTTOS TO EL PASO.

Leave Correlitos-Visit the silver mines of Messrs. Flotte and ZuloagaAttempt of a peon to escape-Rio Santa Maria-Recent fight of Ameri- 
cans with the Apaches here-Broad open plains-Continued rain-The Salado-The Medanos or Sand Hills-Painful night's march-Samalayuca-Arrival at El Paso del Norte. . . . . . . . . . 366

\section{SIXTH DIVISION.}

EL PASO TO THE GULF OF MEXICO.

\section{CHAPTER XXXVII.}

INOIDENTS AT EL PASO DEL NORTE.

Preparations for completing the Survey of the southern boundary of New Mexico-Withdrawal of the military from El Paso-Importance of El Paso as a military post-Its business-Eneroachments of the Apaches -Depredations of the Comanches-Suggestions for a better protection of the frontier-Colonel Langberg-Visit to Fort Fillmore-The Mesilla valley-Visit to the Organ mountains-Silver mines-Grand scenery-Return-Bracito and its battle-field-Preparations for leaving El Paso-Mail party attacked by the Comanches-Decide to go by way of Chihuahua-Laxity of the Mexican eustom house-Departure of Lieutenant Whipple and party for the Gila-Organization of parties.

\section{CHAPTER XXXVIII.}

EL PASO TO CHIHUAHUA.

Departure from El Paso-Accident at the start-Farewell to friends-San Eleazario-Fording the Rio Grande-Wagon upset-Guadalupe-Ascend the table-land-Grassy plains, and open country-Ojo de Lueero -Laguna de los Patos-Country overflowed-Wagon mired-More accidents-Carrizal-Ojo Caliente-Rio Carmen-Encounter with the Apaches-A man killed-Animals lost-Ojo de Callejo-Mexiean soldiers-Precautions to avoid a surprise-Laguna de Encinillas-El Penol-El Sauz-Rio Sacramento-Battlefield-Notice of the battle -Arrival at Chihuahua. . . . . . . . . . . . . 401 


\section{CHAPTER XXXIX.}

\section{CHIHUAHUA AND ITS VICINITY.}

Repairs on wagons-Mr. Flotte and his persecutions-The road infected by Comanche Indians-Guard hired-General Trias-Governor Cordero - A dinner and ball-Ladies of Chihuahua-Dinner to General Trias -Obtain important documents relating to the boundary-Description of Chihuahua-Causes of its decline-Its mines-The expulsion of the Spaniards-Labors of the Jesuits-Aqueduct-The Cathedral-Mine of Santa Eulalia-Casa de Moneda-Commerce-How carried on-Agricultural products-Alfalfa and its value-Heaps of scoria-Grazing lands-The plateau-Immense herds of cattle $\rightarrow$ Height of the table land-Climate-Diminutive dogs.

\section{CHAPTER XL.}

OHIHUAHUA TO THE RIO FLORIDO.

Departure from Chihuahua-Additional escort-Mr. Flotte with his family join us-Bachimba-Santa Cruz-Grist mill-Smelting works-Saucillo-Attack of the Comanches-La Cruz-Las Garzas-Ford the Conchas-Santa Rosalia-Its defences erected against the Americans during the war-Ramada-Rio Florido-Guajuquilla-Fertile valleyMonument to our Lady of Guadalupe-Search for meteorites-Hacienda-Blanca-Wagon upset in an acequia-Hacienda de Concepcion-Curious mass of meteoric iron-Account of meteorites in the vicinityHacienda del Rio Florido. . . . . . . . . . . . . .

\section{CHAPTER XLI.}

RIO FLORIDO TO PARRAS.

A mule kidnapped-La Noria-Cerro Gordo-Enter the State of Durango -Another escort-Miserable condition of the Mexican soldiers--Recent battle here with the Comanches-La Zarea-Vast herds of eattle and horses-Searcity of wood-Droves of horses-San Pedro del GalloRio Nasas-Fertile valley-Culture of cotton-Corn-fields without irrigation-La Noria de Pedrecina-Silver mines-Cuencame-Another 
escort of civilians-La Noria Curena-Rio Buenaval-Pozo CalvoDepredations of the Comanehes-Alamo de Parras-Viesca minesLa Pena-Break down-Cold weather-El Pozo-Recent incursion of Indians-Reach Parras. . . . . . . . . . . . . . . 465

\section{CHAPTER XLII.}

PARRAS TO SALTILLO.

Parras-Its vineyards-Numerous springs-Orchards-Plantations of the Agave-Extent of its cultivation-Pulque-Hacienda Arriba-Its extensive wine vaults and granaries-Visit to the churches-The Alameda-Departure from Parras-The Hacienda Abajo-Don Manuel de Ibarra and General Wool-Cienega Grande-Ceguin-VequeriaGigantic Yuceas-Hacienda de Patos-Don Jacobo Sanchez-His large estates-Claims for indemnification on the United States-Village of Peons-Encantada-Arrival of a courier with despatches from. Washington-Buena Vista-The Barrancas-Ramble over the battlefieldRelies found-Reach Saltillo-No work on a feast day-Fine churchCotton factories-Dr. Hewison-Economical use of water. . . . . . 482

\section{CHAPTER XLIII.}

\section{SAITILLO TO RINGGOLD BARRACKS.}

Leave Saltillo-Accident at the start-Enter the Rinconada Pass-A night in the defile-Los Muertos-Ampudia's redoubt-Magnificent seenery -Hacienda of the Rinconada-Sierra Mitra-Santa Catarina-Suburbs of Monterey-Loma de Independencia-Arrival at Monterey-Pronunciamentos-Visit the Bishop's palace-Beautiful valley-The citadelProsperity of the eity-Its climate-Elevation-Departure-MarinRamos-Carrizitos-Dense chapporal-Miss the road-Cerralvo-Puntiagudo-Bad road-Mier-Trade for serapes-Texan Mier expedition - Character of the Rio Grande above Mier-Ascent of a steamboat to Loredo-Ancient oyster beds-Rio San Juan-Mexican brigade-Camargo-Cross the Rio Grande-Arrival at Ringgold barracks. . . . 499

\section{CHAPTER XLIV.}

RINGGOLD BARRACKS TO CORPUS OHRISTL.

Rio Grande surveying parties-State of the Survey-Despatehes from Washington-Proviso affixed by Congress to the appropriation for 
the Commission-Letter of the Hon. Alex. H. H. Stuart, Secretary of the Interior-Money withheld-Compelled to disband the Commission and return home-Unfortunate situation of the party-Send the train and government property to San Antonio-Leave for the coast - The grassy prairies of Texas-San Colorado-Wells at Santa Teresa -Ravages of the Comanches-Night alarm from mustangs-Abundance of deer and antelope-Los Olmos-Immense drove of mustangs -Exciting race over the prairie-Horse lost-The prairie on fire-Rio San Francisco-Agua Dulce-Arrival at Corpus Christi. . . . . . 513

\section{CHAPTER XLV.}

CORPUS OHRISTI TO WASHINGTON.

Corpus Christi-Its fine position-Geographical features of the countryNueces bay and river-A norther-Its effects on the fish in the lagunas-Leave Corpus Christi in an open boat-Shallow bays and lagunas of the Gulf-Vast numbers of water fowl-Bays of Aransas and Espiritu Santo-Reach Decrow's Point-Matagorda bay and its commerceEmbark for New Orleans-Galveston-Arrival at New Orleans-Voyage up the Mississippi, and by way of Louisville, Cincinnati, Cleveland, Buffalo, and Albany to Providence-Arrival at home-Proceed to Washington.

Results of the Labors of the Boundary Commission, . . . . . . 539

\section{NATURAL HISTORY.}

The Natural history of the regions traversed-Animal life on the deserts -Quadrupeds-Reptiles, their great variety and number-Peculiar vegetation of the deserts-The "prairie dog" and its habits-The antelope, etc. . . . . . . . . . . . . . . . 555

\section{ADAPTATION OF THE COUNTRY FOR A RAILWAY.}

Brief remarks on the geography of the countries traversed by the Boundary Commission, and upon its adaptation for a railroad connecting the Atlantic with the Pacific. . . . . . . . . . . . 565 


\section{CONTENTS.}

xiii

PAfB

\section{INTRODUCTION OF CAMELS.}

Remarks on the introduction of Camels as a means of transportation on the prairies and deserts of the interior. . . . . . . . . 576

APPENDICES, . . . . . . . . . . . . . . . . . 585

INDEX. . . . . . . . . . . . . . . 607 



\section{ILLUSTRATIONS TO SECOND VOLUME.}

\section{W00D-CUTS.}

No. PAGE

1. Interior of Hut of California Indians, . . . 30

2. Summer Huts of the $4 \quad$ " . . . . . 31

3. Figure out in Woon, . . . . . . . . 32

4. Calmornia Indians oatohing Salmon, . . . . 33

5. " " . . . . . . . 34

6. " 6 . . . . . . . 34

7. Geysers, Pluton River, California, . . . . $\quad 42$

8. Golden Gate. Entrande to San Francisoo, * . . 54

9. Quicksilver Furnaces, New Almaden, California, . - 58

10. Monterex, California, . . . . . . . 72

11. Mission of San Luis Rey, California, . • . • 90

12. San Diego, California, . . . . . . . . . 95

13. Mission of San Diego, California, . . . . 103

14. Monument. Initial Point on the Pacifio, . . . 105

15. Well at Alamo Mucho, on the Desert, . . . . 134

16. Junction of the Gila and Colorado Rivers, • . . 158

17. Pagoda Mountain, North of the River Gila, . . 188

18. Petahaya, or Giant Cereus, . . . . . . . 189

19. Insoribed Rooks. River Gilla, . . . . . . . 196

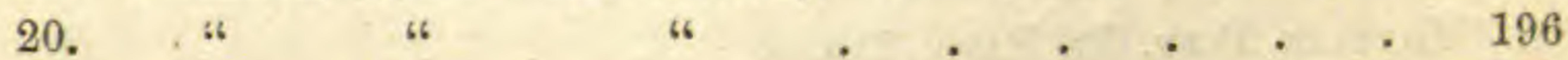

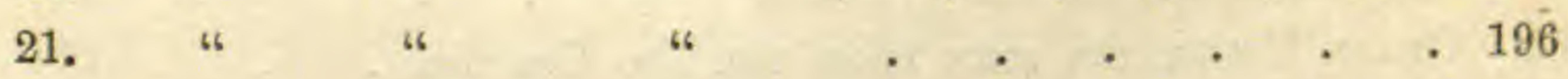


No.

22. Basin of the River GHa,. . . . . . . 205

23. Insoribed Rooks. River Gila, . . . . . . 206

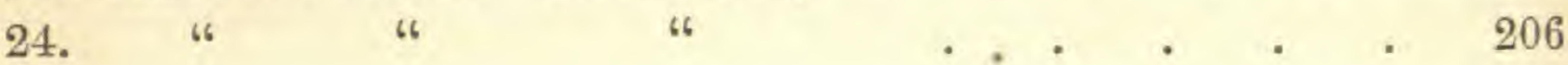

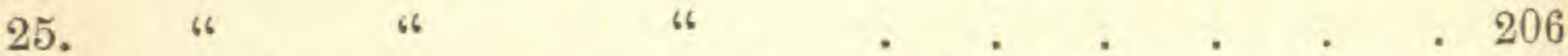

26. Prmo Flute and Bunch of Deers' Hoofs, . . . 223

27. Prmo Indian Weating, . . . . . . . . 225

28. Baskets and Pottery of the Pimos and Coco-Maricopas, 227

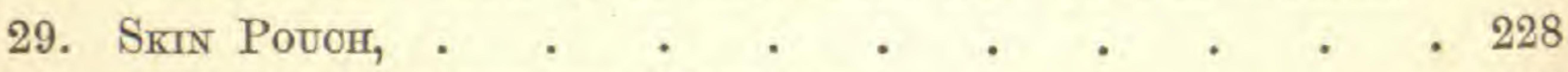

30. Mode of Construoting Wigwams, . . . . . 234

31. Village of the Coco-Maricopa Indians, . . . . 235

32. Interior of a Store-House. Pimo and Coco-Maricopa, . 236

33. Indian Amusements, Shooting at the Petahaya, . . 238

34. Pimo Man and Woman, . . . . . . . 238

35. Ruins on the Salinas, . . . . . . . . . . 246

36. Cultivated Fields and Villages of the Pimo Indians, . 248

37. Pimo and Coco-Maricopa Women, . . . . . 253

38. Fragments of Ancient Pottery. Pivers Gila and Salinas, 255

39. Hueroglyphid on Wall of Casas Grandes, . . . 273

40. Elevation of the Casas Grandes, River Gila, . . . 276

41. Ground Plan of " 6 " . 276

42. Pioncho on the Tuoson Desert, . . . . . 290

43. Meteorite seen at Tucson, . . . . . . 298

44. " " " The HaOIenda de Conomption, . . 298

45. Presidio of Janos, Chimuahua, . . . . . . 340

46. Ruins at Casas Grandes, Chindahua, . . . . . 348

47. " "

48. Part of Ground Plan of Casas Grandes, Chinuahua, . 357

49. Ground Plan of one of the Ruined Buildings at Casas Grandes, . . . . . . . . . 359

50. Fragments of Anchent Pottert from Oasas Grandes, ChiHUAHUA, . . . . . . . 360

$\begin{array}{lllll}51 . & 4 & 6 & 6 & 360\end{array}$

52. Relios found at Oasas Grandes, Chindahua, . . . . 362

53. Desert Platn, View from the Salado, Chihuahua, . 372

54. Muritary Post, El Paso, Texas, . . . . . 383

55. Organ Mountains, seen from the Rio Grande, • . . 393 
No,

56. Apache Ivpians A thackivg The Tratn and Party, Page

57. Carrying Wood to Market, Chindahua . . . . 422

58. Aqueduct and Churoh of Santa Rita, Ohimuahua, - 441

59. Gigantio Yudoa Tree, Parras, . . . . . 491

60. Stampede by Wild Horses on the Plains of Texas, . 523

\section{LITH0GRAPHS.}

No.

1. Ruins at Casas Grandes, Chinuahua, (to face title-page.)

2. Geysers, Pluton River, California, . . . . 40

3. 640.40 .40

4. Napa Valiey from the Obsidiax Hills, Califoría, . 50

5. Asoent to the Quioksilver Mrne, New Almaden, . . 62

6. View on the River Gila, Big Horn Mountain, . 198

7. Oasas Grandes, River Gila, . . . . . . 274

8. Runns at Casas Grandes, Chinuahua, . . . . . 364

9. Organ Mountains, New Mexico, . . . . . . 392

10. Fort Yuma, Junotion of the Gila and Colorado Riviris, (to face title-page, vol, 1.) 



\section{FOURTH DIVISION.}

\section{JOURNEYS AND INCIDENTS IN CALIFORNIA.}

\section{CHAPTER XXII.}

\section{SAN DIEGO TO NAPA VALLEY.}

Arrival of Dr. Webb and his party-Dr. Webb's report of his journeyState of the-survey-Reduction of the Commission-Advance of wages -Diegeno Indians-H'hana Indians-Leave for San Francisco-Its fine harbor-Extensive commerce-Great activity and enterprise of its people-Origin of its name-Contrast between the wants of the Californians in 1770 and 1850-Trip to the Geysers-Benicia-Application to Gen. Hitchcock for an escort to the Commission on its journey backVallejo-Napa village-Napa valley-Its beauty and fertility-Mr Yaunt-His history-Red-wood trees-Their great height-Enormous yield of vegetables-Thermal springs.

On the 11th February, Dr. Webb, with his party, reached San Diego, most of them on foot. - They had experienced great privations, and had lost the larger portion of their animals by famine. The following letter from Dr. Webb shows the character of his journey.

"San Diego, California, February 14, 1852.

"Sir: I have the honor to announce that I arrived here with the little party under my direction on the voL. II. -1 
11th instant, all in good health and spirits, notwithstanding we had to encounter numerous difficulties, undergo some hardships, endure some privations-to be exposed to the hostile attacks and depredations of Indians, and subjected to the loss of most of our animals and much of our clothing, \&c., and were necessarily placed on short allowance-compelled to walk a large portion of the distance, and be our own escort and night guard.

"The mail closes so very soon, that it is impossible for me to render, in detail, a report of the trip at this time. I can only state, in brief, that the party consisted of twelve individuals and twenty-seven riding and pack-mules.

"The animals, which were mostly feeble at the outset, and consequently not suited for such a journey, soon gave convincing proofs that they could not hold out, and daily, after leaving the Pimo villages, became reduced in number-sinking under the combined influence of excessive heat, deficiency of grazing, and destitution of water. Of the twenty-seven, but three were in a suitable condition to be brought in; five more I left at Williams's rancho, about fifty miles distant, to recruit; and the remainder sank under their loads at various places on the desert, and were necessarily abandoned to their fate; which was either to fall into the hands of roving Indians, who, like so many hungry vultures, were continually hovering around, anxiously awaiting an opportunity to avail themselves of any accident or misfortune that might occur, whereby they could gain possession of any of our property; or should they elude the Indians, their fate most 
inevitably was, in their enfeebled state, to become an easy prey to the hungry wolves, which in great numbers were constantly prowling about, making night hideous with their howlings; and not unfrequently so impatient were they to seize upon the poor animals, that they could be seen skulking close to our camp in broad daylight.

"The loss of pack-mules of course occasioned a sacrifice of much other property, as we had no relief mules with us. Most of our cooking utensils were dropped from time to time, at various places on the route. We had also to cache all of our camp stools and other furniture, some of our bedding, much clothing, books, papers, etc. Eventually, we were compelled to abandon our tents: so that rain or shine, wet or dry, we had to stop at the end of our day's journey in the open air, without any means of protection by day from the scorching heat of the sun; and at night we stretched out upon the ground, unsheltered from the inclemency of the weather, and the cold searching blasts and chilly atmosphere, though at mid-day the dry, brain-burning heat, was almost too much to bear. Soon after sunset, an icy feeling, nearly as intolerable, would pervade us; the variations between night and day often amounting to sixty and seventy degrees of temperature.

"Twelve days of the journey I walked, having relinquished my animal for pack-mule purposes before we reached the junction of the Gila and Colorado Rivers. Subsequently, others followed the example; until at length but two retained possession of animals. 
"We had no escort; and therefore, after walking all day, we were obliged to take our turns at standing guard at night. Our provisions became so diminished in quantity as to compel me to put the whole party on short allowance. We lived principally on meat, mush, and mutton, without any vegetables. But one sheep (long, lank, raw-boned animals) was allowed to twelve men for four days, and even then our last meat was consumed a week before our arrival; and we were forced to deprive ourselves of a portion of our mush to furnish food to our animals, owing to the entire absence, for several days on our route; of all grass, shrubs, and trees.

"Much is said by travellers respecting the desert of Sahara; but, in barrenness of verdure, destitution of water, tremendous storms of sand, etc., etc., it is doubtful if any tract of land can surpass the jornada which we crossed. Indeed much of this country, that by those residing at a distance is imagined to be a perfect paradise, is a sterile waste, utterly worthless for any purpose than to constitute a barrier or natural line of demarcation between two neighboring nations.

"Notwithstanding our many perils, privations, and suffering, mostly attributable, when traced to the true source, to our imperfect outfit at the Copper Mines, from the negligence, wilfulness, or some other unjustifiable cause on the part of those whose duty it was to attend to the business; notwithstanding the many additional obstacles thrown in the way; notwithstanding the continued succession of disappointments which we encountered in numerous shapes, and of varied hue, where the doing or neglecting to do, depended 
upon the will of man; thanks to the protecting care of a divine and overruling Providence, we escaped unharmed from the many dangers with which we were surrounded, and the difficulties in which we were involved, and have brought in our little party in the enjoyment, as already observed, of good health and spirits.

"I remain, sir, very respectfully, yours,

(Signed) THOMAS H. WEBB,

Secretary to Boundary Commission.

"Hon. J. R. Bartlett,

"Commissioner, etc."

The animals brought in by the several parties were greatly reduced by their long and painful journey, owing chiefly to their poor and scanty food along the Gila, and from that river to the coast. They were now placed in a grassy valley near the mission, some five or six miles distant, where the feed was pretty good; but they were so completely broken down, that many weeks would be necessary to recruit them. The surveying parties during this time were engaged in reducing their observations and in plotting their maps.

Although the entire boundary along the river Gila was not completed, it was a source of peculiar satisfaction to me that we had accomplished so much. It is more than the most sanguine in the Commission expected to perform in so short a space of time, surrounded, as the operating parties were, with so many serious impediments. To cross a wilderness, such as it may in truth be called, from the Rio Grande to the 
Pacific Ocean, a distance of more than eight hundred miles, would at any time be a labor of difficulty. But when this whole line is through a desolate region, with a scanty supply of grass for the animals; with large tracts destitute of water, and no means of procuring provisions; and furthermore, when nearly the entire distance is invested by hostile Indians, the work is one for the near completion of which we could not be too thankful. The whole came through in good health, and with the loss of but one man, Thomas Harper, an attendant on instruments in Lieutenant Whipple's party, who was unfortunately drowned whilst bathing in the Colorado. The amount of public property lost or abandoned on the journey was not large, and could easily be replaced in this country.

During my short stay at San Diego, I was busily occupied in paying off and reducing the Commission. Several of the assistants desired to leave here, and the larger portion of the mechanics and laborers. In fact, I found it difficult to keep such as were necessary to take care of the animals and other property, as well as the cooks and servants needed to attend the several messes. Wages were exceedingly high, and I was compelled to advance the pay of all that remained to the California rates, which were from fifty to eighty dollars a month for servants, cooks, teamsters, and herdsmen. After reducing the parties, and placing those who remained in comfortable quarters (for the weather was cold and wet), I made my arrangements to go to San Francisco, in order to procure a new outfit of tents and camp equipage; to have the instruments repaired and put in order; to lay in provisions for our 
return; and to negotiate my drafts on the government to meet these several expenditures, as well as to pay the officers and men attached to the Commission.

No event that is worthy of mention occurred here, except a visit from a band of Diegeno Indians. A chief and several of his tribe were sent to me at my request by a Californian gentleman. They were a miserable, ill-looking set, with dark brown complexions and emaciated bodies; and though the weather was cold, they were but slightly. clad. Articles of old and cast-off clothing, such as a tattered shirt and pantaloons, were all that the best could boast of. One, I think the chief, had a piece of a horse blanket around his cadaverous-looking body. I managed to get from them a vocabulary of their language; though I must confess that, with the exception of the Apache, I never found one so difficult to express, in consequence of the gutturals and nasals with which it abounded. I finally got the words so correct, that the Indians could recognise them, and give me the Spanish equivalents. I tried to write down some short sentences, but was obliged to give up the attempt as unsuccessful. I could not combine the words so as to be understood, in a single instance. These Indians occupy the coast for some fifty miles above, and about the same distance below, San Diego, and extend about a hundred miles into the interior. They are the same who were known to the first settlers as the Comeya tribe.

I also found an Indian here from the Upper Sacramento River. He had been taken prisoner by the American troops about three years before, and was now living with some of the officers. He was quick and 
intelligent, and answered promptly my questions relative to his tribe and country. I could not, however, ascertain the precise locality of his people, which he called the Hhana tribe-the $H$ a deep guttural. I got from him a complete vocabulary of his language.

On the 24th of February, I embarked with several officers of the Commission in the steamer Sea Bird, for San Francisco. The boat stopped on the way at the several ports of San Pedro, Santa Barbara, and Monterey; but as the weather was boisterous and attended with rain, I did not land. On the evening of the 27 th we reached San Francisco.

To give an account of this wonderful city which has sprung into existence in the last four years, and whose rapid growth and extraordinary prosperity have astonished the world, is not my intention. No city on the face of the globe has ever attained the position that San Francisco has in the same period; and it is yet progressing. It is now almost the first in population on the western coast of the American continent; and but a few years will elapse before it will surpass all the rest. In point of commerce, the great ports of Europe and on the Atlantic coast of the United States alone, can vie with it. As the outlet of the principal and almost only rivers of California, it will continue to bear the same relation to the interior as New Orleans and New York do to the United States east of the Rocky Mountains. The harbor of San Francisco is one of the most spacious in the world, easy of access, of a convenient depth for anchorage, and protected from storms. The city itself now presents a strange medley of buildings, from the rudest hovel and canvas tent to the ele- 
gant mansion and the most substantial warehouses. The former, however, are rapidly giving way to the latter; and now that bricks of a superior quality are made here, and excellent building stone is found near at hand, no one will think of putting up wooden buildings within the city. In the streets of San Francisco all is bustle and confusion. Crowds are constantly passing and repassing. The wharves are thickly lined with magnificent ships from every quarter of the globe, pouring in their thousands of immigrants, and discharging their valuable cargoes. The ocean steamers, each bearing from five hundred to one thousand passengers, are weekly arriving; while the river boats, which take their daily departure for the interior every morning and evening, present the same moving crowds going and coming as the Hudson River boats at New York. All go full; and one is as much puzzled to find a spare seat or stool on which to rest his weary limbs, as on board the excursion boats from our Atlantic cities. The stages and other means of conveyance are equally crowded. The throng moves to and fro, from the city to the mines and the interior, and thence back again to the city. Go to the business streets, and the auctioneer's hammer is heard at every turn, knocking off to the anxious bidder every article of commerce. Stocks, gold mines, ships, whole cargoes of merchandise, are bought and sold with the same freedom as in the Royal Exchange of London, the Bourse of Paris, or in Wall-street, New York. There are customers for every thing, and an. abundance of gold to meet any purchase however large. There is no project too great for the Californian of the present day. He is ready for any undertaking, whether 
it be to make a railroad to the Atlantic, to swallow up Mexico, or invade the empire of Japan. New York is now the first city on the American continent, and San Francisco is destined ere long to be second.

San Francisco is said to have obtained its name in the following manner: "When Father Juniper Serra received his orders from the Visitant-general respecting the names which he was to give to the new missions in California, he observed that the name of the founder of their order was not among them, and called the attention of his superior to the fact, exclaiming, "Is not our Father San Francisco to have a mission?" to which the Visitant-general replied, "If San Francisco desires a mission, let him show you a port, and he shall have it." In the year 1769 an expedition was dispatched from San Diego, for the purpose of settling Monterey. The expedition missed the port, but discovered a much larger and finer bay further to the north, which had been till then unknown. The commander of the expedition and his religious associates decided that this discovery must be the work of St. Francis, and accordingly they gave his name to the place, setting up a cross, and taking possession after the usual manner.*

To show the striking contrast between the wants of the zealous priests who colonized California in the year 1770 and the Americans of 1850, I give another quotation from a letter written by the same excellent man to Father Palou. "As May made a year since I received a letter from any Christian country, your Re-

* Palou. Vida del Padre Fray Junipero Serra, Mexico, 1787, p. 88. 
verence will imagine how deficient we are in news: but for all that, I only ask you and your companions, when you can get an opportunity, to inform me what our most holy Father the reigning Pope is called, that I may put his name in the canon of the mass; also to say if the canonization of the beatified Joseph Cupertino, and Serafino de Asculi has taken place; and if there is any other beatified one, or saint, in order that I may put them in the calendar, and pray to them; we having, it would appear, taken our leave of all printed calendars. Tell me also, if it is true, that the Indians have killed Father Joseph Soler in Sonora, and how it happened; and if there are any other friends defunct, in order that I may commend them to God; with any thing else your Reverence may think fit to communicate to a few poor hermits separated from human society. We proceed to-morrow to celebrate the feast of Corpus Christi (although in a very poor manner), in order to scare away whatever imps there possibly may be in this land." *

The Californians of our day, instead of asking for information about beatified men or saints, in order to put them on the calendar and pray to them, would feel a much deeper interest in knowing the state of political parties in the Atlantic States, or the prices of stocks, of sugar, and whiskey; and where one would care to hear about the Pope of Rome, a hundred would prefer news respecting the Emperor of China. $†$

* Palou. Vida de Fray Junipero Serra, p. 102.

$\uparrow$ I have reference now to the interest felt in the present contest in China between the rebel Tien-teh and the Tartar sovereign. 
For three weeks after I arrived in San Francisco it rained incessantly, confining me most of the time to the house. The result was a great rise in the rivers, so that the mining regions were laid under water, and became impassable. The Sacramento was so swollen as to inundate the city of the same name. This state of things prevented me from visiting the interior, and particularly the gold region. Having a couple of weeks still to spare before our camp equipage would be ready, I determined to avail myself of this brief space in visiting some of the many interesting objects in which California abounds. To examine the gold mines in so short a time with any satisfaction, seemed impracticable. I therefore concluded to visit some localities which were less known, and which would be a greater novelty than the gold region, with which I already felt pretty well acquainted through the daily accounts of them in the newspapers. I had heard an interesting description of some geysers and a volcanic region at the head of Napa Valley, which I determined to visit as soon as the travelling would permit.

Accordingly I left San Francisco on the 17th of March, accompanied by Dr. Webb and Mr. Thurber, for Benicia, where we arrived in two hours. Our steamer was crowded with passengers, chiefly bound for the mines, among whom were a number of Chinese. These men were dressed in their native costume, and each carried with him a huge pair of boots, showing plainly to what region he was destined.

Benicia was for a while the rival of San Francisco; though I cannot see why such aspirations should have been indulged in for a moment. It is situated on the 
Straits of Carquinez, about thirty miles from San Francisco, on a gentle slope, which becomes almost a plain as it approaches the water's edge. It contained at the time of my visit about 1500 inhabitants, including the soldiers now stationed here. Its buildings are mostly of wood, and among these are several hotels. The best of them is the "American," a neat and well-kept house, where we stopped. It was then the Head-quarters of the Pacific division of the U. S. Army. The large deposit of Quarter-master's and Commissary's stores had been recently removed hither, and efforts were making to have the Navy yard here also. The Pacific Mail Steam Ship Company had its depot here, and next to the Navy yard was the most valuable accession it could possibly enjoy. The steamers all lie here until a few days before sailing, when they move down to San Francisco. This company furnished much business to the place with its large coal depot, ship yard, and various workshops, where several hundred men were constantly employed. The military post is about a mile from the town, and consists of a few wooden buildings.

I called on General Hitchcock, commanding the Pacific division of the U. S. Army, for the purpose of obtaining an escort for the Commission from San Diego to the Pimo villages on the Gila. This seemed necessary, as the command of Colonel Craig amounting to twenty-five men, which accompanied the surveying parties down the Gila, had all deserted but five, on their arrival at San Diego; and of these, three were non-commissioned officers. General Hitchcock, with the promptness and liberality which have ever distin- 
guished him, at once acceded to my request, and gave me an order on the commanding officers at San Diego and Fort Yuma to furnish me with such a force as they deemed necessary.

It was from Benicia that we were to take the road to Napa Valley. On making known to General Hitchcock my desire to visit the Geysers, he kindly furnished me with horses and a pack-mule for the purpose. To Major Allen, the Quarter-master, I am also indebted for his promptness in facilitating the wishes of myself and party in our proposed trip, and for sending me a trusty man.

March 19th. Our horses, mule, and attendant were promptly at the door by 7 o'clock; and after breakfast we took our departure. Proceeding along the shores of the bay, we passed the great projected city of Vallejo, the once intended capital of the State. It now stands naked and alone, its large houses tenantless. As the capital of California it might have become a place of importance; but without such factitious aid there is nothing to build it.

Here we entered Napa Valley. The hills on both sides as well as the valley were covered with a luxuriant growth of wild oats, and immense herds of cattle were roaming about feasting on them. Wild flowers of varied hues were thickly scattered around, and every thing showed that the heavy and continued rains had given new life to vegetation. Our course was now a northerly one, directly up the valley. Napa Creek, which we saw at a distance, makes up it, and affords sufficient water for small vessels, several of which we saw gliding up. The valley soon became perfectly 
level, without a hill or depression. In many places ploughmen were at work turning up the soil, which was of the richest description. Barley appeared to be the principal grain sowed, this being in more general use for horses than oats, and found to give a better yield. In one place I noticed a hill, the whole of which had been sowed with barley, presenting a field of more than a hundred acres. The soil here was loose; and as the water had run off, the ground was in a fit state for cultivation. The valley below was still very wet, and would not be in a fit state to plough for weeks yet. On this account, the declivities possess an advantage for early planting, over the level plains.

At 2 o'clock reached the village of Napa, where we dined. Distance travelled, twenty miles. The road was excellent, except in two places, where the valley was still wet, and where our horses sank deep in the mud. Napa Creek is navigable to this point, even for vessels of a large burden, should it be necessary to bring them here, which will hardly be the case. Near the town is the hulk of a ship. It was bought by a gentleman in San Francisco for a trifle and brought here, where it is used as a storeship, as well as for the residence of the owner and his family. She cost much less than it would have done to erect a small dwelling, and the owner has besides the advantage of a large warehouse. She lay close by the river's bank; and with a doorway cut in her side, the entrance was made quite easy. A steamboat now runs to San Francisco, which will tend to populate rapidly this beautiful valley, and render the town of Napa the centre of one of the richest agricultural districts in the State. After 
dinner we rode five miles, to the house of Joseph W. Osborne, Esq., a merchant of San Francisco, who had invited me to make him a visit. Mr. O. had preceded us a couple of days, and met us at his gate, giving us a warm reception.

Mr. Osborne's place was the most beautiful and picturesque I had seen in the valley. In fact, it was the only house wherein there was any attempt at taste and comfort; for the country was too new to expect much in this way yet. But even his was a small and unpretending cottage after the New England fashion. The valley here is about four miles in width. Where it opens on St. Pablo Bay it is about six miles, but it gradually contracts towards the north. At the entrance it is an open plain, destitute of trees, and covered with luxuriant grass; but here it assumes a new aspect, such a one, too, as I had not before seen in the country. It is now studded with gigantic oaks, some of them evergreen, though not so close together as to render it necessary to cut any away to prepare the land for cultivation. These magnificent oaks are found sometimes in long lines, and again in clusters of twenty or thirty, forming beautiful groves; then again a space of ten or twenty acres will occur without a single tree. If this romantic valley were transferred to the older countries of Europe, it would be taken for the domain of a prince or a nobleman. It answers to the idea one has of the old and highly cultivated parks of England, where taste and money have been lavished with an unsparing hand, through many generations. As one emerges from or enters each grove, he involuntarily expects some venerable castle or mansion to appear; 
or to find himself among some secluded villages. But in the entire length of the valley there are no houses to be found within a less distance than five miles of each other, and these too of the most humble and unpretending character. What is singular, and to me unaccountable in these groves of large trees is, that there are no young ones, none but the venerable and full-grown oaks, which, doubtless, for centuries have held exclusive sway over this wide-spread and beautiful domain. Nor is there any undergrowth of other trees and shrubs. I can only account for this deficiency by attributing it to fires since the occupation of the country by the Spaniards; or, by supposing that the immense herds of cattle, which for a century past have occupied the valley, have browsed upon the shrubs and young trees, until they destroyed them, and afterwards kept down the shoots as they sprang up.

The valley is hemmed in on both sides by ranges of low mountains, running north and south, which are generally covered to their very summits with forest trees. Here and there bold rocks jut out, presenting the most fantastic outlines; while between the valley and the mountains runs a lower range of rounded hills, dotted with small bushy oaks and pines, which present a fine contrast with the more sombre hues of the mountain foliage. Occasionally the gigantic palo colorado (red wood) raises its tall head far above every other object, making even the huge oaks appear diminutive.

In the midst of the valley winds a small stream, called Napa Creek, its course marked by the graceful VOL. II. -2 
willows that grow along its margin. This creek is chiefly supplied by springs near the head of the valley; but during the rainy season several mountain torrents empty their waters into it-indeed, some of them I was told contribute a portion during the whole year.

The larger portion of Napa Valley was still in the state in which nature had left it, but had all been taken up by recent settlers, and was fast being brought into cultivation. A road had just been laid out through its centre, and every farmer was occupied in marking out his land and dividing it into lots inclosed by substantial rail fences. Ploughs were cutting up the virgin sward in all directions; and in one place I saw a ditching machine in operation. It answered the double purpose of making a ditch four or five feet wide, with an embankment of sufficient height to answer for a fence or wall. This machine was worked by two or three oxen and a windlass. It is a rapid method of accomplishing two most important objects; and the mound is said to keep the cattle out as well as a high fence.

Mr. Osborne's men were all New England farmers, several of them from Rhode Island; and it is astonishing to see how much more work one of these men will perform than a Mexican or Californian. He pays them seventy-five dollars a month, and finds them, which pays him better than employing ordinary hands at half the price. Mr. O. has owned this property but one year; and a furrow was never turned on it or a seed sown, until he came into possession. He has now more than a hundred acres under cultivation, a considerable portion of which is protected by a post and 
rail fence of red wood. Many fruit trees, grape vines, flowering shrubs, etc., are in a flourishing condition around his house. In no part of the Atlantic States or Mississippi Valley could such improvements be shown in the same time, except on prairie land.

March 20th. This morning we called on Mr. Yaunt, a Missourian, and one of the oldest settlers in the valley. Mr. Y. came here some twelve or fifteen years ago, and obtained a large grant of land from the Government; he, however, has cultivated very little of it, but has used it, like the other great landholders of the country, for a cattle range. The other original grantees of land in Napa Valley were Mr. Fowler, Dr. Bale, an Englishman, and Don Salvador Vallejo. The usual measure of land in this country, as well as in Mexico, is the square league, containing about five thousand acres. Señor Vallejo, who was the largest proprietor here, owned six square leagues, or thirty thousand acres. It is well for the country that these large estates are now being divided and brought into market. They will, doubtless, ere long be eagerly sought after, on account of their extraordinary fertility and beautiful situation, by gentlemen who wish to get away from the bustle of a great city, and enjoy the retirement of a country life.*

I was desirous to have Mr. Yaunt accompany us

* In an agreeable work by Lieutenant Revere, I find the following history of Mr. Yaunt: "This old man had led an adventurous and checkered life; in the course of which he had fought under Jackson at New Orleans, and in the Seminole war had been taken prisoner by the Indians, and actually bound to the stake. $\mathrm{He}$ had been a hunter and a trapper, and Indian fighter at large, in the heart of the continent, until 
to the Geysers, and he readily promised to go; but as he did not appear at the time appointed, we waited for him till twelve o'clock, and then determined to proceed without him. Mr. Osborne now joined our party, and we resumed our journey.

The valley continued as before, level, and without

his combative propensities were gratified-and he finally found himself one day at the "jumping-off place," and made his first attempt at ocean navigation on the bosom of the broad Pacific. In the unpretending skiff of an otter hunter, often unaccompanied save by his trusty rifle, he coasted the shores and islands of California in search of the pelt of his valuable prey. While employed one day (in the year 1836) in his regular pursuit, he chanced to steer his skiff into the navigable creek or estuary of Napa, rightly judging it a place of resort for his furry friends. The valley was then inhabited by none but Indians; and he made his way up to a beautiful spot, a few miles from his boat, which had been selected for a rancheria by a tribe called the "Caymas." Here he sat down to rest; when suddenly there flashed upon his mind, like a gleam of light, a long-forgotten prophecy of an old fortune-teller in his native State. He declares that the sibyl had predicted the spot of his future residence in terms exactly answering to the description of this valley, including all the accessories of grove, plain, mountain, river, and even " medicine water," as the Indians call the springs. The old man pondered over this prophecy, counted his gains, which had been considerable, and philosophized over the vicissitudes of human life, not forgetting, however, to examine the valley more carefully. On his next visit to Monterey, he became a citizen of California, and obtained a grant of land, embracing the charmed spot indicated by the Western witch. He then came and settled it, purchasing cattle with his gains in the "lower country." But the happy valley then swarmed with Indians, jealous of white men, and constantly fighting among themselves; so that this elysium was turned into a pandemonium by their screams and warwhoops. He quitted his skiff, formed an alliance offensive and defensive, with the rancheria of Caymas, erected a log house, after the manner of his ancestors in the days of Daniel Boone, and with his faithful rifle-the only fire-arm in the valley-not only stood and repelled the 
a hill or an undulation. A luxuriant growth of grass, studded with brilliant wild flowers, lined our path. As we continued north, the adjacent hills became more thickly wooded, particularly with pines and firs; the red-wood, a species of cypress, still more conspicuous, raising its tall stem far above the others.*

attacks of the rival rancherias, but attacking in turn, exterminated the unruly, sustained the wavering, and, single-handed, bullied the whole valley into submission. Many a weary, and anxious, and watchful night did he spend ere this result was achieved; but once accomplished, his sovereignty remained undisputed; the conquered became his servants; and the allies of Caymus remain to this day his laborers and his farm hands."-Tour in California, p. 95.

* This tree is remarkable for the great height which it attains. I have been told by credible persons that specimens are now growing which are three hundred feet in height; and I have seen persons who have measured fallen trunks two hundred and sixty-six feet in length. It is one of the most important vegetable productions of California ; and besides the various uses to which it is applied when sawed into boards, it is extensively employed for fencing purposes, the grain being so straight that it splits with the greatest ease; indeed, before the introduction of sawmills, it was usual to split logs of the red wood into planks.

It is also said to be very durable. Colonel Fremont saw posts which had been in the ground three fourths of a century, without traces of decay. The houses built by the Russians at Bodega many years since, are of this timber, with posts sunk in the ground, into which the horizontal pieces are mortised. The planks upon the sides are about three inches thick, and had been but little smoothed off after being split. No signs of decay could be detected even in the posts. At this place, Captain Smith erected a steam, grist, and saw-mill, in 1845 , being the first structure of the kind in the country. He states that they could not saw logs much over four feet in diameter, and never cut any less than eighteen inches; and yet the average number of cuts or logs, each of sixteen feet in length from a single tree, was between eight and ten.*

\footnotetext{
nis

* Report of P. T. Tyson to the Secretary of War, on the Geology and Topography of Califor-
} 
Passed the farm of Mr. Yaunt, and soon after that of Señora Bale, the widow of an English physician,

Fremont describes the largest red-wood measured by him to be fifteen feet in diameter, and 275 feet in height. Lieut. Stoneman, U: S. Army, speaks of another of about the same height, and twenty-one feet in diameter. The largest tree seen by Mr. Tyson (quoted above) was in the forests near Bodega : it had been cut down and a portion removed; the stump was twelve and a quarter feet in diameter, clear of the very thick bark. He saw many trees of nine or ten feet, and those of six and eight feet, were very common.

After examining these forests to some extent, Mr. Tyson says he "measured off a space equal to one seventh of an acre, which was estimated to contain about an average of the forests of that region, and found within it three trees about one hundred feet high and eighteen inches thick, and twelve others varying between four and eight feet in diameter, and from 180 to 230 feet high." It is difficult to form an idea of the product of timber upon an acre containing the proportion within the fractional part above noted, without an arithmetical calculation, when it will be found to produce about one million feet of boards, one inch thick, besides five hundred cords of wood from the tops and limbs.

Captain Smith thinks he alone has seen ten thousand acres of such forest, and Mr. Tyson saw many acres which would yield considerably more in proportion than the measured space.

Judge Thornton speaks of pines which " measured, at a height of between six and a dozen feet above the ground, forty feet in circumference, their bark nearly a foot thick, and between two and three hundred feet high." Between Paget Sound and Fort Harrison, some of the fallen trees have been found to be 265 feet in length. "These trees are perfeetly straight and without branches for a distance of 150 feet. In many places where these trees have fallen, they present barriers to the vision even when the traveller is on horseback."-Oregon and California, Vol. I. p. 350 .

Mr. Walter Hitchcock gives the following account of forest monsters which fell under his observation:

"The big trees (for there are 131 of them over ten feet in diameter standing on the limits of a few acres) stand in Mammoth Tree Valley, 
who settled and died here. This lady has a large estate, which contains more improvements than any

about thirty miles north of Sonora, in Calaveras county. The rhammoth tree which has been felled, was bored down with long augers, and took four men twenty-two days to get it down. The stump stands about six feet above the level of the ground, and its top has been made level and smooth, which required sixteen days work. I measured it from the inside of the bark across to the inside of the bark, and it measured twenty-five feet, and is perfectly sound clear to the heart. The bark, to the height of 52 feet, has been taken from the trunk in sections, and sent to the fair at New-York. If the top half of the tree were taken off, so as to make a level surface, a stage eoach with four horses might be driven on it, from the butt towards the tip, a distance of 166 feet, it being at this length ten feet in diameter. At the length of 280 feet, it is four feet in diameter. At this point it was broken off in falling, and the tip was broken into fragments so fine I could not measure them; but its height had been taken before it was felled, and set down at 300 feet. It is called arbor vitce; but it is not fully decided to what variety it belongs. It is a little curious that no other trees of the same kind can be found less than seven feet in diameter, and this tree is estimated by a scientific gentleman from San Francisco to be 3,100 years old.

"There are many others still standing, of the same kind, which are monsters; some even larger than this, but not sound. One, called Uncle Tom's Cabin, has a more commodious room in it than many miners' cabins. There are some large ones blown down, and one I must not fail to describe. It was evidently decayed before it fell, and in its fall broke off sixty feet from the roots. This part is hollow; and I cannot give you a better idea of its size, than by telling you that I rode my horse through it from end to end. At the end where it is broken off, the shell is very thin, and as I sat on the horse, I could not reach my hand to the inner surface, over my head; but half-way through, the shell was as much as three feet thick over my head, and more than that under the horse's feet, and here it was necessary to lean forward. But this is not the largest. There is another one blown down, which measures 110 feet in circumference and 410 feet in length: This, too, is hollow; and if the hollow were enlarged a little, it would make a very good rope walk." 
other farm in the valley. In her orchard I noticed pear and peach trees, and grape vines in abundance; while around the house were rose bushes and other flowering shrubs. The lady was at work in her garden, in which she seemed to take a deep interest; while frolicking around her were six beautiful children, whose light hair and fair complexion indicated their Anglo-Saxon parentage. Passed other farms, some of which, particularly Mr. Keller's, bore the marks of an old settlement, from the extent of its fences, its barns, saw-mill, and other improvements. Here was a large orchard of peach trees in full bloom; which trees, I was told, were brought round Cape Horn from the Atlantic States. Every thing here was in a flourishing condition; although in the form and arrangement of the buildings a sad deficiency of taste was visible.

A ride of three miles further brought us to Mr. Kilburn's, a Missourian, with a Californian wife. We stopped here for the night, and were disappointed in not finding $\mathrm{Mr}$. $\mathrm{K}$. at home. He is another old resident, having been some seven years in the valley. As this gentleman was familiar with the district we were about to visit, we had relied on his accompanying us; or, failing to do so, we had hoped to obtain such information from him as would enable us to find the objects of which we were in search. Mrs. Kilburn received us kindly, although we were all strangers to her; nevertheless she seemed a little flustered when we told her we had come to pass the night there. She is quite young, good-looking, and has an interesting family of little ones around her, who, like the children before 
mentioned, exhibit their Anglo-Saxon descent. A fine supper was soon prepared for us; after partaking of which, we were directed to our beds in the chamber above, all clean and comfortable.

The valley for the last few miles had diminished much in width, being not more than a mile at Mr. Kilburn's farm. The soil, too, had changed from a black loam to clay and gravel. Nevertheless, vegetation seemed quite as luxuriant, and the valley presented a greater variety of trees. The oak, which, as I have stated, monopolizes the valley below, here gives way to the lofty pine, spruce, red-wood, cedar, \&c.

I had heard at San Francisco of the large yield of vegetables on this farm, and made inquiry as to its truth. I found the statement to be correct; and that from two acres of onions planted near the house, $\mathrm{Mr}$. Kilburn had realized last year, in the market of San Francisco, eight thousand dollars in cash. He also raised an immense number of cabbages and other vegetables. In explanation of this, I ought to mention that onions are considered the most valuable of all vegetables among the gold miners, on account of their antiscorbutic properties. They grow here to an enormous size, and give an immense yield. My own experience convinces me of the great value of onions where there is a predisposition to scurvy, and there is no vegetable which one craves more than this. Many have I bought at twelve and a half cents a piece, and eaten with more relish than I ever did an orange.

In our ride to-day, we crossed the valley to examine some thermal springs, which are somewhat celebrated here. They are in a plain near the base of a small hill 
of conglomerate rock; but owing to the wet and boggy condition of the valley, we were unable to approach within thirty feet of them. Columns of steam. were rising from them on all sides. These springs had been visited by Professor Shepard the year before, and some account of them given by him to the public.* The temperature is said to be constantly changing. Professor S, heard that there was a place near the foot of Mount Helena, where the hot waters formerly flowed, but which had now ceased. This report induced-him to visit the spot. "Externally," he says, "there was no uncommon appearance to indicate the locality. Neither a surplus or a scarcity of vegetation, and no appearance of scoria, tufa or travertine, as might have been expected." In one place, however, he found it slightly warm on the surface; and on excavating to the depth of two feet, it became so hot that he could not bear his hand in the mud and clay. He inserted the bulb of his thermometer, and the mercury at once rose to one hundred and twenty degrees. The temperature of the springs we visited, varied from 105 to 169 degrees.

* See Silliman's Journal, Nov. 1851, p. 154. 


\section{CHAPTER XXIII.}

THE GEYSERS OF PLUTON RIVER, AND RETURN TO SAN FRANCISCO.

Mount Helena-Russian inscription-Digger Indians-Dwellings-Mode of fishing-Dress-Pass the mountains-Meet bear hunters-Mode of cooking without utensils-Pluton River-The Geysers-Description of these phenomena-Effect of the water on wood-Extent of volcanic action-Return to Camp-Abundance of grizzly bears-Recross the mountains-Return through Napa Valley-Visit to the Obsidian hills -Extensive use of this material by the Indians-Return to San Francisco.

March 21st. Resumed our journey after breakfast; and at Mr. Fowler's, three or four miles distant, met a man who manifested much curiosity in our researches, when he found us inquiring about mines and the volcanic region. He showed Dr. Webb a specimen of ore, which, he said, was from that vicinity. The doctor at once pronounced it zinc, and expressed a doubt about its being found in the state in which it was exhibited to him. But the man insisted that his account of its origin was correct, and furthermore offered to conduct us to the spot; whereupon we set off together under his guidance. Crossing the valley to the opposite side, he led us up a deep ravine, where he leaped from his horse and pointed out the rock from 
which he said the specimen was taken. An examination showed it to be nothing but serpentine. He led the doctor to several ledges at some distance, but their character was the same. He had evidently been imposed upon, for he acknowledged afterwards that he did not find the specimen himself. Many tricks of this kind are practised on the ignorant, and they even sometimes lead scientific men astray.

While this man was hunting up his imaginary treasures, I ascended a small hill and took a sketch of the beautiful scenery around. Directly before me on the eastern side of the valley loomed up Mount Helena or Moyacino of the Russians. This is the highest mountain for a great distance around, none within seventy or eighty miles having as great an altitude. On its summit is an inscription in Russian characters on a plate of copper, giving the latitude and longitude of the place. We met several persons who had seen the tablet. The Russians had a settlement called Fort Rosse on Bodega Bay, opposite this mountain; and the tablet was doubtless placed there to show the line of boundary which Russia claimed.

The view here exhibited the finest alpine scenery I had yet seen in California, and showed that we were advancing northward as well as reaching a higher elevation.

Reached Mr. Knight's, twelve miles from Kilburn's, at noon. Here the valley grew quite narrow, or rather terminated, it being intersected by a range of hills. At this place, another valley opened some two or three miles in width, and extended about ten miles farther to the north. 
Mr. Knight is a young man from Vermont, who came across the continent about seven years before our visit, with the first emigrants to Oregon. As the country did not suit him, he pushed his, way southward, until he struck this valley. He owns a large tract of land here; but in consequence of his distance from market, he has, very wisely, turned his attention from cultivating the soil, to that of raising stock. His isolated position, and the hills of grass and wild oats which surround him on every side, render it a most advantageous one for this purpose. Although surrounded by wild beasts and warlike Indians, and with no neighbor within twelve miles of him, he had not forgotten all the enjoyments that belong to civilized communities, as was evinced by a piano-forte and a case well filled with books.

An Indian village stood a few hundred yards from the house; and at my request Mr. Knight went out and brought me three of the most intelligent among them, from whom I obtained a full vocabulary of their language. Like many other tribes of the country, and of this region in particular, they appeared to have no name for themselves as a people. By the white people, these and all other Indians between the Sacramento and the coast, and thence through the central parts of the State, are called "Diggers," or "Digger Indians," from the fact that they live chiefly on roots, which they collect by digging. I therefore set them down as Indians of Napa Valley. We had met with several small bands, and passed a few villages on our way up; but from none could I learn that they had any name for their tribe. This fact will account for 
the great diversity in the names of the California Indians as given by travellers. In examining the various books on this country and articles in scientific journals, I find tribes mentioned by names which are not elsewhere to be found; and in my own inquiries I have found tribes who called themselves by names which I never heard of before. This has induced me to believe that the small tribes or bands, which abound here more than in any other part of North America, when asked to what tribe they belong, give the name of their chief, which is misunderstood by the inquirer to be that of the tribe itself.

Their houses are circular, and from twelve to thirty feet in diameter, the interior usually excavated about three feet below the surface of the ground. Within this circle posts are planted, forked at the top, upon which rest poles reaching from one to the other. The spaces between the posts are filled in with sticks or tules, against which the earth is firmly banked up outside. The roofs are dome-shaped, and, in the smaller houses, supported by a single post in the centre, on the forked top of which rest two main rafters, with their outer ends planted in the ground. From these are stretched stout poles, about a foot apart and thatched with sticks and tules, or rushes closely interwoven, and covered with a solidly pressed layer of earth about a foot thick, making a roof completely water proof in the heaviest rains. In some villages the houses have but one aperture, which is on the top of the roof, and serves for both door and chimney. This is entered by a sort of rude ladder, or by notches cut in the centre-post. Others have an opening at the 


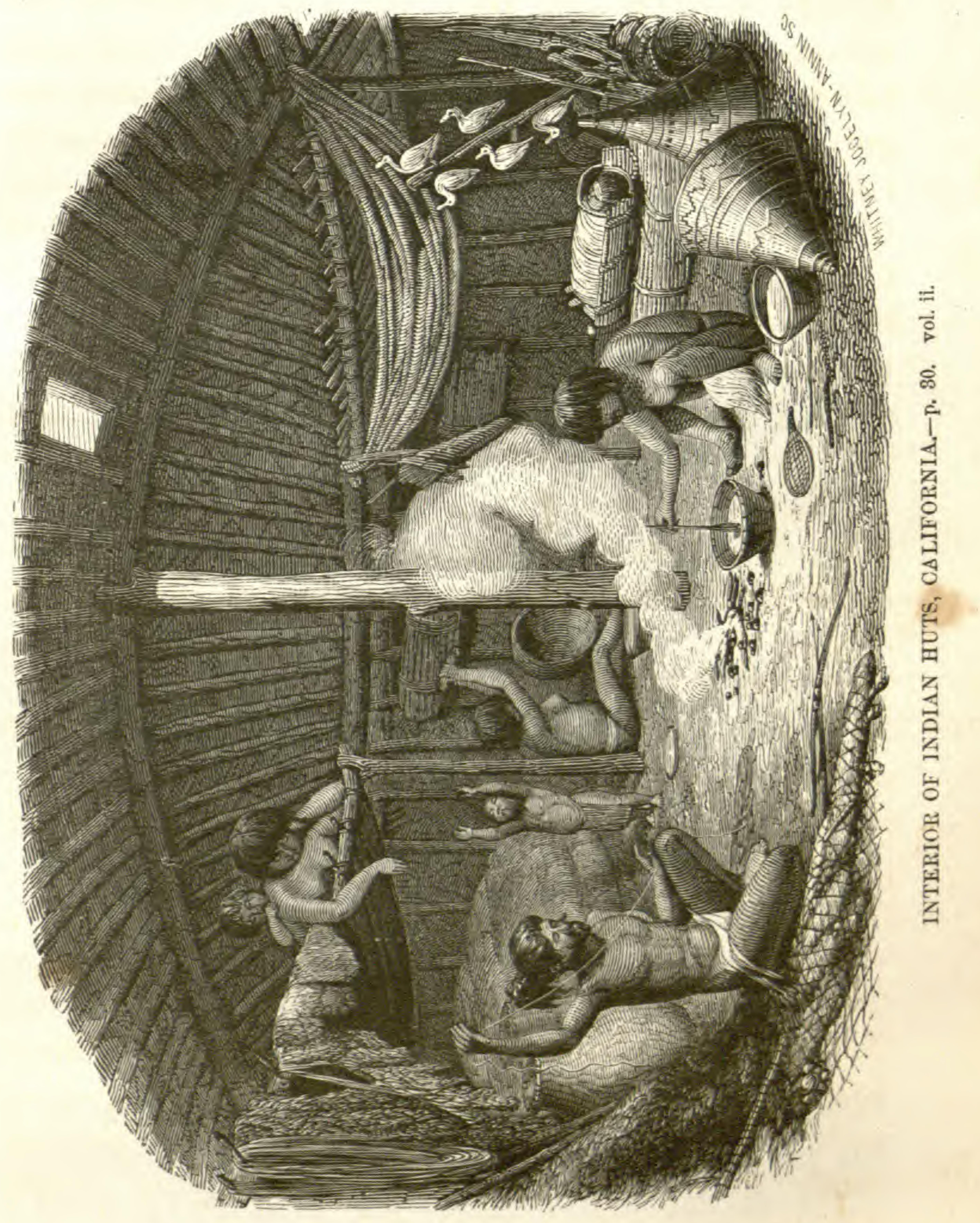



side, so small as not to be entered except by crawling on the hands and knees. Around the sides of the interior are wide shelves, formed of poles and rushes resting on forked posts, which serve for beds.

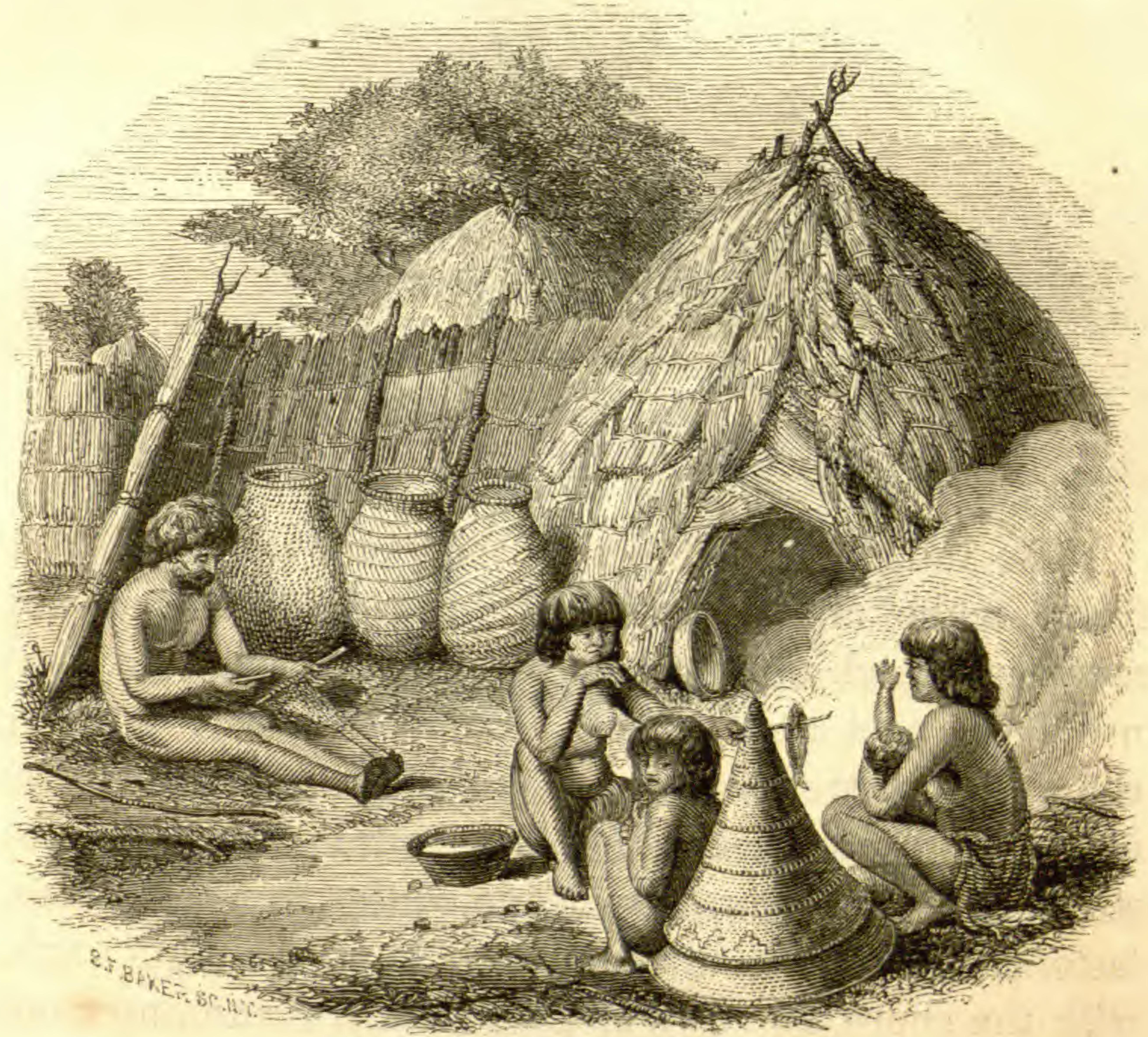

Summer huts of Californis Indians.

In the view of the interior of one of their dwellings is seen a number of decoy ducks which they use to good advantage. Although the California tribes exhibit much skill in fishing and in trapping game, and the erection of their dwellings, they show little ingenuity in the arts of design. The accompanying rude figure in wood, of a woman and child, which was 
found on the coast, is all that I have seen of their carving.

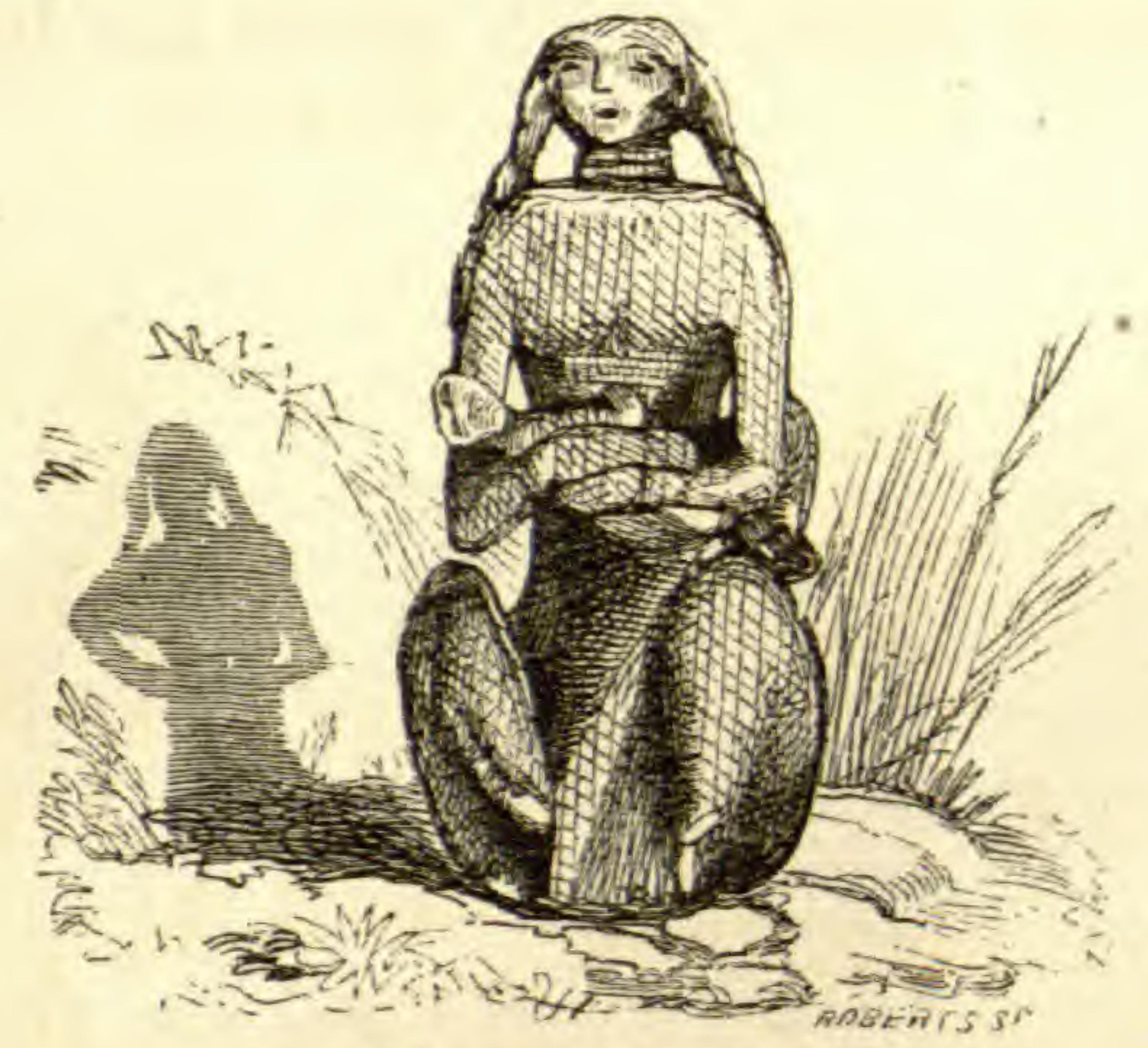

Figure ent in wood.

The Indians dwelling near the great rivers of California make much dependence upon the salmon and sturgeon which they can take. For this purpose they use both nets and spears. When the river is wide, the nets are stretched by means of booms projecting from the banks, sometimes a hundred feet into the stream. These booms are made of the trunks of trees, fastened together at the ends, and kept at a right angle with the shore by stays of grape, vine stretching from the boom to trees or stakes. Beneath the outer end of the boom is a float or raft of tulé, upon which is stuck a branch gaily trimmed with feathers and other ornaments, as a charm to secure success. Other charms, usually made of bunches of feathers raised upon poles, are displayed along the bank, where are also one or two huts for the party in attendance. One of the party holds constantly in his hand a line attached to the net, by means of which he can feel when a large 
fish is entangled, whereupon the net is hauled in and the prize secured.

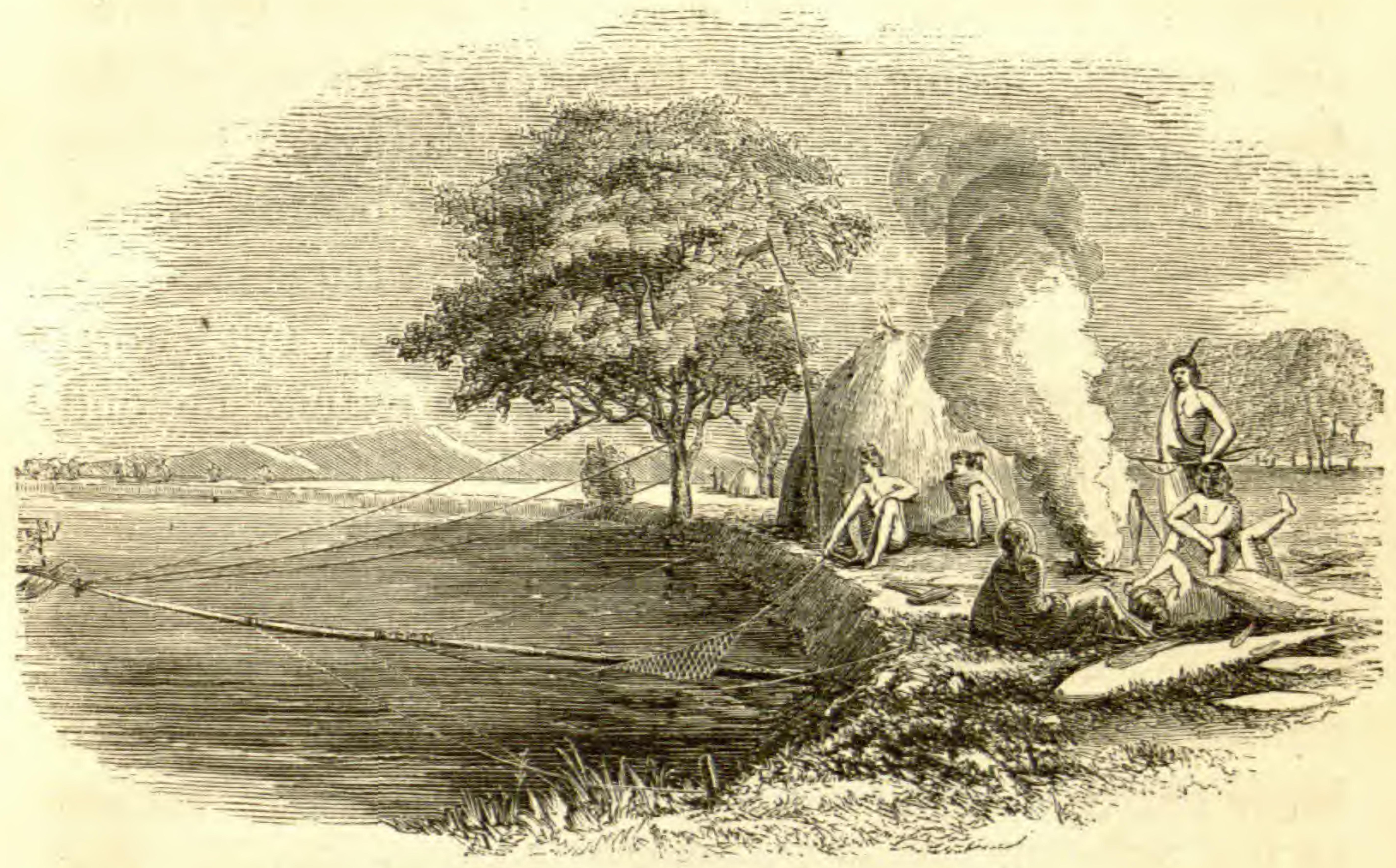

California Indians catching salmon.

When a sturgeon is caught, the spinal marrow, which is considered a delicacy, is drawn out whole, through a cut made in the back, and devoured raw, with a rapidity quite startling to one not aware of the strength of an Indian's stomach.

The spear is a very ingenious and effective contrivance. When thrown into a fish, the head, which is of bone with a line attached towards the point, detaches itself from the pole, which serves as a drag to weary out the fish. As soon as the pole can be seized, nothing remains but to haul the prey in.

The men either go naked or wear a simple breechcloth. The women wear a cloth or strips of leather around their loins. A basket pointed at the lower

VOL. II. -3 
end, is in universal use among them, for gathering the roots and seeds which form their chief subsistence. This is carried on their backs, supported by a band across the forehead. Their arms of defence are bows and arrows. Some tribes, however, make use of the spear or lance. In one respect the California Indians differ from all others. I allude to their beards, which are generally permitted to grow. It is true they are not as thick and bushy as in the white race, but'short, thin, and stiff. I have never seen them extend beyond the upper lip and the chin. The hair of all the California Indians I have seen is cut short.

After partaking of an excellent dinner, we took leave of our host. For several miles our journey extended over a plain hemmed in on all sides, on which large herds of cattle were grazing; then came ranges of low hills, all covered with wild oats or clover. The cattle truly luxuriated here. A ride of twelve miles, alternately over low hills and valleys, and winding through clusters of trees and shrubbery, brought us to the establishment of MacDonald, the last settler in this part of the country, towards Oregon. We received a cordial welcome from Mr. MacDonald and his wife,a young woman of twenty, who must have some courage to settle down in this lonely spot. On making known my intention to visit the volcanic region, $\mathrm{Mr}$. MacDonald consented to be our guide, although busily engaged in putting in his crops.

Having an hour or two to spare before dark, I took a sketch of the valley and adjoining mountains, all of which presented a most picturesque appearance. The valley is here very limited, being confined to 
patches of from twenty to fifty acres, but all connected by a small and never-failing stream of excellent water. The object of our friend in settling here was to secure to himself a large tract of land without encroachment. Thus he has a section of good tillable land of one hundred and sixty to two hundred acres, and on the low hills around it about four thousand acres excellent for grazing purposes. Having secured all the valley, no one would take up land on the hills. His section would, therefore, give him the use of the large tract adjacent, which was all he required.

March $22 d$. Took an early breakfast, and started at seven o'clock. MacDonald led the way, and we followed him in Indian file. We had now no more beautiful valleys or grassy plains to traverse. Nothing but a succession of lofty and rugged mountains lay before us, through the intricacies of which we had to wind our way. There was no road, nor even a trail, save those made by wild animals, of which there was an abundance in these parts. Our guide often directed our attention to the huge tracks of the grizzly and brown bear, and again to those of the elk, which constantly crossed and recrossed our path. He had been several times to the place we were going, and knew the country well; yet so wild and rugged was it, so dense the forest, and with such a succession of ascents and descents, that he sometimes seemed at a loss which way to go. The general direction was well known; but among such a number of deep gorges and ravines, mountains, hills, and valleys, it was no easy task to select the right one; and a mistake in the mazes of such a place would leads us into inextricable difficulties. 
At noon, having been five hours in the saddle, we stopped to rest ourselves, as well as our animals, on one of the elevated spurs, from which we had a grand view of a vast stretch of country towards the coast. Some ten or fifteen miles distant lay Russian River, winding its way along a beautiful valley, bounded by a succession of hills; and beyond this rose the coast range of mountains. While the animals were grazing, I took a sketch of this enchanting spot.

Pursuing our journey still over hills and through ravines; forcing our way among the thorny chapporal and thickets;-now winding along the side of a steep hill, where a single misstep would throw horse and rider some hundred feet below, and now leading our frightened animals up some precipitous ascent where it was unsafe to ride them, we at length reached the summit of the mountain beyond. From this elevated point the view was grand beyond description. On the east, far in the distance, the horizon was bounded by the snow-capped summits of the Sierra Nevada, forming a well marked line with the deep blue of the horizon. Nearer, and on every side, lay mountains of every variety of form; some rugged and bare; others covered with a deep Alpine foliage, while others again of less height, from their yellow hue, seemed clothed with the rich verdure of wild oats. Four or five miles distant, in an opening surrounded by rugged mountains, lay Clear Lake.

After following the summit we were now on, for a couple of miles, we began to descend again into the deep gorge, through which runs Pluton River, on whose banks are the volcanic phenomena and geysers of 
which we were in search. The descent was here so steep that we were obliged to dismount from our animals and lead them down. Our progress was now necessarily rapid, and we soon reached the base of the mountain. Here we suddenly came upon four men, who had come out a few days before us from MacDonald's to amuse themselves in hunting the grizzly bear. We reached this place at four o'clock, a distance of but sixteen miles, after a most fatiguing journey; although the beauty and variety of the scenery well repaid us for the effort. As there was still a descent of five hundred feet to the stream, and a mile to the geysers, we determined to leave their examination till morning, and devote the remainder of the day to rest and the preparation of our dinner.

As the hunters had nothing but bear's meat in store, three of them took their rifles and went out to procure a deer for dinner. In less than an hour all returned, each bringing with him the hind quarters of a fine deer, having been equally successful in their short hunt. While they were absent, our servant had made a fire, and got a kettle of boiling water ready for making coffee. In ten minutes after their return, the venison and bear's meat were roasting before the fire, and emitting the most appetizing odors.

The method of preparing a fine game dinner without a single cooking utensil deserves to be mentioned. First, a number of sticks are cut about two feet in length, the size of one's finger, divested of their bark, and sharpened at one end. These correspond to the spits in civilized roast-ovens. The meat is now cut up into pieces about three quarters of an inch in thickness 
and half the size of one's hand, with a hole in the centre. Through these the sharpened stick is thrust, and its lower end planted in the ground before the fire. As our fare consisted of venison and bear's meat, successive layers of each were put upon the sticks, the fat of the latter, as it dripped down, basting and furnishing an excellent gravy to the former. In fifteen minutes, with occasional turning, the dinner was pronounced ready to be served up.

Being unprovided with the luxury of a table, we seated ourselves on the grass, beneath the wide-spreading boughs of a tree, and a few yards from the fire, in order to be near the kitchen, and to have our meats and coffee warm. Before each person was stuck in the ground a stick of the roasted meat. A bag of hard bread (pilot bread), some sugar, salt, and pepper, were placed near, and each man was provided with a tin cup filled with coffee. Thus furnished, and with sharp appetites, we fell to, and never was a feast more heartily appreciated. Our coffee and bread were excellent; and those who were not satisfied with one stick of meat, found another ready at the fire when the first was gone.

By the time we had finished our dinner, it was dark. We then sat for an hour or two listening to the feats and adventures related to us by the hunters before referred to, all of which were exciting and full of interest; after which, one by one, we rolled ourselves in our blankets, and dropped asleep, dreaming of grizzly bears, elk, venison, and the wild scenery we had been enjoying during the day.

March $23 d$. Was up by sunrise, after an excellent 
night's rest; and took a bath in the waters of a little stream that tumbled down within twenty feet of our camp-fire, by which time our breakfast was ready. This was a counterpart of yesterday's dinner, viz., bear's meat, venison, hard-bread, and coffee. Having dispatched it, we set off for the geysers: Dr. Webb, with his hammer and leather bags for minerals, and with boxes and bottles for small zoological specimens; Mr. Thurber, with his portfolio for plants; and I, with my sketch-book. We were all provided with pistols or rifles besides. It would have been easier and attended with less risk, to make the descent on foot; but we were obliged to go on horseback, on account of having to ford the stream. The river or creek was from thirty to forty feet wide where we crossed it, about half up the horse's middle, and very rapid. On either side, the banks were rocky and steep, rendering it somewhat difficult, though with steady animals not a dangerous passage. About a quarter of a mile' from the opposite bank we dismounted, unsaddled our animals, and staked them out to feast themselves on the rich clover which there abounded, and then completed our journey on foot. A few hundred yards brought us to the first of the geysers, or "volcanoes," as they were called by our guide. I should not forget to remark, that we saw in several ravines, as we passed along, traces of former volcanic action. The rocks were bare, and in a decomposed state, showing the effects of heat or fire, although no heat was then perceptible.

At the first place we stopped, there was a show of about half an acre of decomposed granite, and other rocks, from cavities in which issued fumes of sulphur 
and small quantities of steam. At these places were beds of crystallized sulphur; and in others, sulphur was exposed on turning up with a stick the exterior crust. There was every appearance around us that the rocks had been subjected to an intense heat, which was now gradually abating. After collecting specimens of the sulphur and adjacent rocks, we continued further up.

Another quarter of a mile, over steep hills and across deep ravines, brought us to the principal "geysers." Here was truly a grand prospect, and difficult to describe by one unacquainted with such scenes; for to speak with scientific precision of such a remarkable spot as this, the writer should be familiar with volcanic regions and know something of similar phenomena. The action here was confined within a narrow ravine, in the mountain side, running nearly at right angles with Pluton River, which we had crossed. The banks were from one hundred and twenty-five to one hundred and fifty feet in height, breaking in from the mountain, which rose up from ten to fifteen hundred feet above, and were wholly composed of decomposed rocks. In the chasm beneath us, columns of steam were spouting out on every side; while deep at the bottom, ran a small rivulet. Vegetation of luxuriant growth crowded close upon the crumbling rocks, consisting of various kinds of shrubbery, pines, oaks, firs, \&c.

We clambered down to the spot where the scoria or burnt rock first appeared, and seated ourselves under the shade of a pine tree. From this point I took a sketch looking down the gorge. On each side of where we sat, some twenty or thirty feet below, a 


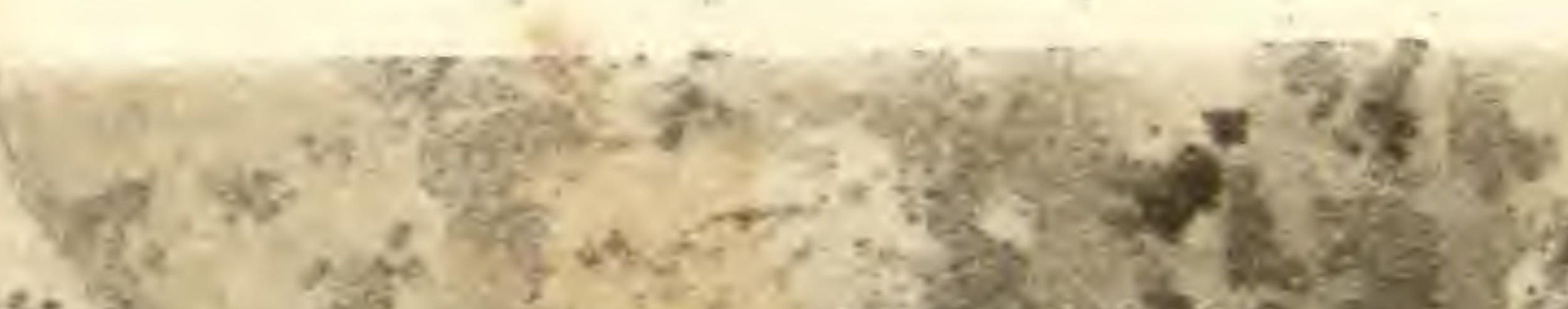

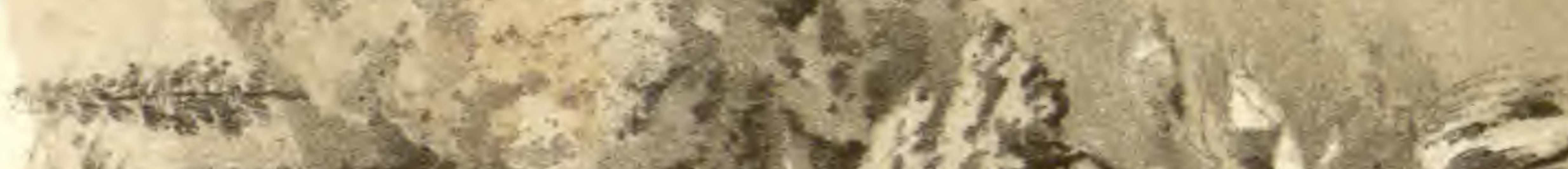

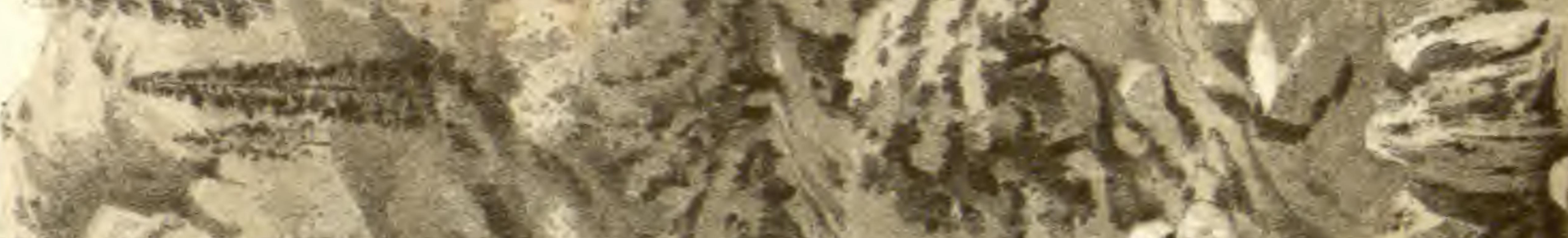

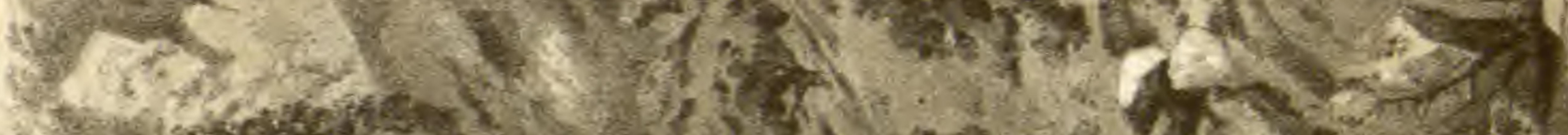

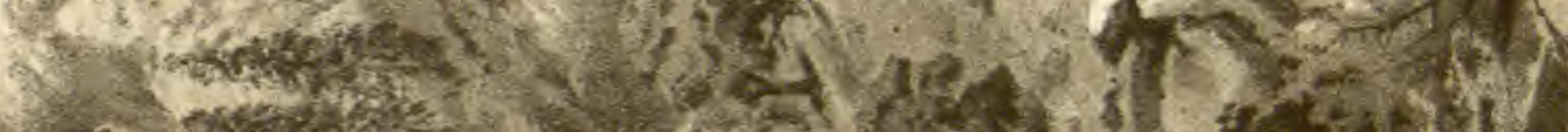

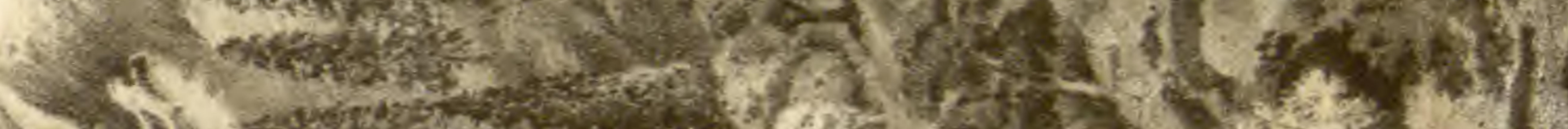
Het

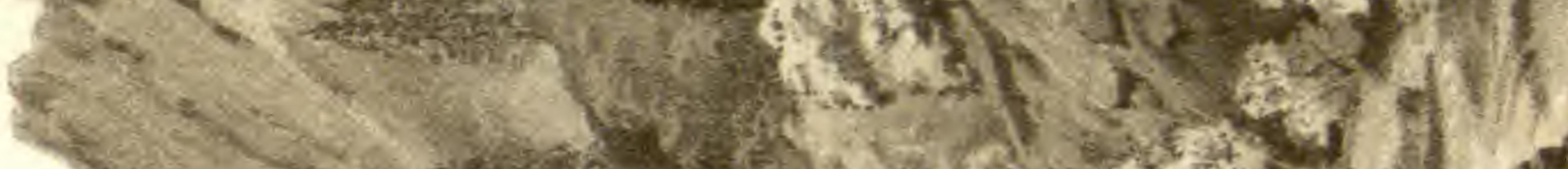

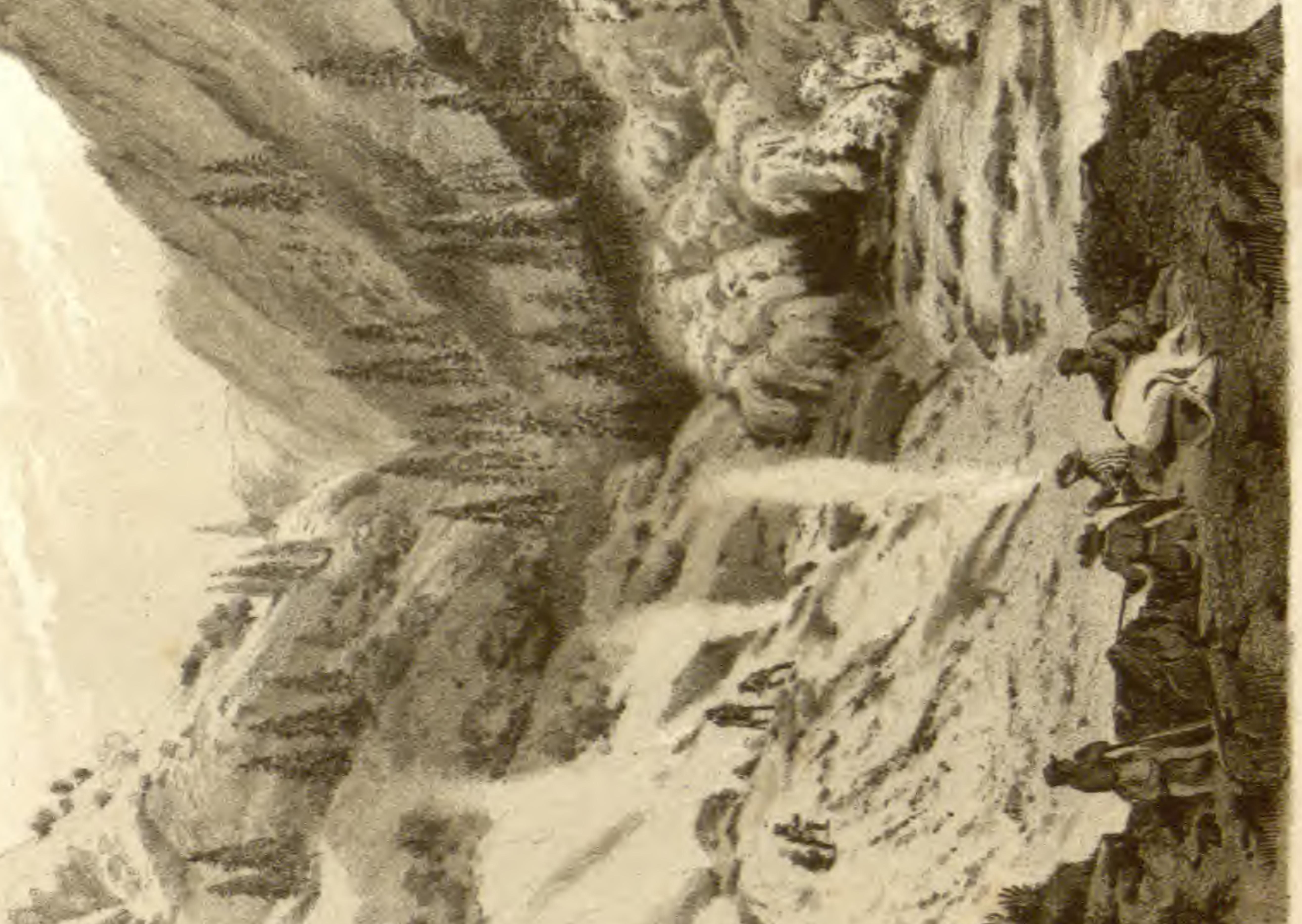

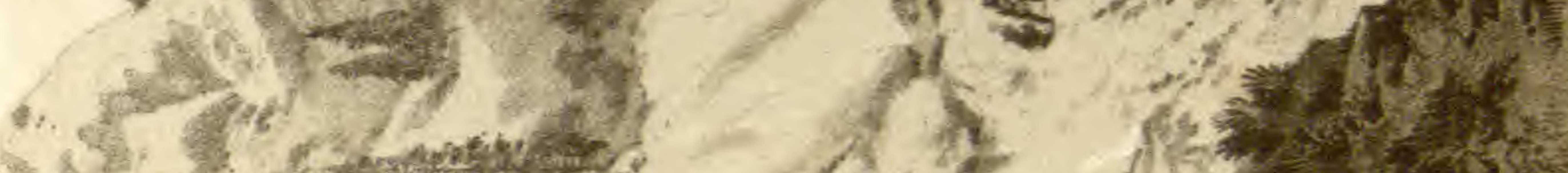

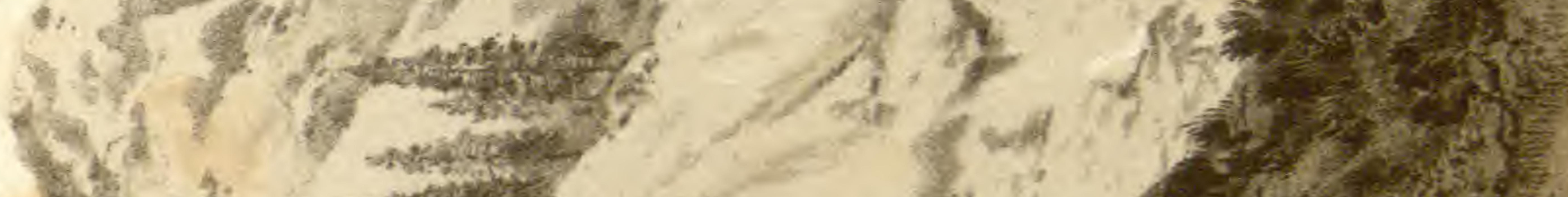
(1)

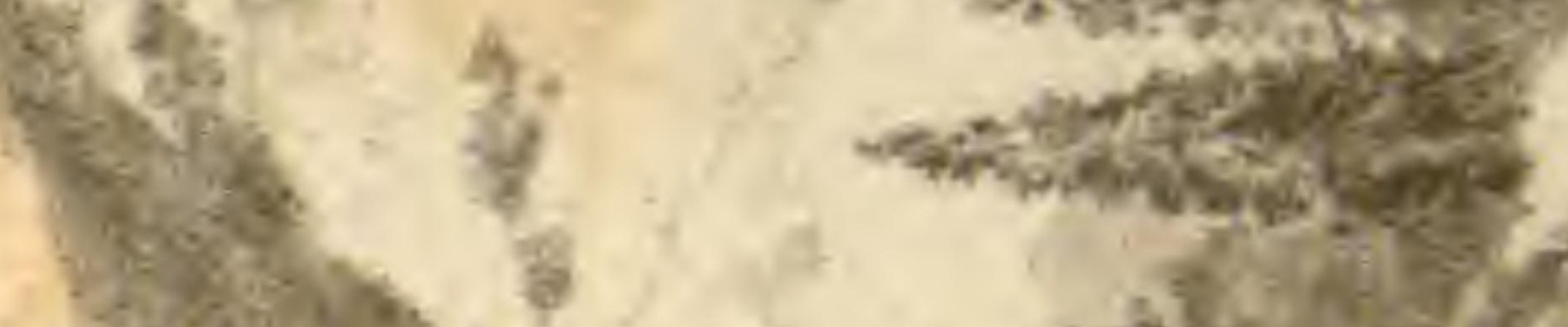

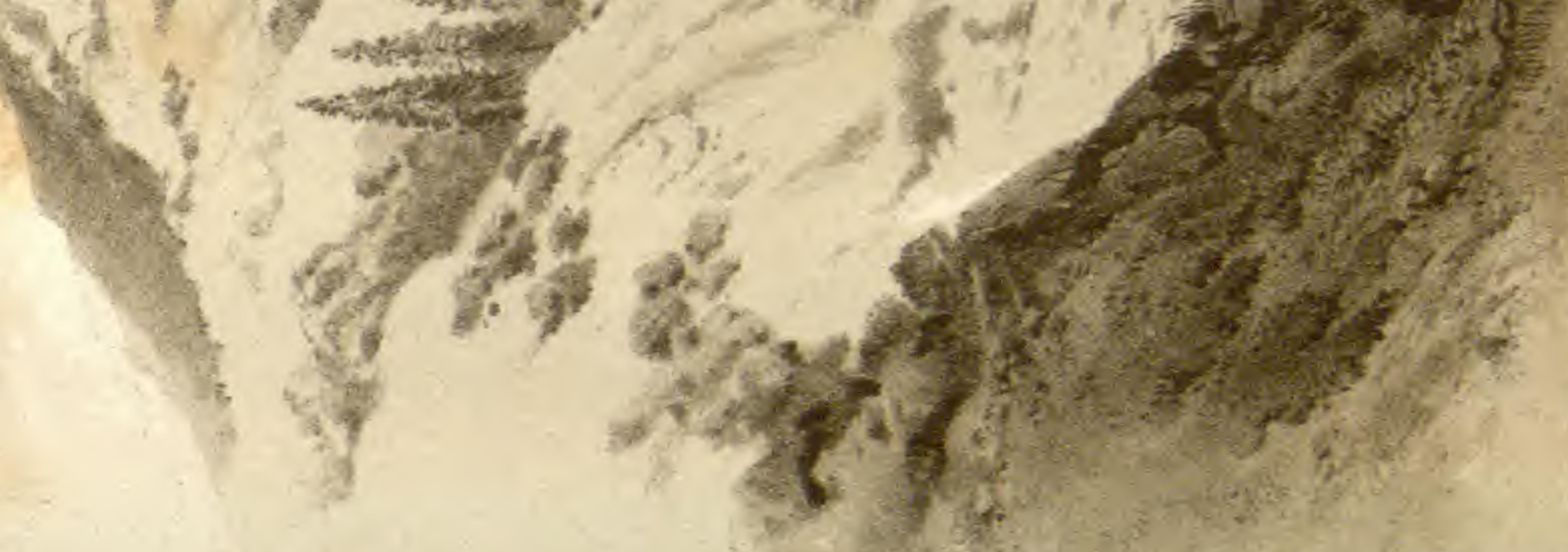



small stream came tumbling down, concealed from view by dense foliage, and united at the base of a jutting mass of rocks, as seen in the sketch. I thrust a staff, which I carried with me, some three or four feet into the crumbled granite beneath; which led us to think it not quite safe to remain where we were. From this place, we got down with some difficulty to the bottom of the gorge, where the main stream ran. The water was here cold and pure, exhibiting no unpleasant taste. A few yards further brought us into the midst of the puffing geysers, or steam-jets; for I knew not by what other name to call them. Fumes of sulphur here met our nostrils at every step, while the rustling steam, as it spouted from a hundred cavities, completely enveloped us. The latter did not issue in one continuous column, but at short intervals, as from the "pipe of a high pressure engine. It was with some difficulty that we could breathe here among the fumes of sulphur and the steam; and we crouched low in the bed of the rocky stream to avoid them. In cavities along both banks, and near the running brook, was boiling water, which rose and fell, accompanied by a loud gurgling noise, resembling that of a gigantic steam condenser. In one of these cavities, stones as large as an egg were in a state of commotion, presenting a curious resemblance to a pot of boiling potatoes. I held my hand fifteen inches above this boiling pot, at, which distance the water scalded it. From this cavity to the running stream, was just the width of my hand; though the surface of the boiling water in the cavity, was about a foot above the running water. The whole of this violent commotion was accompanied by a tremendous 
noise beneath the earth's surface, quite equal to and resembling that made by several ocean steamers, letting off their steam through their large pipes, loud, deep, and harsh. There was no cessation to this awful roar, but one continued noise, as though a vast workshop beneath was in full operation.

The banks of the gorge were now too steep to attempt to ascend, nor would it have been safe to do so among so many jets of steam, boiling caldrons, and fumes of sulphur; so we made our way down the gorge in the very bed of the stream, jumping from rock to rock, first on one side and then on the other, and occasionally, where the stream took a leap, letting ourselves down in the best way we could. Thus we worked our way along for about an hour, filled with admiration and wonder at the mysterious workings of nature around us. The water, as we advanced, grew warmer, in consequence of accessions from the boiling cavities along its margin, until the stream became quite hot. We had here an opportunity to select a bath of any temperature, from one of icy coldness to that of one hundred and fifty degrees; and we did not fail to improve it in some of the deeper basins of the stream, which seemed prepared by nature for such a purpose.

Having thus refreshed ourselves, we clambered up the opposite bank; and as we had now passed through that portion of the gorge which had been affected by the heat, we lay down awhile under the shade of a tree on the bank of Pluton River. Looking up here, we saw before us, at the distance of a few hundred yards, another of these volcanic wonders. This was directly on the north-east bank of the stream, and was marked 


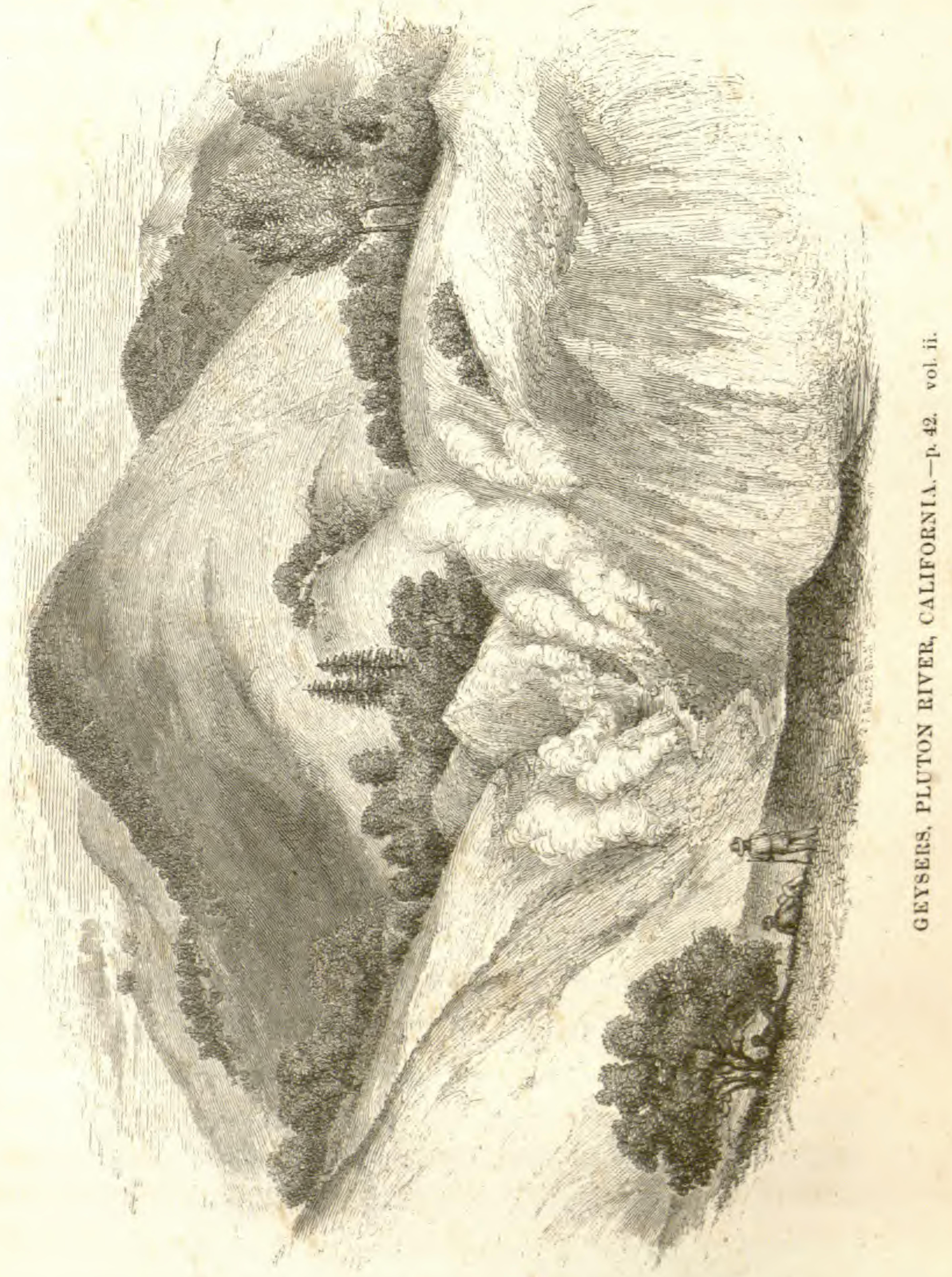



by a patch of decomposed rock of a whitish cast, covering about an acre. Here also jets of steam issued forth, but not in so many places, nor with as much force as within the gorge just described. Dr. Webb and Mr. Thurber examined it, and afterwards visited several others, further up the river; but none of them were found to equal the first in grandeur. I remained behind with Mr. Osborne, to take a sketch from the bank where we stood, showing these last named geysers, and the deep mountain gorge through which Pluton River runs. The scenery here was truly grand. Immense pines grew on the mountain sides and tops, while oaks and smaller trees filled the narrow valleys and ravines, which the rains had made. Just below us ran the river, dashing over rocks in its steep descent, and often concealed by the thick foliage which overhung it.

Mr. Osborne and myself then returned and crossed the foot of the gorge where the great geysers are, with the intention of getting a view of the chasm looking up towards the point from which I had taken my first sketch. To reach this point was easier said than done, and proved the most difficult and only dangerous adventure of the day. However, by lying flat on our breasts and working a resting-place or notch with our feet in the crumbling rocks, and occasionally laying hold of a projecting root, we succeeded in reaching the desired point. Here, on a projecting cliff, grew a few shrubs of the manacita, beneath which I crept on my hands and knees; and having reached the point, sat down and took a sketch, while my companion refreshed himself beneath the shade. 
From this point is a fine view of the chasm or gorge, with the little stream at the bottom, and the jets of steam spouting from its sides. The projecting rock, near which I took the first sketch, is seen at the head of the gorge, and in the centre of the picture. Close upon the decomposed rock appears the luxuriant vegetation; while the mountain, towering far above all, forms the background.

The decomposed rocks, of which I have so often spoken, are in general of a whitish cast, curiously interspersed with spots of every hue. I noticed many patches of deep red, and some of light yellow and green; while here and there were others of black, brown, and slate color.

Having completed my sketches, we hastened back to the place where we had left our animals. Here we threw ourselves on the grass in a deep grove near the bank of the mountain torrent, to await the return of Dr. Webb, Mr. Thurber, and MacDonald. At the same time I sent my servant ahead to our place of encampment to build a fire, put on a kettle of water, and make other preparations for dinner. Within half an hour our friends made their appearance, when we mounted our nags, recrossed the river, and, after a little hard tugging up the mountain, reached our camp fire in safety, delighted with the adventures of the day.

I am not aware that this interesting spot has been visited by any man of science, except Professor Shepherd, of Western Reserve College, Ohio; and as his experience and profession better fitted him for investigations in such phenomena than mine, I quote a 
portion of his remarks, which will convey a fuller and clearer idea than my feeble description. My time while there was short, and mostly spent in making sketches, and in collecting a few specimens of sulphur and of the contiguous rocks; nor had I the means of testing or examining the waters.

"You may here find sulphur water," says Professor Shepherd,*" "precisely similar to the celebrated White Sulphur of Green Brier County, Virginia, except its icy coldness. Also red, blne, and even black sulphur water, both cold and hot. Also pure limpid hot water, without any sulphur or chlorine salts; calcareous hot waters, magnesian, chalybeate, etc., in almost endless variety. Every natural facility is afforded for either vapor, shower, or plunging baths. Where the heated sulphuretted hydrogen gas is evolved, water appears to be suddenly formed, beautiful crystals of sulphur deposited (not sublimated as by fire), and more or less sulphuric acid generated. In some places the acid was found so strong as to turn black kid gloves almost immediately to a deep red. * * * From numerous experiments made here and in the mountains of Virginia, I am confident that all sulphur springs possess a high temperature, after descending below the cold surface water. Notwithstanding the rocks are so hot as to burn your feet through the soles of your boots, there is no appearance of a volcano in this extraordinary spot. There is no appearance of lava. You find yourself standing not in a solfatara, nor one of the salses described by the illustrious Humboldt. The rocks

* Silliman's Journal for November, 1851, p. 156. 
around you are rapidly dissolving under the powerful metamorphic action going on. Porphyry and jasper are transformed into a kind of potter's clay. Pseudotrappean rocks are consumed much like wood in a slow fire, and go to form sulphate of magnesia and other products. Granite is rendered so soft that you may crush it between your fingers, and cut it as easily as unbaked bread. The feldspar appears to be converted partly into alum. In the mean time the boulders and angular fragments brought down the ravines and river by floods are being cemented into a firm conglomerate; so that it is difficult to dislodge even a small pebble, the pebble itself breaking before the conglomerate yields.

"The thermal action on wood in this place is also highly interesting. In one mound I discovered the stump of a large tree silicified; in another, a log changed to lignite or brown coal. Other fragments appeared midway between petrifaction and carbonization. In this connection, finding some drops of a very dense fluid, and also highly refractive, I was led to believe that pure carbon might, under such circumstances, crystallize and form the diamond. Unfortunately for me, however, I lost the precious drop in attempting to secure it.

"A green tree cut down and obliquely inserted in one of the conical mounds, was so changed in thirtysix hours that its species would not have been recognised except from the portion projecting outside, around which beautiful crystals of sulphur had already formed."

According to the statement of MacDonald, our 
guide, who had made several visits to the geysers, their activity has greatly diminished, or we saw them under less favorable auspices than usual. He said that when last here the water spouted up from five to ten feet in height; that the jets of steam were much larger and more steady; and furthermore, that a day often exhibited a material difference. That the action has lessened, and nearly ceased, is certain as respects the first one we visited; for it now appears like an expiring fire.

When Professor Shepherd visited this place, a year before us, he says that within the space of half a mile square he "discovered from one to two hundred openings, through which the steam issued with violence, sending up columns of steam to the height of one hundred and fifty to two hundred feet," * * * and again, "throwing out jets or volumes of hot scalding water some twenty or thirty feet, endangering the lives of those who stood near. In some places the steam and water came in contact, so as to produce a constant jet d'eau, or spouting fountain, with a dense cloud above the spray, affording vivid prismatic hues in the sunshine." With such jets of water and steam as these, the grandeur of this extraordinary spot would be greatly enhanced.

Our dinner was soon ready, and we seated ourselves on the grass again, with appetites sharpened by a long fast and a laborious tramp of nearly ten hours. Sticks of the same delicious bear's meat, and renison were placed before us, with a second course, on smaller sticks, of some fine grouse which MacDonald had shot. This was a bird I had not before seen. It was larger than the ordinary prairie fowl, and proved 
delicious eating. A bath followed our repast, after which we rolled ourselves up in our blankets and lay down for the night. The novelties of the day occupied our attention for an hour, when we quietly dropped off, and slept as soundly under the protection of the spreading oak as beneath a tent or in the most luxurious chamber. These were the first nights I spent in the open air, on the bare ground, since I was taken sick near Ures; and I felt a little uneasiness at being so exposed. But I neither took cold nor suffered any other inconvenience from it, although in the month of March. One soon becomes habituated to this mode of life, and is less liable to colds and illness than when sleeping under a roof with the addition of comfortable fires.

I learned from the hunters who were with us the first night that this region abounds in game, particularly bears, elk, and deer. They had been here but three days before our arrival, and in that time they had seen no less than thirty-two bears, most of them of the grizzly species; the others of the brown and black varieties. Of these they had killed and obtained two; three they had wounded and lost. Of deer they had also killed many. The bear's sense of smelling is so good, that they soon found out our proximity, and gave us a wide berth. Deer were seen all around us.

March 24th. Our excellent guide and hunter, MacDonald, called us to breakfast at daylight; soon after taking which we mounted our animals and began the ascent of the mountain, whose summit we speedily attained. On looking at the valley beyond, we found it completely buried in a fog, the tops of the mountains alone being visible. These appeared like islands 
and long necks of land in the midst of a vast body of water. While we were on the crest of the high range, a dense fog so completely enveloped us that we could see nothing but the point on which we stood. We made our way back much more rapidly than we came, it being earlier in the day and much cooler; so that by twelve o'clock we were at MacDonald's place, where we dined and allowed our animals to feed and rest.

At half-past two we bade farewell to our kind and hospitable hosts, Mr. and Mrs. MacDonald, and resumed our journey. Stopped for fifteen minutes at Mr. Knight's, when we again pushed on, and reached Mr. Kilburn's at sunset. This gentleman was now at home, and gave us a warm reception. We learned many particulars from him corroborating the statements we had heard of the extraordinary fertility of the soil. in Napa Valley, as well as the great yield of vegetables on his own land, of which I have before spoken.

March 25th. Took an early start, first making inquiries of Mr. Kilburn about the locality of some hills of "black flint" which we had heard of. We had occasionally picked up along the road small pieces of obsidian, and were extremely desirous to find whence they came. After many inquiries we were directed to the farm of Mr. Kelly, who has a small mill on Napa Creek, a short distance from the road. We found Mr. Kelly at home; and on making known our wishes to examine the place referred to, he took a spade and accompanied us to the spot, about half a mile distant, on the eastern side of the valley. We found it to be a spur of the mountain ridge, about eighty feet in voL. II. -4 
height, projecting quite out into the plain. The whole seemerl full of obsidian, covered with a layer of earth, on which is a thick growth of trees and shrubbery, save on the summit, where there is less soil. Here in many places the surface was covered, from six to twelve inches in depth, with broken pieces and small boulders of this volcanic substance, resembling a newly made macadamized road.

Taking the spade, I scraped away the fragments and loose pieces to reach the mass below. This we found existing in a conglomerate state. The mass in which the obsidian is imbedded is quite soft and friable towards the surface; so that it was difficult to detach it with the obsidian adhering to it, except in very small pieces. The largest of the specimens obtained was about the size and shape of an ostrich's egg, from which they diminished to that of a pea. Many presented sharp angles, where they had come in contact and been broken. The substance in which the obsidian is imbedded resembles a coarse mortar of lime, sand, and gravel. I took a sketch of Napa Valley from these hills, showing Mount Diabolo in the distance, which is plainly seen from San Francisco and Sacramento.

Obsidian is used by the Indians for their arrowheads in all parts of North America west of the Rocky Mountains. It is found too among many tribes to the east of this range. The ancient Mexicans made of it the knives which they used in their sacrifices. We found small fragments of it along the Gila, wherever there had been any Indian villages; and also among the ruins of the Casas Grandes, in Chihuahua, 


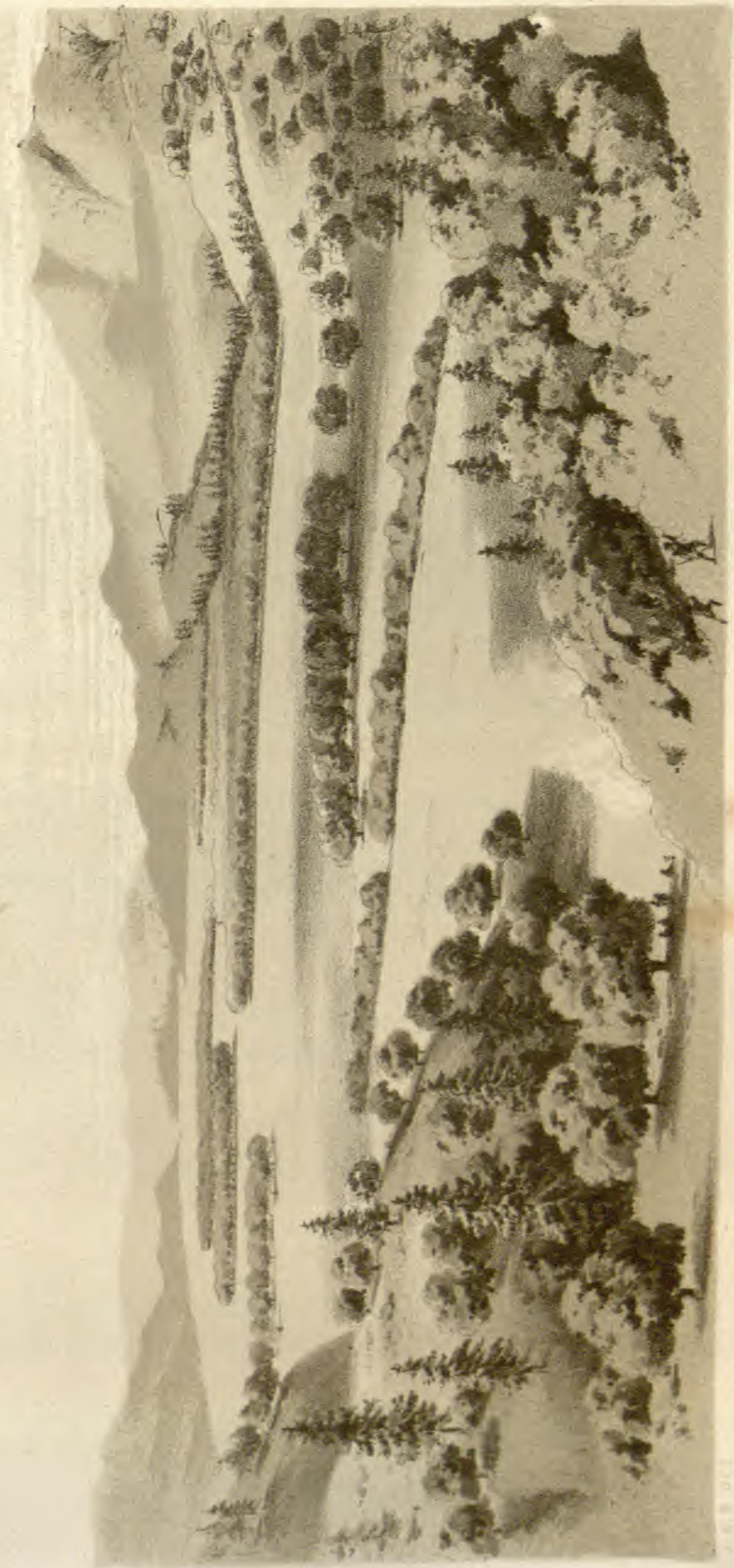



as well as those of the Gila and Salinas Rivers. The Apaches had arrows pointed with the same material. Yet I know of no other locality where obsidian is found in place in any of the regions visited by the Boundary Commission except this. All the specimens we saw were black, occasionally with a smoky or brownish tint.*

We now continued our journey, and reached Mr. Osborne's at two o'clock. After dinner we rambled over the adjacent hills to obtain a better view of this delightful valley, which -lost none of its beauties from whatever point it was observed.

On the opposite side of the mountains which bound Napa Valley on the west, is Sonoma Valley. This is similarly situated, running north and south between ranges of low mountains. It likewise possesses great fertility, but has not the picturesque beauty of Napa. The same may be said of the valleys of Petaluma, Novato, and San Rafael.

March 26th. Took an early breakfast and bade adieu to our kind and gentlemanly host, who intended to follow us in a few hours. We did not wait for him, as he wished to stop on the way, and I was desirous to pay my respects to General Hitchcock and the other officers at Benicia before returning to San Francisco.

* Obsidian is said by Pliny (Nat. Hist. xxxvi. 26) to have been first found in Ethiopia by a person named Obsidius, from whom it derives its name. It occurs also in various parts of Europe, Asia, and America, and in the vicinity of most voleanoes. Pliny says that gems, and sometimes whole statues, were made of it. He also speaks of four elephants of obsidian, which were dedicated by Augustus in the temple of Concord. 
As it was quite cool, we were enabled to ride fast and reach Benicia by two o'clock. Took dinner, and afterwards walked out to the military post, when I made my calls upon the officers there. Mr. Osborne joined us at five o'clock, and at seven we took the steamboat for San Francisco, whęre we arrived at nine. 


\section{CHAPTER XXIV.}

\section{THE QUICKSILVER MINES OF NEW ALMADEN.}

Leave San Francisco-San José Valley-Fertility of the soil-Mission of Santa Clara-San José-New Almaden-Quicksilver mine-Mode of extracting the ore-Large tanks of quicksilver-Account of the quicksilver mines of Spain-Production of this metal in all parts of the world-Situation of the New Almaden mine-Descent into it-How worked-Laborers-Extent of the mine-Effect of the mercury on laborers-History of the mine-Return to San Francisco-Captain Sutter-His history.

I REMained in San Francisco until the $2 d$ of April, to close up my business there before returning to San Diego. To make the most of my time while in California, I determined to undertake the journey to Monterey by land, first sending forward our outfit and supplies.

No event of interest happened while here except a trip which, in company with a small party, we attempted to make in the steamer Active, Capt. Alden, attached to the U. S. Coast Survey, to the Faralones. These are some small rocky islands, which lie twentyfive or thirty miles off the entrance to the Bay of San Francisco. The party, however, were so late in assembling, that after getting outside the entrance or Golden Gate, it was found we could not reach the 
islands before nightfall ; in consequence of which the voyage was abandoned.

April 2d. Left San Francisco at 8 o'clock in the stage for San José, forty miles distant. We were accompanied by Doctor A. Randall, a gentleman of science long resident in the country, and familiar with its localities of interest. Our course was south through the San José valley, which in many respects resembles the beautiful valley of Napa. It is entirely flat, with scarcely an undulation. Like the former, it is filled in many places with large wide-spreading oaks. There are also spaces for miles destitute of trees or shrubs, resembling the broad grassy plains of lower Texas; while again appear beautiful groves and clusters of oaks, cypresses, and sycamores, as picturesquely disposed as if planted by the hand of a skilful landscape gardener. The soil is rich, and was covered with a luxuriant growth of wild clover and grass. This valley extends for more than a hundred miles towards Monterey, being separated from the coast by a range of low mountains. Its width for a long distance after leaving San Francisco is not less than fifteen miles, though it diminishes as we approach San José. Yet this entire valley has all been taken up, and covered with claims upon claims; so that for many years to come the lawyers will doubtless derive the largest income from it. As yet there are few settlers upon it, and but little land under cultivation. When we take into consideration the extraordinary fertility of the soil in California, it will be seen that such an immense tract as this San José valley is capable of producing a vast deal towards supplying the State with food. Its 


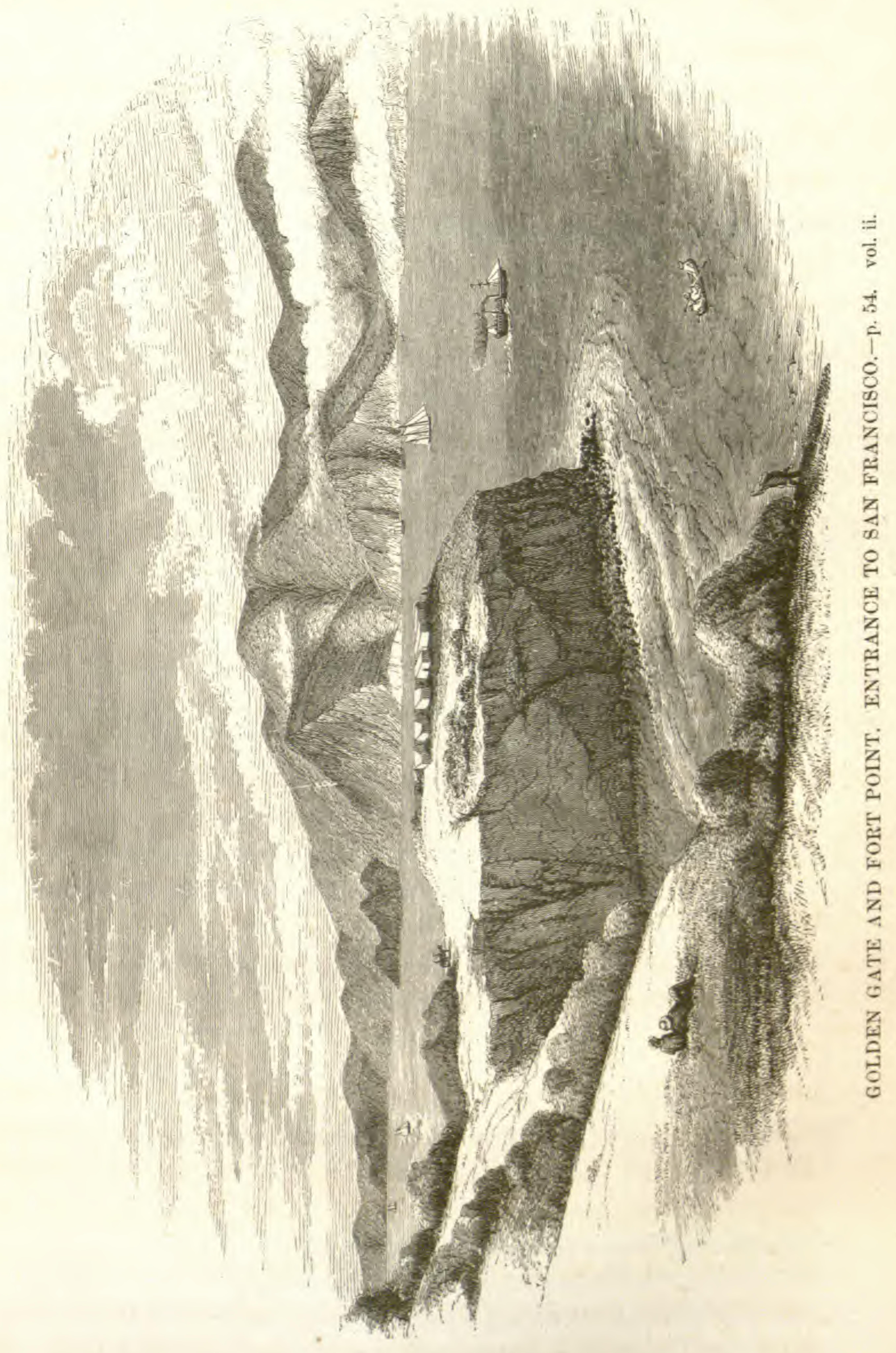



value is justly appreciated by the people; as is shown by the readiness with which the stock for a railroad to connect San José with San Francisco was taken up.

The road is excellent for the entire distance, and the stage rolled rapidly over it. Three miles from San Jose we passed the mission of Santa Clara, a collection of old buildings with a church. Here the land seemed to have been long under cultivation, judging from the long rows of venerable and gigantic overgrown oaks which border the road. There were also some fine large orchards and vineyards here, which belong to the mission. But the stage did not stop; and we had no time to examine it. At half-past four, we reached San José.*

* I cannot refrain from quoting a passage-from Vancouver, one of the most reliable of the early voyagers to California, giving an account of his journey from Mọnterey to Santa Clara. The reader will be struck with the resemblance between this district as described by him and the beautiful valley I visited north of San Francisco.

"We considered our route to be parallel to the sea-coast; between which and our path, the ridge of mountains extended to the south-eastward; and as we advanced, their sides and summits exhibited a high degree of luxuriant fertility, interspersed with copses of various forms and magnitude, and verdant open spaces enriched with stately fruittrees of different descriptions. About noon we arrived at a very pleasant and enchanting lawn, situated amidst a grove of trees at the foot of a small hill, by which flowed a very fine stream of excellent water. We had not proceeded far from this delightful spot, when we entered a country I little expected to find in these regions. For about twenty miles, it could only be compared to a park which had originally been planted with the true old English oak; the underwood that had probably attained its early growth, had the appearance of having been cleared away, and had left the stately lords of the forest in complete possession of the soil, which was covered with luxuriant herbage, and beauti- 
Santa Clara was but recently occupied by a priest; it has now shared the fate of all the other missions of the State, which have either been abandoned or have fallen into the hands of speculators.

April 3d. After breakfast, walked about the town, but found nothing of interest. The pueblo of San José, is an old place; its admirable situation, at the head of the rich and beautiful valley I have described, attracted the attention of the Americans soon after the subjugation of the country, and it was selected as the capitol of the State. This gave to it an impetus, and brought it at once into notice. Many hotels and other buildings soon sprang up, a large city was laid out, and, as is usual in such cases, much money was made and lost. Butits growth wąs as suddenly checked by the subsequent selection of another place for the future capitol. It is situated about five miles from the southern extremity of the Bay of San Francisco; and being in the centre of one of the most fertile districts in the State, it will yet become its first agricultural town.

On inquiring for Indians here, I learnt that there was a woman of the San Luis Obispo tribe, living in the place. I lost no time in calling upon her, and found she was married to an American. She proved, as I had heard, to be quite an intelligent person, about 35 years of age, living in a comfortable house with her family around her. On my requesting to know the principal

fully diversified with pleasing eminences and valleys; which, with the lofty range of mountains that bounded the prospect, required only to be adorned with the neat habitations of an industrious people, to produce a scene not inferior to the most studied effect of taste in the disposal of grounds."-Vancouver's Voyages, vol. ii. p. 16. 
words of her language, she readily complied; and in a few hours, I obtained a most satisfactory vocabulary.

In the afternoon, we took the stage for New Almaden, thirteen miles distant. Our route lay through a valley. of anequalled beauty, the entire distance being dotted with large oaks and sycamores, with an occasional clump of firs and red-woods, the latter towering high above all others. There are some clusters of these redwoods of enormous size between here and Monterey, of which we heard much, and regretted that we had no time to visit them. On reaching the town, I drove at once to the house of Mr. Young, the superintendent of the quicksilver mines, to whom I had a letter of introduction from Captain Hallock, U. S. A. of San Francisco, one of the officers of the Company.

April 4th. New Almaden consists exclusively of the buildings belonging to the company which owns the quicksilver mine. It embraces furnaces, storehouses, dwelling-houses for the officers and laborers, offices, mechanics' shops, \&c. Many of them are of wood; but a large and fine range of substantial brick buildings is now in the process of erection, to take the place of the wooden ones. The novelty of the business of extracting the quicksilver from the cinnabar, required a number of experiments, involving a very heavy expenditure; for there was but one other mine in the world, that of Almaden in Spain, where the operation was carried on on a large scale, and it could not be expected that a rival company like this, whose operations would effectually destroy the monopoly the latter had for ages enjoyed, would be permitted to derive any information from their long experience. Machine- 
ry of various kinds was thereforre imported from England and the United States at enormous cost, much of which has since been rejected, either on account of the great expense of running it, or its inadequacy to perform the service required. Six furnaces are now in operation reducing the ore, all of which seem to be alike, and of the most simple construction. On these furnaces the ore is heaped. A steady, though not very strong fire, is then applied. As the ore becomes heated, the quicksilver is sublimed; and then being condensed, it falls by its own weight, and is conducted by pipes which lead along the bottom of the furnace to small pots or reservoirs imbedded in the earth, each containing from one to two gallons of the ore. The furnaces are kept going night and day, while large drops or minute streams of the pure metal are constantly trickling down into the receptacles. From these it is carried to the store-house, and deposited in large castiron tanks or vats. These are of various shapes and sizes, and are fixed in solid beds of stone and mortar. The largest, a square vat between four and five feet across, contained twenty tons of pure quicksilver. By way of illustrating the great specific gravity of this metal, a board was placed on it, upon which I sat, thus floating upon a bed of quicksilver; yet my weight did not sink the board to the depth of a quarter of an inch. On thrusting my bare arm into this vat, a most singular and chilling sensation was produced. I then took a stick of light and porous wood, which I immersed for about a minute; and when I withdrew it, the metal had penetrated through every portion of it, so that in weight it was little less than the quicksilver itself. 


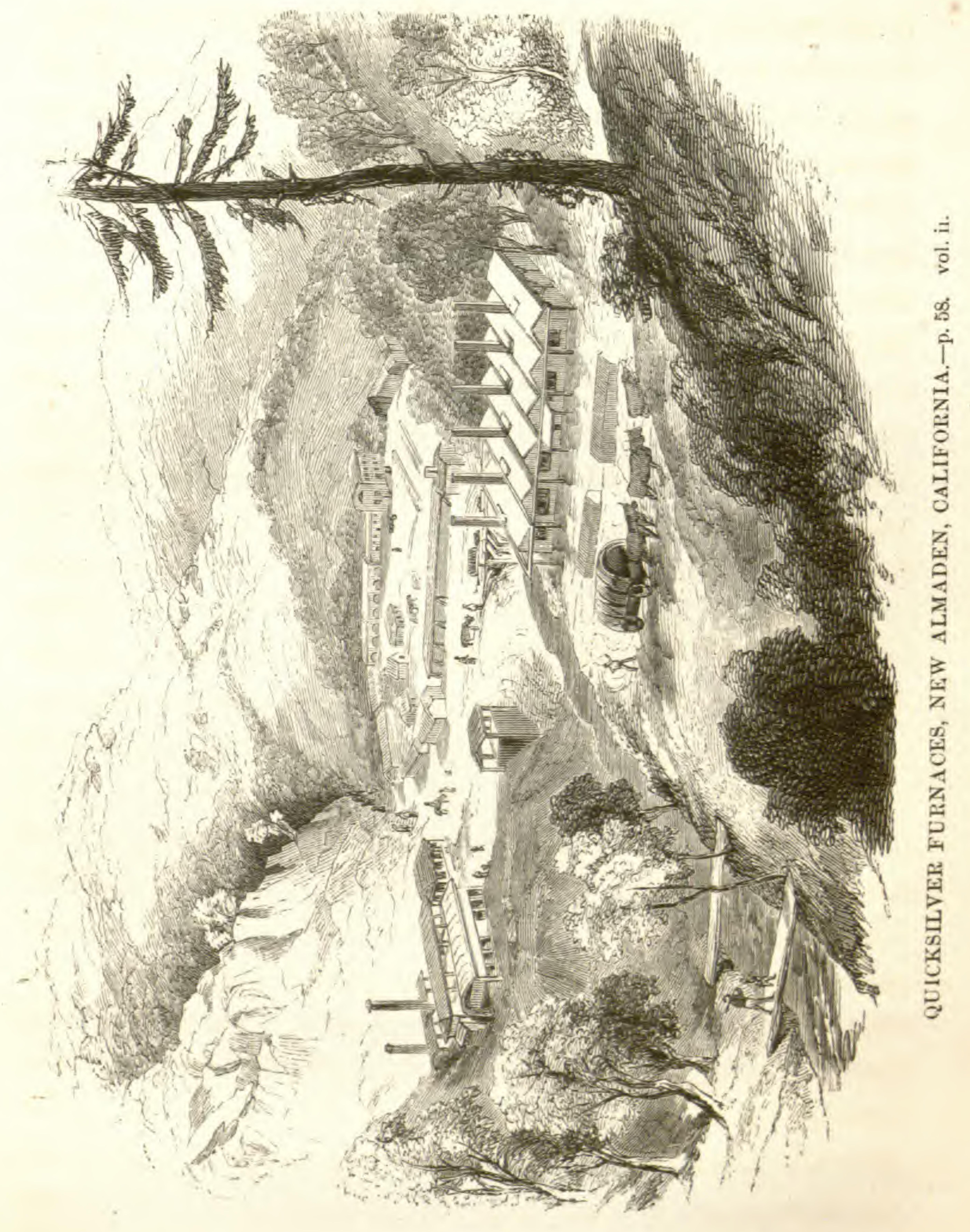



In the warehouse the metal is prepared for market. This is done by putting it into wrought iron flasks or canisters 'holding 75 pounds each. It is dipped up with ladles, and poured into the flasks through an ordinary tin funnel. The opening or neck of the flask (which in form is something like a junk bottle) is then stopped with a close-fitting screw, put in with a vice, so as to make it tight as possible. These flasks, which weigh twenty-five pounds each, are all made in England, where I suppose they can be furnished much cheaper than in the United States. From the warehouse the flasks are transported by ox-carts to tidewater, about twenty miles distant, whence they are shipped to San Francisco. The present (1852) price of the metal there is sixty cents a pound, a very great reduction from that which the quicksilver from Spain has commanded, though of equal quality. A shipment of a thousand flasks was lately made to Canton, by way of an experiment. In China it is chiefly used in the manufacture of vermilion and other articles of commerce.*

* As this is the only quicksilver mine yet known in the United States, and is only second in the world to that of Almaden, in Spain, a few words on the latter, and of other quicksilver mines, do not seem inappropriate.

Quicksilver, or mercury, has been known from the earliest ages, but is found nowhere in large quantities, except in Spain and California: Almaden has long been famed for its mines of this metal, which, according to Bowles, are the richest in their produce, the most instructive as to the mode of working them, the most curious for their natural history, and the most ancient in the world. We find them mentioned in Theophrastus, three hundred years before Christ, and Vitruvius also speaks of them. Pliny places Cisapona, or as it is sometimes written Sisapona, 
I did not learn what quantity was produced at the time of my visit here, but have since seen it stated to be about one thousand flasks per month, or nearly a million pounds a year. According to Dumas, the an-

in Bætica, and says that this mine was kept sealed with the greatest care, and was only opened to take the quantity of cinnabar necessary for the consumption of Rome. (Nat. Hist. xxxiii. 7.) The Romans considered this mineral poisonous; but notwithstanding this, their matrons painted their faces with it, and their painters employed it as a pigment. The Romans certainly worked this mine, but no traces remain of their labors. The Moors, perhaps owing to some prejudice, did not work it.

"The country about Almaden abounds in iron mines; and what is more surprising, in the same mine we find iron, mercury, and sulphur, mixed so as to form one mass. The neighboring hills are found of the same stone, and on all of them the same species of plants grow; from which we may infer that the mercury does not possess any poisonous qualities, as is generally supposed, injurious to vegetation.

"The brothers Mark and Christopher Fugger, of Germany, undertook to work this mine, and contracted to give the government four thousand five hundred quintals (of $100 \mathrm{lbs}$. each) of mercury, annually; but not being able to fulfil their promise, they abandoned it in 1635 , together with the silver mine of Gualcanal, which they also had. While connected with these mines, however, their riches became proverbial in Spain, and their descendants live at present in Germany, with the rank of princes. A branch of this family afterwards took the mine, and worked it till 1645. In the following year, the government undertook the management of it. Don Juan Bustamente established the furnaces, and also troughs for cooling the mineral. These furnaces are twelve, and are called by the names of the twelve apostles. Each is capable of containing ten tons weight of stone. The furnace is kept burning for three days, and the same period is required for cooling."-Introduction á la Geografica Fisica y la Historia Natural de España.

The other quicksilver mines worthy of notice, are one at Huancavelica, in Peru; at Idria in Carniola; in Hungary, Transylvania, and the district of Deux Ponts in Germany. There is a mine of cinnabar near Alicante, and another not far from San Felipe in Spain. Mercury has 
nual product of the Spanish mine at Almaden is about three millions of pounds.

April 4th. After breakfast we set out on foot for the mine, which is situated near the top of a mountain immediately adjoining the works. The ascent begins directly in the rear of the store-houses, by a well con-

also been found in China and Japan: and though the amount of the produce is unknown, it is believed to be considerable.

Le Play, a French geologist, who visited Almaden in 1833, describes the mines as being richer than at any former period, furnishing anually nearly $2,244,000$ pounds of mercury. About seven hundred workmen are employed under ground, and two hundred in the operations connected with extraction of the metal from the ore at the surface.

According to Dumas, the following mines yield annually, the annexed number of quintals of mercury (a quintal is 108 lbs. avoirdupois, nearly) :

$\begin{array}{lrrr}\text { Almaden (Spain) } & 25,000 & \text { to } & 32,000 . \\ \text { Idria } & 6,000 & \text { " } & 10,000 . \\ \text { Hungary } & & & \\ \begin{array}{l}\text { Transylvania } \\ \text { Deux Ponts }\end{array} & 700 & \text { " } & 900 . \\ \text { Palatinate } & 400 & \text { " } & 500 . \\ \text { Huancavelica } & 180 & \text { " } & 200 . \\ & 3,000 & \text { " } & 3,000 .\end{array}$

At present, it is understood that Messrs. Rothschild, of London, have the control of the Almaden mines.

During the year 1853, the total exports of quicksilver from San Francisco, amounted to 18,800 flasks, valued at $\$ 683,189$. All this, together with the large amount used in California, was the produet of the New Almaden mine. The following shows to what points the quicksilver was exported: "Hongkong, 5,642 flasks, valued at $\$ 180,272$; Shanghae, 812 , $\$ 31,199$; Canton, $366, \$ 14,125$; Whampoa, 300 , $\$ 11,500$; Calcutta, 50, $\$ 1,875$; Mazatlan, 2,811, $\$ 96,250$; Mazatlan and San Blas, $255, \$ 10,000$; San Blas, $1,942, \$ 72,463$; Callao, $1,800, \$ 66,500$; Valparaiso, 1,977, \$71,875; New-York, 1,845, \$77,180 ; Philadelphia, $1,000, \$ 50,000$." 
structed road of gradual and easy ascent, which the Company has been engaged in making for the last six months. It is a mile in length, and is now only used by mules; but it is intended to use carts and wagons on it. It winds the whole way along the side of the mountain, rising twenty-five feet in every hundred until you reach the mouth of the mine, at an elevation of a little less than one thousand feet above the commencement of the ascent.

About one hundred and fifty feet, in a direct line below the opening, they were digging a tunnel for the purpose of intersecting the main shaft. This tunnel, which is cut entirely through the solid rock, had already pierced the mountain seven or eight hundred feet, and will, when completed, be not much short of one thousand feet. It is about eight feet high, and between eight and ten feet wide. This will prove a vast saving in labor; for the ore up to the time of our visit was transported on the backs of men in leather sacks from the bottom of the shafts to the entrance to the mine, a distance of from two hundred and fifty to three hundred feet. It is not the cinnabar alone that has to be thus carried from the bottom of the mine, but the refuse rock, which forms a greater bulk than the ore itself. It cannot be separated in the mine, but has all to be brought to the surface.

We waited for Mr. Bester, the engineer, to join us before entering the mine; and as he had not returned from San José, where we left him, we determined to forego the examination of its interior to-day, and content ourselves with what we could see on the surface. 


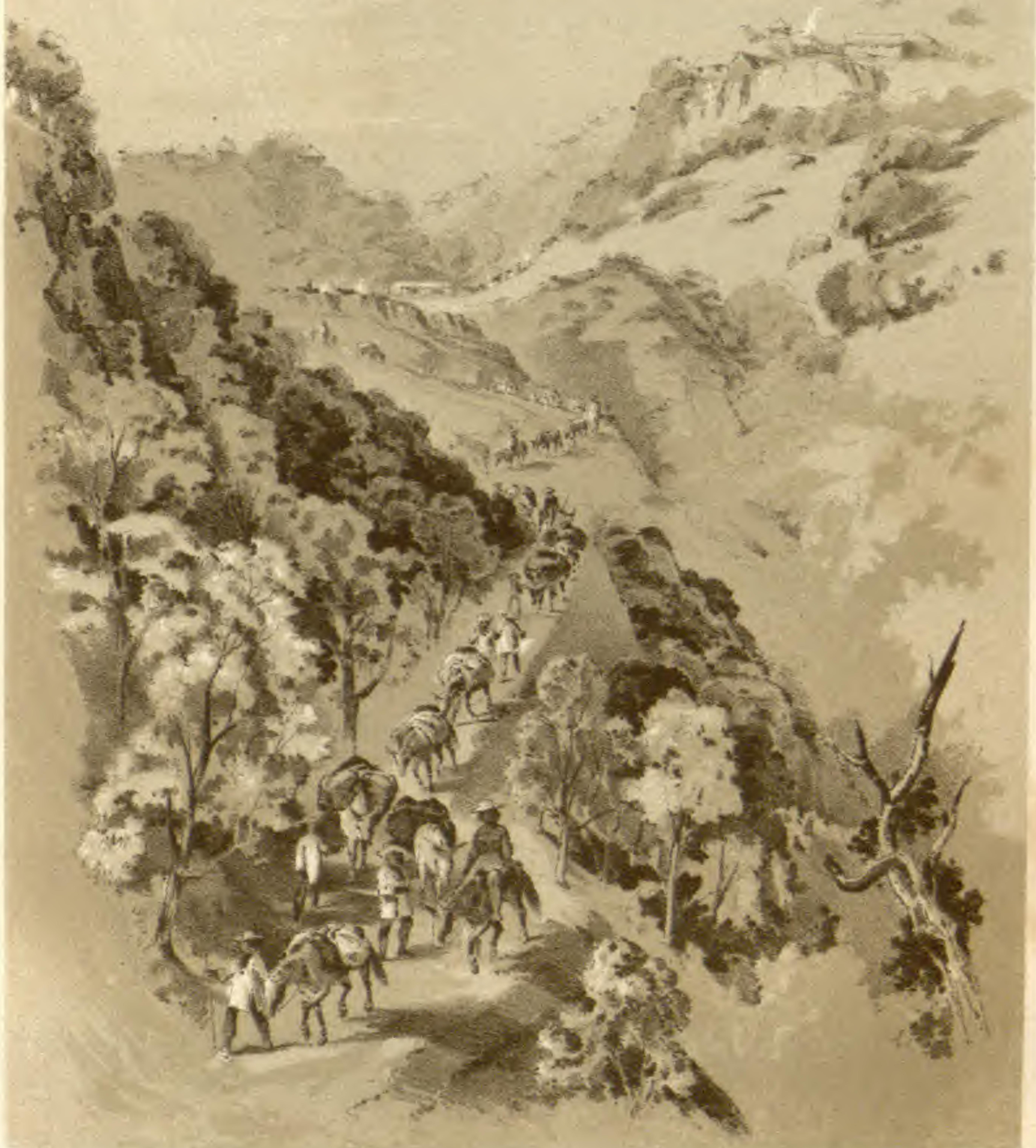

QQUICKSILVEA MINE. NEW ALIGABEN 

The mountain rises one hundred and sixty feet above the entrance to the mine, terminating in a cone. On a level with the entrance, a quarter of a mile distant, is the village, perched on the very summit of a rock, in which the miners live with their families. This mountain, as well as the others adjoining it, is covered with grass, and dotted with small oaks to its summit. There is nothing to distinguish the mountain in which the mine is worked from the others; hence it is reasonable to suppose that they may also contain veins of cinnabar. The intervening valleys are well wooded, and have a thick undergrowth.

April 5th. Set out this morning for the mine, accompanied.by Mr. Bester, on mules, as the journey up was fatiguing, and we wished to preserve our strength for the exploration of the various shafts. On reaching the entrance, we found all actively employed;the laborers emerging every minute from the mines, bent under the weight of their loads, which they deposited under a shed about eighty feet from the opening. Here the ore was separated, the refuse being thrown down the hill, and the rest laid aside to be sent to the furnaces. At the same time the mulada, or collection of some eighty or a hundred mules, was being loaded with the ore. This was put into sacks or panniers of raw hide, which hung across their backs like saddle-bags, each mule carrying on an average a carga, or three hundred pounds. Men stood by with a balance, in which every mule load was weighed, so that the exact quantity of ore sent to the furnaces is known. The weighing is also necessary; as the company pays so much a carga for bringing it 
from the bottom to the surface, and for transporting it from the mine to the furnaces. This plan is preferred by the proprietors to that of employing the laborers directly themselves. The work is wholly performed by native Mexicans or Californians, the overseers and contractors who employ them being their countrymen, though of a better class. These men understand the management of their countrymen better than Americans do; and the Mexican laborers are better arrieros, and understand all that appertains to the mule better than Americans.

The laborers wore no clothing, save a breechcloth, and a handkerchief around their heads. The arrieros had on but little more; a fancy colored calico shirt being the extent of their additional costume. The laborers who bring up the ore to the surface make from forty to fifty trips a day. The mules make but two journeys from the mine to the furnaces, completing their day's labor by one o'clock. They are then turned out to feed in the valley or on the mountain side, where the grass is good. With so little labor, they are always in fine condition. About two hundred men are employed in the various operations carried on here.

After being provided with torches, consisting of a candle fastened to the end of a stick, we commenced the descent of the mine, Mr. Bester, the engineer, taking the lead. We first advanced some sixty feet in a horizontal direction, after which the shaft takes a turn downwards, and soon after becomes perpendicular. In such places the descent is made on a single notched $\log$, which is preferred by the miners to the 
common ladder; and although very awkward at first, we soon got used to it. With one hand you take hold of the ladder, and with the other the torch. These ladders, although almost perpendicular, are seldom more than twelve or fifteen feet long, being separated by intervals, where the descent is more gradual, with steps cut in the rock. In this way we passed down through various shafts or veins to the bottom of the mine, two hundred feet below the entrance. Passages following the veins of ore extend in every direction, sometimes horizontal, then perpendicular, and again at every inclination. Their whole extent now exceeds seven thousand feet. When a vein is struck, it is followed as far as it can be with safety, whatever may be its course. The engineer, who keeps before him a map of the mine, is obliged to have an eye to the support of the superincumbent mass. Some of the veins are five feet in diameter, others half that size. Some are also richer than others.

In each of the veins is a single miner; for not more than one can work to advantage in these narrow recesses. Picks, drills, and crowbars are the tools used. The miners are paid in different ways; some at a stipulated price for each foot of the rock excavated, and others at a certain rate per carga (three hundred pounds) of ore carried to the surface. On reaching the greatest depth, where the ore is very rich, I took a pick and knocked off some fine specimens. We now retraced our steps, and reached the open air in safety.

It is an evidence of the admirable system pursued here, and the watchful care exercised by the company over their employees, that no accident has yet happened voL. II. -5 
to any miner or carrier engaged in these subterranean labors. The workmen, nevertheless, are not without their fears, and have taken their own method to secure themselves from harm, by placing in a niche just within the entrance to the mine, an image of their saint, very prettily decorated with muslin and gaudy silks. Before this every man falls on his knees, and says his

- prayers, invoking the protection of the saint during the day. I have never seen a more happy and contented set of laborers than these.

Knowing the effects of mercury on the system, the question will naturally arise in the mind of the reader as to whether those employed in the mine or about the furnaces suffer from their close contact with the ore or the quicksilver. The miners, and those who merely handle the cinnabar, are not injured thereby; but those who work about the furnaces, and inhale the fumes of the metal, are seriously affected. Salivation is common; and the attendants on the furnaces are compelled to desist from their labor every three or four weeks, when a fresh set of hands is put on. The horses and mules are also salivated; and from twenty to thirty of them die every year from the effects of the mercury.

The ore, after it is deposited near the furnaces, is separated according to its quality. The larger masses are first broken up, and then all is piled up under sheds near the furnace doors. Seven or eight days are required to fill the furnaces, extract the quicksilver, and remove the residuum, the latter being the most dangerous part of the process. All is done as much in the open air as possible, the furnaces being merely protected by a roof. 
I took several sketches of the village of New Almaden, as well as of the exterior of the mine, and the picturesque scenery in the vicinity. The company possess a large tract of land here, including mountain, hill, and valley. Much of it is well timbered. A fine stream of water runs directly through the village; and on its very margin is a natural soda spring, which may yet make this spot doubly attractive.

This mine was long known to the Indians, who resorted hither for the vermillion which they could collect from the cinnabar. They had dug some thirty or forty feet into the mountain; but it does not appear ever to have been worked by the Spaniards. In recent times, its commercial value was first discovered by Señor Castillero, who became its legal owner. Don José Castro, who subsequently became proprietor of it, sold out his interest to Barron \& Forbes, an English house doing business in Mexico. Another partner is Mr. Walkinshaw, an English gentleman long resident in Mexico, and well skilled in mining. This gentleman now resides about a mile from New Almaden, on one of the natural parks which I have before described, and which he is rendering still more beautiful by the introduction of fruit-trees, vines, flowering shrubs, etc. To this gentleman, to Mr. Young, the superintendent, and $\mathrm{Mr}$. Bester, the engineer, I feel under many obligations for the civilities extended to me and the gentlemen who were with me, in our visit to New Almaden and its mine. After a sumptuous dinner, we took the stage and returned to San José.

April 6th. 'In coming to San José, I had the double object in view of visiting the quicksilver mine, and of 
continuing on by land to Monterey; but I here learned that it would be impossible to proceed further by land, as the heavy rains and freshets a few weeks before, had carried away the bridges, and rendered the streams impassable, except by swimming the horses. This I did not feel disposed to do: so the only alternative was to return to San Francisco, and go to San Diego by water. We accordingly took the stage at 8 o'clock, with twenty-one passengers inside and out; and reached San Francisco at 4 o'clock in the afternoon.

I remained in San Francisco six days, waiting for a steamer to San Diego; and during this time I had the pleasure of meeting with Captain Sutter, whose name is well known to all who have heard or read of the recent history of California. The history of his early adventures has been on several occasions presented to the public by letter-writers; so that it will be superfluous at this time to relate them, excepting the following anecdote, which I have not seen in print.

"While in Oregon, whither he had come from the United States, Captain Sutter met with a party who gave such a glowing account of California and particularly of the valley of the Sacramento, that he determined to visit it, believing it to be precisely the rich country and salubrious climate of which he was in search. But to get there was not so easy, there being then no communication from Oregon by sea. He therefore shaped his course for the Sandwich Islands, and from thence to Mexico. At San Blas or Mazatlan, he found a vessel about sailing for Monterey; he embarked in her, and afterwards reached the Bay of San Francisco, nearly twelve months after leaving Oregon. But the country 
he was in search of was a perfect terra incognita even to the people who then composed the settlement at Yerba Buena; nor could he gain any information respecting the river which lea to it, or even as to where it entered the bay. His scheme of settling in the interior among the wild Indians, was considered a dangerous one, and efforts were made to dissuade him from it; but he had made up his mind to go, and accordingly got a small boat and set off with a few men to find the Sacramento River. They coasted along the bay in vain for several days, and were about to abandon their search, when one night as they were moving slowly along by moonlight, Captain Sutter himself discovered an opening which proved to be the mouth of that river. He passed up it, and selected the spot where he built his fort, and of which he afterwards obtained a grant from the Mexican government."

When we hear of the pioneers of the West, we imagine them to be such as our Daniel Boon, who led the life of a hunter, trapper, and Indian fighter, until his home was surrounded by settlers, when he again moved farther off, desiring always to be beyond the pale of civilization. Captain Sutter was not of this class; although he has had his share in fighting the battles of Europe, as well as encountering the Indian on the prairie. He has the manners of an intelligent and courteous gentleman, accustomed to move in polished society. He speaks several languages with fluency. He is kind, hospitable, and generous to a fault; as very many Americans know who have lived on his bounty. Had he been permitted to retain his immense estate on the Sacramento, and dispose of it as wanted by actual set- 
tlers, he would have been one of the richest men in America; but speculators took advantage of his easy disposition, led him into wild speculations, induced him to lend his name to a large amount, and thus extorted from him or compelled him to give up all of his valuable property, but the Hock farm, where he now resides. He still seems cheerful, and endeavors to make the most of his misfortunes. When I saw him, he told me he had not visited San Francisco for a year.*

* Captain Sutter is a native of Switzerland, from 55 to 60 years of age, and of fine personal appearance. He was one of the officers of the Swiss Guard in the Revolution of July, during the reign of Charles X. After this he emigrated to the United States, became naturalized, and resided several years in Missouri. From thence he went overland to Oregon, and in 1839 reached California. He bought out the Russian establishment at Fort Ross and Bodega, when the Russians abandoned their settlement in California. His fort on the Sacramento was a large inclosure, five hundred feet in length by one hundred and fifty in breadth, where he had under his control a body of Indians, whom he employed in cultivating the soil. After obtaining his large grant from Mexico, that government made him military commander of the frontier. 


\section{CHAPTER XXV.}

\section{RETURN FROM SAN FRANCISCO TO SAN DIEGO.}

Leave San Francisco-Monterey-Its harbor-Society-Californian ladies -Father Juniper Serro's account of Menterey in 1770-Visit to the Mission of San Carlos at Carmel-Father Garces' visit in 1777-Leave Monterey-Point Conception-San Pedro-Visit to Los Angeles-Rich prairies-Large herds of cattle-Vineyards and wines-Indians of the Missions-Mission of San Gabriel-Return to San Pedro-Craw fishArrival at San Diego-Preparations for return to El Paso-Engage Mr. Leroux as guide-Trip to Los Coronados-Description of these islands-Sea Lions-Climate of San Diego-Visit to the Mission of San Luis Rey-Extensive buildings-Fine Valley-Kechi Indians-History of Father Peyri-Deseription of the harbor of San Diego-Viscaino's account of San Diego in 1602-Father Juniper Serro's account in 1769-Mission of San Diego-Picturesque situation-Fine lands-Olive trees-Society of San Diego-Initial Point and monument on the Pacific.

On the 14th of April I embarked in the steamer Ohio for Monterey, at which place I intended availing myself of a polite invitation given me by Captain Ottinger, of the United States revenue cutter Frolic, to take passage with him for San Diego, His duties required him to stop at the various ports between the two places, which would give me a better opportunity to see the country than by remaining on board the steamer. We went to sea at five P. M. with a large number of passengers, and, having but little wind, 
shot rapidly through the "Golden Gate." Outside it was so calm, that the broad surface of the Pacific resembled an ocean of glass.

April 15th. Reached Monterey at eleven, A. M., where I found Captain Ottinger with his beautiful little craft.

The coast between San Francisco and Monterey presents nothing but low sandy hills, covered with chapporal or scanty verdure. Large quantities of sand are blown up from the sea, and in many places overtop the vegetation.

On coming to this place from San Francisco, one is struck with its remarkable dulness; yet until the discovery of gold in the country, it was the chief place on the coast, and the capital of California. Many of its houses are now deserted, or in a dilapidated state, and the grass may be seen growing in its streets.

The town is prettily situated on a gentle slope of land, facing the north, about two miles from Point Pinos, which forms the southern extremity of the harbor or roadstead. The harbor is not a good one, being exposed to the prevailing north-westerly winds, and exhibiting a long beach, with as troublesome a surf as the open sea. From the southwesters it is well protected by Point Pinos. On the east is a succession of small hills, rising one above the other directly from the slope on which the town stands, and covered chiefly with pines. Behind, and immediately contiguous to these, rises the coast range of mountains. On the north, the bay makes a broad semi-circular sweep some fifteen or twenty miles distant, terminating at a point 


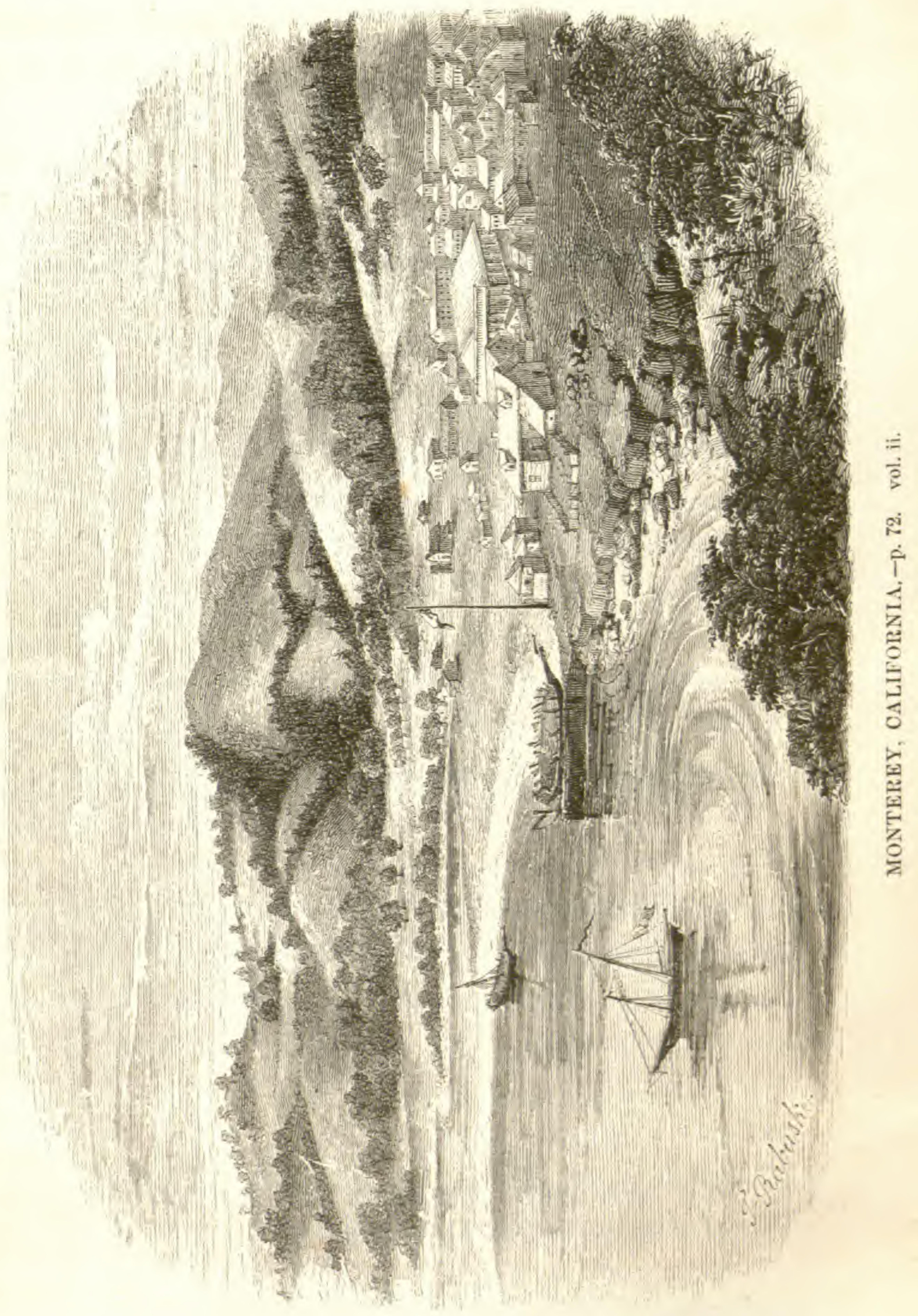



on the ocean opposite to, though far outside of, Point Pinos, and not visible from the town. The houses are of two classes; first, those of adobe, belonging to the old town. These are large and well built, many being of two stories, with projecting eaves to protect them from the sun. Those of wood are of recent erection, and have not the substantial appearance of the adobe buildings; these latter have very thick walls as a security from the earthquakes, which, though not severe, are quite common here. An old church stands alone upon the plain east of the town, which appeared to be in a ruinous condition. Beyond this is a lagoon, said to have been formerly connected with the bay, but now separated from it by a sandy beach, and a grassy meadow, about a quarter of a mile in width. The old presidio, or garrison, is on an elevation back of the town, towards Point Pinos, and is now occupied by United States troops.

Monterey has always been noted for its excellent society; and although the Americans have monopolized every other town in the State, it still preserves much of its original character. The old Californian or Castilian families are still in the ascendancy; but the young Americans and other foreigners are making terrible inroads upon them, and carrying off their fair daughters. Many officers of the United States army have married in California; and from what I heard, here and at other places, others intend following their example. The young señoritas certainly possess many attractions; and although shut up in this secluded. part of the world, without the advantages of a good education, or of intercourse with refined society, they 
need not fear a comparison with our own ladies. In deportment they are exceeding gentle and ladylike, with all the natural grace and dignity which belong to the Castilian nation. Their complexion is generally as fair as the Anglo-Saxon, particularly along the sea coast, with large black eyes and hair. In this respect they differ much from the Mexican ladies of the interior, who are generally brunettes. In form too they differ from their Mexican sisters. The latter are too often short and stout, while the Californian ladies are as slender and delicate in form as those of our Atlantic States. I was struck too with the elegance and purity of their language, which presented a marked contrast with the corrupt dialect spoken in Mexico.

The Californians as a people appear superior to the Mexicans, which may be attributed to two causes. Both countries, it is true, were colonized by the same race; but I think a superior class of men came to California, who have preserved their Castilian blood from all admixture with that of the aborigines. There were, doubtless, fewer of the poorer class too who came here, owing to the greater length and cost of the journey, and the increase by immigration has been trifling since. The original colonists possessed large tracts of lands, and have ever since continued in an isolated state, marrying among themselves, and enjoying a life of luxury and ease. The climate, unlike that of Mexico, is healthy and invigorating; while the humid atmosphere of the coast gives a fairness and brilliancy to the complexion unknown to the dry and burning plains of Mexico.

Although San Francisco will always rank first in 
the scale of Californian cities, by reason of its superior harbor and great commercial facilities, Monterey will become the residence of gentlemen of fortune, on account of its more genial climate and its distance from the noise and bustle of a great city. It will be to San Francisco what Newport is now to New York.

The following account of Monterey was written by the Reverend president of the California missions, F. Junipero Serra, to his biographer, Father Palou, in a letter announcing his arrival at this place. It appears that an expedition sent by land to Monterey failed to reach it, but found San Francisco; and that subsequently two other expeditions, one by land the other by water, were sent in search of it. In the latter of these was Father Junipero. He thus writes:*

"Long live Jesus, Mary, and Joseph!

"Reverend Father, Professor, and President, Fr. Francisco Palou:

"My dearest Friend and Sir:-On the 31st of May, by the favor of God, after a painful voyage of a month and a half, the packet San Antonio, commanded by Don Juan Peres, arrived and anchored in this horrible port of Monterey, which is the same, unaltered in appearance and condition, that it was when visited by the expedition of Don Sebastian Viscayno, in the year 1603. It gave me great satisfaction to learn that eight days previous the land expedition had arrived, and with it Father Juan, and that all were in good health. When the holy day of Pentecost arrived,

* Relacion Historica de la Vida y apostolicas Tareas del padre Fray Junipero Serra, por Fr. Francisco Palou, p. 101. Mexico, 1787. 
which was on the $3 \mathrm{~d}$ of June, the whole of the officers, naval as well as military, and all the people, assemibled together in a small ravine, where the Fathers caused an altar to be erected, and the bells to be rung. They then chanted the Veni Creator, blessed the water, erected and blessed a grand cross and the royal standards, and chanted the first mass that was ever performed in this place. We afterwards sung the Salve to our Lady, before an image of the most illustrious Virgin, which occupied the altar, and then I preached a sermon. We concluded the festival with a Te Deum. After this the officers took possession of the country in the name of our Lord the King, whom God preserve. We all dined together in a shady place on the beach; the whole ceremony being accompanied by many volleys and salutes, on the land as well as from the vessels. To God alone be the honor and glory!

"With regard to the former expedition, its not finding the port of which it was in search, and having asserted that it did not exist, I will express no opinion, and will not judge of their motives. It is enough to say, that it has been found, and the duty performed, although rather late. This I desire may be made known to the Visitor General, and to all those who feel an interest in this spiritual conquest.

"Mission of San Carlos de Monterey. June, the day of San Antonio Padua, 1770.

"I kiss your hands, etc.

"FR. JUNIPERO SERRA."

April 16th. This morning I got a horse and rode out to the Mission of San Carlos, on the river Carmel, 
four miles from Monterey. The ride was a. delightful one over gentle hills, and through valleys with beautiful grassy slopes, thickly wooded with pine, fir, and oak trees. The whole country about Monterey presents a most pleasing prospect to the eye, after seeing the parched and barren hills along the coast.

The Mission establishment, which consists of a church and the usual accompaniments of a large inclosure with ranges of small buildings, stands upon a little elevation between the hills and the sea, from which it is distant only a few hundred yards. The church which is built of stone, has two towers, containing six bells; its walls are very thick, with an arched roof, and supported by heavy buttresses. The towers, as usual, differ. The adobe buildings near, were all in a state of ruin, and tenantless; not a human being was to be seen near, while the rank grass and weeds which monopolized the ground, showed that even curiosity did not often tempt visitors to its deserted precincts. One corner of the church began to show the ravages of time: its cornice had fallen, and weeds had already taken root among its opening orevices. The remains of an orchard and vineyard, are still seen near, in a decaying state. Small pine trees cover the hills within a short distance of the church; and on its other side, the ocean rolls up its waves with a dull monotonous sound, which adds to the solitary feeling of the place.

Near by, the river Carmel, a diminutive stream, to which the appellation of brook would be more appropriate, emerges from a valley between two high ranges of grass-covered hills, and falls into the sea. Up this valley I noticed ploughed fields and ranchos; beyond. 
it higher mountains arise, completely shutting in the river on the East.

This Mission was for some time the residence of the Fathers Juniper Serra, and Francisco Palou, two of the most distinguished of the early Catholic missionaries in California. When Father P. Font arrived in Monterey, in 1777 , from Sonora, in Mexico, with a body of men to strengthen the Colony at that place, he says the "Father President, F. Junipero Serra, with four other priests, came from the mission of San Carlos to welcome us, and we chanted mass in thanksgiving for our safe arrival;" and it "was determined that we should go to the mission of Carmel, as there were no lodgings for us here." *. . He states that there were seven priests at the mission, that it was "an excellent spot, and the land very fertile."

April 17th. Set sail from Monterey in the U. S. revenue cutter Frolic, Captain Ottinger. The wind was ahead and light; so that by dark we were scarcely beyond Point Pinos, so named from the pines which grow upon it, and which distinguish it from the barren head-lands on the Californian coast.

April 18th. At sea. With a fresh breeze from the north-west, we scudded along finely. It is necessary to keep at a distance from the land, as there are no light-houses on the coast.

April 19th. Hailed the Pacific mail-steamer Northerner as she passed us, and put letters on board for the United States, as we should be too late for the mail at San Diego. Towards evening the winds died away,

* Manuscript Relation, in the possession of the author. 
leaving us within a quarter of a mile of Point Conception. This is a plateau extending a couple of miles beyond the coast range of mountains. Saw two or three ranchos, surrounded by clusters of trees, and large numbers of cattle grazing upon the declivities of the mountains and upon the plain, which, to judge from its brilliant green hue, was covered with rich grass. In the night, the wind came around from the north-east with a thick fog.

April 20th. The northern point of the island of Santa Rosa, bore south six miles. Light winds and calms during the day. At 2 P. M. the steamer Active, of the Coast Survey, passed us. At nine, saw a light ahead and pursued it for an hour or more, thinking the vessel it was in might prove a smuggler. Finally came up with and hailed her; when she was found to be a small craft bound to the islands in search of sea-lions, which abound there, and are taken for the oil they furnish.

April 21st. Light winds during the day, with fog and haze. Could discover no current. Reached San Pedro at 9 P. м., and came to anchor. The wind blew quite fresh from the north-west during the night.

April 22d. San Pedro is an open bay or roadstead, about fifteen miles across from the two points which bound it, and scarcely deserves the name of a harbor. It is exposed to the prevailing winds, and affords no protection save on the east and north. When caught with a southerly gale, vessels are obliged to stand across to the islands of Catalina, twelve miles distant, for safety. It is the Port of Los Angeles, twenty-nine miles distant, and contains but two houses. These are quite 
large, being used as warehouses for merchandise, as well as for dwellings. Vessels stop here for water, which has to be carted from a distance of three miles. Many also provide themselves here with beef, which is furnished at a less rate than at other places.

I was desirous to visit Los Angeles for the purpose of buying mules, which were scarce and high at San Diego. Soon after breakfast I went on shore with Captain Ottinger, and we both took the stage then about to start for Los Angeles. There were twelve passengers to go, who filled two ordinary lumber wagons, each drawn by four mules. On leaving the cøast, the road was somewhat hilly for a few miles. Passed several lagoons about three miles from San Pedro, in which were large numbers of ducks, plover, curlew, and snipe, embracing varieties which I had not before seen; on leaving these, we entered upon a broad plain, which extencied as far as the eye could reach, unbroken by hill or tree. This plain, the surface of which was slightly undulating, was covered with luxuriant grass and clover; and sometimes a patch of yellow mustard, growing to the height of five or six feet, filled a space of a mile or two. Flowers of brilliant hues were thickly scattered over the plain, giving it here and there a tingle of purple, orange, or yellow. In every direction, the eye fell upon large herds of cattle and horses luxuriating on the rich grass; so numerous were they, that at one time there could not have been less than ten thousand head in sight.

It was here that a skirmish took place between Commodore Stockton, or a party sent by him, and the Californians; but from what I could learn, it was little 
more than a running fight, in which no great harm was done by either party.

We reached "La Ciudad de los Angeles," the City of Angels, at 4 o'clock, and put up at the "Bella Union," a very indifferent hotel. At the rnost miserable tavern in the back woods, I have found better accommodations than at this place.

After dinner, I called at the office of the "Los Angeles Star," to obtain a file of the paper, which contains a series of articles on the Californian Indians. Mr. Rand, one of the editors, cheerfully complied with my request, and gave me the papers I desired. I also met Mr. Hayes here, a gentleman connected with the bar, who, with Mr. Rand, manifested much interest in the objects of my inquiry; and Mr. Hayes kindly offered to accompany me to the mission of San Gabriel, twelve miles distant, where resided Mr. Hugo Reid, the author of these papers. These gentlemen informed me that Mr. Reid was better acquainted with the Indians of that portion of the State than any other person. With the hope therefore of obtaining more information on this subject, I gladly accepted the proposal of Mr. Hayes; and we agreed to set off for the Mission as soon as horses could be procured.

After waiting two hours, the horses promised $\mathrm{Mr}$. Rand were still not forthcoming; we were therefore compelled to give up our ride this afternoon, and postpone it until morning. I regretted this, as I had intended to pass the evening at the Mission, and return in the morning in time to take the stage back to San Pedro. The horses were promised to be saddled and at the door by 5 o'clock in the morning.

voL. II -6 
Spent the hour that remained before dark in walking over the hills with Mr. Hayes. Los Angeles is situated in one of the finest agricultural districts in the State. It has at various times contained from fifteen hundred to two thousand inhabitants, and was formerly a place of much wealth. There are many large haciendas and ranchos in the valley, which is in a high state of cultivation, abounding in orchards and vineyards. Judging of the wine I saw, and the imperfect mode followed in producing it, there is no doubt that an article of superior quality might be made here in abundance.

I saw more Indians about this place than in any part of California I had yet visited. They were chiefly "Mission Indians," i. e. those who had been connected with the missions, and derived their support from them until the suppression of those establishments. They are a miserable squalid-looking set, squatting or lying about the corners of the streets, without occupation. They have now no means of obtaining a living, as their lands are all taken from them; and the missions for which they labored, and which provided after a sort for many thousands of them, are abolished. No care seems to be taken of them by the Americans; on the contrary, the effort seems to be, to exterminate them as soon as possible. One of the most intelligent of them, who was brought to me by the kindness of my friends here, was unacquainted with the name of the tribe to which he belonged, and only knew that it had been attached to certain missions. I obtained from him a vocabulary, which I found on examination, to be the Diegeno language, with some words different from that obtained at San Diego. 
A pril 3d. Up at daylight, to reach the Mission of San Gabriel by breakfast-time; but the horses were not ready, as promised. After waiting three hours, we concluded to breakfast here. The horses at last were brought, the only excuse for the delay being that they could not be caught before. It now began to rain; but hoping that it would not continue, we set off, Mr. Rand accompanying me. But after we had got about three miles, the prospect for fair weather grew less encouraging; and as we were already pretty wet, we thought it best to give up the jaunt and return, much to my regret. Being thus disappointed in seeing the Mission, I was kindly furnished by the editors of the "Los Angeles Star" with the following brief account of it, which had appeared in their paper a few days before:

"Situated in the midst of a fertile valley, surrounded with abundant timber, and supplied by a thousand springs, with an inexhaustible flow of water, the Mission of San Gabriel flourished and became exceedingly rich. Authentic records are said to exist which show that at one time the mission branded fifty thousand calves, manufactured three thousand barrels of wine, and harvested one hundred thousand fanegas (two hundred and sixty-two thousand bushels) of grain a year. The timber for a brigantine was cut, sawed, and fitted at the mission, and then transported to and launched at San Pedro. Five thousand Indians were at one time collected and attached to the mission. They are represented to have been sober and industrious, well clothed and fed; and seem to have experienced as high a state of happiness as they are adapted by nature to receive. 
"These five thousand Indians constituted a large family, of which the Padres were the social, religious, and we might almost say political, heads.

"Living thus, this vile and degraded race began to learn some of the fundamental principles of civilized life. The institution of marriage began to be respected, and, blessed by the rites of religion, grew to be so much considered that deviations from its duties were somewhat unfrequent occurrences. The girls, on their arrival at the age of puberty, were separated from the rest of the population, and taught the useful arts of sewing, weaving, carding, etc., and were only permitted to mingle with the population when they had assumed the characters of wives.

"When at present we look around and behold the state of the Indians of this country-when we see their women degraded into a scale of life too menial to be even domestics-when we behold their men brutalized by drink, incapable of work, and following a system of petty thievery for a living, humanity cannot refrain from wishing that the dilapidated Mission of San Gabriel should be renovated, its broken walls be rebuilt, its roofless houses be covered, and its deserted halls be again filled with its ancient industrious, happy, and contented original population."

I noticed here quantities of craw-fish, weighing from two to ten pounds, which are taken in this bay. We ate of them, and bought a quantity to take to our friends in San Diego. Their flavor resembles that of the lobster, but is so much inferior that they would hardly be tolerated on the tables of the Atlantic coast. We went on board our vessel before dark, and im- 
mediately got under way, with a strong wind from the north-west. Our little craft scudded before it with great speed, the log showing thirteen and a half miles an hour. This continued during the night, carrying us rapidly towards our place of destination.

April 24th. Passed Point Loma at eight o'clock, and before nine anchored at San Diego. The first news I heard was the removal of Mr. Gray as surveyor, and the appointment of Major Emory in his place. This compelled me to discharge all Mr. Gray's party, and commit the completion of the survey of the Gila to Lieutenant Whipple,-an arrangement which reduced the party about to retrace its steps to the Rio Grande about two fifths.

We now set vigorously to work to prepare for our return. Our animals, which were so completely used up in the journey out, had now recovered their strength, with the exception of five or six, which were past recovery. I had been unable to purchase any mules at Los Angeles or elsewhere to the north, and was compelled to depend wholly upon San Diego and its vicinity to make up our deficiencies. Our camp equipage had been procured in San Francisco; but the harness and pack-saddles needed mending and putting in order. The wagons also required the labor of the blacksmith and carpenter on them.

A few days after my return, I was waited upon by Mr. Antoine Leroux, of New Mexico, the celebrated guide who had conducted Colonel Cooke and his brigade to California in 1846, '47, and who had a short time before arrived with the exploring party under Captain Sitgreaves, which he had conducted by the 
Zuñi River to the Colorado, and thence by Fort Yuma to California. Mr. Leroux now wished to return to New Mexico, and offered me the services of himself and two men, together with several pack and riding mules, for a moderate compensation. As my party was now quite reduced, and as it was necessary to hire more men, I gladly accepted the proposals of Mr. L., and placed the animals and arrieros directly under his charge, with orders to prepare the train as soon as possible for the march.

While these preparations were being made, Lieutenant Whipple and his assistants were busily occupied in reducing his astronomical observations, and in plotting the maps of the survey of the Gila as far as it had been carried. Duplicates were also made of all the notes connected with the survey, which were transmitted by an officer to Washington for safe keeping. For Lieutenant Whipple's Report of the survey of the Gila, see Appendix D.

Before Captain Ottinger left, he invited me, with others of the Commission, to accompany him on in excursion to the Coronado Islands, a small group lying twenty miles from San Diego. Some ten or twelve gentlemen availed themselves of the Captain's politeness; and, on the morning of the 5 th of May, the "Frolic" stood out to sea with a north-west wind, which brought us to the islands in three hours. We came to anchor about a quarter of a mile east of the larger and more southerly island of the group.

One party immediately went with Captain Ottin. ger to examine the anchorage about the islands, while the other landed. This island rises so abruptly from 
the sea, that it was with some difficulty that we could find a landing place. Seeing a little nook, which the dashing waters had worn away from the rocky mass, we made for this, and succeeded in getting on shore. From this place it required much labor to clamber up the rocks for some fifty feet; after which the ascent became easy, and we met with no difficulty in reaching the crest of the island, half a mile distant. The island is a solid wedge-shaped rock, about five hundred feet high, save at the point where we landed, where it is slightly shelving. It runs north-east and south-west, and is about a mile in length, by half that in breadth at its widest part. Towards the northern end its breadth is less than a quarter of a mile. There is some soil on its surface; yet it is entirely destitute of trees. A few small shrubs are seen; and wherever there is soil, it is covered with grass and a great abundance of wild flowers, which in certain spots are so numerous, that they appear like patches of orange, purple, and yellow, when seen from the water. I walked across and along the whole length of the island, but could descend in no place except where we landed. Cacti and other plants grew among the rocks, of which Mr. Thurber obtained specimens.

About a mile to the north-west is another island of nearly the same dimensions as that we were upon, and between them two smaller ones, or rather two masses of rocks, some fifty feet high, without any vegetation. It was among these that Captain Ottinger wished to examine the depth of water; and he was gratified to find excellent anchorage there. Vessels may, therefore, anchor on both sides of these islands, and be well pro- 
tected against south-east and south-west gales. The protection from the north-west wiñds would not be so good. One of these small islands was found to be covered with sea-lions, huge animals as large as an ox. The creatures were asleep when the party landed, and suffered themselves to be approached by the seamen, who for mere sport killed several, by knocking them on the head with stones. Some were believed to weigh as much as one thousand two hundred pounds. Some fine. fish were taken by the boats; and all were again on board.before dark. After starting on our return, the wind died away and left us becalmed, so that we did not reach San Diego until the following morning. The Coronados were discovered and named by Sebastian Viscaino, in the year 1602, when he entered the port of San Diego.* *

The harbor of San Diego abounds in excellent fish; but, owing to the deficiency of timber, there is but little game. Rabbits are plentiful, and occasionally a deer is brought in. On the hills near, and for many miles around, grow wild oats in great profusion, furnishing an excellent fodder for horses and cattle. The other productions are wheat, barley, maize, beans, and vegetables of various kinds. The climate is mild and healthy. During the months of March, April, and May, fogs are frequent in the morning; and up to the time when we left, there was scarcely a morning or evening when a little fire was not necessary. The atmosphere is at all times more moist, with much less heat, than at San Francisco and the adjacent country.

* Torquemada, Monarquia Indiana, lib. v. Voyage of Viscaino. 
While the preparations were being made for our journey, I made a brief visit to the Mission of San Luis Rey, forty miles north of San Diego. This is the latest of all the California missions, and was founded in 1798. It stands in a rich valley, from one to two miles wide, and is about three miles from the ocean, being separated therefrom by a range of hills. Of all the missionary establishments in the State, this possesses the most extensive as well as the most imposing structure. It is built of adobe, although stone and brick are used in some portions of it. It faces the south, and has a front of five hundred and thirty feet, the greater portion of which exhibits a colonnade of some architectural beauty, although but sixteen or eighteen feet high.* On the front is also a church ninety feet in depth, with a tower and dome. North and south, the dimensions are upwards of six hundred feet. This vast space included every thing that appertained to the mission. On the south-eastern corner is a small Campo Santo. Next comes the church with the priests' apartments immediately adjoining, and a small inclosure, or garden, shut in by the church walls on one side and by the main build. ing on the other. This garden was handsomely laid out, and still contains a variety of fruit and ornamental trees. The main building is about three hundred feet square, with a colonnade in front. In the interior, is an open area of the same dimensions, with a beautiful colonnade all around. In the centre of this was a garden; but the only plant of interest that remains, is a

* The general plan of this building and its admeasurements have been mislaid, so that I am unable to give the exact dimensions. 
pepper tree. This stands in a circular bed elevated four or five feet above the area, and is protected by a wall.

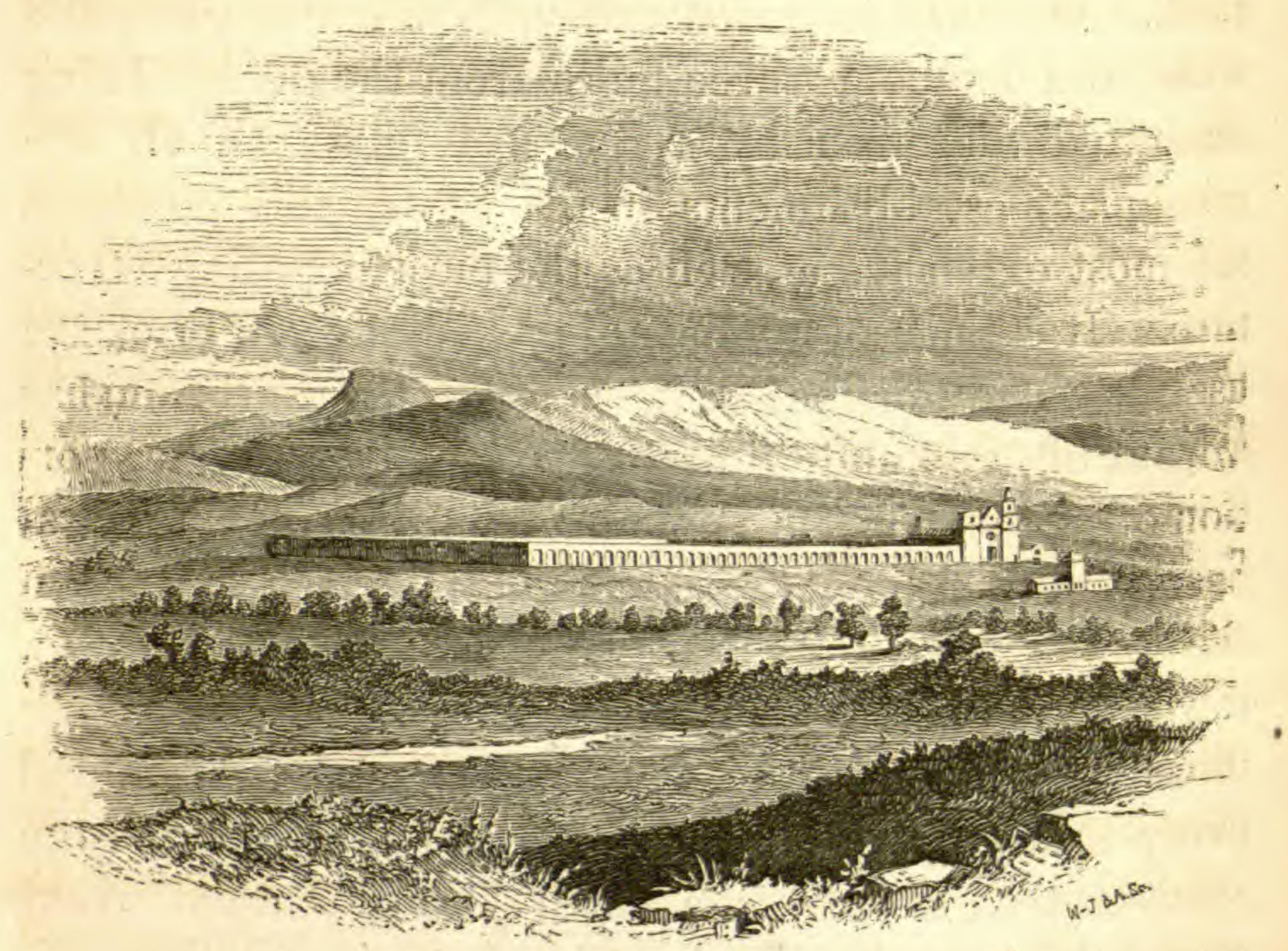

Mission of San Luis Rey, California.

On the four sides of this extensive area are double rows of apartments, some of which are very large, including reception rooms, dining halls, sleeping apartments, kitchen, \&c. In the rear were corrals or inclosures for cattle; so that every thing appertaining to this vast establishment might be brought within its walls. It is all in a good state of preservation except the north-west corner of the area, where the roof has fallen in. Some of the cattle yards and stables are also out of repair. But the church, and nearly all the apartments occupied for dwellings, are still habitable. 
This establishment had been abandoned with most of the other Californian missions; but when the United States became the possessors of the country, several claimants sprang up for it, and its valuable lands adjacent, some resting on purchase, pretended or real, and some on other grounds. It is said to have been purchased by some native Californians from the government about the time the country was changing owners, who sold it to the Americans. Its ownership will be settled by the Board of Land Commissioners appointed by the United States government for the purpose. In the mean time General Hitchcock, commanding the Pacific Division of the U. S. Army, has placed a file of soldiers here, to protect the property and keep off plunderers and squatters.

I remained here two nights, accompanied by Dr. Webb and Mr. Pratt, artist of the Commission, and was hospitably entertained by the Sergeant in charge; the officer in command being absent in San Diego. In such a place as this, with such a range of buildings and cultivated grounds, a prince or a nabob might luxuriate to his heart's content. Near by is an extensive orchard and garden, inclosed with high walls, and filled with every variety of fruit-trees; but the acequias, or irrigating canals, had been neglected, the dams and embankments washed away, and the beautiful gardens and shady walks, where the devotees passed the long hours when not attending to their religious duties, were all overflowed. A swamp filled with rushes and rank weeds had taken possession of these walks and groves; and here the screaming heron and other water. fowl had their hiding-places. 
The Sergeant, at my request, sent for an old Indian of the neighborhood, who called himself a chief. On learning that an officer of the U. S. government wished to see him, he made his appearance with three others of his tribe. The old man presented himself in the dress of a Mexican officer-a blue coat with red facings trimmed with gold lace, and a high military cap and feather. He was quite communicative, and answered my questions readily. In giving me the words of his language, he enunciated them with great distinctness, and would not be satisfied with my pronunciation until all could at once recognise the word. When I had completed my vocabulary, and read off the native words, he evinced great pleasure as he repeated the corresponding word in Spanish, occasionally exclaiming Bueno, or Muy Bueno! He called his tribe the Kechi.

On inquiring as to the state of things when the padres were here, the old man heaved a deep sigh. He said his tribe was large, and his people all happy, when the good fathers were here to protect them. That they cultivated the soil ; assisted in rearing large herds of cattle; were taught to be blacksmiths and carpenters, as well as other trades; that they had plenty to eat, and were happy. He remembered when three thousand of his tribe were settled in the valley, dependent upon or connected with this mission. Now he said they were scattered about, he knew not where, without a home or protectors, and were in a miserable starving condition. A few hundred alone remained in some villages up the valley, a few miles from the mission. $\mathrm{He}$ spoke with mnch affection of Father Peyri, its 
original founder, who had resided here for thirty-four years. At no time, he said, were there more than sixteen Spanish soldiers here, who occupied a building facing the mission, which is still standing.

Father Antonio Peyri took possession of this Mission of San Luis Rey (i. e. St. Louis the king) in the year 1798. He first built a small thatched cottage, and asked for a few cattle and Indians from the mission. At the end of his thirty-four years residence, he left it stocked with nearly sixty thousand head of domesticated animals of all sorts, and yielding an annual produce of about thirteen thousand bushels of grain. After so many years of successful labor, in which he expended the most valuable part of his life, the worthy Father left his mission with only what he judged sufficient means to enable him to join his convent in the city of Mexico, where he threw himself upon the charity of his order. The toil of managing such an establishment, would be sufficient motive for a man of Father Peyri's age to retire; but the new order of things, which had introduced new men and new measures, accelerated his resignation. Whatever his motives may have been, his voluntary retirement in poverty, to spend the remainder of his days in pious exercises, must be applauded by the religious; and his noble disinterestedness by all.

Mr. Alexander Forbes, who met the venerable Peyri, and who has given us this account of his history, thus closes his remarks on this mission, and the affection entertained by the Indians for their pastor: "The best and most unequivocal proof of the good conduct of these Fathers, is to be found in the unbounded affec- 
tion and devotion invariably shown towards them by their Indian subjects. They venerate them not merely as friends and fathers, but with a degree of devotedness approaching to adoration. On the occasion of the removals that have taken place of late years, from political causes, the distress of the Indians in parting with their pastors has been extreme. They have entreated to be allowed to follow them in their exile, with tears and lamentations, and with all the demonstrations of true sorrow and unbounded affection. Indeed, if there ever existed an instance of the perfect justice and propriety of the comparison of the priest and his disciples to a shepherd and his flock, it is in the case of which we are treating. These poor people may indeed be classed with the 'silly sheep' rather than with any other animal; and I believe they would, in the words of the poet, even 'lick the hand though it was raised to shed their blood '-if this were the hand of the friar." *

The harbor of San Diego is second only to that of San Francisco on the Californian coast. On the north and north-west, it is formed by Point Loma, a neck of land which stretches far into the ocean terminated by a bold bluff, one of the most prominent and well-marked headlands on the coast. From this the shore takes an easterly direction for about four miles, when it turns and runs from twelve to fifteen miles towards the south. The southern and western shores of the bay, are low and sandy. The south-western shore is no more than a sand beach, connected by a narrow neck with the

* Forbes's California.-London, 1836, p. 230. 
main land, and for the greater portion of its length is little more than a natural breakwater. The northern part of this neck is more elevated and about a mile

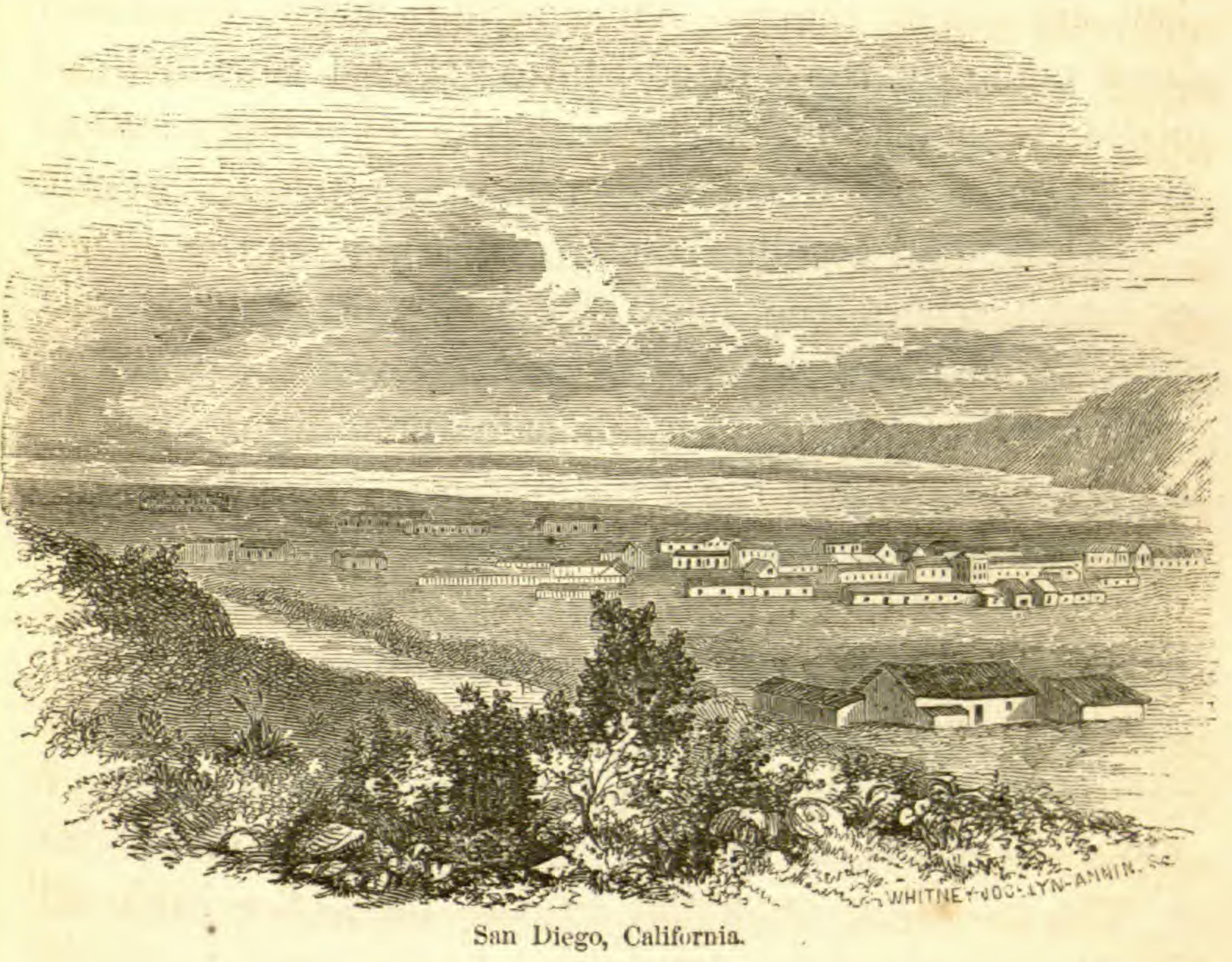

across. Point Loma and the northern shore of the bay, is a promontory about two hundred feet high, and nearly two miles wide, tapering off gradually with a succession of hills as it approaches the town. These hills were covered with chapporal; their declivities, both on the side of the ocean and of the harbor, being cut into deep ravines. At the base on the inner side, is good grazing.

The entrance to this harbor is not more than three or four hundred yards wide. There is a deep channel leading into the inner harbor, which requires some skill in 
navigating; but when once the entrance is passed, there is an abundance of water. I saw large ships some six miles within this harbor, and was informed that the Pacific mail steamers; and one of our frigates, had also been there. An accurate survey has lately been made by the United States "Coast Survey" and elaborate maps published with the soundings and all the bearings laid down, to enable navigators to enter it.

About half a mile from Point Loma, is the Playa, or beach, where the mail steamers, and other vessels, stop for coal and supplies. It is convenient of access with any wind, and affords a safe anchorage. Here is a small village, and the "hide houses" which have become somewhat celebrated from the graphic account of life in California, and the process of curing hides, given by Mr. Dana, in his "Two Years before the Mast." They still stand precisely as he describes them, and are now only used as barns or store-houses. A fine road along the beach leads to the old town of San Diego, standing on a flat at the base of a high hill which extends about two miles to the south: this flat reaches more than a mile into the bay, preventing the nearer approach of vessels or boats. It also extends northwardly to a shallow opening on the north side of the promontory before described, called "False Bay."

At San Diego, a small stream runs into the bay; but during the summer, it becomes dry. At its floods, it brings down great quantities of sand, which are deposited in the channel; whence fears of serious injury to the harbor have been entertained. To obviate this, it has been proposed to change the course of the river to False Bay, into which it formerly run. It would no 
doubt be beneficial, and the plan is worthy the attention of the government.

Three miles south of San Diego is another town near the shore of the bay, which was surveyed and plotted by Mr. Gray, U. S. Surveyor to the Boundary Commission, while on duty here. This is called "New San Diego." It consists of a few substantial frame houses, and is the depot for the United States Subsistence and the Quarter-master's Departments. A large and fine wharf was built here at a great expense; but there is no business to bring vessels here, except an occasional one with government stores. There is no water nearer than the San Diego river, three miles distant. Efforts indeed are making to find it with an Artesian well; but with what success, remains to be seen. There is no timber near, and wood has to be brought some eight or ten miles: nor is there any arable land within four miles. Without wood, water, or arable land, this place can never rise to importance. At the head of the bay are some good lands with pastures for grazing. The bottom lands along the stream back of the old town of San Diego, possess great fertility, and with proper attention might be made very productive.

The admirable harbor of San Diego and its position on the coast, will always make it an important stopping place for shipping; but whether the Playa or beach near the entrance, the old town of San Diego, or "Gray Town" as New San Diego is called by the people of the old town, will have the ascendancy, remains to be seen: - each has its advantages and disadvantages.

It appears from the early Spanish writers, that the promontory north-west of the harbor was once well voL. 11 . -7 
wooded; a fact not generally known. The earliest published account of this harbor, must possess an interest for all who watch the progress of California. The reader, too, will perceive, as in the case of San Francisco and Monterey, that the early discoverers saw the great advantages of the places; although it was left for the Americans one hundred and fifty years later to avail themselves of them. The United States were in possession of California before the discovery of its gold placers; and although they have been the means of its rapid advancement to the extraordinary rank it has now attained, yet it is certain that, even without the gold, it would sooner or later have become what it now is, from its agricultural resources and great commercial advantages.

Sebastian Viscaino having been employed as early as the year 1594 in the "pacification and conquest of California," was selected as the head of an expedition fitted out for further explorations and colonization in 1602. After touching at various places in Lower California, it reached the Coronados Islands. "To the north of these islands," says the narrative, "on the main land, is the famous harbor called San Diego, which the squadron entered at seven in the evening, on the 10th of December; and the day following, the general ordered several persons to survey a forest lying on the north-west side of the bay. This expedition was undertaken by Ensign Alarcon, Captain Peguero, Father Antonio de la Ascension, and eight soldiers. In this forest they found tall and straight oaks and other trees, some shrubs resembling rosemary, and a great variety of fragrant and wholesome plâts. 


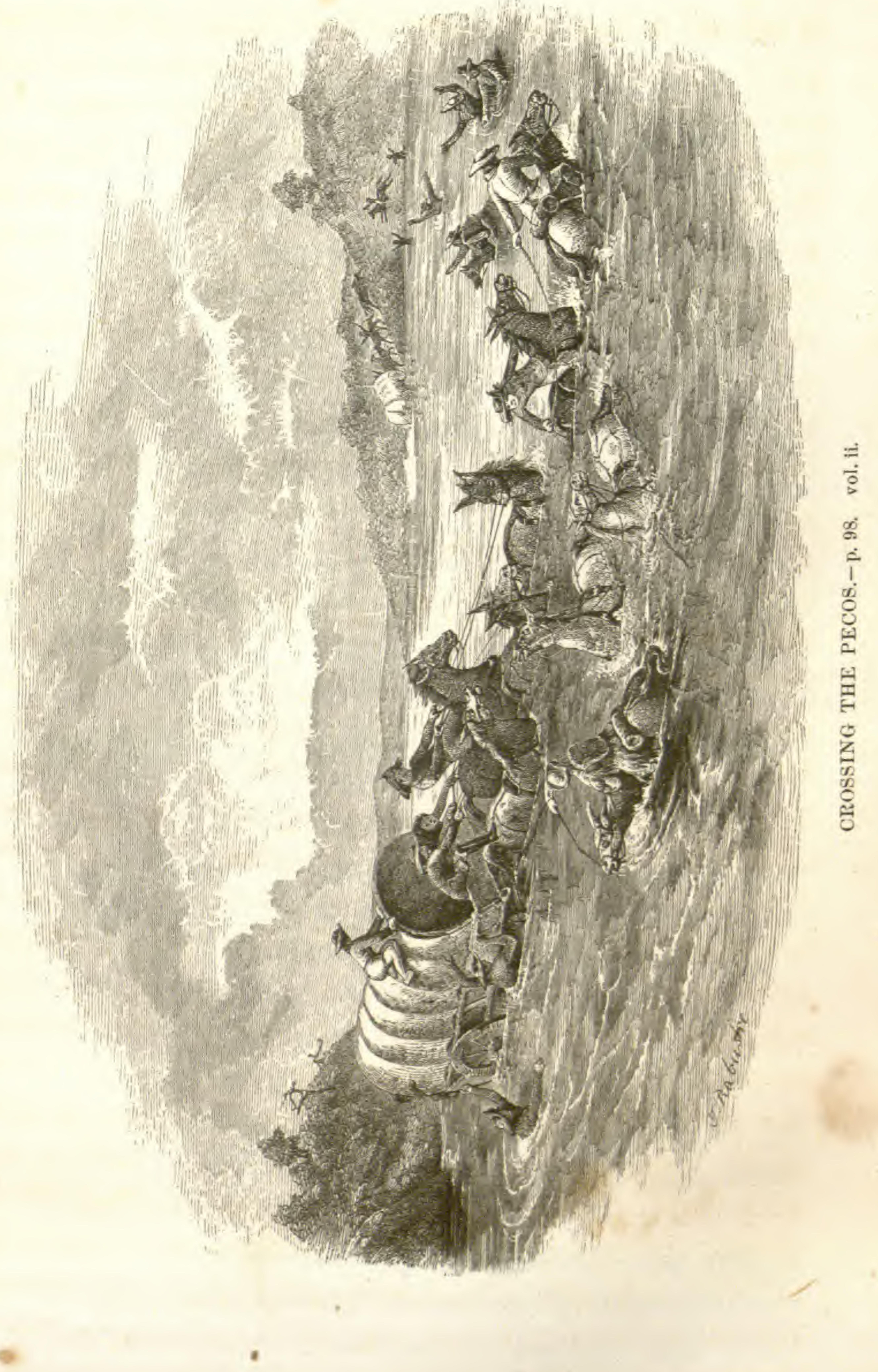



The high grounds commanded a view of the whole harbor, which appeared spacious, convenient, and well sheltered. The forest borders on the harbor, towards the north-west, and is about three leagues in length, and half a league in breadth. And to the north-west of the wood is another harbor. On their return with their report to the general, he ordered a tent to be pitched for religious worship, and that the ships should be cleaned and tallowed, the people in the mean time being employed in wooding and keeping guard. They had their water from a little island of sand, where they dug deep trenches, in which, during the flood, the water was fresh and good, but on the ebb salt. One day a sentinel placed in the wood gave notice that he saw a great number of Indians coming along the shore, naked, and their skins daubed with black and white colors, and armed with bows and arrows. On this the general desired Father Antonio to go and offer them peace. He was attended by Ensign Juan Francisco and six soldiers. On coming up to the Indians, having made signs of peace with a bit of white linen, and throwing the earth up with their hands, the savages immediately delivered their bows and arrows to the soldiers. Father Antonio embraced them; gave them bread and necklaces, with which they were greatly pleased. But on coming to the general's quarters, the Indians, at the sight of such a number of men, drew back to a little eminence, from whence they sent two women. These approaching the general's tent with a timid air, the religious and others made them presents of beads, biscuits, and strings of bugles; and then dismissed them, to give their countrymen an account 
of the usage they had met with from the strangers. Their report was doubtless very favorable; for soon after they all came with them to see the Spaniards. Most of them were painted or besmeared with black and white, and their heads loaded with feathers. The general and others received them with great courtesy, distributing among them several things, and a great many fish which had been caught with the net in their presence. The kind of paint they used looked like a mixture of silver and blue color; and on asking them by signs what it was, they gave them a piece of metallic ore, from whence they made it; and signified by signs that a certain people up the country, who had beards and were clothed like the Spaniards, made from this material very fine ribbons, resembling the laces on the soldiers' buff' coats; and some like that on a purple velvet doublet, in which the general was then dressed; adding, that these men, by their dress, complexion, and customs, seemed to be of the same country with themselves. The Indians were quite transported with the good treatment shown them, and every third day came for biscuit and fish, bringing with them skins of several kinds of beasts, as sables, wild cats, and the nets with which they catch them."*

Another interesting account of San Diego is contained in a letter written by Father Junipero Serra to Father Palou, in the year 1769 , when the former landed here for the purpose of establishing the mission : $†$

"My dear Friend and Sir:-Thank God, I arrived

* Torquemada Monarchia Indiana, lib. v.

$\uparrow$ Palou. Vida de Fray Junipero Serra, p. 76. 
the day before yesterday, the first of the month, at this port of San Diego, truly a fine one, and with reason famous. Here I found those who had set out before me, by sea as well as by land, excepting such as died on the way. The brethren, Fathers Crespi, Biscayno, Parron, and Gomez are here, and, with myself, all well, thanks be to God. Here are also two vessels; but the San Carlos is without seamen, all having died except one and the cook. The San Antonio, although she sailed a month and a half later,

- arrived twenty days before the San Carlos, losing on the royage eight seamen. In consequence of this loss, the San Antonio will return to San Blas, to procure seamen for herself and the San Carlos. The causes of the delay of the San Carlos were, first, the want of water, and, second, the error which all were in respecting the situation of this port. They supposed it to be in thirty-three or thirty-four degrees north latitude; and strict orders were given to Captain Vila and the rest to keep out in the open sea till they should arrive in thirty-four degrees, and then make the shore in search of the port. As, however, the port in reality lies in $32^{\circ} 34^{\prime}$, according to the observations which have now been made, they went far beyond the port, thus making the voyage much longer than was necessary. The people got daily worse from the cold and the bad water; and they must all have perished, if they had not discovered the port about the time they did; for they were quite unable to launch the boat to procure more water, or to do any thing whatever for their preservation. The Father Fernando did every thing in his power to relieve the sick; and although he 
arrived much reduced in flesh, he had not the disorder, and is now well. We have not suffered hunger or privations, neither have the Indians who came with us; all have arrived fat and healthy. The track through which we have passed is generally very good land, with plenty of water; and there, as well as here, the country is neither rocky nor overcome with brushwood. There are, however, many hills, but they are composed of earth. The road has been in many places good, but the greater part bad. About half way, the valleys and banks of rivulets began to be delightful. We found vines of a large size, and in some cases quite loaded with grapes; we also found abundance of roses, which appeared to be the same as those of Castile. In fine, it is a good country, and very different from that of Old California. We have seen Indians in immense numbers; and all those on this coast of the Pacific contrive to make a good subsistence on various seeds, and by fishing; this they carry on by means of rafts, or canoes made of tule (bulrush), with which they go a great way to sea. They are very civil. All the males, old and young, go naked; the women, however, and even the female children, were decently covered from their breasts downwards. We found in our journey, as well as in the places where we stopped, that they treated us with as much confidence and good will as if they had known us all their lives; but when we offered them any of our victuals, they always refused them. All they cared for was cloth; and only for something of this sort would they exchange their fish or whatever else they had.

"From this port and intended mission of San 
Diego, in Northern California, 3d July, 1769. I kiss the hands of your Reverence, and am your affectionate brother and servant,

\section{"FR. JUNIPERO SERRA."}

Six miles from the town of San Diego, following up the valley, is the venerable Mission of the same name, a spot possessing great picturesque beauty, and

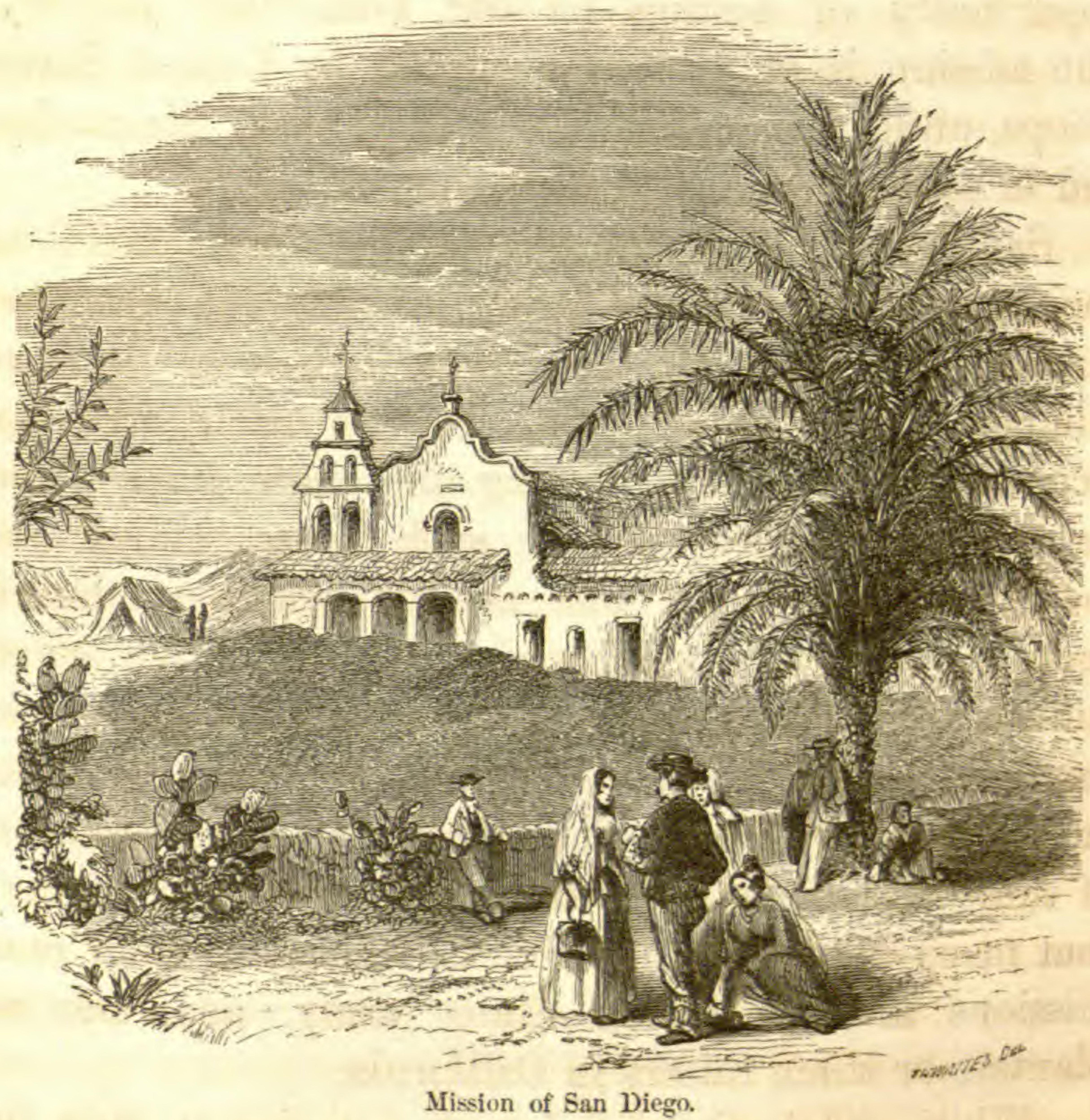

surrounded by fertile and well watered lands. It was the last of the California missions that was abandoned; and but five years ago its ancient library and its 
priest still remained. The buildings, which are of adobe, are not extensive, but are in good preservation. They possess more of an Oriental appearance than any similar establishments. There was formerly a large vineyard and orchard, containing figs, peaches, etc., a portion of which is still in existence. The place is celebrated also for a flourishing orchard of olive trees, which still remains, yielding a great abundance of olives, the excellence of which we had an opportunity of testing on our homeward journey. The mission is at present occupied by United States troops, under the command of Colonel J. B. Magruder, and in consequence is kept in good repair.

San Diego, like Monterey, is noted for its excellent society. There remain many of the old Castilian families here, who have preserved their blood from all admixture with the Indians. In this circle, all Americans and foreigners visiting the place have experienced much pleasure; for such is its refined and social character, that one almost imagines himself again enjoying the delights of home. The Californian ladies are said to possess all the finer qualities of the sex, whether of the head or the heart, and to make most excellent wives. Such have been the attractions of these fair señoritas for the young American officers, that many have been induced to relinquish their commissions in the United States army, and become planters or stock raisers in California.

While detained here, I took occasion to visit the monument erected at the Initial Point, on the Pacific, of the boundary between the United States and Mexi$\mathrm{co}$, one marine league south of the southernmost point 
of the Bay of San Diego." It is an obelisk of white marble, resting on a pedestal, and is about twenty feet in height. It stands near the margin of the tableland, about two hundred yards from the sea shore, and bears the name of the Commissioner, Surveyor, and Astronomer of the two governments, together with the latitude and longitude, viz. :

Latitude north, $32^{\circ} 31^{\prime} 59^{\prime \prime} 58^{\prime}$;

Longitude, $7^{\mathrm{h}} 48^{\prime} 21^{\prime \prime} 01$ west from Greenwich.

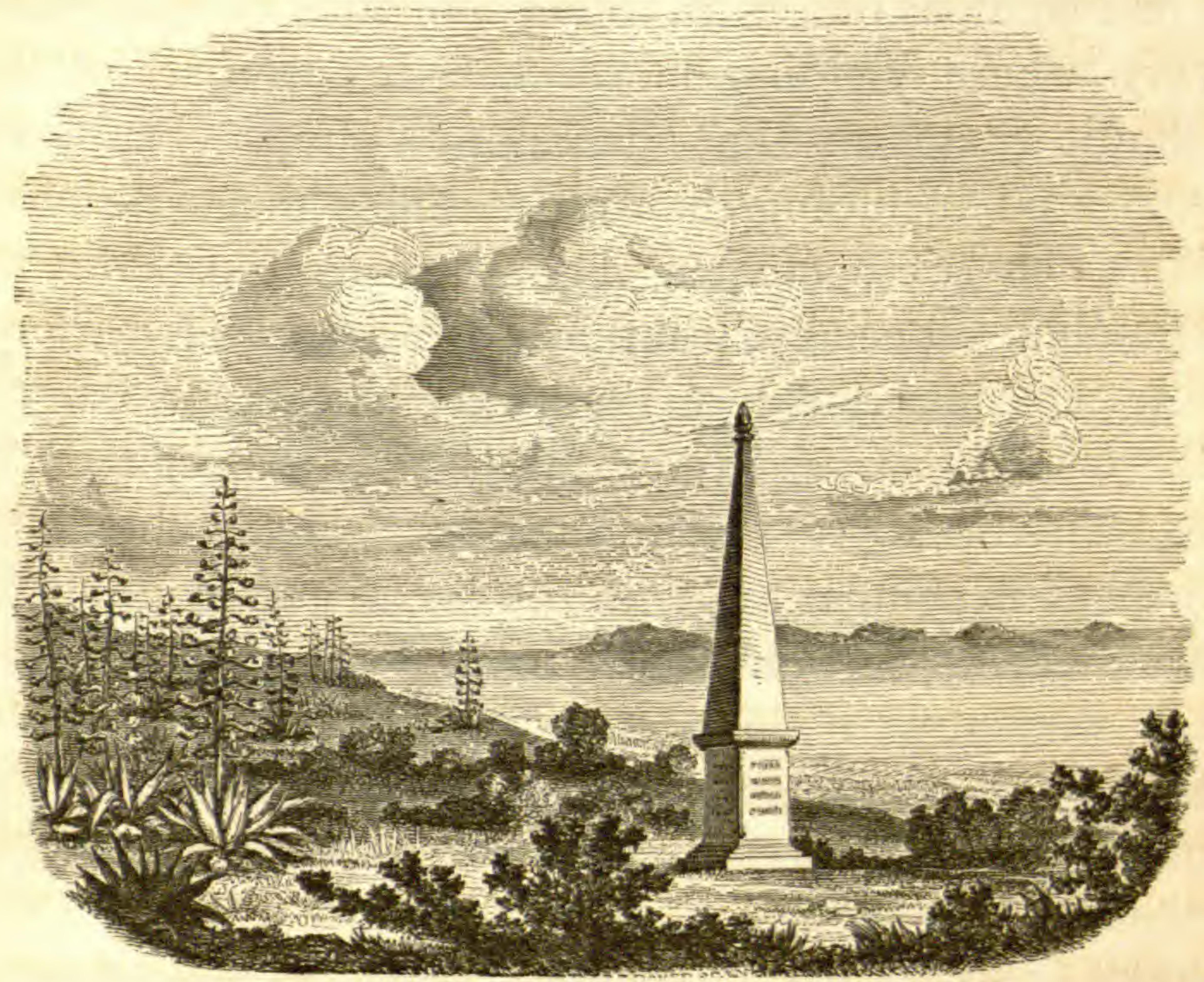

Monument at Initial Point, Pacific.

This monument stands directly opposite the Coronado Islands, and is seen from a great distance on land as well as by vessels at sea. On the table-land around and south of it, grow large numbers of the beautiful agave. 
My journeys through California were not sufficiently extensive to enable me to discuss at length its agricultural resources, nor would an essay of such a character properly belong to a "personal narrative." But I saw sufficient in the valleys of San José, Napa, Carmel, near Monterey, Los Angeles, San Luis Rey, and San Diego, to enable me most confidently to assert that a finer agricultural country does not exist on the face of the globe. Cereals of every description, wheat, maize, barley, peas, rye, and oats grow to perfection, some in one portion, others in other portions of the State, every where yielding more than in any part of the Atlantic States or the Mississippi Valley. Fruits of every kind, including the grape, apples, pears, peaches, plums, cherries, etc., arrive at perfection. But in vegetables especially, whether we regard their variety, their enormous yield, or their excellent flavor, California certainly surpasses any thing I have ever seen in the United States. But the valleys I have mentioned are small in comparison with the broad and magnificent basins of the Sacramento and San Joachin Rivers and their numerous tributaries. The head waters of the San Joachin and the Tulare plains, which are yet unexplored and unsettled, are said to be admirably adapted to the cultivation of rice and cotton. The southern part of the State is more barren, having fewer streams and valleys, with little or no timber. But here occur those large grassy plains or prairies, such as that between the coast and Los Angeles, so well adapted to the raising of cattle. East of the mountains which form the continuation of the Sierra Nevada is a broad sandy desert, extending from the 
head of the Gulf of California to the unexplored region and great Central Basin, with which we have been made acquainted by Colonel "Frémont. This desert is from one to two hundred miles in width, and alike destitute of water and vegetation, excepting a few thorny shrubs and cacti.

Before leaving California, I take this occasion to acknowledge the favors rendered to the Boundary Commission by the officers of the United States army in California. To General Hitchcock, for the facilities afforded me in my journey to the Geysers, and for an escort of twenty-five men to the Pimo villages. To Lieutenant Eddy, Commissary of Subsistence at San Diego, for provisions furnished us during our stay in the country, and for our homeward journey, as well as for various acts of kindness and attention shown to the members of the Commission. Also to Colonel J. Bankhead Magruder, commanding at San Diego. To this gentleman in particular, both personally and in behalf of the government, I feel under the deepest obligation. At a time when we were left without a carpenter or blacksmith, and when none could be procured, this officer permitted me to send to his mechanics my wagons for repairs, and my animals to be shod, without which aid I could not have left San Diego. In other ways he was of great service to me and the Commission, both during our stay in the country, and while preparing for the journey before us. 



\section{FIFTH DIVISION.}

\section{SAN DIEGO TO EL PASO, ALONG THE GILA.}

\section{CHAPTER XXVI.}

SAN DIEGO TO ALAMO MUCHO.

Preparations for the journey to El Paso-Leave San Diego-Accident to wagon-Snook's rancho-San Pasqual-Gen. Kearney's battle at this place-Indian village-San Pasqual Mountain-Difficult ascent-Reach camp at Santa Isabel-Deficiency of transportation-Leroux dispatched for another wagon-Indians of Santa Isabel-A Mormon arrives with a wagon-List of return party-Journey resumed-Luxuriant valleySan Felipe-Indians-Their mode of life-Narrow mountain passVallecita-Desert appearance-Carrizo ereek-Increased barrennessIntense heat-Mules run away-Skeletons and carcasses of animalsImmense destruction of sheep-Utter desolation-Wagon upset-Sacket's Well-Dig for water-Meet Lieut. Sweeney in pursuit of deserters from Fort Yuma-Arrival of bearer of dispatches-Alamo Mucho.

Aвоuт the middle of May the members of the Commission left their quarters at San Diego, and encamped some six miles distant near the Mission; where there was good grazing, and where the animals had been chiefly kept since our arrival. They were now busily engaged in completing the preparations necessary before setting out on so long and difficult a journey as 
that before us. It was quite doubtful whether we should have sufficient means of transportation; and to make sure of this, all the provisions, tents, instruments, personal baggage, etc., were sent out to the camp. Here they were separated and weighed, or an estimate made, so as to enable us to judge whether our two wagons and twenty pack-mules would be sufficient. Uncertain how long we should be in reaching El Paso, we took seventy days' rations; in addition to which were a quantity of medical stores and anti-scorbutics, including fruits, vegetables, pickles, etc., as these important articles were not to be procured on the way.

I was ill at this time with fever and ague, and thought it most prudent to remain in quarters until the parties had got ready to move, and in fact had passed to a considerable distance into the interior, beyond the reach of the fogs and humid atmosphere of the coast. On the 26th, they commenced their march, intending to stop at Santa Isabel, fifty-six miles distant, where I was to join them.

Several days before this, I sent off twelve head of beef-cattle belonging to the Commission, with an escort of six soldiers, with orders to remain at Fort Yuma until my arrival. This plan was recommended to me, as the cattle could not keep up with us after reaching the great desert; and when they entered upon that much dreaded region, it was thought best that they should not stop, but keep on day and night until water was reached. A number of cattle were sent at the same time to supply the garrison at Fort Yuma.

For my journey, I had provided myself with a small wagon to be drawn by two mules, and a fine American 
horse, which had been ridden across the country by Mr. Gray. All the other members of the Commission, as also the laborers, servants, cooks, and arrieros, were provided with mules, which experience had shown to be best for long journeys. They endure fatigue better than horses, will thrive where horses will starve, and in case of accident or emergency, may be used to carry burdens or be harnessed to a team. It was with considerable difficulty that I could procure good mules here; and for those that I obtained, I paid from seventy-five to one hundred dollars each. Nearly every thing we had, including the tents, was new, our former equipments having been to a great extent abandoned on the journey out, as the animals failed, or as they had become past restoring, from eighteen months' use, and constant exposure to a dry heat, rain, or snow.

On the 26th of May, I left San Diego, in company with Dr. Webb, in my small wagon, drawn by two mules. These excellent animals, I must observe, were the same that I started with from the coast of Texas in September, 1850. They had served me in my rapid journey to El Paso, and three times back and forth from that place to the Copper Mines. They had drawn my carriage in my first journey to Sonora, and subsequently, with four others, brought a loaded wagon from the Copper Mines to San Diego. Notwithstanding these journeys and their constant use since we had been in California, they were in as fine condition as when they left the shores of the Atlantic.

My wagon was pretty heavily laden; and ere we had got a mile beyond San Diego, in turning aside for a train, it ran into a gully with such force as to spring 
the wooden axle-tree and bend the iron one. "The injury did not appear to be serious; and as the road, though hilly, was very good, we hastened on. But this little accident, trifling as it seemed at first, proved a constant source of annoyance to us throughout the journey.

Ten miles from San Diego, is Soledad hill, which is very steep and difficult to pass. One of our loaded wagons had upset here a few days before. The whole country hereabouts is hilly, and destitute of trees, except in the small valleys, where the accumulation of water after rains has sustained a few mezquit trees. The hills on both sides, and as far as the eye can reach, are covered with a thick growth of wild oats. Several families have lately settled here, who make a profitable business of cutting these oats and carrying them to market at San Diego, where they are in good demand. In the afternoon, we reached San Pasqual River, a small and limpid stream, running through a rich valley covered with fine grass, and in which hundreds of cattle were grazing. About a mile in advance, we saw a large rancho, to which we directed our course, having been invited to pass the night there. This was the hacienda of Mrs. Snooks, a California lady, the widow of an Englishman, who now resides at San Diego. Word having been sent to the family occupying the rancho that I would stop here, we met with a hospitable reception, and were provided with an excellent supper and beds. This was formerly one of the largest stockraising establishments in the country; but the high price of cattle at San Francisco has induced the owner to drive them thither for sale. There were, however, still, 
many hundreds remaining. The distance to San Diego is called thirty-six miles.

San Pasqual was the scene of an action between the United States troops and those of Mexico during the late war. Our army was at one time in a perilous situation, from which it was relieved by assistance sent by Commodore Stockton, then at San Diego. I add in a note Colonel Kearney's brief report of this affair.*

May 29th. At seven o'clock, we took leave of our hospitable friends; and continuing across the plain and

Head Quarters, Army of the West,

San Diego, California, Dec. 13, 1846.

* "Sir: In my communication to you of yesterday's date, I brought the report of the movements of my guard up to the evening of the 5th instant, in camp near a rancho of Mrs. Snooks, about forty miles from San Diego."

* * * * * * * *

After giving the details of his position, and of his officers, the General thus proceeds :

"As the day (December 6) dawned, we approached the enemy at San Pasqual, who was already in the saddle, when Captain Johnston made a furious charge upon them with his advanced guard, and was in a short time after supported by the dragoons, soon after which the enemy gave way, having kept up from the beginning a continual fire upon us. Upon the retreat of the enemy, Captain Moore led off rapidly in pursuit, accompanied by the dragoons mounted on horses, and was followed, though slowly, by the others on their tired mules. The enemy, well mounted, and among the best horsemen in the world, after retreating about half a mile, and seeing an interval between Captain Moore with his advance and the dragoons coming to his support, rallied their whole force, charged with their lances, and, on account of their greatly superior numbers, but few of us in front remained untouched. For five minutes they held the ground from us, when our men coming up, we again drove them, and they fled from the field not to return to it, which we occupied and encamped upon. A most mel-

VOL. II. -8 
along the valley near the river, we reached, in six miles, the Indian village of San Pasqual, consisting of forty or fifty rude huts of mud, grass, and poles. A few patches of ground seemed to be cultivated; but,

ancholy duty now remains for me : it is to report the death of my aidede-camp, Captain Johnston, who was shot dead at the commencement of the action; of Captain Moore, who was lanced just previous to the final retreat of the enemy; and of Lieutenant Hammond, also lanced, and who survived but a few hours. We had also killed, two sergeants, two corporals, and ten privates of the First Dragoons, one private of Volunteers, and one man attached to the Topographical Department. Among the wounded are myself (in two places), Captain Gillespie, and Captain Gibson, of the Volunteers ; one sergeant, one bugler, and nine privates of the Dragoons; many of them receiving from two to ten lance wounds, most of them when unhorsed, and incapable of resistance. Our howitzers were not brought into action; but coming to the front at the close of it, before they were turned so as to admit of being fired apon the retreating enemy, the two mules before one of them got alarmed, and, freeing themselves from their drivers, ran off among the enemy, and were thus lost to us. The enemy proved to be a party of about one hundred and sixty Californians, under Andreas Pico, brother of the late Governor. The number of their dead must have been considerable; though I have no means of ascertaining how many, as just previous to their final retreat they carried off all excepting six. The great number of killed and wounded proves that our officers and men lave fully sustained the high character and reputation of our troops: and the victory thus gained over more than double our force may assist in forming the wreath of our national glory. I have to return my thanks to many for their gallantry and good conduct on the field, and particularly to Captain Turner, First Dragoons, and to Lientenant Emory, Topographical Engineers, who were active in performance of their duties in conveying orders from me to the command.

"On the morning of the seventh, having made ambulances for our wounded and interred the dead, we proceeded on our march, when the enemy showed himself, occupying the hills in our front, which they left as we approached, till reaching San Bernardo, a party of them took 
on the whole, the place bore a miserable appearance. Few Indians were seen, as they were still indulging in sleep.

Crossing the San Pasqual River again, we reached the base of the hill, or rather mountain, of the same

possession of a hill near to it, and maintained their position till attacked by our advance, who quickly drove them from it, killing and wounding five of their number, with no loss on our part.

"On account of our wounded men, and upon the report of the surgeon that rest was necessary for them, we remained at this place till the morning of the 11th, when Lieutenant Gray, of the navy, in command of a party of sailors and marines, sent out from San Diego by Commodore Stockton, joined us. We proceeded at ten A. M., the enemy no longer showing himself, and on the 12th we reached this place; and I have now to offer my thanks to Commodore Stockton, and all of his gallant command, for the very many kind attentions we have received and continue to receive, from them.

"Very respectfully, your obedient servant, (Signed)

\section{"Brigadier General R. Jones, \\ "Adjutant General, U. S. A."} S. W. KEARNEY, Brigadier General, U. S. A.

"The eminent services of Commodore Stockton," says Lieutenant Revere, " at this most important and critical juncture, can hardly be too highly extolled. While the party press at home were making free with his proclamations, and denouncing the decided course which he had taken the responsibility to adopt, those who were at the seat of war regarded him as the sheet anchor of their hopes, and were able to see that his whole conduct was suited to the emergency which had arisen. To his gallantry, wisdom, sagacity, and prudence, to his timely and energetic measures, the people of the United States are chiefly indebted for the rapid and final suppression of the Californian insurrection, which at once and for ever sealed the destiny of the most magnificent and opulent territory in the world."-Tour in California, p. 171 . 
name, the terror of all travellers when accompanied by wagons. We had heard much of this hill, and were fully prepared to undertake the labor of passing it. To keep our seats in the wagon was out of the question; so we all got out, and literally put our shoulders to the wheels. The driver, while he held the reins, braced up the wagon to prevent its upsetting, and Dr. Webb and myself alternately pushed behind or chocked the wheels. The mules tugged with all their strength, and we moved steadily though slowly on, stopping every forty or fifty feet to let the animals rest. The road pursued a zig-zag course, winding along the side and around the hill, which somewhat lessened the difficulty of the ascent. But the steepness was not the greatest difficulty to encounter. This consisted in the "sidling" places, where the wagon could not stand upright, and required to be held up with ropes while ascending or descending. Then, again, portions of the road were very rocky, and much gullied by running water. Occasionally there was a cessation of hills, and a short piece of good road; but then soon came descents, which were attended with more trouble than the ascents; for the wheels had to be locked, and the wagon held up with ropes.

In this way we journeyed the whole day with little variation. San Pasqual forms part of a high mountain ridge running north and south. From its summit we had a fine view of the surrounding country, though lesser hills extended far along its base. I have no doubt that a closer reconnoissance of the country would make known a more practicable route than this, by 
avoiding such a frightful mountain. It answers well enough for pack-mules, for which I presume it was constructed; but it was never attempted to be passed with wagons until Colonel Cooke crossed it in 1847. A variety of trees and shrubbery grow along the road, with the greatest abundance and variety of wild flowers, for the most part, as is usual in this country, of brilliant colors.

The long descent from this mountain, after the higher portions had been passed, was comparatively easy. We then reached valleys covered with live-oaks, and affording an abundance of grass. Next, several small hills, with intervening valleys and patches of woodland, were passed, until we reached Santa Isabel. When within a couple of miles of this place my mules began to show the effects of their toilsome day's journey, and the wagon was nearly disabled. Fearing they would not get in, I took my servant's mule and hastened on to our camp, which I reached at seven o'clock, and sent two fresh mules back to the assistance of my party. Soon after Dr. Webb came in, and reported that the axle-tree had given out, and the wagon could proceed no further; so that it was necessary to send pack-mules to bring in its contents, and also provisions for the men. I now took possession of my tent with its appurtenances, and sat down to an excellent supper, prepared in anticipation of my coming. It was pleasing to find myself once more in a tent for the first time since I was taken ill at Ures. It was invariably the case, that we all enjoyed better health when in camp and on our march, than when shut up in quarters with little or nothing to do. An 
active, moving life in the open air always brings with it a good appetite and sound sleep, and is the surest antidote to, or rather preventive of, disease. Distance travelled to-day, twenty-two miles.

I found my party encamped a mile beyond the Indian village of Santa Isabel, in one of the most lovely groves of large branching oaks that it had ever been our fortune to meet with. It is closely hemmed in on three sides by high hills, all of which are thickly wooded, while a clear mountain stream passes directly through it. Grass in abundance grew all around us, on which our mules were luxuriating. The tents were all pitched beneath trees, and but a few feet from the stream to which I have alluded.

Soon after I arrived, Colonel Craig, commander of the escort, called and reported his men ready for our march. He had been furnished by Colonel Magruder with six additional soldiers, who were to accompany us to Fort Yuma. Lieutenant Whipple was occupied during the evening in taking astronomical observations, as the weather was now elear and pleasant, a very perceptible change having taken place since we left the coast.

Soon after the train had left its camp near the Mission of San Diego, it was reported to me by Mr. Thurber (who acted as Quarter-Master in addition to his other duties), that another wagon would be absolutely necessary. I accordingly directed that he should send Mr. Leroux at once to the Mormon settlement at San Bernardino, about a hundred miles distant, to purchase a wagon from some of the recently arrived emigrants, and should await his return at Santa Isabel. Mr. Leroux, 
who but a short time previous had been to that place, and knew many of the Mormons, set off on his errand. May 30th. Remained in camp. Got my wagon in, and made a new wooden axle-tree. Found the iron portion much bent and very weak. Lashed the two strongly together with rawhide.

Santa Isabel is an Indian village, and was once a place of some note, when the missionary establishments were in the ascendancy. A roofless church and a few miserable huts, are now all that remain. Nevertheless, the inhabitants cultivate the soil, and by means of irrigation, which they well understand, raise wheat, maize, pumpkins, and beans. The vine succeeds very well here, and was formerly cultivated to a considerable extent. The land near is very fertile, which had induced some Americans to select it for their homes. The long neglected fields were being turned up, which gave the valley a pleasant appearance. Several of the Indians, who belong to the Diegeno tribe, visited our camp to-day. They were dressed in their holiday clothes, such as red and white shirts; while the chief. Tomaso, who seemed an intelligent man, wore an old coat trimmed with silver lace, which had once belonged to some Mexican officer.

May 31st. Remained in camp. In the afternoon Mr. Leroux returned, accompanied by a wagon, which was driven by its owner, a Mormon, named Smithson. After paying him, I invited him to remain with us over night, as he had had a fatiguing day's journey. We were much amused during the evening in listening to the history of our Mormon friend, who also enlightened us with a lecture on the peculiar doctrines of his sect. 
He seemed a harmless, though zealous man, ardent in his religious belief, and was I should think, a fair specimen of his fraternity. His people had lately purchased the extensive haciendas and buildings at San Bernardino, covering several miles square, for seventy thousand dollars, one half of which amount they had paid in cash. This is one of the richest agricultural districts in the State, and is said to have been a great bargain.

June 1st. In consequence of the heat, I deferred leaving until 6 o'clock in the evening. As the party was now got together, I give the names of those composing it.

John R. BaRtLett,

Commissioner.

Thomas H. Webb, м. D. Secretary and Surgeon. George Thurber Quarter-Master, Commissary, and Botanist.

Henry C. Pratt, Malcolm Seaton, Antoine Leroux,

Draughtsman and Artist. Assistant Surveyor. In charge of Pack-mules; with servants, cooks, arieros, and teamsters. We had but two wagons, the remainder of our camp-equipage and provisions being transported by pack-mules. Dr. Webb and myself, rode in a small wagon, which I bought in San Francisco, and which turned out to be a very poor affair, made to sell, and not for such a journey as lay before us. We also had riding animals for a change, and in case of accident to the wagon.

The party to complete the survey of the Gila, was as follows:

Lieut. A. W. Whipple, Corps Topographical Engineers, Astronomer in command. 
Hugh Campbell,

Frank Wheaton,

Henry C. Force,

John J. Рratt,

John O'Donoghue,

Charles A. Gicquel, with flag-bearers, attendants on instruments, laborers, servants, cooks, arrieros, and teamsters, making altogether about twenty-five men. This party had both wagons and pack-mules as well as myself; and all, both officers and attendants, were mounted on mules or horses.

Lieut. Colonel L. S. Cratg commanded the escort, now reduced by desertion to five men of his own command, with a detail of ten men from that of Colonel Magruder, at San Diego.

The entire party embraced six wagons, twenty-five pack-mules, and about fifty officers and men, mounted.

June 1st. The day being very hot, we did not strike our tents and leave camp until 6 o'clock, P. M., when Colonel Craig and myself led the way. The road was very good along the valley where it was level; but there were many deep gullies, which required the use of ropes to keep the wagons in an erect position. Our course had been north-east. The scene changed as we passed around the spur of the ridge which bounded the eastern part of the valley. Here a broad plain opened to us, with but few trees, although well covered with grass. Our course now lay south-east. The moon rose remarkably bright; and, with a cool and comfortable night, we jogged steadily along and made good progress. Towards midnight we entered a thick grove 
of oaks, which so closely lined the road, that it was with some difficulty that we found our way through them. It was a beautiful spot for an encampment, and we felt quite disposed to stop; but we knew of no water near. The grass, too, was quite sparse. We therefore pushed on to the Indian village of San Felipe, near which we encamped at 2 o'clock in the morning. I immediately threw myself down and enjoyed a delightful sleep, such as none can appreciate but those who have tried a camp life. Distance travelled, twentyeight miles.

June $2 d$. Found ourselves in a valley without woods, in the lower part of which was a marshy spot with pools of water. Early in the morning our tents were thronged with Indians, who appeared to belong to the Diegeno tribe. They were a filthy looking set, half clad and apparently half starved. During the day, we saw many men and women wading about the marsh gathering roots and seeds; of which two articles and acorns, their principal food consists. The women seemed to be the ehief laborers, the men lounging about the camp most of the day. The improvidence of this people seems almost incomprehensible. A very little exertion would have repaid them with all the wheat, maize, and vegetables, required for their subsistence. To these they might add a few cattle, which, in this country, may be obtained for a mere trifle from the ranchos, whose increase in this fine valley would give them a plentiful supply of meat. As it is, they have neither corn nor meat, and spend ten times as much labor in collecting the roots, seeds, and other wretched food they live on, as would be necessary by 
cultivating the soil to prodnce bread, fruits, and meats in abundance.

Their village consists of twenty-three miserable old huts or wigwams built of straw and rushes. Some were covered with raw hides of various colors. A few small patches of ground were cultivated, not exceeding altogether a couple of acres. This was not for the want of land, as there are many hundred acres of good land around them, which by irrigation could be made very fertile. From appearances near the village, I was led to believe that there had long been a settlement here, there being not only traces of former buildings in every direction, but also of acequias or trenches for irrigating the lands.

At 4 P. M. struck our tents. The road continued good for six or seven miles, its course still south-east. The grass had now disappeared, and the thorny chapporal which had taken its place was the first indication that we were passing into a desert region. We now entered a cañon, or mountain pass, caused, like most others, by the action of running water for ages. This pass had been used only for mules, until Colonel Cooke entered the country with wagons. Not being able to get through, he was obliged to come to a halt, and open a passage with axes and hammers through the solid rock, a work of great labor. This defile consists of perpendicular walls of rock about fifteen feet high, and of a width barely sufficient for wagons to pass. In its bed are large masses of rock reaching to the axle-trees. At the narrowest point one of our wagons stuck fast; but after taking out the mules, by dint of lifting and prying, we at length 
got through. The space here was but two inches wider than the axle-trees of the wagons. There were, also, several steep and rocky descents where the wheels had to be locked, and the wagons held back with ropes. This pass was not less than three miles in length; and should two trains meet here, it would prove a serious business for both.

The descent into the valley beyond, continued gradual for several miles; but at length our course was stopped by a bold rocky hill running directly across it. This we ascended, over a very bad road; but bad as it was, it was better than the descent, which was the most perfect break-neck place that a wagon ever attempted to pass. It was exceedingly steep, filled with large loose rocks, with an occasional perpendicular leap of three or four feet. I feared that our wagons would not hold together, even if they escaped being upset. But the only accident that happened, was the breaking of our two remaining barometers, a very serious one for the meteorological observations.

At the bottom of this hill, we continued for five or six miles through a valley, with no other vegetation than the usual desert plants and cacti, accompanied by the great agave which seemed to luxuriate in this barrenness. At 11 o'clock, P. M., we reached Vallecita, eighteen miles from San Felipe, where we pitched our tents among some willows.

June $3 d$. Vallecita, as its name indicates, is a little valley, surrounded by lofty and barren mountains. Pools of sulphurous water are found among the willow bushes, but not a tree was to be seen. The grass, too, had changed, having here a wiry character. A depot of 
provisions is kept at this place, with a file of soldiers, for the supply of Fort Yuma, and of government trains passing and repassing. A few horses are also kept here, to facilitate the communication between Fort Yuma and San Diego. The distance between those places is about two hundred and twenty-five miles, and Vallecita is about half way. Beyond it, towards the Colorado, there is little or no grass; so that trains, after they have crossed the desert, usually stop a day or two here, to recruit their animals.

A band of Diegeno Indians live here, to whom the arrival of a train is an event of some importance. They made their appearance early this morning, dressed in their holiday clothes, and appeared more cleanly than any Indians we had seen. Nearly all wore clean white or fancy calico shirts, their only garment; pantaloons being regarded by all Indians as useless articles of dress. These people were formerly connected with the Missions, and hence call themselves Christians; but they now live in a most degraded state of indolence and poverty. They cultivate beans and pumpkins, and pick up an occasional mule, which serves them for food; though their main reliance is upon the acorns, which they collect and store up in large baskets for winter use. The labor of preparing them for food is, like almost all other labor, performed by the women, who were to be seen in front of every hat wielding their heavy stone pestles. When the acorns are reduced to flour, it is washed to remove the bitter taste, and then cooked into a kind of gruel, or made into bread. These Indians were very attentive to us, bringing us wood (which is very scarce here) and water, 
and otherwise assisting about the camp. They seemed amply repaid with a few old clothes, or any fragments of food that remained.from our tables. Our culinary department was always the great point of attraction to these poor creatures, who would often form a double circle around the camp-fires, much to the annoyance of the cook. The weather was excessively hot to-day, the mercury standing at $105^{\circ}$ Fahrenheit in the shade under the bushes.

Took our departure, at 6 P. м. Each mile we advanced, grew more barren. The road continued through deep sand or loose gravel, reminding us that we had fairly entered upon the desert of which we had heard so much. On leaving this valley, all traces of grass disappear. A few stunted shrubs armed with thorns, strove hard for an existence; and the wonder is, that any vegetable life can flourish amid such barrenness. But the cacti and agave seem to delight in such arid and desert regions, as though the intense heat and dry atmosphere were the vivifying influences that nourish them. The bleached bones and dried carcasses of oxen, mules, and sheep, began to mark our road, mementos of the sufferings of former parties. The moon still shone bright, while we journeyed slowly on through the heavy sand for twenty miles, till, at one o'clock in the morning, we arrived at Carrizo Creek. I had got considerably in advance of the wagons, and without waiting for them or my tent, stretched myself on the bare earth (for it was so warm that a covering was unnecessary), and was soon lost in sleep.

June 4 th. Carrizo Creek* is one of those remark* Carrizo, means reed grass (Arundo phragmites). 
able streams which sometimes spring up in desert regions. It rises in the very centre of barrenness, flows for about a mile, and is again absorbed by the desert. It has worn for itself a bed about fifteen feet below the plain. It is from three to nine inches in depth, and varies from six feet to as many yards in width. Where the banks have been washed away, it receives, in several places, accessions from springs; but when these cease, the stream grows less and less, until it is all absorbed by the sands. In the ravine or bed formed by this water, mezquit bushes grow to the height of ten or twelve feet, the deep green of their foliage presenting a pleasing contrast with the desolation around, and marking the course of the stream from its beginning to its end. The grass, which grows in a few patches, in little nooks which receive their moisture from the creek, is very coarse and wiry; and of this there is not enough to supply the few passing trains that come this way. The heat here to-day was insupportable, the mercury ranging at $114^{\circ}$ in the shade. The rays of the sun beat through our tents, so that we could not remain in them. Some retreated beneath the wagons; while myself and others found our way into little gullies or ravines beneath the clay banks, where, partly sheltered by the banks and partly by bushes, we passed the day.

We had much trouble here with our mules, who did not like the coarse grass before them; so that while the herders thought that they were quietly trying to pick up a living on the margin of the stream, they were off at full speed for Vallecita, where they had a recollection of better fare. . Some were arrested in their 
flight within a few miles of camp, while others were not overtaken until they had reached the grassy patches they were in search of. This is a common habit with mules, and often impedes the progress of a train. I have known them, where the grass was poor, to retrace their steps twenty-five miles for the sake of finding better. Experience showed us that in such places as this the animals must be closely watched, and at night tied up to the wagons.

We noticed a peculiarity in the water here, which was that, although sweet, it did not quench the thirst. We all drank incessantly without being satisfied.

As we entered the great desert here, and expected to find no water, except by digging, until we reached the Colorado, one hundred miles distant, we filled all our kegs, canteens, empty bottles, and every thing else that would hold water. I then directed the wagons to be loaded, the mules packed, and the train to move at sunset.

I have forgotten to mention that we saw along the banks of Carrizo Creek, near our camp, an innumerable quantity of the bones and dried carcasses of sheep, a rare occurrence in a region infested by hungry wolves; but numerous and hungry as the wolves are, there is such a thing as satiating their appetites, and of this we had an example before our eyes. Here were the bodies of many thousands of sheep lying in piles within the space of a hundred yards. This wholesale mortality is said to have been caused by their eating of a poisonous plant; but as we could find no specimens of such a plant, we believed that the poor creatures, after traversing the desert and being probably three or four 
days without water, had drunk themselves to death. Most of the bodies were in the immediate vicinity of the stream.

It was not until half-past seven o'clock, P. M., that we moved from camp. The road continued heavy through loose sand and stones, making it impossible to move more than two miles an hour. Six or seven miles brought us to a steep sand hill, which no team alone could ascend. Ten mules were accordingly hitched to each wagon, when by dint of tugging, and a good deal of beating and hard swearing, the poor animals reached the summit with their loads. One of Colonel Craig's wagons was upset and rolled over and over to the bottom of the hill, but fortunately escaped with no other damage than that of smashing the medicine chest; which, however, was a loss we afterwards severely felt.

This was the most.desolate spot we had seen, presenting indeed the very climax of barrenness. We were surrounded in all directions by hills of clay, their sides cut into deep ravines. As far as the eye could reach by the light of the moon, which rose at ten o'clock, not a sign of vegetation appeared. I believe there had not been a day, from the time of our landing on the coast of Texas till we trod the shores of the broad Pacific, that we had not seen the mezquit in some form, or the common prickly pear. Here they could not exist.

June 5th. Reached the water-holes called Sackett's Wells, twenty-four miles from Carrizo, at 3 o'clock this morning. Before leaving camp last night, I sent four men with spades in advance, in order that they might. voL. II. -9 
sink some holes, and have a small supply of water for us on our arrival; but as they were ignorant of the place and were unfamiliar with the best indications of water, they had accomplished little. Some more experienced hands now set themselves busily at work in an arroyo, or place where there was a slight depression in the desert, marked by some mezquit bushes, whose freshness showed that water sometimes reached their roots. After digging about six feet, the water began slowly to enter; and by dipping it up with a basin, we managed to supply our animals.

The desert where we were now encamped, is an open and remarkably level plain, with scarcely an undulation. On the south-west, twenty miles distant, is a range of lofty mountains, which forms its limit in that direction. On the north and east, it is bounded by the horizon, no mountains or hills being visible. The soil is either a fine gravel, or loose sand. The vegetation is exceedingly sparse, consisting chiefly of stunted mezquit and the larrea Mexicana. Near the arroyo, where water sometimes finds its way, a few mezquit bushes have attained the height of ten feet, whose brilliant hue is most agreeable to the eye, amid so much barrenness. A little grass was found in clumps about a mile from our camp in an arroyo, whither our animals were sent. This, with the young shoots of the mezquit, was all they had. At sunrise this morning, the mercury stood at $92^{\circ}$, and at noon $108^{\circ}$ in the shade. Distance from Carrizio Greek, twenty-five miles.

Lieutenant Sweeny arrived this morning from Fort Yuma in pursuit of two deserters from that post, and 
remained with us during the day, believing himself to be in advance of them, and that they would stop here for water. In the afternoon Mr. Jenkins reached us from San Diego. He was the bearer of dispatches to me from the government, having left El Paso del Norte on the 19th February. He came by way of Chihuahua and Mazatlan; and had encountered serious obstacles on his route. As there was no party coming across the country by the Gila route, he was obliged to pass through Mexico, which had taken him nearly four months.

As it was too hot to march at all during the day, we continued as before, to make our journeys at night. At 7 р. м. left camp, taking the lead as before in my little wagon, with Colonel Craig riding on a mule at my side, while the wagons and train followed closely behind. The road for the first few miles was heavy; after which, we struck the hard gravel, where it was so smooth that we increased our pace. After keeping with me for an hour and a half, the Colonel left me, saying he would ride back and see to the wagons, as some of them were dropping behind. This course was usual with him. He felt a heavy responsibility upon his shoulders, and deemed it his duty to watch every part of the train. He considered his post to be in the advance; but during every march, whether at night or by day, he rode around the train, to see that all was right, and that his men observed proper vigilance. At 11 o'clock the moon rose, when we could see our way better. The pack-mules, which had been in the rear, soon after came up, and, as was usual with them, pushed by me. On long marches, pack-mules always increase 
their speed as they progress, when it becomes difficult to restrain them to the gait of those in wagons. The road continued very good during the night; so that, with the bright light of the moon and the air moderately cool, we made good progress. As morning approached, the road became heavier; when my mules fell back, the pack-mules still keeping on at their former pace. We had now to get out and walk; and this relief to the poor animals enabled us at length to reach the stopping place known as the Alamo Mucho, where water is obtained by digging.

Although there may have been cotton-wood trees here in former times, all have now disappeared; for we saw nothing but stumps and a few miserable mezquit trees. 


\section{CHAPTER XXVII.}

\section{ALAMO MUCHO TO FORT YUMA.}

The Desert-Dry basin_ "New River"-Alarming news from the trainColonel Craig's encounter with the deserters from Fort Yuma-Report of Sergeant Quin-Dr. Webb returns in search of Colonel Craig and Sergeant Bale-Loss of wagons on the Desert-Great heat-Return of party with the body of Colonel Craig-Sergeant Bale's returnFurther particulars of the encounter with the deserters-Burial of Colonel Craig-Word sent to San Diego-Prompt action of Colonel Magruder-Arrest of the murderers by Indians, and their execution-Colonel Craig's character and services-March resumed-Cooke's Well-Colorado River-Banks washed away-A passage cut through the woodsArrival at Fort Yuma-Depredations by the Yuma Indians on the camp at night-Unsuccessful pursuit-Lieut. Whipple commences crossing the Colorado.

June 6th. Reached Alamo Mucho on the desert, at 7 o'clock this morning, after a journey of twelve hours without a moment's rest, in which time we had made forty-five miles. In long marches like this with pack-mules, it is not considered advisable to stop; for no rest can be given to the animals without relieving them of their packs, to do which and replace them would require at least two hours. If a packtrain stops without relieving the mules of their burdens, the animals lie down and attempt to roll, an operation which disarranges the packs and often does 
much injury. When there is grass and water, it is well, on long marches by daylight, to rest an hour or two during the heat of the day. Feed and water at such times, with rest from their loads, affords much relief; but when there is nothing to offer the weary animals, it is decidedly the best course to hasten on and complete the journey, unless it is too long to be accomplished in a day.

The desert here is a vast open plain, extending as

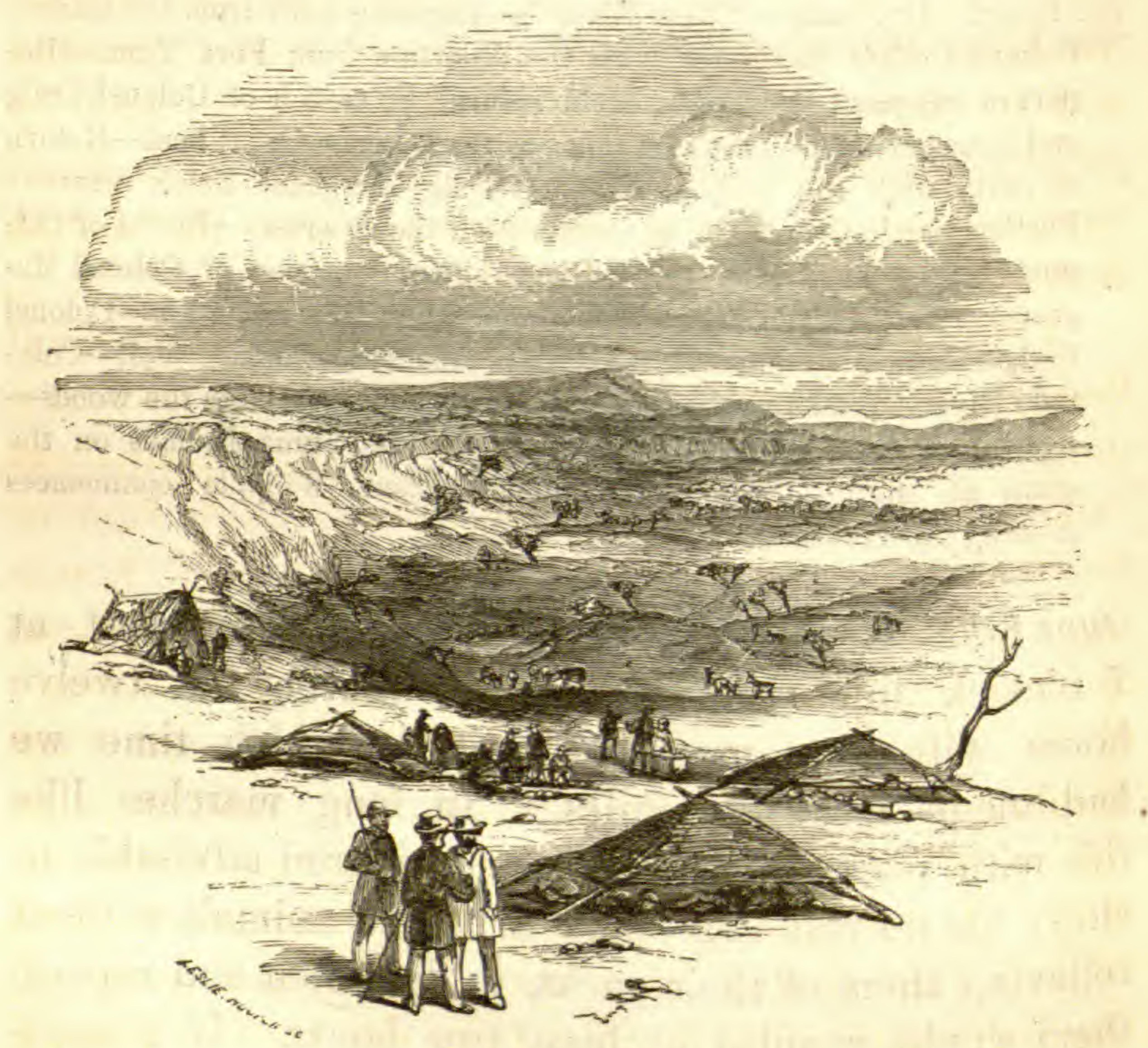

Well at Alamo Mucho.

far as the eye can reach on every side, except on the south-west, where a chain of mountains appears some 
thirty or forty miles distant. The undulations are few and slight. Near our camp was a steep bank about sixty feet high, extending for miles, and descending to a great depression or basin, which appears to have been the bed of a lake. It was in this bed that the wells or pits were sunk from which we obtained water.

About twenty-five miles back from this place we crossed a ravine or arroyo some twenty or thirty feet wide, and about ten feet below the surface of the desert, that forms the bed of what is known as the "New River." Three or four years ago, this ravine was filled with water, as well as a large basin connected with it. The water suddenly appeared here, and by passing emigrants was hailed as a miracle and direct interposition of Divine Providence, like the manna furnished to the Israelites of old.

This phenomenon is now well known to proceed from the Colorado River, which some years rises to a great height, overflowing its banks and the adjacent valley, and sometimes running back through lagoons and depressions in the desert for many miles. It was one of these great risings of the river that caused the sudden appearance of the mysterious "New River" of the desert, which remained two years, and then dried up. By similar inundations the great basin at Alamo Mucho has doubtless been, and may again be, filled. I was told by persons in California who had crossed this desert, that they had found pools of brackish water several miles from the road. These I presume to be deeper basins, where the water stands longer than in the "New River" or the dry basins passed by us. 
On the table-land or plain of the desert the vegetation is scanty, consisting of dwarfish mezquit and larrea. In the basin near us were patches of grass, which, with the young twigs of the mezquit bushes, formed the food of our animals. In certain portions of the desert it is extremely annoying to travellers when the wind blows, as clouds of sand then fill the atmosphere. When one of our parties crossed it in January, they were overtaken by one of these storms, from which they suffered greatly, particularly as their animals had perished, and they were forced to traverse it on foot.

Within two hours after my arrival, others of the party who were mounted came in, and among them Mr. Malcolm Seaton, who reported to me that about break of day the train had fallen in with the two deserters of whom Lieutenant Sweeney was in pursuit; that Colonel Craig, having at once recognised them by their dress and muskets, spoke to them, and asked them where they were going. They replied, to Vallecito. The Colonel told them he knew they were deserters from Fort Yuma, and advised them to return with him. After parleying a while, they told him they would not return; that they were desperate, and would shoot any one. who attempted to arrest them. Colonel Craig called for Sergeant Quin, of his command, and Sergeant Bale, the non-commissioned officer sent with the men furnished by Colonel Magruder. Mr. Seaton then left, under the impression that Colonel Craig would succeed in persuading the deserters to return with him. Besides the soldiers with the train, there were twenty or more men on whom the 
Colonel could have called, had he deemed their aid necessary. As the wagons began to lag, Mr. Seaton hastened on to camp.

About an hour after, Sergeant Quin rode into camp, his hat gone, and in a great state of excitement. He stated, that soon after he and Sergeant Bale had left the train, according to Colonel Craig's orders, they came up with the two deserters; whereupon the latter halted, and declared they would go no further, but must settle the business on the spot. Colonel Craig again expostulated with them, and used every argument to induce them to surrender themselves, and return with him to Fort Yuma, but in vain. The Colonel told them who he was, and said that, if a return to the Fort was so repugnant to them, he would endeavor to have them assigned to his command, in which event they might accompany the Commission. He then dismounted from his mule and handed his revolver to Sergeant Bale, at the same time throwing off his sabre. Thus disarmed, he approached the deserters, showing that he intended no violent measures, and believing that when he pictured to them the difficulties before them in crossing the desert, they would yet consent to abandon their desperate undertaking.

At this moment, the Colonel's mule, being without his rider, moved off, and had got some fifteen or twenty yards, when the Colonel directed Sergeant Quin to stop him. He did so, and had thereby separated himself from the Colonel and Sergeant Bale, when he heard the report of muskets, and looking 
round, saw Colonel Craig stagger and fall. The next moment he saw Sergeant Bale rapidly discharging his revolver at the deserters, his mule at the same time prancing about; when presently both of them fell. He immediately advanced in the direction of the Colonel; but before he had got many steps, the deserters rushed towards him, discharging a revolver which they had taken from Bale. Believing that both the Colonel and Sergeant Bale were killed or overpowered, and seeing but little chance for himself against too armed and desperate men, he put spurs too his horse, and made his way as fast as possible to my camp.

As soon as the wagons came up, I ordered an ambulance to be prepared to return with a party in search of Colonel Craig and the missing sergeant, who, I hoped, might yet be found alive. As the mules had now come nearly fifty miles without rest, food, or water, they could not be immediately sent back. Six of the best, however, were at once selected, and a good feed of oats given them. Bedding, clothing, water, and provisions were put in the ambulance, and the whole placed under the charge of Dr. Thomas H. Webb. It was two o'clock in the afternoon before the party could be got off, Lieutenant Whipple and several others accompanying.

From the information given by the party with the train, the encounter with the deserters took place full thirty miles from our camp. To retrace their steps this distance, with our weary animals, journeying beneath an overpowering sun, would require the remainder of the day, and a good portion of the night; yet I deemed it my duty to remain here, though we were 
in the heart of the desert, unprotected by a tree or bush, and exposed to a more oppressive heat than we had ever before experienced. As there was but little grass to be found, I caused the last of our corn and oats to be distributed to the animals, giving about two quarts to each.

Disasters seldom come alone; and to add to the misfortunes of the day, Jesus Ortiz, one of the teamsters, came in and reported that the tire of one of the wheels having come off, his wagon had broken down, and in this disabled condition he had left it twelve miles back. As his mules were perishing for water, he had hastened on with them.

After the animals had been watered and had grazed for an hour on the straggling tufts of grass and mezquit bushes, I dispatched a party back with an empty wagon, to bring forward the contents of the broken one. They returned during the evening, and reported that the fore wheel was completely demolished and past repairing, and that the wagon could not be used without another wheel. They also reported that they had seen seven Indians, who kept at a distance, but followed them for several miles.

In the afternoon, Mr. Johnson and an express rider arrived from Fort Yuma, and remained several hours to rest and water their animals. They were bound for San Diego. On hearing of the disaster to our wagon, they informed me, that about seven miles in advance we should find a wagon in good order, which had lately been abandoned, and with which we could replace our disabled one. This was very welcome news to me; for we were not in a condition to lose a 
wagon at this stage of our journey. I therefore sent out a party with mules in search, which soon after returned, bringing with them a very good vehicle. Disasters of this kind are of common occurrence on the desert, where mules give out or perish. One of our own wagons, in excellent order, was thus abandoned by the party which crossed here in January, and was soon after made a prize of. Two years previous to our crossing the desert, when a large number of emigrants went over it to California, I was told that more than a hundred good wagons, with harness, pack-saddles, and a vast quantity of camp equipage, were scattered along the road. Many of these were subsequently taken away by parties from the settlements, who came out for them with fresh animals; while others were broken up and used for fuel, or parts taken to restore the injured ones.

Such was the eventful day of the 6 th of June, with the heat at $108^{\circ}$ Fahrenheit. We pitched our tents, and rolled up the sides to catch a little air; but it was like the African siroceo, and seemed as though issuing from a heated furnace. I found a little bower, about three feet high, made of bushes, and covered with raw hides, into which I crept, and passed the day. This retreat had been constructed by Captain Davidson, who the week before our arrival had been here from Fort Yuma for the purpose of opening a well.

June 7th. In camp at Alamo Mucho. Remained as quiet as possible, moving only from my tent to my little bower. The men were occupied in enlarging the well, as it required much time to dip up the water, which was done with a bucket. The supply 
was barely sufficient for the demand, which, in consequence of the great heat, was constant both for man and animals. The thermometer stood at $106^{\circ}$.

At two o'clock in the afternoon, Dr. Webb and his party returned, bringing with them the dead body of Colonel Craig. They did not reach the scene of action until nearly ten o'clock at night, owing to the heaviness of the road, and the wearied condition of their animals. They then had much difficulty in finding the body, it being more than a mile from the spot to which they had been directed by the sergeant. After dividing, and searching in various directions, they formed a line from the road, placing men at such distances from each other that the intervening spaces could be carefully observed. In this manner they at length met with tracks, which finally led them to a spot where the Colonel's loose riding coat was found. Soon after they came to his hat, and finally to his corpse, which was discovered extended on the ground, and carefully covered with a blanket: "The scene," says the Doctor, in his report to me, "was a sad and sickening one, and produced a strong sensation upon all present, and particularly on the Colonel's body servant. It was evident from appearances that the Colonel did not long survive the wound inflicted, or experience much, if any, severe suffering.

"The ground around was as undisturbed as though he had laid himself down to rest, and composedly gone to sleep. Had he lingered long in the exposed situation where he was, there being neither tree nor shrub to afford shelter, his sufferings, as the sun got high in the heavens, would have been extreme, 
independent of what he might have undergone from the wound.

"Not many feet distant," continues Dr. Webb, "we saw the dead body of Sergeant Bale's horse, which had been perforated by a musket ball. The sergeant was nowhere to be found. I became satisfied that he had left the ground, probably without being mortally wounded. He had evidently, previous to his departure, taken his own blanket from the saddle, and with it covered the remains of the Colonel; for men who would brutally nuurder a fellow being, it was not for a moment to be presumed would have the slightest regard for the appearance or protection of the mutilated relics. The corpse I caused to be carefully rolled up and placed in the ambulance; and at three o'clock in the morning we mournfully commenced our return march.

"After proceeding about ten miles on our way back, we noticed ahead of us a man reclining by the road side; and on reaching him, much to my satisfaction, he proved to be the missing sergeant.

"When he joined the Colonel, he was told the purpose for which he was summoned; and upon some inquiry being addressed to him, he stated that whilst ready to obey orders, from his knowledge of the desperate character of the deserters, he was confident they would not be taken without bloodshed. However, as already observed, the Colonel's feelings of kindness outweighed all apprehensions of danger, if he entertained any, and overbalanced all regard for selfprotection. Having completely disarmed himself, and lessened his security still further by sending his 
sergeant for the stray mule, one of the deserters (Corporal Hays) said to the other, 'Now is our chance, as there is only a man apiece;' whereupon they levelled their muskets, took deliberate aim, and fired. Hays, who shot the Colonel, was within five feet of him.

"The buck-shot from Condon's musket passed through the calf of Sergeant Bale's leg, the ball at the same time pierced the body of the horse which he was riding. He discharged two or three shots from the Colonel's revolver; but the prancing of the animal under the wound received, prevented true aim being taken. The horse almost immediately fell; and before the sergeant could disentangle himself from the trappings, the deserters caught hold of him, and wrenched away the revolver, but promised to inflict no additional injury upon him if he would remain quiet, which, under existing circumstances, he very properly engaged to do. He asked them to allow him to go to the Colonel; to which they did not object. They inquired if the Colonel had not some brandy with him. $\mathrm{He}$ replied; probably not, the Colonel not being a drinking man. However, they went to the body ere life had left it, and searched, and probably rifled, the pockets, as some small articles known to belong to the Colonel have not since been found.

"They then turned in pursuit of Sergeant Quin, discharging several shots at him, their object probably being to obtain the two mules. Quin, as already remarked, effectèd his escape with his own animal; but they secured the Colonel's. Both mounted it, and made directly for the mountains." 
For the finale of this melancholy affair I refer the reader to the accompanying note.*

* While the party were engaged in searching for Colonel Craig and the Sergeant, the express rider from Fort Yuma, on his way to San Diego, overtook them; which gave Dr. Webb an opportunity to send intelligence to that place, Vallecito, Santa Isabel, etc., etc., relative to the probable fate of Colonel Craig, in order that suitable measures might be taken to apprehend the deserters, should they present themselves there.

As soon as the news was received by Colonel Magruder, commanding at San Diego, he sent expresses to the various military posts and settlements, and aroused the Indians in Southern California, whereby he was enabled to establish a cordon across the country with a view of intercepting the murderers. The routes are so few, and the watering places so well known, that this object was easily attained. A reward, too, was offered the Indians, to induce them to thoroughly scour the country and prevent the escape of these men. It was not many days before a party of Indians engaged in this duty discovered two men with muskets; and believing them to be the murderers, all but two concealed themselves. One of these Indians was a chief, an exceedingly shrewd man, who desired to secure his prize without bloodshed. They, therefore, professed friendship for the men, and proposed to buy their muskets; an offer which the deserters gladly accepted, money being more important to them now than weapons. They were accordingly paid eight dollars each, and the cunning Indians thus became possessed of their arms. But one of the deserters being still in possession of a large revolver, it was necessary to disarm him of this before they could make sure of their prisoners. The Chief, therefore, manifested a great curiosity as to this singular weapon, and asked the man to let him examine it. Not suspecting the object of the Indian, who he supposed had never seen a revolver before, he unhesitatingly handed it to him for inspection. The Chief no sooner had it in his possession, than he stepped back and presented it to the breast of the deserter. The two Indians now gave the war-whoop; whereupon the rest of the party, numbering some twelve or fourteen, sprang from their hiding-place, and at once surrounded the prisoners.

They were conducted to the Mission of San Diego, and there surren- 
I was desirous to take the body of Colonel Craig to Fort Yuma for burial with military honors; but Dr. Webb pronounced this impracticable, owing to its rapid decomposition, as it would require two, if not three, days to reach that place. A deep grave was, therefore, dug in the desert near our camp, and a few rods from the margin of the great basin. At sunset, when the mules had received their packs, the wagons had been loaded, and the party were ready to move, a procession was formed, and the mortal remains of our excellent and much beloved friend, borne upon a cot by four soldiers, were consigned to his lonely grave. I read on the occasion the burial service of the Church of England. There was neither mound, rock, nor tree to mark the spot; a dreary solitude reigned around us, uninterrupted by a single object, save the animals and men belonging to the party. Even the wind had died away; and in the silence that accompanied our sad and solitary rites, Wolfe's beautiful lines on the burial of Sir John Moore involuntarily suggested themselves to every mind.

In order that the spot might be identified, a wooden cross was erected at the head of the grave, on which was inscribed:

\section{"LIEUT. COL. L. S. CRAIG, U. S. A.}

Died June 6, 1852."

dered to Colonel Magruder. After much delay, arising out of the question whether they should be tried by a military court martial or by the civic courts, they were finally tried, condemned, and hanged at San Diego, in presence of a vast multitude, among which were many Indians. The murderers were both Englishmen, and are said to have been deserters from the British army. 
Colonel Craig was an officer of whom the army and the nation had just cause to feel proud. He entered the army from the love he felt for a soldier's life, and without the advantages which a military education at West Point is supposed to confer. Yet such was his devotion to his profession, such the skill he acquired in it, and such the bravery shown by him when called to serve his country, that he soon attained the rank of captain, and was breveted Lieutenant Colonel for gallant service rendered at the battles of Cherubusco and Molino Del Rey. His whole soul was absorbed in his profession, and he spared no pains to render his command skilful in the use of their arms. He was always most punctilions in the discharge of duty; and however much his command was reduced by sickness or absence, he kept up his daily drills and parades with as much rigor and discipline as though an entire regiment were under his charge. Towards his men he manifested the interest of a father as well as that of a commander, and was greatly beloved by them in return. During the stay of the Commission at San Diego, when nearly all the officers attached to it took advantage of the necessary detention to visit other parts of California, he remained in camp with his men, nor did he leave them for a single day, even when desertion had reduced their number to five. It was a source of deep mortification to him, that men who had followed him through the severe campaigns of the Mexican war should desert him here, for the sake of pecuniary advantage. His genuine kindness of heart, honesty of purpose, and rigid adherence to duty, had won for him 
a large circle of devoted friends among civilians, as well as among his brother officers.*

At 8 o'clock in the evening we left camp, our hearts filled with sadness. Passed several wagons in good condition which had been abandoned by their owners, among them some large ones, which bore the letters U. S., showing, as we were afterwards told was the case, that they had belonged to government trains, the mules of which had perished. The whitened bones of animals marked the road in many places, terrors to passing emigrants. At twelve o'clock the moon arose, before which time we had much difficulty in finding the road; for so little was the desert travelled, that it was only by taking a star for our guide that we managed to keep in the right direction. I rode a mule all this night, and found it no easy matter to retain my seat in the saddle. Such, in fact, was the case with many

* I eannot refrain from relating an anecdote to show that Colonel Craig's kindness was extended to animals as well as his fellow beings. In our various marches across deserts, our animals often suffered much for want of water, and in consequence of the intense heat, required great attention. Notwithstanding the Colonel had men to take care of his horse, so fearful was he that he might not receive proper care, that at the close of a march he always accompanied his horse to the water (when it was to be had), and, after seeing the animal well washed and cleaned, would himself give him the luxury of a good sponging. The result was, his horse was always in fine condition, and without the ailments incident to constant use under the saddle in a hot climate. On one occasion when we made a long march, and encamped without water for the animals, and but a scanty supply for ourselves, a little was spared to the officers to wash themselves in the morning. The Colonel made a request to each of them, to refrain from using soap, that he might have the water they had used for his horse; by which means he collected a gallon for the use of his favorite. 
of us; and some of the party were so much overcome with drowsiness, that fastening their mules to bushes, or to their legs, they lay down on the desert, and stole a few minutes' sleep. The road continued very sandy, and consequently very fatiguing to our jaded animals, which had had but little food for the last four days. As there was no necessity for keeping with the wagons, I hastened on with the pack-mules and several men who were mounted, and reached the next watering place, known as Cooke's Well, at six o'clock in the morning, having been ten hours in the saddle. The distance from our last camp, was twenty-eight miles. After some time, finding that neither the wagons nor my carretella (small wagon) came in, I sent back some of the pack-mules to their aid. But even with this assistance, they did not come up until three or four hours after my arrival,

June 8th. At Cooke's Well. On reaching here this morning, we were so much fatigued that we did not pitch our tents, but threw ourselves down on the bare sand beneath some mezquit trees, and were soon lost in sleep. The water obtained here was from a hole dug in the earth some ten or twelve feet deep, in a place about twenty feet lower than the general level of the desert. It had to be dipped up in a bucket, and passed to a second person midway towards the top, who emptiedit into a basin on the surface, from which the animals drank. There was no grass here, but a thick growth of mezquit trees about twelve feet high, with very wide spreading branches. These were loaded with beans, on which our half-famished mules fed freely, for it was all we could give them. As these trees afforded a 
good shade, we remained beneath them during the day, which was as hot as before, the mercury ranging as high as $106^{\circ}$. But even with this heat, we deemed it a great luxury to be surrounded by such a delightful grove, after the total barrenness and desolation with which we had been surrounded for so many days. We had now left the plateau of the desert, and were upon the bottom-land with an alluvial soil. The party were so much exhausted with the last night's march, and the exciting events which preceded it, that I determined to remain quiet during the day, and not leave until the moon arose.

June $9 t h$. Left camp at half-past one in the morning, when the moon afforded a feeble light, without which it would have been impossible to find our way. The whole party kept close together, with a sharp look out; as we were now in the country of the Yuma Indians, with whom the Americans are at war. We learned too, from the express that passed us on the desert, that bands of these. Indians had been seen here two days before. Our journey was through a bottom filled with mezquit and cotton-woods; and from the great quantity of fallen trees of a large growth, one is led to believe that the whole bottom, from the point near Cooke's Well, which is fifteen miles from the river, must have been covered with water within a few years, and for a considerable time too, to cause such a destruction of timber.

For several miles after leaving the desert, and between that and the bottom land, there ran along our left a great sand-drift, or belt of moving sand, which extends far to the northward, and seems to be gradual- 
ly encroaching upon the bottom. It is about forty feet high, and in its progress swallows up the largest trees of the valley. It is so loose as to be impassable for animals, and very difficult for men.*

At 6 o'clock, our eyes were greeted with a sight of the great Colorado River, twelve miles below its junction with the Gila, at a place called "The Algodones," and soon after, we halted upon its bank It was much swollen, and rushed by with great velocity, washing away the banks and carrying with it numberless snags and trees. The water, though sweet, was much charged with mud, giving it a dark reddish appearance, whence its name. We had seen no stream since leaving the Mississippi (the rivers in Upper California excepted) at all comparable, in point of size, to the Colorado.

After watering the animals, I thought it best to proceed a few miles further. Lieutenant Whipple, who had been here before, and was familiar with the country, said we should find a grove of.mezquit trees, which would furnish food for the animals; for the valley of the Colorado affords no grass. Near this spot is a rocky spur of the adjacent hills, called "Pilot Knob," extending to the river, where we found the remains of a stone fort built a few years before, by a party of Americans, who established a ferry here. On this ridge was one of the iron monuments erected by the Boundary Commission the year before, which the

* Since my return, I have been informed by Major Andrews, U. S. A., who was stationed at Fort Yuma at the time of my visit, that this belt of sand is about four miles in width, and from twelve to fifteen in length. 
Yumas had already overthrown. The road ran along the river's bank, which, as well as the bottom-land, was filled with a dense forest of willows, cotton-woods, and mezquit. But we had not proceeded far before our progress was suddenly arrested at a place where the road was entirely washed away. We now retraced our steps a short distance, but found it impossible to get along with the wagons without first cutting a path. All our axes were therefore brought into requisition; but as much time appeared to be necessary to accomplish this work, and as the pack-mules could push through, Mr. Leroux led the way followed by Dr. Webb and myself. On reaching the spot selected by Mr. L. for the encampment, the mules were unpacked: we endeavored to lead them to the water, but found to our surprise that it could not be approached, in consequence of a high abrupt bank caused by the rushing waters of the Colorado. We accordingly saddled up again and pushed on towards Fort Yuma, which appeared a few miles in advance, the stars and stripes waving from the flag-staff first greeting our eyes through the dense foliage of the valley. When within a mile of the Fort, our further progress was stopped by a sluice which extended across the road, as broad as the river, and caused by its overflow. It seemed to run far into the interior, and to be passable only with boats. Perceiving a rude wigwam on the river's bank, the Doctor and myself took possession of it, and, hitching our mules to trees, lay down to rest ourselves; for it was then noon, and we had been in the saddle since one o'clock in the morning.

An hour after I was aroused from my sleep by a 
messenger from Major Heintzelman, commanding at Fort Yuma (whose sentinels, ever on the watch, had discovered our approach some hours before), inviting me to the Fort, and sending a scow with men to take us across the sluice. Dr. Webb and myself availed ourselves of the invitation, the rest of the party with the wagons not having yet come up. We proceeded on foot, and, after crossing the sluice, were met by several officers, who conducted us to the Major's quarters. We received a warm reception from them all; for visitors and countrymen are an exceeding rarity in this out of the way spot. A few emigrants, it is true, pass on their way to California; but they seldom reach here before August. Major Heintzelman invited me to take up my quarters with him, while Dr. Webb remained with Lieutenant Paige. The other officers we met here were Major Andrews, Captain Davidson, Lieutenants Curtis, Hendershott, Sweeney, and Bond, and Dr. Milhau.

The train and the remainder of the Commission encamped on the opposite side of the sluice, my wish being to cross the Colorado as soon as possible, which could be done as easily from that place as from the Fort.

June 10th. The officers of the Commission crossed the sluice this morning and came up to the Fort, where they were all kindly received and hospitably entertained.

I now commenced arrangements for crossing the Colorado, which, in consequence of the great rise in its waters, and their increased rapidity, was a matter of much difficulty and risk. There was nothing to 
cross in but a small and indifferent scow, which could carry but one wagon at a time, and but a small number of animals. The entire number to be ferried over were one hundred and thirty-six mules and horses, twelve oxen, and seven wagons with their contents. Anxious that Lieutenant Whipple should not be detained a moment with the survey of the river Gila, which was to commence at its junction with the Colorado, and be carried to the point where the work was suspended in January, I directed his party to be moved over first, and as soon as the scow, which needed some repairs, could be made ready. The thermometer stood to-day in the shade at the Fort, where there was a current of air, at $105^{\circ}$; yet, as we were now quiet, it did not seem more oppressive than when in New York at $90^{\circ}$.

June 11th. The startling news was brought me this morning, that the Yumas had entered our camp the preceding night, and stolen fifteen of our animals, including my valuable horse, the same that had been ridden by Mr. Gray in his journey across. He was the finest I had seen in the country, and had been brought to New Mexico from Kentucky. But this was trifling to the loss of so many riding and packmules, as it was impossible to replace them here. There had been two men on guard during the night; but they knew nothing of our loss until the animals were missing in the morning, when the footprints of the Indians became visible. The animals, which had all been staked, or tied to trees, seemed to have been loosened and led away without the least noise by these accomplished marauders. I gave orders to take the trail and set off in pursuit, not with the expectation of 
overtaking the Indians and recovering our property, but with the hope that, in the hurry of escape, some of the mules might have got away, which we might recover. But the pursuit was not attended with success. The parties returned after following the trail six or eight miles, which was as far as they could go with safety; as the enemy might be lying in ambush, and overcome their pursuers when little expected. Experience has shown the utter futility of pursuing well mounted Indians on such an occasion, after they have got three or four hours the start; for they urge on their animals to the utmost speed. Mr. Leroux, who is an old trapper, guide, and hunter, and whose life for twenty-five years has been spent in New Mexico, has been often engaged in fights with the Indians, as well as in pursuing them to recover stolen animals. He says the only way to overtake them in such cases is, to take provisions for several days, and on first setting out in pursuit, not to hurry the animals, but follow the trail at a steady and moderate pace while daylight lasts. At night stop and rest; and as soon as daylight appears, continue the pursuit in the same manner, taking care not to overwork the animals. By thus continuing the chase, the third day will in most cases bring you up with the enemy; whose proximity can be ascertained by any experienced hunter, from the freshness of the trail, the manure of the animals, etc. It then becomes necessary to proceed with caution, and with scouts ahead. When the Indians are discovered, the pursuers keep at a distance concealed, and govern themselves by circumstances, whether to make an open attack, or wait until they have encamped 
for the night and then surprise them. When Indians find themselves pursued, they run for several days, and then scatter, so that it is impossible to catch them; but if they suppose they are not followed, they stop at the end of one or two days.

Lieutenant Whipple commenced crossing with his party this morning. It had been the practice to swim animals across the river; but it was now so swollen and rapid, as to preclude the possibility of so doing. They had therefore to be ferried over in the scow, a few at a time. The wagons were unloaded and taken over empty. Even with the aid of all our men, the progress in crossing was slow; and on several occasions the scow, failing to reach the landing place on the opposite bank, was swept away by the current between two and three miles down stream, before a landing could be effected. It had then to be towed up again with much labor, until it reached some nook or low spot in the bank where the animals could be landed. In this manner several hours were sometimes required for a single crossing. 


\section{CHAPTER XXVIII.}

\section{FORT YUMA AND THE ADJACENT COUNTRY.}

Orossing of the Colorado continued-Description of Fort Yuma-The Colorado and Gila Rivers-The adjacent country-Rich alluvial bottoms -Facility of irrigation-Ruins of the old Spanish Missions-Difficulty of supplying Fort Yuma-Plan for surveying the head waters of the Gulf of California-Frustrated by Colonel Graham-Discovery of the Colorado in 1540 by Alarchon-Later voyages-Difficulties in navigating the Colorado-Attempt of a steamer to ascend the river-Its velocity and height-Fort Defiance-Massacre of Dr. Langdon and his party by the Yumas-Indians of the Colorado-Early tribes not identified-The Yumas-Cocopas-Mohavis-Extent of Alarchon's voyage in 1542Fathers Kino, Font, and Garces.

June 12th. At Fort Yuma. Lieutenant Whipple continued crossing his party over the Colorado, and commenced the survey at the mouth of the Gila.

An express was sent by Major Heintzelman to San Diego with the particulars of Colonel Craig's death, in order that additional efforts might be made to arrest the murderers.

Colonel McCall, Inspector General U. S. Army, arrived to-day, accompanied by Lieutenants Bond and Gardiner, to inspect the troops at Fort Yuma.

June 13th. In accordance with the orders of Gene- , ral Hitcheock, Major Heintzelman detailed Lieutenant 
G. W. Paige, with twenty-seven men as an escort, to accompany the Commission to the Pimo Villages. They commenced crossing the Colorado to-day; but, owing to the swiftness of the current, were so unfortunate as to swamp their boat, which was laden with provisions. Excepting this accident, the parties of Lieutenants Whipple and Paige got safely over, and encamped on the margin of the river.

June 14th. Sent the cattle over to-day, a more troublesome task than was expected. As they refused to lie down in the small scow, they were lassoed and thrown, and then drawn into it by their feet with mules. Qnce, just as the scow reached the opposite bank, one of the cattle broke loose, leaped into the river, and swam back; the current carrying him so far down, that he escaped into the woods, and could not again be found.

June 15th. While the parties were still engaged ingetting across the river, I took occasion to make repairs on the wagons. My small wagon, in addition to the axle-tree, had given out in other places. An examination showed plainly that it was an article "made to sell," and not to use. Every portion was found defective, all flaws being carefully covered up with paint. With no other conveyance than this for our long journey, Dr. Webb and I had a poor prospect ahead. The Doctor's riding mule was among the number stolen. The wagon we had picked up on the desert was found to be loose in many parts, requiring repairs. In consequence of the loss in horses and mules that we had sustained by the Yumas, we were obliged to add some hundred pounds to each 
of the wagons, and an additional weight to each packmule; besides which I nearly filled one of the wagons belonging to the escort. We should thus have to resume our journey with every wagon and mule loaded to the utmost, and without a single spare animal to replace any that might be broken down or lost.

In repairing injuries to our wagons, every facility had been furnished me by Major Heintzelman, and by Major Andrews, United States Quarter-master at Fort Yuma. For their aid also in crossing the river, and for many acts of kindness extended by the officers here to myself and the gentlemen associated with me in the Commission, I take this occasion to express my acknowledgments.

My cook ran away last night; which event, though it gave me the use of one more mule, deprived me of a functionary whose services could not easily be dispensed with.

June 16th. Fort Yuma stands upon a rocky hill at the junction of the Gila and Colorado Rivers, and on the north-west angle of the bank of the united stream. The Colorado comes from the north, and, where it receives the Gila, is about five hundred yards wide. A bend, which the Gila takes about fifteen miles from its mouth, makes it come from the south to join the Colorado. The united stream first takes a westerly course, forcing itself through a cañon in a chain of rocky hills seventy feet high, and about three hundred and fifty yards in length. After sweeping around some seven or eight miles, it again assumes a southerly direction; and after a very tortuous course for about a hundred and thirty miles, it empties into the Gulf of 


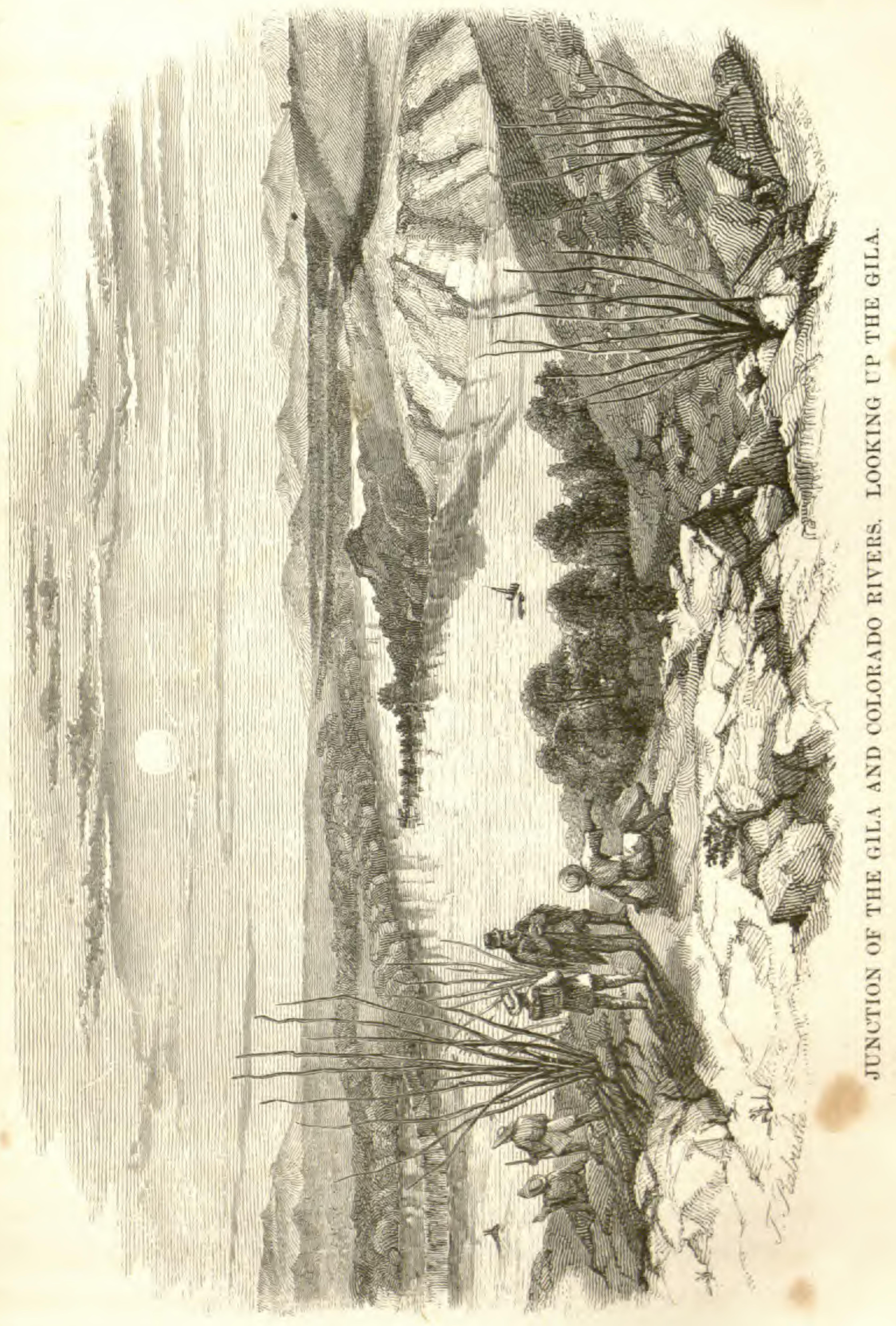



California. The rocky hills extend four or five hundred yards north of the junction, and between two and three miles to the south of it. Beyond the latter termination rises the great plateau, or desert. The Colorado flows through a bottom or valley from two to four miles in width, thickly covered with cotton-wood and mezquit; beyond which is the desert, from sixty to seventy feet above the valley. As far as I could judge, from a bird's-eye view taken from Fort Yuma, I should think the bottom-land of the Gila was from three to four miles wide near the junction. The portion towards the river is thickly covered with cotton-wood, and with willows on the margin, while that further back has nothing but mezquit. A fine panoramic view is presented of the whole country, from the summit of the hills on which the fort stands. Looking northward, the course of the Colorado can be traced for about fifteen miles, when it suddenly winds around the base of a mountain ridge, and diverges to the north-west. In this direction the view is most exten: sive. Ridge after ridge of mountains is seen, one rising above and beyond the other, for a distance of about eighty miles. The higher chains assume the most varied and fantastic shapes, resembling cupolas, minarets, pyramids, domes; chimneys, etc. One of these singular summits is called the "Chimney Rock;" and from Fort Yuma is the most striking object in the landscape. It is said to be fifteen miles distant in a direct line, and about thirty following the course of the Colorado.

On the east of the Colorado is the delta of the Gila. How far this extends back cannot be seen, the trees 
shutting off the view of the desert. On the north and west the line of the desert is perceived at a distance of about three miles, this line of view being interrupted by the isolated mountain called "Pilot Knob." At the south, short isolated ridges of mountains are seen at a great distance. Mr. Pratt took a panoramic view of the country here, which will convey a better idea than any description I can give.

The Gila was not over fifty yards wide at its mouth; but its width varies much in different seasons, being influenced by the rise of the Colorado, as well as the state of its own waters. The Colorado was now so high as to cause the Gila to flow back full fifteen miles. The Gila was still low, and, except near the junction, but a diminutive stream. It is doubtful whether it can ever be navigated, except at its floods, and these are by no means regular. At such times flat-bottomed boats might pass to the mouth of the Salinas, near the Pimo villages.

The singular bend which the Colorado takes after it receives the Gila, gives to the United States both its banks for the distance of seven miles from the junction, or to the point where it resumes its southerly course. This arises from the stipulations of the fifth article of the treaty with Mexico defining the boundary line, which says, that "a straight line shall be drawn from the middle of the Rio Gila, where it unites with the Colorado, to a point on the coast of the Pacific Ocean, distant one marine league due south of the southernmost point of the port of San Diego." The land on the southern bank of the Colorado which we thereby obtain is of little value for agricultural purposes; but should a considerable 
town be built where Fort Yuma now stands, which is altogether probable if a railway should ever pass here, it will be an advantage to the United States to possess both the banks of this river for so long a distance.

The bottom-lands of the Colorado below the junction bear the traces of former cultivation, acequias being seen in many places. Whether this cultivation was by the Spaniards while they had a mission here towards the close of the last century, or whether by the Indians at an earlier period, is not known. But from the large trees, both erect and fallen, which now cover the bottom, even where the ditches appear, the cultivation, in my opinion, was anterior to the occupation by the Spaniards. I have never seen bottom-lands of this character which might be more easily irrigated. The banks of both rivers are here low; and the descent near Fort Yuma would permit the opening of a canal a few miles above, which would irrigate the whole valley. When a stream is far below the level of the bottom-land, and its fall but slight, it is necessary to make the canal so long that the expense will not warrant the undertaking. The active and enterprising commander here intends bringing these rich lands into cultivation as soon as he has completed the quarters for the men, upon which he is now engaged. Should he do so, he will be able to furnish his command with what they now most stand in need of-a good supply of vegetables.

Close by Fort.Yuma the traces of the old Spanish Mission buildings may still be seen. These consist of partly demolished stone walls of small buildings; though a few years since the walls of a church were also

voL. II.-11 
visible. At the time of our visit these had been removed, and used for building the barracks. There were two hundred soldiers, artillery and infantry, here, under the command of Major Heintzelman. The officers and men were living in tents, covered with sheds made of branches to protect them from the sun. The post was established the year previous, but, not receiving the usual supply of provisions, had been abandoned for several months. The command was as comfortably situated as the nature of the place and its inaccessibility would allow; but long deprivation of fresh provisions and vegetables had engendered the scurvy among the soldiers.

The fort had heretofore been supplied by land from San Diego, at an enormous expense; but a partially successful attempt had just been made to supply the place by water. A vessel loaded with stores was sent up the Gulf of California, and succeeded in getting some distance up the river; but owing to the strong current she could not reach the fort. Wagons and scows were therefore sent down to bring up the provisions, a labor attended with nearly as much risk and expense as bringing them all the way by land from the coast. It was in contemplation to procure a small steamer for fetching the supplies from the head of the gulf. Such a vessel could meet with little or no difficulty in getting up, and could also be used to advantage in exploring the Colorado above the fort.

In connection with the survey of the river Gila, it was my earnest desire to explore and survey that portion of the river Colorado which extends from the point where it receives the Gila to the Gulf of Califor- 
nia, a distance now understood to be about one hundred and thirty miles, by the sinuosities of the river.

With this view, I recommended to the Hon. Alex. H. H. Stuart, Secretary of the Interior, that Lieutenant I. G. Strain, of the Navy, an officer attached to the Commission, should be directed to take the four iron boats belonging to it, and survey the head waters of the Gulf of California, and the river Colorado to the mouth of the Gila. Lieutenant. Strain accordingly proceeded to Washington, and submitted to the Hon. Secretary of the Interior the plan embraced in the following letter:

"Washington, D. C., October $31,1850$.

"Sir :-In reference to the duty to which J. R. Bartlett, Esq., the United States Boundary Commissioner, requested I should be assigned, I have the honor herewith to submit two projects-one of which, I hope, may merit your approval.

"In assigning me to the command of the flotilla, composed of four boats belonging to the Boundary Commission, it was suggested thatin consideration of the important results which must accrue to the country from the early exploration and survey of the river Colorado below its junction with the Gila, as well as that of the upper waters of the Gulf of California, without which the former would be nearly valueless, - the Navy Department might be induced to detail the requisite number of seamen for the management of the boats; which would thus materially lessen the outlay of the fund appropriated for the prosecution of the Boundary Survey. No men could be obtained better adapted to this duty than seamen.

"The importance of the examination proposed by Mr. Bartlett, is obvious to every one aequainted with the present state of our new territories on the Pacific, while the peculiar nature of the case does not place the duties in any particular department of the government. The examination of the upper part of the Gulf, and that portion of the Colorado between its mouth and junction with the Gila, cannot be considered as pertaining to the 'Coast Survey,' as it is entirely embraced in the 
territory of the Mexican Republic; yet the treaty of Guadalupe Hidalgo, giving to our citizens free ingress to the valleys of the Gila and Colorado, through the Gulf, which is the only route available for the purposes of commerce, makes an early examination of equal importance to that of any portion of the coast of our newly acquired territories.

"Could the sympathies of the Navy Department be enlisted in favor of this examination, and crews assigned to the boats already built for the use of the Boundary Commission, the service could be effectually and economically performed.

"If, however, the government should not deem such measures desirable, I would respectfully suggest another project, which, though it would not possess all the advantages of that already suggested, would prove the most economical mode of prosecuting the explorations and surveys with the funds which are now, or may be placed hereafter, at the disposal of the Interior Department and the Boundary Commissioner.

"The second project is as follows: That the four boats should be dispatched, in charge of two passed midshipmen and five seamen, in a steamer which will sail about the first of December to Mazatlan; and that I should be authorized to proceed to El Paso, where the Commission will be compelled to winter, and obtain from the party at that point a sufficient number of men to man the boats, and proceed with them overland to the port of Guaymas, on the Gulf of California, to which points the boats will be conveyed from Mazatlan in a coasting vessel.

"From Guaymas we could easily ascend the Gulf in our boats to the point where it would be desirable to commence our examinations.

"The advantage of this plan will be its economy; as it will require but a few persons, who may be obtained from the navy, in addition to those who are already drawing pay and subsistence from the government. At present, the number of men forming the main body of the Commission is greater than can be advantageously employed; while the scarcity of provisions at El Paso, owing to the drought of last season, will make their subsistence enormously expensive during the winter. The horses and mules now belonging to the Commission, will have to be sold at $\mathrm{El}$ Paso, or sustained at a heavy expense during the winter: and by employing a portion of them to transport the party to Guaymas, no additional expense will be entailed upon the Survey, as they and the men can be more economically subsisted on the journey than at El Paso. 
"The adoption of this plan would incur no additional outlay commensurate with the object in view, which can never be attempted under more favorable auspices. My opinion as to the superfluity of men now with the Commissioner, you will find supported by letters now in your department.

"My views relative to the great expense of subsisting a large party of men and animals at El Paso during the ensuing winter, will be corroborated by Colonel J. Rogers, special Indian agent, who is familiar with the present state of the country; while the opinions which I have expressed, relative to the importance of the explorations proposed by $\mathrm{Mr}$. Bartlett, you can assure yourself of by reference to the accompanying condensed narrative, which, you will observe, confirms the opinion published by the Hon. T. Butler King as to the fertility of the valley of the Colorado, and its future importance to our country.

"To display the feasibility of a journey from El Paso to Guaymas, I have also inclosed a narrative of a journey through that region.

"Very respectfully your obedient servant,

"I. G. STRAIN,

"Lieut. U.S. Navy, attached to Boundary Survey.

" Hon. Alex. H. H. Stuart,

Secretary of the Interior."

The distinguished gentlemen then at the head of the Interior Department, ever anxious to promote the cause of science, and particularly where the acquisition of "knowledge of our newly acquired possessions was concerned, thought favorably of my suggestion, and the plan of Lieut. Strain, and, as I was informed, would have permitted that officer to carry it into effect. Before, however, he had an opportunity to do so, Brvt. Lt. Col. Graham had been detailed as Principal Astronomer, \&c., to the Commission, and Mr. Stuart deemed it proper to refer Lieutenant Strain's letter and papers to him. The plan, strange as it may appear, was objected to by Colonel Graham. In reply, he remark- 
ed that it was "an injudicious arrangement, and ought to be dispensed with;" that, although "by the late treaty, our citizens have the right of ingress and egress through the Gulf of California," we might "give offence" to Mexico by the proceeding; and that the expenses attending this Survey could not be legitimately met from the appropriations granted by Congress for the Survey." But the last and most extraordinary assertion is, that such an examination as Lieutenant Strain proposes, in connection with the Survey, should not be intrusted to a naval officer. " "I have been frequently engaged on surveys for the last thirty years," says Colonel Graham, "of rivers, harbors, and portions of the sea-coast, and always found the best persons to manage the boats employed on such service, were the engineers and surveyors charged with, and responsible for, the execution of the duty." Colonel Graham's letter to Secretary Stuart, embracing his objections, will be found in Appendix E.

As the defeat of my plan has been a serious injury both to government and to commerce, I shall show that, both by the treaty with Mexico and my instructions, I had authority to make the examination referred to.

The sixth article of the treaty of Guadalupe Hidalgo provides, that

"The vessels and citizens of the United States shall, in all time, have a free and uninterrupted passage by the Gulf of California, and by the river Colorado below its confluence with the Gila, to and from their possessions situated north of the boundary line defined in the preceding [Vth] article; it being understood that this passage is to be by navigating the Gulf of California 
and the river Colorado, and not by land, without the express consent of the Mexican government."

The United States government, knowing that opportunities would be presented, in the course of the extensive surveys intrusted to me, to acquire important geographical knowledge relating to the immense frontier along the line to be explored and surveyed, fully authorized me to seek such facts. In his instructions to me, the Hon. Secretary of the Interior says : "As the organization of the Commission under your charge has been made for the purpose of collecting information relative to the country contiguous to the boundary line, in addition to the running of that line, it is desirable that you should avail yourself of every opportunity afforded by your passage through the unexplored regions of Texas, New Mexico, and California, to acquire information as to its geography, natural history, \&c., when it can be obtained without retarding the progress of the Survey." " My duties required me to send boats to the mouth of the Gila to survey that portion of the river, as well as to carry provisions there for the surveying parties; and I should have been guilty of neglect had I not endeavored to take advantage of this opportunity to examine the upper part of the gulf, and that portion of the Colorado between its mouth and the junction with the Gila. A minute survey of the entire gulf, about which Colonel Graham has made calculations, was not contemplated by either Lieutenant Strain or myself. The great obstacle to the ascent of the Colorado is 
the tidal wave at its mouth, which has been noticed by all who have attempted to ascend it; and although the United States has been in possession of California six years, no official survey, exploration, or reconnoissance has yet been made of the head of the gulf, or of the river below the Gila. The want of this is my apology for giving some notices of the entrance of this river by its discoverer and subsequent explorers. *

As early as the year 1540, Fernando Alarchon, in a voyage to explore the Gulf of California, by order of Antonio de Mendoça, Viceroy of New Spain, discovered the mouth of the Colorado. It appears that "the pilots and the rest of the company" made serious objections to entering the river, and proposed that the fleet should return. "But," says the persevering navigator, in his letter to Mendoça, "because your Lordship commanded me, that I should bring you the secret of the gulf, I resolved that, although I had known I should have lost the ships, I would not have ceased for any thing to have seen the head thereof: and therefore I commanded Nicolas Zamorano, pilot major, and Dominico del Castello, that each of them should take a boat, and their lead in their hands, and run in among these shoals, to see if they could find out

* I should do injustice to Major Heintzelman not to notice his efforts to explore the Colorado below Fort Yuma. He was unprepared with instruments for an accurate survey; yet he did make a reconnoissance to ascertain the feasibility of getting his supplies up, which enabled him to lay down approximately the course of the river. I am indebted to him for a copy of this map, which is now in the hands of the engineers of the Commission, and is all the material they possess for making a map of this portion of the country. 
the channel whereby the ships might enter in; to whom it seemed that the ships might sail up higher (although with great travail and danger). And in this sort I and he began to follow our way which they had taken, and within a short while after we found ourselves fast on the sands, with all our three ships, in such sort that one could not help another; neither could the boats succor us, because the current was so great that it was impossible for one of us to come unto another. Whereupon we were in such great jeopardy that the deck of the Admiral was oftentimes under water ; and if a great surge of the sea had not come and driven our ship right up, and gave her leave, as it were, to breathe a while, we had there been drowned. And likewise the other two ships found themselves in very great hazard; yet because they were lesser, and drew less water, their danger was not so great as ours. Now, it pleased God, upon the return of the flood, that the ships came on float [floated], and so we went forward. And although the company would have returned back, yet for all this I determined to go forward, and to pursue our attempted voyage; and we passed forward with much ado, turning our stems now this way, now that way, to seek to find the channel. And it pleased God that after this sort we came to the very bottom of the bay; where we found a very mighty river, which ran with so great a fury of stream that we could hardly sail against it. In this sort I determined, as well as I could, to go up this river. And with two boats, leaving the third with the ships, and twenty men, myself being in one of them, with Roderigo Maldonado, treasurer of this fleet, and Gaspar de 
Castilleia, comptroller, and with certain small pieces of artillery, I began to sail up the river." *

We hear little more of attempts to enter the Colorado until those of the missionaries about the middle of the last century. In 1746, Father Consag made a voyage for the purpose of exploring the Gulf of California. He reached its head, and found the river. "At. the entrance," he says, "is a triangular island, which divides the stream into two arms, one in California, running northward, and the other on the opposite side, running north-west. The people went ashore, and found themselves between two rapid currents: one of the rivers ebb, and in the other the sea was flowing in with no less impetuosity, so that they had a very narrow escape." + He attempted to go up the Colorado; but the current was so rapid that the boats could not stem it, and having no ropes to tow them, the project of further exploration was abandoned.

The only attempt in recent times to enter the Colorado before the occupation of California by the United States, of which I have knowledge, is that of Lieutenant Hardy of the British navy. $\downarrow$ This gentleman was sent out by an English company connected with the pearl fishery in the gulf; and in the course of his explorations he visited the Colorado. He has given us a plan of the mouth of the river, accompanied by soundings; which bears every mark of correctness, with the exception of an error in laying down the river Gila. For this he mistook a small branch falling

* Hakluyt's Voyages, vol. iii., p. 425. London ed. of 1600.

† Venega's California, vol. ii., p. 308.

$\ddagger$ Travels in the Interior of Mexico. London, 1829, p. 320 . 
into the Colorado about ten miles up; or it may have been $a$ sluice filled with the rushing water from the tides of the gulf. This latter I think the more probable supposition. The Gila, as I have already mentioned, is known to enter the Colorado at more than a hundred miles from its mouth.

Lieutenant Hardy found two small islands at the mouth of the river, and entered by the western channel; where there was, at the narrowest point, but a single fathom of water, the width varying from ninety to two hundred yards. Owing to the narrowness of the channel, he was obliged to stand in so close to the shore that the jib-boom nearly touched it. The western bank was here high and perpendicular. The tide was running at the rate of nine miles an hour. With all his care, the vessel was thrown on shore, where she lay eight days. The flood and ebb tides swept by with the same velocity; and on one occasion the receding tide left his vessel one hundred and fifty feet from the water. He waited in vain for slack water, in order to replace the rudder, which had been unshipped. "But in the Colorado," he says, "there is no such thing as slack water. Before the ebb has finished running the flood commences, boiling up full eighteen inches above the surface, and roaring like the rapids of Canada."

Since the foregoing was written, I have read an account of the most recent attempt to ascend the Colorado, which is given in the accompanying note.*

* This statement is contained in the San Francisco Herald of June 11th, 1853: 


\section{A few weeks before my arrival here, a fight took} place between eight soldiers and a body of Yuma Indians, in which the former were all killed. The

Mr. Turnbull left San Francisco in the schooner General Patterson, with stores for the garrison at Fort Yuma. At the mouth of the Colorado he met with a serious obstacle in the number of sand-banks and the high tides. "The tide," he says, "rises from twelve to sixteen feet every twelve hours; the tidal wave, being sometimes four feet high, carries every thing before it. If a vessel strikes on a sand-bank at high tide, she becomes high and dry in a little while, and may remain so for weeks before she can be got off. Fortunately, the General Patterson, shortly after entering the mouth of the river, met a whale-boat containing the mates and four of the crew of a vessel belonging to Mr. Turnbull, which had been lying in the river for several months. They had been engaged in obtaining soundings, and were consequently enabled to pilot the Patterson up, without stopping at every moment to try whether she was over one of the dreaded sand-banks. In this way she ascended the river thirty-three miles in two days, and anchored. No other vessel had ever before made the same distance in less than twenty days. Mr. Turnbull, with a party, took a whale-boat at this point, and ascended the river to Fort Yuma, upwards of a hundred miles.

"The river was swollen almost to a torrent by the melting of the snow at the head waters; and the country for fifteen miles on both sides was entirely inundated, the water standing four feet deep upon its banks. The current was running at the rate of seven or eightomiles an hour, and multitudes of floating snags of trees were rushing down. So completely was the country overflowed, that Mr. Turnbull found in a distance of 'a hundred and twenty-five miles but two dry spots on the banks where he could cook his food. He was obliged to sleep on board his boat, as there was no land to be seen.

"Within a few miles of Fort Yuma, he heard of the loss of the steamer Uncle Sam, which it was his purpose to run regularly on the Colorado. He had brought out machinery for her in the Patterson, which would have enabled him to stem the current of the river, and probably to have ascended considerably above the Fort. He has not yet given up his purpose, and will take the hull of another steamer out, the machinery being still at the Fort." 
Indians approached the soldiers, and drew their fire, when a large number, who lay in ambush, rushed upon them with the short clubs which form their principal weapon, and put them all to death. Major Heintzelman in turn sent several parties against them, and drove them all from the banks of the Colorado for some eighty miles above, destroying their corn fields and their villages. They had been so cruel and treacherous to the various parties of Americans passing here, and had manifested. so much hostility towards the troops, that it was found useless to attempt to conciliate them, or make any treaty with them, unless they themselves were forced to come in and ask it. They have often made treaties with the Mexicans, only to break them when a favorable opportunity offered to plunder and murder. When Lieutenant Whipple was here, in 1849 , with a party of engineers, to determine the point of junction between the two rivers, and establish the monuments on the boundary line, he remained several months among them, on terms of intimacy and friendship.*

One afternoon while here, Major Heintzelman and myself made some experiments to ascertain the velocity of the Colorado below the junction. The result gave us $5 \frac{1}{4}$ miles per hour. But it must be remembered

* Since the above was written, Major Heintzelman has been completely successful in reducing " the Yumas. He pressed them so hard that they at length came in and begged for peace, which was at once granted them, and a treaty made. They now occupy the rich bottomlands near Fort Yuma, which they cultivate, raising wheat, corn, melons, beans, etc.; and the best feeling exists between them and the Americans. 
that the river was then much swollen. When low, it flows at the rate of about two miles an hour. It is then but four feet deep at the fording place at the Algodones, where we first saw it; and at such times wagons, mules, and cattle may easily cross. When the engineering parties crossed here in January, they swam their mules and were taken over in boats by the Indians. By a stake planted below the junction; Major Heintzelman ascertained the rise of the river to have been thirteen feet and six inches, when at its highest point, which it attained on the 13th of June, while the Commission was here.

Four miles below Fort Yuma are the remains of a fortification called Fort Defiance. This is the spot where we first encamped, and were unable to reach the water. It was an old ferrying place, and the scene of a massacre by the Yumas the year before our visit, the particulars of which I will state.

In 1849, when large numbers of people from the United States and the adjacent province of Sonora were emigrating to California, many came by the Gila and crossed the Colorado here. At this time, as there was no garrison on the spot, nor any white settlers, the Yumas derived quite an advantage from aiding emigrants to cross, having by some means obtained a boat or scow for the purpose. A party of Americans, seeing a prospect of a lucrative business by the establishment of a ferry, dispossessed the Indians of their boat, drove them from the river, and would not permit them to help emigrants across or otherwise have any thing to do with them. The leader in this affair was a Dr. Langdon, of Louisiana. The ferry was established at 
the rocky spur before alluded to; upon which, directly on the bank of the river, they built a rude fort wherein they could defend themselves. This, in contempt for the natives whom they had dispossessed of their rights, they called Fort Defiance.

The party which originally established the ferry was fitted out by J. P. Brodie, Esq., a gentleman living at Hermosillo, in Sonora, of whom I have before spoken: he advanced the money for the purpose, and retained an interest in it. While this gentleman had the direction of affairs, no further offence was given to the Indians, and emigrants were always treated well and fairly dealt with. Not long after, however, a man named Gallantin was employed by Dr. Langdon, or in some other way became interested in the ferry. He turned out to be a bad fellow, and was supposed to be a fugitive from justice. He treated the Indians most brutally, and practised all sorts of impositions upon the passing emigrants, charging about four dollars a head for every one who crossed the river. He also extorted large sums from the Sonorians when returning to their homes from the mines, when he found or believed they had any considerable amount of gold with them.

When Dr. Langdon found out the character of Gallantin, he endeavored to get rid of him, but found himself unable to do so. About this time Gallantin took occasion to visit San Diego; and there his party got into a fight, in which a soldier was killed. Gallantin was arrested and imprisoned, but made his escape back to the Colorado with a supply of liquor. The men having fallen asleep, either from the effects of liquor or of fatigue, the Yumas, who had watched their oppor- 
tunity, rushed upon them with their clubs, and massa cred every soul at the ferry, embracing some twelve or fifteen persons. Three men were at some distance in the wood cutting timber; these, seeing from the actions of the Indians that something was wrong, succeeded in concealing themselves, and made their escape by joining a party of Mexicans who soon after came along. A large sum of money, all that had been saved by Langdon and Gallantin (estimated at from fifteen to thirty thousand dollars), fell into the hands of the Indians; and this was freely used by them in supplying their wants from the emigrants who afterwards passed. They knew little of the value of gold, and would sometimes give four or five doubloons for an old worn-out blanket, or a, gold eagle for a tattered shirt.

No sympathy was felt for the men who had thus lost their lives; but the event tended to encourage the Yumas in acts of violence, in which many innocent and unoffending parties perished. I heard of one occasion on which a party of emigrants crossed while the Yumas retained the ferry. The Indians showed friendship for them, and assisted in making their fires and in taking charge of their animals. The party cooked their meal, and sat down quietly to eat; for although numbers of the Yumas were about their fires and the camp, their presence caused no uneasiness, as they were unprovided with arms. But on a sudden, at a given signal, they each seized a billet of wood from the fire, and knocked out the brains of the Americans.

The ferry is at present well conducted, and though 
the facilities for crossing are not as great as they might be, they are perhaps as great as the expenses of carrying it on will warrant. I paid one dollar for each man, two dollars for each mule and ox, ten dollars for each wagon, ten dollars for each wagon load, one dollar for each mule load, \&c. The total expense for crossing the Commission and the escort, amounting to five hundred and four dollars.*

Of the Indians who occupy the country near Fort Yuma, the largest and most important tribe are the Yumas. These people occupy both sides of the Colorado both above and below the junction with the Gila. But how far they extend to the north is not known; probably not less than a hundred miles. Of the tribes to the north of them, very little is known. There has

* In consequence of the great demand in California for sheep, large numbers have been driven thither from New Mexico, as well as from Chihuahua and Sonora, all of which cross the Colorado near Fort Yuma. -I spoke of the heaps of dried carcasses and skeletons which we saw at Carrizo Creek; but it seems that the desert is not the only difficulty which the owners have to contend with. During the previous winter, the Yumas took advantage of the temporary abandonment of the Fort by the troops, to molest the parties of passing emigrants, particularly when they could rob them of their mules, cattle, and sheep. The most flagrant case, was the loss of 4,217 sheep, belonging to Mr. Joseph White. He had succeeded in getting them over the Colorado in safety, and was preparing to cross the desert. But at this time the Indians began to press them hard, killing and stealing the sheep. To add to the misfortunes of the drovers, their water gave out, and the sheep could not be forced to travel during the day in consequence of the intense heat. The men, to save their lives, hastened on to the water, leaving the sheep until they could return. The Indians, who followed them close, took advantage of their situation, and drove them off; and thus the whole flock was lost.

VOL. II. -12 
been, no communication with them either by travellers or by the government. The early missionaries who traversed that region have placed on their maps several tribes, whose very names have now disappeared. On the old maps there are found west of the Colorado the Genigueh, the Chemeguabas, the Jumbuicrariri, and the Timbabachi, tribes of whose existence in our day we know nothing. The missionaries who mention them, are correct in all their statements, as far as we are now able to judge, and it is therefore probable that there were small tribes bearing the above names. Father Kino, who was here in the year 1700, mentions the Quiquimas, Coanpas, Bajiopas, and Cutganes, while the distinguished philologist Hervas, in his "Catálogo de las Lenguas," names many others, the authority for which, is the early missionaries. At Fort Yuma, we heard of a tribe called the Mohavi, who occupy the country watered by a river of the same name, which empties into the Colorado about one hundred and fifty miles above the fort. They are said to be a fine athletic people, exceedingly warlike, and superior to the other tribes on the river. On the eastern side, the same missionaries notice the Tehuas, Cosninas, and Moquis. A tribe of the first-named family lived in New Mexico. The Cosninas I presume to be the same as the Coch-nich-nos, whom Mr. Leroux met in his late journey down the Colorado, although, on account of their hostility, he had no intercourse with them. The Moquis are still known, being one of the semi-civilized tribes with which we have had some intercourse. This people cultivate the soil, raise numbers of sheep, live in large villages, and manufacture a superior blanket 
both of cotton and wool. The Yumas speak of the Hawalcos and Yampaos tribes, on the eastern bank of the river, who make blankets. The Mexicans also speak of a tribe called the Tontos, or fools, on the eastern bank of the river; who are said to be allied to the ${ }^{*}$ Apaches. It is probable that, with the exception of the great tribes, they are known among each other by different names, which have some connection with the mountains or rivers near which they dwell, or with some peculiarity which distinguishes them from each other. Thus the Yumas are also called Cuchans; and, as I have before stated, the Diegenos, who derive their name from San Diego, are the Comeya of early times. It is also certain that many tribes which the missionaries found in California and the northern parts of Mexico, are now extinct.* On the Gila, no tribes have any fixed habitation; nor are any lands irrigated and cultivated, until the district occupied by the Coco-Maricopas and Pimos is reached, two hundred miles to the east. The Yumas occasionally range up and down the Gila, but only on predatory excursions. They strictly belong to the Colorado near the junction with the Gila, where they were found by the earliest explorers.

Between the Gila and the Gulf, and near the latter, there is also found a tribe called the Cocopas. They occasionally visit Fort Yuma, and profess to be at peace with the Americans. They are less numerous than the Yumas, with whom they are at war. Recently a party of the Yumas were surprised by them, their chief and

* Of the existing and extinct tribes of Indians I shall speak at length in my Essay on the Ethnology of these countries. 
many others killed, and the party completely routed. At the latest accounts the Yumas were preparing for a campaign against them; and as their numbers are much larger, it may result in the annihilation of the - Cocopas, who would not be the first tribe which the warlike Yumas have extinguished.

When Lieutenant Whipple was at the junction of the Colorado and Gila rivers, in 1849, engaged in astronomical observations for the Boundary Commission, he was constantly surrounded by the Yuma Indians, and had therefore a good opportunity to observe their habits. $\mathrm{He}$ has permitted me to copy from his journal the following notices of them. When he reached the Colorado, he was met by Santiago, one of the chiefs, who conducted his party to their village, where they were surrounded by great numbers of the Indians. "The women are gemerally fat, and their dress consists of a fringe made of strips of bark, bound round the hips and hanging loosely to the middle of the thighs. The men are large, muscular, and well formed. Their countenances are pleasing, and seem lighted by intelligence. Their warriors wear the white breech; and their hair hanging in plaits to the middle of their backs, is adorned with eagle's feathers, and the rattle of a rattlesnake. They are exquisite horsemen, and carry their bow and lance with inimitable grace." While the party remained at the lower crossing waiting for a road to be cut, the Indians were very sociable, carrying them grass, beans, melons, and squashes; for which, they received in return tobacco or money. They professed great friendship for the Americans, and declared that they "had never stolen from the 
emigrants, nor maltreated them in any way; but the Indians higher up, and near the mouth of the Gila, they represented as being a desperate set of rascals." Lieut. Whipple afterwards met the head chief, Pablo, who wore a scarlet coat trimmed with gold lace, with epaulettes of silver wire, and, to crown all, green goggles. His legs and feet were bare, but he did not allow that to detract from the dignity of his manner. At this time the Yumas had extensive fields of maize, and patches of melons and squashes.

When the party under Dr. Webb crossed the Colorado, in January, the good feelings of these Indians towards the Americans had changed. They had already murdered the party of Dr. Langdon and Gallanton, and had had difficulties with several parties of emigrants. Dr. Webb and his companions, therefore, held but little intercourse with them. The Indians ferried them across the river, taking the opportunity to drown a mule or two, which they afterwards secured and ate. At the same time Mr. Pratt took some sketches and portraits of them, and Dr. Webb obtained a complete vocabulary of their language.

I have before stated that Fernando Alarchon discovered and entered the Colorado in the year 1542 . The narrative of his remarkable voyage at this early period shows that the zeal for adventure and discovery was quite as great at that period as now. He states that he went up the river eighty-five leagues, which is quite probable; when his further progress was arrested by lofty mountains, through which the river ran, where it was impossible to draw their boats. This was unquestionably the great cañon, where the moun- 
tains cross the river, and through which it has worked for itself a deep channel. This cañon is known to all the trappers, and is said to extend from two to three hundred miles, throughout which distance it is only passable in two or three places. As he progressed, Alarchon made diligent inquiries about the country and people. In reply he was told that the river ran much further up into the land than he had yet come; but his informers did not know its head, as it was still very far in the interior. He learned also that many other streams fell into it. As far as he went, he found the natives cultivating maize. They brought him cakes of maize and loaves of mezquique.* Neither wheat nor beans were known to them. To ascertain this fact, our traveller took with him these articles, which he showed the Indians, and at which "they expressed much wonder." He found cotton growing, but nowhere saw any fabrics made of it; whence he naturally was led to believe that they knew not the art of spinning and weaving. The natives told him that there were twenty-three different languages spoken along the river.

It is a singular fact, that although Francisco de Ulloa explored the Gulf of California in 1539, and Alarchon in 1542 , at which time the latter discovered and passed up the Colorado, the fact that California had been ascertained to be a peninsula came to be forgotten, and it was regarded as an island until some time.

* I imagine the mezquique to be flour made of the mezquit bean, which is now used by the California Indians, as well as by the Coco-Maricopas and Pimos of the Gila. 
between the years 1698 and 1701 . This rediscovery was made by Fathers Kino and Sedlemayer, two of the earliest and most distinguished of the Jesuit missionaries, who in consequence were able to open a communication by land with the missions of Lower California, which had already been established.* Kino, next to Alarchon, followed up the Colorado beyond its confluence with the Gila; and was the first to preach the Gospel among the Indians, who were then very numerous in this region. He made five separate journeys to the Gila and Colorado Rivers between the years 1694 and 1706 ; and on one occasion intended to cross over to Monterey, in Upper California, from which he was only prevented by an accident. He established a mission near the mouth of the Colorado and one at the mouth of the Gila. The former did not last many years. The latter was in existence as late as 1776 , when Fathers Pedro Font and Garces came with a large party from Sonora to replenish the missions of California, but chiefly that at Monterey. + Fathers Garces and Eirarch remained at the Colorado, and Font proceeded to the coast. Garces afterwards made extensive journeys

* This question seems to have awakened much interest among the geographers of the period. Captain Mange accompanied Father Kino in the journey referred to, and his letter announcing the discovery, with great detail, is given in Alegro's Hist. de la Comp. de Jesus en Nueva España. Vol. III.

† I obtained in Monterey, by the kindness of Dr. A. Randall, a copy of the manuscript journal of Father Pedro Font, together with the map which illustrates both the journeys of Font and Garces. The existence of this map was not before known, and it may be regarded as of great value. 
up the Colorado, and established a mission among the Moquis. He was soon after killed by the Indians, and the Colorado Mission destroyed.

Nоте.-I have several times spoken of the state of the thermometer. At all times it was placed beneath the shade of a tree, and hanging against it. In no case was it hung in the tent, where the heat was much greater. Our barometers had all been broken before reaching the Colorado, except mine, an aneroid, which I gave to Lieutenant Whipple, in order that his records might be kept complete. So with my thermometer. It was lost, and I was afterwards obliged to refer to Lieutenant Whipple's. Before leaving Fort Yuma, Dr. J. L. Milhau, surgeon of the post, at my request, kindly furnished me with a copy of the meteorological register kept at the Fort for the month previous to my departure, from which I have made the annexed extract:

State of tHe Thermometer (Fahrenheit) at Fort Yuma, at the junetion of the Colorado and Gila Rivers, from May 20th to June 16th. Lat. $32^{\circ}, 42^{\prime}, 09^{\prime \prime}$. Long. W. from Greenwich, $117^{\circ}, 37^{\prime}, 09^{\prime \prime}$.

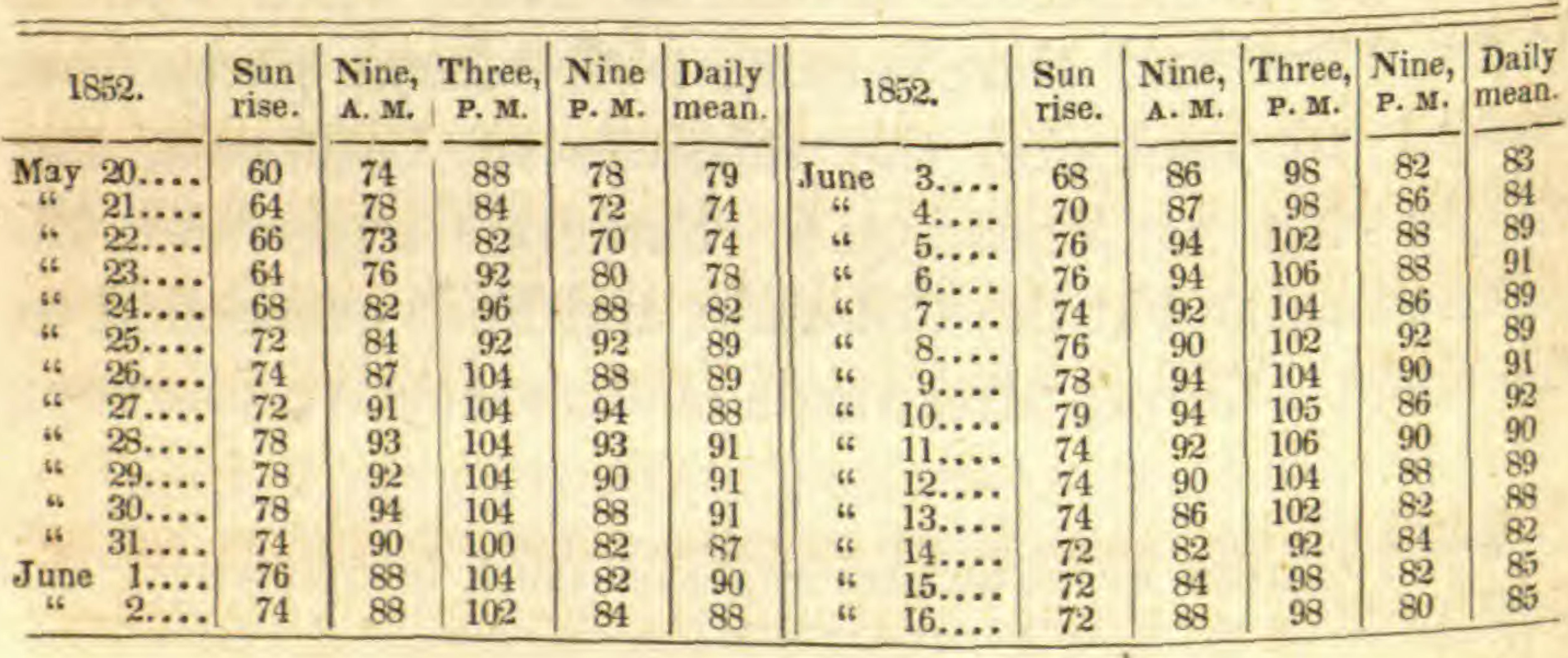

In this case the thermometer was suspended beneath a thick bower of bushes, which effectually shut out the sun at all times, while there was a free circulation of air around. The Fort stands on an isolated rock about eighty feet above the plain. 
FORT YUMA TO THE COCO-MARICOPA VILLAGES. 185

\section{CHAPTER XXIX.}

FORT YUMA TO THE COCO-MARICOPA VILLAGES.

Leave Fort Yuma-Absence of grass along the Gila-Petahaya or Giant Cereus-Gila trout-Meet the surveying party-Inscribed rocks-Excessive heat-Night marches-Wagons found-How caches are madeParticulars of the murder of Mr. Oatman and his wife-Basin of the Gila-More sculptured rocks-Cross the Jornada-Great bend of the river-Another desert-Toilsome march-Reach the Coco-Maricopa villages.

June 17th. Major Heintzelman told me this morning that, from the peculiar barking of the dogs during the night, he believed the Indians had been near the fort. Soon after one of the herdsmen came in, and reported that he had discovered many Indian foot-prints around the base of the hill. The ferrymen, who slept near, were aroused at the same time, and saw from the hill two fires in opposite directions, two or three miles distant, near the banks of the Colorado. They were doubtless intended for signals. A party of soldiers Was sent out to reconnoitre in the bottom around the fort; and subsequently a detachment of fifteen, under command of Lieutenant Hendershott, was dispatched on a scout.

Our wagons now being completed and every thing in seadiness, we bade farewell to our excellent friends, 
and at four o'clock, P. M., crossed the river to our camp on the opposite shore, accompanied by Major Heintzelman. The mercury at noon to-day stood at $100^{\circ}$ Fahrenheit.

June 18th. We took our departure at five o'clock in the morning. As Lieutenant Whipple was actively employed in completing the survey of the Gila, my own party was reduced to Dr. Webb, Messrs. G. Thurber, H. C. Pratt, and M. Seaton, which last was returning to rejoin his party on the Rio Grande. We had also, of course, the necessary attendants in servants, cooks, arrieros, and herders; and were accompanied by Lieutenant Paige, with fifteen soldiers. Lieutenant Whipple retained the remaining men of Colonel Craig's command, and twelve of those furnished by Major Heintzelman. Our provisions, baggage, and camp equipage were carried partly in wagons and partly on pack-mules.

We took the travelled road, which we followed for two or three hours along the bottom-land on the south bank of the Gila, and then turned off and followed the trail of Lieutenant Whipple, which led to the river. After pursuing this route a couple of miles, we got entangled in so dense an undergrowth, interspersed with little hillocks and dead trees, that our progress was completely stopped. Fearing that our wagons would be broken if we proceeded, we turned back and attempted to regain the road; but in this direction the same impediments presented themselves. Being thus brought to a stand, I sent men out to find the river, as we had already been so long tugging through the bottom that our mules showed mich 
weariness. The Gila was discovered within half a mile; and after doubling the teams to cross a bed of loose sand, we succeeded in reaching it, and there we encamped. No grass was found; but the mules ate with avidity the cane which grew on the river's banks. Distance travelled, fifteen miles.

June 19th. Left camp at six o'clock; and after proceeding through loose sand and arroyos, and cutting our way through the jungle which grew near the stream, we reached the road, and soon after a spur of the mountain ridge around which the river ran. In going down a short and steep hill, the king-bolt of one of the wagons broke, in consequence of which we were compelled to unload it, which detained us about an hour. Continuing our journey, we struck the Gila at one o'olock; where, to our agreeable surprise, we found a small patch of coarse grass, the first we had seen, excepting a tuft here and there on the desert, since leaving San Felipe. For the fifteen days since we left that place our animals had lived almost exclusively upon the mezquit bean, and twigs of willow, cotton-wood, and mezquit bushes. We encamped here, having come twelve miles.

The bottom here does not exceed a quarter of a mile in width, owing to the proximity of the mountains on each side of the river. The vegetation consists of willow and mezquit. We found that Lieutenant Whipple had had a station near us, and had moved forward but an hour before our arrival.

June 20th. Resumed our journey at half-past five in the morning, over a sandy road, and soon after left the bottom and ascended to the table-land, here ele- 
vated about forty feet above it. The vegetation con. sisted of mezquit and palo verde.

After journeying about six miles, we overtook Lieutenant Whipple with the surveying party, and agreed to encamp together six miles further ahead. We proceeded to the point fixed on, which we reached at 11 o'clock and pitched our tents, having made but twelve miles. The bottom-land continued narrow, the desert approaching quite near on both sides of the river. There was no grass; but with cane and mezquit, our mules did very well.

On the northern side of the river, arose a mountain chain about twelve miles distant, presenting a continuation of fantastic summits, among which were three resembling the tops of Hindu pagodas. I took a sketch of these singular mountains; although at such a distance, but little more than the outlines could be discerned.

To-day, for the first tìme since leaving Fort Yuma, we again encountered our friend the petahaya, or Giant Cereus, which we had met with the preceding September in Sonora; and much to our delight, we found it in bloom. The fruit, too, appeared in various stages of perfection. As no full and correct description has yet been given to the world of this extraordinary production of the vegetable kingdom, and as I had the advantage of seeing it at different periods of the year, in flower as well as in fruit, I shall endeavor to give a popular account of it. The buds, flowers, fruit, seed, \&c., were collected by Mr. George Thurber, Botanist to the Commission; and by him a scientific description of it will be prepared, with the aid of a distinguished botanist 


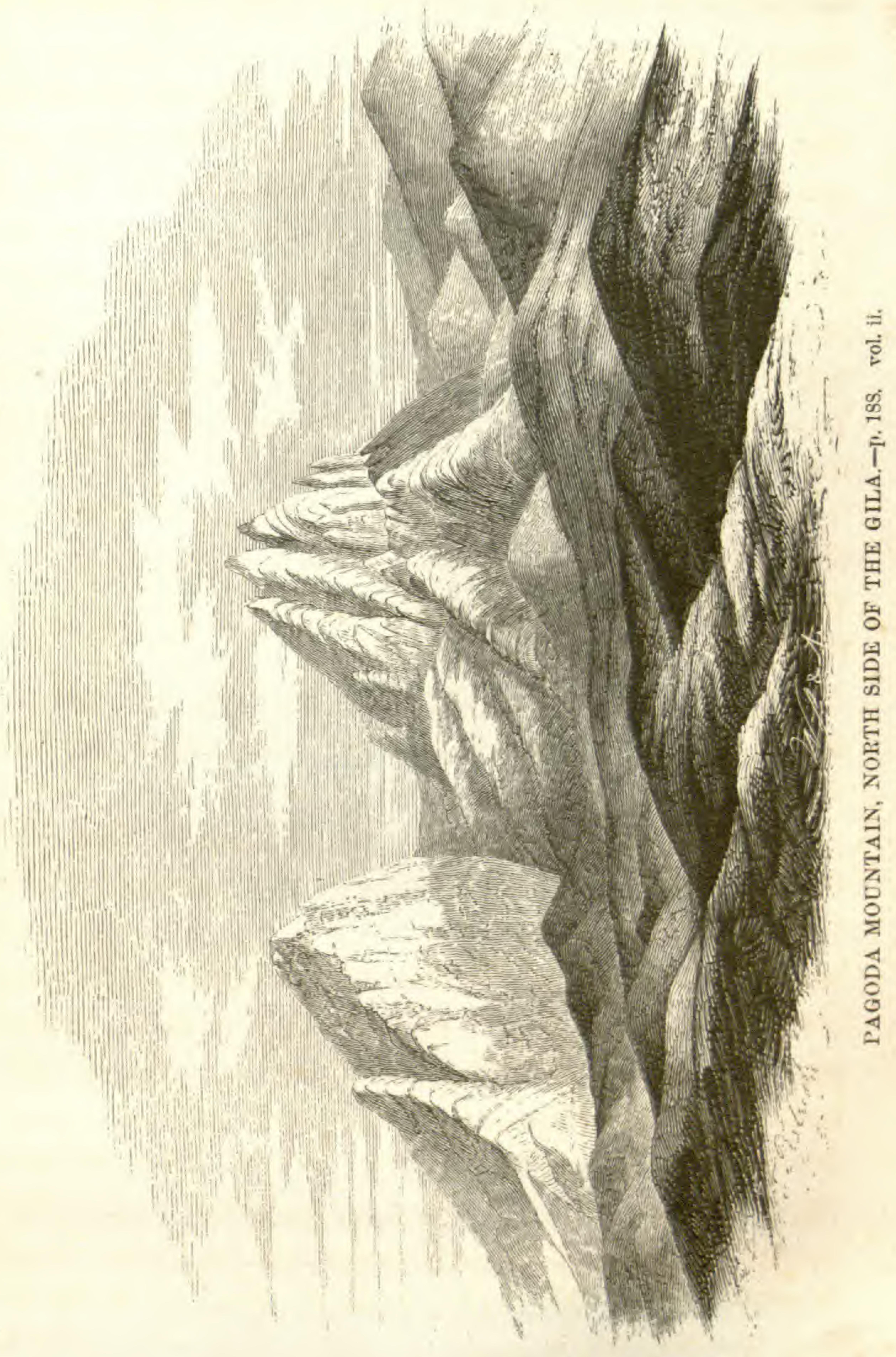


40 
who has paid particular attention to the cactacea of North America.

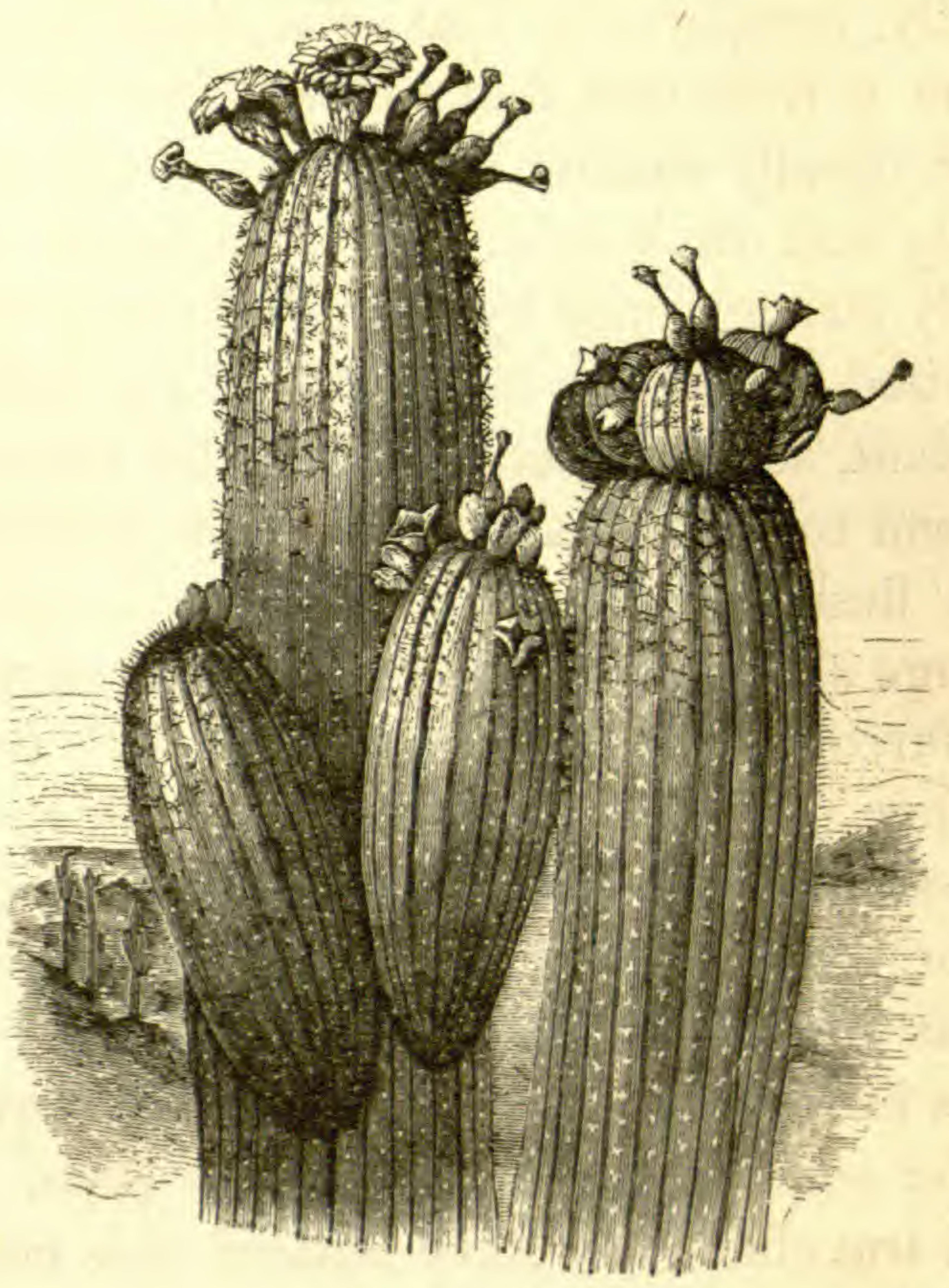

Petahaya.

This curious plant is found on the high table-lands on either side of the Gila, and in various parts of the State of Sonora, growing often in the crevices of rocks, and in other situations where it would seem difficult for any vegetable production to find sustenance. The forms it assumes are various; sometimes rising like a simple fluted column, although more frequently it is furnished with several branches, which, after leaving the main trunk, turn gracefully upwards and rise paral- 
lel with it. Sometimes the branches are singularly contorted; but usually, their disposition is symmetrical, and the appearance of the whole plant has been, not inaptly, compared to that of a giant candelabrum. The stem is from one foot to two feet six inches in diameter, usually smaller near the base, and from twenty to fifty feet in height. This immense column is admirably strengthened by a circle of ribs of strong and elastic wood, which are imbedded in the cellular mass of the plant, several inches within the circumference, and extend to the roots. This woody portion remains after the fleshy substance of the plant decays, looking like a huge skeleton. The stem is marked with longitudinal furrows, which are shallow towards the ground, and deeper and more numerous towards the summit; and above the ribs it is thickly set with clusters of spines or thorns. Of these there are six large and numerous small ones, in each cluster. As the plant increases in age, the larger spines fall off, leaving a ray of smaller ones, which lie close to the stem.

Most travellers who have noticed this cereus, have not been fortunate enough to see the fruit and flower, but have derived their accounts of them from the Indians. On our passage across the country in September, October, November, and December, we saw the tree; and on our return in June and July, we had the satisfaction of beholding the fruit in perfection, and occasional specimens of the flower. The plant probably blooms late in May, or early in June; and the fruit is matured in July and August. The flowers are borne on the summits of the branches, are three inches in diameter, and about the same in length. The petals 
are stiff and curling, and of a cream-white color. The stamens are yellow and very numerous. The fruit is about the size and shape of an egg; sometimes rather longer than the true egg shape, having a few small scales, without spines. The color of the fruit is green tinged with red, when fully ripe. It consists of an outer coat or skin filled with a red pulp, inclosing numerous small, black, smooth seeds. The fruit, when mature, bursts at the top and exposes the pulp, which at this time is rather mawkish to the taste; but a few days' exposure to the sun dries it to about one third its original bulk, and the whole mass drops out of the skin. In this state it has the consistency of the pulp of a dried fig; and the saccharine matter being concentrated by drying, it somewhat resembles that fruit in taste. The Pimo and other Indians, collect the pulp and roll it into balls; in which state it probably keeps the whole year, as it was offered to our party which passed through in January. They also boil the pulp in water, and evaporate it to the consistence of molasses; after which, it is preserved in earthen jars. *

* It has been supposed that the petahaya was first made known by Major Emory in his Notes of a Military Reconnoisance, \&c. in 1847: but I shall show that the plant is by no means new, and that it has been noticed by many of the earlier travellers in the region where it is found.

In describing the plants of California, Venegas says, "The principal is the petahaya, the fruit of which forms the great harvest of the poor inhabitants here. This tree is not known in Europe, and differs from all other trees in the world: its branches are fluted and rise vertically from the stem, so as to form a very beautiful top; they are without leaves, the fruit growing to the boughs; the pulp resembles that of a fig, only more soft and luscious. In some it is white, in some red, and in others yellow, but always of an exquisite taste; some again' are wholly 
A number of the fish called by Major Emory the "Gila trout" were caught near our camp by Mr. Pratt with a hook and line. They proved very palatable, where fresh fish is such a rarity; but the flesh is quite soft, owing to the warmth of the water, and would scarcely be tolerated on the tables of the Atlantic coast. " At a little distance," says Major E., "you will imagine the fish covered with delicate scales; but, on a closer examination, you will find that they

sweet, others of a grateful acid. And as the petahaya is very juicy, it is chiefly found in dry soil."-Natural and Civil History of California. London, 1759. Vol. I. p. 42.

Father Salva Tierra, one of the most laborious of the California missionaries, and who resided in that country in 1697 , speaks of the festivities among the Indians on the occasion of gathering the petahaya. "The three petahaya months," he says, "resemble the carnival in some parts of Europe, when the men are in a great measure stupefied or mad. The natives here, also, throw aside what little reason they have, giving themselves up to feastings, dancings, entertainments of the neighboring rancherias, buffooneries, and comedies, such as they are; and in these whole nights are spent to the high diversion of the audience."-Vol. II. p. 82 .

Alcedo has the following article respecting it:

"Pita Haya (Cactus Pitahaya). Arbol grande y muy singular; porque sus ramas son al modo de cirios histriados, que salien derechos desde su tronco acia lo alto, no llevan hoja alguna, y en la misma rama nace pagada la fruta, que tiene la corteza llena de espinas, y se parece algo a los higos de tuna, aunque la carne es mas blanca y delicada; unas la tienen roxa y otras amarilla distinguiendose tambien en dulces y agridulces; pero muy sabrosas. Monardes $\mathrm{C}$ da el nombre de Cardin y abunda en el Jardin Botanico de esta Corte.-Dicctionario Geografico Historico, Tomo V. Appendix, p. 152. Madrid, 1789.

On referring to Monardes, I find his description does not correspond to the Petahaya, whence it is evident he had reference to something else.

But Hërnandi, another Spanish botanist, has a very full description 
are only the impression of scales." I cannot imagine what led to this mistake on the part of the Major; for a mistake it certainly is. Scales were as plainly seen on all we caught as upon any fish; and I found no difficulty in taking them off with my finger-nails from the smallest specimens. We caught them at different times from eight to eighteen inches in length.

After coming into camp to-day, I determined to push on with my party to the villages of the Pimo

of what he calls the Petahaya Tepexicensis, which is undoubtedly the plant in question.--See Historia Plantarum Nova Hispania.--Vol. II. p. 170. Vol. III. p. 94. Matriti, Anno mdcclxxx.

Baron Humboldt says, "At the foot of the mountains of California, we discover only sand, or a stony stratum, on which cylindrical cacti (organos del tunal) shoot up to extraordinary heights."-Polit. Essay on New Spain, Vol. II. p. 328. This name is probably derived, first, from the flutings of the stem, which resemble the pipes of an organ; and second, from the resemblance which the fruit has in taste to the tunal, or Indian fig.

Pattie, an Indian trader and trapper, who spent six years (from 1824 to 1829 ) in the interior parts of the continent, during which period he passed several times up and down the Gila, says, "A species of tree, which I had never seen before, here arrested my attention. It grows to the height of forty or fifty feet. The top is cone-shaped, and almost without foliage. The bark resembles that of the prickly pear; and the body is covered with thorns. I have seen some three feet in diameter at the root, and throwing up twelve distinct shafts."-Personal Narrative of Six Years Journeyings, \&c. p. 68.

Again, this plant is mentioned by Lieut. Hardy, who visited Sono$\mathrm{ra}$ in the years 1825-28. He speaks of a stick which was used for "detaching the fruit from the tops of the petahaya, a plant of the cylin- drical cactus species, growing from eight to twenty feet in height." And in another place, he says, "Our route lay over a plain, upon which immense quantities of the petahaya were growing."-Travels in the Interior of Mexico, p. 212.

VOL. II. -13 
Indians. There seemed to be no necessity of keeping with the engineers, whose progress was, and would continue to be, slow; besides which their duties compelled them to follow all the sinuosities of the river, and keep by its bank. "This not only increased the distance, but obliged the parties sometimes to cut passages through the bushes for the wagons and packmules, a task attended with much labor, besides the risk of breaking down. Our animals were daily growing weaker for the want of grass; the weather was excessively hot, the mercury ranging every day above $100^{\circ}$ in the most shady places we could find; and we were without vegetables of any sort,-a deprivation which already began to show its effects upon the men. For these reasons, I deemed it best for the health of the party and the preservation of the animals to proceed in advance to the Pimo villages, where an abundance of grass and vegetables could be procured. I accordingly made a division of our provisions with Lieutenant Whipple and his party, and left with him such an escort as he considered necessary for his protection.

June 21st. The road to-day was sandy, and consequently heavy, until we reached the table-land. The vegetation continued as before; mezquit, palo verde, and larrea prevailing, and the great cereus occurring with still greater frequency. At one o'clock we struck the river where it passes within two hundred feet of a bold dark-colored bluff, the termination of a short mountain range, which here is about six hundred feet high, and near which we encamped. Estimated distance travelled, seventeen miles. As the weather con- 
tinued hot, we endeavored, by making very early starts, to terminate our day's journeys by noon.

A number of fish were brought in to-day by the Mexicans resembling the buffalo-fish of the Mississippi. They drove them into a small nook in a laguna near by, and then rushed into the water and killed them with poles. I ate of them at dinner, but found them soft and unpalatable.

Towards evening, when the sun began to lose its force, I took my sketch-book and went to the base of the bluff, where I had noticed as we passed a number of inscribed rocks. I found hundreds of these boulders covered with rude figures of men, animals, and other objects of grotesque forms, all pecked in with a sharp instrument. Many of them, however, were so much defaced by long exposure to the weather, and by subsequent markings, that it was impossible to make them out. Among these rocks I found several which contained sculptures on the lower side, in such a position that it would be impossible to cut them where they then lay. Some of them weighed many tons, and would have required immense labor to place them there, and that too without an apparent object. The natural inference was, that they had fallen down from the summit of the mountain after the sculptures were made on them. A few only seemed recent; the others bore the marks of great antiquity.

Like most of the rude Indian sculptures or markings which I have seen, I do not think these possess any historic value, as many suppose. Where an ingenious Indian, for the want of other employment, cuts a rude figure of a man or an animal on a rock in some 
prominent place which his people make it a practice to resort to, others, with the example before them, endeavor to compete with their brother artist, and show their skill by similar peckings. One draws an animal such as he sees; another makes one according to his own fancy; and a third amuses himself with devising grotesque or unmeaning figures of other sorts. Hence we find these sculptured rocks in large numbers in prominent places. We all had the luxury of a bath here; and though the water was quite warm, we found it very refreshing. We made a practice of bathing wherever we could find water, believing it a better preservative of health than any thing else.

June $22 d$. The heat had been so oppressive both to the men and animals since leaving Fort Yuma, that I determined to make our marches very early in the morning, or at night. The cooks were accordingly roused this morning at three o'clock, which enabled us to get our breakfast and move off by half-past four. The thermometer at sunrise stood at $69^{\circ}$, the lowest we had seen it since leaving the coast; and after the constant heats we had had, this temperature was uncomfortably cool.

We ascended the plateau to cut off a bend of the river; and after keeping on it for four or five miles, we again desended into the bottom, cutting away a bank in order to reach it. The platean was as dreary and desolate as before, stretching away as far as the eye could reach to the south in one vast plain, interrupted at intervals of ten or twenty miles with isolated mountains rising abruptly from it. The road now became better, as it wound through a dense thicket of willows' 

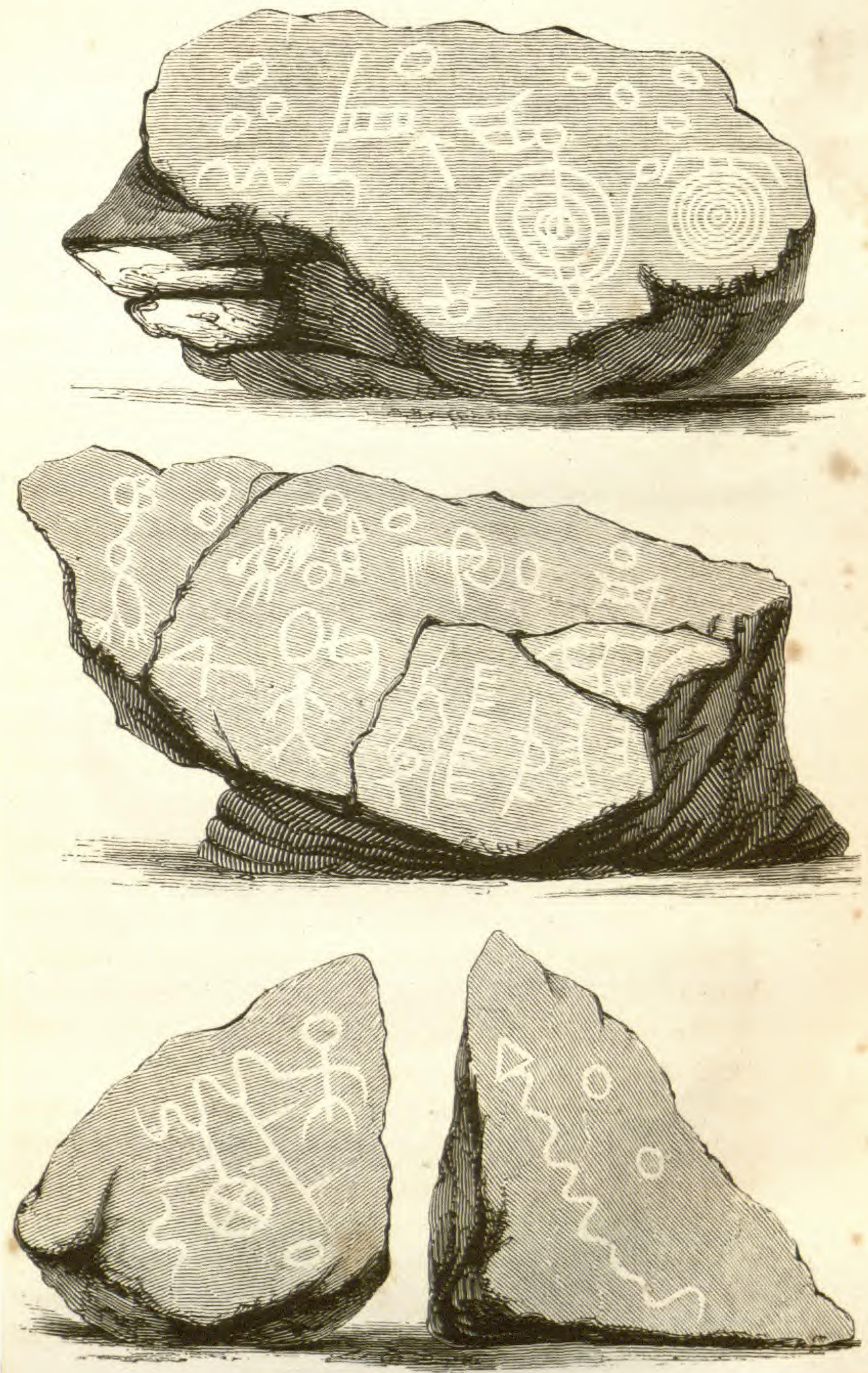

BCULPTURED ROCKS, RIVRR GILA. NO 


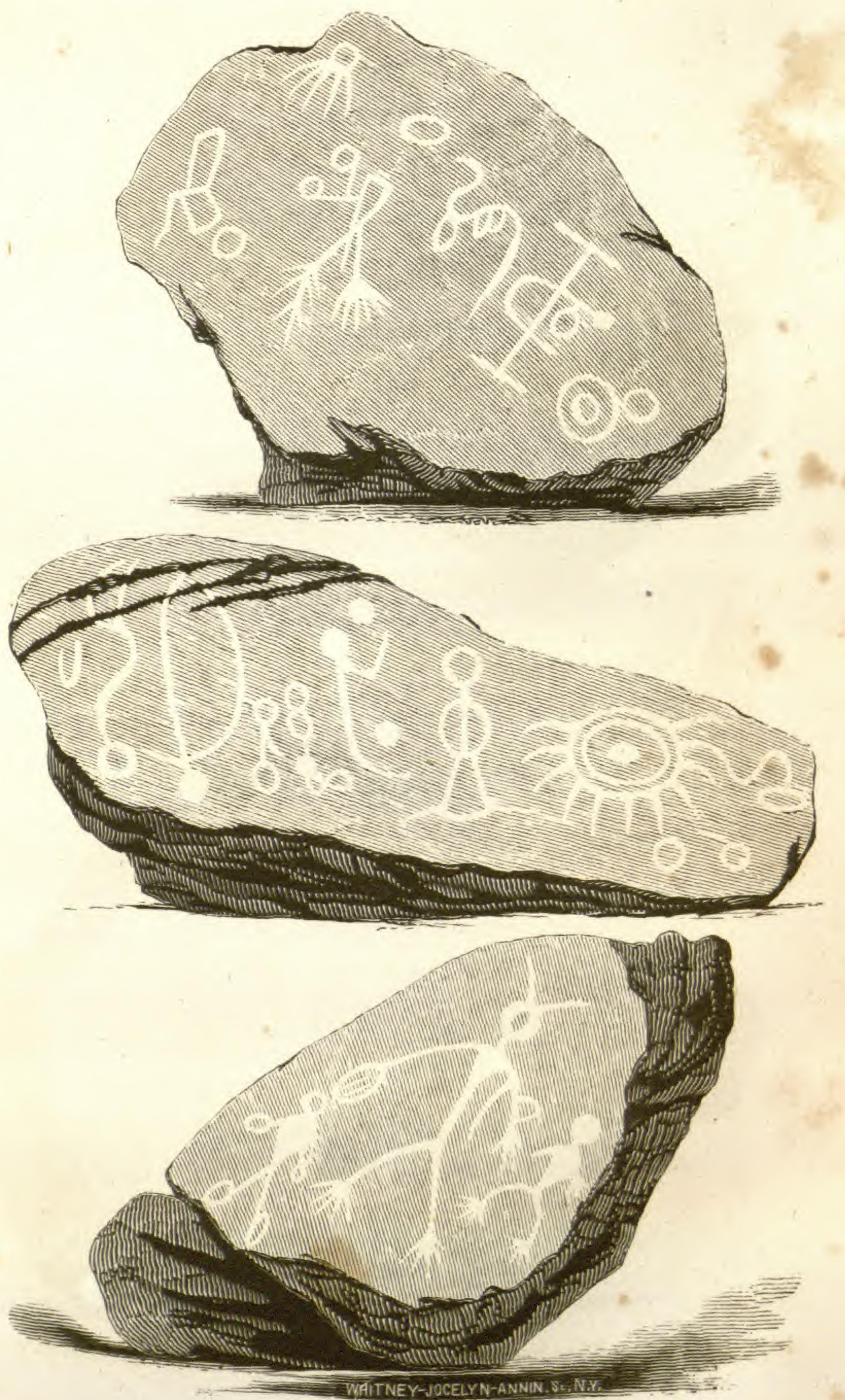

SCULPTURED ROCKS, RIVER GILA. NO 2 . 



$$
\stackrel{0}{0}
$$


+

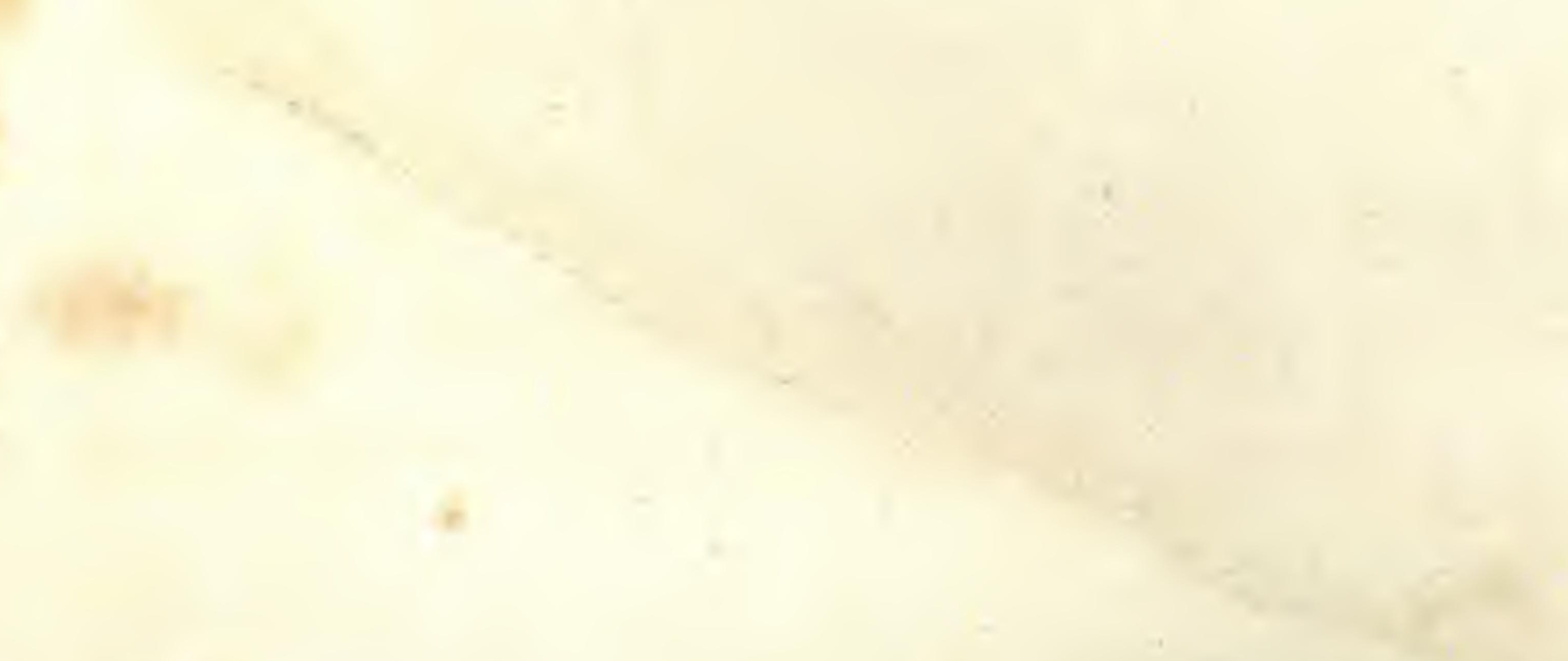

- 4

th 
and mezquit, where we could not see our way ten yards ahead; an admirable place for an ambuscade, although we had no fear of any thing of the kind. It was an agreeable change from the utter barrenness and parching heat of the table-land to find ourselves now in a thick wood. After passing the northern termination of "Big Horn" Mountain, we completed our day's march, and encamped at eleven o'clock in a thicket of willows near the river. Mr. Leroux, who was in advance, soon after rode into camp with a fine black-tailed deer thrown across his mule, which he had just killed, and which proved delicious eating. We occasionally saw these deer, as well as antelopes, as we passed along; but our numbers and the whitetopped wagons alarmed them. Hence it was only by leaving the party and going in advance that our hunters could hope for success.

During the day we passed two abandoned wagons in good condition, save the injury they had received from long exposure to the sun. From one of them we helped ourselves to a king-bolt, to replace the one we had broken a few days before.

From the large quantity of iron strewed about, with fragments of vehicles, tin kettles, and camp equipage, we were evidently at a place where wagons had been broken up and burned. The extent of these traces showed that it was probably the place where General Kearney or Colonel Cooke encamped in 1847. We had discovered their camps in several instances, and many years must elapse before these signs will be obliterated. Distance travelled to-day, eighteen miles. The mountains here are as desolate and barren as 
it is possible to conceive. Not a tree or a shrub could be seen on them, while their bold and abrupt sides are furrowed with huge chasms and gorges. Between the base of the mountains and the bottom-land are low gravelly hills covered with the Spanish bayonet, agave, and various kinds of cacti. Our mules found a supply of cane on the margin of the river, with which, and twigs of willow, they made out to keep up their strength. The Gila here widens considerably, and is proportionably shallow and filled with sand-bars.

June $23 d$. A violent wind arose last night, which made it necessary to put out guys to our tents to prevent their blowing down. A great change in the atmosphere took place at the same time, so that when I awoke, I found perspiration checked, and was suffering from a severe pain in the head. Others were similarly affected.

Left camp at five, A. M., and soon after ascended the table-land, over which we travelled nine miles, the river as before making a large bend to the north. We could trace its course from the bright green line of cotton-woods and willows, as it wound away through - the desert. Passed the grave of an emigrant by the road side, his name being written with a pencil on a strip of board and attached to a tree. Struck the river for a moment, and again took to the table-land, which we followed for about nine miles. We descended where the valley seemed to expand to the width of nearly three miles, above one half of which was thickly wooded with cotton-wood, mezquit, and willow. Here we encamped, on the spot where parties had been before. Near by was a lagoon, which had the appear- 


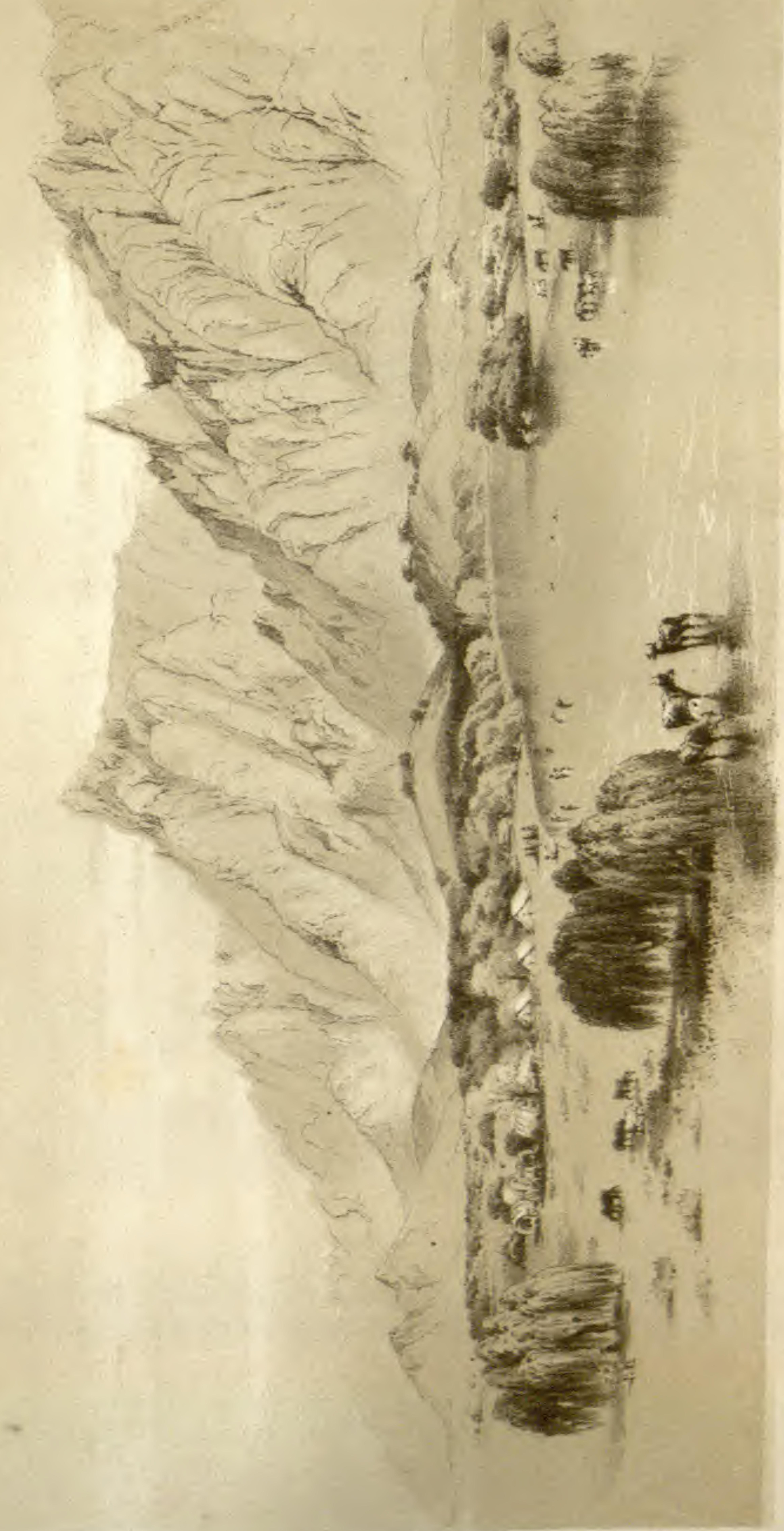




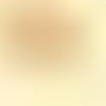

$-x^{2+4}+x^{2}+4=$

4

4trat

(-5.

-

I.

$-54$

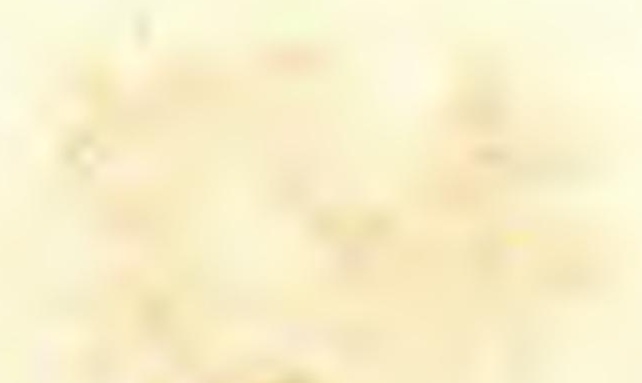


ance of having been recently filled with water. It was now dry, except in a few holes which had been dug to obtain it. We found the water in these holes quite brackish, and unfit to drink; consequently we were obliged to send our animals about a mile and a half through the wood to the river, from which we also brought water for our own use. So thick was the wood, that it was found impracticable to force our wagons through. This was the most beautiful spot we had encamped in since leaving the little valley of San Isabel, in California. We pitched no tents, finding a better and more agreeable protection in the thick and overhanging willows, the leaves of which extended to the ground. Beneath these bushes we were well sheltered from the sun, and passed the most comfortable day we had yet experienced along the parched regions of the Gila. Distance travelled, eighteen miles.

We opened a cache $^{*}$ in the bank here, in which Dr. Webb had buried a quantity of things, when the party under his charge passed down the Gila in December last. Every thing was found safe and in good condition. The wolves had smelled something below the surface, although there were no provisions there, and had dug up and exposed a corner of the tent in which the articles were enveloped. Had either travellers or Indians been here since, they would have car-

* Cache. (French). A cavity or hole in the earth, in which travellers bury their provisions or goods. The word is used by the Hudson's Bay traders, and by the hunters and trappers of the prairies and the Rocky Mountains, even to the shores of the Pacific. 
ried the investigation further. A great deal of property has thus been buried by parties crossing to California, in the hope that they or their friends might at some future time recover it; although it is safe to say that of every hundred caches so made, not five are ever opened afterwards.

In making a cache, it is best to select a spot within fifty feet of a tree, rock, or other prominent object, from which the distance can be measured and the bearings taken. A hole is then dug to such depth as may be required to bury the intended articles, which are to be protected by cloths or boards when necessary. When the hole has been covered over, the earth or sand that remains is scattered about or removed, so as to leave no indications of what has been done. It is well to build the camp-fire immediately over it, as that will account for the disturbance of the ground, and the foot prints about the spot. It is never prudent to make a cache beneath a tree, or in a spot where the party can be watched by Indians or others lying in ambush. When Fort Yuma was abandoned a few months before our arrival there, as it was expected to be re-occupied, many articles which the garrison did not wish to remove were thus hidden. But on their return, they found that their place of concealment had been discovered by the Yumas, and every thing carried off.

June 24th. As the soldiers, being all on foot, were greatly fatigued by their yesterday's march, I determined to allow them until evening to rest, and endeavor to make a march in the night. There was here a little salt grass and cane about the lagoon, with willow 
bushes for the animals; and for ourselves, every luxury that a camp life affords.

Accordingly, as the sun began to throw its long shadows across the hills, and when about half an hour of daylight remained, we moved from camp. The road was pretty good and less sandy than before. We did not now take the table-land, but kept on a lower terrace, which seemed to lead along the spur of a dark rocky hill, until we were suddenly brought to a stand. The river had washed away the terrace, and left no passage. We were therefore obliged to retrace our steps a short distance, and pass over the hills, which were exceedingly rocky, and overgrown with cacti. Not being able to discern the smaller ones among the rocks, the mules were several times stopped by coming in contact with their thorns. From one poor creature the blood flowed as though he had been purposely bled; many of the men, too, had cause to remember this night's march among the cacti. At two o'clock, the moon, which until then had given us a faint light, went down, when we were compelled to stop, as it was impossible to find our way through the light and deep sand in which we then were. The packs were accordingly removed from the mules, although the saddles were left on; and the wagon-mules were tied to the mezquit bushes near. We then lay down on the bare sand just where we were, and, rolling our blankets around us, for it was quite cool, slept soundly until daylight.

June 25th. With the break of day we were again off, having no mules to catch, no tents to strike, or breakfast to get. In an hour and a half we struck a 
sluice of the river, where we encamped. There was no appearance of grass here; but with plenty of willows and cotton-wood, the animals seemed content. As we were all fatigued from our night's journey, we threw ourselves on the sand, and, after a couple of hours' sleep, awoke quite refreshed, and ready for our coffee and breakfast.

All about us we found signs that a large encampment of Americans had been here, with indications of a cache. These were the tires of two wheels straightened and inserted so deeply in the ground that they could not be withdrawn. They were probably land marks, from which bearings had been taken and distances measured. There had evidently been a great breaking up of wagons and destruction of property here. The day was very hot, and rendered more oppressive by the bare sand around us. The bottom land was broad, and but partially wooded. Near us was a sluice, which had been filled when the river was high, or it may have been a bend of the river through which the water had flowed. We did not see the river. Just before sunset, we resumed our journey, continuing a few miles along the river bottom where the road was good. We then ascended about one hundred and twenty feet to a plateau, up a very steep and rocky way, where I much feared our wagons would be crushed; but by the soldiers taking hold, and every man pushing and pulling, we at length surmounted the hill. The road was now hard and smooth, until we came to an arroyo, which we had to descend, and then cross over steep and rocky hills, which again endangèred the wagons. On reaching the crest of the table-land, 
where we descended to the second terrace or bottom, we saw numerous fragments of trunks, boxes, chothing, wagons, with human bones and skulls, showing that it had been the scene of sorne terrible disaster. A soldier of the escort from Fort Yuma revealed to us the mystery.

In March of last year (1851) a party of emigrants, in crossing the continent, stopped at the Pimo villages. Among them was a Mr. Oatman and his family, consisting of his wife, two daughters from 12 to 15 years of age, and a son of 12 years. Mr. O. had with him one or more wagons, and a variety of merchandise; and, contrary to the advice of his, friends, he set off from the village in advance, the rest of the party not being ready to accompany him. Some days after, his little son found his way back to the Pimo Indians, a distance of some seventy miles, having crossed a desert of forty-five miles without water on his way. He reported that the party had been attacked by Indians, his father and mother killed, and his sisters carried off. He himself had been badly beaten by the savages and left for dead. After lying some time, he revived; when he saw the mangled bodies of his parents before him, his sisters gone, and the wagon plundered of its contents. The party soon after set out on their journey, accompanied by the lad and some Maricopa Indians. On arriving at the scene of the disaster, they covered the remains of Mr. Oatman and his wife with stones (for it was impossible to dig a grave), and then continued their journey to Fort Yuma, where they informed Major Heintzelman of the occurrence.

The Major immediately despatched a party of sol- 
diers with provisions for those still behind, and with orders to scour the country, and endeavor, if possible, to recover the missing girls. But they saw no Indians, nor has it yet been ascertainee by what tribe the outrage was committed.

We reached the valley again at 11 P. M., , when we stopped for the remainder of the night, and lay down on the sand to get a few hours sleep. The air was so dry and hot, that tents were unnecessary.

June 26th. Finding no grass, cane, or bushes near us on which the animals could feed, we moved off, soon after 4 o'clock, with the break of day. Our route now lay across a bed of sand so light that the wheels sank deep, rendering it necesary to double one of the teams before we could pass it. Even with the aid of this device, it was slow work. It now became necessary to cross the Gila, as the plateau rose abruptly from the margin of the river, not leaving a passage wide enough for a mule. Our route had hitherto been wholly on the south side since leaving the Colorado. I do not think the north side would present as good a road; besides which, it would be necessary, if the north bank should be followed, to cross the Gila at its mouth, as the Colorado cannot be forded above the junction.

The river where we crossed was about three feet deep in the channel. After getting over, we had to traverse another half mile of deep sand, and then recross, to get on the southern bank once more. At the second crossing my wagon sank so deep in a quicksand, that the mules, after struggling in vain to pull it out, broke the traces and left me alone in the middle of the stream. It was necessary to attach four mules 
to it before it could be drawn out. $\dot{\mathrm{W}}$ e now eontinued another half mile near the base of a black-looking rocky bluff without a tree to shade us. I thought it best to stop here, as we could not reach the next bend in the river before the sun would be too far up to travel. The bottom-land, or valley, which is visible

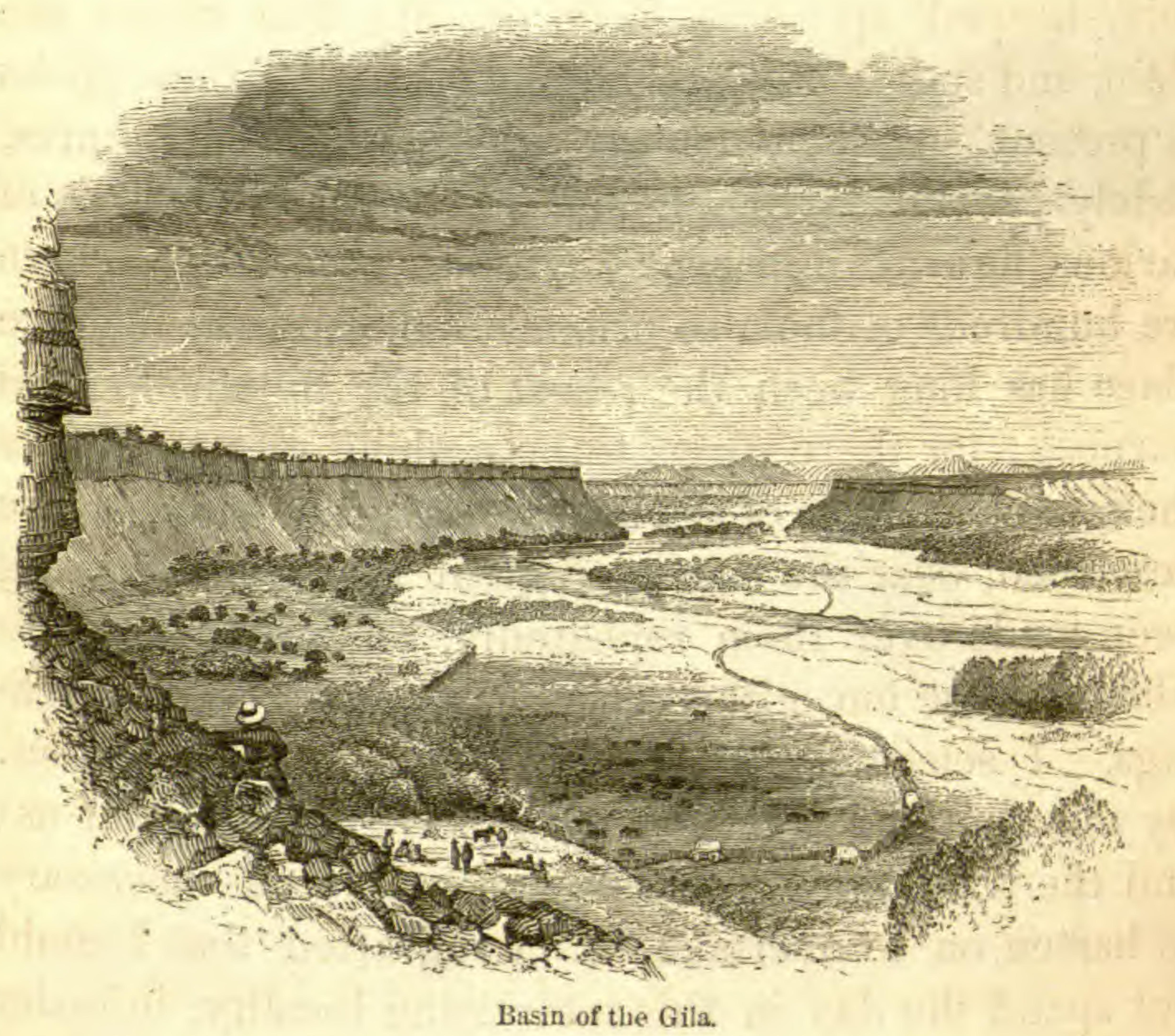

from the summit of this bluff for twenty miles, is altogether sand, with a few clumps of willows on the margin of the river. Not an acre of arable land is visible. The bluff, which is but the termination of the plateau or desert, rises about one hundred and twenty feet above the bed of the stream. The river from here is quite open on the north and west, so that the moun- 
tains on the Colorado which we saw at Fort Yuma were distinctly visible.

In order to examine some sculptured rocks of which I had heard, I left camp at 5 o'clock P. M. accompanied by Doctor Webb, in advance of the train. After crossing a plain for about five miles, we reached the object of our search, which consisted of a pile of large boulders, heaped up some forty or fifty feet above the plain, and standing entirely alone. Such of these rocks as present smooth sides are covered with sculptures, rudely pecked in, of animals and men, as well as of various figures, apparently without meaning. There are hundreds of them so ornamented, showing that the place has long been the resort of the Indians for this purpose; for there seems to be nothing else to attract them here. Many of the inscriptions, like those before described, bear the stamp of great age, others having been made over them repeatedly, rendering it impossible to trace out either the early or the later markings. I selected thirteen, of which I 'made copies. By this time the shades of night were falling about.us; and the train having already passed, it was necessary to hasten on to overtake it. I regretted that I could not spend the day in this interesting locality, in order to copy more of the sculptures, as well as to make a closer examination of the many recesses among the rocks. I do not attempt any explanation of these rude figures, but must leave the reader to exercise his own ingenuity in finding out their meaning, if any.

Leaving this place we entered an arroyo of gravel; and after following it for two or three miles, we ascended a very difficult and rocky hill to the plateau. 

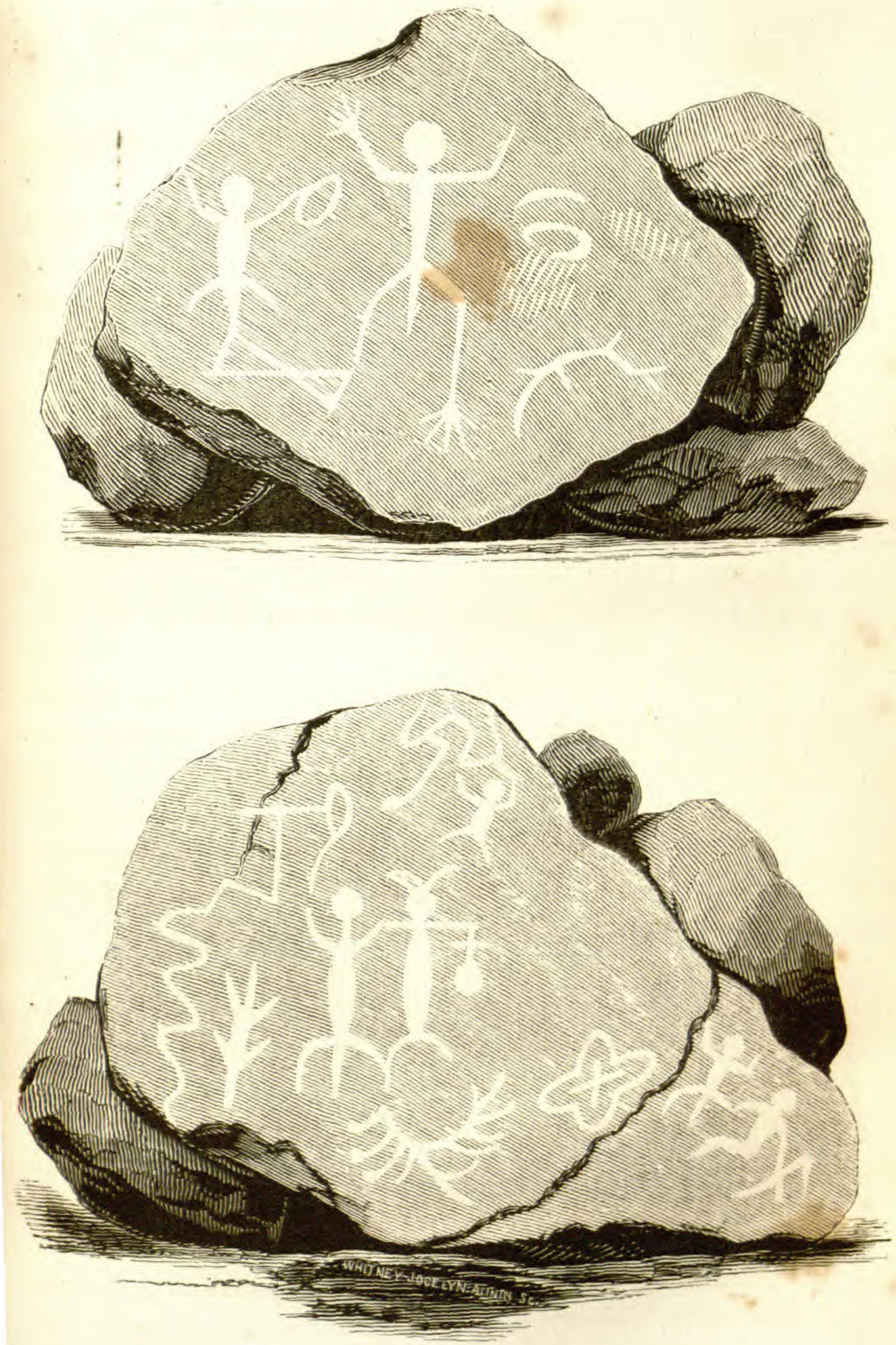

SCULPTURED ROCKS, RIVEK GILA. NO. 4 



$$
\frac{0}{20}
$$




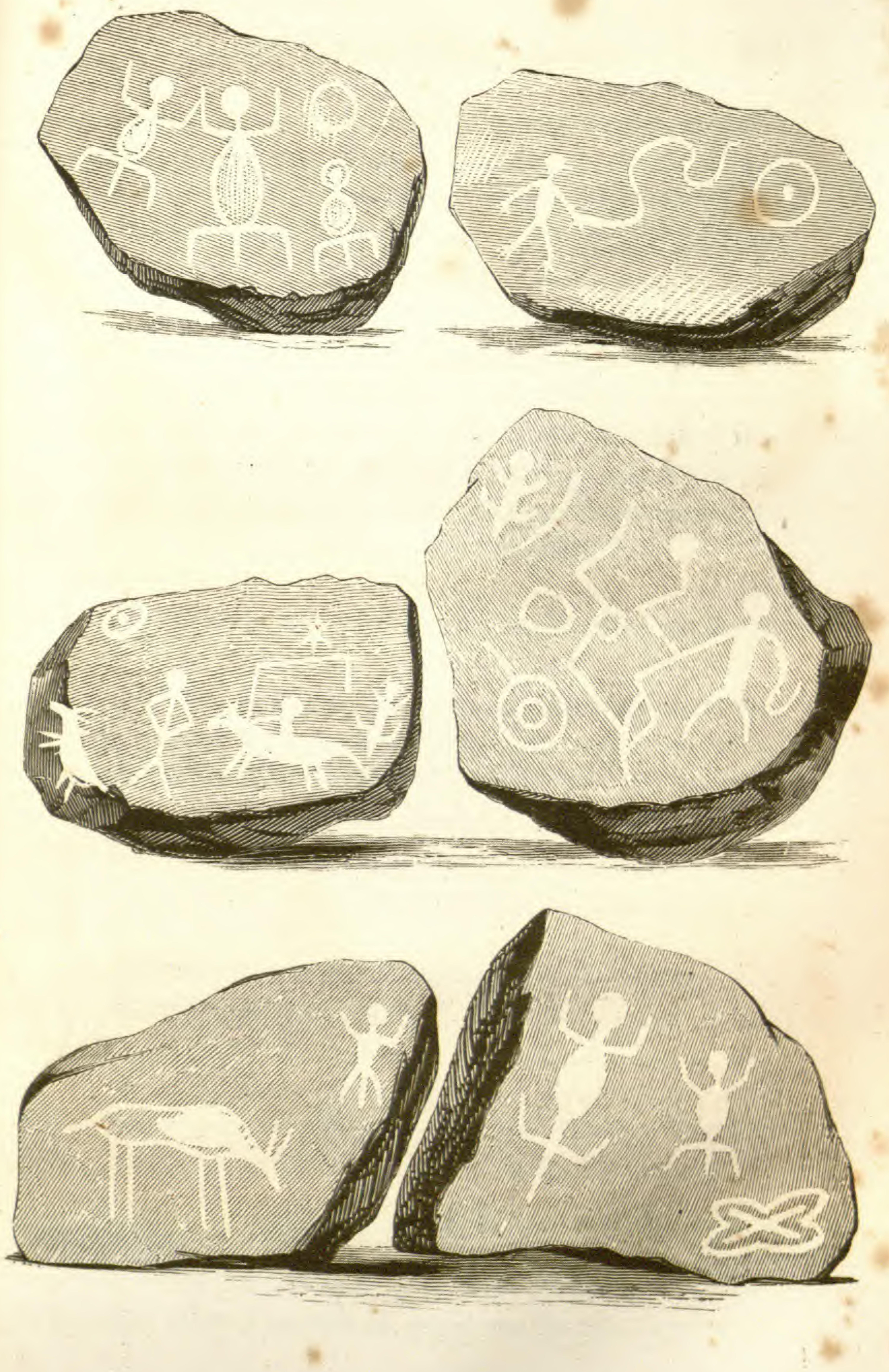

SOULPTURED ROCKS, RITER GILA. SO id 

A spur or projection of this hill had to be crossed; and then, by an easy slope, we again descended to a lower terrace. After marching about eighteen miles, by the bright light of the moon, we stopped the train and bivouacked in the sand till morning, without turning out the mules.

June 28th. We rested comfortably on our sandy beds, and resuming our march before five o'clock this morning, reached a bend in the river four miles distant. As the soldiers had had a tedious march during the night, and evinced much fatigue, I concluded to remain here during the day to give them rest.

Our camp was in a very dense thicket of willows and cotton-woods near the river's bank, into which we cut our way with axes. Here we had an admirable retreat, whose recesses the rays of the sun could not penetrate; and we passed the day with some degree of comfort. The Gila rippled close by; and a deep hole being near us which we thought might have some attractions for trout, should any stray this way, we rigged our lines, and the experiment was rewarded with several fine fish.

In the night we were aroused by the firing of a gun. Every one sprang from his bed, believing an enemy near; but it proved to be an accident. One of the Mexican arrieros, in attempting to pull his rifle out from a pile of saddles with the muzzle towards him, having caught the trigger and discharged it. The stupid fellow narrowly escaped with his life, for the ball passed through his hand.

Soon after five o'clock, P. M., we resumed our journey; and after a march of eight miles across a bend, 
we again struck the river near a point where our surveying parties had had a station, and had remained several days. There we found an abundance of mezquit and willows, but no appearance of grass. Near us was a sluice, which a year before was the main branch of the river, the stream having since found another channel. We bivouacked at this place, doubtful whether we. should find as good feed for the mules by proceeding further, the mezquit beans being now in the best state for the animals.

June 29th. Before the sun had risen we were again on our way, intending to stop at the last watering place, five or six miles in advance. My desire was to keep the animals fresh and in good condition for the march across the long desert which lay before us, and to give the soldiers a day's rest before setting out. The Gila here makes a bend to the north, and is not again seen from the road until it reaches the Coco-Maricopa villages, forty-five miles distant. As there is no water the whole distance, the journey must be made in one march, without stopping; to prepare for it, therefore, we encamped for the day in a metquit grove near the river.

The kegs and canteens were filled with water preparatory for the journey; and in order to give the soldiers a little the start of us, they set off at four o'clock. The train left an hour and a half later, our course being east by north. We entered at once upon the great plateau or desert, where the road was level and hard. The animals moved off at a quick gait, and had seemingly got the idea that they were approaching grassy fields. About fifteen miles brought us to 
a mountain range which had long loomed up before us, and seemed to present an impassable barrier to our progress; but as we drew near, what appeared at a distance to be continuous, now showed many passages through, of easy access, and with an ascent so gradual as to be scarcely apparent. The great mountain chain, as it seemed to us to be, was in reality a collection of detached ridges and isolated mountains rising abruptly from the desert. We were accordingly able to keep on our course, winding through these mountains with scarcely an ascent or descent worth naming. The road was excellent through all the defiles; although there were many small gullies requiring care in crossing, and which shows that there are very heavy rains here at times.

The vegetation on this desert is the same as on the several portions we had from time to time passed over in our journey from the Colorado. The great cereus here raises its lofty head above all other plants, attaining its greatest perfection in this barren and desolate region. We passed several of gigantic dimensions, and others of a variety of forms, exhibiting singular contortions. If one unused to these remarkable plants should suddenly be brought to this place, where he would see before him a vast plain studded with thousands of these cacti, many of which rise to the height of twenty or thirty feet, in a single stem without a branch, he would be very likely, particularly if he saw them as we did by moonlight, to imagine himself in the midst of the ruins of a magnificent palace, the columns of which were alone left standing. The lesser plants, thinly scattered over the plain, are a dwarfish voL. II. -14 
mezquit and larrea Mexicana, with an occasional palo verde in the arroyos.

Towards midnight, the pack-mules passed me; for up to this time I had been in advance. I had observed before, that in long marches, when the wagon-mules became fatigued, those with packs would quicken their pace. My wagon-mules, unwilling to be left, increased their pace, and I allowed them to keep just far enough behind the packs to avoid the dust. As there was no stopping the pack-mules without relieving them of their burdens, Mr. Leroux said it would be far better to push on until we reached the water and grass; and I determined with my little wagon to keep with him. It was.now about two o'clock, and the soldiers as well as the horsemen were so much fatigued, that the wagons were stopped, and all threw themselves down just as they were to get a little rest on the bare desert, hitching their mules to their waists by their long lariats. I left them; and hastened forward with Mr. Leroux and the packs.

June $30 t h$. At daylight we passed the south end of a range of mountains which extend to the Gila, terminating near the mouth of the Salinas River; and at half past six we reached some water-holes, about a mile from the first Coco-Maricopa village, thus making the journey of forty-five miles in thirteen hours. This may be considered slow in the age of locomotives and steamers, or even with stage-coaches; but with a train of emaciated pack-mules, each carrying on his back two hundred and fifty pounds weight, and going the whole distance without a particle of food or water, it is something of a feat. 
It was indeed a pleasant sight to find ourselves once more surrounded by luxuriant grass. Although we had met with a little salt grass in one or two places on the march, which no animal would eat if he could get any thing else, we had not seen a patch of good grass since leaving our camp at San Isabel, fifty-six miles from San Diego. At Vallecita and Carrizo Creek it is indifferent.

As it would yet be several hours before we could look for the wagons and the remainder of the party, we turned the mules out to luxuriate on the rich pasture before them, and creeping under some mezquit bushes soon fell asleep, rest being more desirable than food.

The wagons with the rest of the party, including the escort, came in at half-past ten. We now got, out all the tents, and arranged our camp with much care, as we were to be here for some days, to await the arrival of Lieutenant Whipple and the surveying party. We selected a spot in which there was a pretty grove of mezquit bushes, and there we pitched the tents. The water here is found in several holes, from four to six feet below the surface, which were dug by Colonel Cooke on his march to California. In some of these holes the water is brackish, in others very pure. The Gila passes about two miles to the north; for one half of which distance the grass extends, the other half being loose sand. Major Emory, in his report," recommends parties going to California by this route not to cross the plateau which we had just come over, but to keep to the river, as "the journey is but

\footnotetext{
* Notes of Military Reconnoissance, p. 89.
} 
a trifle longer." The accounts on which he bases this recommendation were erroneous, the route along the river being more than double the distance, as reported to me by the engineers whose duties required them to follow it. It is besides thickly wooded, and would present difficulties to wagons, and even to pack-mules; whereas the road over the plateau which we took is excellent all the way. It is also proper to state, that Lieutenant Whipple and Mr. Gray found the bend of the river to be much greater than it is laid down by Major Emory on his map.*

* Mr. Gray in his official letter to the Secretary of the Interior, from San Diego, relating to the survey of the Gila, says, that "many errors of others who had been along this river, in astronomical observations, were corrected by Lieutenant Whipple."-Senate Doc. No. 119, 32d Cong. 1st Session, p. 307.

It may be mentioned in this connection, that the survey of the Boundary Commission brought to light two important geographical facts. One was, that the Colorado, after receiving the Gila, takes a sudden turn of seven or eight miles to the westward before resuming its southerly direction, which turn gives the United States both banks of the river. The other was the error in laying down the great bend just below the mouth of the Salinas. Yet both these supposed discoveries were made by Father Kino before the year 1700, although they never obtained a place in the maps; for in speaking of this eminent missionary and geographical explorer, Alegro says: "En este viage observó el padre Kino dos cosas, entre otras: la primera que el Gila como á 55 grados de San Gerónimo, despues de haber corrido cuasi constantemente al Ouest, vuelve como por espacio de ocho leguas al Norte. La segunda, que despues de juntos el Gila y el Colorado, corren por doce leguas al Poniente antes de volver ácia el Sur á desembocar en el Seno Californio."-Alegre Hist. de la Compañia de Jesus en Nueva España. Tom. iii. p. 119. 
THE COCO-MARICOPA AND THE PIMO INDIANS. 213

\section{CHAPTER XXX.}

THE COCO-MARICOPA AND THE PIMO INDIANS.

Visit from the Coco-Maricopa Indians-Camp removed to the banks of the Gila-The river dry-No grass-War party-Return to our first camp -Traffic with these Indians-Further accounts of the Oatman family - Francisco the Maricopa interpreter-Feeding the tribe-Visit from the Pimos-Religious notions of these tribes-Their manners and customs-Agriculture-Art of spinning and weaving-Manufactures of cotton-Pottery-Basket-work-Dress-Their attempts at collecting zoological specimens-Villages-Houses and mode of building-Storehouses-Horses and cattle.

In the afternoon our camp was filled with the CocoMaricopa Indians, who had discovered us from some of their look-outs. They all manifested a friendly disposition, and seemed very glad to meet among us so many of their old acquaintances, several of the party having spent some days among them while engaged in surveying the river. The most active and important man among them was a chief named Francisco Dukey. He had been in various parts of Mexico and California, spoke Spanish fluently, and acted as our interpreter. There were three or four others who had lived for some time at Tucson, where they had picked up sufficient Spanish to make themselves understood. 
I told them we wanted vegetables, fruit, green corn, and mules; for which we would pay them in white cotton cloth, calico, red flannel and other shirts; blankets, and trinkets. They generally raise a great many fine melons; but it was too early yet for them. They brought us green corn, squashes, beans, and dried peas. We also bought of them some dried corn (maize) for the animals.

The culinary department, as usual, seemed to have most attractions for our Indian friends, who formed a double row around the fire while cooking was going on. They also crowded into the tents, and occupied all the space about them. When night came, we expected they would leave; but they stretched themselves out on the grass, and passed the night in the camp.

June 30th. As the heat was intense, the mercury ranging from $100^{\circ}$ to $110^{\circ}$, and as we had very little shade, it was thought advisable to get nearer the river, where there were more trees, and where the men would have a better opportunity to bathe, a luxury which they had enjoyed every day since leaving Fort Yuma. The Indians told me we had better remain where we were, as there was no grass near the river. I felt disposed to listen to them; but such was the desire of the party to be on the water that I consented to go, and gave orders to strike the tents immediately after breakfast.

By eight o'clock we set off, under the guidance of Francisco, and followed by fifty or sixty more of his tribe. After crossing a deep arroyo of sand, which is filled by the river at its floods, and pushing our way 
through a thick underbrush of willows, we at length reached the bank of the river, when I found the statements of the Indians too true. There were many fine large cotton-wood trees, beneath which we stopped, and which afforded us a good shade from the scorching rays of the sun; but there was not a blade of grass to be seen, and, what was worse, the Gila was dry! We crossed and recrossed its bed without wetting the soles of our shoes; although by digging a couple of ,feet, we found water for ourselves and our animals.

We now turned the animals loose to browse upon the twigs of the willows and cotton-woods, as there was no other food for them; and I sent Mr. Leroux up the stream, in search of the two great desiderata for the party, grass and water, and shade if it was to be found. In three or four hours, after making a diligent search through the bottom, he returned and reported that the river was dry as far as he had followed it, and that he had met with no grass. In fact, he was told by the Indians, that we should find no grass until we passed the Pimo villages, from twelve to fifteen miles beyond. It was so hot and dry where we were, that we did not pitch our tents, having concluded to retrace our steps in the morning to our first camp at the water-holes.

The dryness of the river was produced by the water having been turned off by the Indians to irrigate their lands, for which the whole stream seemed barely sufficient. It is probable, however, that, with more economical management, it might be made to go much further.

A party of the Coco-Maricopas remained with us 
to-day, who were to set off in the morning on an expedition against their enemies, the Apaches, north of the Salinas. They were gayly dressed, as is the universal custom of the Indians on such occasions, and mounted on good-looking horses. The chiefs who were to lead. the band begged hard of me to lend them a few rifles with the necessary ammunition; which I had to refuse. As an additional inducement, which they thought I could not refuse, they offered to bring me a live Apache boy, and a girl too, if I wished; but having no desire for such additions to our party, I was com pelled to decline the generous proposal.

July 1st. Our Indian friends composing the war party were up at daylight preparing for a start. They seemed to be supplied with small loaves of bread and dried meat, of which they made their morning's meal. They then decorated themselves with all the finery they could muster. Most of them had shirts of white cotton or red flannel, which they had obtained of us, and which they seemed to regard as the beau-ideal of a dress, without the addition of any other garment. Such as had their own cotton blankets, placed them around their bodies in folds, and over this wound their lariats as tight as possible; for the double purpose, I suppose, of bracing their bodies, and of protecting their vital parts from arrows. Those who possessed neither shirts nor blankets, remained as nature made them, with the addition of a little paint. On their head dresses, they had all bestowed more attention than on their bodies. Some had them plastered with clay, so as to resemble huge turbans. Others had decorated the great elub of hair which hung down 
their backs with bits of scarlet cloth, but more of them with the richly-figured sashes or belts of their own manufacture. Some again wore their hair in braids tastefully wound around their heads, intermingled with pieces of scarlet cloth; while a few, less particular as to their appearance, wore it clubbed up behind in a huge mass. The manes and tails of their horses were also set off with bits of white and red cloth. Their arms were solely the bow and arrow: most of them had a skin quiver hung across their backs; though a few carried their arrows in their girdles. There was quite an exciting time as the party were about to start; and several of the Commission desired to take their rifles and accompany them, a request which was of course refused.

Wishing to get back to our old camp in the cool of the morning, we did not wait for breakfast, but were off by five o'clock, and, after another hard tug through the sand, reached the camping ground, where we had every thing we could ask for, except shade, and water to bathe in. The latter was the greatest deprivation. The tents were again pitched, and the camp arranged as it was on the day of our arrival.

The Indians again flocked around us, and in greater numbers than before. The Pimos having heard of our arrival, many of them came also, bringing such vegetables as they had, together with pinole, made both from wheat and corn. Some of the pinole was sweetened with the flour of mezquit beans, which they also brought separate in small earthen vases, or ollas, as the Mexicans call them. The mezquit flour, which is ground very fine, has a sickish sweetness; so that, although I 
became fond of the beans in the pod, and liked to pick them from the trees as we rode along, I could not eat them when dry and converted into flour. They also brought us the fruit of the petahayd rolled up in masses or balls as large as one's fist. In this state it resembles in appearance the pulp of figs, and has something of the same taste mingled with that of the raspberry. We had gathered some as we came along the Gila, but had found none so good as this. All became very fond of it, and our Indian friends found a ready sale for all they brought. Jars of molasses extracted from the same were also offered for sale.

I inquired of the Indians to-day what they knew of the murder of the Oatman family before mentioned. They remembered the affair well; indeed one of the chiefs present had accompanied the party after the committal of the murder. His statement corresponded with what I have related. They charged the Tonto Apaches with the crime, and said, "With God's permission, we will retake the two children, and restore them to the Americans." I told them they should be well rewarded, if they would do so ; and that if so fortunate as to recover them, they might take them to the American Fort (Yuma) on the Colorado; or if they could not carry them there, to the Mexican commanding officer at Tucson.

Among the Maricopas, I noticed to-day three whom I had seen in Ures when there last winter, and to whom I had given notes of recommendation. They now showed them to me carefully wrapped up in several envelopes, and deposited in a bag of black skin. All the chiefs, both Pimos and Coco-Maricopas, have let- 
ters which they have obtained from passing emigrants, recommending them to the favor and kind treatment of others. They prize these certificates very highly.

July 2d. This morning, Francisco, the Maricopa interpreter, breakfasted with me, and, from his ease at table, showed that he had been among civilized people before. He was well dressed, having on pantaloons, a shirt, and hat. He is a man of much intelligence and shrewdness, and expressed a desire to serve us. The Americans who had been through these villages before, he said, had given his people very little, although they had done much for them. They had brought the Americans wood and water, and had acted as guides, sometimes accompanying them many miles, and he himself had acted as interpreter for all parties, but had received little or nothing in return. Besides this, his people had often given corn, melons, and vegetables, to ours; but the Americans had told them they were very poor (as they doubtless were), and had neither clothes nor goods with which to reward their kindness. He said they sometimes received money from the Americans; but it was of little use to them, as they wanted manta (white cotton) and shirts. I told Francisco, in reply, that those he referred to were mostly families of poor emigrants, who had left their homes, and were going to California in the hope of doing better; and that before I left, if his people conducted themselves well, I would not only pay him for all I received, but would make him and the other chiefs of his tribe presents, to induce them to treat all other Americans who might pass their villages with kindness, and supply them with what they could spare. 
There was one practice of this chief that was not so agreeable to me, namely, that of helping his friends to the choicest bits from my table. When we took our places, they all assembled, and sat or stood gaping around. Francisco, during the meal, occasionally handed them a piece of bread or meat; and when we had finished, he coolly piled up his plate, and passed it around among his friends. At first, I was rather amused at the fellow's impudence; but on a subsequent occasion, he carried the joke still further, not only giving them what he had collected on his own plate, but stripping the table of all that remained, so as to leave nothing for my cook and servant. As our supply of provisions was limited, I had no idea of feeding so many hungry mouths, which had an abundance at home; consequently my second invitation to the chief, was the last. Yet he made his appearance regularly every morning while we remained, and gave many hints about being hungry, expressing his surprise to the cook that he did not have a seat at my table. I told him, finally, that it was not the custom among Americans, when they asked a friend to their table, to feed his whole tribe.

This man afterwards became quite a bore to us; for nothing would satisfy his avarice. I gave him shirts, pantaloons, white cotton, and calico, besides beads and trinkets for his wife and children. Lieut. Paige, also, made him some valuable presents; but he constantly asked for more, and was most importunate for whiskey. I told him we had none; but this he seemed to doubt, declaring that we were the first party of Americans he had ever seen that did not drink whiskey. Every 
junk bottle he saw about my tent or wagon, was suspected to contain the forbidden liquor; and nothing would satisfy. him until he examined them himself. After finding in one lemon syrup, in another vinegar, and in a third a mixture for diarrhœa, which communicated an unpleasant pucker to his mouth, the fellow gave up all hopes of obtaining the object of his search. Much harm has been done by Americans in giving this poor and simple-hearted people intoxicating drinks; and it is a matter of satisfaction to me to state, that in my long intercourse with the Indians here, as well as at the Copper Mines with the Apaches, none ever got a drop of liquor from me, or from my camp to my knowledge.

In the evening, while a crowd of Indians were lying or squatting around my tent, I had a long talk with a Maricopa, whose name I forget (but who spoke Spanish well), on the manners and customs of his people. This man was terribly crippled, having a year before been engaged in a fight with the Yumas, in which his party was defeated. He was lanced in many places, beaten with clubs, his hair cut off, and left for dead. After the combatants had left, he revived, and by some means succeeded in getting home. He was still unable to walk, except with a long staff, but had to be lifted on his horse, and rode about with some difficulty. He was quite an intelligent man, and, while we remained, was constantly in our camp.

He said the Coco-Maricopas came here not many years before, to escape from the Yumas, with whom they were constantly at war, and by whom they had been greatly reduced in numbers. Their former range was along the valley of the Gila, on the opposite side 
of the Jornada and towards the Colorado. Their present position adjoining the Pimos, was chosen for the benefit of mutual protection.

This people restrict themselves to a single wife. Their ideas of a Supreme Being, in whose existence they believe, are of so vague a nature that I could not ascertain them with exactness. After death, they believe that their souls go to the banks of the Colorado, their ancient dwelling-place, and there take refuge in the great sand hills, where they are metamorphosed into various animals and birds. Their heads, hands, feet, etc., each become owls, bats, wolves, and other animals. They believe, too, that the souls of their enemies, the Yumas, also find a place there; and that the wars which have so long existed between them on earth, will be continued there, after death.

When a man desires to marry, and has made choice of a girl for his wife, he first endeavors to win over her parents by making them presents. The fair one's attention is sought by another process. To do this, he takes his flute, an instrument of cane with four holes, and, seating himself beneath a bush near her dwelling, keeps up a plaintive noise for hours together. This music is continued day after day; and if no notice is at length taken of him by the girl, he may "hang up his flute," as it is tantamount to a rejection. If the proposal is agreeable, the fair one makes it known to the suitor, when the conquest is considered complete. No girl is forced to marry against her will, however eligible her parents may consider the match. Whenever a girl marries, it is expected that her husband will present her parents with as much 
as his means will permit, to compensate them for the loss of their daughter, whose services are to them a matter of consequence.

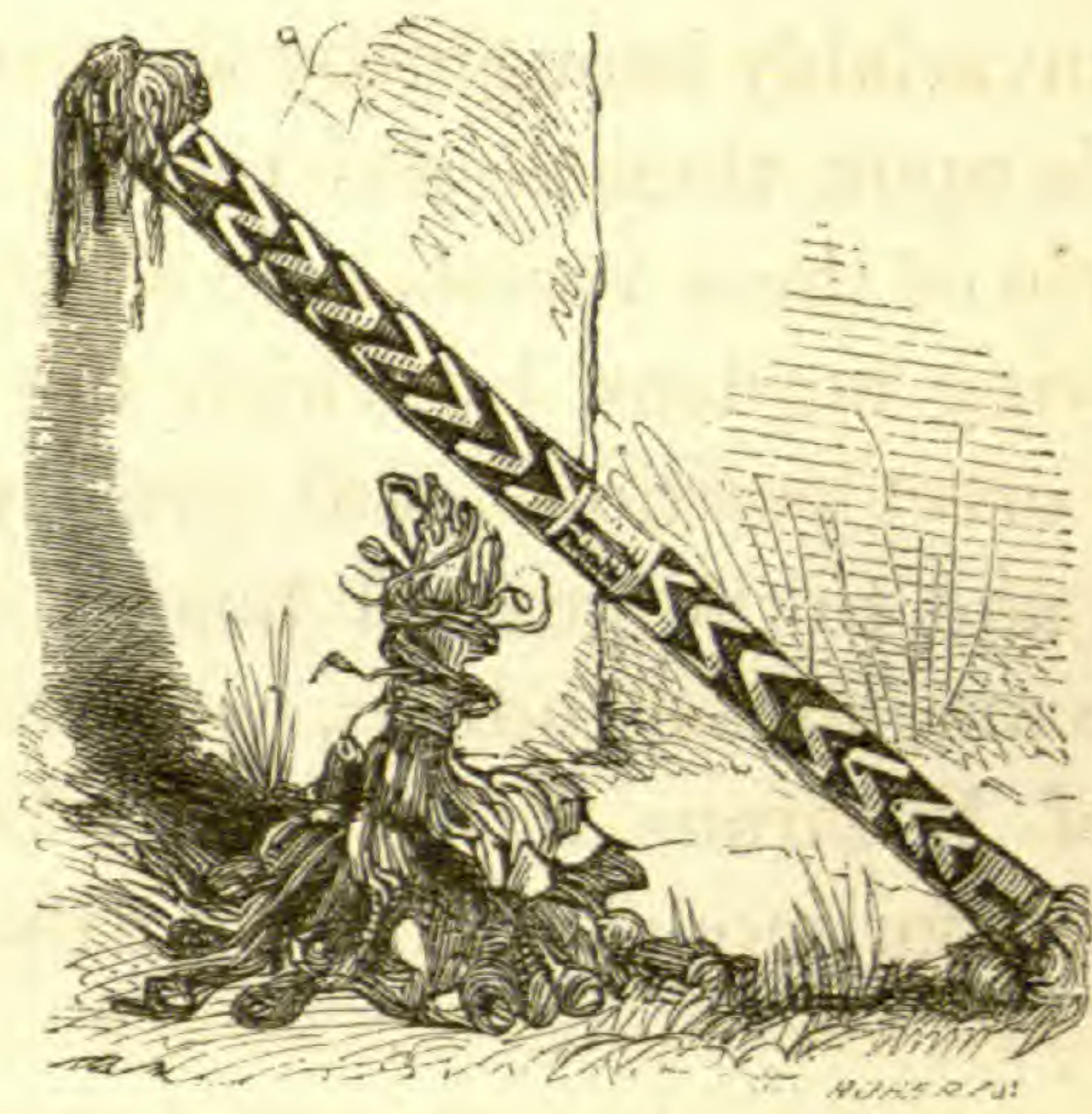

Indian Flute, and Rattle of Deer's Hoofs.

Among both the Coco-Maricopas and the Pimos, the women do the principal part of the work. Besides taking care of the children and attending to the household matters, they grind the corn, make baskets, gather mezquit beans, help till the ground, and sometimes spin and weave.

The men plant and gather the crops, and take care of the animals. This I believe is all they do ; and as the performance of these duties is not a very onerous task, they are idle the greater portion of the time. Their implements of husbandry are steel hoes and axes which they obtain from the Mexicans, harrows, and occasionally a long-handled spade. Grinding corn on the metates, or stones, is a work of great labor, and comes hard on the poor women, who are obliged to get upon their knees, and exert the whole strength of their arms 
and bodies in the task. I have seen women thus employed when the thermometer stood at $110^{\circ}$, while their lords lay stretched out at length on their backs looking on.

Water is invariably brought by the women in large earthen vessels upon their heads resting upon a small cushion. Some of these vessels hold six gallons. This mode of carrying burdens, by which the body is kept in a perfectly erect position, tends greatly to develope the chest and add to the general beauty of the figure. Hence we see among the Indians, as well as among the lower class of Mexicans, forms which Walker might well have taken for models in his "Analysis of Beauty in Women."

As the manners and customs of the Pimos and Coco-Maricopas are the same, with the exception of their rites of burial, I shall include both in describing these customs; although there is little doubt but that the knowledge of the arts which they possess originated with the Pimos. Cotton is raised by them, ${ }^{*}$ which they spin and weave. Their only manufactures consist of blankets of various textures and sizes; a heavy cloth of the same material used by the women to put around their loins; and an article from three to four inches wide, used as a band for the head, or a girdle for the waist. The blankets are woven with large threads, slightly twisted and without any nap. They are made of white cotton, and are without ornament of colors or figures, save a narrow selvage of buff.

* I brought home with me the seeds with samples of this cotton, which was pronounced equal to the best Sea Island. The seeds I distributed among various planters. 
The implements used by these tribes for spinning and weaving are of the most primitive character. A slender stick about two feet long passing through a block of wood which serves to keep up the momentum imparted to it, constitutes the spindle. One end of this rests on a wooden cup inserted between the toes,

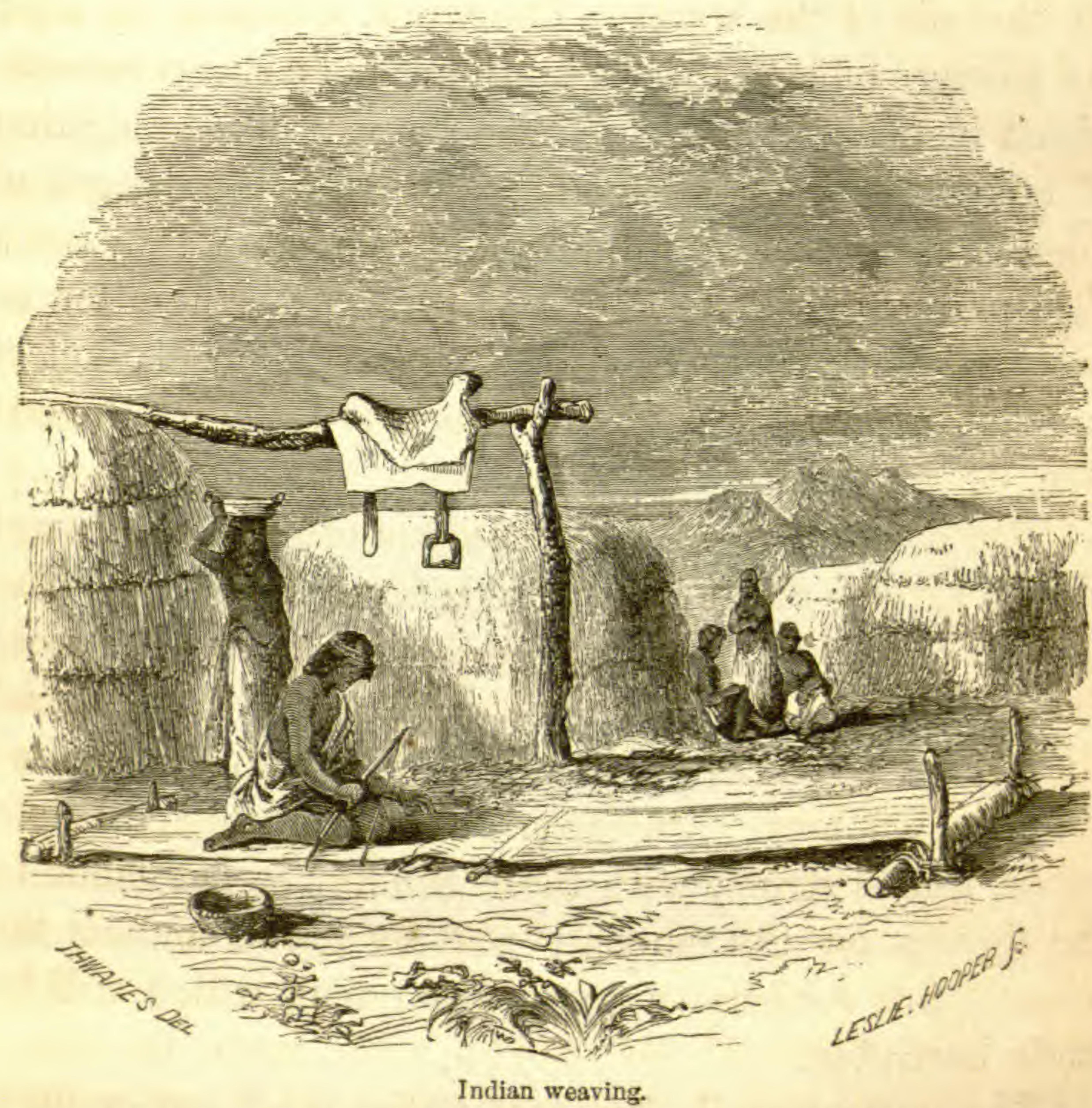

and the other is held and twirled by the fingers of the right hand; while the left hand is occupied in drawing out the thread from the supply of cotton, which is coiled upon the left arm in loose rolls.

In weaving, the warp is attached to two sticks, and voL. II, -15 
stretched upon the ground by means of stakes. Each alternate thread of the warp is passed round a piece of cane, which, being lifted, opens a passage for the shuttle in the manner of a sley. The operator sits in the fashion of a tailor, and, raising the sley with one hand, with the other passes the shuttle, which is simply a pointed stick with the thread wound upon it, between the threads of the warp. The work is beaten up after the passage of each thread by the use of a sharp smoothedged instrument made of hard wood. The operation of course progresses slowly; and from the length of time consumed in spinning and weaving, they set a high price upon their blankets, asking for them ten or twelve dollars in money, or a new woollen blanket of equal size. The weaving is generally done by the old men.

The head-band or girdle consists of a white ground with a variety of figures of red, blue, and buff. The figures are angular, and, though they present a great variety, are all of one general character. The colored portions of these belts are made of wool, and the colors are quite brilliant. On examining the patterns on these bands, one is struck with their general resemblance to the figures on the ancient pottery found among the ruins of this country, a comparison with which will be made hereafter.

The pottery made by these tribes is all red or dark brown, the latter a blending of black and red. The articles made are very limited, though, perhaps, quite sufficient for their wants. In fact, they are the same as those made and in use by the Mexicans. They consist of ollas, or vases, of every size, the largest holding 
about two pailfulls, and the smallest half a pint; jars with small apertures, resembling bottles; basins of different sizes and forms, from that of a milk-pan to a saucer; and oblong vessels of small dimensions used as dippers. All these vessels are painted or ornamented with black lines arranged in geometrical figures, and of a character resembling those on the head-bands.

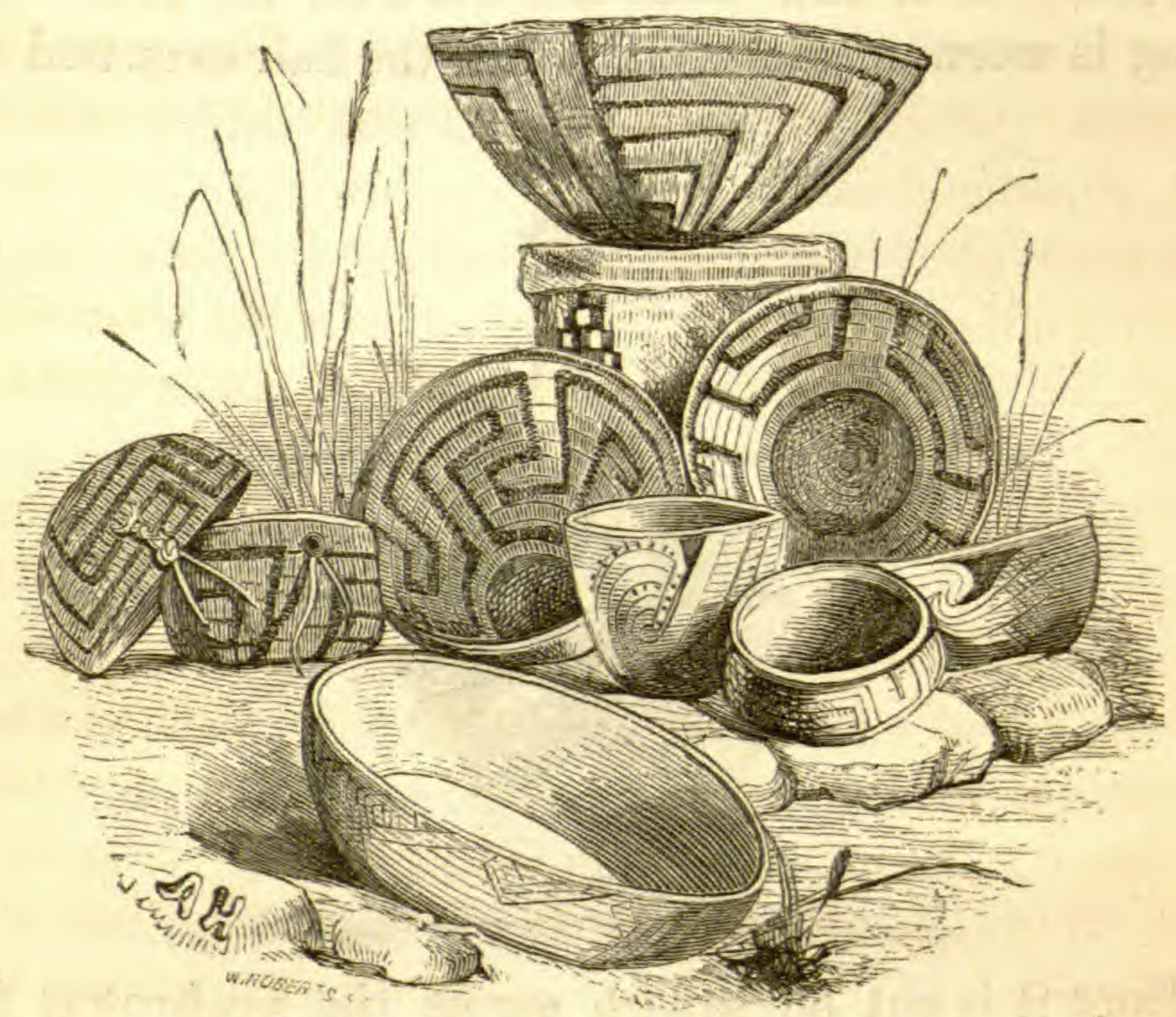

Baskets and Pottery of the Pimos and Coco-Maricopas

The basket work of this people is remarkably well made of willow twigs, and so close as to be impervious to water. The baskets are of various shapes, and are used for different purposes. Those of a large basinlike form are the most common. These they carry on their heads filled with corn or other articles. Like 
the pottery, they are ornamented with geometrical figures, arranged with much taste.

The dress of the Coco-Maricopas and the Pimos is the same. The women fold the smaller blankets or other cloths, and pass them around their loins, letting them hang to their knees. They are sometimes fastened with one of the belts before mentioned, but are generally kept in place by simply tucking one end in. Sandals of raw hide are worn on the feet. Nothing is worn on the head, nor is the hair ever tied up.

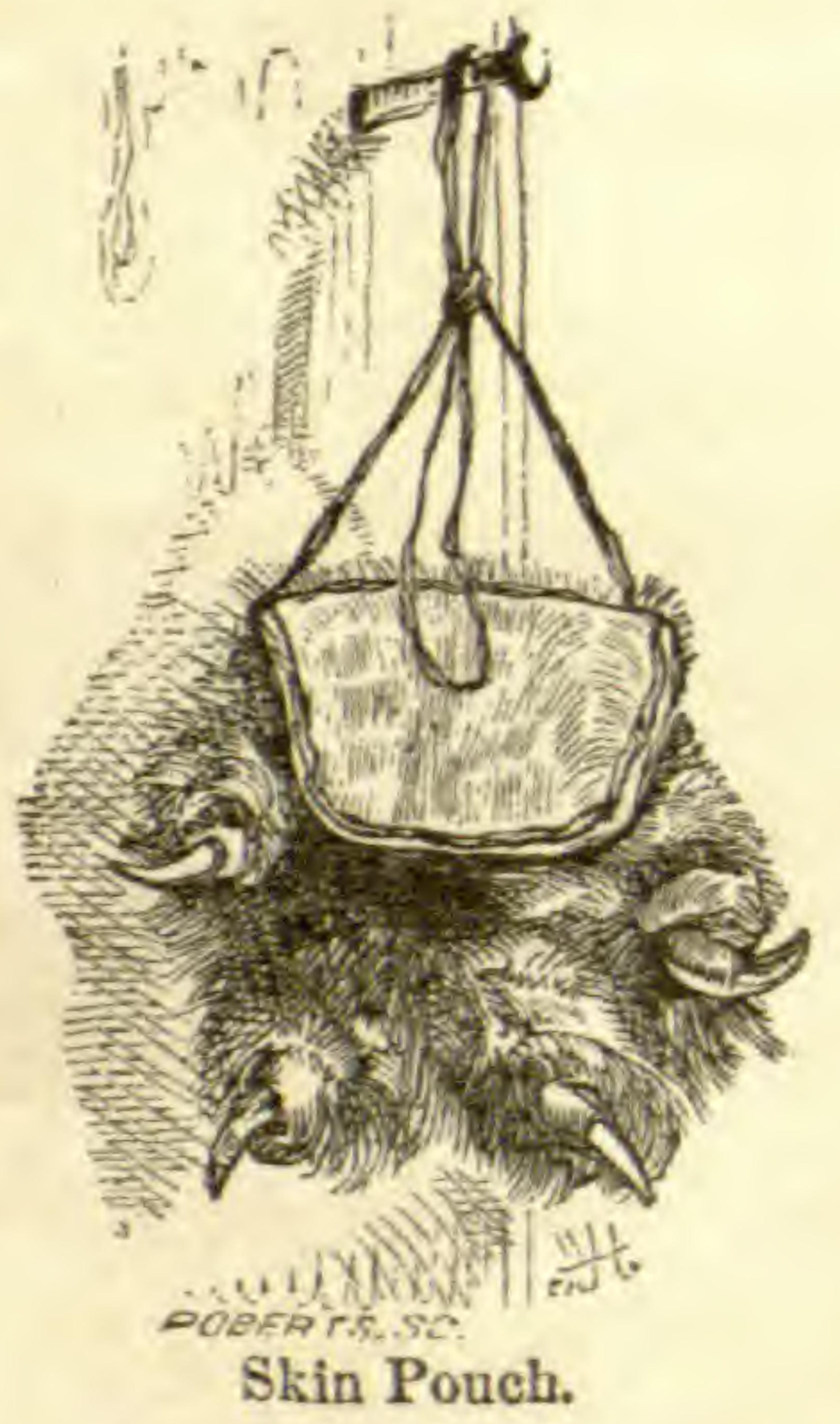

In front it is cut off square across the eyebrows; the rest is suffered to hang loosely over the ears, neck, and about half way down the back, affording a protection to these parts from the intense heat of the sun. It is a universal custom among the women when they arrive at maturity, to draw two lines with some bluecolored dye from each corner of the mouth to the chin. This is pricked in with some pointed instrument, and remains through life. Occasionally a fair one gets a 
string of beads; but I saw more men and boys with these ornaments than women. One boy in particular, who might pass for a dandy among them, wore some twenty or more strings of beads. The body, arms, and legs of the women are naked. They generally have fine forms; for which they are indebted, as I have before remarked, to their mode of carrying burdens on their heads. In this respect, there is a marked difference between them and the men, who are generally lean and lank, with very small limbs and narrow chests. Their labor is so light, and they keep so closely to their villages or the immediate vicinity, that there is no opportunity for physical development. The men in general go naked, except the breechcloth. A few, however, are provided with their native blankets of large size, which they fold and throw over their shoulders in the manner of the Mexicans. Some fasten them around their waists in graceful folds, letting the ends fall to their knees; then drawing a cord between their legs and attaching it to their waists, their garment resembles a capacious pair of pantaloons. I suppose that all are provided with cotton blankets; but, owing to the almost incessant heat of the day, they seldom wear them. At night, when cool, these constitute their sole covering. The head-band is worn by nearly all the men gracefully put on in several folds, with the braided ends hanging down to their shoulders. They also have a large woollen cord, from half an inch to an inch in diameter, of different colors, which they use as a head ornament, twining it around the hair. So many Americans have been among these people, that most of them have obtained ragged or 
cast-off shirts, which they put on on great occasions. By their traffic with the Boundary Commission, they obtained a large number of these garments of a good substantial quality both cotton and woollen. The bright scarlet shirts gave them quite a picturesque appearance. When they visited our camp, every man put on his best garments, no matter what was their fashion, or how many he had. I remember that on one occasion Francisco made his appearance in a pair of pantaloons, with a white shirt, over which was a checked one, and another of red flannel outside of that. For a short time he strutted about the camp, the envy and admiration of his friends. But he soon got tired of sporting such a dress with the heat at $110^{\circ}$; and shortly after we saw him cooling off on the grass, divested of all his finery, which he had carefully tied up in a bundle.

The men wear their hair long, never cutting it except across the eyebrows, down to which it hangs, and thus partially protects the eyes. When loosed, their hair reaches to their knees; but usually it is clubbed up in a large mass on their backs. Their earlocks either hang loose, or are braided in several strands, with little ornaments of bone, tin, or red cloth attached to them. But the decoration of their heads with the bands of which I have spoken, forms the most picturesque part of their costume. They have a singular practice of filling their hair with clay; so that when dry it resembles a great turban. I could not imagine their object in adopting so filthy a custom, unless it was to destroy the vermin. The men also wear a profusion of beads when they can obtain them. 
Some have long strings of sea-shells or parts of shells, which are highly prized. I tried to buy some of them; but the only man at all disposed to sell asked me five dollars or a pair of blankets for a few strings, a price so extravagant that I declined to make the purchase.

The women carry their infants in cradles similar to those of other Indians. I have seen them in camp with a basket of green corn on their heads, and on the top of this the cradle and child. When it gets to be about a year old, it is carried astride on the hip, the mother holding one arm around its body. Although the men and boys go naked, I never saw a girl, however young, without clothes around its hips similar to those worn by the women.

The Indians were much amused by Dr. Webb's collection of insects, reptiles, and small mammalia, which. were preserved in bottles or hanging about our tent. I told the boys to go out and collect for us any curious insects, lizards, or snakes they could find, and that I would reward them for so doing. Instead of letting the boys go, the men, in the belief that they would be well rewarded, went themselves, and in a few hours came very earnestly to my tent with a few grasshoppers and crickets. Although utterly valueless, as containing nothing new, yet Dr. Webb graciously received them, as an encouragement to prosecute their zoological researches further, at the same time informing his new recruits that lizards and horned frogs, which abound on the plateau, would be most acceptable. They now set off again, and we hoped something better from this second effort. About an hour after, some half-a-dozen sturdy fellows marched to- 
wards my tent in single file, with a great deal of importance. The leader advanced with a dignified air, and the Doctor got his bottles ready to receive the specimens which the six men had collected. But his expectations, if he indulged any, of adding new species to his collection, soon vanished, when the man laid upon the table two small lizards, minus their taits, which had been broken off in securing them. For their arduous services in the cause of science, the captors of the tailless lizards coolly demanded a shirt apiece.

Two old chiefs made their appearance to-day, and at once recognised Mr. Leroux as the person who guided Colonel Cooke and his battalion through here in 1847. Mr. Leroux also recognised one whom they called Blanco, as a chief who commanded the Maricopas twenty-five years ago, when a party of hunters and trappers from New Mexico, among whom was Leroux, had a severe fight with them, and escaped narrowly with their lives. On being reminded of it, the old chief recollected the circumstances, which he related, and which corresponded with the account of Leroux.

The valley or bottom-land occupied by the Pimos and Coco-Maricopas extends about fifteen miles along the south side of the Gila, and is from two to four miles in width, nearly the whole being occupied by their villages and cultivated fields. The Pimos occupy the eastern portion. There is no dividing line between them, nor any thing to distinguish the villages of one from the other. The whole of this plain is intersected by irrigating canals from the Gila, by which they are enabled to control the waters, and raise the 
most luxuriant crops. At the western end of the valley is a rich tract of grass, where we had our encampment. This is a mile or more from the nearest village of the Coco-Maricopas. On the northern side of the river there is less bottom-land, and the irrigation is more difficult. There are a few cultivated spots here; but it is too much exposed to the attacks of their enemies for either tribe to reside upon it.

The villages consist of groups of from twenty to fifty habitations, surrounded by gardens and cultivated fields, intersected in every direction by acequias, which lead the water from the Gila. Their mode of irrigation is the same as that practised in various parts of Mexico. Their cultivated fields are generally fenced with crooked stakes, wattled with brush, the thorny mezquit predominating; although I noticed large patches of wheat, a long distance from any village, that were not inclosed.

Their houses are built with stakes, poles, cornshucks, and straw. For the small houses, four upright stakes forked at one end are inserted in the ground. For the larger dwellings nine are used; three on each side, and one in the centre. Across the tops of these, other sticks are laid to support the roof. Next a row of poles is inserted in the ground, a few feet outside the larger upright stakes, bent over towards the centre and fastened to the horizontal beams. These are then united in the centre, forming a slightly rounded top. Smaller poles are now horizontally interlaced with the upright ones, and between them straw, corn-shucks, or rushes are interwoven in large masses, so as to shed the rain and protect them from the intense heat of the 
sun; some are then plastered over with mud. An opening for a door is left, about three feet high, to creep in at. These habitations vary in height from five to seven feet; so that in many of them one cannot stand erect. In fact they are chiefly used to sit and sleep in. - In diameter they are from fifteen to twentyfive feet. In the most westerly village of the CocoMaricopas, from which the annexed sketch was taken, the wigwams are wholly plastered with mud. Their cooking is done out of doors, where the greater portion of their time is passed, beneath a kind of shed or bower attached to the wigwams This is open on all sides, and merely protected from the sun overhead. Beneath these bowers the people are generally seen engaged in their household occupations, only resorting to their better protected abodes in cool or rainy weather. The accompanying sketch shows the manner of erecting these wigwams.

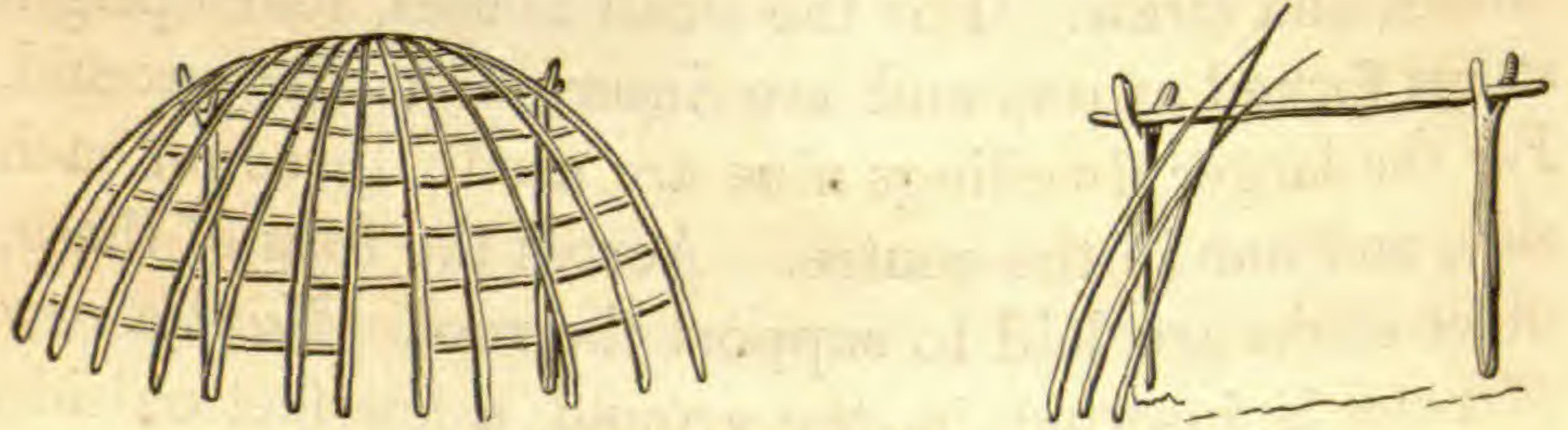

Mode of constructing Wigwams.

Besides the dwelling-places, each family is provided with a store-house or granary. These are built like the Mexican jakals, i. e., with stakes placed close together and about eight or nine feet high. They are better structures than the dwellings, and are probably made more open, in order to give a free circulation of 
air through the grain deposited in them. They are wattled with straw and rushes, and are sometimes coated with a thick layer of mud. As this becomes dry, additional layers of mud are added, which render

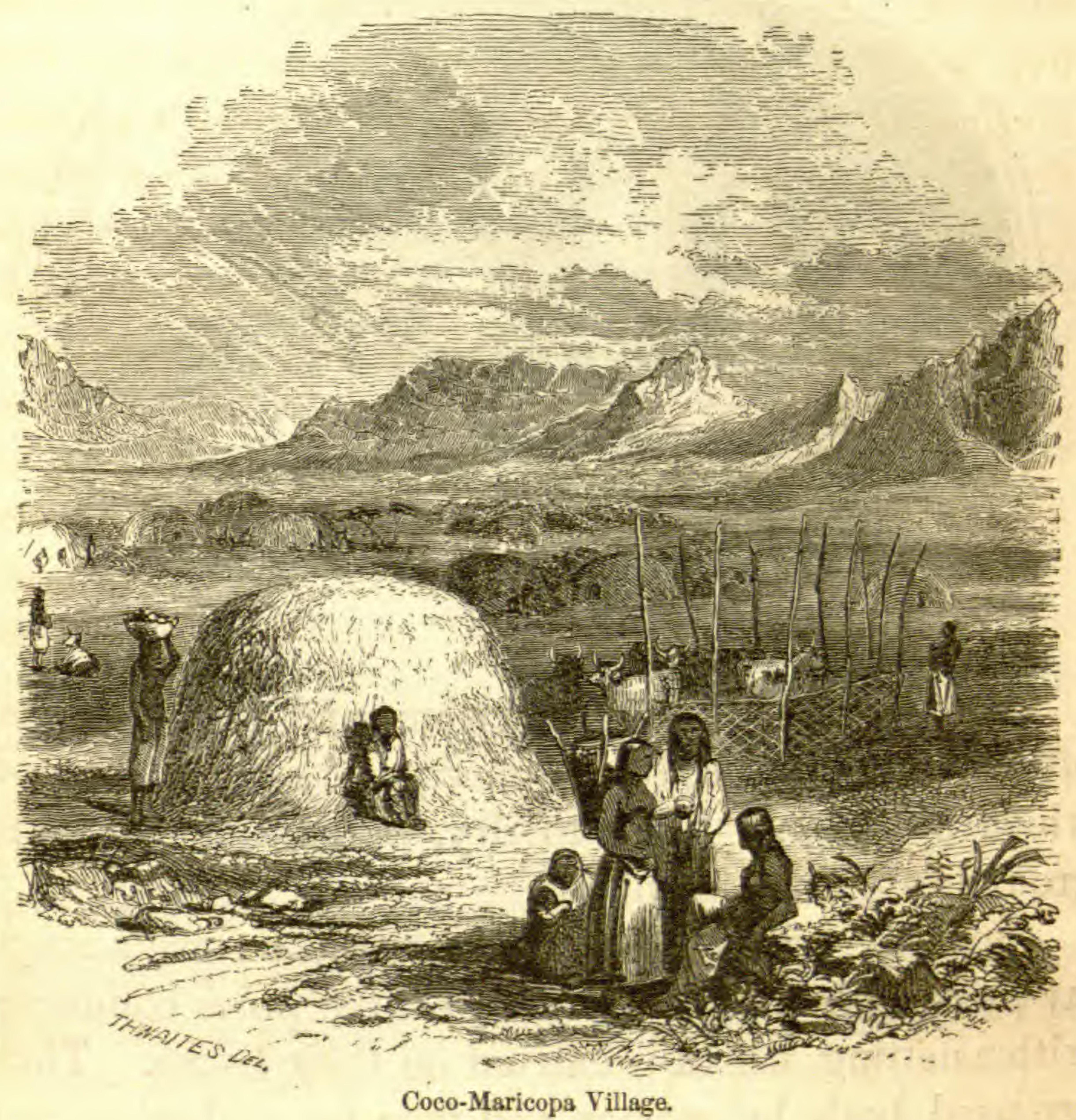

them impervious to water. The wheat and shelled corn (maize) are put into large vases or baskets, from three to five feet high, made out of ropes of wheaten straw. These ropes, which are as thick as one's arm, are coiled around into graceful forms, and sewed together like some kinds of basket work. The vases 
so formed contain ten or twelve, and some even fifteen bushels of grain. The following sketch exhibits a view of the interior of a Pimo granary or store-house.

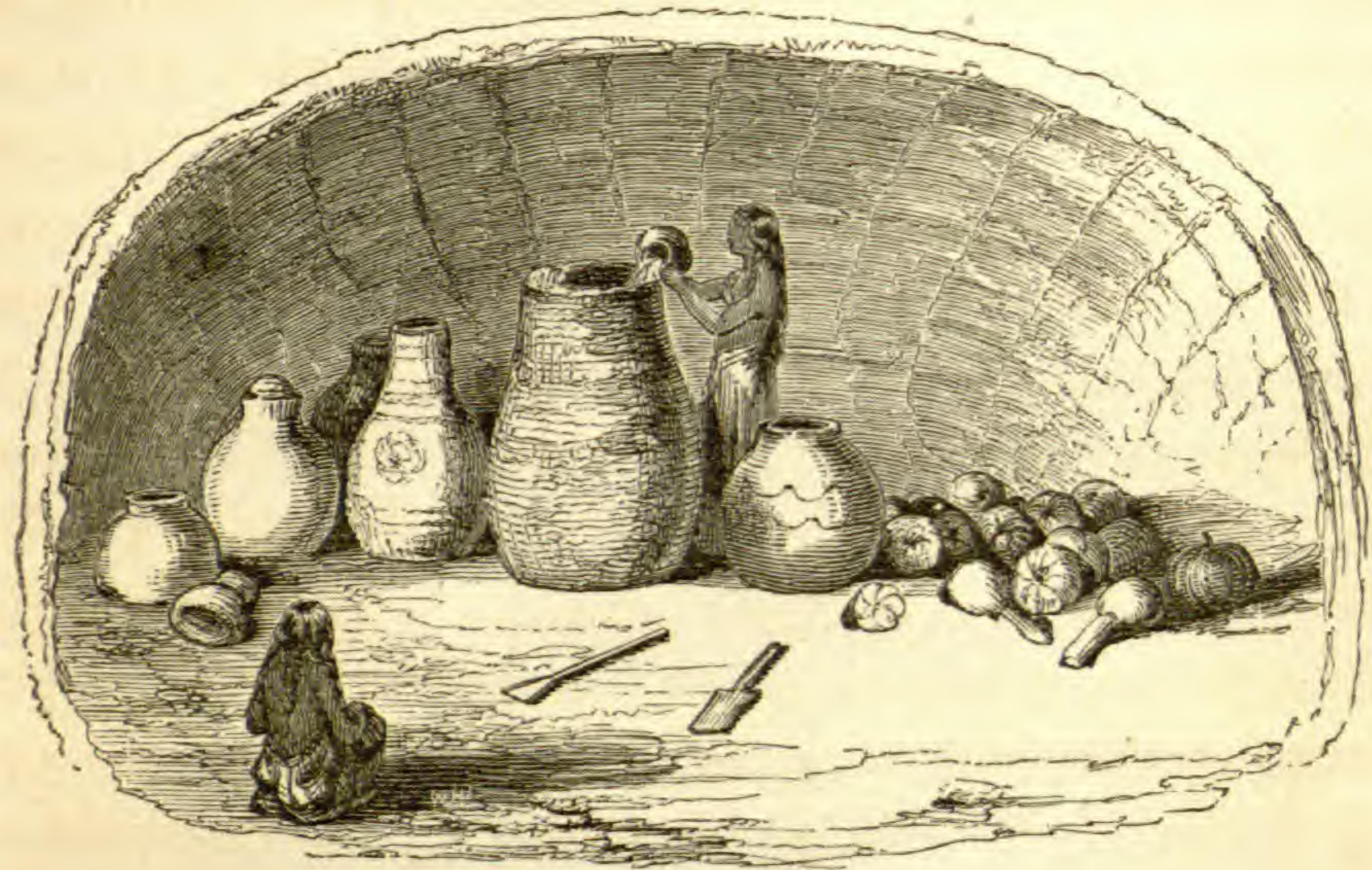

Pimo store-house.

On the tops of their wigwams and granaries may often be seen large piles of mezquit beans in the pod, which are placed there to dry, preparatory to being ground into flour for pinole.

Both the tribes of Indians referred to, use a singular piece of frame-work made of three poles connected with a netting, which is carried on their backs. These are used both by women and men for gathering mezquit beans, corn, and other light articles. They may be seen at every wigwam, and answer the purpose of a wheelbarrow. They are highly prized by their owners, as they are very useful to them, and are made with much labor. For the only specimen I could obtain, I was obliged to give goods to the value of ten dollars. These people possess horses and cattle, though but 
very few mules. I found it impossible to procure a single mule from them during my stay. They breed none, and what they obtain are such as have been lost or abandoned by passing emigrants. They plough but little, finding their hoes quite sufficient for turning up the light soil. When ploughing is resorted to, oxen alone are used. They possess a few carts and wagons, obtained from emigrants, which they use with oxen for agricultural purposes. We saw all kinds of saddles among them, from the best dragoon and Mexican saddles to the simple tree or frame. They find them on the road, where they have been thrown away by parties who have lost their animals. Those who ride bareback use a broad girth, which is passed quite loosely around the body of the horse. Into this one foot is inserted. There seemed to be numbers of horses among them, which with the cattle are left to graze near the villages during the day, and at night are brought into the corrals, or yards, for safety.

The only weapon used by these tribes is the bow and arrow. The short club of the Yumas and the long lance of the Apaches I never saw among them. The constant use of this weapon has rendered them excellent marksmen. Even the boys are very expert in the use of it. I have seen boys of ten or twelve years of age, strike a cent three times out of five at a distance of fifteen yards. It is quite common for them to shoot doves with their arrows, and to bring in half a dozen of these birds after a ramble among the cotton-woods. It is a favorite amusement with both men and boys to try their skill at hitting the petahaya, which presents a fine object on the plain. Numbers 
often collect for this purpose; and in crossing the great plateau, where these plants abound, it is common to see them pierced with arrows.

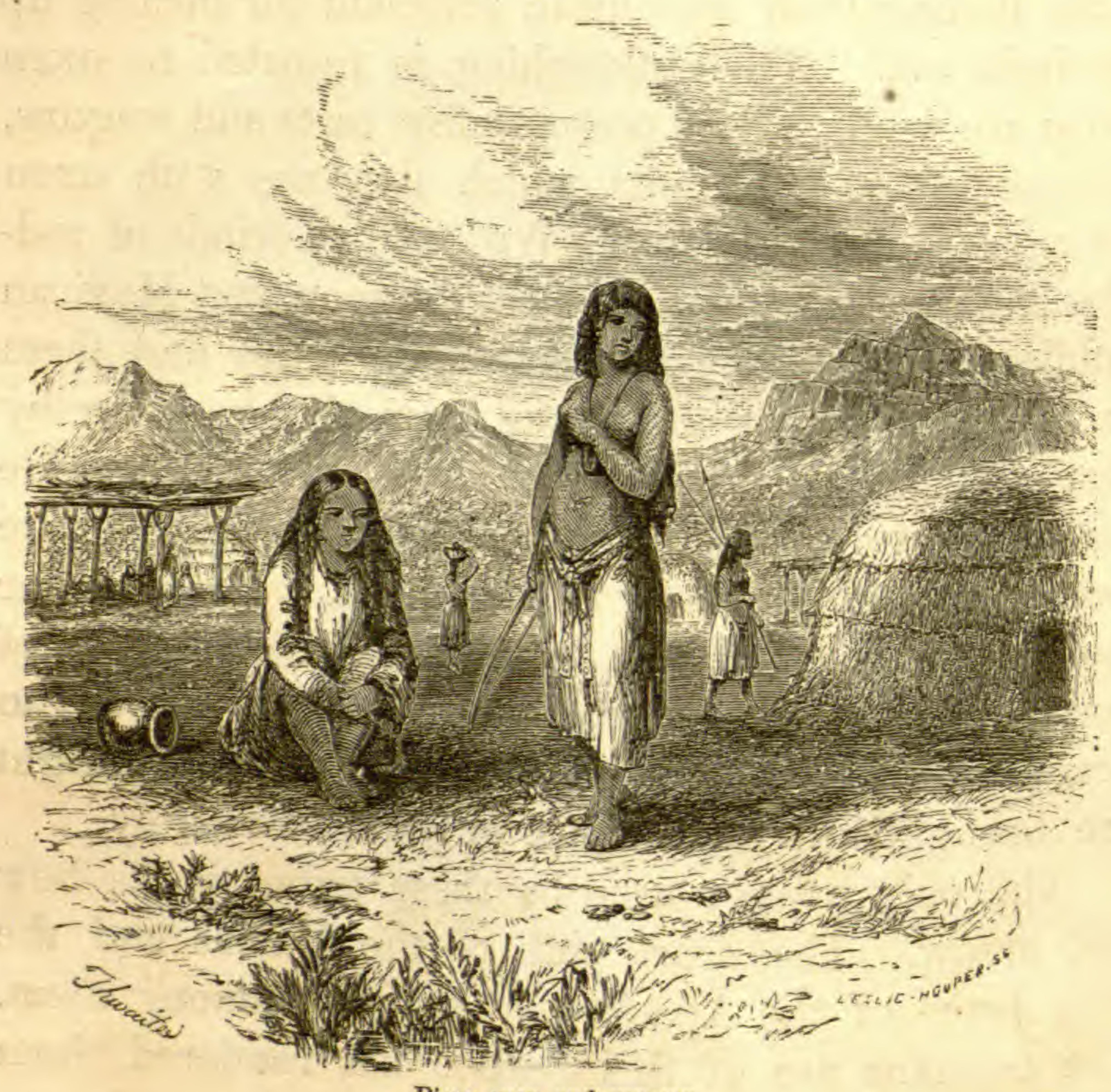

Pimo man and woman. 


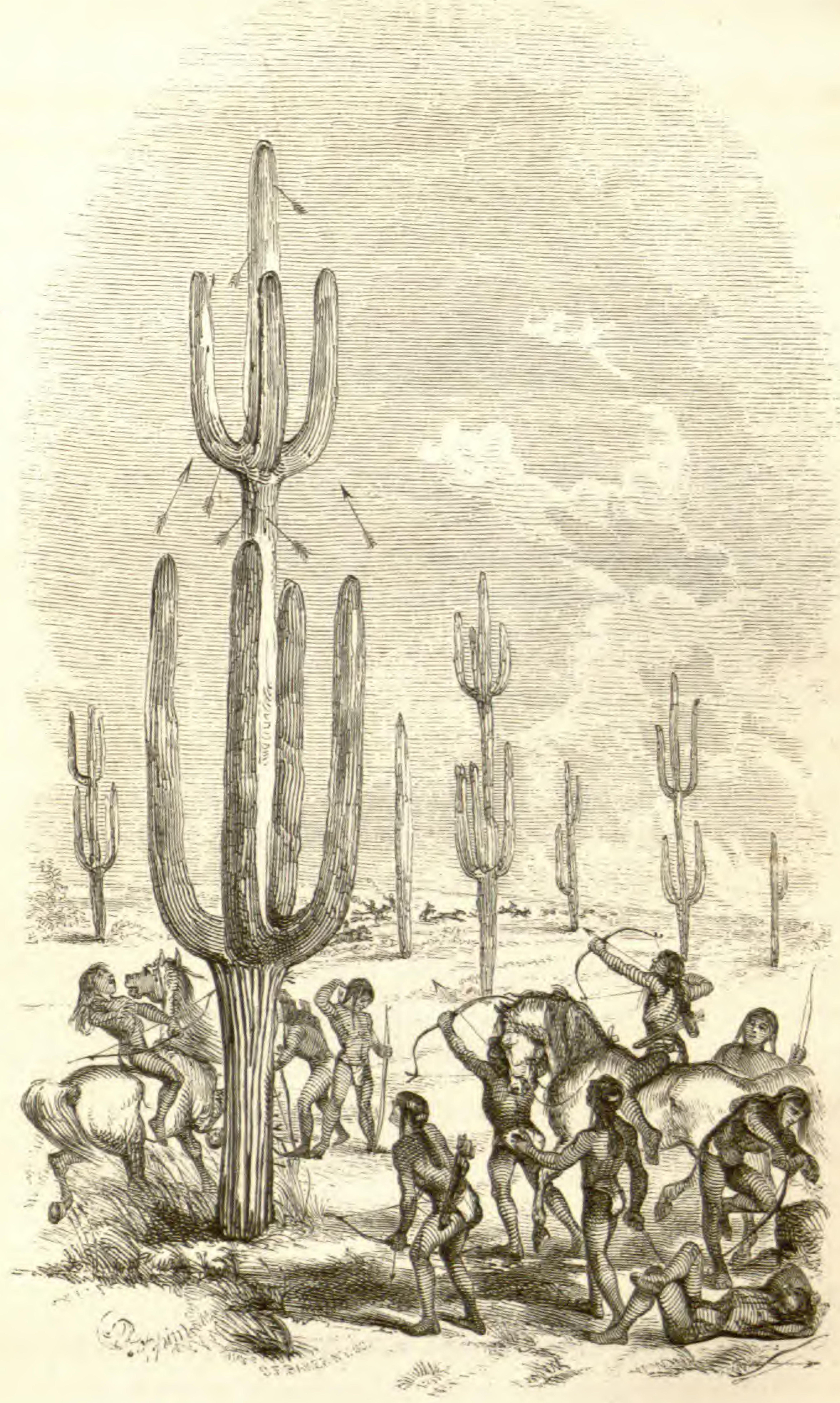

INDIAN AMUSEMENTS. SHOOTING AT THE PETAHAYA. 


\section{CHAPTER XXXI.}

AT THE COCO-MARICOPA AND PIMO VILLAGES.

Journey to the River Salinas-Its rich bottom-lands-Large stream-Pimo Indians-Ruined buildings-Mounds-Broken pottery-Traces of irrigating canals-Ancient population probably large-Return towards the Pimo villages-Are taken for Apaches-Arrival at camp-Arrival of Lieutenant Whipple-Survey of the Gila completed-Trade reopened with the Coco-Maricopas-Presents-Tribe of CawenasRemove to the Pimo villages-Cola Azul and the Pimos-Traffic with them-Conference-Giving presents-Arrival of Mexican traders -Return of Lieutenant Paige with the escort-Leave the villages.

July $3 d$. In order to make the most of my time while waiting the arrival of Lieutenant Whipple and party, I determined to take a short trip up the river Salinas, as far as the "Casas Grandes," or ancient remains said to be there. I asked a couple of Maricopas to go with me as guidès, and offered them a red flannel shirt each for their services. They wished two others to accompany them, if I would take them on the same terms. Finding that I consented so readily, they parleyed a while, and then demanded for each a shirt, six yards of cotton, and sundry small articles, without which they declared they would not go. Francisco, the interpreter, was their spokesman, and I have no doubt urged them to make this demand. I 
refused to accede to it, and told them that Francisco and one other would answer my purpose, as first proposed.

At six o'clock this morning we set off, the party consisting of Dr. Webb, Messrs. Thurber, Pratt, Seaton, Force, Leroux, and myself, with attendants. Lieutenant Paige, with six soldiers, also accompanied us, that officer wishing to examine the opposite bank of the Gila, as well as the lands contiguous to the Salinas, with a view of establishing a military post in the vicinity of the Pimo villages. After crossing the bed of the Gila we pursued a westerly course about eight miles to the point of a range of mountains, near which we struck the bottom-lands. We now inclined more to the north, and in about eight miles struck the Salinas, about twelve miles from its mouth, where we stopped to let the animals rest and feed. The bottom, which we crossed diagonally, is from three to four miles wide. The river we found to be from eighty to one hundred and twenty feet wide, from two to three feet deep, and both rapid and clear. In these respects it is totally different from the Gila, which, for the two hundred miles we had traversed its banks, was sluggish and muddy, a character which I think it assumes after passing the mountainous region and entering one with alluvial banks. The water is perfectly sweet, and neither brackish nor salt, as would be inferred from the name. We saw from the banks many fish in its clear waters, and caught several of the same species as those taken in the Gila. The margin of the river on both sides, for a width of three hundred feet, consists of sand and gravel, brought down by freshets when 
the stream overflows its banks; and from the appearance of the drift-wood lodged in the trees and bushes, it must at times be much swollen, and run with great rapidity. The second terrace or bottom-land, varies from one to four miles in width, and is exceedingly rich. As it is but little elevated above the river, it could be irrigated with ease. At present it is covered with shrubs and mezquit trees, while along the immediate margin of the stream large cotton-wood trees grow. Near by we saw the remains of several Indian wigwams, some of which seemed to have been but recently occupied. Francisco told us they were used by his people and the Pimos when they came here to fish. He also told us that two years before, when the cholera appeared among them, they abandoned their dwellings on the Gila and came here to escape the pestilence.

Owing to the intense heat, we lay by until five o'clock, and again pursued our journey up the river until dark, when, finding a little patch of poor grass, we thought best to stop for the night. Supper was got, and a good meal made from our fish. As we brought no tents, we prepared our beds on the sand.

We had not long been in when we saw a body of twelve or fifteen Indians on the river making for our camp. At first some alarm was felt, until Francisco told us that they were Pimos. They proved to be a party which had been engaged in hunting and fishing. They were a jolly set of young men, dancing and singing while they remained with us. I told them we would like a few fish for breakfast, if they would bring them in. With this encouragement, they took leave vol. II, -16 
of us, promising to fetch us some in the morning. But instead of waiting till the morning, they returned to the camp about midnight, aroused the whole party with their noise, and wished to strike a bargain at once for their fish, a pile of which, certainly enough to last a week, they had brought us. There was no getting rid of them without making a purchase, which I accordingly did, when they left, and permitted us to get a few hours' more sleep.

July $4 t h, 1852$. Left camp at half-past four, A. M., determined not to wait for breakfast, but make the most of our time while it was cool; for it would be impossible to travel, or rather be attended with great inconvenience, during the heat of the day. We continued our course due east up the river, towards some singular piles of rocks with fantastic tops, appearing like works of .art. For some time we all imagined these rocks to be the ruined buildings of which we,were in search-the "houses of Montezuma," as our Indian friends called them. We passed over the edge of a mountain, at the base of which the river ran, and then came to a wide and open plain, stretching some twenty-five or thirty miles eastwardly and southwardly. Entering this, we attempted to cross the bottom, which was so thickly overgrown with weeds and bushes that we could not penetrate it. We tried in vain to get through, but finding ourselves scattered, and fearing we should lose sight of each other, we retraced our steps along the margin of the hill, until we passed the jungle. The bottom now became more open, and five or six miles further brought us to the plateau. On our way we saw many traces of ancient 
irrigating canals, which were the first evidences that the country had been settled and cultivated. But on reaching the plateau we found remains of buildings, all, however, in shapeless heaps. Not an erect wall could be seen. A little mound, conical or oblong, designated the character of the building. In many places I traced long lines of fallen walls, and in others depressions, from which the soil had been removed to make the adobe. On the plain, in every direction, we found an immense quantity of broken pottery, metate stones for grinding corn, and an occasional stone axe or hoe. The ground was strewn with broken pottery for miles. It was generally päinted in a variety of geometric figures. The predominant colors were red, black, and white. The quality of the ware was very fine, more so than that made by the Pimos. I noticed too that much of it was painted on the inside, while at the present time all the pottery of the Indians and Mexicans is painted on the outside.

As it was now growing very warm, we left the plateau and struck off for the Salinas, encamping beneath some tall cotton-woods, where we prepared and partook of a late breakfast.

Mr. Leroux, who had before come down the Salinas, pointed out to me a mountain some six or eight miles off, at the base of which the river San Francisco or Verde enters from the north. Since we struck the Salinas, its course had been mostly east and west; and as far as it could be traced by the cotton-woods and verdure which mark its course, its direction indicated the same. We supposed ourselves now to be from thirty-five to forty miles from its mouth. Look- 
ing east from where we were, the whole prospect was shut in by mountains rising one above the other. I was informed by Leroux, that such was the character of the country all the way to New Mexico; and that there were no more broad desert plains or luxuriant valleys like those of the Salinas and Gila rivers for the entire distance. He came here from Albuquerque, on the Rio Grande, by the valley of the Rio Verde, in fourteen days.

We found the river clear and rapid, as at the first camp, with many trout, whose silvery sides glittered in the translucent stream. The quantity of water passing down the Salinas is more than double that of the Gila, which only becomes a respectable river after it receives the waters of the former. Yet there are seasons when the whole is evaporated, or absorbed by the sandy bed through which it passes, before reaching the Colorado. When at Hermosillo, in Sonora, I met an American who had passed over the same route, and he found the bed dry in many places.

At five in the afternoon, the heat being less, I crept from beneath my shelter of willows, where $I$ had spent several hours, and, accompanied by Dr. Webb, mounted my mule, and left for the plateau in advance of the party. A ride of a mile brought us to the tableland, when we made for a large mound or heap which arose from the plain. In crossing the bottom we passed many irrigating canals; and along the base of the plateau was one from twenty to twenty-five feet wide, and from four to five feet deep, formed by cutting down the bank-a very easy mode of construction, and which produced a canal much more substan- 
tial than if carried across the bottom. It must have extended many miles. The whole of this broad valley appeared to have been cultivated, though now overgrown with mezquit shrubbery.

On reaching the great pile, I found it to be the remains of an adobe edifice from two hundred to two hundred and twenty-five feet in length, by from sixty to eighty feet wide, its sides facing the cardinal points. Portions of the wall were visible only in two places, one near the summit, at the south end, where, from the height of the pile, it must have originally been three or four stories high; and the other at the northern extremity, on the western side. These remains just projected above the mass of rubbish and crum. bled walls. The rest formed rounded heaps of various heights and dimensions, worn into deep gullies by the rain; the whole presenting a striking resemblance to the mounds which mark the site of ancient Babylon.

The higher walls seen in the sketch, probably belonged to an inner portion of the building. Near this is a conical hill, formed, doubtless, by the crumbling away of the higher portion or tower. Near the wall, which projects from the lower portion, at the northern end, are some large masses of this wall which have fallen. The adobe is still very hard, so much so that I could not break it with the heel of my boot. Several broken metates, or corn-grinders, lie about the pile. I picked up a stone pestle and some small sea shells. Along the eastern side are the remains of a long wall, extending beyond the building, now but a rounded heap, which seemed to have formed an inclosure. On the western side is an exca- 
vation about four feet deep, and extending from sixty to eighty feet from the main heap, and along its entire length; from which I suppose the mud and gravel to have been taken to make the adobe. To the northeast, at a distance of two or three hundred feet, are the ruins of a circular inclosure. This was not large enough for a corral; nor could it have been a well, as

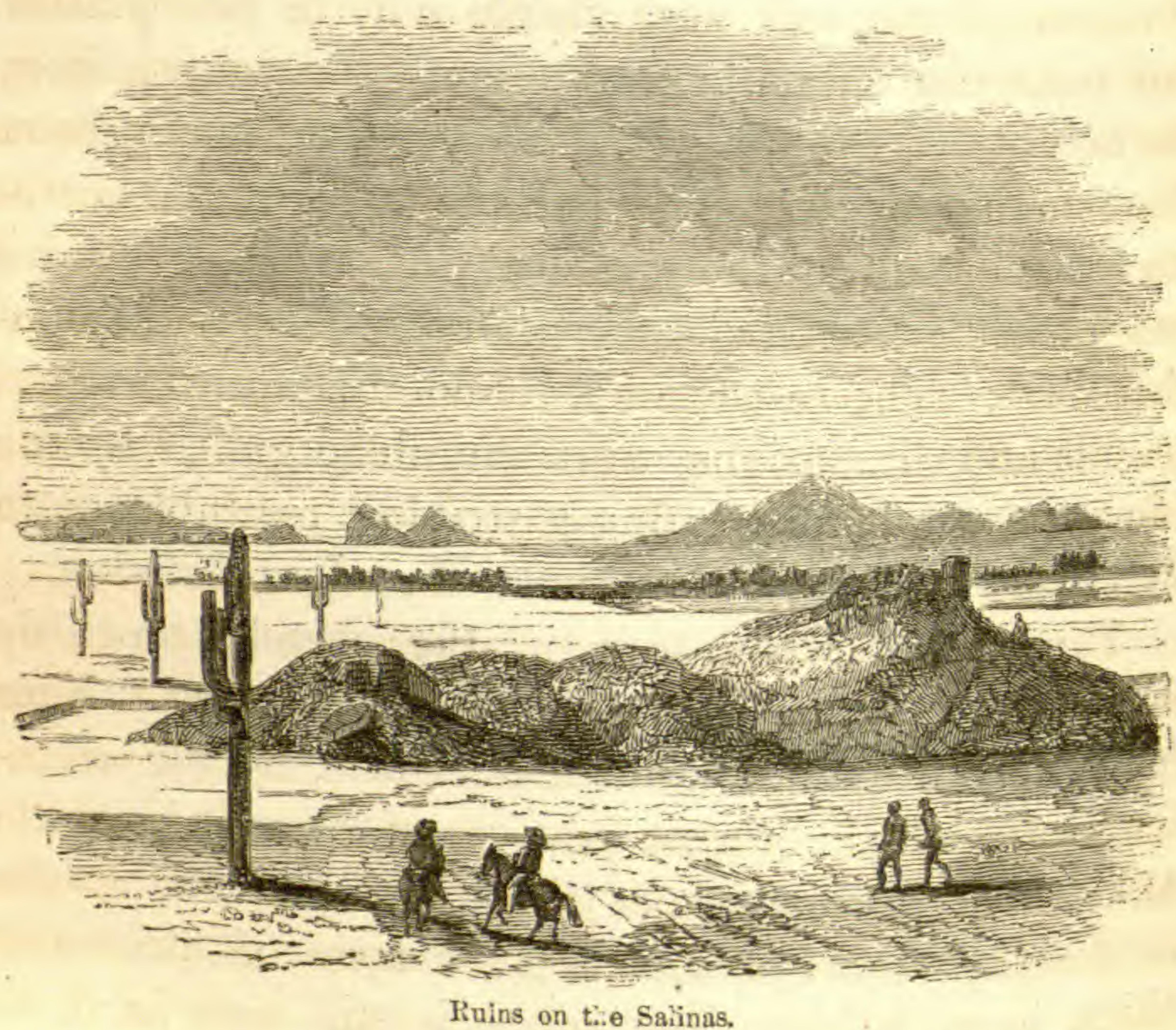

it is too near the margin of the plateau where the canal ran, which would always furnish a supply of water. At the south, two hundred yards distant, are the remains of a small building with a portion of the wall still standing.

From the summit of the principal heap, which is elevated from twenty to twenty-five feet above the 
plain, there may be seen in all directions similar heaps ; and about a mile to the east, I noticed a long range of them running north and south, which the Indians said were of a similar character to that on which we stood. In every direction, the plain was strewn with broken pottery, of which I gathered up some specimens to show the quality, as well as the style, of ornamentation. I also found several of the green stones resembling amethysts which the Indians, after heavy rains, come here in search of. They are highly prized by them. All the early travellers in this country, from Coronado, who crossed the Gila in 1540 , to the present time, have spoken of these so called amethysts. I would have liked to make a further examination of this plain; but our animals had no grass or other feed, nor should we find any until we could reach the Gila, twenty-five miles distant, which prevented me from extending my examinations.

Mr. Leroux informed me that on the banks of the San Francisco, are similar heaps to these, and other ruins, the walls still standing. He thinks that the buildings he has seen on that river, and others in the Moqui and Navajo country, of three and four stories in height, would, if in a ruined state, make similar heaps to those under our notice. I am inclined to the same opinion, and believe that the ruins we visited, belonged to a building of several stories.

There is no doubt that this valley, as well as that of the Verde and Gila Rivers, were once filled with a dense population, far enough advanced in civilization to build houses of several stories in height, surrounded with regular outworks, and to irrigate their lands by 
canals extending miles in length; but they seem to have left no trace or tradition by which we can tell who they were, or what was their fate. I made frequent inquiries of the Pimos and Coco-Maricopas as to the builders of these and the ruins on the Gila, but could obtain no other than the ever-ready, Quien sabe? These, as well as the ruins above the Pimo villages are known among the Indians as the "houses of Montezuma," an idea doubtless derived from the Mexicans, rather than from any tradition of their own. We asked our Indian guide, who Montezuma was. He. answered, "Nobody knows who the devil he was; all we know is, that he built these houses."

After spending an hour here, we took a strongly marked trail, which looked as though it had been travelled for a century, and which led due south towards the Fimo villages. There were other trails, leading in various directions; showing that the plain is much traversed, and the ruins often visited. We journeyed rapidly over the plain, which was a portion of the great plateau or desert. It was a perfect level without an undulation. Not a hill or a ravine intercepted our path. The vegetation was the same as found on the plateau in our journey up the south side of the Gila. Larrea and small mezquit bushes predominated; while now and then the graceful petahaya raised its tall head far above the dwarfish plants of the. desert, often startling us with its sudden appearance. It was near midnight when we entered a thick grove of mezquit, from whose branches were pendent large quantities of the beans of which the mules are so fond. As we had now travelled from twenty-three to twenty- 


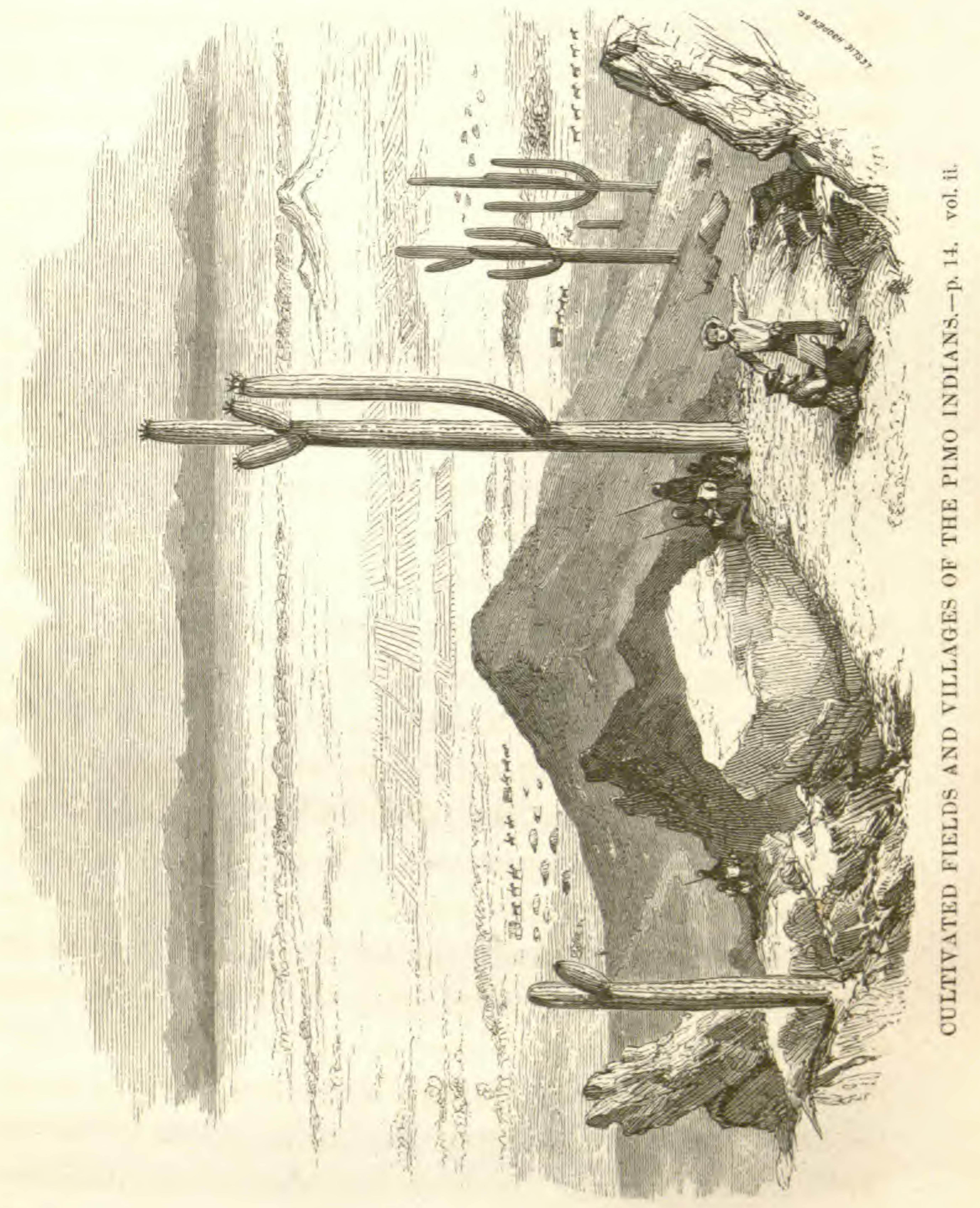



five miles from the Salinas, and did not know the distance to the river, we concluded to stop here. We accordingly hitched our mules by their long lariats to these bushes, on which they could feed, and stretched ourselves beneath their wide-spreading branches, to get a little rest until daylight should again appear.

July 5th. At half-past four, without waiting for breakfast (for the reason that we had none to cook), we resumed our journey, and in two miles reached the Gila, or rather its bed; for it was dry here. As we entered the first fields of the Pimos, the sentinels in the outskirts, seeing us approach in long single file, mistook us for Apaches and gave the alarm accordingly; a very natural mistake, as no party of emigrants or travellers had ever entered their country from the north: We heard the alarm given, and echoed in all voices, from one tree or house-top to the other, until it reached their villages. "Apaches! Apaches!" was the cry from every mouth; and when it reached the first village, it was borne onward to every part of the community, even to their allies the Maricopas. The two Indian guides who were with us, discovered the stampede we had so unintentionally caused among their Pimo brethren, and seemed to enjoy the joke much. In a few minutes we saw the Pimos mounted, bounding towards us in every direction, armed and ready for the contest; others, on foot with their bows and arrows, came streaming after them; and in a short time, the foremost horseman, who was doubtless striving to take the first Apache scalp and bear it as a trophy to his people, reigned his steed before us. As he and those about him, perceived 
their mistake, they all burst into a hearty laugh, which was joined in by the rest as they came up. Assembling around our two Maricopas, they learnt the particulars of our visit to the Salinas. They then all wheeled around; and while a portion acted as our escort to their villages, others fell behind and brought up the rear, so that our entry was that of a grand cavalcade. At 8 o'clock, we reached our place of encampment, having travelled fourteen miles.

In the afternoon, Lieutenant Whipple and his party arrived. They had completed the survey of the Gila, a labor at this season of the year, with the heat at from 100 to 120 degrees Fahrenheit, attended with no small difficulty.

June 6th. As the notes of this survey, and the accompanying astronomical observations, had been obtained with great labor and some suffering. I felt unwilling to expose them to the risk of being lost in a journey across the continent; and, accordingly, determined to remain here a few days longer, to give Lieutenant Whipple an opportunity to duplicate them with the view of sending them back by a messenger to Major Heintzelman, at Fort Yuma, to be forwarded by him to the Secretary of the Interior at Washington.

A brisk trade was carried on to-day with the CocoMaricopas for corn, beans, meal, pinole, and squashes, as well as for the various articles of their manufacture, such as pottery, cotton blankets, baskets, \&c. I gave the trading department into Mr. Thurber's hands, finding it would be better managed by one person. He fitted up his tent for the purpose and made such a dis- 
play of goods as was never beheld before in this community. I also told Francisco, the chief before mentioned, to invite all the chiefs or captains as he called them, of his tribe to come in, and I would make each of them a present of such articles as I had to give. Five, accordingly, presented themselves, and to each of them I gave shirts, a few yards of cotton cloth, some vermillion, beads, trinkets, etc.; with all which they seemed greatly pleased. I told them that these things were in return for the friendship shown, and the assistance they had given to the poor American emigrants who had passed through their country, and that they must continue to aid them when in their power to do so. I added that they would then be considered as the true friends of the Americans, and would be rewarded accordingly; furthermore, that the Americans might be induced to establish a garrison near them, which would protect them and prevent all future attacks from the Apaches.

It was on this occasion, that I gave Francisco so many things, for which he seemed so ungrateful. I found too, that he had told his people to advance the price of their corn, and other things; which made this day's bartering the end of our trade. I felt quite indifferent on the subject, as it was my intention to remove the camp to the villages of the Pimos; for Mr. Leroux had ascertained that they were much better supplied with corn and every other commodity than the CocoMaricopas, and were very desirous that we should divide our time with them for the purpose of trading.

A few Indians of a nearly extinct tribe called the Cawinas, were in camp to-day. Only ten of this tribe 
remain, who are living among the Pimos and CocoMaricopas. Their former dwelling-place was on the Gila towards the Colorado. There they were brought, in contact with the Yumas; and in the constant wars that existed between them and the Cawinas, they were all exterminated, except the small number which had taken refuge here. They speak a language different from the Pimos and Maricopas, and I could find but one man among the latter who understood it. He promised to come and give me the vocabulary, but did not again make his appearance.

July 8th. After breakfast this morning; we struck our tents, and bade farewell to our Maricopa friends, among whom we had been ten days, with many regrets. From the first day of our arrival, they had thronged our camp both day and night; and I am not aware that they ever took an article that did not belong to them, nor had there been any difficulty between us, except their trying to overreach us in trade. But this did not interrupt our friendship, or prevent me from treating them all with kindness. In their intercourse with the whites, they are a docile and inoffensive people; but they exhibit the same cruelty as other Indianss, towards those of their red brethren with whom they are at war. They still have occasional fights with the Yumas and the Apaches; and should any prisoner fall into their hands, they would delight, as much as the Apaches do, in putting him to the torture.

Last winter, while Dr. Webb and his party were here, they saw an example of this. It appears that when Captain Ximenes, with the Mexican Commission, was at the Colorado, they induced an intelligent Yuma 
to return with them. On passing through the villages of the Coco-Maricopas, notwithstanding every effort of the Captain to conceal this man, they discovered him, and by stratagem, got possession of him: The party endeavored to effect his release; but they had not force enough to compel his captors to surrender him, and no presents would induce them to do so. He was put to the torture; and Dr. Webb and the other gentlemen of the U. S. Commission, were invited to join the Maricopas, in the festivities and dances on the occasion.

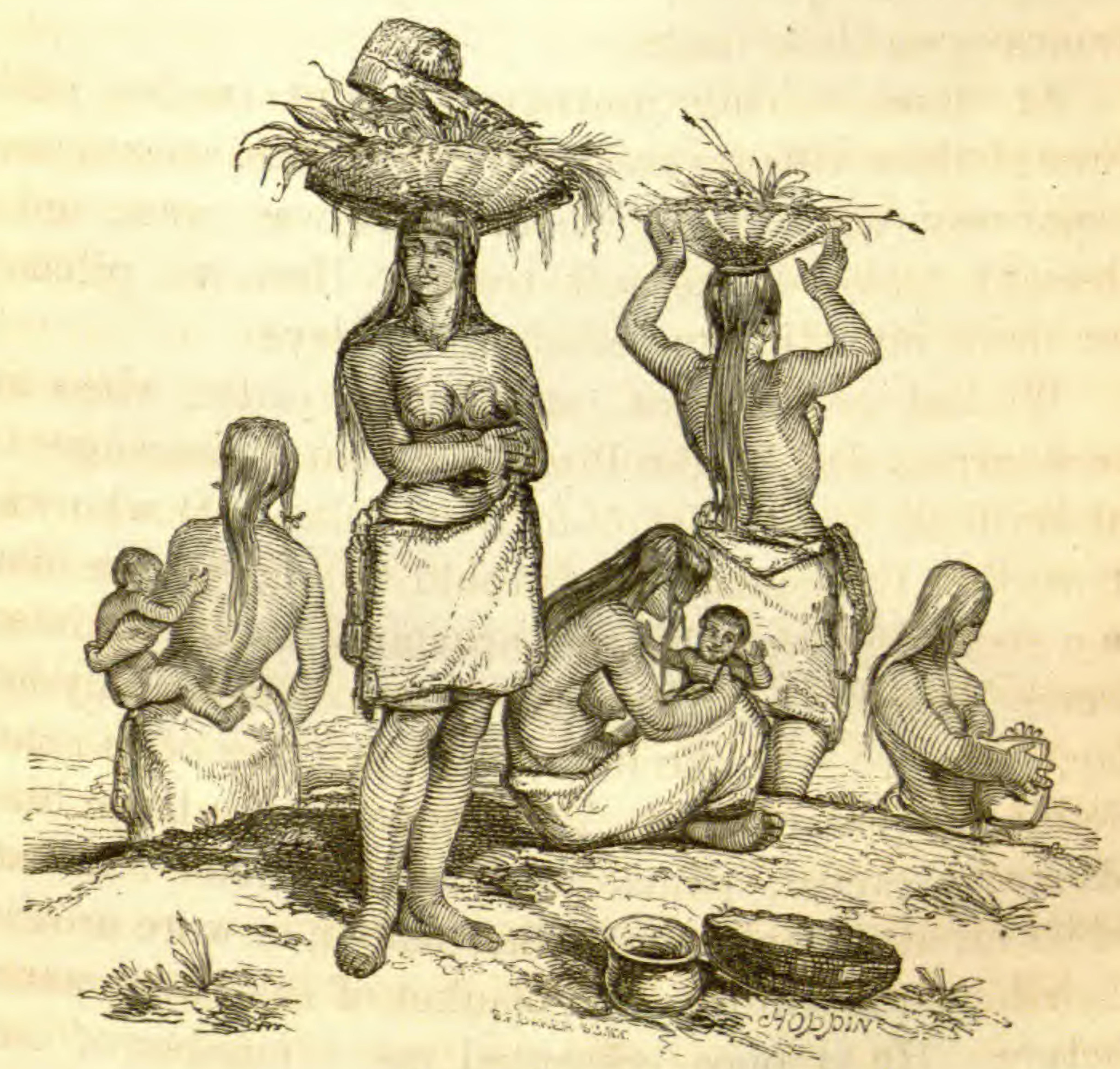

Group of Pimo Indians.

As we rode through the villages, we saw the peo- 
ple engaged in their various occupations. The women were generally at work grinding their corn or wheat. The children were squatting or lying in the shade, doing nothing. The cradle was suspended by a cord to the roof and kept swinging by the husband, wholay stretched at length on his back, or by the children. In these communities, there are men who labor in the fields, while others lounge about the villages doing nothing. They seem to have their dandies and gentlemen of leisure, as well as their more civilized brethren. The women, too, were carrying water on their heads, or transporting other things in the sprawling frames upon their backs.

At noon, having journeyed about twelve miles through these villages and cultivated fields, we reached a spot near an acequia, where there was grass, and a pleasant grove of mezquit trees. Here we pitched our tents, intending to remain a few days.

We had scarcely got our camp in order, when we were surrounded by the Pimos. I sent a messenger to inform their head chief Cola Azul (blue tail) who was at work in the fields, that I would be glad to see him. In a short time he appeared, accompanied by his interpreter Tu-maams. Although it was a dreadfully hot day, when we felt like divesting ourselves of as much clothing as possible, Cola Azul appeared in a large blue blanket overcoat, pantaloons, and a green felt hat, while his attendants were either naked, or wore around their loins the white cotton blanket of their own manufacture. He at once presented me a number of credentials from various American officers, and others, who had passed here, and held intercourse with him 


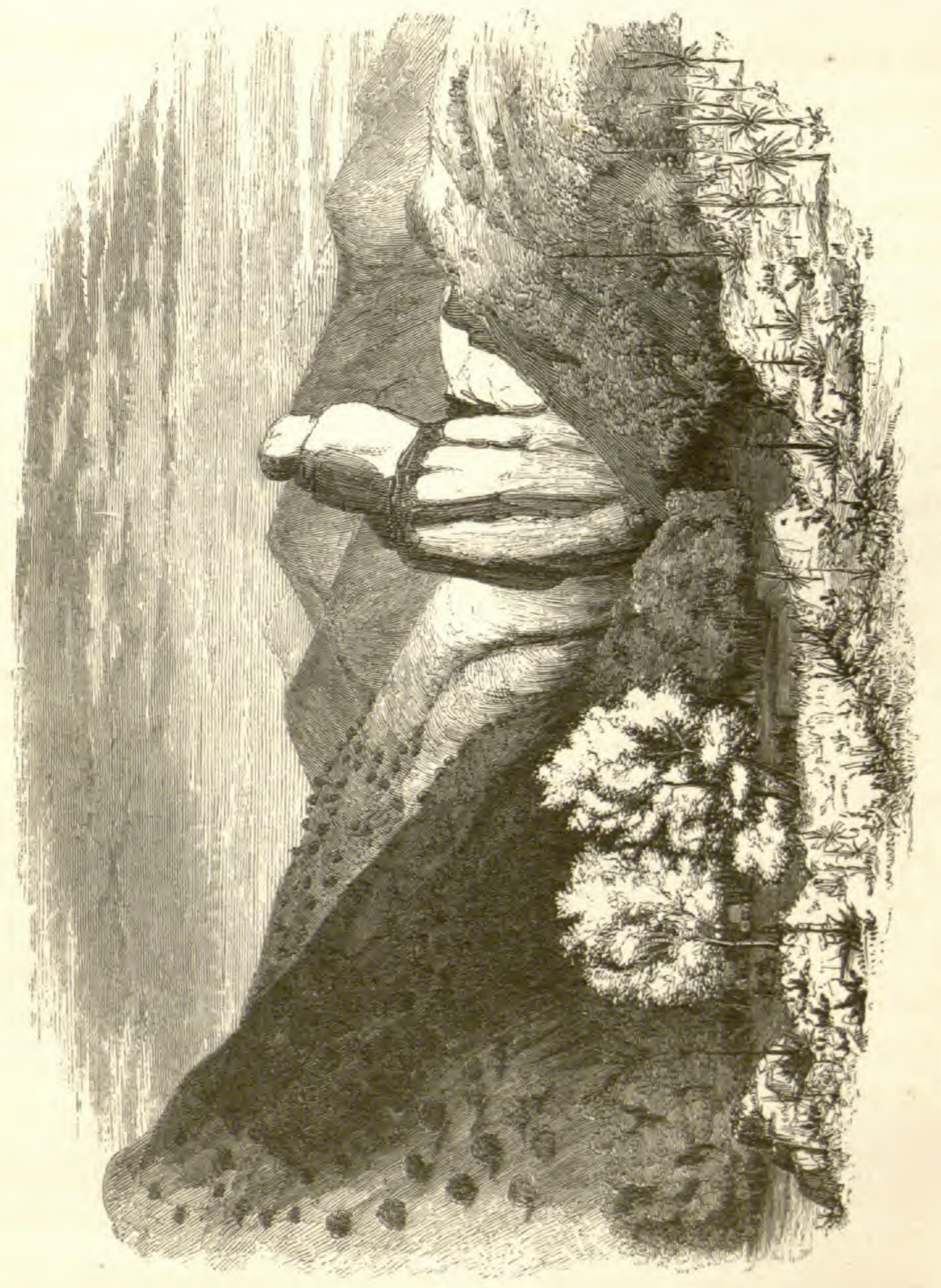

:

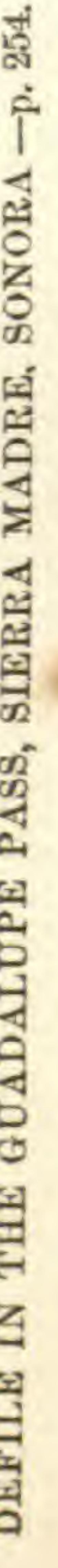





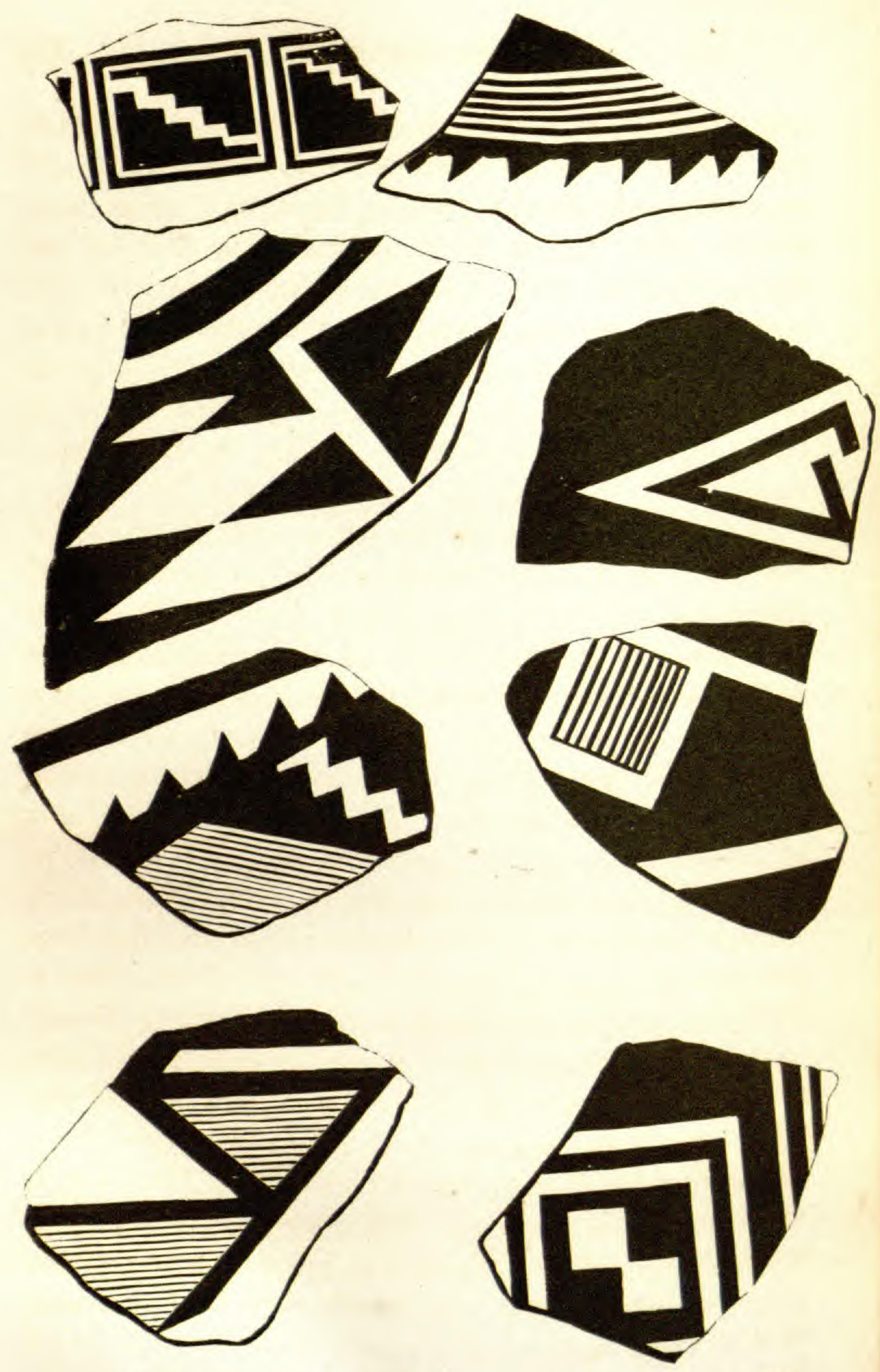

FRAGMENTS OF ANOIENT POTTERY FROM THK GILA AND SALINAS.-p. 255. 
and his tribe-setting forth that he was the head chief, that his people were friendly to the Americans, and requesting all should respect them and treat them kindly. The earliest of these, was from Colonel St. George Cooke. This chief was about 50 years of age, with a fine, amiable expression of countenance, and a quiet and dignified manner. He was greatly beloved by his people, who showed him more deference than I had ever seen extended by Indians to their superiors.

I told this chief who we were, and the object of our visit. He readily comprehended my meaning, and referred to the surveying parties under Mr. Gray and Lieutenant Whipple, which had been operating here during the winter. I told him that, having completed the work, we were now on our return to the United States ; and that having heard of his kind treatment of the Americans who had passed through the villages of his people on their way to California, I wished to see all the chiefs of his tribe and present to them a few articles, as a token of the respect which the American government entertained for them. I added, that I would be ready to receive them the following morning.

July $9 t h$. The day had scarcely dawned when I was awoke by a chattering of strange voices around my tent; on putting out my head, I found to my surprise, that, although it was but 4 o'clock, the Pimo chiefs were already on the spot. This was a little too early for business, and besides, I was not prepared for the proposed conference. It would have been impolite to send them back; so I requested them to wait until I had taken my breakfast, which would be in about three 
hours. They seemed well content with the delay, and the opportunity it gave them to stroll around the camp, and inspect the several culinary processes, from that of the Mexican arrieros with their queer dishes, to the cuisine of the officers, where, if there was no great variety of food, there was to them a curious display of iron, tin, and copper cooking utensils, with some articles for the table that attracted their attention.

At eight o'clock, I was ready to receive the deputation of the Pimo chiefs. The largest tent in the commission had been pitched for the purpose. The ends and sides were opened and rolled up, and trunks placed for the chiefs to sit upon. There were altogether six chiefs, including Cola Azul, besides two interpreters. The latter were absolutely necessary, as there were no Pimos who spoke Spanish. Tumaams, the elder of the interpreters, was born of Pimo and Maricopa parents, and spoke both languages. He therefore repeated what the Pimo chiefs said, to a Maricopa, named Mis-ke-tai-ish, who spoke Spanish; and I communicated with him. This was a roundabout way of talking; but there was no alternative. At the opposite end of the tent were the officers of the Commission. On the outside were congregated crowds of Indians, both Pimos and Coco-Maricopas; for the latter had followed us, and were nearly as numerous as when we were among them. It was quite an animated scene; the women, with their children, equalled the men in number, having come to do a little shopping after the business with the chiefs had been dispatched.

I stated to them as briefly as possible, that the Americans had heard from General Kearney, Colonel 
Cooke, and others, who had passed through their country on their way to California, of the friendly disposition the Pimos had manifested towards them. That the surveying parties belonging to the Boundary Commission, had also spoken favorably of them. That I was not an Indian Agent, such as the United States often sent to make treaties with the tribes, and to distribute presents; but was in command of a party from the American government to trace the Boundary line which separated the United States from Mexico. That having been to California, and completed this duty, I was then on my return to the United States, and should remain a few days with them, to give my animals rest, as well as to procure corn for them, and vegetables for my party. That I also wished to purchase of them, specimens of the various articles which they made, such as their blankets, baskets, pottery, bows and arrows, \&c., to show to the American people, that they might see what they could do ; and that, for these I would give them in exchange, blankets, cotton shirts, and other articles. Furthermore, I told them, as an evidence of my good feelings towards them, and in consideration of the kind treatment they had extended to the Americans, I would present to each of them and to the interpreters, some shirts and cotton cloth. To these I added, for Cola Azul, blankets, calico, beads, and trinkets for his wife and children. Before separating, I requested them to exert themselves in endeavoring to obtain the liberation of the two American girls (Mr. Oatman's daughters) who had been carried into captivity by the Apaches, or other Indians, not known to me.

VoL. II, -17 
They were much pleased with these trifling presents, reiterated their expressions of friendly feelings towards the Americans, and said they would do all in their power to recover the two girls. They believed the Tonto Apaches to have been the murderers of their parents. I told them of the intention of the government to establish a military post near them on the Gila, which would protect them from further attacks of the Apaches. This pleased them much.

After the conference was ended, trading commenced with much briskness. The same articles were bought of them as from the Maricopas, and we were enabled, without difficulty, to obtain all the corn that was necessary for the mules of the whole train. One of their baskets we agreed upon with them for a measure, a certain number of which was the value of a yard of white cotton or a particular kind of shirt. This was quite satisfactory to them; and a much larger quantity of corn was brought in than we were able to take. When we had nearly completed our purchases, Francisco, the Maricopa chief and interpreter, came in and again interfered; but the Pimos did not regard him, and manifested much pleasure when I ordered him out of the camp. They did not like his officiousness, and said he always thrust himself forward whenever a party of Americans or Mexicans came along, and managed to get whatever they had to give away or barter, much to their disadvantage.

July 10th. Three Mexican traders arrived this morning from Tucson, opened their goods at one of the villages, and for a while drew most of the Indians from us: Towards evening they returned, and for the 
few things we wanted, they now asked more than double their former prices. Green corn, which we had bought for one dollar a hundred, in the ear, they now asked four dollars for, and other things in proportion. We had, however, procured every thing we required, - except mules, which we were much in want of. These they had promised to bring us, but had failed to do so.

Lieutenant Whipple joined us to-day, having completed his notes and plottings, and we are again encamped together.

July 12th. As the escort under Lieutenant Paige furnished me by Major Heintzelman at Fort Yuma, had accompanied us as far as was deemed necessary, that officer made arrangements to set out on his return to the Colorado this morning, with his command. I availed myself of the opportunity to communicate with the government, and advise it of the successful completion of the Survey of the river Gila.

We were now to leave the Gila and strike across a desert of ninety miles, where there is said to be neither grass nor water, before we should reach Tucson, the extreme outpost of the Mexicans. I deemed, it advisable, therefore, to move our camp to the farthest point on the Gila, before attempting to cross this jornada. The Mexican traders who arrived yesterday said they had found no water the entire distance; and unless it should rain, of which there was some prospect, (although we had seen none for two months) our animals would undergo great hardships in crossing it. We accordingly set out after breakfast this morning, passing through the last of the Pimo villages and their 
cultivated fields; and, after following the road for twelve miles, turned short off to the north, and encamped for the last time on the banks of the Gila. The river was here much contracted, with steep banks fifteen feet high, and completely overhung with willows and cotton-woods, the latter from the opposite banks, meeting at the top. Its width was less than fifty feet, and its greatest depth did not exceed nine inches. It moved sluggishly along, was well charged with mud, and uncomfortably warm to bathe in. The bottom lands were three quarters of a mile in width on the south side, where we encamped, with a rich soil, and filled with mezquit trees.

But few Indians came in to-day, as we were between six and eight miles above their most easterly village. Those who ventured to follow us, said that it was unsafe to go so far from home unless in large numbers, as bands of the Apaches were constantly hanging about near their villages, watching every opportunity to send an arrow through them, or rob them of their animals. It was so exceedingly hot to-day, that after reaching camp, we lay under the deep shade of the willows, on the river's bank, without pitching our tents. . 
INDIANS OF THE GILA, AND THE CASAS GRANDES, 261

\section{- CHAPTER XXXII.}

INDIANS OF THE GILA, AND THE CASAS GRANDES.

History of the Coco-Maricopas and Pimos-Origin of their semi-civilization-Difference of languages-Their number-Physical peculiaritiesDeserving the attention of Christians and philanthropists-Early accounts of these Indians-First described by Father Kino in 1697Sedelmayer's visit to them in 1744-Father Font's in 1775-Visit to the Casas Grandes of the Gila-Description of these ruins-Evidences of a former large population-Irrigating canals-Broken potteryFather Font's description of their buildings-Singular error in relation to their dimensions-Kino and Mangi's visit to them in 1694-Notion of the Aztec origin of these buildings not well founded-Excessive heat.

HAVING now left these peaceable semi-civilized Indians, a few general remarks respecting them seem to be required.

Some writers have endeavored to point out physical differences between the Pimos and their allies the Coco-Maricopas; but I must confess, that after being constantly with them for thirteen days, I was unable to distinguish one from the other, except by some slight difference in the method of wearing their hair. Their modes of life, as before remarked, are the same, with the exception of their funeral rites. In the valley, or rather bottom-land, which they occupy, there is no 
dividing line between them; nor is there any distinguishing character in their villages. I consider that the arts of spinning and weaving, and of making pottery, now practised by both tribes, and in which they are equally expert, originated with the Pimos, who inherited this knowledge from their ancestors; and that from the earliest period, doubtless for centuries, they have occupied portions of the same valley where we now find them. In leaving their villages, I noticed on the edge of the plateau traces of former habitations, which had been abandoned for a great length of time.

The Coco-Maricopas took up their abode in the valley immediately adjoining the Pimos about thirty years since, from a point lower down the Gila, where they were exposed to the constant attacks of the Yumas and Apaches, which tribes, in consequence of their greater numbers, had nearly annihilated them. They came hither for protection, and formed an alliance, offensive and defensive, with the Pimos. They found the latter possessing the arts of weaving, of. building more comfortable dwellings, of making better pottery, enjoying a more peaceful mode of life, than that to which they had been accustomed. These arts and habits the Maricopas gradually adopted. Their languages are totally different, so much so that I was enabled to distinguish them when spoken. The former is soft and melodious, the latter harsh and guttural. The Pimos bury their dead, while the CocoMaricopas burn theirs. These peculiarities stamp them as distinct nations.

I have not cited the agriculture of these tribes as superior to that of all other Indians; although I may 
be safe in saying, that the system is more extensively and methodically practised than elsewhere. The Yumas, and other tribes on the Colorado irrigate their lands, and raise wheat, corn, melons, etc. The Moquis and the Navajos, far to the north, do the same; and the warlike Apaches, who are more nomadic in their habits than any tribe west of the Rocky Mountains, raise corn when driven to extremities. But the Pimos and Coco-Maricopas have made agriculture more of a system. Their lands are better irrigated, their crops are larger, and the flour which they make from their wheat and maize is quite as good as the Mexicans make, except in their grist-mills.

I am inclined to think that Major Emory in his Report has greatly over-estimated the number of these people. He states, that "the population of the Pimos and Coco-Maricopas together is estimated variously at from three to ten thousand, and that "the first is evidently too low." From information obtained from the chiefs, and the Mexican officers in Sonora, I should not place them above two thousand. Captain Johnston, $\nmid$ another officer attached to the army under General Kearney's command, in estimating them as embracing "over two thousand souls," came very near - the mark. Of the number stated by me, I was told that two thirds were Pimos.

Their complexion is a dark brown, differing from that of the red-skins east of the Rocky Mountains, and from the olive cast of the California tribes. The women have good figures, with full chests and finely

* Emory's Report, p. 86. † Johnston's Report, p. 599. 
formed limbs, owing, in a measure, to the burdens they carry on their heads. The men have small and slender limbs, and, in their physical development, are quite inferior to the tribes between the Mississippi and the Rocky Mountains. This is readily accounted for by their different modes of life. The Pimos exhibit a great simplicity of character, more so, I think, than the Maricopas, preferring to lead the quiet lives of agriculturists to the roving and predatory habits of the Apaches, Comanches, Navajos, and others. But although they do not like wars, they are by no means cowards, and do not hesitate to march against their enemies, the Apaches, when it becomes necessary. There are no tribes of Indians on the continent of North America more deserving of the attention of philanthropists than those of which I am speaking. None have ever been found further advanced in the arts and habits of civilized life. None exhibit a more peaceful disposition, or greater simplicity of character; and certainly none excel them in virtue and honesty. They are quite as industrious as their necessities require them to be. Possessing no market for the sale of their produce, they raise but little more than is necessary to supply their own wants. To do this, with a soil of great fertility, and water at their command, requires but little labor. Hence, after their crops are in, they have nothing to do until the season arrives to gather, them. Their granaries are then filled with wheat, corn, beans, pumpkins, squashes, mezquit beans (their substitute for sugar), and the fruit of the petahaya; and after that, they undergo another long season of inactivity. Our Missionary Societies and Boards of 
Education could not devote a portion of their means to a more worthy object, than to send teachers and mechanics among this interesting people before they become contaminated by intercourse with the whites, and the seeds of evil are sown, which, when ripened, will exert the same baneful influence upon them as they have upon all other aboriginal tribes, leading to their degradation and final extinction. They will be found willing pupils, having expressed a great desire to be taught to read, and to obtain a knowledge of the mechanic arts.

Among the Indians visited by Coronado and Marco de Niza, about the middle of the sixteenth century, in their extensive journeys through the regions between the Rio Grande and the Pacific, although it is certain that the former crossed the Gila, I am unable to discover any allusion to the Pimos, or to the district occupied by them. In the diary of an expedition made by the ensign Juan Mateo Mangi, who accompanied Father Kino, in the year 1697, after visiting the Casa Grande (of which I shall hereafter speak), he says: "On the margin of the river, distant one league from the Casa Grande, we found a town in which we counted one hundred and thirty souls." " The author continues: "Having traversed four leagues, we arrived at the town of Tusonimon, which is so named from a great heap of horns, from the wild or sylvan sheep, which appears like a hill; and from the number that

* I am indebted for this extract to Mr. Schoolcraft's valuable work on the Indian Tribes, vol. iii., p. 301. It is from a manuscript in the archives of the City of Mexico, from which it was copied by Buckingham Smith, Esq., Secretary of the United States Legation. 
there are of the animals, they make the common subsistence of the inhabitants. From what can be seen of the highest of these houses, there appears to be a country of more than a hundred thousand hastas in extent.*

"The heathen Indians received us with jubilee, giving of their provisions to the soldiers; and we counted two hundred persons, who were gentle and affable. Remaining there to sleep, the Father and I instructed them, through the interpreters, in the mysteries of our Holy Faith; on which they besought us that there might be baptized fifteen of their children and seven sick adults."

Four leagues from the Casa Grande would bring us about to the spot where we were then encamped, and near to the villages of the Pimos, which, in former times, extended much further up the Gila than they do at present. The great country which the writer saw here was doubtless the plain where the villages now stand, and the great plain to the north, extending twenty-five or thirty miles to the Salinas.

But Alegro, $\uparrow$ in recounting the arduous labors of Father Kino, relates other particulars of the Pimos and Coco-Maricopas, and the interviews between them and this zealous missionary. Kino found, in 1698, the most friendly relations existing between them, and noticed the difference in their languages and dress. But their manners and customs were the same; and

* Measure of a lance, about three yards in length.

† Hist. de la Compañia de Jesus en Nueva España, tom. iii., pp. 83 and 103 . 
the worthy Father particularly noticed "their peacefulness and their gentleness." They were alike desirous to be baptized and instructed, a desire that Kino willingly gratified. He estimates their numbers at four thousand; but whether or not this includes both tribes, is not clear. They then irrigated their lands as now; and had large cultivated fields of wheat. The CocoMaricopas were then situated beyond the Pimos, probably on the Salinas and Gila, below the junction. Father Kino, in another expedition to the Gila, took with him two Pimo Inaians from the mission at Ures to act as his interpreters, which enabled him to communicate freely with these tribes.

In an anonymous manuscript of a Jesuit, dated 1764, descriptive of Sonora, ${ }^{*}$ where he lived many years as a missionary, the writer speaks of the Pimos, who were on the precise spot where we now find them inhabiting both margins of the Gila. "The towns of that people," he says, "which occupy ten leagues of the mild vale along it, with some islands, abound in wheat, maize, etc., and yield much cotton; to them also is referred the fabrication of the finest kinds of pottery, whose remains form one of the archæological indications of the Gila valley."

But the most circumstantial account of the Pimos is that of Father Pedro Font, who, with Father Garces, made, in 1775-'76, a journey from the Presidio of Orcasitas, in Sonora, to Monterey, in California, of

* Extract from a MS. entitled, "Descripcion Geografica Natural y Curiosa de la Provincia de Sonora. Por un Amigo del Servicio de Dios. Año de 1764," in Mr. Schooleraft's History, Condition, and Prospects of the Indian Tribes, before referred to, vol. iii. p. 304. 
which I have before spoken. They passed down the Gila, which river they struck about the place where we were now encamped. The towns were then called Uturituc and Sutaguison. I now quote from the journal of Father Font, a manuscript copy of which is in my possession :

November 1st. 1775 . We left the laguna at half-past nine А. м., and at one Р. м. arrived at Uturituc. The Indians (according to my calculation about one thousand) received us in two files, the men on one side, the women on the other; and when we alighted, they all came by turns to salute us, and shake hands with us, first the men.and then the women; and they manifested great joy at seeing us. They lodged us in a large shed of boughs, which they erected on purpose, and (although Gentiles) planted a large cross in front thereof, and then went and fetched water to the camp for the people.

"November 2d. This being All Souls' day, we three priests said nine masses. We left Utnrituc at 11 A. M., and at 3 P. .. stopped on the banks of the Gila, near the town of Sutaguison, having travelled about four leagues. The inhabitants of the pueblo (town), some five thousand souls, came out to receive and salute us with demonstrations of great joy. On the road we passed two other pueblos."

At the period referred to, it appears that the Coco: Maricopas were not with the Pimos; but in journeying down the Gila, at the distance of seventeen leagues from the villages of the latter, our travellers met with a tribe whom they call the Opas; and fifteen leagues farther, they encountered the Coco-Maricopas, which, 
says Font, "are the same as the Opas." By following the course of the river, which it appears the Fathers did, the thirty-two leagues they travelled from the Pimos, would bring them to the western end of the jornada, where they found the Coco-Maricopas.

It has been asserted that "the Maricopas have removed gradually from the Gulf of California to their present location in juxta-position with the Pimos." * I cannot learn that they ever were on the Gulf; although it appears from the missionary authorities. that there was a band of them on the western bank of the Colorado, "living in a valley thirty-six leagues in length, and, for the space of nine leagues, remarkably fertile and pleasant," who were "allied to the CocoMaricopas of the Gila." But from the early accounts of the Indian tribes on the Gila, it appears they occupied the valley from a point west of the jornada, where Father Font found them in 1775 , to the Salinas above its mouth. Father Sedelmayer met them in 1744, about the same place on the Gila, living on peaceful terms with the Pimos, and used them for his guides to the Colorado. It appears that at this time, too, they were living on the Salinas, in the very district that we passed over in our visit to the ruins on that river.

In his description of this country, Venegas + speaks of the river Assumption, which he says, is " composed of two rivers, the Salado and Verde.". These, on their

* Emory's Report, p. 89.

$\uparrow$ The Salinas, where it unites with the Gila, was originally called the Assumption. The San Francisco, which enters the latter from the north about forty-five miles from its mouth, was called the Verde (green) and also the Azul (blue) river. 
way to the Gila, run through a very pleasant country of arable land, inhabited by the Coco-Maricopas, who are separated from the Pimos by a desert, although united to them in consanguinity. Their kingdom is bounded on the west by a desert and mountainous country, extending to the rancherias of the Yumas, who live along the river Colorado, but below its junction with the Gila.." *

It therefore appears that the Coco-Maricopas were found early in the last century on the opposite side of the jornada, or desert of forty-five miles, which reaches to the villages of the Pimos; and that thence they extended east, occupying the banks of the Salinas, to a point north of the latter, from which, as Venegas says, "they were separated by a desert." They also traversed the country south of the Gila, where they are often located on the early maps.

It is not my intention in this work to enter into any ethnological disquisitions respecting these Indians; as they will form the subject-matter of another work. I will merely observe that, notwithstanding the deadly hostility existing between the Coco-Maricopas and Yumas, their languages are nearly the same. The Comeya, or Diegenos, of the Pacific coast, will also be found closely allied to them.

July $12 t h$. In the hope that the Pimos might bring us in some mules, as promised, I determined to remain another day before leaving the Gila, and to employ it

* Venegas, History of California. Vol. II. p. 184. See also Clavigero, Storia de California. Hervas, Catálogo de las Lenguas. Vol.I. pp. 337 to 343 . 
in making a visit to the eelebrated "Casa Grande" or "Casa de Montezuma," as it was called by our Indian friends, alike with all other ancient remains in the country.

I left early this morning, accompanied by Dr. Webb and Mr. Thurber, taking as guides two Pimo Indians, one of them Misketaiish, who spoke Spanish. We were all mounted on mules. - After following the road for two miles, we turned to the east and struck General Kearney's trail, which we found still deep and distinct, although but the trail of a single file. It is sunk three or four inches in the hard gravel plain; and as it will continue to be followed by other parties passing along the Gila, as well as by the Indians, it may exist for centuries, an enduring monument of that remarkable campaign. General Kearney had with him a mountain howitzer. The narrow ruts made by the wheels were as distinet as though it had just passed along; the six years which had elapsed since the march of that officer, have scarcely begun to deface them.

After following this trail in an easterly direction, about eight miles across the plateau, which was covered with small mezquit trees, we turned off to the southeast. Another mile brought us to the building of which we are in search, rising above a forest of mezquit. For two or three miles before reaching it, I had noticed quantities of broken pottery, as well as the traces of ancient acequias or irrigating canals, along the bottom-land, portions of which we occasionally crossed on our left. This bottom is a continuation of that occupied by the Pimos, although much narrower, it being only a mile in width near the ruins. It is thickly 
covered with mezquit-trees from twelve to twenty feet in height; among those on the plateau, the tall and graceful petahaya occasionally thrusts forth its thorny arms, like so many solitary columns or giant candelabra. The bright walls of the ancient edifice presented a striking contrast with the deep green foliage of the "trees which surrounded it.

The "Casas Grandes," or Great Houses, consist of three buildings, all included within a space of one hundred and fifty yards. The principal and larger one is in the best state of preservation, its four exterior walls and most of the inner ones remaining. A considerable portion of the upper part of the walls has crumbled away and fallen inwards, as appears from the great quantity of rubbish and disintegrated adobe which fills the first story of the building. Three stories now stand and can plainly be made out by the ends of the beams remaining in the walls, or by the cavities which they occupied; but I think there must have been another story above, in . order to account for the crumbling walls and rubbish within. The central portion or tower rising from the foundation, is some eight or ten feet higher than the outer walls, and may have been several feet, probably one story, higher when the building was complete. The walls at the base are between four and five feet in thickness; their precise dimensions. could not be ascertained, so much having crumbled away. The inside is perpendicular, while the exterior face tapers towards the top, in a curved line. These walls, as well as the division walls of the interior, are laid with large square blocks of mud, prepared for the purpose by pressing the material into large boxes about two 
feet in height and four feet long. When the mud became sufficiently hardened, the case was moved along and again filled, and so on until the whole edifice was completed. This is a rapid mode of building; but the Mexicans seem never to have applied it to any purpose but the erection of fences or division-walls. The material of this building is the mud of the valley, mixed with gravel. The mud is very adhesive, and when dried in the sun, is very durable. The outer surface of the wall appears to have been plastered roughly; but the inside, as well as the surface of all the inner walls, is hard finished. This is done with a composition of adobe, and is still as smooth as when first made, and has quite a polish. On one of the walls are rude figures, drawn with red lines, but no inscriptions. From the charred ends of the beams which remain in the walls, it is evident that the building was destroyed by fire. Some of the lintels which remain over the doors are formed of several sticks of wood, stripped of their bark, but showing no signs of a sharp instrument. The beams which supported the floors, were from four to five inches in diameter, placed about the same distance apart, and inserted deeply in the walls.

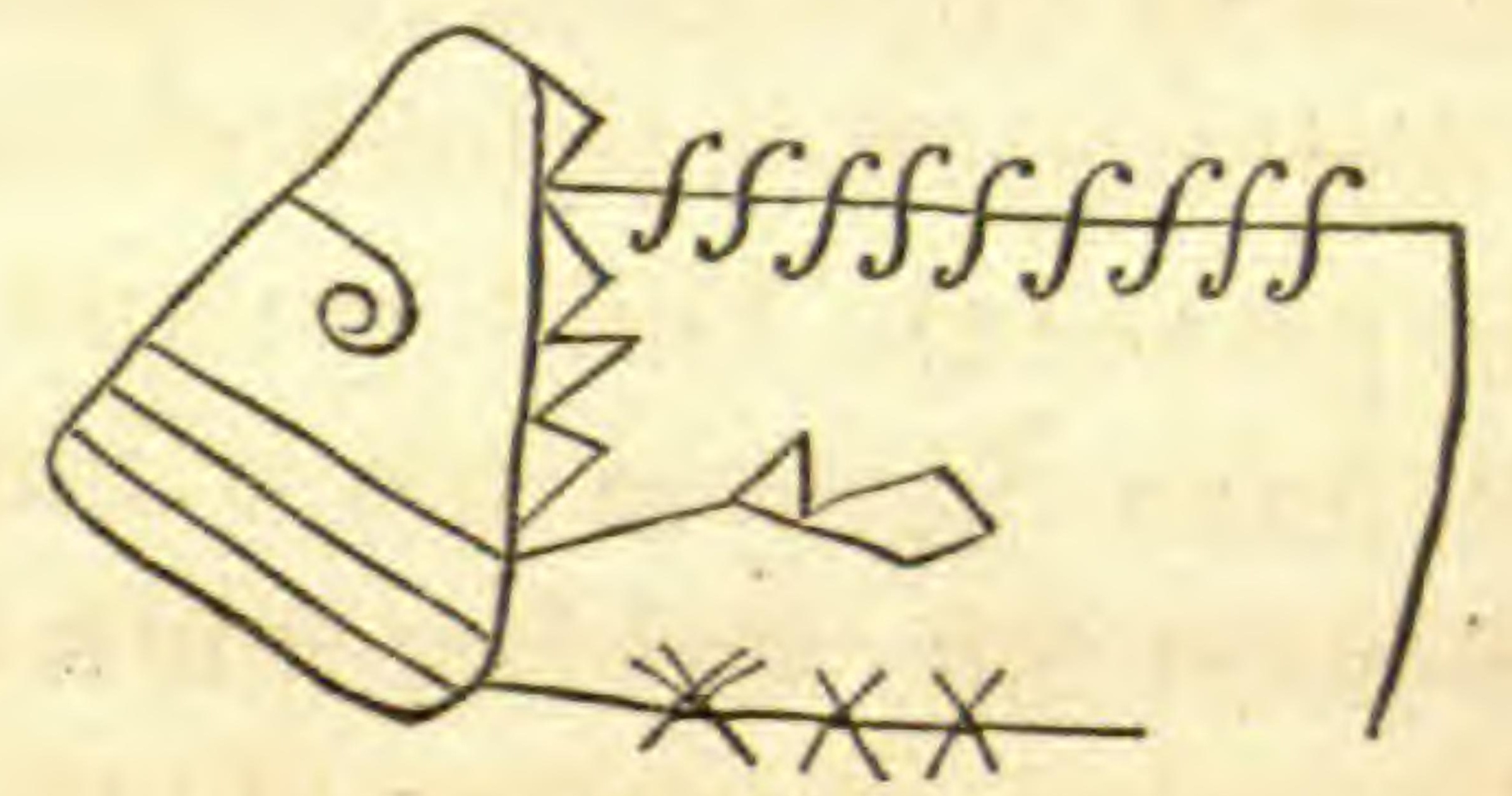

Hieroglyphic.

Most of the apartments are connected by doors, besides which there are circular openings in the upper VOL. II. -18 
part of the chambers to admit light and air. The ground plan of the building shows that all the apartments were long and narrow without windows. The inner rooms, I think, were used as store-rooms for corn ; in fact, it is a question whether the whole may not have been built for a similar purpose. There are four entrances, one in the centre of each side. The door on the western side is but two feet wide, and seven or eight high; the others three feet wide and five in height, tapering towards the top,- - a peculiarity belonging to the ancient edifices of Central America and Yucatan. With the exception of these doors, there are no exterior openings, except on the western side, where they are of a circular form. Over the doorway corresponding to the third story, on the western front, is an opening, where there was a window, which I think was square. In a line with this are two circular openings.

The southern front has fallen in in several places, and is much injured by large fissures, yearly becoming larger, so that the whole of it must fall ere long. The other three fronts are quite perfect. The walls at the base, and particularly at the corners, have crumbled away to the extent of twelve or fifteen inches, and are only held together by their great thickness. The moisture here causes disintegration to take place more rapidly than in any other part of the building; and in a few years, when the walls have become more undermined, the whole structure must fall, and become a mere rounded heap, like many other shapeless mounds which are seen on the plain. A couple of days' labor spent in restoring the walls at the base with mud and gravel, would render this interesting monument as durable as 


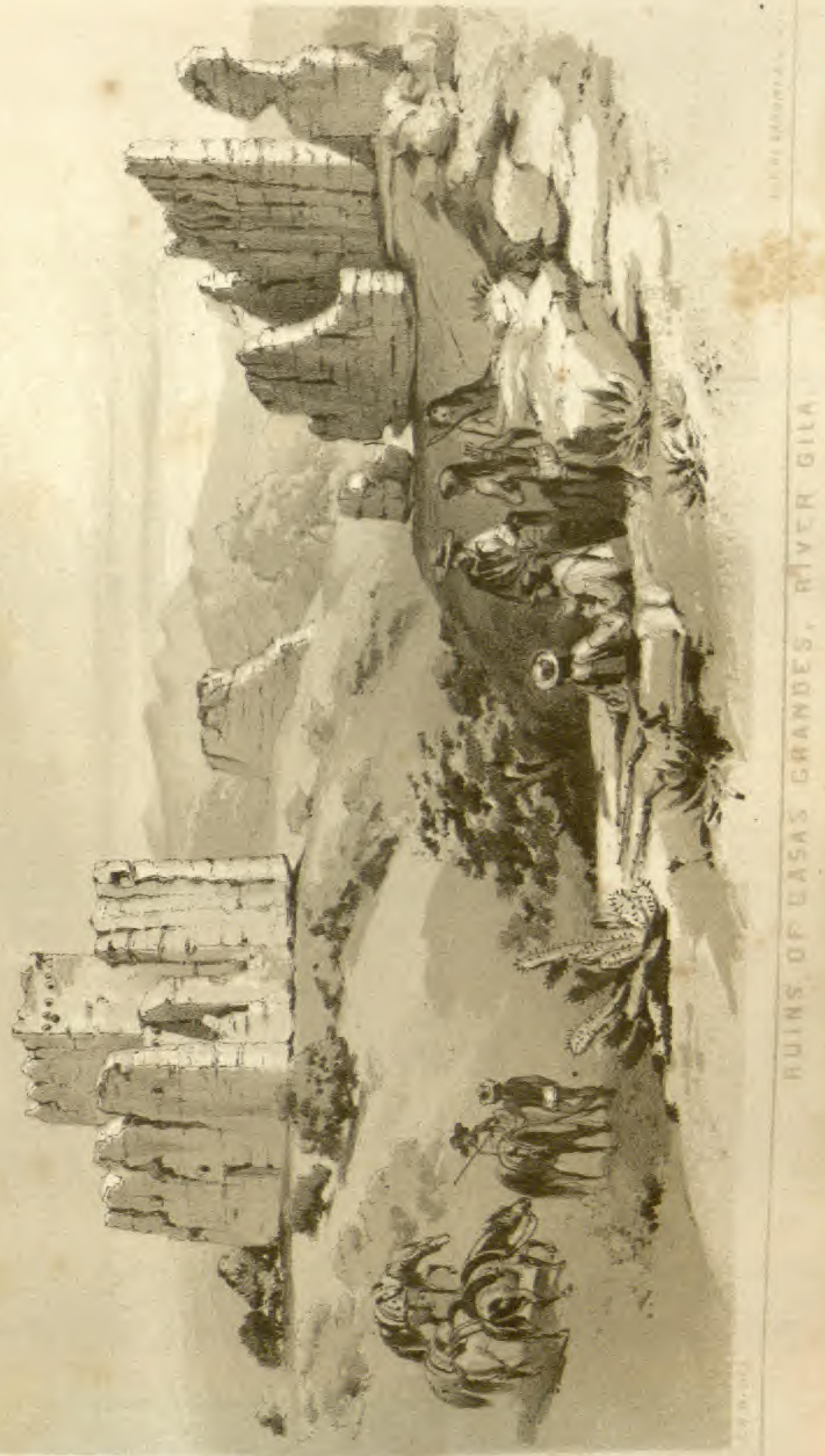



brick, and enable it to last for centuries. How long it has been in this ruined state, is not known; we only know that when visited by the missionaries a century ago, it was in the same condition as at present.

The exterior dimensions of this building are fifty feet from north to south, and forty from east to west. On the ground floor are five apartments. Those on the north and south sides extend the whole width of the building, and measure 32 by 10 feet. Between these are three smaller apartments, the central one being within the tower. All are open to the sky. There is no appearance of a stairway on any of the walls; whence it has been inferred that the means of ascent may have been outside.

On the south-west of the principal building is a second one in a state of ruin, with hardly enough of the walls remaining to trace its original form. The accompanying ground-plan will show what portions of the walls are standing. The dark lines represent the erect walls, the faint lines the heaps of fallen ones. The central portion, judging from the height of the present walls, was two stories high; the outer wall, which can only be estimated from the debris, could not have been more than a single story.

North-east of the main building is a third one, smaller than either of the others, but in such an utter state of decay that its original form cannot be determined. It is small, and may have been no more than a watch tower. In every direction as far as the eye can reach, are seen heaps of ruined edifices, with no portions of their walls standing. To the north-west, about two hundred yards distant, is a circular embank- 
ment from eighty to one hundred yards in circumference, which is open in the centre, and is probably the remains of an inclosure for cattle. For miles around
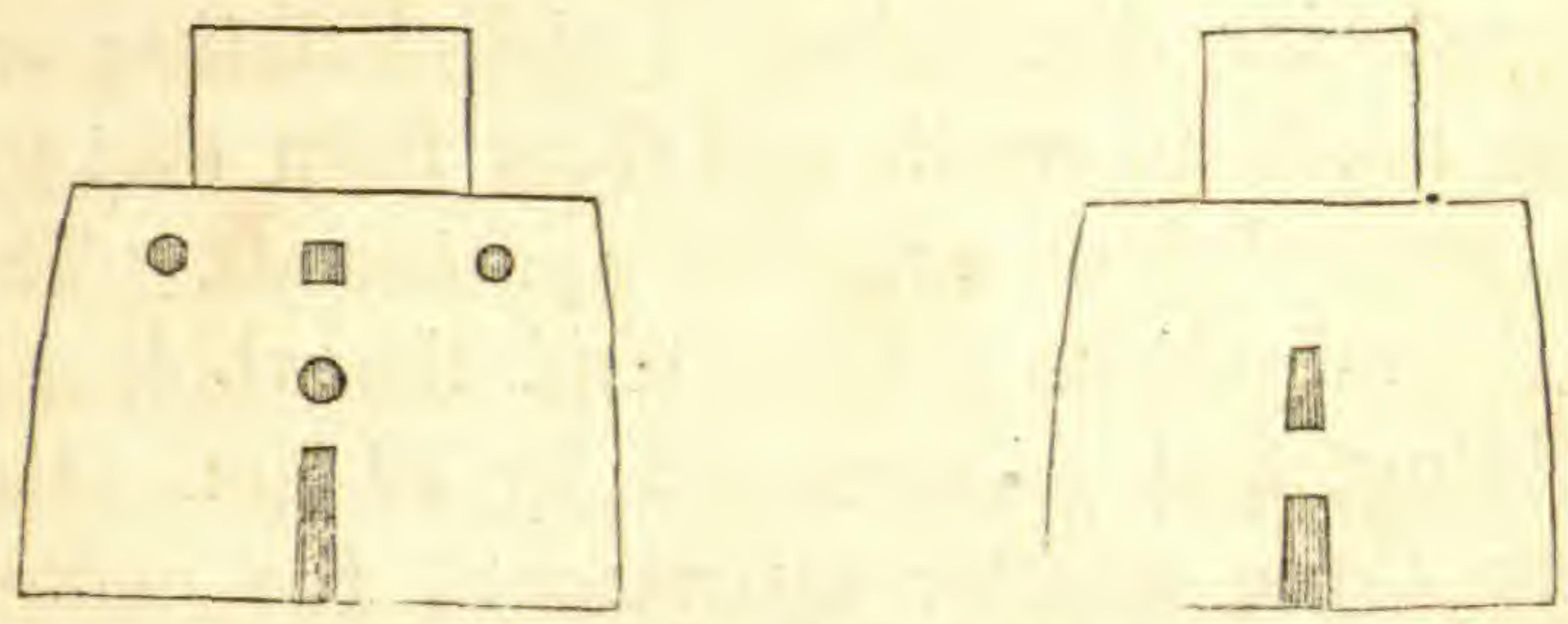

Elevation of Casas Grandes, Rio Gila.

these in all directions, the plain is strewn with broken pottery and metates or corn-grinders. The pottery is red, white, lead-color, and black. The figures are
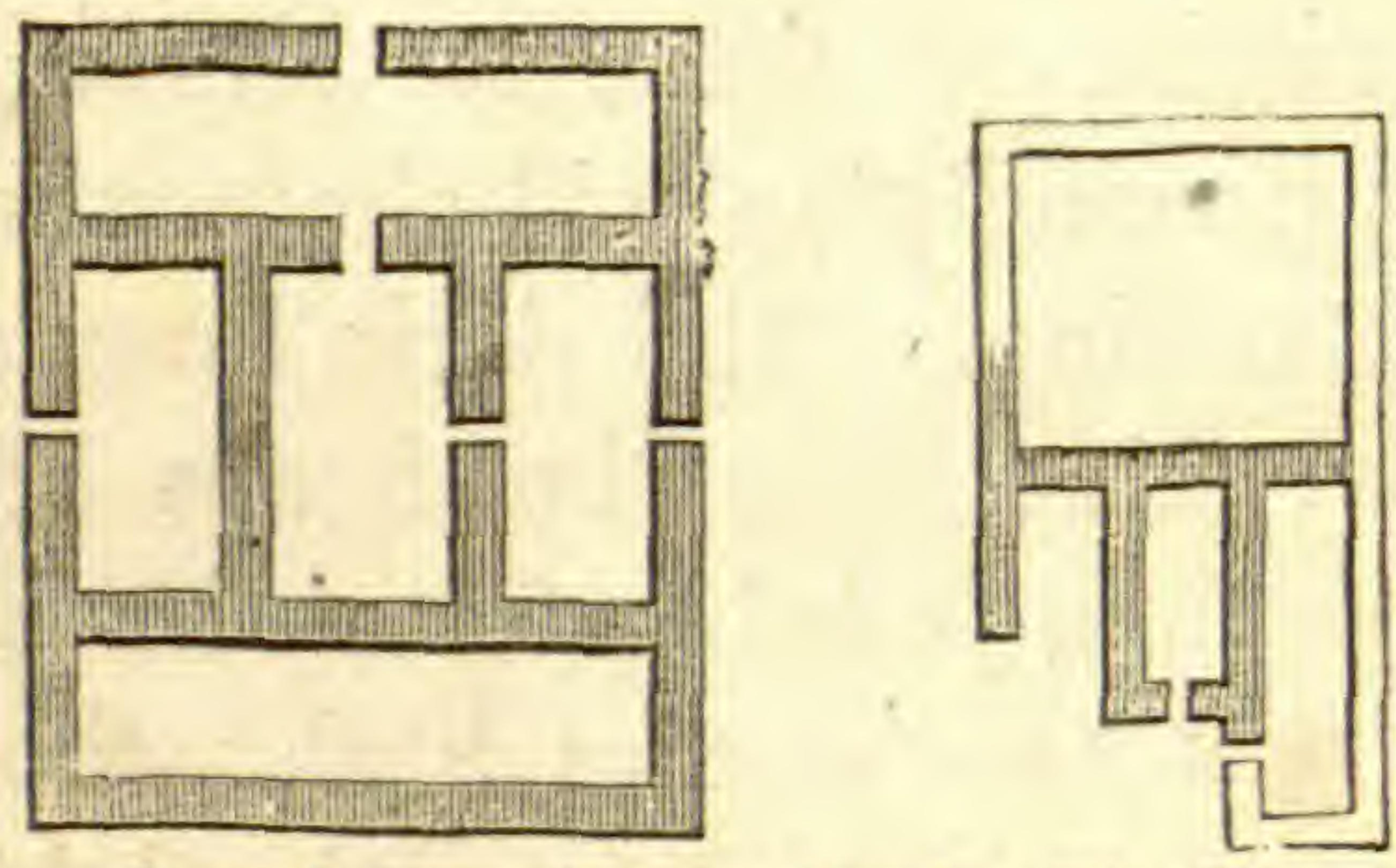

Ground Plan of Cases Grandes, Rio Gila.

usually geometrical and formed with taste, and in character are similar to the ornaments found on the pottery from the ruins on the Salinas and much further north. Much of this pottery is painted on the inside, a peculiarity which does not belong to the modern pottery. In its texture too, it is far superior. I collected a quantity of these fragments, from which I selected the larger pieces. Those containing the most 
interesting patterns are represented in the accompanying engraving.

The origin of these buildings is shrouded in mystery. They were found much as they now appear by the earliest explorers of the country, who were told by the Indians that they had been built five hundred years before. One thing is evident, that at some former period the valley of the Gila, from this ruin to the western extremity of the rich bottom-lands now occupied by the Pimos and Coco-Maricopas, as well as the broad valley of the Salinas, for upwards of forty miles, was densely populated. The ruined buildings, the irrigating canals, and the vast quantities of pottery of a superior quality, show that, while they were an agricultural people, they were much in advance of the present semi-civilized tribes of the Gila. But this civilization extended far beyond the district named. From information given me by Leroux, it appears that ruins of the same sort exist on the San Francișco or Verde River; and Captain Johnston and Major Emory both saw similar evidences of wide-spread population far above the district in question. What connection this ancient people had with the Moquis and Zuñis, and with the "seven cities of Cibola," visited by Marco de Niza and Coronado, remains to be settled. This is strictly an ethnological question, requiring evidences and arguments which do not properly belong to this work. So with regard to the identification of particular tribes yet in existence as the descendants of this ancient race, philology renders us the most reliable aid. But I have omitted speaking of philological analogies, as they belong to another topic, and would 
occupy too much space to be introduced here. Little has yet been done for the ethnology of the Indian tribes west of the Rocky Mountains, except by Mr. Hale, in his elaborate and admirable "Ethnology and Philology of the United States Exploring Expedition." But I have reason to believe, that when the various languages of Mexico, California, and of the tribes between the Colorado and New Mexico, are subjected to a rigid examination and comparison, some interesting facts will be deduced.

The most detailed of the early accounts of the ruins on the Gila is that of Father Pedro Font, to whose interesting and reliable journal I have before alluded. As these ruins have been misunderstood by many, and an important error propagated respecting them, I will give an extract from the diary of this missionary from the manuscript copy obtained by me in California :

"The Commandant determined that we should rest to-day, and thus we had an opportunity to examine the large building called Montezuma's House, situated at the distance of one league from the river Gila, and three leagues E. S. E. of the laguna. We were accompanied thither by some Indians, and by the Governor of Uturituc, who on his way related to us a history and tradition respecting said house, handed down from their forefathers, and composed altogether of fiction confusedly mixed with some Catholic truths. We carefully examined this edifice and its ruins, the iconographical plan of which I here lay down; and the better to understand it, I give the following explanation and description: 
"The large house or palace of Montezuma, according to the histories and meagre accounts of it which we have from the Indians, may have been built some five hundred years ago: for, as it appears, this building was erected by the Mexicans, when, during their transmigration, the Devil led them through various countries until they arrived at the promised land of Mexico; and in their sojourns, which were long ones, they formed towns and built edifices. The site on which this house is built is level on all sides, and at the dis. tance of about one league from the river Gila, and the ruins of the houses which composed this town extend more than a league towards the east and other cardinal points; and all this land is partially covered with pieces of pots, jars, plates, etc.; some common, and others painted of different colors, white, blue, red, etc.; which is a sign that this has been a large town, inhabited by a distinct people from the Pimos of the river Gila, who do not know how to manufacture such earthenware. We made an exact survey of this edifice, and of its situation, which we measured in the mean time with a lance; and this measure I afterwards reduced to geometrical feet, which gave a little more or less than the following result:

"The house forms an oblong square, facing exactly to the four cardinal points, east, west, north, and south; and round about it there are ruins, indicating a fence or wall, which surrounded the house and other buildings, particularly in the corners, where it appears there has been some edifice like an interior castle or watch-tower; for in the angle which faces towards the south-west there stands a ruin, with its divisions and an 
upper story. The exterior wall extends from north to south four hundred and twenty feet, and from east to west two hundred and sixty feet. The interior of the house consists of five halls; the three middle ones being of one size, and the two extreme ones longer. The three middle ones are twenty-six feet in length from north to south, and ten feet in breadth from east to west. The two extreme ones measure twelve feet from north to south, and thirty-eight feet from east to west." $\%$

The Casa Grande, as described in this extract from Father Font, has been alluded to by many authors, and the dimensions, as given by him, quoted; but all have mistaken the meaning of the writer in the dimensions. He speaks of the house around which "there are ruins, indicating a fence or wall which surrounded the house and other buildings; " and then goes on to say, that "the exterior wall extends from north to south four hundred and twenty feet, and from east to west two hundred and sixty feet." Nearly all the writers who refer to the building (and there are many, among which may be named Baron Humboldt himself*), quote these dimensions of the "fence" or "exterior wall," as those of the edifice itself. It is possible that the manuscript referred to by Baron Humboldt differed from that in my possession; for the extract from Font's journal, contained in Mr. Schoolcraft's work on the Indian tribes, says: "The exterior

* Father Pedro Font's Journal from Oreasitas, in Sonora, to Monterey, California, in $1775,{ }^{\prime} 76$, '77. MS.

† Political Essay on New Spain, vol. ii. p. 301. 
wall of the house is four hundred and twenty feet," etc.* What follows clearly shows this to be an error; for it says, "the interior of the house consists of five halls," and then gives the dimensions of each apartment, which nearly correspond with my admeasurement. $\dagger$

Mr. Gallatin is the only writer, as far as I know, who understood the greater dimensions alluded to as referring to an exterior wall. After giving the size of the building and its apartments from Father Font, he says, "Around the whole there are indications of an external wall, which included the house and other buildings," four hundred and twenty by two hundred and sixty feet.

The earliest account of this building is that of Mangi, who, in company with Father Kino, visited it in the year 1694, on which occasion he said mass in it. $\$$ His relation also exists only in manuscript. "There

-was one great edifice," says he, "with the principal room in the middle of four stories, and the adjoining rooms on its four sides of three stories, with the walls two yards in thickness, of strong mortar and clay, so smooth and shining within that they appear like burnished tables, and so polished that they shone like the earthenware of Puebla.

"At the distance of an arquebuss shot twelve other

* Font's admeasurement was in Spanish geometrical feet, which differ from the English foot of twelve inches. p. 300 .

$\uparrow$ History, Condition, and Prospect of the Indian Tribes, vol. iii.

‡ Trans. of Amer. Ethnol. Society, vol. ii. p. 86.

$\S$ See extract from Mangi's Diary, in Schoolcraft's History and Condition of the Indian Tribes, vol. iii. p. 301. 
houses are to be seen, also half fallen, having thick walls, and all the ceilings burnt, except in the lower room of one house, which is of round timbers, smooth and not thick, which appeared to be of cedar or savin, and over them sticks of very equal size, and a cake of mortar and hard clay, making a roof or ceiling of great ingenuity. In the environs are to be seen many other ruins and heaps of broken earth, which circumscribe it two leagues, with much broken earthenware of plates and pots of fine clay, painted of many colors, and which resemble the jars of Guadalajara, in Spain. It may be inferred that the population or city of this body politic was very large; and that it was of one government is shown by a main canal, which comes from the river by the plain, running around for the distance of three leagues, and inclosing the inhabitants in its area, being in breadth ten varas," and about four in depth, through which perhaps was * directed one half the volume of the river, in such a manner that it might serve for a defensive moat, as well as to supply the wards with water, and irrigate the plantations in the adjacencies."

By the foregoing extracts it will be seen that these buildings were in much the same condition as that in which we now see them, although a century and a half has elapsed since Mangi's visit. He was told of other ruins " a day's journey to the north on another stream "flowing into the Gila, which were doubtless those on the Salinas that I have described.

* About twenty-seven feet. See also Alegro's Hist. de la Compaña de Jesus, en Nueva España, tom. iii. p. 84. 
I have been unable to learn from what source the prevailing idea has arisen of the migration of the Aztecs, or ancient Mexicans, from the north into the valley of Mexico, and of the three halts they made in their journey thither. This is another idea which has been so widely promulgated that it has settled down into an acknowledged fact, although I confess I have seen no satisfactory evidence of its truth. People have got too much in the way of ascribing all ancient remains to the Aztecs. We hear of them on the shores of Lake Michigan, where some have located the famous city of Aztlan. Other remains are spoken of in the Navajo country, south of the Great Salt Lake, where the Aztecs are said to have tarried a while. Again they are placed at the "Casas Grandes," on the Gila; whence they are supposed to have gone to a place north of the city of Chihuahua, where extensive remains are said to exist. The traditions which gave rise to this notion are extremely vague, and were not seriously entertained until Torquemada, Boturini, and Clavigero gave them currency, but they must now give way to the more reliable results from linguistic comparisons. No analogy has yet been traced between the language of the old Mexicans and any tribe at the north in the district from which they are supposed to have come; nor in any of the relics, ornaments, . or works of art, do we observe a resemblance between them. The explorations and investigations recently made, and others now in progress, may throw further light on this subject, which I shall now dismiss.

After three hours spent at the ruins, the hottest, I 
284 indians OF THE GILA, AND THE CASAS GRANDES.

think, I ever experienced, we set out on our return to camp. Our Indian companions, having got out of water (of which we had none to spare), set off in advance to reach the river, and there wait for us. They were quite reluctant to go alone even a couple of miles, for fear of the Apaches; and I doubt whether they would have ventured even then without us, had they not been driven to do so by extreme thirst. As our canteens were all exhausted before leaving, we were obliged to follow their example. We found the river's bank about fifteen feet high, and so abrupt that it was with some difficulty we reached the water. After following the route by which we came, and crossing on our way several of the old irrigating canals, from which the ancient people who occupied the valley derived their water, we reached our camp at three o'clock, much fatigued though amply repaid by our day's excursion. The mercury had stood in the shade, beneath the trees, at $119^{\circ}$ Fahrenheit, between the hours of ten and three o'clock.

I found a few Indians in camp, among them a messenger from Francisco Dukey, the Maricopa interpreter, who, ashamed to come himself, had sent another to me, begging that I would give him a written recommendation to show to other Americans. His request was peremptorily refused. 


\section{CHAPTER XXXIII.}

\section{CASAS GRANDES TO SANTA CRUZ.}

Leave the Gila-Terrific storm on the desert-Encounter a party of Americans at midnight-Stopped by the darkness-Unpleasant siturationPack-mules and cattle missing-Picacho mountain-Vegetation of the desert-Second night's march-Arrival at Tucson-General BlancoArrival of Mexican troops-Campaign against the Apaches-Meet Mr. Coons with 14,000 sheep-His disasters-Visit from Gen. Blanco and his officers-Repairs on wagons-Tucson and its valley-MeteoriteSan Xavier del Bac-Beautiful church-Spanish and Anglo-Saxon colonization-Incessant rains-Presidio of Tubac-Meet Inez Gonzales, the captive girl-Her sad fate-Uncertainty of irrigated lands-California emigrants-Calabasa-Picturesque valley-Tumacacori-San LazaroMore emigrants-Reach Santa Cruz.

July 13th. The heat continued excessive. The thermometer had ranged every day since our arrival at the Maricopa and Pimo villages at from $100^{\circ}$ to $119^{\circ}$ between the hours of 10 and 3 ; in fact it had scarcely fallen below 100 between these hours since we struck the desert beyond the Colorado. During the week we were at Fort Yuma, as well as during our journey, there was but little variation. The nights remained comfortable all the time; so that in the open air a single blanket was necessary.

Having a long march before us, we left camp at halfpast 4 P. M., desiring to reach a mountain forty-five 
miles distant, or half way across the great jornada, the following morning, although we had little hope of finding water until we should get to Tucson. The mountain referred to is called the "Picacho," a name applied to every high abrupt peak. Our course lay a little to the east of south, direct for the Picacho, across a vast open plain. A short range of mountains on the west, within a mile of the road, was soon passed. On the east was a lofty range fifty miles distant, with no intervening objects. The road was excellent; and our animals being fresh, we hurried them on as fast as it was prudent to do. As we progressed, there seemed to be a likelihood of rain, which was somewhat increased by a perceptible change in the air. The prospect before us was dismal enough, in the midst of the wide-spreading desert; for by night-fall we had passed the mountains on our right, and were soon far from any landmark.

As the sun sank below the horizon, the dark cloudbank which we had observed far to the south ascended, and we could see the rain already falling on the distant mountain. Night now set in; the thick clouds rose higher and higher, and before nine o'clock had completely obscured every star. Shrouded as we were in darkness, it was no easy matter to find our way through the low mezquit bushes scattered over the desert. But nature's light-house opened its portals, and the vivid lightning flashed around us; so that the black mountain, our beacon in this desert, seemed constantly before us. Up to this time I had taken the lead in my wagon; but as my mules became alarmed, rendering it impossible to get along, I placed Mr.Leroux, who rode a milk-white mule, immediately before mine. 
His animal could be seen, and all followed hirn. Peals of the most terrific thunder burst upon us, leaving scarcely an interval of repóse. Next came violent gusts of wind, accompanied by clouds of sand and dust, reminding one of the African simoom. The wind was from the south, and brought the sand directly in our faces. To avoid it was impossible. Not a tree was to be seen; no ravine appeared where we could shelter ourselves; and the nearest mountain was yet twenty miles off. . Lastly came torrents of rain, and this terrific storm was at its height.

Slowly we journeyed on, drenched to the skin, notwithstanding our overcoats and India rubber garments. The march before us must be made, and the sooner the "Picacho" was reached the better. To stop, was to endanger our animals; for no pools had yet been seen where the rain had accumulated, so that we had neither water nor grass to give them. At midnight, in the midst of this extreme darkness and rain, where one would about as soon expect to meet a human being as in the middle of the broad ocean, we were suddenly brought to a stand by the sound of voices! "Who comes there? Quien vive?" were quickly cried by a dozen voices in English and Spanish, and as quickly answered, "Friends! Amigos! Who are you? Where are you from? De donde viene?" etc., and in a moment we were surrounded by horsemen, pack-mules, and the accompaniments of a large party. Were they Indians, or Mexicans, or Americans-friends or enemies, ran through my mind, till the sound of English voices dissipated my apprehensions. It proved to be a party of between forty and fifty Americans, 
bound for California. We stopped about ten minutes to exchange a few words, though we could not distinguish faces. This we were, in a measure, compelled to do, to separate our animals from those of the passing train, for all were now mixed up together. The party was from Missouri, and had come by the way of El Paso. They gave us some news from the latter place, which was very acceptable. Inquiries were made by each party about the grass and water on the route, when, the animals becoming restive, we bade them adieu, and resumed our journey.

Up to this time, the tempest had not in the least abated. Indeed the darkness seemed growing still thicker, while the flashes of lightning were becoming less frequent, which rendered it more difficult to keep on our course. After a longer interval than usual, the heavens were again lighted up, when I found myself going in an opposite direction to the right one, and the party much scattered. Leroux came up, and said that it was absolutely necessary to stop where we were; as some of the pack-mules were missing, and it was impossible to keep together or find our way in such impenetrable darkness. I accordingly had my mules taken out and hitched to my wagon; the same was done with the teams. All the pack-mules that could be found, were brought together; and the horsemen fastened their animals wherever they could find a bush. Dr. Webb and myself remained quietly in our wagon.

In the midst of the storm Mr. Thurber, with a great deal of perseverance, succeeded in making a fire. This was done by taking the leaves of some books that had seen their best days, and protecting them from the 
rain with an India rubber coat, until well lighted. To these was added some dry wood found in the wagons; and when bushes were piled upon the whole, a blazing fire was the result. This served as a guide to our scattered people, some of whom had found themselves among the emigrating party, with their faces turned towards the Gila!

June 14th. As soon as we could see, the animals were mustered; when three mules with their packs, two donkeys, and our three remaining beef-cattle, were missing. Two Mexican arrieros were left to hunt up these animals, and the train resumed its journey. The road was now very muddy, and every depression in the desert became filled with water, making the travelling quite heavy.

Soon after starting we met the rest of the party that we encountered in the night. They had become separated from those in advance, and had been compelled to await the return of day. Among them were several women on mules, who appeared to have had a sorry time of it. The "Picacho" was still far ahead; but after watering the animals, we pushed on, and at 11 o'clock reached its base, where we encamped: I had been eighteen hours in my seat, and was glad to throw myself on the ground beneath the shade of a mezquit bush, and get some sleep. After an hour's rest I got up and made a fire for my cook, who was still deep in his slumbers; and by one o'clock we had our breakfast. This forty-five miles was the most fatiguing day's journey we had yet had, including the exposure during the whole night to such a tempest of wind and rain.

VOL. II. -19 
The vegetation of this desert is the same as that near the Gila, viz., dwarfish mezquit at intervals, larrea Mexicana, palo verde, and cacti; the great petahaya luxuriating as usual in the barrenness. A tuft of grass was occasionally seen, and now and then some brilliant flower that had ventured to "waste its sweetness on the desert air."

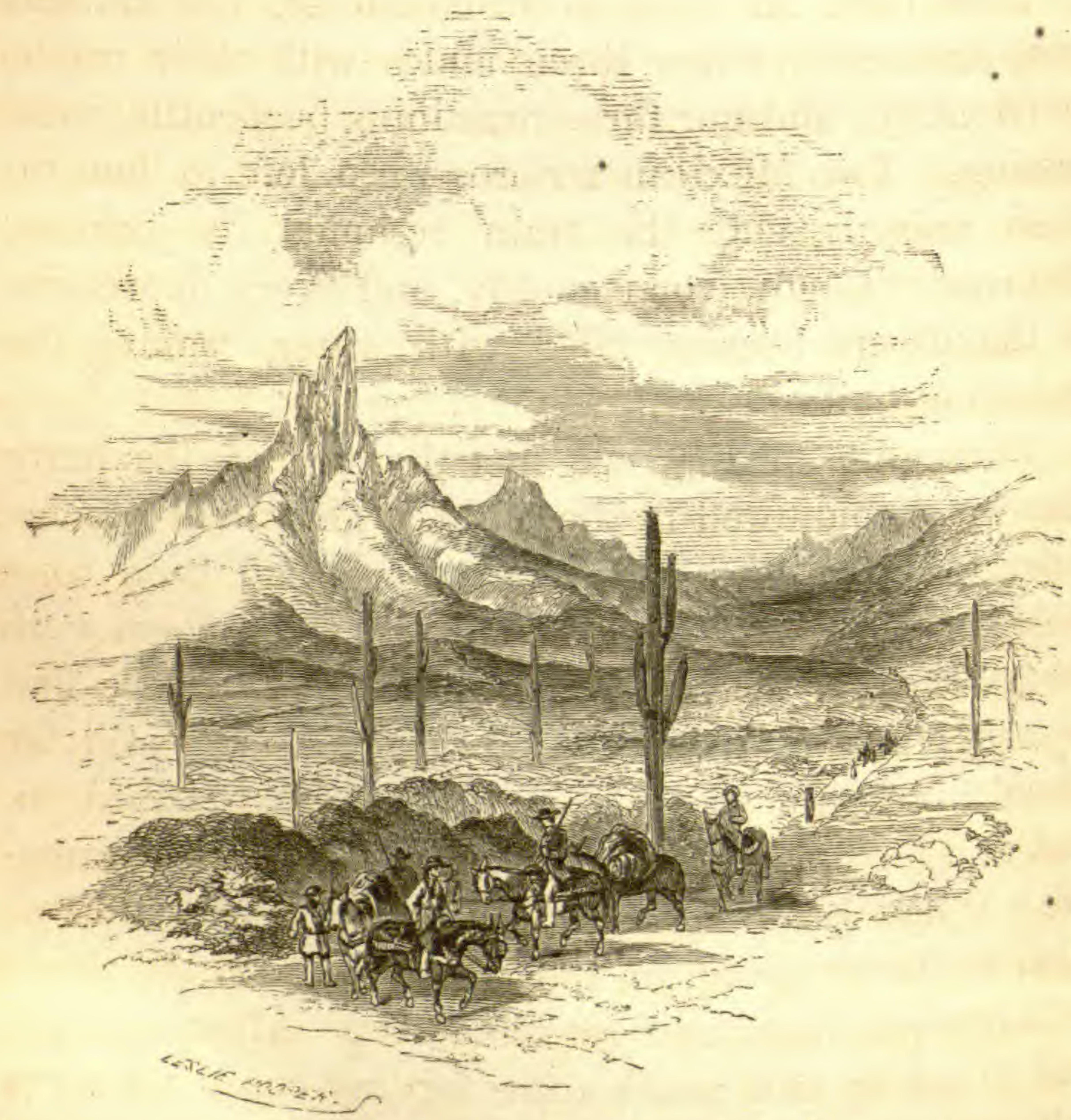

Ticacho of the Tucson riesert, from the South.

The mud holes here were filled with water, but so turbid that we could not taste it. We had enongh, however, in our canteens and kegs for drinking purposes. There was quite a thicket of mezquit here, and 
an excellent place for a camp. The animals found a tolerable supply of food in the tufts of grass, and mezquit beans.

At 5 o'clock in the afternoon we started again, although we had had but little rest. I would have remained till morning, but our water was nearly out. The road had by this time become quite dry, and we rolled on at a steady gait of three miles an hour. Soon after leaving, the sky became overcast, and we feared a repetition of the storm; but it did not occur, and, although we had considerable difficulty in keeping our course, we were enabled to continue our journey through the entire night.

July 15th. At 5 o'clock this morning, being in advance of the train, we reached some mud holes containing a little water, which our thirsty animals drank with eagerness. During the night, many who were mounted on mules were so much fatigued as to be unable to retain their seats in their saddles; so dismounting, and tying their animals to the bushes, or to their bodies, they lay down on the desert, and refreshed themselves with a couple of hours sleep. At seven, the wagons with the rest of the party came up; and, although but eight miles from Tucson, such was our fatigue after two long nights' ride, that we determined to remain here to-day. Much to my regret, no tents were pitched; for a heavy shower eame up in the night, which wet most of the party to the skin. I was so fortunate as to make my bed beneath a wagon; where, protected by an India rubber blanket, I passed a comfortable night, and scarcely knew of the rain that was falling around me until morning. 
July 16 th. We started with a heavy road, and made but slow progress. The wagons got mired several times in crossing arroyos, one of them so deeply that it became necessary to unload it before it could be released; while another, in passing a deep gully, plunged so suddenly down, that the tongue was snapped off.

We reached Tucson at ten o'clock, A. M. As we passed the garrison, a body of Mexican soldiers were entering, who had just arrived from the south on a campaign against the Apaches. Among the officers standing at the gate I recognised Captain Barragan, who was in command at Santa Cruz when we reached that place in October last. Hearing from him that General Blanco was within, I left the train and accompanied the Captain to pay my respects to him.

General Blanco informed me that the depredations of the Apaches had lately been more frequent than ever. Many animals had been stolen in the immediate vicinity of Tucson, Tubac, and Santa Cruz; and many Mexicans had lost their lives. The troops had had some skirmishes with the Indians, in which Coletto Amarillo, one of the chiefs who so frequently visited us at the Copper Mines, was killed. The General furthermore told me that when on his march he fell upon a large Indian trail, and noticed among the footprints several made by new American shoes, which he readily distinguished from the Mexican shoes by their larger size and heels. He believed that there were Americans among them, or that they had murdered and robbed some party of emigrants. In October, when the weather should be cooler, and the rainy season past, it was his intention to make a campaign against 


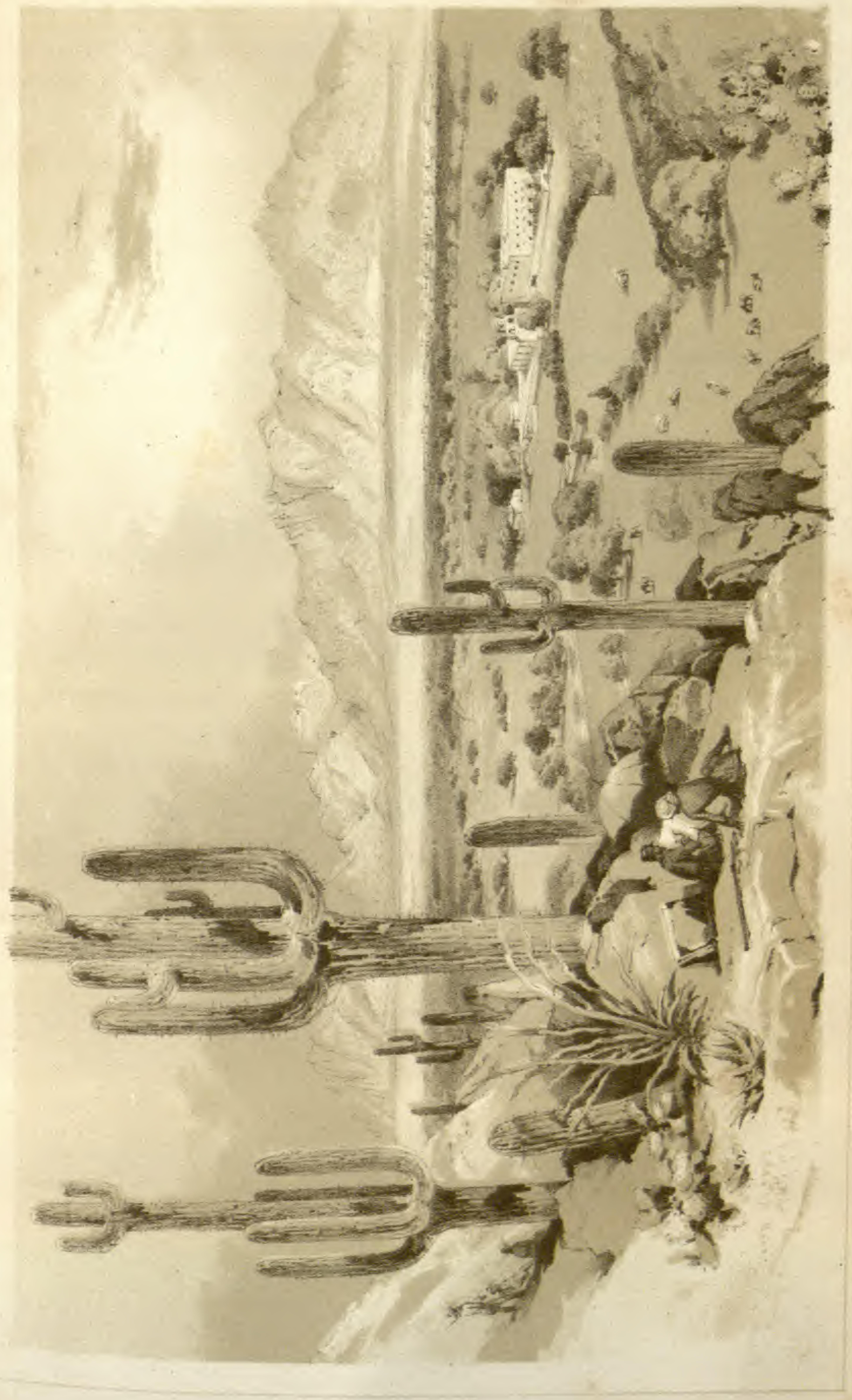

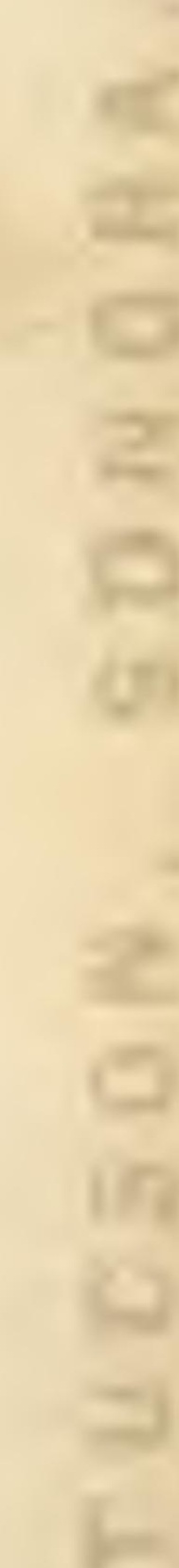



the Apaches on the Gila, and thence go to the MogoIlon Mountains, near the Copper Mines. After half an hour spent with the General, I rode a mile from the town, and there found my party encamped on the banks of the Santa Cruz River, where there was an abundance of grass.

Near our camp we found Mr. Coons, an American, on his way to San Francisco, with 14,000 sheep. For the protection of this large flock, he had sixty persons, forty-five of whom were Americans, and fifteen Mexicans. He quieted our anxiety as to grass and water, having found an abundance of both on his route. There had been much rain, and the grass was in consequence in fine condition. He had met many Indians near the Guadalupe Pass, but would not allow them to enter his camp. When near Janos, a party of Apaches rushed among them during the day, and succeeded in running off fourteen mules and horses. Mr. Coons was entirely unprepared for the attack, particularly as the rascals approached him from the town where they had been. Before he could get a party mounted, the robbers had got a long start of them, which rendered pursuit in vain. This loss so disabled Mr. C., that he was compelled to return to the city of Chihuahua, purchase more animals, and strengthen his party; which detained him six weeks. His party was now well armed, and he felt himself strong enough to cope with any roving band that might attempt to interrupt him.

General Blaneo with his staff, and several other officers from Tucson, escorted by a troop of lancers, called on me in the afternoon. These lancers were well dressed and equipped, and made a handsome 
appearance. I was by no means well prepared for the visit; for the wagon which contained my tent and baggage, being the one which had met with the accident before mentioned, had not yet reached camp: I was therefore obliged to receive him in another and very small tent, not large enough for one half the officers who accompanied him. It began to rain too at the time, which added to my dilemma. However, there were other tents pitched, in which these gentlemen took refuge. General Blanco again spoke of our common enemy, the Apaches, and of operations against them. He recommended that the American troops should attack them north of the Gila, while the Mexicans should receive them as they came south for refuge. I told him that my views agreed with those he had expressed, and that I had suggested a similar plan of operation to the United States government in a recent dispatch sent from California.

The General tendered me the use of his blacksmith's shop, and any other facilities I required to repair my broken wagons; of which I was very glad to avail myself, although we found it difficult to obtain a piece of wood for a new tongue. My little wagon also wanted repairs, and some of the animals required shoeing. There was, therefore, no alternative but to remain here a day or two. I would have regretted this delay more, had not the grass been so good that I believed the mules would be benefited by it. In the evening the rain set in hard, and continued during the night. But we were now in good tents, with water, grass, and wood around us, so that we had no cause for complaint. 
July 17th. Sent the wagons up to the town; but only one man was found who professed to be a blacksmith, and could work upon them. Sent four of my men up to assist; but altogether they made little progress, for the want of tools.

Tucson is the most northern town in Mexico, and a very old place. It is found on the oldest maps, and is referred to by the early missionaries. It has always been, and is to this day, a presidio or garrison; but for which the place could not be sustained. In its best days it boasted a population of a thousand souls, now diminished to about one third that number. It stands on the plateau adjoining the fertile valley watered by the Santa Cruz River, a small stream which rises ten miles north-east of the town of Santa Cruz, whence it flows south to that place. It then takes a westerly direction for about ten miles, after which it flows northward through Tubac and Tucson, and soon becomes lost in the desert. The lands. near Tucson are very rich, and were once extensively cultivated; but the encroachments of the Apaches compelled the people to abandon their ranchos and seek safety within the town. The miserable population, confined to such narrow limits, barely gains a subsistence, and could not exist a year but for the protection from the troops. More than once the town has been invested by from one to two thousand Indians, and attempts made to take it, but thus far without success. These Apaches have become reduced quite as much as the Mexicans; so that two hundred warriors are about the largest force they can now collect.

In addition to the river alluded to, there are some 
springs near the base of a hill a mile to the west of the town, which furnish a copious supply of water. Near these is a hamlet, and a large hacienda, which in former times must have been very rich. It is now in a decayed state, and but a small portion of its fine lands are cultivated. This hacienda is seen in the foreground of the annexed sketch of Tucson.

Wheat, maize, peas, beans, and lentils are raised in perfection; while among the fruits may be named, apples, pears, peaches, and grapes. The only vegetables we saw were onions, pumpkins, and beans; but in such a fertile valley all kinds will of course do well,

The houses of Tucson are all of adobe, and the majority are in a state of ruin. No attention seems to be given to repair; but as soon as a dwelling becomes uninhabitable, it is deserted, the miserable tenants creeping into some other hovel where they may eke out their existence. We found three hundred soldiers in the place, although the average number for some years past has not exceeded twenty.

The bottom-lands are here about a mile in width. Through them run irrigating canals in every direction, the lines of which are marked by rows of cottonwoods and willows, presenting an agreeable landseape.

I ascended a rocky hill above the hacienda mentioned, about a quarter of a mile from our camp, and had a fine view of the valley and surrounding country. This hill was covered with cacti of every variety, among which the petahaya was most prominent. The fouquiera, yucca, and agave, were also luxuriating 
among the rocks; for scarcely a particle of soil could be seen. Below was the valley, its fields and acequias defined by the long lines of shrubbery and trees. The town is seen on the border of the plateau, where the desert begins, and stretches off to the east, to a high range of mountains about fifteen miles distant. In these mountains is a singular cliff of rocks resembling a huge castle. Like other mountain ranges, these take a south-easterly direction and extend nearly to the San

- Pedro. Directly south lies the valley of Santa Cruz, presenting to the eye an agreeable contrast to the barren mountains and the long line of desert on either side.

The two men left on the desert to hunt up the missing animals arrived to-day. They went back to the Pimo villages, and found the pack-mules following the emigrants that we had met.

July 18 th. I went out this morning and completed my sketch of the valley and town from the hill visited yesterday. The men were still at work on the wagons, to be completed by evening. I bought some sheep here at three dollars ahead, as our live stock was getting low.

In the afternoon I called to take leave of General Blanco, and at the same time examine a remarkable meteorite, which is used for an anvil in the blacksmith's shop. This mass resembles native iron, and weighs about six hundred pounds. Its greatest length is five feet. Its exterior is quite smooth, while the lower part which projects from the larger leg is very jagged and rough. It was found about twenty miles distant towards Tubac, and about eight miles from the road, 
where we were told are many larger masses. The annexed drawing gives the appearance of this singular mass. There is another larger mass within the garrison grounds, of which I did not take a sketch. With much labor Dr. Webb broke off a fragment of this meteorite for the purpose of analysis.

Nearly all our Mexican arrieros got drunk to-day, and caused much disturbance in the town. I would have discharged them, but could find none to take their places.

July 19th. We were off this morning before the sun had risen, and soon entered a thickly wooded valley of mezquit. A ride of nine miles brought us to the mission of San Xavier del Bac; truly a miserable place, consisting of from eighty to one hundred huts, or wigwams, made of mud or straw, the sole occupants of which are Pimo Indians, though generally called Papagos. In the midst of these hovels stands the largest and most beautiful church in the State of Sonora. It is built of brick on the summit of a low hill, and has two towers and a dome. In a square, around and directly connected with the church, are some adobe houses, which were occupied when the Mission was in a flourishing state. All save one are now tenantless, and this, which adjoins the church, is occupied by the only Mexican family in the place. The train passed directly through, while a few of the gentlemen and myself drew up at the church door to examine its interior.

This church has more pretensions to architectural beauty than any I saw in the country, although its general character is the same. It is elaborately orna- 


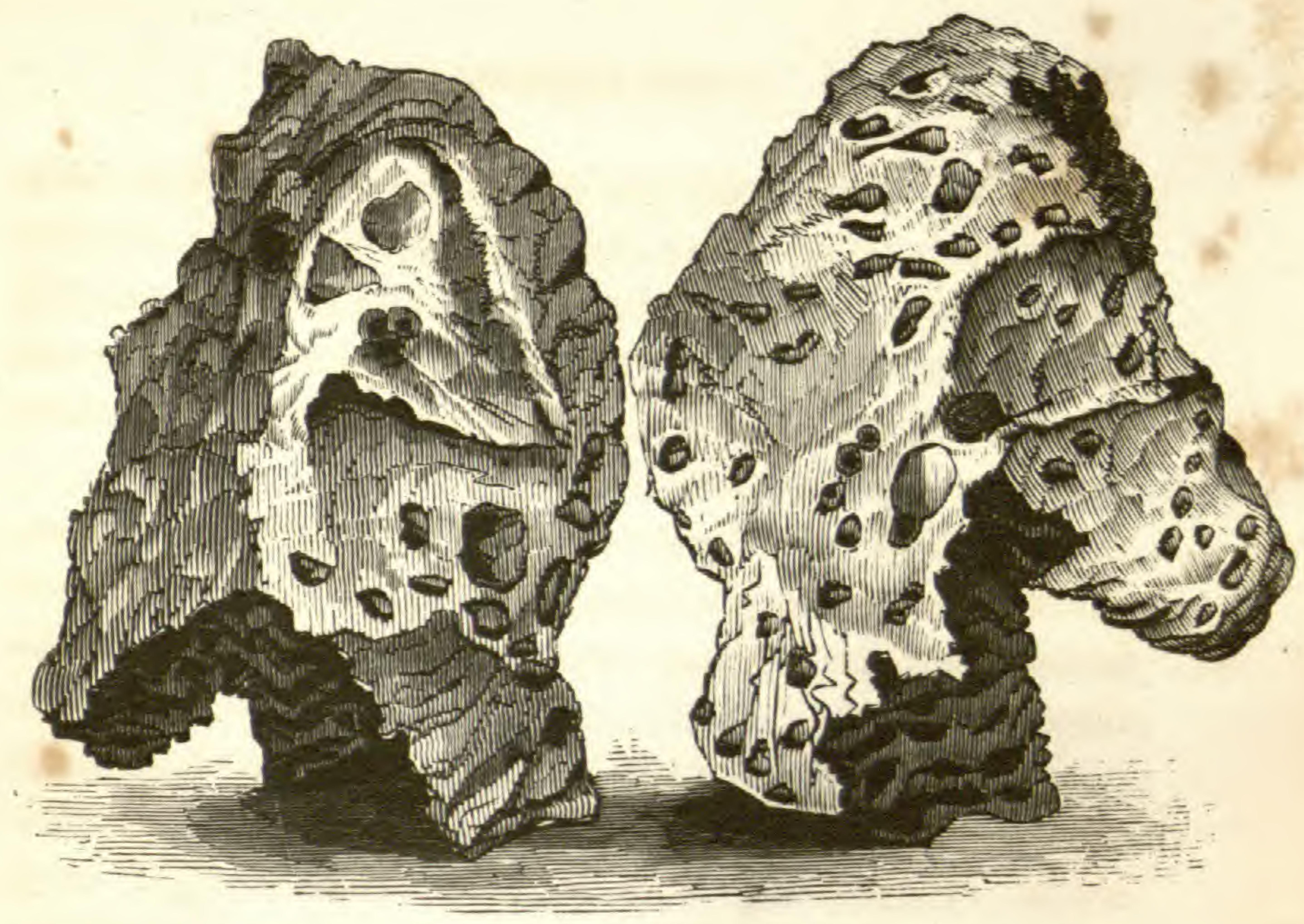

METEORITE AT THE HACIENDA DE CONCEPCION, SHOWING OPPOSITE SIDES

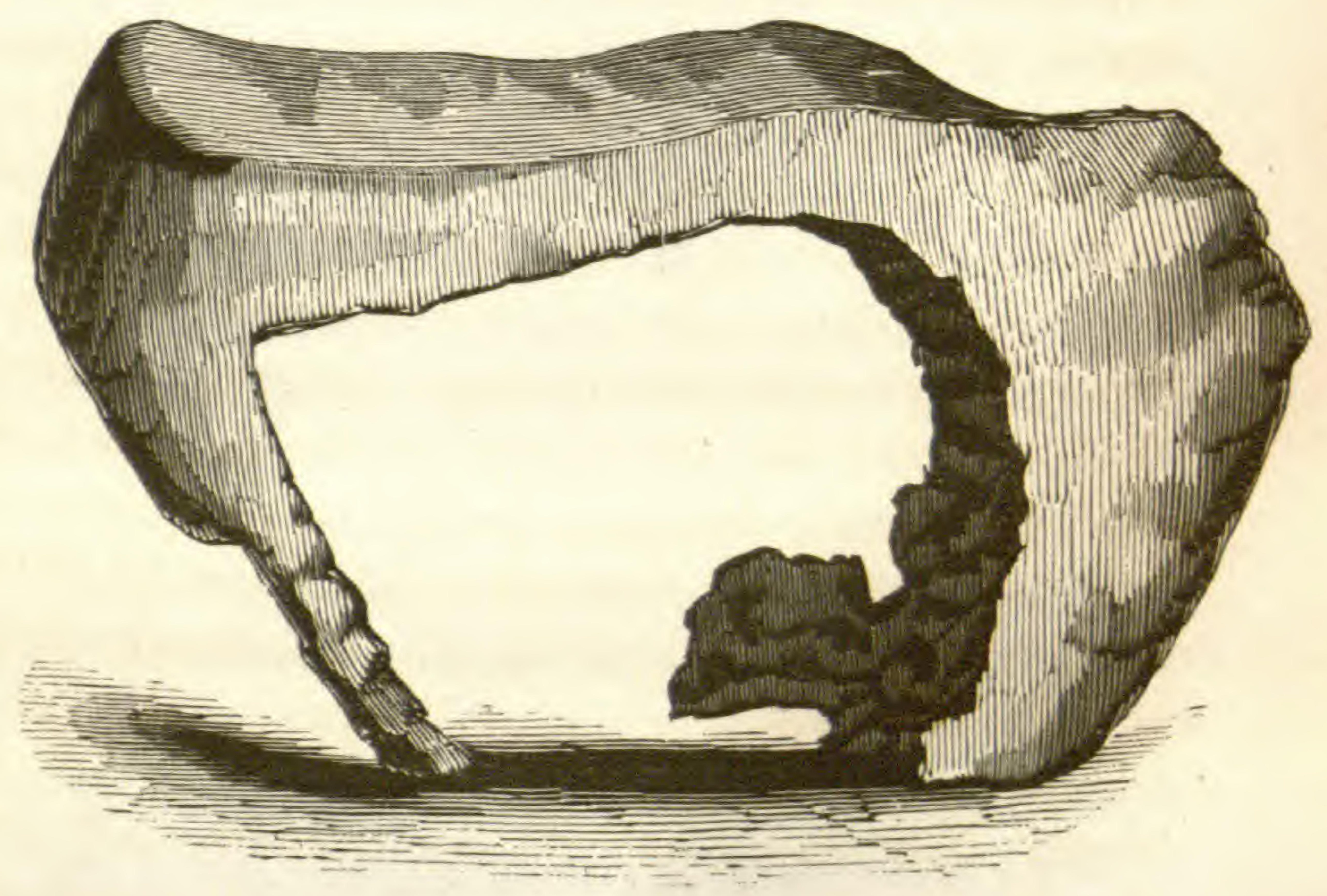

METEORITS AT TUCSON.-p, 298. 

mented inside and out, and contains many decorations new in architecture, partaking neither of the Greek, Roman, nor Gothic orders. Along the eaves is a row of queer looking creatures, the like of which cannot probably be found, even in this country of strange animals. The interior is gaudily painted; and from the profusion"of gilding, one might suppose the Mission to have possessed a gold placer. Around the altar, and in the niches, are many wooden statues, from the size of a foot to that of life. The poor Indian doubtless believed them all to be saints, and made his offerings accordingly, although about one half are statues of old Spanish cavaliers and figures of Chinese mandarins. There are besides angels and archangels, or figures intended to represent celestial beings with wings, five or six, feet high, springing from the walls. This church was built towards the close of the last century from the produce of the Mission lands, and is throughout in a good state of preservation. It appears that there was a previous structure here, erected by Father Kino as early as $1700 . *$

What a marked difference there is in Spanish and English colonization! Here the zealous Missionary preceded all others, planting the cross along with the banner of his country. Then commenced the work of baptizing; and as soon as a sufficient number of converts had been made, a fertile valley was chosen, and a church erected with buildings to accommodate some hundreds. Next came the colonists, whose main efforts p. 119.

* Alegre, Hist. de la Comp. de Jesus en Nueva España,-Tom. iii. 
were to support the Mission and its priests. The Anglo-Saxon pioneer entered the wilderness with his axe, his plough, and his rifle; and after he had erected his own dwelling, the mill and blacksmith's shop rose up. Lands were brought into cultivation, the mechanic arts flourished; and when the colony became large enough and rich enough to support a passtor, a church was built. For the results of the two modes of colonization, compare Texas, New Mexico, California, Sonora, and Chihuahua, before the three first became annexed to the United States, and the States of Ohio, Indiana, Illinois, and Michigan. The latter had attained more wealth, more population and importance, and had done quite as much towards promoting Christianity in the first ten years after their settlement, as the former States had in two centuries.

Near by is a fertile valley, a very small portion of which is now tilled: although from appearances, it was all formerly irrigated and under cultivation. I tried in vain to purchase vegetables. A more thoroughly lazy set of people, I never saw. The Pimo and CocoMaricopa Indians of the Gila, are infinitely superior to them. Whether a proximity to the church and the worthless half-civilized Mexicans has reduced them to this state of indolence and poverty, I know not; but if so, they would better have remained in their native valleys, and never seen the faces of white men.

Leaving the village, we rode on a mile further, and stopped in a fine grove of large mezquit trees near the river, where there was plenty of grass.

We remained here until 3 o'clock, P. M., when we resumed our journey along the valley as before, 
through a forest of mezquit trees, but had not proceeded more than an hour before it began to rain in torrents, the wind blowing directly in our faces. Believing the shower would soon pass over, I turned my wagon round and stopped. Those on horseback drew up under trees; but there was little shelter from them, so violently did the rain pour down. After an hour's delay, we pushed on. The road was now exceedingly muddy, the ravines and gullies were filled with water, and our progress was very slow. After journeying eight miles, making seventeen in all since morning, and being much in advance of the train, I deemed it prudent to stop. The wagons would not probably get in before night, after which, it would be unsafe to travel, owing to the washing of the road by the rains; for we had in many places to avoid it, and force our way through the woods.

The clouds indicated more rain; so I set to work and had a good fire in readiness for my cook when he should arrive. Those who were with me followed my example, and we soon had several large fires blazing, and a good stock of wood in.

As soon as the train got in, all hands set to work to pitch the tents, and take the necessary precautions to keep them in their places before the storm should be upon us. Guys were fixed to all the tents, which were further supported by being attached to the wagons; for the ground was so soft that the pins would not hold. Trenches were dug around each one, to keep it dry as possible; and we were quite ready for it, when the rain again began to fall. After a hearty supper, we retired to rest; but it was only to be routed 
out again, for the storm soon increased in violence, and every moment we expected our frail coverings would be torn to shreds or blown down. And, in fact, notwithstanding our efforts to make them more secure, one of the tents was hurled from its fastenings and blown more than a hundred yards before it was arrested.

Juily 20th. The rain having continued the whole night, we were much delayed in getting off this morning. The whole country was drenched with water, and the road almost impassable for our heavily-loaded wagons. After a hard journey of eighteen miles, we stopped at the banks of the river; and strange as it may appear, notwithstanding all the rain that had fallen, the river, such is the uncertainty of the streams in this country, was quite dry. Fortunately, in some cavities in the river's bed we found water enough for our present wants.

Our march was a straggling one to-day, as some of the teams could not keep up. My baggage wagon in particular, which also contained my tent and cooking utensils, did not get in until after dark. One of the mules broke down to-day, and was taken out of the team. Others showed signs of great exhaustion, from the heaviness of the road and the long march.

July 21st. It having rained most of the night, and every thing being wet, we were unable to leave before nine o'clock. After journeying over a muddy road for nine miles, we reached Tubac, another presidio or garrison, consisting of a collection of dilapidated buildings and huts, about half of which were tenantless, and an equally ruinous church. Captain Gomez, who com- 
manded at Fronteras, at the time of my visit there with Colonel Craig in May, 1851, was in command here, and came out to meet us as we passed through the plaza.

To our infinite astonishment and regret, we learned that Señorita Inez Gonzales, the Mexican girl whom we had liberated from captivity, and restored to her parents at Santa Cruz in September, was living at this place with the officer just named. Captain G. himself, although acquainted with all the circumstances of her restoration, did not mention her name to me; but having been informed of the fact from others, I asked him if she was at his quarters. He replied that she was, but was quite ill, and furthermore that she was about to return with her mother to Santa Cruz. On telling him that I must see her, he invited me into his house, whither I was accompanied by several gentlemen of the Commission. The poor girl seemed very glad to see us. She was not ill, but evidently felt under some restraint, as the Captain remained during the interview. She seemed very sad and unhappy; and when asked if she would accompany us back to the States, as we had before invited her, she knew nọt what to say, and, fearing to give offence to her new captor, looked to him for a reply. The interview was a very unsatisfactory one, and we were all quite reluctant to leave her in such a position; but Captain Gomez assured us she would return home with her mother, who was then in Tubac. The next day we accordingly took. leave, expecting that the party she accompanied would overtake us.

In a book of travels in a strange country, one is 
expected to describe every town he visits; but as for this God-forsaken place, when I have said that it contains a few dilapidated buildings, and an old church, with a miserable population, I have said about all. It was established as a presidio almost a century and a half ago, and usually maintained a population of four hundred souls. It was abandoned a year before our arrival, but had since been repopulated, and might have comprised at the time of our visit a hundred souls. The bottom-lands near it, along the Santa Cruz River, are quite rich, and can be made to produce the same grain, fruit, and vegetables as at Tucson. At the rancho of Calabasa, in the same district, is a gold mine which was once productive, but the fear of the Apaches led to its abandonment.

As an example of the uncertainty of crops from artificial irrigation in this country, I will mention a circumstance which occurred at Tubac.

The preceding fall, after the place had been again occupied, a party of Mormons in passing through on their way to California was induced to stop there by the representations of the Comandante. He offered. them lands in the rich valley, where acequias were already dug, if they would remain and cultivate it; assuring them that they would find a ready market for all the corn, wheat, and vegetables they could raise, from the troops and from passing emigrants. The offer was so good, and the prospects so flattering, that they consented to remain. They therefore set to work, and ploughed and sowed their lands, in which they expended all their means, anticipating an abundant harvest. But the spring and summer came without 
rain: the river "dried up; their fields could not be irrigated; and their labor, time, and money were lost. They abandoned the place, and, although reduced to the greatest extremities, succeeded in reaching Santa Isabel, in California, where we fell in with them.

We had got but a mile from Tubac, when one of the wagons broke down and became a total wreck. We were travelling on level ground at the time, and the accident was wholly unexpected. On examination, it was found that the rim and spokes of one of the wheels had become loose, and giving way simultaneously, the wheel was crushed. This let the axletree down with such force as to break off the end. A new fore-wheel and axle-tree were now necessary, together with some blacksmith's work, without which the wagon would be useless. I accordingly sent to Captain Gomez, to learn if he could render us any aid; but to my regret he sent me word that there was not a mechanic in the town, nor tools of any description. As there was no prospect of moving further until some change was made in our transportation, and perhaps some articles left, I gave orders to pitch the tents and turn out the mules, there being plenty of grass and wood near, with the Santa Cruz River, now full of water, within a hundred yards of us.

In the midst of our dilemma, and while we were pondering what to do, a train of some twelve or fifteen emigrant wagons hove in sight, and in a few minutes reached our camp. It was a pleasant event to meet a party from home once more; although they had no news to tell us, as they had left their homes in Arkansas in May, and had now been nearly three months on voL. II. -20 
their journey. The party consisted of forty persons, including men and women. Their wagons were all drawn by oxen, six of which were attached to each. As before, the chief inquiries were about the state of the road, the grass and water, and lastly the Indians. We learnt from them that there had been abundant rains on their route, and that the grass was excellent, and water abundant. This was cheering news to us, and better than we could give in return.

On conversing with the leader of the party, I found him disposed to sell one of his wagons; and after some parleying we agreed upon the terms, which were two hundred dollars. The bargain was no sooner made than the wagon was empted of its contents, consisting of baggage and old furniture, and was taken possession of by us. It was a large, strong, and well made wagon, and bore the name of "ark," painted upon its side in large letters. It required some changes to adapt it to mules, which we at once set about making. In the mean time Mr. Leroux went to the town to try and sell the broken wagon, which only lacked an axle and wheel to-be as good as ever. But the people knew that we must leave it behind us, and they declined to take it at any price. We accordingly stripped it of its tongue, coupling-pole, hounds, iron bolts, and nuts, broke up one of the wheels for tent-pins, and abandoned the remainder.

July $22 d$. We did not get the "ark" ready until noon, when we resumed our journey. The weather was now so moderate that we could travel during the day, which was a great relief to us. The road was good during this day's journey, and the new wheel 
behaved very well. The valley continued about half a mile wide, thickly covered ${ }^{*}$ with mezquit trees of a large size. The bottom-lands resembled meadows, being covered with luxuriant grass, and but few trees. The immediate banks of the river, which is here as diminutive as near Tucson, are lined with cottonwood trees of a gigantic size, resembling our largest elms. In some places there are large groves of these trees, rendering this part of the valley the most picturesque and beautiful we had seen. At four o'clock, we reached one of these groves on the river's bank, where we encamped.

A mile before reaching camp, we passed the ruins of a large rancho known as Calabasa; for every large rancho or hacienda has its name and place on the map. Even after the establishment has been abandoned, and its walls have crumbled to the ground, the name remains. This custom is prevalent throughout northern Mexico. Along the valley of the Rio Grande and in New Mexico are a host of names on the map applied to ranchos, and sometimes to places where neither villages nor ranchos now exist. The same may be said of Sonora and Chihuahua, and where there were no settlements locations were given. A stranger on looking at one of these maps would imagine the country thickly settled, whereas there might not be a village, rancho, or even a single inhabitant, where he is treated to a long list of names, including half the saints in the calendar, all the apostles, and the Holy Lady of Guadalupe into the bargain.

This Calabasa, I was told by Leroux, was a thriving establishment when he visited it twenty years ago. 
A large tract of land was then under cultivation, and herds of cattle were reared on the adjacent hills. But the stream did not furnish a sufficient quantity of water to irrigate it, without cutting off entirely the towns of Tubac and Tucson; and consequently it was abandoned. This is the difficulty with these small watercourses; for having few or no tributaries to keep up the supply, as our northern streams have, and frequently running a course of several hundred miles before they terminate, their water cannot be drawn off without destroying the crops below them, and even depriving the people and animals of water to drink.

I ascended one of the low hills here, about two hundred feet in height, which approached within one hundred and fifty yards of the river. This range crosses the stream, and runs far to the south on the western side. From these hills the plateau extends some ten or fiften miles on both sides, when it strikes the mountain ranges. On the east is the mountain called Santa Rita, the highest within a hundred miles: in fact it is higher than any we had passed since leaving the Gila; and on its opposite side, where I was in September last, there is none of so great an altitude for one hundred and fifty miles. From the point where I stood, I could see the mountain at the base of which my party was lost last year in trying to reach Santa Cruz, This place was directly east of us, about twelve or fifteen miles distant.

During our journey to-day, some five or six miles back, I noticed the ruins of Tumacacori. Its beautiful and picturesque church showed finely among the thick grove of trees by which it is inclosed. The 
church is a mile from the road; and supposing that we should pass it, I made no inquiries, but kept on, until I got too far to return. It seems that there was a path leading to it, which Mr. Pratt and some of the horsemen took, but which I did not observe. Mr. P. took a sketch of it. Tumacacori was formerly a mission of note. It was connected with the presidio of Tubac, and had been lately abandoned in consequence of the incursions of the Apaches.

- Passed to-day two parties of emigrants on their way to California. They each had from twelve to fifteen wagons, all drawn by oxen, and were from the State of Arkansas. Numerous questions were asked, as on former occasions, about grass, water, and the Indians. We learnt from these people that there were many parties of emigrants behind, and that we should probably fall in with them every day. The emigrants from Arkansas and Texas all take the southern route, by way of El Paso; while those from the more northern States go by way of Independence and the Great Salt Lake.

A party of Mexican soldiers from Tueson overtook and passed us after we had encamped, carrying in a palanquin their Colonel, who was ill with a fever. As there was no medical attendant at the place, they were taking him to Arispe.

Soon after, a second party of soldiers stopped and encamped near us, probably for the sake of security against the Apaches; for they feel perfectly safe when under the wing of a party of well-armed Americans. This valley is a favorite haunt of these freebooters; and although we saw none, there is no doubt but they 
both saw and followed us. They keep to the hills near by, where they can overlook the road, and are sure to pounce upon any small and unprotected party of travellers; for not a week passes without depredations and murders.

July $23 d$. The valley to-day was more contracted, owing to the proximity of the hills, which in many cases reached the stream, compelling us to cross them. The country grew more picturesque and diversified, exhibiting alternate valleys and gentle hills. In the former were groups of large walnut-trees, whose deep green fóliage presented a striking contrast with the lighter and yellowish hue of the cotton-woods, and the brighter green of the willows. The intermediate spaces between the hills and the stream exhibited a luxuriant growth of grass. But it must be remembered that the enchanting aspect which every thing now wore in this valley does not continue. It was the rainy season, when vegetation presents its most attractive garb. In a few weeks the daily showers would cease, and the parching sun would dry up every thing but the cacti, which do not seem to be benefited by rain, and the large trees of the valley, which find moisture enough in the earth to sustain them until the rainy season again comes round. The grass then withers and dies, and the stream furnishes barely water enough to supply the immediate wants of the people.

Passed a party of emigrants with nine wagons, each drawn by ten oxen. The men were hardy and good-looking, being just such as are wanted in California. This train, as well as the others we had met, 
had more oxen than were required to draw the wagons; but the owners were taking them to market as beef cattle, and found it much easier to yoke them to their wagons than to drive them loose. Some of these wagons drawn by five yoke of cattle did not contain more than five hundred pounds weight, while the capacity of the team would suffice for five or six thousand pounds.

At three o'clock, we encamped in a fine grove of trees near the river, having travelled twenty miles. A heavy rain set in just before we stopped, attended with thunder and lightning.

July 24th. Got an early start this morning. The valley grew still more contracted; in fact for miles there cannot be said to be any valley, the stream simply winding its way among the hills. Eight miles brought us to the old rancho of San Lazaro, where we found an encampment of fifty or sixty emigrants from Arkansas, bound for the land of gold.

Before these people knew who we were, they expressed much surprise at seeing a large and well-organized party going eastward; some exclaiming, when they saw we were Americans, "Holloa, strangers, haven't you mistaken the road-you're going the wrong way-this is the way to Californy!" Similar expressions were made by almost every party we met; but when they found we had been to California, and could give them some information about it, there was no end to their inquiries. All seemed to have their thoughts upon gold; for they invariably asked whether the yield continued as great as at first, what we thought of its holding out, etc., etc. 
Several of this party were sick, particularly women and children. On hearing this, I stopped to give Dr. Webb an opportunity to visit and prescribe for them. The Doctor had done the same for other parties which we found were unprovided with medicines, or any of the comforts required in their condition. The constant rains they had been exposed to, with no protection but their wagons, had caused much sickness among them; and it was pitiful to see these poor emaciated and suffering creatures lying beneath the trees, resting a day or two, until they could recover strength enough to proceed.

In my former journey through Sonora, we stopped at San Lazaro, a large deserted hacienda, with extensive orchards and fertile grounds around it. Leaving this, we kept along up the stream, over a rough road, for nine miles, and reached Santa Cruz at eleven o'clock. Travelled distance to-day, seventeen miles.

I sent the train and party a mile beyond the village, to encamp where there was plenty of grass, and where the men would be away from the contaminations of a low Mexican population, miserable filthy, and poor as this was.

I called on our old friend, Padre Bernardino Pacheco, and took breakfast with him. He had much to relate to us that had transpired since our last visit. The Apaches, he told us, had made several attacks on the people within half a mile of the town, and had carried off many of their mules and cattle, and murdered five of the inhabitants. The last attack was made two weeks before our arrival, when they were pursued by a party of soldiers, in which a Polish officer 
in the Mexican service was shot by a rifle ball in his arm, from which wound he was then suffering severely. We also learned that the three men who joined us at Santa Isabel, California, and who left us on the desert at the time Colonel Craig was killed, had reached here about the time of the affray with the Indians. They took part in it, and one of them received a wound.

After a couple of hours spent in the town, I rode forward to our camp, where the tents and wagons had been arranged in a square, for the better protection of the men and animals in case of an attack from the Indians, who, we were told, were constantly prowling about the neighborhood, and watching an opportunity to surprise any party whom they thought unprepared, or to run off any animals not sufficiently guarded. 


\section{CHAPTER XXXIV.}

\section{SANTA CRUZ TO THE PRESIDIO OF JANOS.}

Shoeing mules and repairing wagons at Santa Cruz-Standing guardSad fate of Inez Gonzales-Sickness of the town-Boldness of the Apaches and their constant inroads-Wretched state of the people-Leave Santa Cruz-Country assumes a new aspect-Rio San Pedro-Enter the mountains-Agua Prieta-Prepare for a fight-False alarm-Meet Col. Garcia with Mexican troops-Enter Guadalupe Pass-Wagon upset -Description of the country-A better route suggested-Take the Janos road-More emigrants, and their encounter with a bear-Two human bodies found-Open country-Reach Janos.

July 25th. At Santa Cruz. Since leaving Fort Yuma, we had had no opportunity to complete the repairs on the wagons, some of which were much injured and had been temporarily patched up with raw hide or otherwise. Besides the iron work to be done on these, many of the mules required shoeing. "It was necessary, therefore, that this work should be done here, as we should have no other opportunity until we reached the frontier towns of Janos or Carrelitos in the State of Chihuahua, still nearly two hundred and fifty miles distant. The Guadalupe Pass, which we had twice been through, and with whose difficulties we were well acquainted, was yet before us, besides some very rocky mountain ridges. I therefore deemed it advisa- 
ble to shoe the fore feet of all the team mules, leaving the pack and riding mules, with few exceptions, to go as they were. It would have been well to shoe them all; but the difficulties in the way of getting any thing done compelled me to dispense with such work as was not absolutely necessary.

There was a blacksmith's shop in the village, a bellows, and an anvil, but very indifferent tools. Then there was no charcoal, and no shoes or nails. The first step, therefore, was to send three or four men with pack-mules to the mountains for wood, and several others to guard them, and prevent a surprise by the Apaches. This obtained, we had to burn it into charcoal; and then three of our most ingenious men were dispatched to the blacksmith's shop, to assist in forging the shoes and nails, and in shoeing the animals.

I took my turn last night, for the second time, in that most disagreeable of all our duties, standing guard. The arrangements which we made before starting from the Pimo villages, where our escort left us, were, that two of the men should stand guard for two hours, commencing at 8 o'clock, and that this guard should be relieved every two hours until the camp was called in the morning, and the mules turned out to feed. But I was unwilling to trust to all the men, fearing that due diligence would not be observed. The officers therefore agreed, without exception, to take their turn; one to stand every night till 12 o'clock, and another from that hour till the morning. This was an arduous duty; but our safety absolutely required it. To rise before day and travel until three or four o'clock in the afternoon, and then stand guard half the night, was a 
duty that we all felt severely, and each dreaded the night when his turn came. Last night was a very bad one, in fact, the worst we had experienced during our journey (the march across the Tucson desert always excepted), as it was exceedingly dark, and the rain came down in torrents. I kept a light burning in my tent the whole night, and made my rounds with a lantern. The strict watch kept by us during the march, no doubt saved us from robbery; and, if there had been nothing to fear from the Indians, it was a safeguard against the Mexicans, who are as great thieves as the Apaches. We had suffered much from theft in our last visit to Santa Cruz, and took good care that this pilfering should not be repeated.

In the afternoon I called on Padre Pacheco with Dr. Webb, to make inquiries about Inez Gonzales. The result was very. unsatisfactory. He manifested an interest in the welfare of the poor child, but said that he had no control over her or her family, and that his influence or exertions would avail nothing against the plans or the doings of the military officers. Their power was supreme, particularly in an outpost like this. From all the information I could gather from the Padre, it was evident that unfair means had been resorted to by Captain Gomez; first, in getting her away from her home under some pretence, and secondly, in depriving her of her liberty, and preventing her return with her mother to Santa Cruz. I have not before observed that the mother overtook us the day after leaving Tubac, and accompanied our train to her now desolate home.

Believing that Governor Cubillas of Sonora, a gen- 
tleman of high character and fine feelings, with whom I became acquainted at Ures, would interest himself for his young countrywoman, I addressed him a letter at length, requesting his interference on her behalf.

Dr. Webb was called upon to-day to visit many sick families-also the Polish officer who had been wounded in the fight with the Apaches, and Captain Murphy, the officer in command at this place. The town appeared to be very sickly, fevers being the prevailing form of disease. Of the troops here, which numbered a hundred men, thirty were disabled by illness. The prevalence of fevers arises from the proximity of a large marsh between here and San Lazaro.

In walking into town, I met parties of the inhabitants promenading. The women were neatly dressed, mostly in white, with dark rebosos over their heads; while the men who accompanied them were armed with muskets or lances, without which they never venture beyond the walls. Even at the distance of our camp, which was within a mile of the town, our visitors were invariably armed. So with those immediately under the walls tending cattle, or in the fields ploughing, all had their fire-arms at hand. Such is the state of things in this place. Of course, agriculture is neglected, and the people, being confined to that portion of the valley near the town, are able to raise barely enough for their own subsistence.

On one occasion last winter, a party of Apaches actually entered the town during the day, and drove off a number of mules. These robbers were within gun-shot of the garrison, from which they were perceived by a sentinel. Yet such was the terror they 
inspired, that no attempts were made, either by the military or the inhabitants, to repel them or rescue the animals. Outside the walls were a number of cattle. These the robbers did not think proper to take, as they could not keep up with the mules. They therefore lanced them where they stood; and their bleached bones still remain under the walls, within a stone's throw of the dwellings, as testimonials of Mexican cowardice.

I cannot conceive what object there is in supporting this miserable population of less than two hundred souls, in an outpost where they are liable to the constant attacks and depredations of savages. The adjacent valley is not occupied, although one of the finest in the State. Better would it be for the government to take the whole population, not only of Santa Cruz, but also of Tubac and Tucson, remove them to the central parts of the State, and provide them with other land of equal value. As there are tracts equally good which are at present unoccupied, the government would be savers by this arrangement. The expense of maintaining a battalion of five hundred troops in this quarter for two years, is greater than would be the cost of removing the whole population in question. If this is not practicable, then the government should encourage emigration to these valleys, and enable the people to protect themselves. It is quite possible, and I think it probable, that the town of Santa Cruz will be eventually abandoned by the present miserable remains of its inhabitants; they will be compelled to this step to save themselves from starvation, or from being finally cut off by their more brave and warlike enemies. July 26th. This day our teamsters and arrieros 
took advantage of our delay here, to get drunk, and make a serious disturbance in the village. The authorities preferred a complaint against Jesus Lopez, a Mexican in the employ of the Commission, for ill treatment of a respectable woman, into whose house he unceremoniously entered and then beat her severely. They asked if I would punish him, or would allow them to do so. I sent word, in reply, that while we were in Mexico, we were amenable to its laws-that this man knew them, and if he had transgressed them, he must suffer the consequences. I afterwards heard that he was fined and imprisoned. He was the same man who killed the Apache at the Copper Mines, and had given me trouble at every settlement where we had stopped. I was therefore glad to get rid of him, and found no difficulty in filling his place. In fact, had I permitted them, half the population would have availed themselves of the opportunity that presented, to get away, it mattered not where to.

One of Lieut. Whipple's teamsters also got drunk here, drew his pistol on the Padre, and abused several others. This man was likewise imprisoned, but was liberated at the Lieutenant's request. To keep the men in camp was impossible. They would creep out at night; and if sent to the village on an errand, they would get drunk and kick up a row. Yet some of these very men were the best and most reliable in my employ, when on the march, and away from the contaminations of a low Mexican town.

The shoeing progressed slowly, it taking longer to make a nail than an American blacksmith would require to shoe an animal. 
Padre Pacheco and another gentleman dined with me to-day. They came armed with swords and pistols ; and I afterwards perceived that a deputation from the village, a portion of the good pastor's flock, fearful that he might be harmed, had followed him with their muskets, and waited outside my tent until he should return. The Padre brought me a bottle of wine, and another of excellent vinegar, which was very acceptable, together with a few vegetables; in return for which, we gave him a few articles that he could not obtain here.

Dr. Webb was engaged the whole day in gratuitously attending upon the sick. In the afternoon, a heavy rain set in.

July 27th. A large party of emigrants from Arkansas, via El Paso, arrived just before night, and encamped near us. They had twenty wagons, each drawn by five yoke of oxen. Soon after their arrival, they applied to me for flour. I told them I had barely sufficient to take us to El Paso, and directed them to apply to a mill in the town where it was for sale. I heard afterwards that they made a demand on the Padre for provisions; and that they treated him rudely, sitting down without ceremony in the little piazza at his door, where they commenced playing cards with each other, and annoyed him exceedingly by their boisterous manner and insolence.

July 28 th. Our repairs and shoeing being completed, we resumed our journey early this morning. Many of the inhabitants earnestly begged to be employed or to be permitted to accompany us, offering to aid us in any way in their power, without compensation. Feeling 
pity for the poor creatures, I told several that they might accompany the train, if they would furnish their own provisions and transportation. Four of them followed us on foot; and I afterwards found that the Mexican arrieros, and the cooks, kept them at work when in camp in bringing wood and water, as well as in herding the mules, and gave them their food for so doing.

- Hearing from the emigrants who arrived last evening, that the road taken by them from the San Pedro river was very bad for loaded wagons, I determined to avoid it by following a path little known, which was some ten miles further. Instead, therefore, of passing directly over the hills on leaving the valley, we kept on three miles to the termination of these hills, and then took an easterly, though very tortuous course, keeping most of the way in valleys, and avoiding the mountains altogether. As we passed out of the valley, I observed a long train of wagons winding over the hills on the other road, accompanied by many horsemen. This was an emigrating party, which we had been told we should meet; but we were not near enough to speak with them.

After winding through these valleys for four miles, we ascended to the plateau, to which we kept for six or eight miles over a smooth gravelly plain, without a tree or a bush. The valleys below were studded with small oaks, and covered with luxuriant grass; in fact, I was told at Santa Cruz, that in former years large herds of cattle were raised here. The country seems admirably adapted for the purpose, and in other hands, or when the Apache robbers are exterminated, will voL. II, -21 
again become a grazing country. Not a head was now to be seen; nor is there another settlement, a single habitation, or a spot of cultivated ground between Santa Cruz and Janos in the direction we were travelling. At two o'clock the rain began to fall in torrents; and soon after, seeing a small basin of water near a grove of large walnut trees, we stopped and encamped, having travelled fifteen miles.

This was the first day, since leaving the valleys of California, that we had met with oak groves and broad pastures. The whole country here assumed a new aspect, resembling the hills and valleys of Vermont or New Hampshire, rather than Mexico. Involuntarily we looked at the turn of every hill, as we wound through the valleys, to meet with farm houses, cultivated fields, herds of cattle, and an agricultural population; but all was silent as the grave. An occasional wolf sneaked across our path, or a herd of antelope bounded over the plain, reminding us that we were far from all human habitations.

July 29th. The road or path we travelled yesterday was very faint, and could no longer be traced. Our only course, therefore, was to follow the valley, which we knew must lead to the San Pedro. After keeping along it for three or four miles, Leroux set off over the hills, to see if he could find any trail. He at length found one, which he recommended us to take; as following the valley might lead us to some cañon, and thus involve us in difficulties. We therefore altered our course from east to south, which we kept for four miles, and then entered the old road. Near this, we met two suspicious looking characters with guns, 
an unusual event in these regions. We first discovered them at a distance, and on applying our spy-glasses, were still more puzzled, as they resembled Americans. On coming up, they proved to belong to a party of emigrants ahead, which they had left some hours before in search of deer or other game. They seemed as much surprised as ourselves at the meeting, and had many questions to ask. Their party was short of provisions, about which they felt more anxiety than about the state of the road or the grass.

After striking the road, our course was again due east through a fine valley watered by a small stream; the western tributary or source of the San Pedro. We followed this valley for about six miles, and met a train of twenty or twenty-five ox-teams, with emigrants for California. We stopped a few minutes to exchange news with them, as well as to ask sundry questions about the state of the road, grass, water, and Indians; the result of which was more satisfactory to us than to them.

On the south side of the valley we were traversing, were bold rocky cliffs, about a hundred feet high; while on the opposite side, it was bounded by low hills of gravel. The valley was covered with grass, but not a tree or shrub was visible. We crossed the stream over a rocky ledge, where there was but a few inches of water. Shortly before reaching it, we passed on our right the ruins of a village, which appeared to have been long deserted. Amid these ruins, on the summit of a hill, there seemed to have been a fortification. We encamped directly by the crossing near the base of a hill, where there were traces of previous 
encampments. We estimated the distance travelled to-day at fourteen miles, making altogether, by the route we had come, twenty-nine miles from Santa Cruz; while the usually travelled road does not exceed eighteen. Yet I would advise all travellers with wagons to turn to the right after crossing the San Pedro, and take our route, thereby avoiding one of the worst mountain passes in the whole distance to California. With pack-mules, the shorter route should of course have the preference.

July 30th. Passing round the base of the hill near our camp, we ascended the plateau, and then pursued a course due east, over a plain as level as a floor, and without a tree or shrub, covered with short grass that had sprung up since the rains. Five miles further, we again descended into a valley or bottom, through which ran a small stream, where we met another party of emigrants. After keeping the bottom for five miles, we reached a swampy place, caused by a recent accumulation of waters from the heavy rains. In the midst of this was a stream, or rather, I think, a gully, filled with water, which was running very rapidly. It was from two to three feet deep, and full of deeper holes, so that even the horsemen met with some difficulty in crossing. Fearing that we should break the tongues of our wagons in plunging down so abrupt and short a bank, the picks and spades were got out and both banks cut down; we then all got over in safety.

Crossing this boggy plain, our course continued eastward, through a bottom, for about six miles, the plateau bounding the valley on both sides. In the afternoon we began to ascend gradually through the 
same valley, and at half-past three encamped near a stream, where the water merely stood in holes. It was very good, though, from appearance, not permanent. Near us was a large cotton-wood tree, the only one to be seen; so that it was with difficulty we could find scraps of wood enough to cook our dinner.

From our camp we could see the mountain near Santa Cruz bearing due west. The rain set in before night, and continued several hours; and as we were in a very exposed situation, it was necessary to put extra fastenings to the tents. Distance travelled to-day, fifteen miles.

July 31st. Every thing was drenched with rain, which prevented an early start. We still kept due east, through an open defile in a mountain range, which ran north and south, with an easy and gradual ascent. On both sides were conical hills from three to four hundred feet in height, detached from the adjacent mountains, and destitute of trees and shrubbery. In fact, scarcely a tree or bush had been seen since we left the vicinity of Santa Cruz. As the country continued bare to day, the men picked up every fragment of wood or brush we passed, and threw it into the wagons. It would be prudent for all parties travelling this country to provide themselves with wood whenever an opportunity offers, and always keep on hand a supply for three days. We were told by all the emigrants we had passed, that their greatest difficulty had been to procure fuel; and they cautioned us to secure it when we could, and not wait until we encamped.

At two o'clock the rain began to fall; but as there 
was no water to be seen, we were reluctantly compelled to keep on until near night, when we reached a stream, called by Leroux "Ash Creek," where we encamped. He said it was the same place where Colonel Cooke stopped with his battalion in 1846, and from which several parties were sent out in search of water, as it was then dry. The stream is so called from the ash trees which grew near it, but which have now nearly disappeared, It is the toughest and best wood for repairing wagons; and passing trains have stopped here to cut new tongues, and make other repairs. Distance travelled, twenty miles.

August 1st. Our general course was still east, through defiles in the mountain's ridge we were then crossing, for about four miles, when we emerged into an open plain from twenty-five to thirty miles across. Keeping the same direction, slightly descending for nine miles, through a level plain covered with mezquit chapporal, we reached Agua Prieta, or the "Black Water Creek" of Colonel Cooke. My readers will recognise this as the spot were I encamped at the time of my visit to Fronteras in May, 1851, when I was accompanied by Colonel Craig and a small party. It was then dry; but now it was filled with a dark muddy water, whence it derives its name. This, like many other small streams we had lately passed, we now know is not permanent. After heavy rains, it receives the washings of the broad plains, which rise gradually on either side for many miles.

As the next water we expected to find was at San Bernardino, eighteen miles distant, I thought it best to go no further, although it was but, twelve 
o'clock, and we had come not over thirteen miles. But as there was a bright sun, we could not do better than devote the remainder of the day to drying our tents, blankets, saddles, and every thing that had been carried on mules. The packs were therefore overhauled, and their contents, as well as the bedding, spread out to dry. The road to-day had been excellent, as it had for the most part since leaving Santa Cruz.

Towards evening, an-alarm was given by the Mexican arrieros that the Apaches were upon us, and after our mules, then a mile off. All flew to arms; and in two minutes every animal about the camp was saddled, mounted, and off in pursuit, or rather to the aid of our caballada, which we could see approaching at full speed, followed by the herdsmen and arrieros, yelling and screaming at the top of their voices to keep up the stampede. The mules were evidently as much frightened as the Mexicans; and such a state of commotion we had not beheld since we left California. - Far across the plain we could see the supposed enemy approaching on horseback, making directly for the eamp at full speed. Having got my rifle ready and cocked, I drew out my telescope to ascertain the number of the enemy, now about a mile off. To my great relief, I perceived that several were clad in dark coats, and that all wore hats, some of them black. This showed that they were neither Apaches nor Mexicans; for the former do not wear hats at all, and the latter at this season wear white calico shirts, with straw hats. In a few minutes the supposed enemies were with us, and proved to be a party of American 
emigrants in advance of a train of wagons, which our people did not see, or they would have caused no alarm. Perceiving the stampede they had caused, and hearing the yelling of the arrieros, they had hastened. forward to quiet our fears.

This party consisted of thirty-five persons, men, women, and children, with mule-wagons and horses, from Arkansas and Texas. Their wagons had turned off to the left to a spring, where there was better water than in the stream two miles below us. After spending an hour in giving us some interesting, news from our friends at El Paso and on the Rio Grande below that place, they took leave of us and rejoined their party. They had seen a party of forty or more Apaches two days before near the Guadalupe Pass.

August 2d. We moved off at seven; the morning clear and pleasant, and with the satisfaction of having dry tents and clothing once more; for we had escaped the rain last night, probably from being so far from the mountains. Our course was still east, across the plain, to a high conical mountain capped with a rocky bluff. The road was excellent until we reached the base of this mountain, when it became hilly, though not bad. After winding among these hills for three or four miles, we again emerged into a broad plain, in the middle of which stood the ruined hacienda of San Bernardino. We now descended again very gradually over a plain filled with mezquit chapporal, and six or seven miles further brought us to the hacienda. Distance travelled, eighteen miles.

Just as we were entering this plain, we met Colonel Garcia, with a detachment of two hundred Mexi- 
can troops from Tueson, on a campaign against the Apaches. A more miserable set of men I never met, certainly none calling themselves soldiers. Some of them were destitute of shirts, others of pantaloons, and some had neither coats nor hats. Some wore overcoats, without a rag of clothing beneath. They had seen no Indians, as might be expected, although forty were observed here the day before. In all probability the wily enemy had perceived them, and would follow them, in the hope of stealing some of their animals, and piercing some of them with a lance or an arrow.

These campaigns against the Indians are utterly useless, nor can they be attended with success. During the last two years that the Mexicans have been operating against them on this frontier, not fifty have been killed. The Indians are too cunning to risk an open fight, even with such antagonists. Their mode of warfure is by stratagem, and they must be encountered with their own weapons.

August $3 d$. We kept on our easterly course towards the Guadalupe Mountains. Met a train of oxteams with emigrants from Arkansas, and soon after entered the famous cañon, where there was an abundance of water and grass. In passing a small ravine, one of the wagons upset, discharging its contents upon a poor Mexican who happened to be seated inside, because too ill to sit upon his mule. Dr. Webb was sent for, but found the man not seriously injured. Fortunately the wagon was not broken; so that after a little delay all was made right again, and the train continued through the defile until three o'clock, when we stopped and pitched our tents where the road 
takes a sudden turn, and leads over the mountains, through the much-dreaded Guadalupe Pass. I noticed near this spot traces of a large encampment, which Leroux said was one of Colonel Cooke's in 1846.

August 4th. We commenced the ascent of the mountain immediately after leaving camp; and the animals being fresh, we reached the summit of the first hills with ease. I took my rifle and set off on foot, keeping near the train, as it would have been imprudent for the party to scatter in such a place. The descent of the first hill was difficult, being full of short turns, rocky and very steep. About half way down, we took the mules out of my wagon, and let it down by hand, the driver taking the pole, while four of us held it back until it reached the bottom. The baggage and subsistence wagons were got down in safety by attaching ropes behind and to one, side, to which ten or a dozen men held on, thus preventing them from upsetting or making a too sudden descent. The only vehicle that met with an accident was that containing Lieutenant Whipple's valuable instruments. Although more pains were taken with it than with any other, it was upset, and its contents thrown out, but happily without any damage either to the instruments or the wagon.

The worst is a chalky hill, near the last in the pass: It is exceedingly smooth and steep, with short and very abrupt turns, so as to render it impossible to double a team, or even hitch six mules together to advantage. To ascend this place with loaded wagons, is impossible. I sent Leroux off in the morning in advance with the pack-mules, directing him to pass all 
the hills, then discharge his loads, and return and meet me at the base of the chalky hill mentioned. I found him there on my arrival; and we set to work at once to discharge the wagons. This being done, the contents were put upon the backs of the mules, which were sent ahead again to deposit their loads. We then took hold of the wagons; and by alternately pushing them and chocking the wheels, the mules got them up this formidable ascent with comparative ease. While this was going on I took a sketch of the pass, which will convey a better idea than a written description. It will be found in the first volume.

On the summit of the hill we met a train of wagons with forty persons bound for California. They were a substantial hardy looking set of people, and had been four months on their journey from Arkansas.

A magnificent view of the country in every direction is obtained from this spot. On looking back the way we had come, the whole pass with its defiles and mountains, its forests of oaks and pines, its deep gorges and grassy valleys, lay before us; while in the very centre, protruded a huge pile of rocks of a light green and whitish color, presenting a pleasing contrast with the rich hue of the foliage around. Some of the hills were covered with grass, and others were dotted with clumps of cedars, although small live and post oaks predominated. Beyond the pass could be seen the high conical mountain beyond San Bernardino; and in the dim distance, an elevated chain near the San Pedro River, at the base of which we passed. The perspective of these receding mountains, the furthest more than a hundred miles distant, was exceedingly beautiful. 
Before one o'clock we had passed all the hills; when the wagons were reloaded, the mules packed, and we continued our journey. I here turned off and took the old Janos road, believing it to furnish a shorter route to El Paso than that by the Copper Mines, which we took in our journey into Sonora last year; besides I was desirous of varying my course, and examining the country further south. This road has been travelled for nearly two centuries, or since the first settlement of the country. It is the only route practicable for wagons between Chihuahua and Sonora, and was only made so by Colonel Cooke. Nor is there any other for pack-mules, except one a short distance to the south leading from Correlitos to Babispe. Further south the great Sierra Madre is impassable for more than five hundred miles.

When Colonel Cooke set out from Santa Fé for California, he came down the Rio Grande to the present ford at San Diego, and thence to Ojo de Vaca. His most direct course would then have been west across the unexplored region lying between that place and the San Pedro; but as his guide, Leroux, knew nothing of that country, he deemed it prudent, when so many lives were dependent on him, to follow a route with which he was acquainted. Accordingly he led them in a south-westerly course to the Guadalupe Pass, through which he knew there was a trail from Janos. In reaching this he had to pass over a district of fiftytwo miles to Las Playas without water, in which his men suffered severely from thirst; and on reaching the pass, he was obliged to cut a road for his wagons, as wheeled vehicles had never before gone that way. 
Emigrating parties, and all others, are much indebted to this gallant officer for opening this road, which otherwise would have remained in its ancient condition to the present day. But with all the labor that has been or may hereafter be bestowed upon it, it can never become the great thoroughfare for emigrants to California. The mountain pass must always remain an impediment. The long tract from Ojo de Vaca to the Playas without water, is another; and the Guadalupe Pass presents the same diffieulty in the dry season. A fourth objection is the distance, which is fully a hundred miles greater than a course nearly west from Ojo de Vaca, coming out near Tucson.

The latter route was taken by the Commission last year, and the longest stretch without water was less than forty miles. Our government should send out a party to make explorations within our line of boundary; when, I doubt not, a route would be discovered which would shorten the distance at least one hundred and fifty miles, besides furnishing wood, water, and grass in abundance. It is desirable, too, that we should have a road as far as possible within our own territory, and not pass, as at present, the whole distance from El Paso to the Colorado through that of Mexico.

The summit which we had now attained, by a tortuous ascent of from ten to fifteen hundred feet in fifteen miles, is the level of the great central plateau. A broad plain here opens to the view eastward and southward, extending far and wide, with short detached ridges of mountains, running generally from north-west to southeast. Our course was south-east, to a range of mountains whose direction is east and west, fifteen miles dis- 
tant. This great plain is lost in the horizon at the north-east, there being no mountains in sight; in a south-westerly direction, the Guadalupe range is seen some fifty miles distant, verging eastward, until it unites with the great chain of the Cordilleras.

Our course lay towards a portion of the mountains where I presumed the pass to be. The plain was perfectly level and the road excellent, without a stone, a tree, or a bush. When we had reached its centre, where there was a slight depression, we found that the drainage of the adjacent slopes had made it so miry as to be impassable by the direct road. We therefore diverged to the right, keeping on higher ground, and got safely across. At 3 o'clock it commenced raining, with the wind from the south-west, when we would gladly have stopped; but there was neither wood nor water at hand. We were, therefore, obliged to keep on another hour, when a spring with a small pool of water was discovered at the base of a plateau or terrace which extended about three miles from the mountains. Here we encamped. Estimated distance travelled, eighteen miles, including the Guadalupe Pass. Grass was abundant around us, and some oaks half a mile distant furnished us with fuel.

August 5th. We kept along the terrace for three miles, and then entered a defile which led directly across the lower portion of the mountains. This defile was at first of easy ascent, through groves of small oaks and cedars, and over a carpet of rich verdure. From this the road led directly up a hill, which, though not steep, was a very hard one for the animals, being wholly composed of loose and rolling stones. The poor 
creatures had a severe tug of it; and although I ascended slowly on foot, I reached the summit nearly an hour before all the wagons got up.

Here we found a party of from forty to fifty emigrants with ten ox teams. While waiting for our wagons to come up, we seated ourselves beneath the trees, and entered into conversation with these people, who were quite an intelligent party, both of men and women. The usual inquiries were made of us about the road and the prospects in California. The women were very inquisitive, chiefly as to the difficulties they had yet to encounter. They had already been five months on their journey from Arkansas, and had lost several of their party by death; and one of the men had had a narrow escape from a large brown bear but an hour before, on the hill we were now about to descend. The skin of the animal lay before us, bearing authentic testimony to his immense size.

It seems that as three of the men were scouring the adjoining woods, one of them discovered this bear, and discharged his rifle at him. The bear limped off into an adjacent thicket; the man followed; and as he approached the animal's place of concealment, the infuriated creature sprang from the thicket and seized him. He was of course thrown, when a hard struggle took place for the mastery. The bear bit him severely in the leg; while the man, after a violent effort, succeeded in getting his knife from its sheath, and plunged it into the animal's body. The struggle took place on the brow of a steep hill, and near the brink of a precipice some twenty feet in height. Over this they both fell together, the bear, fortunately, being underneath, 
and striking on his back. This saved the man from injury, and released him from his antagonist's embrace. Lacerated as he was, he arose and prepared to act on the defensive, expecting the bear would again give battle; but the latter, not feeling very comfortable from his wounds and his fall, stood quietly gazing at the man, for some moments, and then leisurely turned around and walked away. The man was not so badly injured as to prevent his walking; and, as soon as the bear was out of sight, he called to his companions, and pointed out the direction taken by the animal. Following the track, they soon discovered him, and dispatched him with a couple of well-directed shots.

We now descended the opposite slope of the mountain, which, though long and tedious, was not precipitous. Reaching the base in safety, we stopped on the banks of a beautiful little stream, which had its source in the mountain. Here it was thought advisable to water the animals and make a noon halt, as it was uncertain whether we should find water again for many miles. After a delay of three hours, which afforded us an opportunity to dine, we resumed our journey, keeping near the stream for three miles, and then striking off into a very broad and level plain from twentyfive to thirty miles across, on which not a tree or a bush was to be seen. Low gravelly hills of a conical form rose from the plain on our left from fifty to two hundred feet in height, covered with grass, but destitute of trees. On our right, about four miles distant, rose a high and isolated mountain with bold rocky sides. Opposite this we stopped at nine o' clock and encamped without water, having travelled twenty miles. 
August 6 th. We continued our journey across the plain in a direction east south-east. With the exception of a little rise of ten feet, to reach a gravelly platean, the whole plain had been a perfect level since we entered it the day before. It was entirely open on the west, being limited in the far distance by the Guadalupe Mountains, while on the east none were seen.

This great plain, from its position and extent, I think unites with that we crossed on Cooke's road, at the dry lake or "La Playa;" for when there, I noticed that the plain stretched far to the south-west, unlimited by the mountains.

Our attention was arrested to-day by the sight of the remains of two human bodies, but whether of Mexicans or Americans we could not determine. What was left of their clothing consisted of white shirts and narrow white cotton drawers. The latter article is not worn by Mexicans, which led us to suppose the murdered men might have been our countrymen.

In the afternoon we crossed a fine clear stream, thirty to forty feet wide and about two deep, occasionally expanding into ponds twice that depth, and encamped on the opposite bank where there was excellent grass. This stream is a branch of the river which passes Janos and Correlitos, the latter being known both as the San Miguel and as the Casas Grandes River. Like other streams in Mexico, it takes the names of the several towns it passes. In it we caught a sufficient number of trout to give us all a meal. We also collected specimens of unios, which abound here. About a mile to the east, several large adobe houses were seen belonging to an estate which had recently been VoL. 11. -22 
abandoned in consequence of the depredations of the Indians. Distance travelled, twenty miles.

August 7 th. We resumed our journey, keeping along a terrace of gravel about ten feet above the plain. The road continued excellent, as it had been since leaving the Guadalupe Pass. In eight miles we passed around the southern extremity of a hill, from which a gentle descent of a mile brought us to the old Presidio of Janos, the extreme outpost of the State of Chihuahua. 


\section{CHAPTER XXXV.}

JANOS TO CORRELITOS, AND VISIT TO CASAS GRANDES.

Janos, an old military post-Its decline-Aid a party of American emigrants-A Thomsonian doctor-Difficulty in fording the Casas Grandes River-Arrival at Correlitos-Smelting works-Unhealthiness of the people-Barranca Colorada-Visit to the town of Casas Grandes-Extensive ruins-Resemblance to those on the Gila-Fertile valley-The river and its tributaries-Modern town-Return to Correlitos.

IT is so rare an event for trains or travellers to enter Janos from the west, that our approach created quite a sensation among its quiet people. We stopped in the main street as we passed along, and were at once accosted by some. Americans, who advised us to encamp near the river on the opposite side of the town ; which we did, and found good grass near.

Janos is one of the seven presidios or military posts, a line of which was formed along the frontier as early as 1718. The others were Galeana, Carrizal, Norte, Coyome, San Eleazario, and San Carlos. These posts were of great service in subduing the Indians and protecting the inhabitants, and were connected with a greater chain which extended from San Antonio in Texas to San Francisco in California. A direct and constant communication was kept up between these 
posts until the period of the subversion of the Spanish rule. They have since been retained and occupied for the same purpose as before, but have dwindled from respectable garrisons of well disciplined soldiers, to a mere handful of raw militia, as undisciplined as they are wanting in bravery.

In the year 1826, the force in Janos consisted of six commissioned, and ninety non-commissioned officers and privates, and was supported at an annual cost of $\$ 26,894$. It now numbers twenty soldiers; but this force is augmented from time to time by larger bodies of troops, when sent on campaigns against the Indians.* Like every other frontier town which we had visited, whether in this State or in Sonora, its population is diminishing, and its houses falling to decay, in consequence of the inroads of the universal enemy, the Apaches. The present population is but three hundred, and even these dare not venture far beyond the town, but lounge out a miserable existence beneath the shade of the adobe walls, changing their position as the shadows change. The streets have a desolate and forsaken appearance. No one seemed to be at work; and such as were not squatting under the walls were engaged in gambling. The presidio buildings occupied by the military, are in a state of ruin.

Before going to camp, I rode to the quarters of the commanding officer, Colonel Medina, who had extended many civilities to Colonel Craig and a surveying party of the Commission under Mr. John Büll, the preceding year, while reconnoitering the country be-

* Escudero. Noticias Estadisticas de Chihuahua.-p. 56. 


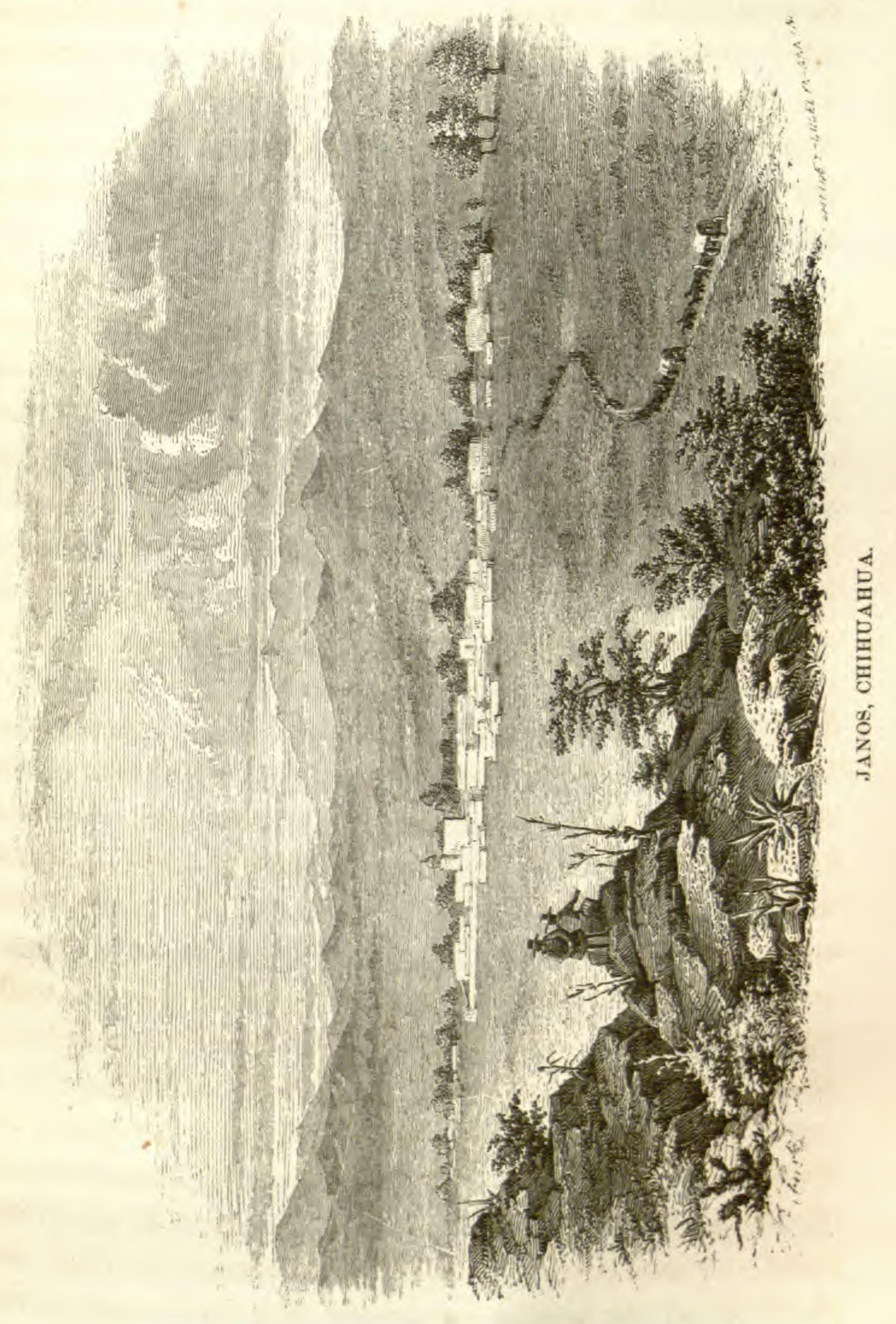



tween El Paso and the Copper Mines. The Colonel, however, was taking his siesta, and I had not the pleasure of seeing him.

We found here seven Americans, who had left one of the emigrating parties a few days previous, in the belief that they could reach California by an easier route and at less expense than by keeping with the rest. Their plan was to go to Ures, Hermosillo, and Guaymas, where they intended to take a vessel for San Francisco. On my representing to them all the difficulties that would attend a journey that way, and the delay they would be likely to meet with at Guaymas, where there might be no vessel leaving for a month, they became convinced of their error, and determined to leave the same evening, and endeavor to overtake their friends. This they could easily do, as they were on horseback, while the party they wished to rejoin were travelling with ox-teams. But they were in trouble about their animals. Two of them, having strayed away, had been recovered by the Mexicans; who refused to deliver them up, on the ground that they belonged to the party which had left. I accordingly addressed a note to Colonel Medina, stating such facts as to satisfy him of the ownership of the animals; whereupon he complied with my request, and ordered the men who held them to deliver them up forthwith.

We found an American "herb," or "Thomsonian" doctor, as they call themselves, here. He had come thus far with some of the emigrating parties for California; but finding no physician either in Janos or in the adjoining town of Correlitos, he had left his party and commenced practice on the spot. He said he had 
in two weeks cleared three hundred dollars. He made his bargains beforehand, as he told us, and had just undertaken the case of a man who was to pay him $\$ 150$ if he gave him relief, and $\$ 300$ if he effected a cure. He seemed quite sanguine of getting the latter sum.

August 8. A horse died last night from the bite of a rattlesnake received three days before. We started this morning, pursuing a course south-east by east across an open and level plain about 12 miles in width, and of a desert-like character, which it assumes immediately after leaving the river. In one instance, I noticed a patch of grama grass half a mile in width, extending across the plain as far as the eye could reach. This desert, or plateau, is but little elevated above the bottom lands of the river, and is composed of a fine gravel. The bottom lands along the San Miguel are fertile, and yield abundant crops of wheat, corn, and the usual products of the country; although, at present, much of this fine soil has been suffered to run waste, on account of the hazard of cultivating it. There was formerly much stock raised here; but so completely have the Indians got possession of the vicinity, that there are not horses and cattle enough left to cultivate the soil.

The road continued excellent, and the train made good progress. On our left I noticed the course of the river winding across the plain, marked by a long line of cotton-woods. Crossing this plain, we passed around the base of some gravelly hills, and then continued in a more easterly direction over a similar plateau for ten miles, which brought us to Correlitos, a town standing on the eastern bank of the San Miguel, or Casas Grandes River, as it is called here. 
On arriving at the river, I found, greatly to my surprise, a large and rapid stream, much swollen by the late rains, and about 100 yards in width. At first we hesitated whether to cross the stream at once, or wait till the following morning; as the people said the water would then be several inches lower, provided there was no more rain. We concluded, however, to attempt it as it was; which was fortunate for us. After some search, a fordable place was found; and notwithstanding the strength of the current, we succeeded with care in getting every thing over in safety. As a general rule, it is best always to cross a stream immediately, so as to encamp on the opposite side; for should there be a fall of rain, or an overflow of the river from other causes, it might be found impassable in the morning, and perhaps continue so for several days. Four mules which had been driven along several days with sore backs and otherwise disabled, being unfit to go further, were abandoned here.

August 9th. As a supply of fresh meat and vegetables was wanted, I determined to remain here a few hours, and after breakfast walked to the town, about a quarter of a mile distant, to see what could be had; for we were yet 160 miles from $\mathrm{El} \mathrm{Paso,} \mathrm{and} \mathrm{could}$ procure nothing after leaving this place. I had sent to the town immediately on our arrival last evening, to engage some cattle or sheep, and was told that they would be in the corral this morning for selection; but when I called, they were still several miles off. Some men were sent after them; and in the mean time, I went to examine some large furnaces, where the silver is extracted from the ore taken from a mine in the vicinity. 
Although these smelting works are a very indifferent and primitive affair, yet they are said to produce a large amount of silver, and to yield to their owner, Señor Zuloaga, a handsome income. The ore is taken from a mountain eighteen miles distant, and brought hither in carts to be smelted. The owner was absent; but the superintendent was very polite to us, taking us through the establishment and pointing out the several processes used in extracting the metal, as well as explaining to us the various qualities of ore.

One of the greatest difficulties which attend the smelting here is the scarcity of firewood. As there are no forests near, the roots of mezquit bushes are almost exclusively used. These roots, it is true, afford excellent fuel; but they are obtained with much labor, and the supply must sooner or later cease, as no more is produced.

Correlitos is a mud-built modern town, containing about four hundred inhabitants, who depend wholly upon the mine and smelting works for their living. There is some fine bottom land near; but little of it is cultivated. At the time of my visit, the streets were filled with mud holes, half full of putrid water, in which swine were wallowing; and the people looked sickly as well as filthy, caused by the strong fumes of arsenic which proceed from the furnaces and are disseminated through the town. These fumes were so powerful, that when the wind blew towards our camp, half a mile distant, they were quite offensive. The superintendent gave me some fine specimens of ore, as well as of the product in its various stages as it undergoes reduction. 
The Apaches, I was informed, had been very bold here of late. Three weeks before our arrival a band of twenty-six had ventured within two miles of the town, where they surprised a party herding mules and cattle. They killed three men, and drove the animals off. These Indians had also, within the same period, run off a large portion of the stock of Mr. Flotte, an American living at Barranca Colorada four miles distant. No attempt at pursuit and recapture had been made.

At 11 o'clock the beeves had not come in, nor the promised regetables; and as it would require an hour or two after the cattle arrived to kill one and distribute the meat, making it too late to leave to-day, I directed the mules, which were already hitched up and ready to move, to be unharnessed and turned out to feed. To make the most of my time, I determined to visit Casas Grandes, a town twenty miles to the south of us, where there were said to be extensive ruins of an aboriginal race. Hastily putting our blankets, firearms, and some provisions into my wagon, Dr. Webb and myself, accompanied by a Mexican servant, set out on our excursion.

I had long known of the existence of these ruins, which are spoken of by various writers on Mexico, and had made frequent inquiries about them, during the winter I spent in El Paso, of old residents there and of persons from the city of Chihuahua, without getting any satisfactory account of them. All said there were some old adobe buildings there in ruins; but whether they belonged to the present or to an earlier race of Indians, they knew not. At any rate, all agreed that they were not worth visiting. 
On reaching Correlitos, I made the same inquiries, but with no better results. When I had come to the conclusion that the ruins, of which so much had been said, must have crumbled away and disappeared, a Mexican who had heard of my incuiries, and who felt some interest in the antiquities of his country, called upon me, and advised me by all means to visit the place, now that I was within so short a distance of it, assuring me that there was much there to repay my curiosity.

Following the river up in a course nearly south, we reached the village of Barranca Colorada, four miles distant, where I stopped to call on $\mathrm{Mr}_{6}$ Lewis Flotte, an American gentleman long resident there, and the owner of a silver mine which is situated in the same mountain with that of Mr. Zuloaga, whose smelting works I visited at Correlitos. Mr. Flotte had gone to Chihuahua; but his mayor-domo received us politely, and showed us through his works, which are more extensive and better arranged than those at Correlitos. He had six furnaces, four of which were in full blast, while the hearths were being replaced on the others preparatory to their being lighted again. The machinery which kept the bellows in motion was propelled by mules. The superintendent took us through the establishment, describing the various processes, and gave us a set of specimens of the ores. We learnt here, as we did at Correlitos, that Mr. Flotte had been badly treated by the owner of the other mine, and that he was about to sell out his estate in consequence.

On my expressing a desire to visit this mine; which 
we should pass on our way to El Paso, the superintendent gave me a note to the mayor-domo at the mine, after which we resumed our journey.

Following the river, which we crossed near Barranca, we kept down the valley about sixteen miles, when we came to a beautiful grove of large cottonwood trees, extending from the river across the bottom to the very bank or edge of the plateau, which here rises from twenty to twenty-five feet above the valley. Passing this grove, we suddenly emerged into a broad and luxuriant valley or bottom, extending as far as the eye could reach towards the south. From the plateau, we could trace the course of the stream by the deep green foliage of the long line of cotton-woods which grow on its banks.

From the point where I stood I noticed, about a mile distant, the ruins of a large building on the verge of the plateau, near which the road passed. As we approached, several others of lesser dimensions were seen, both on the platean and in the bottom near its base. It required but a glance at these buildings to show what they were, the first being a church, with its entire walls standing, together with a portion of its tower. Remains of tombs were also visible; but from the decayed and weather-worn appearance of the walls, the church had long been abandoned. The ruins near were those of haciendas and ranchos, some of them quite extensive; from which I inferred that the town was originally here, though it now stands two miles beyond.

As we entered the town, which bears on account of these ruins the name of Casas Grandes, we attracted 
much attention from its quiet and retired inhabitants, who, in this remote and secluded spot, are seldom disturbed by visitors, save those who come on some errand connected with the church. Casas Grandes is not a place of business, nor is it on any great thoroughfare,

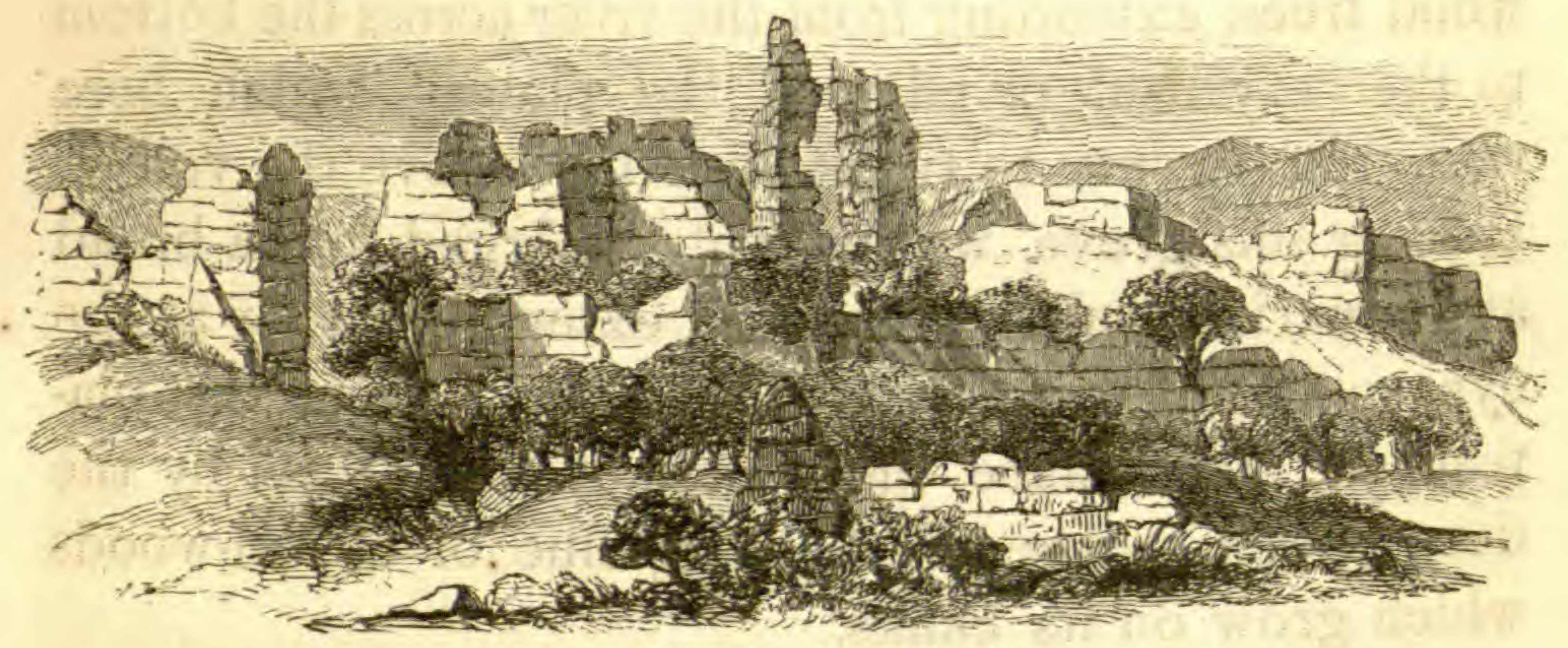

Ruins at Casas Grandes, Chihuahua.

which would enable its citizens to derive advantage from passing travellers. Its whole dependence is upon the rich and luxuriant valley, which is here about two

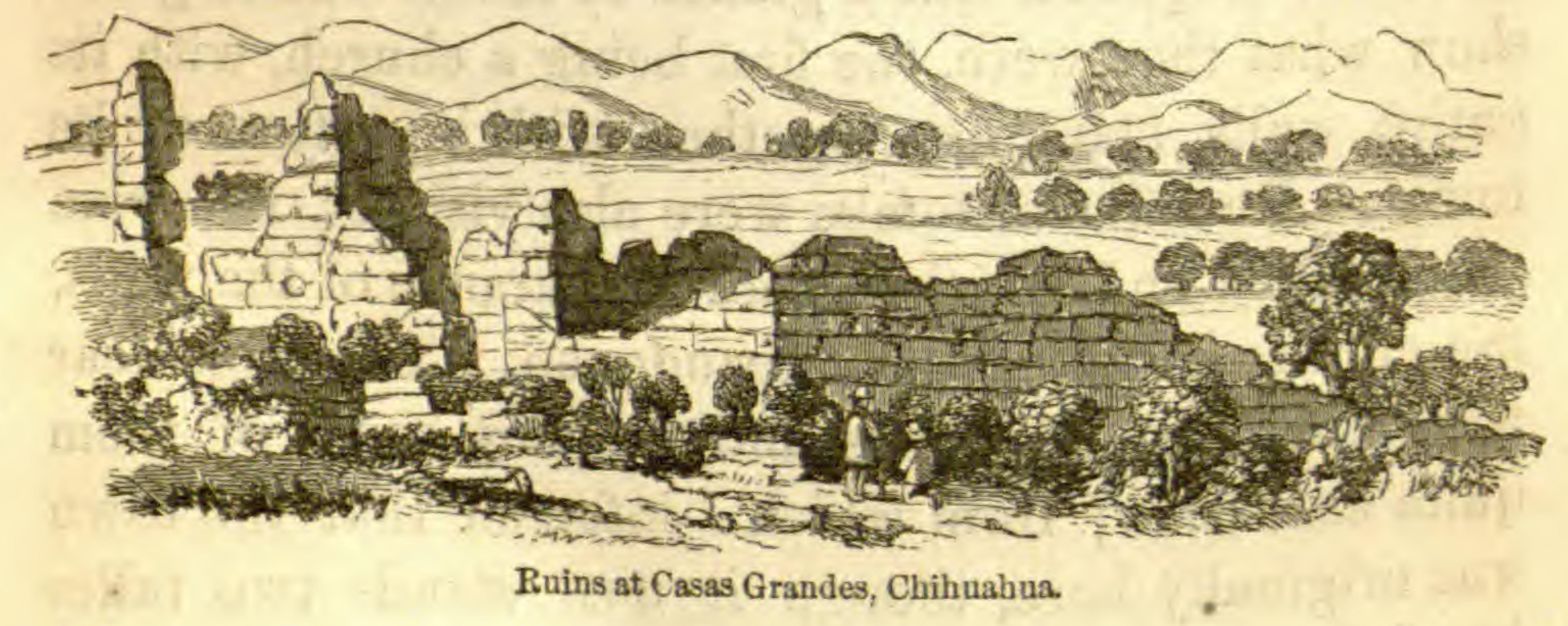

miles wide, and which among Mexicans would be said to be in a high state of cultivation. This, is speaking comparatively; for what in Mexico is considered 
súperior cultivation, would be thought very slovenly tillage in the United States.

I had letters of introduction to two gentlemen living here, which I sent on in advance by my Mexican servant, that he might find the persons to whom they were addressed, and then 'return and meet me. Unfortunately, both the gentlemen were absent. The man, however, had shown the letters to another gentleman, who had read them, and who requested that we should stop at his house.

We accordingly drove up to a respectable looking adobe house, where we were met by well-dressed persons, and received with much politeness. Being conducted into the house, we were scarcely seated before the room was pretty well filled with visitors, to see who the strangers were. I made myself and companion known, as well as the object 'of our visit; viz., to see the ruins near by, or as they called them the "Casas de Montezuma." Our host soon began to make preparations for dinner; but as it was then five o'clock, and but little time remained before dark, I requested him to defer the meal until evening, that we might make the most of our time in examining the ruins while daylight lasted.

This being arranged, Dr. Webb and myself set off for the ruins, accompanied by our host and three or four others. Being but half a mile from the village, they were soon reached, when, after a hasty walk among them, I seated myself on a small knoll, or mound, and occupied myself while there remained any light in making a sketch. The Doctor, in the mean time, was engaged in searching among them for relics. We re- 
turned while we could see to find our way back through the thick mezquit chapporal, and partook of an excellent supper with such appetites as people might be supposed to have who had not eaten since sunrise. The evening was spent in questioning our friend about the ruins, and in selecting. some fragments of pottery from a peck or more which the boys who had accompanied us had picked up, I having set them to work for the purpose.

The ruins of Casas Grandes, or Great Houses, face the cardinal points, and consist of fallen and erect walls, the latter varying in height from five to thirty,feet, and often projecting above the heaps of others which have fallen and crumbled away. If the height were estimated from their foundations, it would be much greater, particularly of those in the central parts of the building, where the fallen walls and rubbish form a mound twenty feet,above the ground. If, therefore, the highest walls now standing have their foundation on the lowest level, they have a height of from forty to fifty feet; and as these ruins have stood exposed to the elements for more than three centuries, they must originally have been much higher. Indeed the thickness of the walls, some of which are five feet at their base, would indicate that they must have been much higher than they now appear.

From a close examination of what remains of the building or buildings, I came to the conclusion that the outer portions were the lowest, and not above one story in height, while the central ones were from three to six stories. Hence the large heaps of ruined walls and rubbish in the centre, and in consequence the bet- 
ter preservation and support of that portion of the edifice. By far the larger portions which have fallen are the exterior walls. This arises from the moisture of the earth and the greater exposure to rains. The central parts are in a measure protected by the accumulation of rubbish; and by the greater thickness of their walls.

I should observe that every portion of this edifice is built of adobe, or mud, and that nowhere, as far as I could trace the foundations, could I discover any walls of stone. The point in which it differs from the work of the Spaniards or modern Mexicans, is in the mode of constructing the walls. The latter employ regularly made brick, from fourteen to sixteen inches in length, about twelve in width, and three or four in thickness, often mixed with chopped straw and gravel, and baked in the sun-a mode adopted ages ago by the primitive inhabitants of Egypt, Assyria, and other Oriental countries, and practised by them at the present day. But the buildings of which I now speak are built with large blocks of mud, or what the Mexicans call tapia, about twenty-two inches in thickness,

- and three feet or more in length. In fact, the length of these blocks seemed to vary, and their precise dimensions could not be traced; which induced me to believe that some kind of a case or box was used, into which the mud was placed, and as it dried, these cases were moved along. It is true, they may have been first made in moulds or cases, and, after being dried, placed on the walls; but the irregularity and want of uniformity in these layers as to their length, leads me to believe they were made on the walls themselves. 
The mud is filled with coarse gravel from the platean, which gives greater hardness to the material. In this respect I consider it superior to the modern adobe, which is oftener made without any gravel or straw, although in the better class of buildings, I have seen both used.

In the town of El Paso there are some old division walls from three to four feet high, connected with the earliest buildings in the place, that are built of large blocks of adobe, well filled with gravel, of a similar character with those in the "Casas Grandes;" but in no buildings of the Mexicans have I seen them used. I have also seen modern fences made in the same manner of the common mud taken from the fields.

All adobe walls, whether of buildings or mere fences, decay first at their base, from the moisture; which . causes them to fall over. Such is the case with the modern as well as the ancient buildings. When prostrate, the water easily permeates them; in a few years they crumble in pieces, and are reduced to the original mud and gravel from which they were made.

The outer walls of the Casas Grandes are only to be traced by long lines of rounded heaps parallel to, or at right angles with, the walls now standing; while here and there a corner of the original wall may be seen, or where it was intersected by a transverse wall which tended to support the other and bind them together. These corners often retain their erect positions long after the other portions have fallen. So with the higher and more massive walls of the interior, which are five feet in thickness at their base : the sides or longer walls have "fallen, while the corners, with a 
few feet on either side, still tower far above the other parts, resembling at a distance the isolated columns of a ruined temple. In so ruinous a state are these buildings, that it is extremely difficult to trace their original form. In approaching them one first meets with the low walls or embankment, which any where else would be taken for a work of nature; but the transverse heaps connecting them with the standing walls at once show them to have been similar, though of less height. A closer inspection brings to view a portion of a corner which has not fallen. As the visitor approaches the interior, where the edifice is in a better state of preservation, he becomes confused among the erect and fallen portions; for the longer sides are mostly prostrated, while the shorter ones, and those forming angles, are standing. In this dilemma I found it best to take a stand upon the highest point, which is a mound in the very centre of the erect walls, as well as the centre of the edifice. From this point, after having examined and traced the exterior portion, one may form a tolerably correct idea as to the arrangement of the edifice. It was not until I had walked several times around it and traced its inner apartments, that I could satisfy myself of its actual outline.

At first I believed that there were three separate buildings, even when I took my sketch, as there were three large heaps, apparently unconnected, each having portions of erect walls. But on closer examination, I found that they had been connected by a low range of buildings, which may have been merely courts, as they Were of but one story. On the supposition, therefore, that all were connected either by low buildings or VOL. II. -23 
corridors, the entire edifice must have extended from north to south at least 800 feet, and from east to west about 250 . On the south side a regular and continuous wall can be traced, while the eastern and western fronts are extremely irregular, with projecting walls. There appears to have been several courts within the inclosure, of greater or less dimensions.

The general character of this extensive range of buildings is the same as that of the Casas Grandes, ${ }_{6}$ near the Pimo villages, on the Gila, and they are unquestionably the work of the same people. The material, too, is the same as that of the ruins on the Salinas. Like the edifice on the Gila, it is built with huge blocks of mud, laid up in the same manner, though, from some cause, probably the lesser tenacity of the adobe, the walls are in a greater state of decay. In no other way can this decay be accounted for, unless a greater antiquity is allowed for these than for the Gila edifice, which would be contrary to all preconceived opinions of them. The ruinous state of these buildings may also be attributed to the more frequent rains to which they are exposed than those on the Gila.

The walls of the present building are much decayed; in fact one half of their thickness is washed away, and it is only by digging below the surface that their original thickness can be seen. In the Gila edifice, the inner surface of the walls is as perfect as though the mason had but yesterday passed his trowel over them, and the exterior ones are but little injured. In these ruins, on the contrary, no portion of the surface is visible. I sought for this, in order to ascertain if they had been plastered inside or out; but it could only be 
decided by digging to the foundation, which I had not time to do. Several portions of the walls within the area, and in particular one midway between the most southwardly building and the one to the north, had fronts precisely like that on the Gila; their doors were similarly placed, and receded towards the top, and the same circular openings were seen in the upper partition walls. So much of the walls had washed away, that I could not trace the cavities where the beams were inserted, and hence was unable, as in the Gila edifice, to ascertain the number of stories, or how the beams were laid. Not a fragment of the wood forming the beams or lintels could be discerned. Many doorways remained; but the lintels being gone, the tops had crumbled away or fallen.

Although these ruins are alluded to by many of the earlier as well as the recent writers on Mexico, I have been unable to find in any author an accurate or full description of them. I have been particularly desirous to see some early account, that I might know their appearance when first seen by the Spanish colonists, who traversed this country anterior to the year 1600. Ribas, one of the earliest writers on the aboriginal tribes, who has given the most minute details of the labors of the first missionaries, and the conversion of the several tribes of Central and Northern Mexico, says nothing of these remains, although he describes the nation that occupied the country where they are found, their manners, customs, religion, etc. I find, however, in Clavigero* a brief account, which that

* History of Mexico. 8vo. ed. vol. i. p. 151 . 
laborious investigator doubtless had authority for. He repeats the old story that this edifice, "agreeably to the universal tradition of these people, was built by the Mexicans in their peregrination." That it consisted of "three floors with a terrace above them, and without any entrance to the under floor. The door for entrance to the building is on the second floor, so that a scaling ladder is necessary." This would show that at some period since the settlement of the country its floors remained.

The other details in Clavigero are incorrect, and unquestionably refer to another edifice, which was built of stone, was roofed, and "surrounded by a wall seven feet thick." He also calls it a "fortress," which term cannot be applied to this structure. I am of opinion that our author either mistook the sense of the writer he obtained his information from, or has blended the descriptions of two different buildings.

Garcia Conde also states* that this edifice is known to have had "three stories and a roof, with stairs outside probably of wood," and that the same kind of structures are found at the present time among the pueblos of the independent Moquis," north of the Gila. $\mathrm{He}$ also repeats the story of the Aztec emigration, and that this was the third stopping-place of that people on their way from the North to the valley of Mexico.

There is a class of apartments in this edifice, the object of which I am unable to conjecture, unless they were intended as depositories for maize, beans, and other agricultural products, or in other words, a gra-

* Ensayo Estadistico sobre el Estado de Chihuahua, fol. p. 74. 
nary. These apartments, which are arranged along one of the main walls, are twenty feet in length, by ten in breadth, connected by doorways with a small

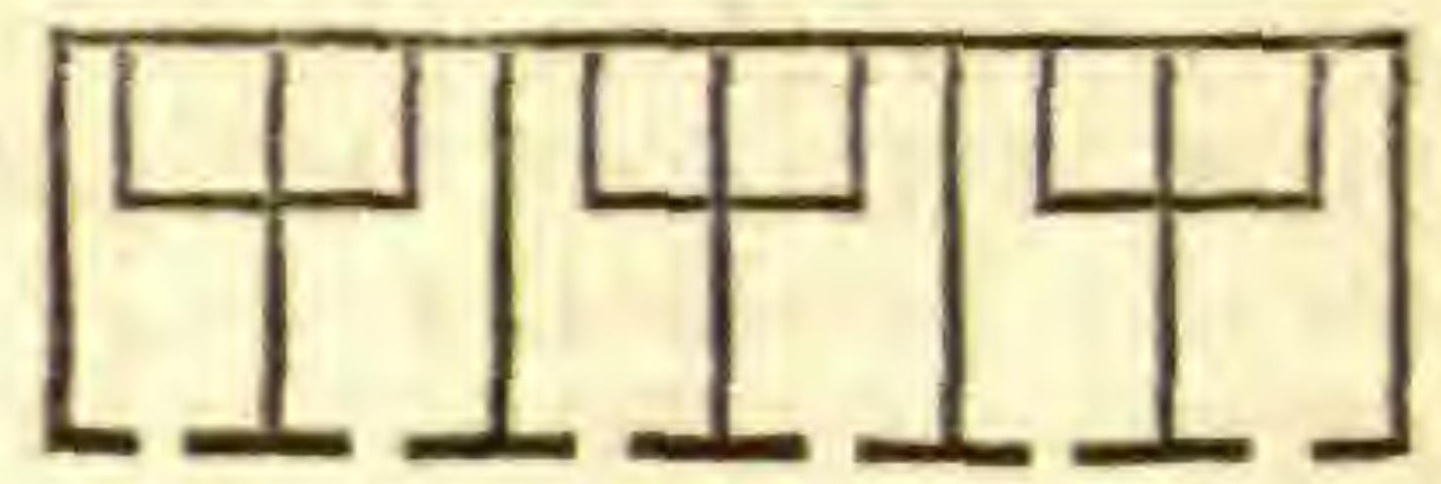

Part of Ground Plan of the Casas Grandes, Chihuahua.

inclosure, or pen, in one corner between three and four feet high. Beside these, there are many other exceedingly narrow apartments, too contracted for dwellingplaces or sleeping-rooms, with connecting doorways, and into which the light was admitted by circular apertures in the upper part of the walls. The number and extent of these long and narrow apartments, without windows, led me to believe they were used for granaries. There were also large halls; and some inclosures within the walls are so extensive, that they could never have been covered with a roof, but must have been open courts. The lesser ranges of buildings, which surrounded the principal one, may have been occupied by the people at large, whose property was deposited within the great building for safe keeping. Although there is less order in the tout ensemble of this great collection of buildings than in those at the north; the number. of small apartments, the several stages or stories, the courts within, and some of the minor details, resemble in many respects the large edifices of the semi-civilized or Pueblo Indians of New Mexico.

The position of these buildings differs from that of those near the Gila and the Salinas. The latter were built upon the plateau or table, just above the 
bottom land which their occupants had cultivated. The former stand on the declivity, with portions extending both on the plateau and on the bottom. The bank here is about twenty feet in height. Why so built I cannot imagine, unless excavations were made in the bank for store rooms. Wherever these old structures are found, they show much sagacity on the part of their builders, who must have had some object in view in adopting the plan just mentioned. As a general custom at the present day, among the Mexicans, their villages and ranchos are built upon the plateau above the valley, or cultivated bottom, and on spots where there is no vegetation, except such plants as are peculiar to the deserts. Not a blade of grass can flourish there. I supposed this to be for two reasons: first, that the valleys are sometimes overflowed, and in rainy seasons are extremely wet and damp; while on the gravelly plateau, which is hard and smooth, it is always dry. The second reason is, that being elevated, the people have a good view of their cultivated grounds, can trace their cattle and herds with ease, and discover the approach of an enemy.

On the western or upper side, some sixty to eighty yards from the building, are three mounds of loose stones, about fifteen feet high, no doubt the burial places of the chiefs or great men. I would have opened these, but had not the time or facilities for so doing. If these were burial places, and there are no indications of places of sepulture elsewhere, some valuable relics might be found beneath them.

I made particular inquiry of my Mexican friends, who were familiar with every spot of ground in this 
vicinity, whether they had ever discovered the Campo Santo, or burial ground, of the builders of these edifices; but they all declared they had found none.

West of these, about two hundred feet distant on the plateau, are the remains of a building, the dimensions of which I did not take, but think it about 150 feet square. But small portions of its walls remainenough, however, to show the nature of the building, which could not have been more than one story high. It was divided into a number of compartments, of equal dimensions, except the corner ones, and resembled some of the low buildings connected with the large edificesadjacent.

The following is an outline of the ground plan as indicated by the lines of the walls.

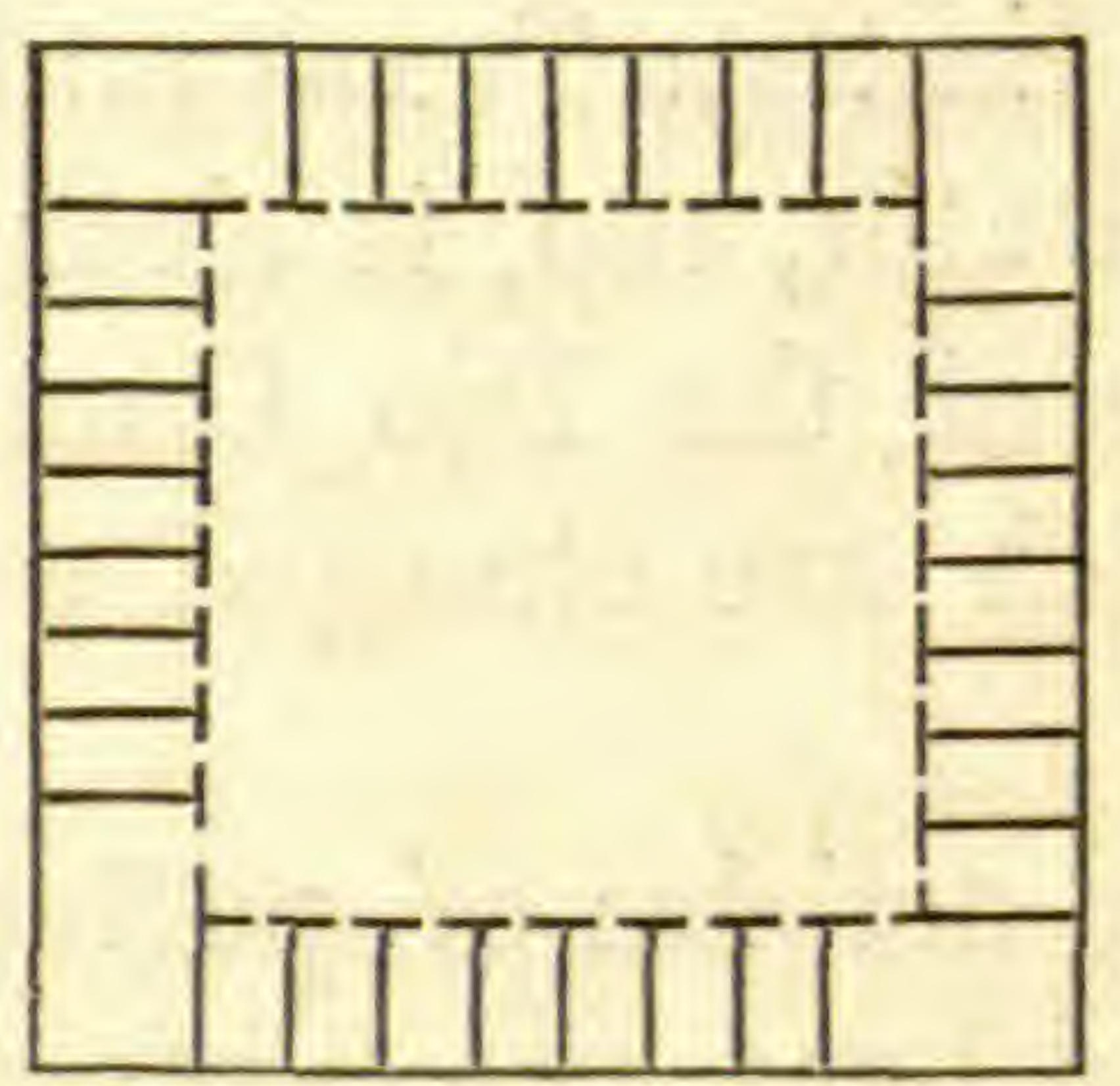

Ground Plan of one of the Casas Grandes, Chihushua.

The plain for some distance south, I was told, was covered with traces of old buildings; but they were mere heaps, without a distinct form to show the nature of the original structure. In the valley they are also found.

Garcia Conde also mentions* a second class of

- Ensayo Estadistico sobre el Estado de Chihuahua, p. 75. 
ruins, which are very numerous along the margin of the Casas Grandes and Janos rivers, for a length of twenty leagues and a breadth of ten. At a short distance, he says, they uniformly have the appearance of small hills or mounds, and in all that have been excavated, there have been found jars (cantaros), pitchers, ollas, * etc., of pottery, painted with white, blue, and scarlet colors; corn grinders (metates), and stone axes, but no instrument of iron.

The builders of this edifice, and the occupants of the rich valley in the vicinity, showed much sagacity in their choice of so fine a region for agricultural purposes. There is none equal to it from the low lands of Texas, near San Antonio, to the fertile valleys of California, near Los Angeles; and, with the exception of the Rio Grande, there is no river of equal size between those of Eastern Texas and the Colorado of California. The water, too, is clear and sweet, unlike the muddy waters of the Rio Grande, the Pecos, and the Colorado, which are charged with vegetable matter and earth.

Many beautiful articles of pottery have from time to time been found here, the texture of which is much superior to that made at the present day by the Mexicans. This pottery has chiefly a white or a red ground, ornamented with a variety of angular figures:

* Ollas (pronounced oyas) are the most common of all the utensils of pottery used by the Indians or present Mexicans. They are of various capacities, from half a pint to six gallons. Suspended by a cord over the fire they are used for cooking in, and are in universal use for earrying water. The household utensils of the poorer Mexicans consist entirely of an assortment of these useful articles. 

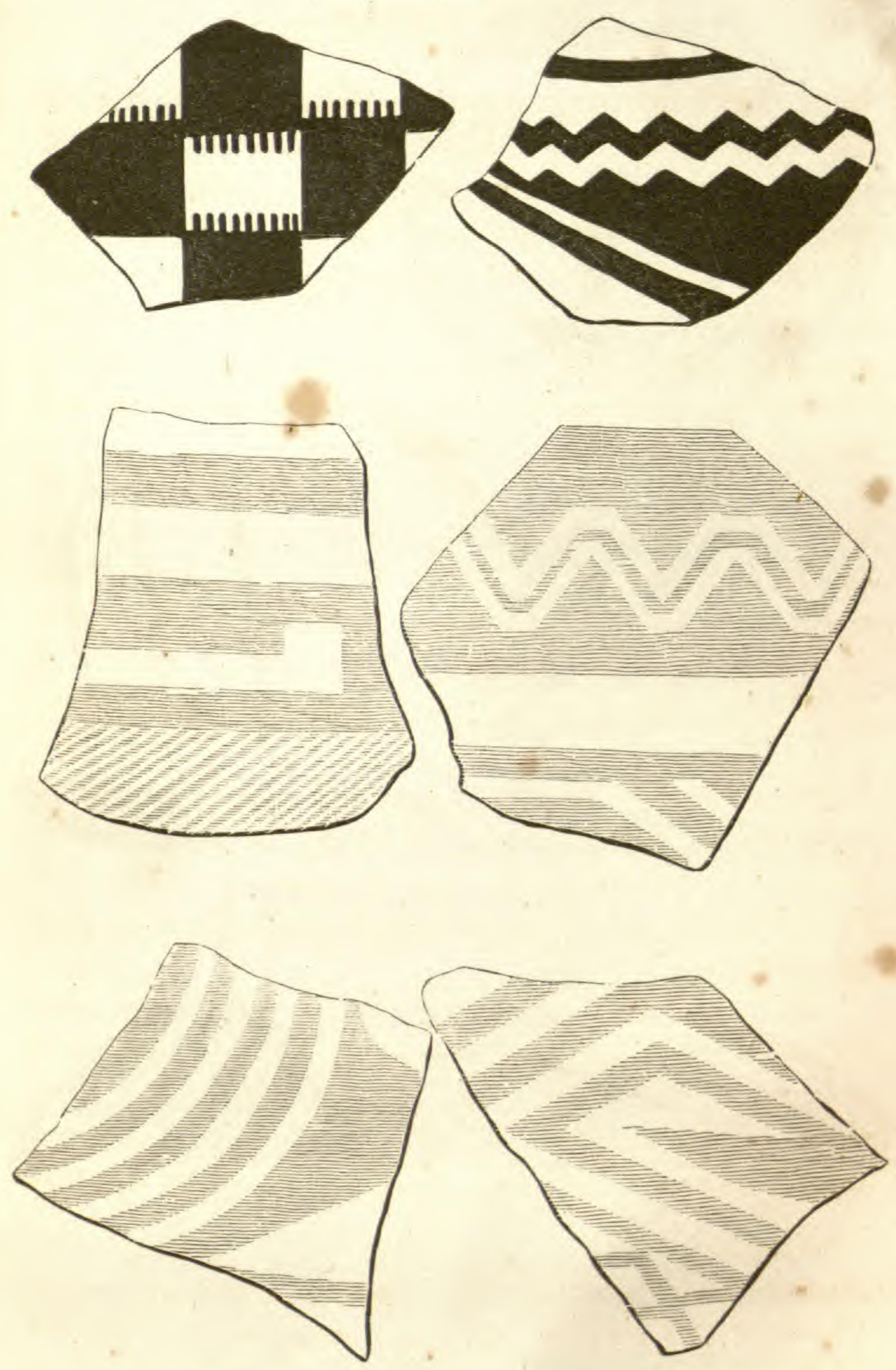

FRAGMENTS OF ANCIENT POTTERY FROM CASAS GRANDE,, CHIBUAHUA, 


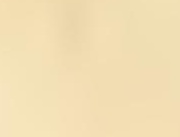

$\sqrt{2}$

1

civ

and
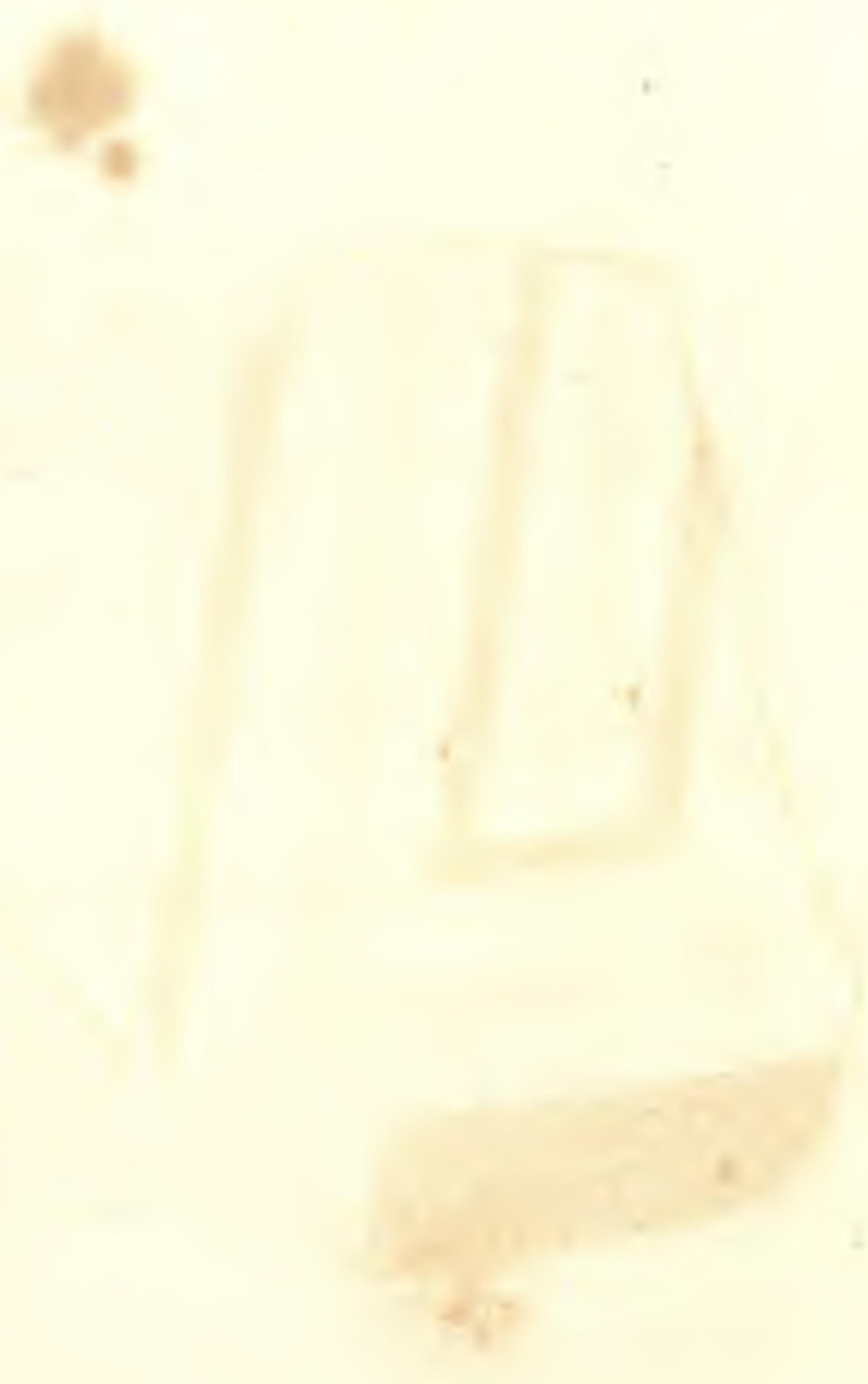

18.

$=$ 

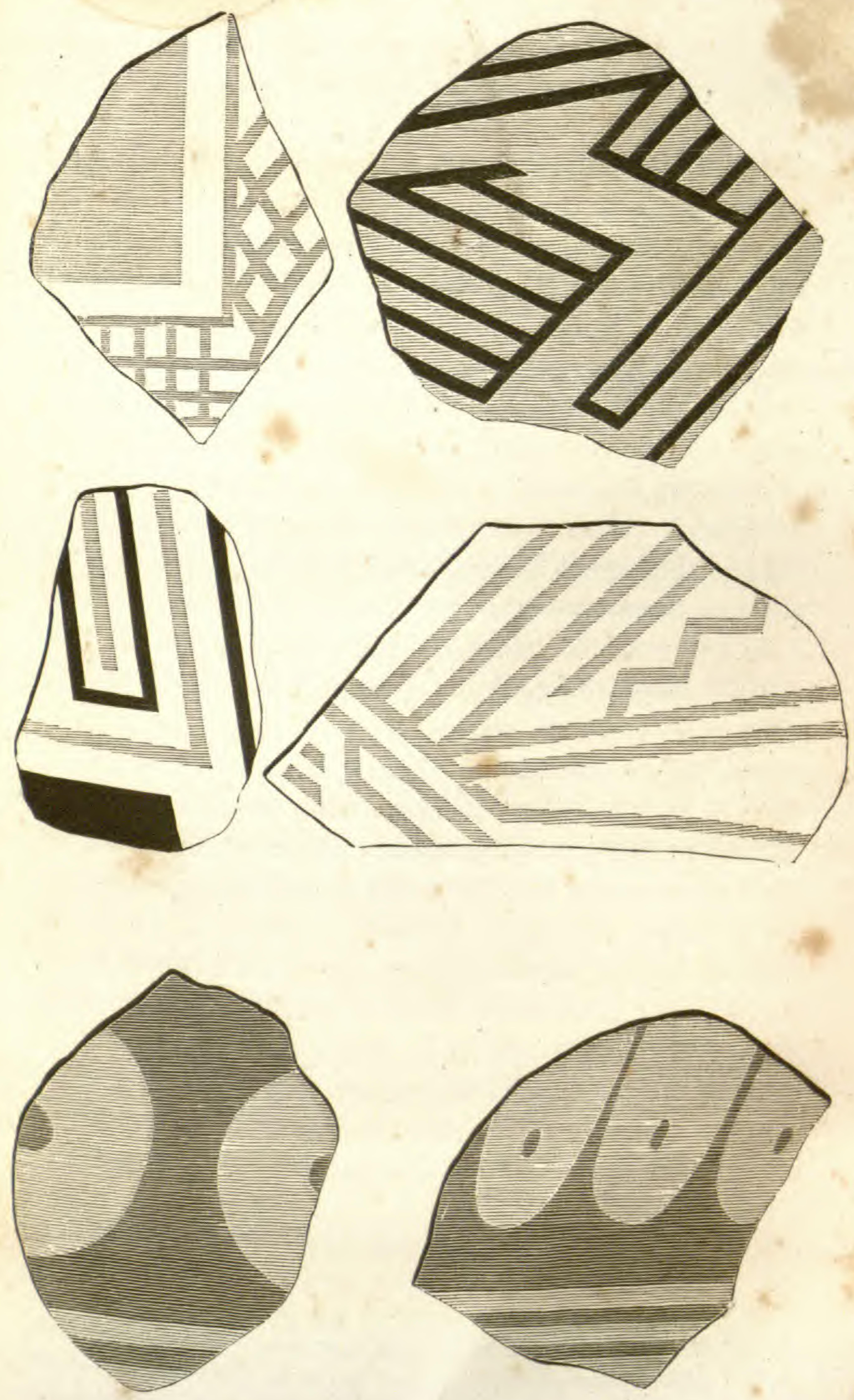

FRAGMENTS OF ANCIENT POTTERY fRoM CASAS gRANDES, CHIHUAHUA. 
those on the white ground being black, red, or brown; and on the darker material, black. I made inquiry for any relics that had been found, and. was successful in obtaining a fẹw. One of these was a small black jar; another a vessel in the form of a tortoise, of reddish pottery; and the third a beautifully sculptured stone pipe. Such relics are eagerly sought for by the people of Chihuahua and other large towns, and - when perfect command a high price. I heard of many such; but they were in towns beyond my reach. I requested a friend to procure drawings of these and forward them to me, but have not yet received them, and the only addition I am able to make to those which I obtained, is a drawing from one found by Lieut. Hardy, a copy of which I give, rather to show the style of ornament than the form.* I also saw, at the house of the gentleman who was so polite to us, a fine metate taken from the ruins, about two feet in length, handsomely cut from a block of dark stone, a drawing of which I made. Similar ones are occasionally found there; and in my rambles I saw several broken ones.

The whole valley and plain for miles about these ruins is strewed with fragments of pottery. I collected a number of specimens exhibiting various patterns, in order to show the taste of the makers in ornamental

* Hardy's Travels in the Interior of Mexico in 1825-8. This author spent a couple of hours at these ruins, and procured the jar referred to, which he says was in excellent preservation. "There were also," continued he, "good specimens of earthen images in the Egyptian style; which are, to me at least, so perfectly uninteresting, that I was at no pains to procure any of them." p. 465. 
design, as well as for the purpose of comparing them with the pottery found at the Gila and the Salinas. They will also serve for comparison with the pottery of the Moquis, Zuñis, and other Pueblo Indians, as well as with the ornaments made by the present Pimos and Coco-Maricopas. When so little remains of a people, the smallest fragments of their works of art become important. It is for this reason I have given so many specimens of their ornaments.

On the summit of the highest mountain south-west of the ruins, and about ten miles distant, there was pointed out to me an ancient fortress of stone, from which the whole country for a vast extent can be viewed. It is attributed to the same people who erected the "Casas Grandes," and was doubtless intended as a look-out. This fortress can be discerned with the naked eye, and on looking at it through my spy-glass, it showed quite distinctly. I did not visit it, as it would have required a day, which time I could not spare.

We were told that this building was a stone fortress of two or three stories, with a very solid foundation. I think that the description of Clavigero refers both to the adobe edifices I have described and to this fortress, and that the worthy historian was not aware of their being separate structures.*

* This edifice is constructed on the plan of those of New Mexico, that is, consisting of three floors, with a terrace above them, and without any entrance to the lower floor. The doorway is in the second story, so that a scaling ladder is neeessary; and the inhabitants of New Mexico build in this manner, in order to be less exposed to the attacks of their enemies. No doubt the Aztecs had the same motives for raising 


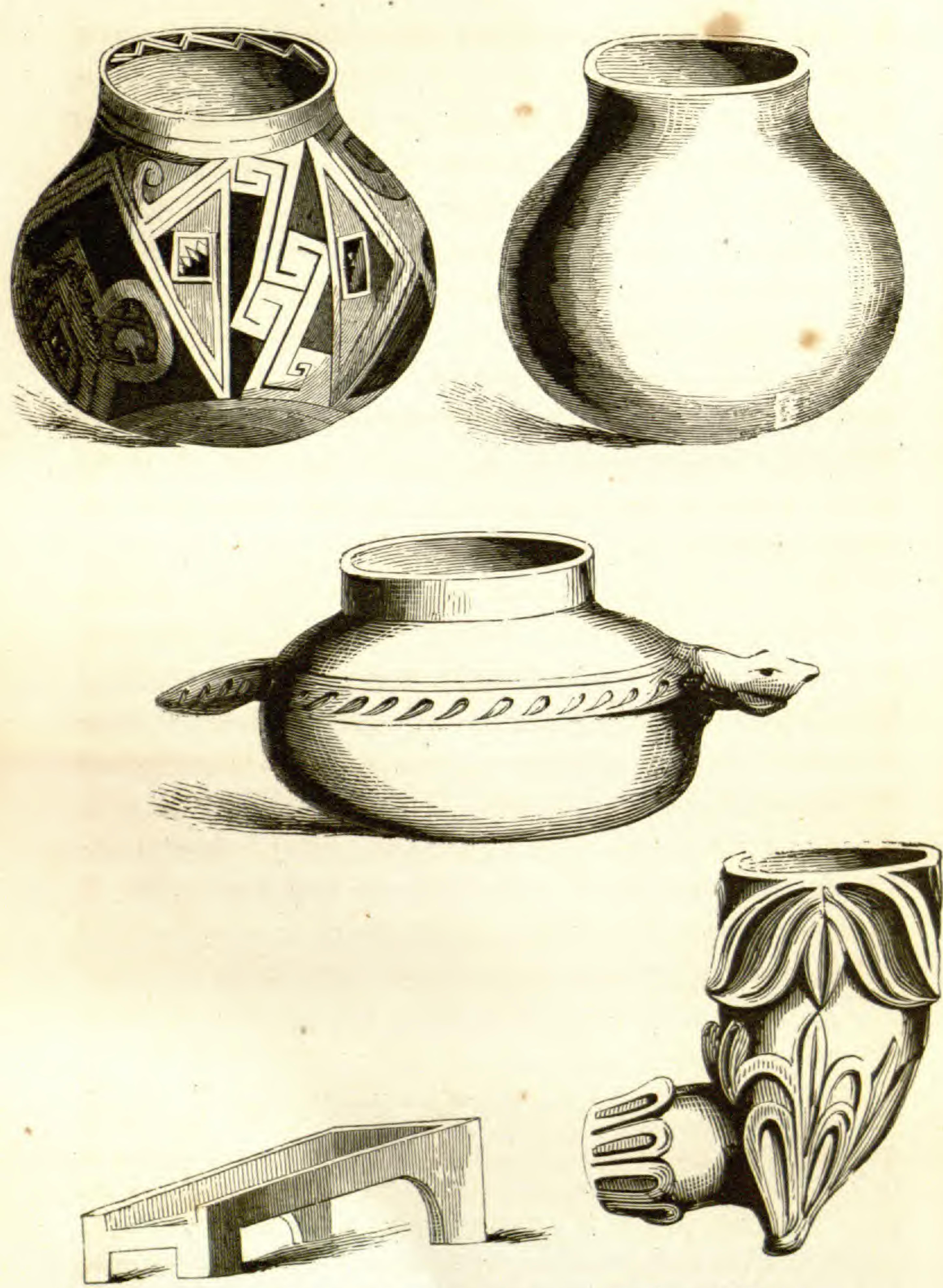

RELTOS FOUND AT CASAS GRANDES, CHIHUAHUA.-p. 362. 
The Casas Grandes River rises about a hundred miles N. W. from the city of Chihuahua, whence it flows in a course nearly north by the town and ruins of the same name, the towns of Barranca, Colorada, Correlitos, and Janos, and, after a course of $62 \frac{1}{2}$ leagues, is discharged into Lake Guzman. It receives a tributary nine miles north of Janos; a second one at that town, which bears its name; and a third about ten miles below the ruins called Temeivaca. Yet notwithstanding these tributaries and the large volume of water, it often dries up, and remains only in pools barely sufficient for the population and the herds of cattle which graze upon its banks.

The valley here is about two miles in width, covered with luxuriant fields of grass, wheat, and corn. The river passing through its centre is marked by a line of gigantic cotton-woods, while in various detached spots are groups of the same. The acequias which intersect the valley in every direction, are, like the river, lined with a thick growth of shrubbery.

Beyond the valley rises the plateau, which has a gradual ascent to a low range of hills about eight miles distant; beyond which, with some miles of inter-

their edifices on this plan, as every mark of a fortress is to be observed about it, being defended on one side by a lofty mountain, and the rest of it being defended by a wall about seven feet thick; the foundations are still existing. In this fortress are stones as large as a mill-stone, to be seen : the beams of the roof are of pine, and well finished. In the centre of this vast fabric is a little mount, made on purpose, by what appears, to keep guard on, and observe the enemy. There have been some ditches found in this place, and a variety of domestic utensils, earthen pans, pots, jars, and little looking-glasses of itzli (obsidian).-Clavigero's Mexico. 
vening space, rises a lofty ridge of mountains. I took two general views of the ruins, one from the west, seated on the top of the little mounds referred to, in which the whole extent of the buildings is shown, with the valley and mountains beyond. This I have shown in three parts, to exhibit them more distinctly. Two of these are wood cuts; the third, the small lithograph. The other is taken from a point near the south-eastern corner, showing portions of the walls which are not seen in the first sketch. This view is given in the large lithograph facing the title-page of this volume. As may be seen in the sketches, low mezquit bushes have taken root around the buildings, as well among its walls as in its apartments. On the west, the plateau extends to a range of low mountains, about five miles distant, running in a line from northwest to south-east. The river bottom and adjacent plateau are about fifteen miles in width, which is about the average width from Janos tó Casas Grandes. Proceeding south, these mountains appear to approach, thereby contracting the plateau and valley. The latter, I was told, continues fertile far to the south, and is as highly cultivated as any portion of the country.

August 10th. From our hospitable friends we learnt that the town contained about 400 inhabitants. They are strictly an agricultural population, and have extensive fields of grain and orchards near. Maize is the chief product, and is sent in large quantities to Chihuahua and El Paso, where it finds a ready market. The people seemed industrious and happy, and were apparently in a better condition than we had found 


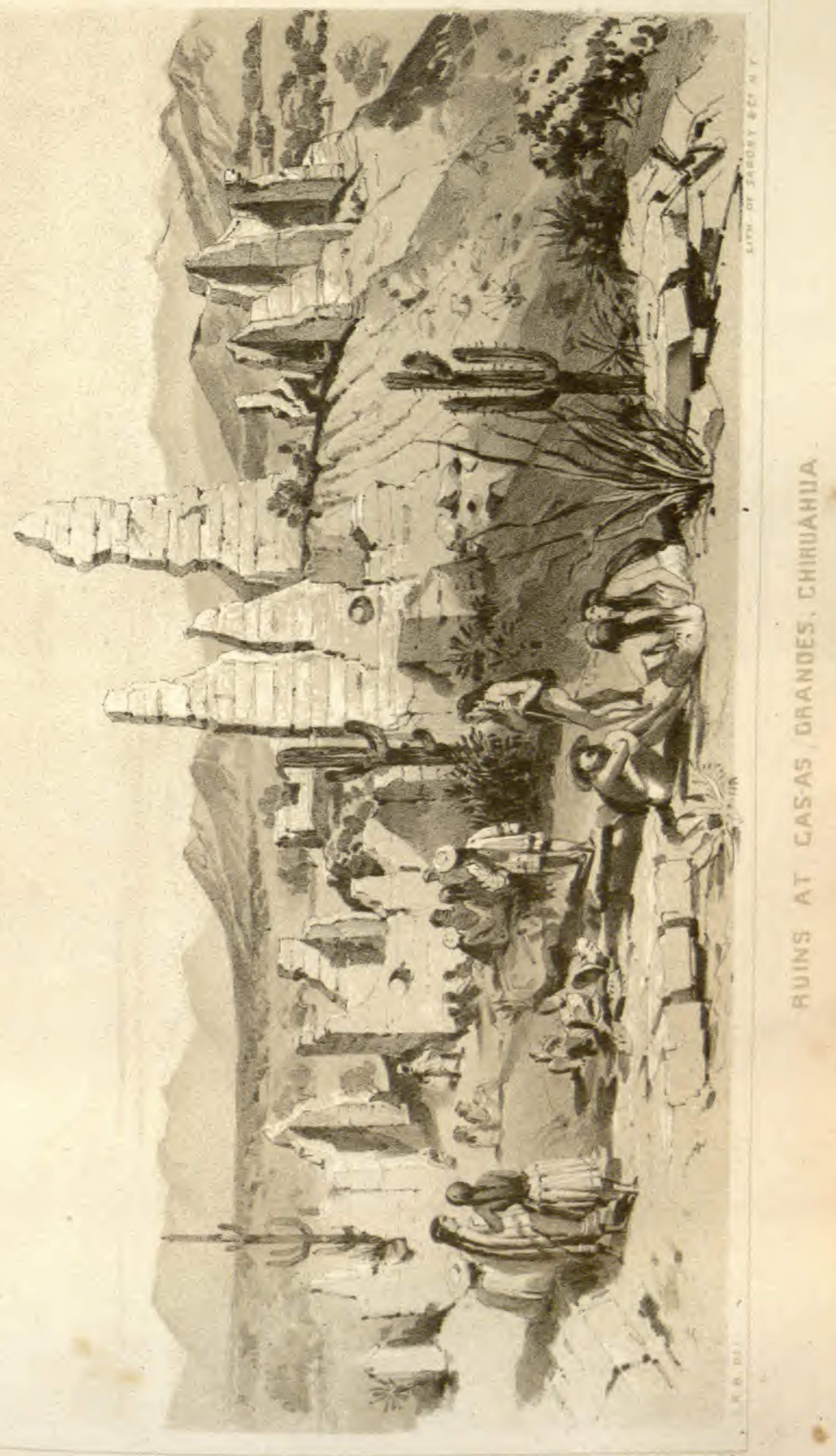


them in the other frontier towns. They are somewhat troubled by the Apaches; and we noticed two crosses near the ruins, and four on the road to Correlitos, the evidences of their murderous propensities.

We were up by sunrise, and found a cup of coffee ready for us; after which we again set out for the ruins, accompanied by four men, whom I had engaged to dig among them.

We first dug in a large apartment where some metates had been discovered, and which it,was believed had been a sort of kitchen; but we found nothing but broken pottery, an obsidian arrow-head, and some small marine shells. Leaving Dr. Webb to superintend these excavations, I set to work to take a ground plan of the buildings, as far as it was possible to do so; but the Mexicans who undertook to assist me were far from adepts in the business, and caused me much annoyance. This was not a little increased by the troops of men, women, and children, who flocked around me until it seemed that half the population had turned out, apparently with the idea that we possessed some secret information regarding buried treasures there. I was unable to complete my survey of the edifice and its numerous walls, which it would have required the labor of several men, for at least two days, to accomplish in a satisfactory manner.

At 11 o'clock, being pretty tired and hungry, we returned to the house of our friend to breakfast; after which the wagon was brought up, and we set out on our return to Correlitos, where we arrived at four o'clock, well pleased with our excursion. 


\section{CHAPTER XXXVI.}

\section{CORRELITOS TO EL PASO.}

Leave Correlitos-Visit the Silver Mines of Messrs. Flotte and ZuloagaAttempt of a peon to escape-Rio Santa Maria-Recent fight of Americans with the Apaches here-Broad open plains-Continued rain-The Salado-The Médanos, or Sand-hills-Painful night's march -Samalayuca-Arrival at El Paso del Norte.

August 18th. We left Correlitos at 8 o'clock, A.M., and took an easterly course over a plain of very gentle ascent for about fifteen miles towards a conical mountain. We then entered a defile, and soon after reached the base of the mountain, where we found water, and encamped.

In this conical mountain are the two silver mines of Señor Zuloaga and Mr. Flotte, whose smelting works we had visited at Correlitos and Barranca. As soon as the camp was arranged, I set off with several others to inspect them. The mines are on the opposite sides of a ravine or indentation, which makes up into the mountain, and their entrances are not more than a hundred yards apart. On the hill sides, around and above the entrances, are the habitations of the workmen; most of them are built of the rock excavated in mining, and from a little distance have a most singular appearance. 
I first went to Mr. Flotte's mine. I presented my letter of introduction to the superintendent, a native Castilian, and was received by him with the politeness that characterizes his countrymen. After sitting a short time in his house near the entrance, we were each provided with torches; whereupon we descended the mine, following the footsteps of our guide, the superintendent himself It was quite muddy, owing to the late rains. The shaft was between six and seven feet high, branching off in various directions. We traced it to its bottom, which was eighty varas, or about 240 feet, from the entrance. The principal vein of ore is about five inches in thickness; there is also another of one inch. Both have a dip of about 45 degrees. The entire length of the various shafts is 300 varas, or 820 feet. On returning to the house of our attentive guide, he presented us with fine specimens of the ore. We did not go further than the entrance of the other mine; as it was late, and the mine did not materially differ from the one we had examined.

August 12th. Our journey to-day was twenty-five miles. After leaving camp, our road wound for a couple of miles through the hills, and then emerged into a broad plain, interspersed at intervals of two or three miles with conical hills, from one to three hundred feet in height. Some of these were capped with a ridge or mass of stone, of a reddish color, resembling a work of art. Five miles further brought us to Walnut Creek, a small run of water, which is dry except at this season, and even then contains but little water. Half a dozen walnut trees of a small size, grow upon its banks, whence its name. After crossing this rivulet, 
our course was north-east without variation, over a slightly undulating plain, covered with grama grass. A dark line of trees now showed itself far in the distance, indicating a water-course, which we reached at 5 o'clock, and which proved to be the Santa Maria. The road had been excellent since leaving Correlitos, including the mountain defile. A heavy cloud arose as we approached the stream; and we had barely got our tents pitched and well stayed, before it burst over our heads, accompanied by a violent wind.

When a few miles from camp this morning, a man got up from behind a bush, where he appeared to have been concealed, and joined the train. He proved to be a Mexican, who wished to accompany us to El Paso. Soon after two men on horseback overtook us, and handed me a note from the superintendent of the mine, stating that one of his men had run away, and asking permission to take him in case he had joined our train. I could not, of course, interfere in the matter, and gave orders that the men should not be obstructed in arresting the runaway. The poor fellow, who was a peon, was very reluctant to return; but his captors were armed with sabres and rifles, and all resistance was unavailing. As we journeyed on, we saw blows inflicted on the poor creature, who was, no doubt, destined to spend the remainder of his days at hard labor for the benefit of his owner. Our Mexican arrieros were anxious to liberate him; but as we were on Mexican territory, with liberty to go whither we pleased in the performance of our official duties, interference would have been unjustifiable.

August 13th. We remained two hours longer than 
usual this morning, to give the mules a chance to feed. Near us were some walls of old stone buildings, where a number of stone arrow-heads, and clippings of jasper, flint, and obsidian were found, showing that here had been a work-shop of the natives.

A few weeks previous, a party of four Americans was here surprised and surrounded by a band of some 15 or 20 Apaches. The men were armed with rifles and pistols, which enabled them to keep the savages at bay. Whenever the latter exposed themselves, the Americans gave them a shot, and killed, as they believed, several. After being thus encompassed for three days, protected in a measure from the arrows of the enemy by a little wall which they raised, and after they had all been wounded, one of their number crept out at night and made his way to Correlitos, where he applied for relief. It was granted; but they were compelled to pay $\$ 500$ for it.

I ascended a hill near our camp, from which I could trace the course of the Santa Maria, by the line of trees along its banks. A broad plain extended for many miles on either side without a tree or a shrub.

Our course continued north-east, without change, over the same level plain we had been traversing, of clay or gravel, with occasional patches of grass and a few mezquit bushes. Passed some holes of rain-water, where we stopped to water our animals. The hills and mountains, which here and there rose up from the plain, were quite picturesque, the conical and pyramidal forms prevailing with the hills; while the mountains, which were from 1500 to 2000 feet high, presented the most fantastic outlines, resembling castles, domes, and minVoL. II, -24 
arets. Some of these were of a deep red, others of a yellowish cast. There were no continuous ranges to be seen; but all were isolated, or in groups, rising abruptly and extending but a few miles.

At 3 o'clock, the usual black cloud began to rise at the south, portending rain, which warned us to make our camp before it reached us. We took advantage of a little patch of grass, where the animals might obtain a scanty meal, and stopped. Every man without exception, at once set to work; and within a very short space of time the tents were pitched, trenches dug, and the camp-fires made. Scarcely was this completed, when the storm was upon us; and but for the extra ropes and stays put to the tents, all would have been blown away. But as it was, we sat quietly within, listening to the peals of thunder, and watching the vivid flashes of lightning. We needed not to seek for a stream or a spring, for in a very few minutes the depressions in the plain around our camp furnished an ample supply, both for man and beast. We made 18 miles to-day, over an excellent road. The country around is of a most desolate character.

August 14th. Six miles from camp brought us to a hill, on which was a smooth rock covering about half. an acre, to the right of the road. In this rock I counted twenty-six artificial cavities within a few feet of each other. They were from twelve to eighteen inches deep, and about six in diameter; and had been dug out by the Indians for mortars in which to pound their maize. The place was thickly covered with various kinds of cacti as well as the agave and yucca. The common prickly pear abounded with its luscious look- 
ing but unwholesome fruit, of which our men partook with some caution.*

From the summit of this rocky hill, which is about three hundred feet high, we had a fine view of the vast plain around us, stretching in every direction as far as the eye could reach, and unlimited by any continuous range of mountains. Short isolated ridges rose up at intervals of from ten to twenty miles, and between them the conical hills before referred to. Immediately below, about a mile distant, was the Salado, or Salt Lake, from two to four miles across; although after rains it is doubtless much larger. Some ten or fifteen miles to the north-west, I noticed what appeared to be another small lake, which may have been the Laguna de Santa Maria. Although from its whitish appearance, it may have been but the salt bed of a dry lake. $\dagger$ I took a sketch of the country here, with a curious coneshaped hill in the foreground, on the summit of which is a mass of rocks resembling a tower. Similarly crowned hills were seen during the day's march.

We made a noon halt at some pools of fresh water near the Salado; as it was my intention to go as far as possible to-day, so as to shorten the march of to-morrow, in which we did not expect to meet with any

* It is said that too much of this fruit will cause fever and ague. Whether this be true or not, I cannot say; although I do know, that on several occasions, illness was produced by a too free use of it.

† In my former journeys, we frequently saw these playas, or dry lakes; and even when within a quarter of a mile, it was utterly impossible to say, whether they contained water or not. On these occasions the party would be equally divided in opinion, nor could all be satisfied until we really touched them. 
water. We got off again at 4 o'clock, but had not gone more than eight miles before the heavens began to be obscured by a black cloud, which rose behind a lofty pinnacled mountain on our right, one of the most singular and picturesque we had seen. Mr. Leroux rode ahead with others, to search for a patch of grass, as the plain around us was almost destitute of vegetation. Fortunately he found a small one where the hungry animals might obtain a scanty feed, a short distance in advance, where we halted. We made but fifteen miles to-day, a short march; but in this, and many other days' journeys, we were compelled to stop short of our intended places of encampment, in order to get up our tents and arrange the camp before the rain came on. I stood guard this night, and found it rather uncomfortable, as it rained most of the time; yet I made my hourly rounds, stumbling several times over mules, which I could not see in the darkness.

August 15th. Keeping a north-easterly course, our whole day's march was over a broad plain with few undulations, and no hills or mountains near; the road good as before. The day was damp and cloudy. At 4 o'clock, P. M., we stopped, having travelled about twenty miles.

We now approached the most dreaded portion of our journey since crossing the Tucson desert, south of the Gila. This was the Médanos, or Sand-hills. All the emigrants we had met spoke of these, and the great difficulties that attended their passage. By doubling their ox-teams, that is, by putting from 12 to 15 oxen to each wagon, they had succeeded in passing them. Two trips were thus required for each 

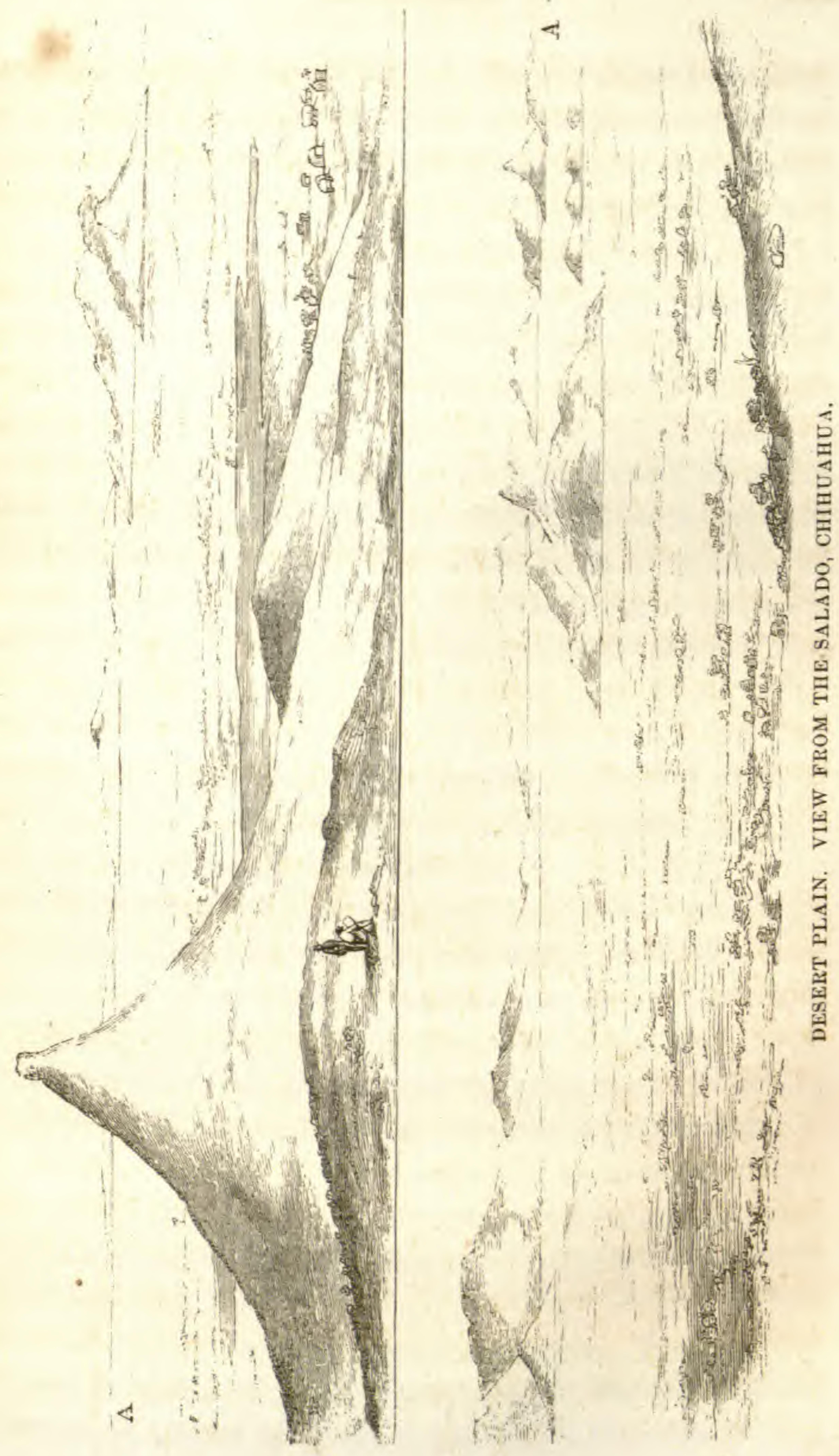

team, occupying the whole of two nights and one day to accomplish the passage, although but six miles across. Owing to the intense heat and glare of the sun on the white sand, the crossing was never attempted except at night. We were now favored by the rain; and it was thought best, notwithstanding our day's march, to . make the passage of the hills this night; the weather would be cooler and the sand more compact from the rain.

The place where we stopped was about two miles from the sand hills. We accordingly dined, and let the animals feed, and at 7 o'clock, P. M., resumed our march. Upon consultation, it was thought best for Leroux to leave a couple of hours in advance of the wagons with the train of pack-mules, and go as far as Samalayuca, a spring two miles beyond the hills, in case he could not find water nearer. He was then to discharge his loads and return to the wagons, to give us such aid as might be necessary.

The first three miles were not very bad; for though the sand was loose, it was not deep; still it was a steady pull up a gradual ascent. As we proceeded, the sand grew deeper, and the vegetation less, until nothing but a few half-buried mezquit bushes were to be seen. An aromatic shrub was also noticed here.

At a great depth there is probably some moisture which sustains these plants; but even with this, it is remarkable how they can survive in the midst of such an intense and dry heat, in a spot where, for more than nine months in the year, there is no rain. Every thing around us had a strange wintry aspect, the white sand resembling banks of snow, from which the tops of the 
bushes projected. At nine o'clock, Leroux returned to us with the pack-mules, when we stopped and unloaded the wagons, to transfer their contents to the animals' backs. It was now raining fast; and as the mules had had a tedious march over the sant hills and back, Leroux thought it best to remain where he was until-day-light, while we pushed forward with the wagons, now almost empty.

Slowly and with hard tugging, we again advanced, but not noiselessly; for the incessant hooting and yelling of the teamsters, accompanied by the cracking of their huge whips, and not a few of those terrible oaths which they seem to consider it their privilege to use, made the air resound in the midst of the solitude that reigned around us. At every fifty feet it was necessary to stop, and let the tired animals breathe and get a moment's rest; then would the air resound again with the screams of the men and the lashing of the whips; then was every shoulder literally put to the wheels and the back parts of the wagons, before they could again be started. But with all this pulling and pushing, this hard swearing and beating, the poor jaded animals often stalled, and could not, with all the aid the men could give them, start the wagons an inch. The team was then doubled; and when the twelve mules had succeeded in hauling the wagon up some little rise, the descent would prove a great relief, and enable them to get forward a few rods unaided.

The reader will have an idea of the sand here, when I state that the hub of the fore wheel was only the breadth of my hand above its surface. This too, was with wagons not half filled, and at a time when 
the hills are easier to pass than at any other, on account of the rain, which packs the sand, and prevents the wheels from sinking as deep as they would if it was entirely dry.

In this manner we pushed and pulled, making a gradual though slow headway, until one o'clock, when the mules refused to go further. The poor creatures held their noses to the ground, and patiently bore the beating of their cruel drivers. It was all to no purpose; further they would not go. In the five hours we had been tugging, we had not made more than four miles through the hills, and there were yet about two miles more before we should get through. There was no alternative left but to remain until morning, by which time the animals would get a few hours' rest. As my carratella (little wagon) was quite light, and my mules in good condition, I pushed forward, going myself on foot, and before four o'clock in the morring: passed the hills, and reached the place where Mr. Leroux had stopped with the packs. Several of the wagons also managed to get through, leaving only three behind.

This had been one of the most tedious nights of our long journey. I was on my feet from 7 o'clock in the evening, when we entered the sand-hills, till four in the morning, making nine hours, in which time we advanced but eight miles. It rained the whole night; yet such was my fatigue, that several times, when the mules stopped to rest, or became stalled, I threw myself on the wet sand and stole a few moments' sleep.

On reaching camp, I sent back six mules, which, 
with those left with the wagons, enabled them all to get through a few hours later. We did not go on to the spring talked of, which was two miles further, but stopped at some holes of rain water immediately at the foot of the hills.

The Médanos, or Sand-hills, are a peculiar feature in this country, stretching in a line from north-west to south-east for some twenty miles, as far as I could judge. Nearly destitute of vegetation, their light yellow or whitish appearance presents a strong contrast to the deep brown of the adjacent mountains, which form the background of the landscape. This sand is very light and fine, and forms deep ridges resembling the large waves of the ocean. When the wind blows, this sand is set in motion, filling up the former valleys, and forming new drifts or hills. The road is then entirely obliterated; not a foot-print or wagon rut being left to show its direction. The whitened bones of mules and cattle project here and there from the sand, with an occasional carcass which has dried up before the wolves discovered it. Although these hills lie on the direct road from El Paso to the city of Chihuahua, which is shorter than any other by sixty miles, it is invariably avoided by trains or loaded wagons. These take the river route, which passes entirely beyond their furthest southern extremity. Persons on horseback, pack-mules, and light pleasure wagons, alone attempt to cross the hills.

The place is also attended with danger on account of the Apaches, who well know the helpless condition of animals passing, and take the opportunity to attack parties. From Correlitos, there is no other to El Paso 
for wagons; and a train loaded with corn from the Casas Grandes valley, was attacked here a year before by these savages, and all the mules driven off. The distance travelled the last twenty-four hours from beyond the Salado was twenty-eight miles, including the passage of the Médanos.

August 16th. All, both men and animals, were so much exhausted with fatigue, that we were compelled to lie by to-day. In the afternoon, we had the usual shower.

August 17th. Two miles brought us to the spring known as Samalayuca. It is a complete oasis in the desert, and consists of a small pool of water, in and around which are bushes and trees. It seems to be placed here by nature, for the weary and thirsty traveller, by whom the route would else be impassable. On the west there is not usually any water nearer than the Salado, thirty miles distant, which is also the distance of El Paso, the nearest point to the north. Eastward is San Eleazario, twenty miles.

The rain of yesterday had made the road so heavy, that I feared we should not reach El Paso as I wished. But a few hours' heat of the sun so improved its condition, that I determined to push on in advance of the train; and as we were near our journey's end for the present, I did not hesitate to force my mules to their utmost. We ascended gradually from the spring for about ten miles, when we reached the level platean, which was as smooth and barren as any desert we had seen. About ten miles from El Paso, the road descends from the highest table to a lower terrace, and for five miles continues over broken ground with low hills and 
gullies, when it strikes the bottom-land of the Rio Grande. The sight of the rich valley of this river, with its groves and forests of cotton-wood, filled my mind with the most pleasing emotions. I was again approaching civilization, at a place too where I had passed an agreeable winter, and where I had many kind friends. This long journey from the Pacific, which had occupied us for eighty-one days, was now at an end, and we should have a little rest. Soon the cultivated fields and the vineyards opened before us, and at 6 o'clock we again entered the town of El Paso del Norte. The first familiar faces we met were those of Captain Jimenes and some of the other officers of the Mexican Commission. From them we learned that Lieutenant Wilkins, the commanding officer of the U.S. troops at El Paso, and Mr. Henry Jacobs, the disbursing officer of the U. S. Commission, with a small file of troops, had been out several miles to meet us, and had just returned. They had heard of our approach by a messenger whom I despatched two days before. After some delays in fording the Rio Grande, I reached my old quarters at Magoffinsville, opposite the town, at 10 o'clock, P. M.

August 18th. The remainder of the party were unable to get through last night, and came in this morning.

Of this journey, now concluded, which embraced about eleven hundred miles, about one half was performed while the thermometer ranged above $100^{\circ}$ during the day, and the other half when there was scarcely a day without a heavy rain. To Lieutenant Whipple, the chief engineer and astronomer in charge 
of the survey of the Gila, and his several assistants, the government and the country cannot award too much praise for its successful accomplishment under such privations, and hardships, together with so many and such serious difficulties.

As regards the health of the party on this journey from California, it was generally good. A few cases of scurvy occurred among the escort; and during the last two weeks before reaching El Paso, many began to be afflicted with rheumatism, and fever and ague, from their constant exposure for thirty-four days to rains. There were also some cases of bowel complaints from time to time; but all readily yielded to medicine. One most painful casualty it was our lot to meet with, in the death of the excellent officer and friend who commanded our escort, Colonel Lewis S. Craig. 



\section{SIXTH DIVISION.}

\section{EL PASO TO THE GULF OF MEXICO.}

\section{CHAPTER XXXVII.}

\section{INCIDENTS AT EL PASO DEL NORTE.}

Preparation for completing the Survey of the Southern Boundary of New Mexico-Withdrawal of the military from El Paso-Importance of El Paso as a military post-Its business-Encroachments of the ApachesDepredations of the Comanches-Suggestions for a better protection of the frontier-Colonel Langberg-Visit to Fort Fillmore-The Mesilla valley - Visit to the Organ Mountains-Silver mine-Grand sceneryReturn-Bracito and its battle-field-Preparations for leaving El Paso - Mail party attacked by the Comanches-Decide to go by way of Chihuahua-Laxity of the Mexican Custom House-Departure of Lieutenant Whipple and party for the Gila-Organization of parties.

THE first step now to be taken was to close up all the business of the Commission, and to prepare for joining the surveying parties on the lower Rio Grande. I had advices here from Major Emory, the principal Surveyor of the Commission, advising me of the progress made. on that portion of the line. Two parties had been actively engaged in the work; and Major E. believed the survey would be completed as far as Loredo by 
October, and the whole line to the mouth of the river by the 4 th of March, 1853, if no unforeseen obstacle was placed in the way.

There yet remained to be completed that portion of the line on the parallel of $32^{\circ} 22^{\prime}$ north latitude, which was to extend west three degrees from the Rio Grande, and thence north to the Gila. Of this line Lieutenant Whipple, while acting as chief astronomer, had surveyed and laid down with great minuteness about one half, and had also determined and marked its western termination. I now directed the same officer to organize a party, and as soon as the train could be got ready to take the field again, to resume and complete the survey of the line referred to, in the same manner in which he had begun it.

The next step was to prepare for the return of myself and party, to rejoin Major Emory at Eagle Pass (Fort Duncan). More wagons had to be procured for Lieutenant Whipple as well as for myself; and all those that had come through from California required more or less repairs. The harness, tents, and camp equipage too required a thorough overhauling; as the continued wet weather and constant marching had told severely on every thing. I was so fortunate as to find mechanics here, who were at once employed and set to work. In the mean time the mules had to be brought to a condition fit to undertake as long a journey as that they had just completed. They were, therefore, given rations of corn and sent to the mountain near, where there was grama grass in abundance. But they had become so thin, that many weeks would be necessary, under the best care, to bring them up. 
I was sorry to find on my arrival, that the military post, which was here when I left the year before, had been broken up and the troops withdrawn, with the exception only of a small detachment under Lieutenant Wilkins, which was quartered at Mr. Magoffin's rancho, in the same building where I was. To the regret of all the inhabitants, even this small force was withdrawn a few weeks after.*

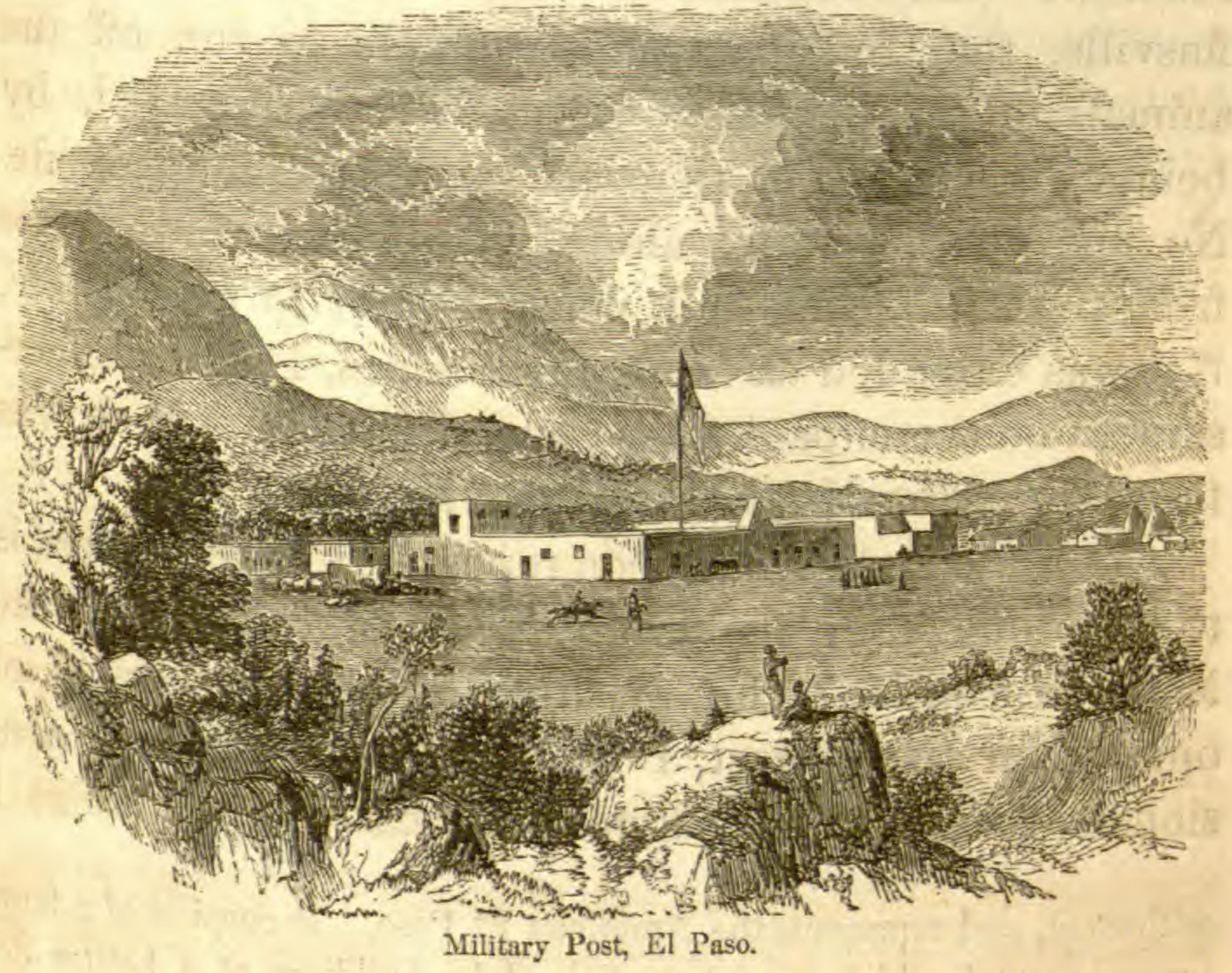

* The town of El Paso del Norte, so frequently alluded to, is on the Mexican side of the river. On the American side there was no settlement until after the war, and the rich bottoms were but partially eultivated or suffered to run to waste. At present, there are three settlements here, viz., Mr. Coon's rạnch with its adjoining buildings, which was formerly the military post; Mr. Stevenson's ranch, with another group of buildings; and Magoffinsville. This last is now the prineipal 
The Apaches had been more bold than usual during the spring and summer of 1852 ; and the whole frontier had suffered from their inroads. Many men had been killed within a few miles of El Paso; and at the astronomical observatory, at Frontera, eight miles distant, a man was pierced with arrows while herding the animals within a few rods of the house. Mr. Magoffin's corral had been several times entered, and his mules stolen; and many other citizens there had been sufferers. On two occasions, while I remained at Magoffinsville, the Indians made attempts to run off the animals of the Commission, but were frustrated, by being discovered in time to prevent the stampede. No one could venture alone, with safety, three miles from the settlement, and when I went to take a ride, if it was extended as far as three miles, I felt it necessary to be accompanied by several friends. Such was the state of the Mexican frontier in $\mathbf{1 8 5 2 .}$

As the question has been repeatedly asked, What is to be done with the large tribes of Indians on the Mexican frontier? and as there is still a diversity of opinion on the subject, I shall take the present occasion to make a few suggestions, based upon what I

settlement, and represents the American El Paso. It consists of a large square, around which are substantial adobe buildings of a better description than usual, embracing some six or eight large stores and warehouses, well filled with merchandise. This town is admirably situated, and belongs wholly to James W. Magoffin, Esq., an American, long resident in Mexico, whose energy and public spirit will undoubtedly make it the principal place on the frontier. Its position, as astronomically determined by Lt. Whipple, is, Latitude North, $31^{\circ} 46^{\prime} 05^{\prime \prime} 5$. Longitude West from Greenwich, $7^{\circ} 5^{\prime} 24^{\prime \prime}$. Distance due South to the centre of the channel of the Rio Grande, 2,226 feet. 
have learned from personal observation, and my intercourse with the Indians.

It is known that we already have along this frontier, but chiefly in the State of Texas and the territory of New Mexico, a large military force, embracing full two-thirds of the army, which is supported at an enormous expense. Military posts have been established at various points on the Rio Grande, and in the very heart of the Indian country, in Texas, and NewMexico. Yet two of the largest and most widely spread tribes, the Comanches and the Apaches, are as actively hostile to the Americans and the Mexicans as they were before the country occupied by them, became a part of the Union. At no period have the incursions been more frequent, or attended with greater atrocities, than at the present time. The Comanches pass across the Rio Grande into Mexico, in bands of 300 or 400 , and penetrate the very heart of Chihuahua; they have passed into Durango and Zacatecas, and have traversed Coahuila and Nueva Leon. The extent of the depredations and murders committed by them would be appalling, if summed up.* Yet the system flourishes in full vigor, notwithstanding the efforts made to suppress it on the part of the United States, in compliance with the solemn stipulations of the Treaty with Mexico.

The depredations of the Apaches are less serious, only because their numbers are less, and they have a more thinly settled country for their operations. In

* Some idea of the extent to which this predatory warfare is carried on, can be formed from the following report of the amount of stock stolen by the Indians in the territory of New Mexico, from the 1st of August, VOL. II. -25 
Mexico these are confined to the northern portions of the States of Sonora and Chihuahua. These regions, once inhabited by a peaceful and happy population, are now deserted, and the fertile valleys they tilled are reverting to the condition of a wilderness.

The numbers of both these tribes have been, in my opinion, much overrated. That of the Comanches, from the most reliable information I could obtain, falls short of 12,000 . Their range is from the Mexican States alluded to, to the Buffalo region, north and east of Santa Fé. In the fall and winter season their home is near the Rio Grande, in the Bolson de Mapimi, a vast basin shut in by high mountains at the west. Here they enjoy uninterrupted possession of a wide extent of country, whence they make their sallies into the heart of Mexico. The Apaches, whose number does not exceed 5000 , ${ }^{*}$ extend from the vicinity of the Pecos through the States of Chihuahua, Sonora,

1846, to the 1st of October, 1850, as taken by the Assistant-Marshals of the United States:

\begin{tabular}{|c|c|c|c|c|}
\hline Counties. & Sheep. & Males. & Horses. & Horned Cattle \\
\hline Santa Fé & 16,260 & 570 & 267 & 894 \\
\hline Taos & 17,080 & 1,032 & 1,764 & 5,600 \\
\hline Rio Arriba & 43,580 & 1,960 & 658 & 2,382 \\
\hline San Miguel & 50,000 & 7,000 & 3,000 & 21,000 \\
\hline $\left.\begin{array}{c}\text { Santa Aña and } \\
\text { Bernardo }\end{array}\right\}$ & 154,915 & 749 & 987 & 1,302 \\
\hline Valencia & 171,558 & 376 & 372 & 1,463 \\
\hline Total, & 453,293 & 12,887 & 7,050 & 31,581 \\
\hline
\end{tabular}

* It is no easy matter to form a correct estimate of the number of Indians in a tribe, unless they are actually counted. This is evident from the varying reports of different agents and travellers. In the tables of the Indian population of the United States, in Mr. Schoolcraft's great 
and the territory of New Mexico, to the confines of the Colorado of the West. They are less nomadic in their habits than the Comanches, and have districts in which their families permanently reside.

This tribe, from the time they are first mentioned by Father Kino, in the year 1694, have been a nation of robbers. Their hand is against every other tribe, and that of all others against them. It was they who drove out the peaceable people and semi-civilized tribes from the Gila, and destroyed the builders of the ancient edifices we have spoken of. Every account we have represents them as a treacherous and bloodthirsty people, living by plunder alone. They have made repeated treaties with the States of Sonora and Chihuahua, only to be broken on the first favorable opportunity; and the treaties recently made with the United States have been as little regarded.

I proposed to the principal chiefs that they should abandon cattle-stealing, and cultivate the ground; telling them if they would do so, the U. S. government would instruct and protect them, giving them blankets and clothing besides. The old chiefs said they could not adopt this new fashion, although the boys and

work, the Comanches are variously set down, from the year 1846 to 1850 , at from 12,000 to 20,000 . The Apaches embrace so many bands, and are so widely scattered, that it is extremely difficult to enumerate them. $\mathrm{Mr}$. Schooleraft, from the latest authorities, puts the Apache bands in Texas at 3500 in New Mexico at 6000 , and in the unexplored parts north of the Gila at 2000 , making altogether 11,500 ; which I think too high. It is unusual to find 200 of them together; and throughout the States of Sonora and Chihuahua, I heard of the same chiefs that we met and with whom we kept up so long an intercourse at the Copper Mines, and who were, of course, accompanied by the same bands. 
young men might do so. They said they would not rob or murder the Americans, but could not be brought to promise the same with regard to the Mexicans.

What, then, is absolutely necessary, for the sake of these Indians themselves as well as of our frontier population, is to convince them of the overwhelming superiority of force on our side; and to show them that, if they wish to escape utter extermination, they must lay aside their predatory habits, and learn to live by the labor of their own hands.

To effect this, a change should be made in the system pursued at the frontier posts. Soldiers should not go into quarters, and then quietly remain devoting themselves to agriculture. Better would it be for the government to pay double the price it now does for its wheat and corn, than to employ the soldiers in cultivating it; for the consequence of the present system is, that by their attending to the fields, they become unfitted for and neglect their proper duty as soldiers.

I would suggest, that with the opening of the spring, the soldiers should leave their quarters, and be kept moving from one point to another. Let them be a few days in a mountain pass, next at some oasis in the desert whither the savage must resort to satisfy his parching thirst, and again in some of those beautiful valleys covered with luxuriant grass, which are also his resort after his predatory excursions, that he may recruit his animals. This active life would be much more agreeable and healthy for the men than the inactivity of a garrison, and would tend more to overawe and'subdue the Indians. 
A difficulty arises when the Indians, on being pursued, take refuge in Mexico, where our troops cannot follow them. Some arrangement should be entered into by which small bodies of U. S. soldiers may be permitted, on such occasions, to enter Mexican territory within prescribed limits. This plan would be agreeable to the Mexican authorities, as they informed me.

I have no doubt that much might yet be accomplished by sending suitable agents among the Indians; men who are at heart philanthropists, and who will earnestly engage in the work of ameliorating their condition. Much good could be done, too, by sending mechanics among them, particularly carpenters and blacksmiths, also a supply of implements of husbandry. Most of the tribes beyond the Rio Grande are more or less agriculturists; and an attempt should be made to bring the wild Apaches and Comanches into the same condition. The pursuit most immediately adapted to their nature and habits would be the raising of cattle and mules; a business which they could most profitably pursue, and which they fully understand already. The rising generation could be advanced a step further, and taught the first principles of agriculture.

A plan has been proposed in California to drive all the tribes of that country to New Mexico. This is wrong; and the project ought not, for a moment, to be entertained. As a writer on the subject remarks, it would be "turning New Mexico into an area for the mutual extermination of the Indians, or else driving a portion of them from their old homes to join the 
predatory bands which are now desolating that country. The policy of concentration is a pernicious one, and can have but one result: it will stimulate their fondness for war, and render necessary an armed and an annihilating protection to our citizens. Besides this, there is but little game in that country, and the arable lands could not support such numbers as would be brought into it if the plan should be carried out.

- The only excursion I was able to make, while waiting for the train to be got ready, was to Fort Fillmore. Towards the close of September, Colonel Langberg of the Mexican army, and military inspector of the frontier, proposed to me to visit Colonel Miles, commanding at that Fort; I gladly took advantage of the opportunity.

On the day appointed I took my carriage, and, accompanied by Colonel Langberg, Dr. Webb, Mr. H. Jacobs, and ten dragoons, set off for Fort Fillmore, about 45 miles distant from El Paso; which we reached at sunset, and where we were politely received by Colonel Miles and the officers with him.

This Fort was established in 1851, when the military posts at Doña Ana and El Paso were abandoned; as it was thought that its position was better than either of those, and that it would be sufficient for this frontier. It contained at the time of our visit about two hundred soldiers, infantry and dragoons, under the command of Colonel Miles of the 3d Infantry. It occupied a commanding position above the bottom-lands; whence the valley of the Rio Grande can be seen for many miles. Nearly opposite is the town of Mesilla: and extending above and 
below it, is that portion of the bottom-lands known as the "Mesilla Valley," * which is now occupying the public attention, as connected with the boundary dis-

* Mesilla is the derivative of the Spanish mesa, table; and, as here applied, means a small plateau, or table-land, to distinguish it from the great table-land which extends for many hundred miles on both sides of the Rio Grande, and which is not susceptible of cultivation. It was without an inhabitant until the year 1850 .

At the close of the war with Mexico, the majority of the inhabitants of Doña Ana determined to leave that place, in consequence of the encroachments of the Americans, who endeavoured to despoil them of their property. Whether the Mexican occupants of the town and lands adjacent were the lawful owners or not, it is needless to inquire; it is sufficient to say that they had long been in undistarbed possession.

With this resolution, a spot was selected on the opposite or western side of the river, eight or ten miles below Doña Ana, which, it was believed, would be within the limits of Mexico. In the month of May, 1850 , this people established themselves there, and named the place "La Mesilla." To increase the colony, the government of Mexico offered to give lands to other actual settlers; which offer induced large numbers of dissatisfied Mexicans living in New Mexico and in the small settlements along the Rio Grande, in Texas, to remove thither. More than half the population of Doña Ana removed to Mesilla within a year.

When the boundary line was agreed upon, in December, 1850 , and it became certain that La Mesilla was south of it, the fears they had begun to entertain were removed, and a day was set apart for publie rejoicing. After this, the population increased much on account of the inducements offered; and in October, 1852, the Prefect of El Paso stated that it numbered 1,900 souls.

Very few Americans settled there-in fact, none but traders; and it is probable there never were twenty altogether.

Last summer (1853) some speculators attempted the same imposi-
tions as were practised when they were citizens of New Mexico, by
claiming their lands. This created such dissatisfaction, that they threat-
ened to leave, and again become citizens of the United States. At this 
pute. The town of Cruces is about three, and Doña Ara about eleven miles further up the valley. The bottomlands are exceedingly fertile on both banks of the river; and I am not aware that they are better situated or more productive on one bank than on the other. The barracks at Fort Fillmore are as yet quite rude, being mere jackals, that is, built of upright sticks filled in with mud. They were hastily put up; but it is the intention of Colonel Miles to have more substantial buildings of adobe erected forthwith. There is no better material in this country for buildings than this.

I took the opportunity while at Fort Fillmore to visit a silver mine, which had been discovered a few months previous, and which was now being worked by its owner, Hugh Stevenson, Esq., of El Paso. The mine is situated in the Organ Mountains, about eighteen miles east of the Fort; and as these mountains are the haunts of the Apaches, Colonel Miles kindly furnished us with an escort of ten dragoons, commanded by Major Steen, an officer familiar with this region, and experienced in Indian campaigns.

By taking an early start we reached the nearest point in the mountains, about twelve miles distant, before 10 o'clock, having traversed a desert plain with a gradual ascent the whole way. On reaching a defile which leads across the ridge. Major Steen and Dr. Webb took a portion of the dragoons and went to the

time some mischievous persons put the idea into their heads of saving their property by denying the jurisdiction of Mexico ; and this is doubtless the foundation of the statement that they desire to be annexed to the United States, 


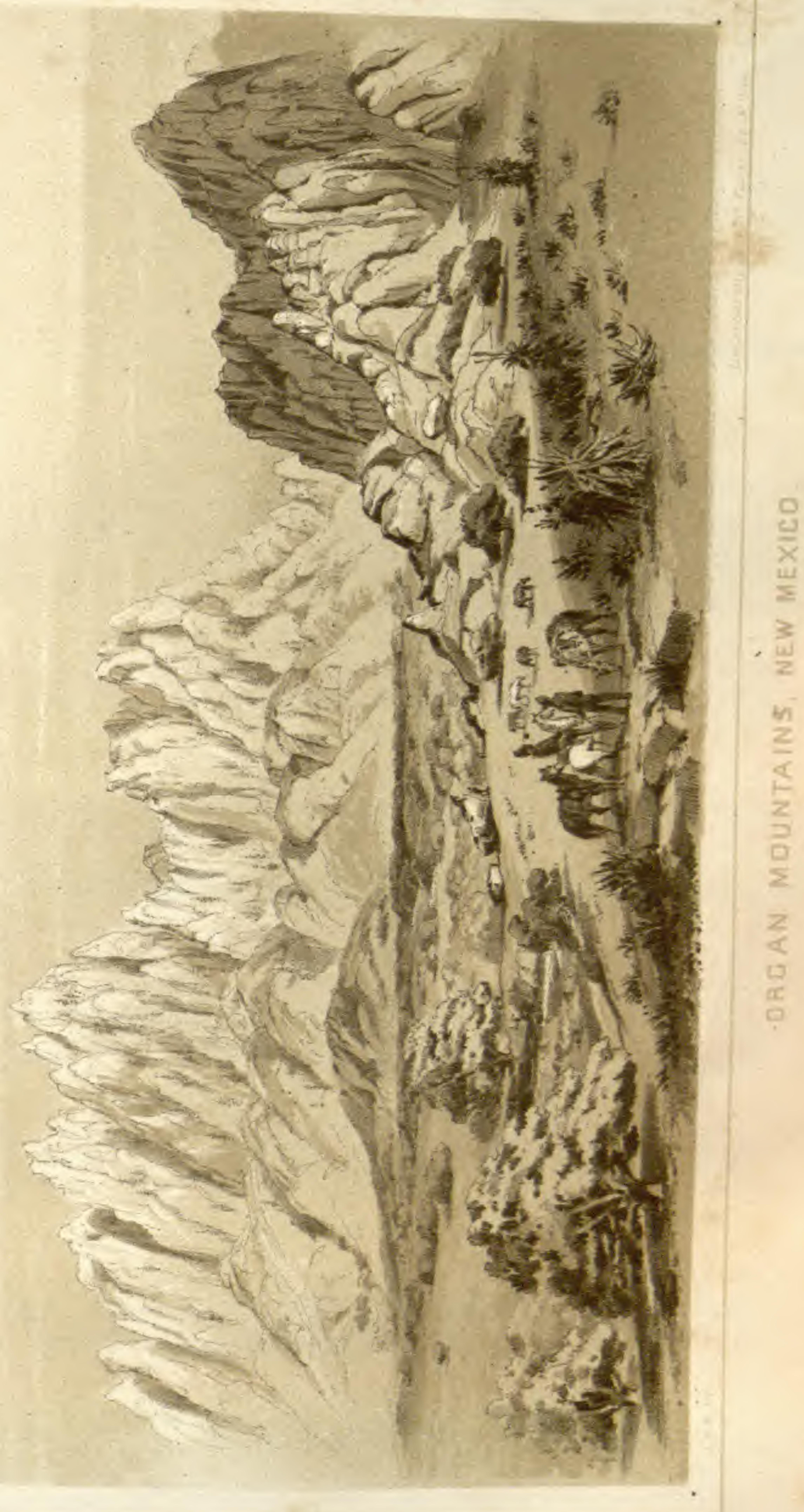




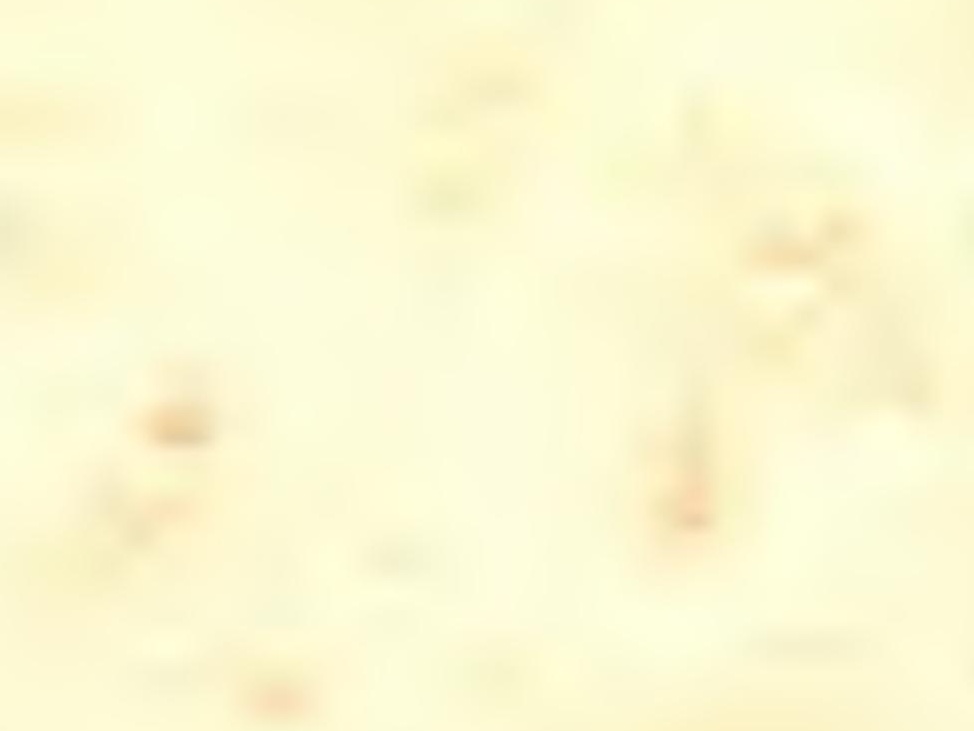

\section{$\sqrt{2}+x^{2}$}

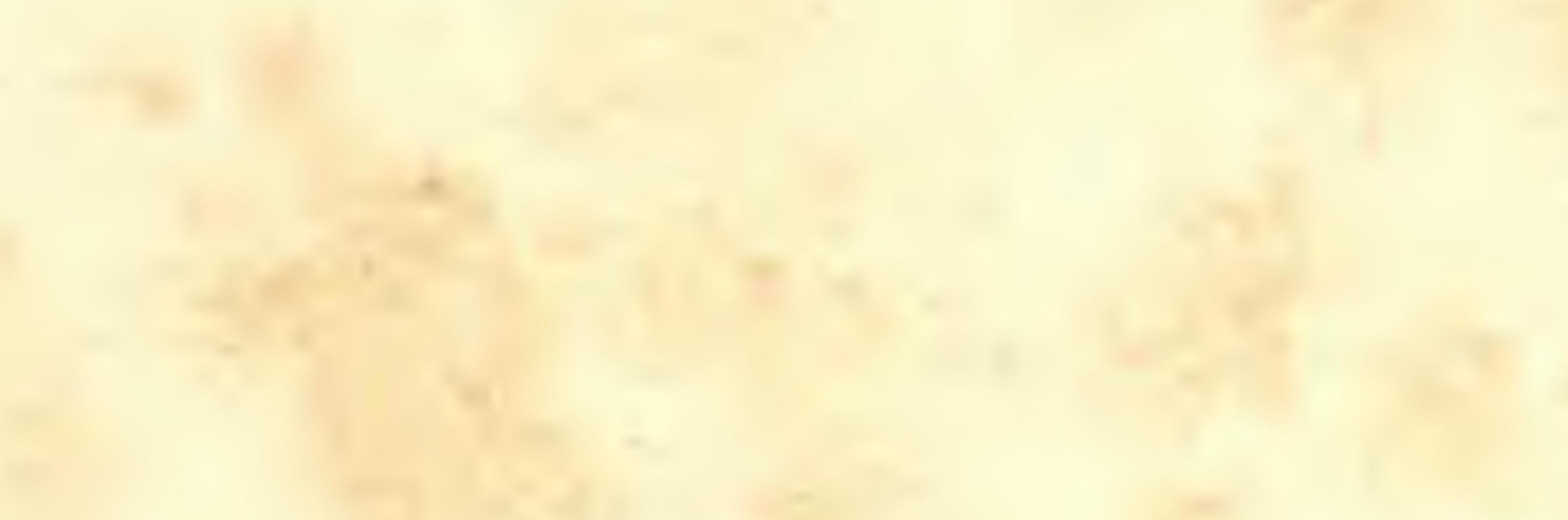

20.

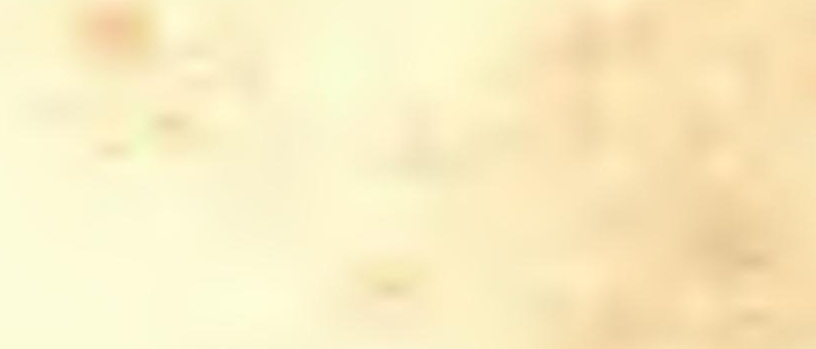

(20)

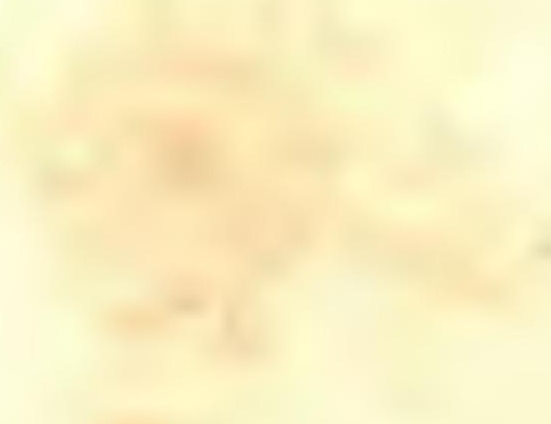

$+4+35$

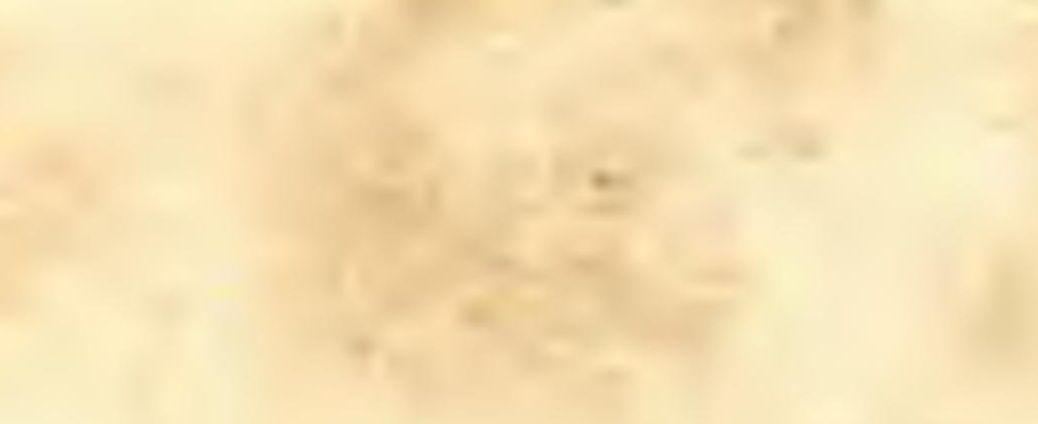

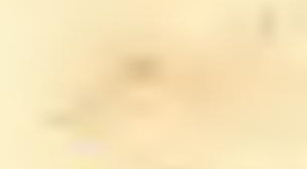

I

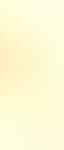


mine, which was about five miles farther to the north, while I remained with the rest to examine the defile. I then took my rifle, and walked a couple of miles through it and the deep gorges which indent the ridge. In this ramble I passed a beautiful little stream, which, rising far within the defile, wound its way along through

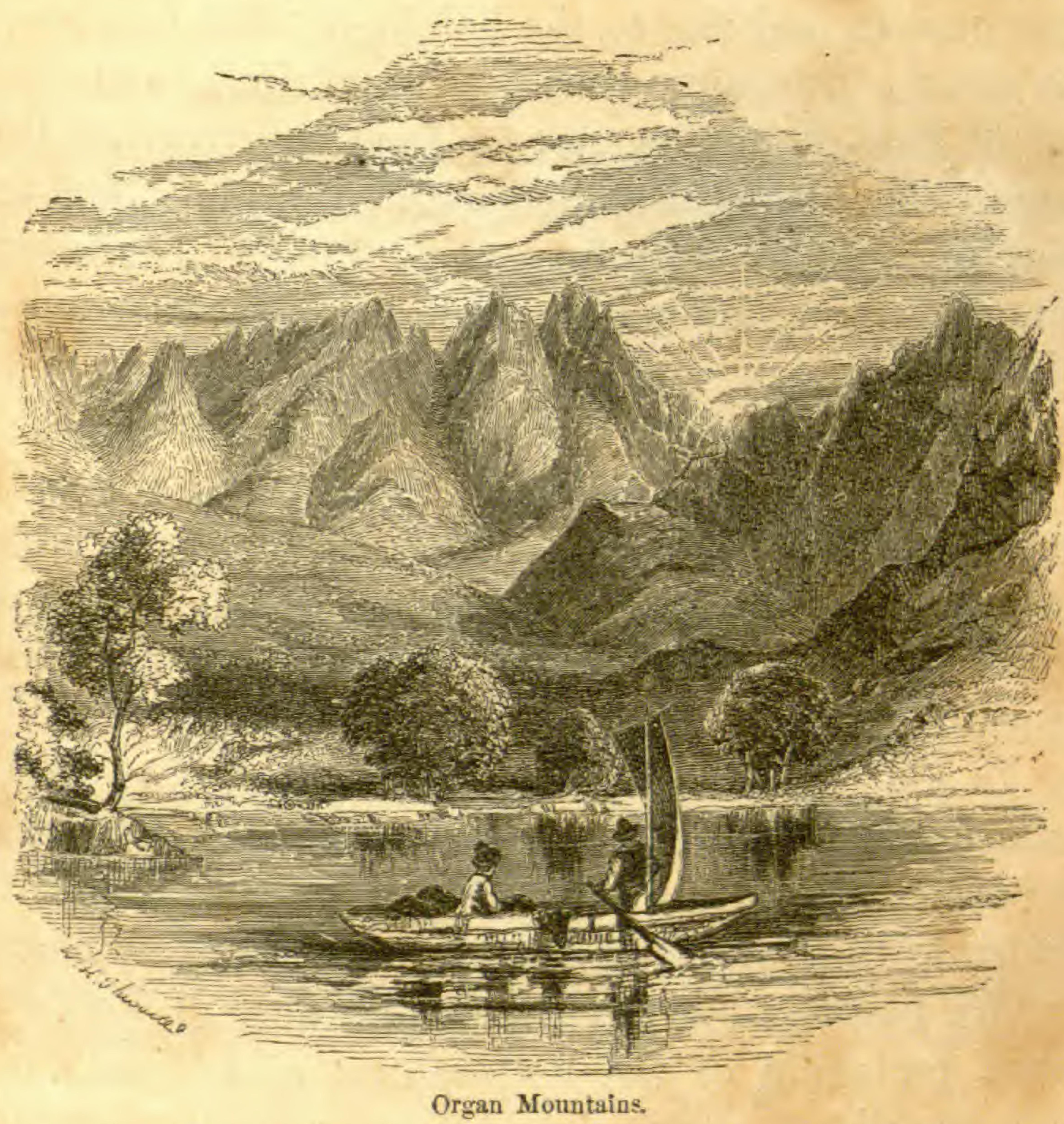

many intricacies, where it had worn for itself a deep bed, until it tumbled over the rocks in a single fall of some fifty feet. Although the quantity of water was small, the fall was exceedingly picturesque. When far up in this mountain, whither I was led with some of 
the dragoons in pursuit of a deer, we saw fresh Indian tracks; and not knowing but an arrow or a lance might be thrown at us from behind some rock or bush, we thought it best to return.

The "Sierra de los Organos," or Organ Mountains, are so named from their pinnacled summits and sides, which resemble the pipes of an organ. They are of a light gray granite, and rise to the height of 3000 feet above the river. The range runs north and south, and joins the El Paso Mountains, not far from the town of that name. The defiles are filled with large pines, and the more open valley, with live-oaks. Pine timber is here cut and drawn by mules to where it can be reached with wagons.

From the place where we halted and lunched, I took a sketch of these mountains and of the defile through which I had passed. A small stream flowed near us, marked by a line of fine large oaks. Midway between this spot and the mountains rises a bold mass of white granite.

In the afternoon Major Steen and Dr. Webb returned from the silver mine, bringing specimens of the ore. We then harnessed and saddled up for our return to the Fort, which we reached at nine o'clock.

We passed a few days very agreeably at Fort Fillmore, partaking of the hospitalities of Colonel Miles and his officers. This visit, too, was rendered doubly agreeable, by the society of four American ladies, belonging to the families of the officers, who had had the courage to accompany the army on its toilsome march of three months across the plains. These were the only American ladies I had met between San Antonio 
and the Pacific coast, and were, I believe, the only ones on this portion of the frontier.

On our return we made a noon halt on the banks of the river, near the spot where the gallant Doniphan won his first laurels, the battle-field of Bracito. Although this place is laid down on the maps, there is no town nor even a single habitation to mark the spot. The battle was fought on an open plain, the very last place one would expect the Mexicans to choose for meeting an invading army, unless confident, as it appears they were, of overwhelming them at once. Had the Mexicans taken a stand in the mountain pass, they might have given some trouble; but even then they could only have retarded a little the progress of the conquerors.*

* I quote from Colonel Doniphan's despatch a brief account of this affair:- " On the 23d of March, we commenced our march from Doña Ana; and on the 25th, our advance of 500 men had halted for the purpose of camping, about three o'clock. Our men were engaged in getting wood and water, when our advanced guard informed us the enemy was rapidly advancing at a short distance. The rear, under Colonel Jackson, was several miles behind; the rally was immediately sounded, and our forces formed in open order on foot as skirmishers. The enemy halted at half a mile, and formed in line of battle. Before we had fully formed, they sent a lieutenant near our lines with a black flag, with a demand that the commander of our forces should go to their lines and confer with their commander; declaring, at the same time, unless it was complied with, they would charge and take him, and neither ask nor give quarter. The reply was more abrupt than decorous- 'To charge, and be d--d.' At the return of the black flag, the enemy commenced his charge, and opened a fire on us from right to left, at about 400 yards. Our forces were ordered to receive their fire without returning it, until it could prove effective. Three rounds were fired by the whole line, before they had advanced within rifle shot. I then ordered their fire to be returned. This 
It had been my intention, when leaving El Paso, to take the San Antonio road as far as the Leona station, about six hundred miles, and there turn off to Eagle Pass, where I expected to meet Major Emory; and for this journey all my arrangements were made. The military escort was alone wanting, and this was one object of my visit to Fort Fillmore, where a portion of the company originally detailed for the purpose were waiting orders. Much to my disappointment I found there but twenty-four effective men belonging to the company, a number barely sufficient for an escort for Lieutenant Whipple.

In this position, I was at a loss what course to take, or how to get out of the country. Every small party coming through from San Antonio had been attacked by the Comanches; and accounts had reached El Paso that bands of three hundred warriors had been seen. At no time had there been so much alarm felt; and I was advised, by the army officers and others, who knew the state of the country, not to attempt the journey, with so small a party as -mine, without an escort. The officers and men of the Commission, myself included, had performed guard duty from the Pimo villages to El Paso; and we did not feel disposed to do it again on the long march to Eagle Pass. At this juncture

was done from right to left, along the whole line simultaneously, which completely checked their advance, and threw them into great disorder. A charge was now made, when the enemy fled to the mountains contiguous. The force of the enemy was 1220 , of which 537 were cavalry. *** The loss of the enemy was 43 killed, and 150 reported at El Paso to be wounded. Our loss was none killed-7 wounded; all since recovered." 
Colonel Langberg kindly tendered me an escort of Mexican soldiers, in case I would take the route by the city of Chihuahua, and thence through the States of Durango, Coahuila, Nueva Leon, and Tamaulipas, to such point as I wished to reach on the Lower Rio Grande. This offer, after due consideration, I accepted, and advised Major Emory of my decision, requesting him to meet me at a point lower down the river than Eagle Pass, which would probably be Comargo.

About this time the mail party from San Antonio arrived. They had been attacked and surrounded by a large body of Indians; but had kept their assailants at bay for several days, by entrenching themselves behind some rocks. This party consisted of men celebrated as Indian fighters, and was commanded by $\mathrm{Mr}$. Wallace, ane of the most intrepid and experienced men on the frontier. Every Indian who exposed himself was instantly brought down by a shot from the unerring rifle, until they were actually driven from the field. Mr. Wallace returned to San Antonio, procured a new outfit, and strengthened his party; he then set out again, and came through with the mail in safety.

During my stay here, one of those events took place which are not unusual on the Mexican frontier, and which sometimes produce a rupture between the Mexican government and its people.

It is known that the duty of sixty per cent. imposed by Mexico on many articles of merchandise, amounts to a prohibition. Yet, owing to the laxity of the customhouse officials, the law has been evaded, and goods regularly admitted at a mere nominal rate. Each collector knows that if he exacts the legal duty, either the 
merchandise will be smuggled in, or some brother-collector, less conscientious and more anxious to pocket the fees, will be ready to compound for a smaller sum. It accordingly became the practice to admit trains of merchandise for the interior of Mexico by paying five hundred dollars on each wagon load. This free and easy way of doing business had certainly the advantage of saving clerk hire, as well as removing the necessity of examining invoices, and all contention as to the cost or value of goods.

A leading merchant of the city of Chihuahua, who for some reason had become inimical to the government, had a train of some sixty or seventy wagons and carts filled with goods, on its way from San Antonio to that city, by the way of the Presidio del Norte. The authorities, being informed of the approach of the train, were determined that it should not pass without a thorough examination and payment of the full duties; to insure which, a military force was sent to the crossing place. In consequence of this unlooked-for obstacle, the whole train came up to El Paso, about two hundred miles out of its way, for the purpose of entering here; but the military force, which was under the command of Colonel Langberg, was ordered hither also, to prevent the entry of the goods except at the full duty. The collector of El Paso was disposed to pass the goods after the usual convenient fashion, in which he was supported by the merchants and municipal authorities of the place; while Colonel Langberg, acting under orders from the capital, was determined that they should not, and declared his intention to arrest and imprison the collector, Don Alejo Garcia Condé, 
if he did not strictly enforce the legal duties. The collector armed himself and his party, and the train prepared to cross and fight their way through. As might be supposed, there was great excitement, and it was feared blood would be shed; but the affair passed off quietly. The train crossed the river, each teamster armed with a whip and rifle; and to avoid a conflict, Colonel Langberg sent an armed guard with the train to Chihuahua, which was followed by the collector, to settle the difficulty there.

On the 1st of October, Lieutenant Whipple took his departure, to complete the survey of the line forming the southern boundary of New Mexico, before referred to.

Lieut. A. W. Whipple, Corps Top. Eng., Astronomer in Command. Hugh Campbell,

Frank Wheaton,

William White, JR.,

GEORGE G. Garner, First Assistant. Assistant and Topographer. Assistant.

Do.

These, with sixteen men as instrument carriers, mechanics, laborers, teamsters, servants, arrieros, etc., made the party. He had also a military escort of twenty-four men. They were all mounted, save the soldiers; while both wagons and pack-mules furnished the necessary transportation.

My own party, then about to leave, comprised,-

DR. Thomas H. Webb, .Sec. of the Joint Commission and Surgeon. HeNRY JacoBs, George Thurber, Assistant Secretary and Disbursing Agent. Henry C. Pratt, Acting Quarter-Master and Commissary, and Botanist. Draughtsman and Artist. 
The following gentlemen, belonging to the engineer corps, accompanied me, to join Major Emory and enter upon their duties on the lower Rio Grande.

Charles Radziminski, Principal Assistant Surveyor.

Malcolm Seaton, Assistant

Henry C. Force, Do.

Do.

John J. Pratt, of Lieut. Whipple's party, returning on account of ill health.

Wm. Ferguson, Carpenter.

Six teamsters, one carriage driver, and six men as servants, cooks, laborers, and herdsmen. 


\section{CHAPTER XXXVIII.}

\section{EL PASO TO CHIHUAHUA.}

Departure from El Paso-Accident at the start-Farewell to friends-San Eleazario-Fording the Rio Grande-Wagon upset-GuadalupeAscend the Table-land—Grassy plains and open country-Ojo de Lucero - Laguna de los Patos-Country overflowed-Wagon mired-More accidents-Carrizal-Ojo Caliente-Rin Carmen-Encounter with the Apaches-A man killed-Animals lost-Ojo de Callejo-Mexican soldiers-Precautions to avoid a surprise-Laguna de Encinillas-EI Peñol-El Sauz-Rio Sacramento-Battle field-Notice of the battleArrival at Chihuahua.

October 6th. All being in readiness to start, the train drew up in front of Mr. Magoffin's store-house, to take in a supply of corn. While standing here, the mules, which had not been in harness for six weeks or more, became uneasy, and, turning suddenly round, broke off two of the wagon tongues; which compelled us to wait another day for repairs.

There is no grass along the river after leaving Isleta. This made it necessary to send off a wagon load of corn, to be delivered to us about eighty miles ahead. In addition to this, each team carried a few bags.

voL. II. -26 
October 7 th. The broken tongues being replaced, the train moved off in the afternoon, in charge of $\mathrm{Mr}$. George Thurber, intending to go as far as Isleta, 12 miles distant.

October 8th. The day had now arrived when I was to take leave of my friends at El Paso. Friends at home, where we have numbers, are not always valued as they should be; but in a country like this, on the borders of civilization, one knows how to appreciate them. I had now been here seven weeks, and during the winter of $1850-51$, five months, while waiting the arrival of the chief astronomer. With many gentlemen here, particularly J. W. Magoffin, Esq., I had transacted business to a large extent, and in a manner which to me, as an agent of the government, was highly satisfactory. To them I take this occasion to express my sincere thanks for the promptness with which they fulfilled my orders, often to their own inconvenience, and for their uniform readiness in accepting my drafts upon the government, when a contrary course would have been detrimental to the public service, and would have subjected me personally to serious embarrassments.

On the occasion of our departure, Mr. Magoffin invited a number of gentlemen to partake of a cold collation, which proved to be one that would have done credit to the caterer of a metropolitan hotel. Although it is difficult at times to procure a piece of fresh meat at El Paso, the delicacies prepared in New York and Paris for foreign markets can always be found here in abundance, though at a high cost.

I left at one o'clock, and in the evening joined the 
train at San Eleazario,* where I passed my first night in camp.

October $9 t h$. The reloading of some of the wagons detained us here several hours, and my troubles with the men began. My cook took the opportunity to get drunk during the night, and for his bad conduct was put in the calaboose. By the aid of my friends here I was enabled to find a good substitute, and we soon after took up our march. The train consisted of my travelling carriage, a very convenient vehicle, which was to form my sleeping-place during the journey; the small wagon I brought from California, in which Dr. Webb rode; and six other wagons containing our provisions, baggage, tents, camp equipage, instruments, etc. All the party were mounted on horses or mules, and well armed; and for a change I had also provided myself with a riding mule. We got off at noon and made fourteen miles, encamping near a pool of water. Our route, most of the way, was along the Rio Grande, over a rich bottom, of which only a small portion was under cultivation.

October 10th. I rode on in advance with several others to examine the crossing, as it was necessary to , ford the Rio Grande here. To my surprise I found the banks very precipitous; and as the river was here much contracted, it was proportionably deep and rapid. With considerable difficulty and some risk I crossed in my carriage; and then, seeing the danger that would

* This name is also spelt San Elceario, which is, I believe, the original and correct mode. But as it is invariably pronounced Eleazario, and so written, by the people, I have adopted that orthography. 
attend the wagons, both in descending and ascending the steep banks, as well as in crossing the river, I hired a Mexican to take a note back to Mr. Thurber, who was with the train, advising him to send men forward with spades and pickaxes, to cut down the banks before the wagons should attempt to pass. 'I then rode on to Guadalupe, three miles ahead, for the purpose of procuring sheep, as well as to notify the Mexican escort, who were to join us here, of the approach of the train.

Colonel Langberg had promised me ten men, if I could wait a few days for their return from Chihuahua; but this I could not do, and was therefore obliged to take up with five, as but few now remained in the garrison. These men soon reported themselves.

After procuring the sheep, and while we were quietly waiting for the train to come up, a messenger arrived with the disagreeable news that the ambulance which contained the personal baggage of Dr. Webb, Mr. Jacobs, and myself, had been upset in crossing the river, and that every thing had been immersed in the water. I hastened back to the scene of the disaster, and found things worse than I had expected. Besides our baggage, a trunk filled with papers, maps, my account books, and the official records of the Joint. Commission, had been wet. Some choice stationery was utterly ruined.

We at once set to work, and spread every thing out on the patches of grass that were near and on the branches of trees; but although the sun was hot, there was not sufficient time to dry all before night.

October 11th. The forenoon was spent in drying our effects and packing them away again. At noon the 
animals were again hitched up, and we moved off once more, passing through Guadalupe, and stopped at a small lagoon, three miles beyond, where we encamped. We could have travelled a couple of hours longer, but were told there was no water within fifteen miles, which we could not make before dark, as a portion of the road was very sandy.

Guadalupe is a miserable looking village. It was founded in the year 1850, as a military colony, at a time when the Mexican government offered inducements to settlers to take up lands. Its population consists chiefly of persons from New Mexico, who preferred Mexican to American rule. Its houses are all built of upright sticks, the interstices filled with mud. There was but one shop in the place, and no mechanic except a blacksmith. There was nothing that indicated prosperity; and the contrast between this village and a new American settlement, was most striking. We looked about for vegetables in vain: a few watermelons were all the place afforded.

October 12th. Last night was very cold, so much so that three or four blankets were necessary. During the day the heat is quite oppressive, so that the thinnest clothing is required; but no sooner does the sun sink below the horizon, than the temperature falls to a degree that compels one to change one's garments and wrap up well in blankets. The mornings are equally cold, until the sun has been up at least three hours. By ten or eleven thick clothing is laid aside.

We left the valley of the Rio Grande to-day, and ascended the table-land, which was thinly covered with chapporal without grass. The road was sandy; 
yet we made fifteen miles, and encamped at Cantarecio, where there is a spring of good water.

October 13th. Our course was to-day south-west towards the direct route from El Paso to Chihuahua; and with the exception of a few places, the road was good. Mezquit grass occurred at intervals sufficient for grazing. No trees were seen, and scarcely any shrubbery; so that our cooks with difficulty procured enough to prepare our food. We made twenty-five miles (at least so it was called by the Mexicans), and encamped at Charco de Grado. The Mexican mode of measurement is very uncertain, unless practised by engineers. The water here is found in small pools, supplied by springs; but so meagre is the supply, that I doubt whether it can be depended upon in the dry season.

October 14th. Our course continued the same as yesterday, over a broad plain, unlimited by mountains, which showed themselves only at intervals of from ten to twenty miles in short ridges, their summits presenting a jagged and fantastic appearance. Turrets and cupolas, huge towers and castles, alternately were seen. These mountains appeared to be destitute of vegetation, except the grama grass, which grows on the debris from the base to the point where the bare rocks arise.

Fifteen miles brought us to the Ojo de Lucero (Venus's Spring), which furnishes but a small supply of water. We did not stop here, but pushed on to the Laguna de los Patos (Duck Lake), six miles further, and encamped near a spot where a stream of clear and delicious water crosses the road. This rivulet comes from a spring near by, and empties into a small 
pond containing a couple of acres, in which many ducks were seen.

Two miles before encamping, we entered the direct road from El Paso to Chihuahua. This road crosses the Medanos or Sand-hills, which we passed on our road from Correlitos to El Paso; and such were the difficulties then presented, that I determined not to attempt it again with wagons. Our route by Guadalupe required two days longer than if we had crossed the Sand-hills; but it was better to lose two days than to disable or break down our animals at the outset of a long journey.

The Laguna de los Patos is the outlet of the river Carmen; and is four or five miles across, varying in extent according to the rainy season. The body of water on our right was doubtless the effect of the late heavy rains; while that on the left, which is properly the laguna, is permanent.

A mile before reaching the lake is a smail hill some twenty feet high, on the top of which is a warm spring. In the plain on our right, which was more or less covered with water, at a distance of eight or ten miles, I had noticed during the day what I supposed to be clouds of dust or whirlwinds; but I afterwards learned from our Mexicans that it was steam from hot springs. The steam sometimes issued forth in jets, rising from fifty to one hundred feet high, and seemed to extend along the plain for a mile or more. I was desirous to examine these springs; but the intervening space was so much overflowed, that it was not considered safe to do so. I could obtain from the arrieros no information about them.

A number of ducks were shot near our camp. 
October $15 t 7$. On leaving this morning, we struck at once into the plain, which, as far as the eye could reach, was covered with water, appearing like a vast lake. We could trace the road by the tall grass and bushes, on which the water was from fifteen to eighteen inches deep. The ground being soft, our wagons sank deeply into it; and it was with the greatest difficulty that our animals could drag them through. A space of a few hundred yards would have been bad enough through such a depth of mire and water; but a steady tug of three or four miles was a very serious matter. Now and then the wagons would plunge into a deep hole, from which it was difficult to extricate them. In one of these the Doctor's carretella sank so suddenly, and to such a depth, that the king-bolt broke, and the fore wheels separated from it. Fortunately a small portion remained, which was kept in its place by straps. This was almost as bad as the deep sand, and we were obliged to make frequent stops to let the animals rest.

We at length reached dry ground, and the wagons succeeded in getting out, except one, the heavy "ark," which mired so deeply that the six mules could not extricate it. We doubled the team; but the mules being unmanageable in the mire and water, the tongue was snapped off. An hour or more was spent in splicing the tongue, when the twelve mules were again hitched on. When all was in readiness for another effort, men were placed with whips at each span of mules: at a given signal, the whips were simultaneously laid on; whoops and yells, mingled with a shower of oaths, followed, and the frightened animals made a united 
spring. The animals cleared themselves, breaking every chain, and leaving the ark where it was. Finding it impossible to extricate it with its contents, it was unloaded, and the twelve mules again attached, when another and united effort brought it to dry land. This was not effected until the men had been kneedeep in mud and water for four hours.

While this was going on we amused ourselves with collecting insects, reptiles, and other objects in natural history, of which quite a number were obtained. At one o'clock we again moved off, over a superb road, and in twelve miles reached Carrizal (country of reed grass), and encamped near an old acequia half a mile from the town, the water in which was scarcely fit for the mules to drink. I did not wish to go to the town, as experience had taught me that it was best to avoid the Mexican settlements. We had not been in one where the arrieros or teamsters did not get into a row, or return to camp in a state of drunkenness. Mr. Thurber rode to the town, and purchased a supply of corn sufficient to take is to Chihuahua, together with some goats, as sheep were not to be had.

Carrizal is an old dilapidated presidio, and now nearly depopulated; more than half the houses being tenantless. The lands about it are rendered fertile by irrigation, and in former years were cultivated. It derived some advantage too from passing travellers and caravans, as it is the only town between El Paso and Chihuahua. The inhabitants being completely at the mercy of the Apaches, they barely gain an existence; for these inveterate robbers boldly enter the place by day and help themselves to what they want; 
whether it be corn, a fat mule, or an ox. The people are too few to make any defence, and quietly submit to be plundered. At the last visit of the marauders, they entered every house, and each provided himself with a blanket, from the shoulders or beds of the inmates.

October $16 t h$. Our route continued over the same broad and boundless plain we had been traversing since we first ascended the plateau from the Rio Grande. Mountains were seen only at a great distance, while nearer at hand a few low hills rose up here and there. Twelve miles brought us to Ojo Caliente (Warm Spring). Although we had made but a short day's march, it was thought best to stop here; as there lay before us a jornada of fifty miles without water, which it would require two full days to accomplish.

Ojo Caliente is a spring which rises from the plain about one hundred and fifty yards from the base of a rocky hill. Its temperature is nearly the same as that of the atmosphere. A small pool about one hundred and twenty feet in circuit, and from three to four deep, is here formed, with a sandy bottom, from which warm water bubbles up in many places; this water has an outlet through a small creek into the river Carmen, in which creek some fish were taken and preserved for specimens. This basin afforded an excellent opportunity for a bath, and the whole party took advantage of it. A well built stone wall, about a yard in thickness, and laid in cement, is built across the basin, apparently for the purpose of raising the water. A portion of this wall is now broken away. I imagine it to be the work of the Spaniards, who, at some former period, have 
resorted hither for the benefit of the water. Notraces of buildings could be found near the pool; yet there may be in the plain near. It is now, and doubtless has long been the resort of Indians, as there are many mortars in the adjacent rocks. Along one side of the hill there appeared to be a rude wall; and on the summit were circles and heaps of stones, which bore the traces of fire. From here a most extensive view was presented, on three sides unobstructed by mountains.

October 17th. By seven o'clock, A. M., we had resumed our journey over an excellent natural road, equal to the best turnpike. About a mile from camp we crossed the Rio Carmen, a considerable stream, although dry during the summer, when the water is most wanted. Our course was due south; and during the thirty-five miles made to-day, not a hill, gully, or ravine, was passed. There was a gradual ascent for at least twenty miles, with no mountains in sight. A few rounded hills were seen at long intervals; and through the openings in these, the plain seemed to extend for sixty or eighty miles. It was covered with a luxuriant growth of grass, with scarcely a bush as large as one's finger. In order to advance as far as possible, we kept on till dark, and encamped without water. A few little twigs gathered as we came along, was all the fuel we could procure.

October 18th. Moved from camp a little after seven o'clock. The plain was open, except on our right, where, at a distance of a mile, ran a ligh range of hills. On starting, I rode on my mule a short distance ahead, accompanied by Messrs. Radziminski, Pratt, Seaton, Force, and Dr. Webb. Soon after we saw the 
train start; whereupon we held in our animals, that it might the sooner overtake us. About a mile from camp we passed a small arroyo, or ravine, pretty well filled with bushes. This arroyo was no sooner passed by the foremost wagon in the train, than we were startled by the most terrific yells and shouting; and on turning our heads, to our horror we saw a band of Indians issuing from the arroyo we had passed, and charging upon the train. We immediately turned about, put spurs to our animals, and rode back with all speed towards the train. The savages, who numbered between thirty and forty (as stated to me by those in the rear), were rushing at full speed with their lances poised, screaming and yelling, endeavoring to break the line and stampede the mules, as they crossed from one side to the other. Others followed, discharging their arrows at the teamsters as they passed; but the teamsters remained each by his team, keeping the mules in their places, and closing up the line: At the same time they kept the enemy at bay by levelling their pistols at them. These men had the presence of mind to keep their seats in the saddle and to hold their fire, which the savages wanted to draw. Had they fired and missed their mark (and the chances were ten to one against their hitting), they would have been pierced by a lance or an arrow the next moment.

The men who were riding by the side of the wagons sprang to the aid of the teamsters, and held the leading mules, which kept them in their places.

Failing in their attempt to frighten the mules and throw the train into disorder, the Indians dashed on towards the rear, and made a furious charge on the 


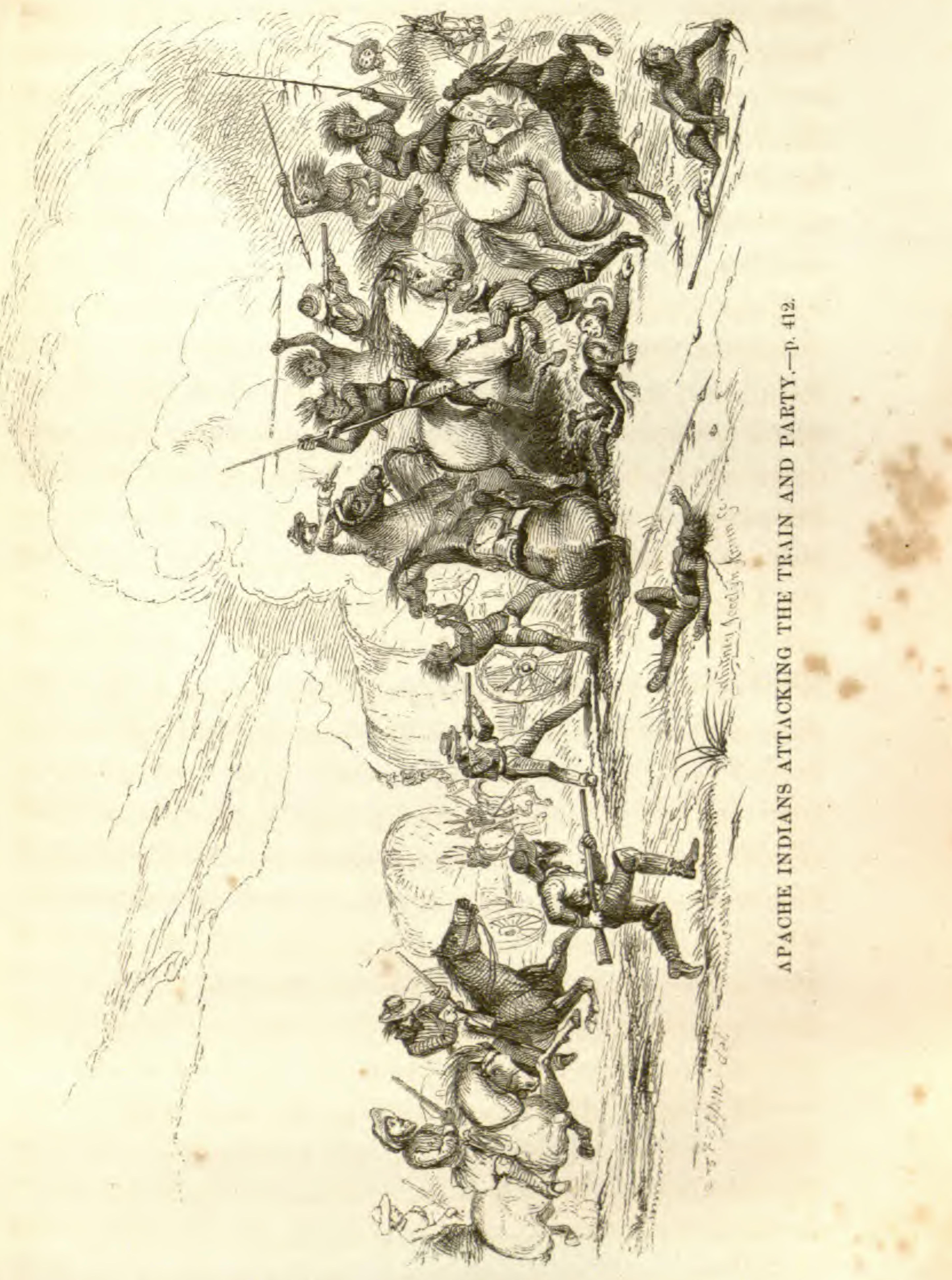


party there who were driving the spare mules and horses. Two Mexicans, herdsmen, were unhorsed by the charge; and a third, being wounded, fell from his animal. He, however, held on to his bridle, when an Indian rushed at him and pierced him to the heart with his lance. The momentary pause of this man made him a good mark for the rifle, and sealed his fate. Several were discharged at once, which brought the fellow to the ground. His companions seeing him fall, ran to his rescue, raised him up, and threw his bleeding body across a mule ridden by another Indian, when they rode off at full speed.

The firing now became general; but the constant motion of the enemy, enabled them to escape. The five Mexican soldiers, who were on foot, stood up to the fight manfully, and were in the thickest of it. They did much, too, towards saving the last wagon, which had got separated, and was one hundred and fifty yards in the rear. The driver of this team, when he saw the Indians between him and the rest of the train, jumped from his mule, and, bringing the leaders around, fastened their heads to the wagon. He then took out his rifle and stood on the defensive, levelling it at each Indian as he approached, and thus keeping them at bay.

The Indians next made for Mr. Thurber, who was still further in the rear, and at the moment engaged in putting some plants into his portfolio. They dashed at him with their lances, and he had barely time to seize his revolver, with which he kept them off. Our men were now close at the enemies' heels; so that, finding themselves in rather a tight place, they made for the 
adjoining hills, pursued by six or eight of our party. The fleetness of their horses and their knowledge of the ground, gave them the advantage; so that after a pursuit of a mile or two, we gave up the chase, fearing the train might encounter a larger body of Indians in ambush, for they scattered in all directions, and concealed themselves among the rocks or ravines of the hills.

The spare animals were all stampeded and lost. They became frightened at the first charge, and, not being fastened, were rushing at the top of their speed over the plain, driven by a portion of the enemy, before we who were in advance could reach them. We lost ten mules and a valuable horse-and secured the horse, saddle, and arms of the Indian that was shot. Two of the wagons were pierced with bullets, and several arrows were found sticking in the wagons near the teamsters.

We dug a grave by the side of the road, and deposited in it the body of the unfortunate Mexican who was killed. This being done, we hastened away from the sad scene, the first and only occurrence of the kind that had befallen the Commission since it entered the field, now more than two years.

We had proceeded but a few hundred yards when we noticed several heaps of stones, some of them surmounted by small crosses, to mark the spots where murders had been committed but a short time before, as appeared by their freshness. Fragments of clothing also lay around, showing that a severe contest had taken place. Fearing that the Indians might rally in larger numbers and renew the attack, two soldiers 
were sent ahead, while the others kept at a distance on the right and left, to give us early notice of the approach of danger.

Eight or ten miles brought us to a point opposite the Ojo de Callego (Spring of the Mountain Pass), a ravine in the mountain on our left, where there was a fine spring in a thick grove of cotton-woods. It seemed a likely place for Indians to conceal themselves in, and, with an enemy at our heels, we had no desire to stop there. We therefore filled our water kegs from a pool near at hand, without entering the ravine. A couple of miles further on, we passed the Ojo de Callecito, marked by a few cotton-woods on the mountain side. Soon after this, we met a body of about twenty Mexican soldiers in charge of a lieutenant from Chihuahua, bound for El Paso. They were the men who had escorted the merchant train from $\mathrm{El} \mathrm{Paso,} \mathrm{to} \mathrm{which} \mathrm{I}$ have before alluded. From them we learned that Armijo's train of empty wagons, which left that place the day before us by way of the Sand-hills, had been attacked by the Apaches near the place of our encounter with them, and had lost six men and thirty mules.

Continuing our march until dark, in order to get as far as possible from the scene of the morning, we encamped on the open plain, making a corral of the wagons and tents, and bringing all into as compact a space as possible. The animals were either tied up close to the wagons or staked within the inclosure, and the guard doubled for the night.

During the day's journey, which did not exceed eighteen miles, mountains were near us on the left. 
The grassy plain continued without bushes; so that we were obliged to gather up dried dung for fuel.

October 19 th. Before daylight the camp was called, and every man was perambulating the corral and the vicinity with his arms in hand; for it is well known that these savages generally take the dawn of day to surprise unconscious travellers. Sentinels were sent out to reconnoitre, and eight men to guard the mules while grazing.

At six o'clock, we moved again over an excellent road as before, the grass luxuriant as far as the eye could reach. Antelopes and deer were seen in herds bounding over the plain, sometimes coming within gun-şhot of us. A few shots were fired without success, the open plain preventing our hunters from getting as near as they wished. Fifteen miles brought us to the Laguna de Encinillas (Lake of Evergreen Oaks), which lay on our right, stretching far off into the plain in a southerly direction. It is said to be about fifteen miles long and three wide, varying according to the season and the rains. This lake, like all others on the high table, while it receives much water, has no outlet. Forming the basin of a vast plain, its waters rise with the rains, and in the dry season are much lessened, and sometimes nearly dry. It is only remarkable, considering the porosity of the soil, and the rapid evaporation from the dryness of the atmosphere, that the whole does not disappear before the return of the periodical rains. As the water was said by our Mexicans to be brackish, we supplied ourselves from a spring about a hundred yards from its shore. After the camp was arranged, I took my gun 
and went to the lake. On tasting the water, to my surprise I found it perfectly sweet, in fact better than that in the spring. It is therefore probable that after the rainy season the lake so fills up that its brackishness is overcome. Its shores, as well as the adjoining plain, are covered with what the Mexicans call tequesquite, or alkaline salt in a state of efflorescence. Brant, ducks, and plover abound in its waters, some few of which we shot.

Soon after we encamped, a stray ox was discovered among the mezquit bushes which skirted the base of the hills. We did not hesitate to drive him to camp for the benefit of the party; for we had been living on very poor goat's meat since leaving Guadalupe. This fine beef proved a valuable accession to our stock of provisions; as many could not stomach the meat of a poor goat, after he had been driven twenty or thirty miles.

Octaber 20th. We continued along the shores of the lake for fourteen or fifteen miles, through a plain covered with grass. This plain was ten-or twelve miles wide, bounded on the east by a range of hills, and on the west by rugged mountains. On the opposite side of the lake appeared a hacienda amid a grove of cotton-woods-a beautiful spot, which might compare with the highly cultivated grounds of a European nobleman; but the mark of ruin was upon it-the Apaches had driven away its occupants, and it was fast crumbling to decay.

Twenty miles brought us to $E l P e \tilde{n} o l$, a large hacienda, near which a herd of cattle was grazing. There did not appear to be any land under cultivation here: vOL. II. -27 
the raising of stock, for which the broad grassy plains are so admirably adapted, seemed to be the sole purpose of the establishment. Near by is a small stream of clear water, bearing the same name as the hacienda, which discharges itself into the lake. On the opposite side of the valley, to the west, and near the termination of the lake, is the village of Encinillas, consisting of a church and a cluster of adobe houses. This village, as well as El Peñol and the vast grounds adjacent, are the property of General Trias, formerly governor of Chihuahua.* His estates at the time of the invasion of the Americans contained many thousand head of cattle, which he gave to his government for the support of the army, and for which, I was told, he has never made a claim.

We passed to-day a train of mule-wagons and a carretella on its way to El Paso. There were but few persons in it, except the teamsters; among them, however, I noticed several women and children. We told them of the attack made on us by the Apaches two days before, and advised them to be on their guard. Three Americans and a Mexican, who were with the train, became so alarmed that they left it, and joined us, to return to Chihuahua.

October 21st. Continued our journey through the same valley, the mountains now converging to a point some miles in advance. In crossing Peñol Creek we found innumerable quantities of wild ducks. The surface of the water was literally darkened with them;

* Don Angel Trias was again chosen Governor of the State in the year 1853. 
and when at our approach they rose, the noise seemed like distant thunder. I shot twelve, and others of the party brought in numbers. They were all teal.

A few miles brought us to the hacienda of El Sauz (The Willow) - a building inclosed by a wall full twenty feet high. This estate also belonged to General Trias. We stopped a few minutes at the gate, and the occupants came out to meet us. We endeavored to buy eggs, poultry, or some other kind of fresh provisions, but found they had "nada," nothing, for sale. This establishment had likewise suffered from the Indians, notwithstanding its high wall, which would inclose many hundred cattle. On one occasion the savages for mere sport lamed a large number of these cattle, and filled up a well near by with their carcasses. On the opposite side of the valley is a village called El Sauzillos, or Little Willows.

After a march of twenty-four miles from El Peñol, we reached the Sacramento River, and encamped near the famous battle-field where Colonel Doniphan and his brave Missourians gained the decisive victory which resulted in the surrender of the city of Chihuahua.

The Mexicans did not show much judgment in the selection of this spot to resist the approach of the invading force. It is on the level summit of a plateau some sixty feet above the valley, and about half a mile in width. The plateau juts directly across the valley we had been travelling, and leaves but a narrow passage to the east. If the Americans had been obliged to march through this valley, the position of the Mexicans would have been a good one. But it was unnecessary for Colonel Doniphan to force a pass, and thus 
give the Mexican batteries full scope to play upon him, when, by diverging half a mile or less to the right, he could avoid them entirely. This he did without delay, unattended with loss; and on reaching the plateau, he advanced at once to the attack with an open field before him. By this course he exposed himself only to the right or western battery, on which he immediately opened his fire, striking terror into the ranks of the enemy, which retreated to the adjoining batteries and entrenchments. These also fell, the Mexicans retreating to a hill on the opposite side of the valley of the Sacramento, where the final conflict took place. This valley is less than half a mile wide, and is intersected by the river of the same name, a stream ten or fifteen yards wide, and about a foot deep.*

* I annex the most brief account of this battle, which is contained in the official report of Lieutenant Colonel Mitchell, one of the fieldofficers:

"Immediately after gaining the table-land on the enemy's left, I took command of the right wing of the army, in obedience to your orders, and at the same time gave the necessary instructions to the traders and teamsters in our rear, so as to form a field-work with the wagons to fall back upon in the event of our being too hardly pressed by overwhelming numbers. After the artillery firing (on both sides) ceased for a few moments, I ordered the right wing, consisting of about four hundred and fifty mounted riflemen, to advance in a gallop towards the enemy's entrenchments on their left.

"During this movement, a battery of five pieces of artillery on the point of a hill, six hundred yards to our right, opened an enfilade fire on the left of our column, which did no execution.

"By a rapid advance, we reached a deep ravine about one hundred and fifty paces in front of the enemy's field-works; here I ordered the troops to dismount and charge as skirmishers. The Mexican troops 
There is a hacienda with other buildings here. A portion of the valley might be cultivated by irrigation ; but it is for the advantages it offers for grazing, that the land is valuable.

October $22 d$. Chihuahua is called twenty miles from Sacramento, which is a large estimate. Resuming our journey this morning, we came in sight of the city on reaching the crest of an elevated plain ten miles distant, from which there is a gradual descent to the city. This plain is of a desert-like character, without grass, and covered with small mezquit bushes. As we approached, and when within four or five miles of the city, it presented a beautiful appearance, surrounded on three sides by picturesque mountains with bold rocky sides quite detached from each other. Chihuahua lies in a basin formed by these mountains, and is encompassed with fine large cotton-woods, from which

maintained their positions with much gallantry until we advanced within twenty or thirty paces of their entrenchments; at this distance the fire of our men was unerring, and any Mexican who raised his head above the breastworks fell. They soon broke and fled in the utmost confusion, and in every direction, towards the surrounding mountains. I immediately ordered the men to remount and charge the battery on our right, which was done in gallant style. When we reached the top of the hill we found that the Mexicans had fled, leaving the whole of their cannon, ammunition, wagons, etc. I saw them retreating in every direction on foot. As cavalry we could have followed and cut off great numbers; but the victory was complete, and I wished to spare the useless effusion of blood.

"The morning after the battle, I entered the city of Chihuahua at the head of two companies of mounted men and two field or mountain bowitzers from Major Clarke's battalion."-Report of Lieut. Colonel Mitchell to Colonel Doniphan. Executive Document No.1, 30th Congress, 1st Session. 
the towers and dome of its cathedral, and the spires of its lesser churches stand out in bold relief against the adjacent hills. To the right and left along the stream which waters it lie many large haciendas deeply buried in groves of luxuriant trees, presenting altogether the most charming landscape we had yet seen in Mexico. On the road we passed many men gathering fuel for the city market. This consisted of dried bushes and brushwood; which, when collected, they tied up in huge bundles, and carried in on their backs.

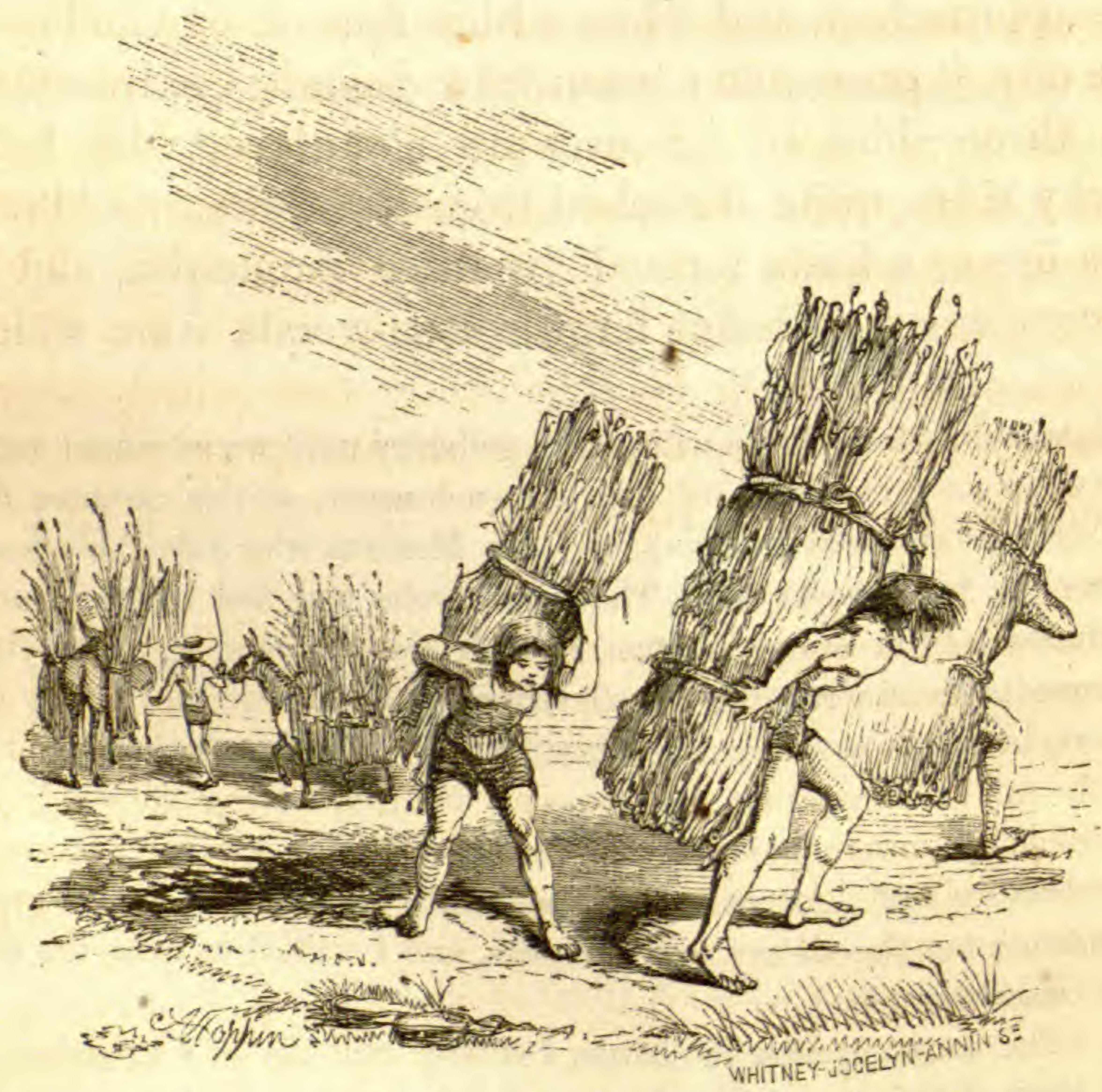

Carrying wood to Chihuahua.

Both men and boys were engaged in this business; some of whom we passed full six miles from the city, 
barefoot and almost naked, sweating under their heavy burdens. Donkeys in trains carrying wood, or completely enveloped in loads of dry corn-stalks, were also wending their way to market. These patient animals are much used by the poorer classes to carry their burdens.

I sent Messrs. Thurber and Jacobs in advance, in the morning, with my letters of introduction for Governor Cordero and General Trias, as well as to select a suitable place for an encampment. This they accomplished, and met us as we entered the city. We drove at once through the town amid a tremendous cracking of whips, which teamsters take particular delight in on such occasions, to the "Buen Viage," a large inclosure with a high wall. Within this all the wagons were driven, and on one side the tents were pitched. This was a great convenience to us, as we were free from the annoyance of the lazy, pilfering class which hover about a town, and by whom a train and party like ours would be considered fair game. 


\title{
CHAPTER XXXIX.
}

\author{
CHIHUAHUA AND ITS VICINITY.
}

Repairs on wagons-Mr. Flotte and his persecutions-The road infested by Comanche Indians-Guard hired-General Trias-Governor Cordero -A dinner and ball-Ladies of Chihuahua-Dinner to General Trias -Obtain important documents relating to the Boundary-Description of Chihuahua-Causes of its decline-Its mines-The expulsion of the Spaniards-Labors of the Jesuits-Aqueduct-The Cathedral-Mine of Santa Eulalia-Casa de Moneda-Commerce, how carried on-Agricultural products-Alfalfa and its value-Heaps of scoria-Grazing lands-The platean-Immense herds of cattle-Height of the tableland-Climate-Diminutive dogs.

OUR journey of two hundred and seventy miles from El Paso had disabled several wagons, which had now to be repaired. It was also necessary to replace the eleven mules we had lost. I determined to engage here a few additional men as a guard; as we yet had a journey of eight or nine hundred miles before us before we should strike the Rio Grande, the greater portion of which distance, I now learned, was infested with the Comanche Indians. This tribe is ten times more numerous than the Apaches; they are among the finest horsemen in the world, possess many fire-arms, which they know how to use, and go in large bands. They are, therefore, far more to be dreaded than the Apaches, whose range we had now passed. 
We had no sooner arrived, than the character of our party was known throughout the city; and many applicants appeared in quest of employment, most of them persons who wanted to get to their homes. Among these were several Americans from Texas, who had come here with merchant trains, and been discharged They earnestly begged for situations, or to be permitted to accompany the train for the protection it would afford them. I selected such men as I required, among them an excellent blacksmith, whom 1 wanted exceedingly, and could not procure at El Paso.

The American consul, Bennet Riddells, Esq., called the morning after our arrival. This gentleman has long resided in this city, and is married to a Mexican lady. Having letters of introduction to a number of the principal citizens of the place, Mr. Riddells accompanied me in delivering them. Among the gentlemen on whom I called, were Señores Chaves, Zuloaga, and Jaques, Captain Bustamente, and Dr. Dubois, the last a French physician of high scientific attainments, and long resident in Chihuahua. Several of the American residents called on me during the day, among them 'Mr. Lewis Flotte, of Barranca Colorada, the gentleman whose silver mine and smelting works I visited on my way from Correlitos to El Paso.

I heard from $\mathrm{Mr}$. Flotte, a reiteration of what I had been told at Correlitos, and at the mine, of his persecutions; in consequence of which, he had been driven to the extremity of selling his mine as well as his estate at Barranca, at a great sacrifice. He had endeavored in vain to obtain protection of the State authorities. The statement of Mr. Flotte was corrobo- 
rated by the American Consul, who was familiar with the facts; and I learned from them that the matter would be laid before the United States government.

General Trias called, and very politely tendered me a furnished house while I remained in Chihuahua; which, however, I declined. Experience had shown us that after once going into camp life, it is better to remain there steadily. One soon becomes accustomed to a tent; and even in cold weather, it is preferable to quarters, unless one is to remain permanently in them. The change from one to the other, invariably produces colds.

General Trias, who was for several years Governor of the State of Chihuahua, is a gentleman of large wealth and fine accomplishments. After receiving his education he went to Europe, where he spent eight years travelling in various parts, although he remained most of the time in England and France. He is well versed in several of the European languages, and speaks English with great correctness. Of English literature he told me he was very fond; and he considered that no native appreciated the beauties of Shakspeare and Milton better than he. With Addison and the belles-lettres writers of England he was also familiar. With large estates, a cultivated mind, and elegant manners, General Trias cannot but exercise a great influence in the State. I have before mentioned the sacrifices he made when his country was invaded by the Americans, which greatly impoverished him. There are not many such patriots in Mexico; if there were, she would not be in the position she now is. There is no doubt that General Trias detests the Americans as a people; yet 
American gentlemen and officers who stop at Chihuahua, are always treated by him with great politeness and attention. He is ardently devoted to Santa Ana, and is considered at the head of the war party in his State.

Governor Cordero, who also honored me with a call, is the entire reverse of General Trias. He is a merchant and banker, the owner of a very large landed property, and is considered the richest man in the State. As a politician, he is at the head of the moderate party.

A few days after our arrival, I heard that the train we passed on its way to El Paso was attacked by the Apaches at the same place where we had the encounter with them, and that it lost twenty-eight mules. Several men were killed, and three of the women made captives.

On the 28th, I was invited, together with the officers of the Commission, to a dinner given by General Trias. Besides the gentlemen who accompanied me, there were about forty others present, embracing officers of the Mexican army and citizens of the place. The entertainment was conducted in true Mexican style, embracing a great variety of dishes served up in as many courses. The waiters were all soldiers, and performed their duty as well as the trained functionaries at our large hotels. A band of music was in attendance, and the affair was, on the whole, an elegant one. Patriotic toasts were drunk, and among those given by the Mexicans were Washington and Franklin. In return we gave the heroes of the Mexican revolution, Iturbide, Hidalgo, Allende, and Jimenez.

On leaving the table, we adjourned to the drawing 
room, where a large number of ladies soon after assembled to a ball. This was an afterpiece as unexpected to us as it was agreeable. The Mexican ladies, it is well known, have a great passion for balls, and are most graceful dancers. They kept it up incessantly, alternating from quadrilles to waltzes and polkas, without manifesting the slightest fatigue. The music was very good, consisting of harps and violins. One would hardly expect to find in a town situated as this is, on the very confines of civilization, twelve hundred miles from the capital, and six or eight hundred from either ocean, so much elegance of manner and taste in dress; for few of the ladies had ever been from home. Many possessed as fair complexions as English or American ladies, although the brunettes predominated. The Mexican like the Spanish ladies have a natural gracefulness of manner, which has been observed. by all travellers, and has captivated most foreigners who have taken up their residence in the country.* On this occasion, one would imagine the most fashionable dress-makers and hair-dressers had been employed, and that Stewart had a branch of his great New York establishment here, from which the gorgeous silks and satins and elegant muslins displayed in such profusion had been procured. I noticed one custom, however, which the Chihuahua ladies have not borrowed either

* It is a fact worthy of mention, that every married American or European whom I met at San Diego, Guaymas, Mazatlan, Hermosillo, Ures, El Paso, and Chihuahua, had, without a single exception, a Mexican wife. Subsequently, in my visit to Parras, Saltillo, and Monterey, I found it to be the same; nowhere did I meet with an American or foreign lady. 
from New York or Paris. This was smoking cigarritos between the dances. It is true these little cigars are mild, and, being exhausted with a few puffs, are not accompanied by the filthy practice of spitting. Gentlemen use their cigars also in the ball-room; so that at times one hás to confront quite a cloud of smoke.

A few days after this entertainment, I invited General Trias, four of his officers, and the American consul, Mr. Riddells, to a dinner in my tent, that number being as many as it would accommodate, with the gentlemen of the Commission who were present.

I took advantage of my stay here to seek for information relating to the northern boundary of the State, and was so fortunate as to find in the Governor's office a large manuscript map of the State of Chihuahua made by Don Pedro Garcia Conde, and Mr. Staples. It appeared that in the year 1833, the Legislature of the State ordered a geographical, topographical, and statistical survey to be made of the State. These gentlemen were the engineers in charge of the work, and the map alluded to was the result.

I also procured a copy of the Statistical Report or Essay made by the same commission," which report was presented to the government in the year 1836 and printed in 1842. In the map and Statistical Report the northern boundary of the State is laid down and defined in latitude $32^{\circ} 57^{\prime} 42^{\prime \prime}$.

Of the map a fac-simile was made by Mr. Radziminski, the principal assistant engineer of the Bounda-

* Ensayo Estadistico sobre el Estado de Chihuahua. Chihuahua, Imprenta del Gobierno, á cargo de Cayetano Ramos. 1842. 
ry Commission, and a certificate appended to it by Governor Cordero, stating that the original was made by Messrs. Garcia Conde and Staples, in the year 1834 . This is now in my possession.

I also obtained a certified copy of the $2 \mathrm{~d}$ Article of the Constitution of the State, in which the boundaries are defined, and which agrees both with the map and the Statistical Report.*

* The following is a copy of the Governor's certificate:

“Gobierno del Estado de Chinuahua:

"El ciudadano Jose Cordero, Gobernador Constitucional del Estado de Chihuahua,

"Certifico: que el articulo $2^{\circ}$, tit. $1^{\circ}$. de la Constitucion de este Estado, promulgada en 7 Diciembre de 1825 y reformada en 7 de Diciembre de 1847 , se halla redactado en los siguientes terminos.

"ARт. ${ }^{\circ} .2^{\circ}$. El territorio de Chihuahua es el que ha poseido $y$ se le ha reconocido hasta ahora entre los $25^{\circ} 53^{\prime} 36^{\prime \prime}$ y los $32^{\circ} 57^{\prime} 43^{\prime \prime}$ de latitud Norte; y entre los $1^{\circ} 30^{\prime} 16^{\prime \prime}$ y los $7^{\circ} 17^{\prime} 52^{\prime \prime}$ de longitud Occidental de Mexico, segun la carta geografica del mismo Estado, formada por los Señores Staples y Garcia Conde en el año de 1834.'

"Y á pedimento del Señor Presidente de la Comision de Limites de los Estados-Unidos del Norte D. John R. Bartlett, le doy esta en Chihuahua á veintisiete de Octubre de mil ochocientos cincuenta y dos.

(Signed)

( Signed)
Jose Codero,

Amado de la Vega.

Ofl. $1^{\circ}$."

" Consulate of the United States of America, Chindahu, October 28th, 1852.

"I, Bennet Riddells, Consul of the United States of America, for Chinuahua, Mexico, do hereby certify, that the above signatures of Jose Cordero and Amado de la Vega are genuine, and thąt Jose Codero is acting Governor of this State, and Amado de la Vega, first official.

"Given under my hand and seal of office,

"Bennet Riddelis, "U. S. Consul." 
Chihuahua is the capital of the State of the same name, and was settled towards the close of the 17th century by some adventurers, for the purpose of working the rich silver mines discovered about that time in its vicinity. When these mines were in their most prosperous state, the city contained more than seventeen thousand inhabitants. According to the census of 1833 , it contained ten thousand six hundred and two; and at the present time, its population does not exceed twelve thousand. This diminution is owing chiefly to the unsettled state of the country for the last twenty-five years. With the general expulsion of the Spaniards which took place after the revolution, this city, in common with every other in Mexico, lost its most active, enterprising, and intelligent citizens. Much of its wealth, too, was then carried away. After this, the mines, which had yielded an amount of silver almost unparalleled, and had enriched thousands, were but imperfectly worked, and many were in course of time abandoned. The rural population being thus deprived of its chief dependence, the haciendas and ranchos which dotted the beautiful and luxuriant valleys met the same fate. In this way Chihuahua has greatly decreased in wealth, in commerce, and in general prosperity.

There is still another cause for the decline of Northern and Central Mexico which deserves to be noticed. I allude to the expulsion of the Jesuits. Whatever may have been the sins ascribed to this religious order, it is an undeniable fact that during their sway these States attained a higher degree of prosperity than at any other period; and with them 
this prosperity departed. This remark will also apply to California while under the dominion of Mexico. No one has ever kept the Indians under such subjection as the Jesuits; and when the latter were expelled, all control over the former was lost. In every large town are seen the fine edifices which were in the course of erection by them. Chihuahua possesses one of these, a large church and college, the walls of which were nearly up. These buildings remain just as they were left.* An apartment in the college was the place of confinement of the patriot Hidalgo and his associates, who were executed here in 1811. It is now a blacksmith's shop.

The city is regularly laid out, with broad and clean streets, some of which are paved, and contain handsome and well-built houses, both of stone and adobe. When of the latter material, they are plastered or stuccoed, and afterwards colored or whitewashed. Most

* Christian sects may cavil about their success among the Indian tribes; but it is an undeniable fact, that the Jesuits during their sway accomplished more than all other religious denominations. They brought the tribes of Mexico and California under the most complete subjection, and kept them so until their order was suppressed. And how was this done? Not by the sword, nor by treaty, nor by presents, nor by Indian agents, who would sacrifice the poor creatures without scruple or remorse for their own vile gains. The Indian was taught Christianity, with many of the arts of civilized life, and how to sustain himself by his labor. By this simple means the Society of Jesus accomplished more towards ameliorating the condition of the Indians than the United. States have done since the settlement of the country. The Jesuits did all this from a heartfelt desire to improve the moral and social as well as the spiritual condition of this people, and at an expense infinitely less than we now pay to agents alone, setting aside the millions annually appropriated for indemnities, presents, etc. 
of them have but one story; yet they are large, and built in squares, with courts in the centre. Having thick walls and few windows, such dwellings are cooler and better adapted to the climate than if built in our northern mode. The rooms are always from fourteen to eighteen feet high, with brick floors, which contribute to their coolness.

An aqueduct supplies that greatest of luxuries, an abundance of pure water. It is well constructed of stone, and, with its long ranges of arches winding over the rough ground and spanning the valleys on its way to the city, presents a highly picturesque appearance. It was built at the close of the last century, and has an extent of about three miles and a half. In addition to this, a small stream runs by the northern part of the city; so that in respect to water, no city is better supplied.

The most important edifice in Chihuahua is its cathedral, or, as it is here called, the parochial church. This stands on one side of the plaza. It is built of cut stone, of a very light color, and has two well-proportioned towers and a dome. The people pride themselves much on this building, which is said to be only second to the great cathedral of Mexico. If strict adherence to the principles of a particular order of architecture constitutes beauty, this edifice will be found wanting. It partakes of the Gothic and the Elizabethan styles, with a profusion of ornament, similar to that which was practised in Spain after the expulsion of the Moors; still its appearance is very imposing, and is equalled by few churches in the United States. Its interior is less chaste than its exterior.

VOL. II. -28 
This church was erected from a fund raised by a tax of one real (twelve and a half cents) on every mark of silver (eight dollars) obtained from the mines of Santa Eulatia, five leagues from the city. The fund was collected during a period of seventy-two years, commencing in the year 1717 , and terminating in 1789. From it was built the Cathedral of Chihuahua, at a cost of eight hundred thousand dollars, and a church at Santa Eulalia at a cost of one hundred and fifty thousand dollars, leaving a considerable sum unexpended. From this may be formed some idea of the richness of the mines of this country. These sums, raised by a tax at the rate mentioned, would require a gross income on the part of the mine of fifty-one million two hundred thousand dollars to erect the former, and nine million six hundred thousand dollars for the latter edifice, or, together, sixty million eight hundred thousand dollars. Nearly a million of dollars a year, for seventy-two years.

The square on which this church stands is occupied with various public buildings; among which, on the east side, is the Governor's Palace, as it is called, but which merely embraces his reception room and the State offices.

There are several other churches in the city, which, though small, are built with much taste. One of these, Santa Rita, is shown in the sketch.

There is a Casa de Moneda, or Mint, here, which I visited. In it silver and gold are coined, but chiefly silver, and that by a most primitive process of manual power. Each State in which there are many mines has a mint, which is let to an individual or firm, and is 
not under the direction of the State or general government. For coining a mark of silver, without separating the gold, the charge is two reals (twenty-five cents); for coining and separating the gold, five reals (sixty-two and a half cents). This coin is said to yield a profit of five per cent. upon its current value at the United States Mint. It is put up in sacks of raw hide containing one thousand and two thousand dollars each. These shrink on drying, and press the coin so closely as to prevent friction. All the silver in the State contains gold, which is separated in large platina kettles, with the aid of sulphuric acid. I saw two of them, which had a capacity of about five gallons. They looked little better than our iron camp kettles, and cost five hundred dollars each.

Among other public places of note is an arena for bull fights, a favorite amusement with the Mexicans. An exhibition took place while we were here; but having once witnessed one of these cruel sights at El Paso, I had no desire to be present at another.

In an open square in another part of the city is a rude monument, of an obelisk form, to the memory of the heroes of the revolution, Iturbide, Hidalgo, Allende, and Jimenez, but without any inscription. On one side of this square was pointed out to me the place where the Emperor Iturbide was shot.

There is a large trade carried on here with the United States, by means of caravans or trains from Saint Louis, Missouri, and San Antonio, Texas. Until very recently, the trade was carried on wholly by way of Saint Louis, Santa Fé, and El Paso, a distance of more than one thousand five hundred miles, and re- 
quiring months for the journey. Latterly, a much shorter route has been opened by way of San Antonio and the Presidio del Norte, lessening the distance of land carriage more than one half. Formerly traders left Missouri with large trains of merchandise, and, on arriving here, opened their stores and sold their goods themselves. This was a very irregular business, leading sometimes to the accumulation of large stocks, and proving ruinous to some of the parties concerned. The trade is now more confined to the resident merchants of the city. Governor Cordero is one of the largest merchants; and next to him are several American houses of high respectability. There are now some fine stores in the town, in which every variety of merchandise can be procured.*

* If a merchant here desires to make his purchases himself in New York or our other great markets, he must leave here in the fall, when it will require from forty to fifty days to reach his destination, by way of New Orleans. His goods must then be purchased and shipped either to Indianola, on the Gulf of Mexico, to be sent by San Antonio, or to St. Louis, Missouri, and thence by water to Independence. Now comes the most difficult part of the transportation (say, for example, from the latter place). Wagons, mules, harness, and the various trappings must be purchased, and teamsters procured; all of which requires much time and a large outlay. The large Missouri wagons, which carry from five thousand to five thousand five hundred pounds, cost about two hundred dollars each; the best Kentucky mules, ninety to one hundred dollars; harness, one hundred dollars; water kegs, extra chains, ropes, etc., twenty-five dollars for each wagon. These large wagons require ten mules each; so that a complete team ready for the plains would cost from twelve hundred to thirteen hundred dollars; and twenty of these, which is not a large train, twenty-six thousand dollars. Then each team must have its teamster at from twenty to twenty-five dollars a month; and a wagon-master or director of the train at from eighty to one hun- 
In the vicinity of the town are many fine gardens, which are irrigated from the aqueduct or the natural stream. We were not here in the season to see their beauties, and I visited them but once. The fruits cultivated are apples, pears, peaches, figs, melons, and grapes. The variety of vegetables is not large; not on account of the incapacity of the soil or the climate to produce them, but for want of attention. Those generally cultivated are beans, peas, maize, red pepper, tomatoes, onions, lentils, beets, cabbages, etc. Wheat, barley, and alfalfa (a species of lucerne), are cultivated on the farms.

The alfalfa is extensively cultivated as far north as El Paso, and is every where considered as one of the most profitable of farm crops, yielding abundantly without irrigation, and possessing the valuable property when once established of flourishing in perennial vigor for any length of time. In the vicinity of Chihuahua, where the climate is mild, it is cut eight times a year, and sold for green fodder at a real (twelve and a half cents) per bunch of twenty-five pounds. Mr. Riddells, our consul here, stated, that from a field of fif-

dred dollars a month. From fifteen to twenty extra mules would be necessary for such a train; as, on their long journeys, accidents cannot be avoided. Men to herd and take care of the animals must also be provided ; and, finally, provisions for the journey. This will give an idea of the expense of fitting out a caravan or train; and if the merchant gets back with his goods in ten months from the time he left, without encounters with hostile Indians, or the loss of any of his wagons and their contents, in fording streams and otherwise, he may consider himself fortunate. It cannot be expected that a merchant will be satisfied with very small profits after such an expedition. 
teen acres he had realized in one year two thousand one hundred and eighty dollars. This field when I saw it, on the last day of October, was as green as our meadows in June.*

I shall not enter into any particulars as to the great number and variety of mines in the State of Chihuahua, as the subject is too extensive to be treated of in a work like the present. I have, however, collected much information respecting it, which may hereafter be given to the public. At present I will merely say, that the mineral wealth of Chihuahua is not surpassed, if equalled, in variety and extent by any State in the world. Silver is the most abundant; but there is also gold, copper, lead, iron, and tin. Cinnabar is also said to be found; but I cannot speak of it with certainty. Of bituminous coal I saw a fine specimen.

* A late San Francisco paper, in speaking of the introduction of alfalfa into California, where it is known as "Chilian clover," says it is greatly in use in the mining districts of Chili, where the lands are very sterile, and rain is of seldom occurrence. "Natural grasses are, therefore, of scanty growth; and the miners are compelled to rely for the maintenance of their animals upon the alfalfa estates, which lie within the narrow valleys of that mountainous region. The supply would, however, be wholly inadequate, were not the plant so remarkably prolific, and possessed of such extraordinary nutritious properties. With the addition of a little barley, it is found to keep mules in the best working condition; and consequently the owner of one of these alfalfa haciendas is able to draw from his estates a much larger revenue than if cultivated in grain. In its green state, cattle feed upon it with the utmost avidity, and acquire flesh so fast, that it is the practice in Chili to drive herds from the grass pastures of the south, for hundreds of miles, in order to obtain the benefit of its use. The land is prepared for the seed of this plant in the same manner as for clover, it being, in truth, of the same family as the latter." 
An idea may be formed of the extent to which mining operations were formerly carried on here from the immense heaps of scoria and dross which lie about the city, and particularly near the bed of the creek, as it is approached from the north. So imperfectly has the silver been extracted from this ore, that a regular business is now carried on in working the scoria over again, which is said to pay.

The high table-land, which forms the larger portion of the State, is not adapted to agriculture; but for grazing and the rearing of large herds of cattle, horses, and sheep, it is unsurpassed. I have heard it stated, that a man who settled near the Casas Grandes River in 1785 , took with him four cows and a bull, from which, in the year 1829 he had become possessor of a herd of forty thousand cattle. The vast plains filled with such numbers of cattle resemble the prairies with their herds of buffaloes. The proprietors of the great haciendas used to pride themselves on preserving a uniformity in the color of their cattle, much as some of the nobility do in England at the present day, though on a grander scale; so that one possessed his thousands of purely black cattle, another white, and a third red. But this is now all done away with: the great herds have disappeared, and there is no longer any safety in rearing them, although the incentive to do so is greater, owing to the demand for the California market.

The arable lands are in the valleys leading to the great Sierra Madre, and along the water-courses. They are extremely productive.

Among the peculiarities of this place it is proper 
to notice a singular breed of diminutive dogs which are found only here, and are eagerly sought for by strangers who visit the place. How these little creatures originated I was not able to learn, although I made many inquiries. These dogs have not the shape of common lap-dogs, or of the stunted, dwarfish curs, with large bodies and short legs, which are of common occurrence; but they possess the elegant form of a full-grown mastiff, with small heads, and slender and delicate limbs and bodies. The hair is short and fine on their backs, while on the lower part of their bodies it is little more than down. The forehead is remarkably prominent, and the eyes large and full. They are also noted for their sagacity. These dogs are highly prized throughout Mexico, and readily command fifty dollars at the capital. In Chihuahua they bring from five dollars to a doubloon (sixteen dollars) each, according to the purity of the breed. Several were brought home by the gentlemen of the Commission. I have two, which weigh respectively three pounds six ounces and four pounds.*

Many persons mistake these Chihuahua dogs for the misnamed prairie-dog, a little animal of the marmot species, about which so much has been said by all who traverse the prairies. Even intelligent travellers who have not seen both have fallen into this error. $†$

* The bitch has given birth to young twice since they have been in the United States, which attained a size and weight about four times that of the mother. The form was the same. This result has been noticed by others, who have attempted to introduce the breed into this country.

† Lieut. Hardy says, "The surrounding country is filled with rat- 
holes as well as excavations, made by a very small species of $\operatorname{dog}$, not much larger than a full-grown rat, who, as the traveller passes, comes out to the mouth of the cave, and barks most angrily at the interruption. I endeavored to catch one; but they are too wary, and instantly enter their holes when pursued. They are known in Mexico by the name of "Chihuahua dogs.'"-Travels in Mexico, p. 446. Had the Lieutenant taken the trouble to ask for the Chihuahua dogs when in the city, he would have found them to be the the most gentle and affectionate little creatures, and that instead of living in "caves" or holes, they spent their time chiefly on people's laps. Of the prairie-dog I shall speak hereafter.

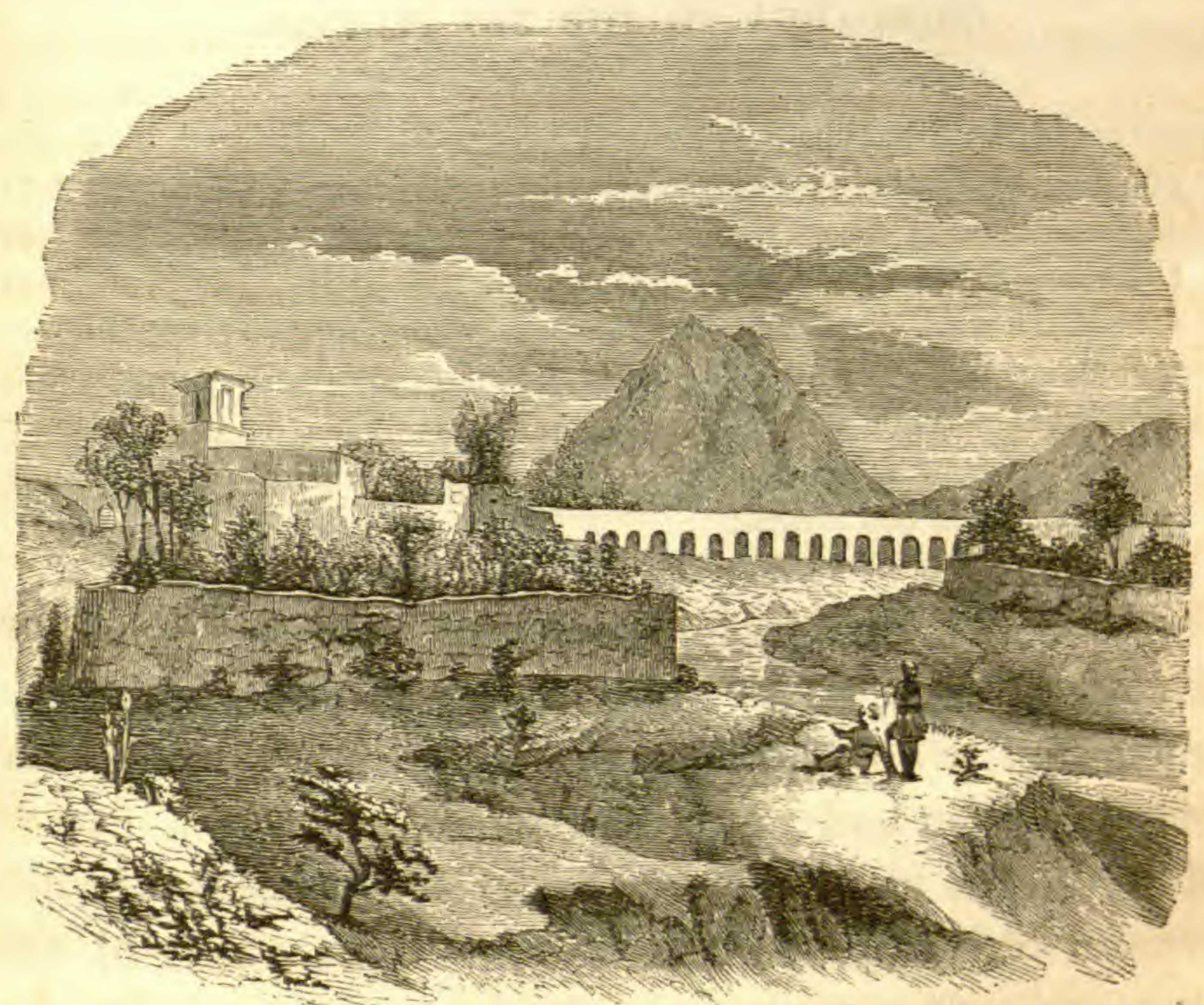

Aqueduct and Church of Santa liita, Chihuahua. 


\section{CHAPTER XL.}

\section{CHIHUAHUA TO THE RIO FLORIDO.}

Departure from Chihuahua-Additional escort-Mr. Flotte with his family join us-Bachimba-Santa Cruz-Grist mill-Smelting works-Saucillo-Attack of the Comanches-La Cruz-Las Garzas-Ford the Conchas-Santa Rosalia-Its defences erected against the. Americans during the war-Ramada-Rio Florido-Guajuquilla-Fertile valleyMonument to our Lady of Guadalupe-Search for meteorites-Hacienda Blanca-Wagon upset in an acequia-Hacienda de ConcepcionCurious mass of meteoric iron-Account of meteorites in the vicinity -Hacienda del Rio Florido.

November 1st. The wagons being repaired, and our loss of animals made good by the purchase of additional ones, we were this day enabled to resume our journey. We had added to our party six men, five as an additional guard for our animals, and a blacksmith. General Trias also furnished us with an escort of ten dragoons. Our party was further increased by the addition of Mr. Lewis Flotte (a gentleman to whom I have repeatedly alluded), who, with his wife, a Mexican lady, and eight children, were to accompany us as far as the Rio Grande, or even to the Gulf of Mexico. He had three carriages and four men, all well armed; and, as he had had considerable experience in Indian 
warfare, we considered him an accession to our strength. A large train of wagons was to leave in a couple of days; but as the number of men with it was small in proportion, it would be of no advantage to us, while it might cause delays. So I preferred starting by ourselves.

All accounts received from the south brought the unpleasant news, that for six hundred miles the road was infested by the Comanches in large bodies, and well armed, and that they had committed greater depredations than ever, attacking not only travellers but villages in open day.

We did not get off until one o'clock, so that our day's journey was necessarily short. We made, however, twelve miles over a good road. On leaving the city, we passed the base of a mountain four miles distant, when we again emerged into an open plain. It was nearly dark when we reached a pond, about half a mile from the road on our right, where we encamped. Around this pond the earth had been banked up to the height of five or six feet, in order that a larger quantity of water might be retained. The grass was good. In a valley a mile distant on our right, was a large hacienda.

November 2d. About six miles after leaving, we entered a cañon, through which we continued for four or five miles: the road quite stony and rough. In this is the dry bed of a stream, which, during the rainy season, is filled with water; and, judging from the appearance of the bushes and drift wood, must quite recently have been much swollen. East of this defile, the mountains which here cross the valley rise abruptly, and 
present quite a picturesque appearance. Rocky strata of varions colors are seen, and the summits of the hills are crowned with masses resembling works of art. About half way through, on the right, is a fine spring, and near by a deserted rancho, now in a state of ruin. What object any one could have in occupying such a spot, I cannot imagine; for there seemed to be no land fit for cultivation or for grazing. In this cañon is a conical hill, around which winds a spiral road, and on whose summit is a stone parapet, the work of some ancient people.

A little further on, we passed another rancho; from the top of the parapet peeped a few heads, and in their midst a huge blunderbuss mounted on a swivel, probably to overawe the Indians. On emerging from the cañon, we entered a broad plain, extending to the south as far as the eye could reach. A few isolated hills were alone seen in the far distance. The plain here was about twenty-five miles wide. Five or six miles further brought us to Bachimba, a cluster of about a dozen houses, with a fine spring of water, which is retained in a pond by a wall below it. From this, the water is conducted to some gardens, in which I noticed many fig-trees. This place is noted for its fine apples; but we were unable to procure any to satisfy us of the truth of the report. Here we encamped, after a march of twenty miles.

November $3 d$. A train of wagons from Chihuahua, belonging to Señor Olivares, joined us last night, and left again before daylight. We continued our journey over the same plain as before, in a direction about south south-east, the road being excellent. Grass 
was scant, the plain being of a desert-like character, covered with low mezquit bushes, various kinds of cacti, yucca, and the fouquiera ; forming as formidable a collection of thorny plants as one need wish to make his way through. No better indication of the desert character of a country is required than the fouquiera, which thrives only in the most barren and arid spots.

Ten miles from Bachimba the road divides, one branch leading south-east to San Pablo, which is the most direct, and the other to Santa Cruz, ten miles distant. We took the latter, in order to obtain a supply of flour there for our journey. This town stands near the San Pedro Creek, a tributary of the Conchos River, and extends for nearly a mile along the valley. Parts of it are compactly built; yet I did not observe a good-looking house in it. Men, women, and children crowded to the doors as we passed, attracted by the cracking of the whips and yells of the teamsters, and seemed to eye us with as much curiosity as though they had never seen a train before. It is said to contain four or five thousand inhabitants. We passed directly through without stopping, and crossed the creek, a fine stream of clear water, which rises in the mountains about one hundred miles to the west, when we were suddenly brought to a stand by a dilapidated bridge, across an acequia. Such was the condition of this bridge, that even the riding animals would not cross it. We had, therefore, to cut branches from the cotton-wood trees, lay them on the bridge, and cover the whole with earth, before we could make it passable. Such a bridge on the great highway from 
the capital to the larger towns at the south and to the city of Mexico, is a disgrace to the State, and more so to the town within half a mile of it. A few hours' labor would render it safe and permanent; yet no one will do it. Each train managed to get over as we did, and appearances indicated that it had long been in the same plight.

Encamped at a village a mile from the stream, near the grist-mill where we were to obtain our flour. I had letters of introduction to the owner, but he was absent. $\mathrm{He}$ is a gentleman of much enterprise, having at this place, in addition to his flouring mill, a cotton gin and smelting furnace. The ore is brought from a mine ten miles distant. There is no wood near, and the furnaces have to be supplied with fuel by digging up the roots of the mezquit chapporal. Heaps of this lay by the road side, from which it is carried on the backs of donkeys or men to the furnaces. I learned that the mine was not profitable, but that another had been discovered, which was to be worked by the same person, who would bring the ore here to be reduced.

November 4 th. Taking an easterly course, we struck the main road from San Pablo in four or five miles after setting out, when we again turned south-east. The road was good, with the same barren plain as yesterday. A tire here fell from one of the wagon wheels, notwithstanding the thorough overhauling they had received at Chihuahua; but such is the dryness of the climate, that these accidents will occur in spite of every precaution. The result was a detention of two hours, to wedge up the tire; after which we pushed on more rapidly, and reached Saucillo, said to be twenty-three 
miles from Santa Cruz, where we encamped, about one hundred and fifty yards from the river Conchos.

As we entered the village, which consists of a cluster of mud houses, mostly in a decaying state, we noticed the whole population running to and fro in a great state of alarm, and at the same time a train of wagons entering from the south. We soon learned the cause of the excitement. The town had been entered an hour before by a band of Comanche Indians; who attempted to drive off the cattle. They were pursued by the men of the place, and in retreating, lanced an unarmed man who was driving cattle. Each of these fiends, out of mere sport, plunged his lance into the poor creature, as they passed him lying on the ground. The people were just bringing in his dead body. The Indians had also attacked the train that was entering, and succeeded in causing a stampede among the loose animals, fifteen in number, which they drove off. To save the rest, the party returned to Saucillo, which they had just left. This was the train of Señor Olivares, which had proposed joining us at Chihuahua.

In their attack to-day, the Indians killed eighteen head of beef-cattle, which they could not drive off. The bodies of eight of these were secured by the villagers; from which we obtained a supply of beef. Such is the course pursued by the Indians. When they cannot carry off cattle, they destroy them; and even when they want food, they do not kill and preserve their meat as the Mexicans do, but take merely what they Want for a meal, and leave the remainder. Hence, the immense destruction of beef cattle and mules. A band of one hundred Indians destroy cattle enough to sub- 
sist ten or twenty times that number; and as they raise none themselves, it may be conceived what inroads they make upon the herds of the Mexicans.

While we were at Chihuahua, the Comanches made a great haul near this place. A large train of wagons, with one hundred and forty mules, on its way from the capital to the fair of San Juan, had just encamped, taken the mules from the wagons, and sent them with four men to a pool of water a quarter of a mile distant. While there a band of Comanches, who lay concealed with their horses in a bush near by, suddenly rushed upon them, stampeded the whole caballada, and succeeded in driving every animal off. The herders and teamsters in charge could no nothing to save them. The owner raised a large party a day or two after, took the trail, and was in pursuit of the robbers when we passed along.

A large portion of the population of Saucillo are miners who work on their own account, called gambucinos. These men perambulate the mining regions much as our Californians do in "prospecting," when they occasionally stumble on a vein which rewards them for their labors. This, however, is but seldom; for, possessing no scientific and but little practical knowledge, their discoveries are almost purely accidental. Around the village are heaps of scoriæ, refuse ore, and broken furnaces, the results of the labors of these silver hunters.

November 5 th. Before starting this morning, all the fire-arms were inspected, and a further supply of ammunition served out. I placed the party under the orders of Mr. Radziminski, chief engineer, who had 
had experience as a military officer. The villagers, who knew the haunts of the Indians, said they were then near our camp, and although we did not see them they had their spies watching our movements. A man was now placed by the leading mules of each team in addition to the teamster, to keep them in place; as our safety depended on the preservation of our animals. Five of the soldiers were also placed with the wagons, and five about fifty yards in advance of the train. The remainder of the party were equally divided between the front and rear.

Our course for the first four miles lay through a thick chapporal, where an enemy might easily lie in ambush and surprise a party. It was, therefore, with some anxiety that we passed this place. On our left, for a mile or more, were ruins of decayed buildings; which led me to believe that the town must have been much larger in former times. Several large acequias, now destitute of water, crossed our road, another evidence that more of the valley had once been cultivated.

Passed some isolated mountains on our left, where there are some silver mines, the ore from which is taken to Saucillo to be smelted; but, whether owing to the poorness of the ore, or defective methods of separating the metal from it, they barely pay the expense of working. There are other mines in the hills to the right which yield more, and are considered profitable. These also belong to Saucillo, or rather to the gambucinos of that place.

About fifteen miles from Saucillo we reached by a gradual ascent the summit of a plateau, when a broad expanse of plain again opened before us. From here voL. II. -29 
we could trace the course of the Conchos by the wood along its banks. This, next to the Rio Grande, is the largest river in the State. It has its rise high up in the Sierra Madre; it first flows in a southerly, next in an easterly, then in a north-easterly, and finally in a northerly course, when it discharges itself into the Rio Grande near the Presidio del Norte. Its principal tributaries are the Florido, De Buenavista, San Pedro, Chihuahua, and Balleza. These, with their lesser branches, water more than a third of the State. The Conchos itself has a course of one hundred and forty leagues, or about three hundred and seventy miles.

In eighteen miles we reached La Cruz, a small village of three hundred inhabitants, and about five miles further Las Garzas, both on the river Conchos. The bottom lands are here broad, and seemed to be highly cultivated. Large haciendas appeared from among thick groves of cotton-woods, and exhibited quite an agreeable spectacle, after several days' travel over barren districts. After passing Las Garzas, we forded the Conchos, here a fine clear and rapid stream about two hundred yards across. After a day's journey of thirty miles, we reached Santa Rosatia, and encamped on the banks of the Rio Florido, a small stream which enters the Conchos at this place.

Santa Rosalia is the most considerable town we had met with since leaving Chihuahua, having almost five thousand inhabitants. It stands on a spur of the plateau in the angle formed by the Conchos and Florido Rivers, about sixty or eighty feet above the valley. Like all Mexican towns we had thus far seen, it is on the decline. There is rather a fine church here in the 
course of erection, built of adobe, except the doorways and windows, which are of the soft sand-stone of the country. Some of the arches which are to support the roof are already finished, and are well built. To raise these arches, the intermediate spaces are built up with adobe and a few timbers, and the arch laid directly on this wall. When the arch is completed, the adobe is removed. This seems a quicker and less expensive mode than to use a framework, as we do.

South of the town are a redoubt and fort erected by the Mexicans when they expected an invasion from General Wool, who they heard was approaching in that direction. These works are all of adobe, and are said to answer well, as a cannon ball will pass through them without making a breach. But the invasion came from the north; and Colonel Doniphan was so uncivil as to give them no opportunity to use their defences, but approached where there were none; so that the labor of the Santa Rosalians was thrown away.

November 6 th. We were detained several hours this morning to set the tires on two of our wagons, which gave me an opportunity to look about the town. Elevated above the plain, I could see for a long distance the valleys of the streams which unite here; they seemed to be quite broad, presenting a fine bottom for cultivation.

We heard from the people here, that a large band of Comanches crossed the Conchos early this morning near Las Garzas, and went towards the mountains on our left; evidently, with the intention of going southwardly towards the settlements, and perhaps of lying: in ambush for passing trains.

At 1 o'clock P. M. we again got off, and, ascending 
the plateau, struck across it in a direction east southeast over a desert plain, with an excellent road. About five miles off on our left, we saw the course of the Rio Florido. It was an hour after dark before we reached the village of Ramada, twenty-three miles distant, on that stream. This is a place of four hundred inhabitants, and contains, along with its tumble-down tenements, a crumbling church. In this last, are some pretty good paintings, but they are suffering much from neglect; for the people are so indolent, that they will not lift a hand, even for a few hours, to fill up the crevices in the decaying walls, to save these once valuable pictures from destruction.

November 7 th. Leaving the valley of the Rio Florido, our course lay south across the plateau, here elevated not more than ten or fifteen feet above the bottom land, which we followed for several hours. Saw several large haciendas along the river with cattle grazing near. We had hoped to reach Guajuquilla to-day; but found it best to encamp at a well about twenty miles from Ramada, as we could not reach that place till after dark. Experience had taught us not to - travel after nightfall when we could avoid it. On reaching these towns or haciendas, we required feed for our animals, which was generally corn-stalks; and unless we made arrangements an hour or two before dark, it could not be obtained. There are other difficulties in approaching these towns after dark, such as the acequias and broken bridges, the difficulty of selecting proper places to encamp in, etc. Where we had to depend on ourselves alone, and were in an unsettled country, it made no difference. 
We obtained water at a well here, for which we had to pay three cents a head for our animals. There was a large hacienda near, the people of which seemed to have no other means of living than what they obtained from this tax on their water. This is not an unusual practice where wells have been sunk at a great expense, and where men are kept to protect them. This was formerly a large stock estate; but being far from any town, its cattle have all been stolen by the Indians.

The plain is here about twenty-five miles wide, - being limited by ranges of mountains that distance apart. At the south, no mountains were visible.

November $8 t h$. Twelve miles brought us to the old town of Guajuquilla (pronounced Wa-hu-ke-yah). It is also known as Jimenes (after the patriot of that name) on the maps; but in no instance did I hear it called by any other than its primitive Indian title. This town is situated near the river Florido, and is the cleanest looking place we had thus far seen in the State, the capital only excepted. Its population is about seven thousand; but for so large a place, it shows very little activity, there being but three or four small shops, containing altogether less goods than would be found in a village store in the United States, where the population did not exceed one thousand. It is altogether an agricultural town, being in the midst of a broad and fertile valley extending along both sides of the river. As it is off the main road, few travellers pass through it. Our little train, therefore, conducted by about forty armed men, brought out to their doors the occupants of the houses in the streets through which we passed. The people were more fair and 
cleanly-looking than usual, and exhibited less of the Indian physiognomy and complexion. Having more wagon tires to set, and some blacksmith's work to do, we took occasion to look about the place, and found the people polite and desirous to serve us. Corn, barley, vegetables, eggs, and poultry, were brought to our camp for sale, for the first time since we entered the country.

South of the town is a small monument built of adobe to the height of about twenty-five feet, in honor of Our Lady of Guadalupe, whose full length portrait, or effigy, stuck into a frame, is inserted in a niche at the top of the monument. The picture is about two feet in length, and appeared to be an ordinary colored lithograph. The monument is an unshapely affair; and seemed to be fashioned in literal obedience to the command, not to máke to oneself "the likeness of any thing in the heavens above, or in the earth beneath, or in the waters under the earth." It is but fair to add, that I was told the monument was built by a priest, who died before he completed his plans.

The river Florido has here a bottom of three or four miles in width; most of it is cultivated, and a considerable portion in cotton, which thrives well here. In fact, there is more land here under cultivation than at any place I had seen in the country, not excepting the valley of the Rio Grande. As an evidence of its secluded position, I was told that there were but two foreigners in it, a Spaniard and a Frenchman, both of whom honored us with visits.

November $9 t h$. In consequence of the deficiency of tools, we made slow progress in repairing our wagons. We had heard at Chihuahua of the existence of large 
masses of native iron, or meteorites, in this part of the State; and we made inquiries respecting them as we came along. We were here told that they were to be found about six leagues distant. Dr. Webb determined to avail himself of our detention to examine these masses. He accordingly procured a guide in the town, who professed to know where the objects of his inquiry were to be found; and taking with him our ten soldiers and three others of our party, he set off from camp. He expected, from the information given him, that he could reach the place in a few hours, and be back early in the morning.

Colonel Doniphan, with the army of the west, left this place for Parras by the Bolson de Mapimi. As that district of country is now in possession of the Comanches and Lipans, who are there some thousands strong, it is not considered safe for parties of less than one or two hundred to attempt it. We avoided it entirely by keeping to the west, though it made the route full three days longer.*

November 10th. Dr. Webb returned this morning without having found the object of his search. It appeared that on reaching the place designated, the guide became somewhat confused; and on being questioned

* I take this occasion to express my acknowledgment to Dr. Wislizenus, whose "Memoir of a tour through Northern Mexico, connected with Colonel Doniphan's Expedition, in 1846-47," has been of great service to me, and was my only guide from Chihuahua to Guajuquillaand again after leaving Parras. I have great pleasure in testifying to the accuracy of this memoir, which is a model of its kind; and I do not hesitate to say, that no official report has ever been published by our government, which, in the same space, embraces so much and such accurate information. 
more closely, the fellow acknowledged that he had not been there in twenty years, and had forgotten their precise locality. He also pretended to be much alarmed on account of the Indians, and declared that it was not safe to go further. The Doctor, however, compelled him to lead them about for miles in every direction, but to no purpose.

In the afternoon we resumed our journey, intending to reach Totonilco, about ten miles distant; but we had not proceeded far before we found the road overflowed by the bursting of an acequia which ran by its side. The wagons sank deep in the mud, rendering it extremely difficult to get along. On both sides of the road were hedge fences, so that we could not turn out. Mr. Flotte's large carriage got mired; and in the struggle to extricate it, the tongue and hounds were broken. In consequence of this delay, night overtook us before we had completed our day's journey, and rendered it difficult to find our way. Finally, in crossing a bridge over a large acequia near the Hacienda Blanca, our large provision wagon, "the ark," broke through a hole, which was not perceived by those in advance, upset, and precipitated its contents into the water. This accident was a serious one, as the vehicle contained all our provisions for forty days. There was no alternative, therefore, but to stop where we were, directly in the road, closely hemmed in with mezquit bushes. Our men were obliged to jump into the water, which was three feet deep and about fifteen wide. Many things sank to the bottom. Our flour, which was in sacks, sugar, coffee, rice, etc., were, thoroughly wet. 
November 11th. Our provisions were spread out in the sun to-day on India rubber blankets and tentcloths. The result of the disaster was the loss of all our sugar, and about one third of the flour. After a few hours' drying, the coffee and rice were stowed away for a further drying in the afternoon, and we again set off. Finding that Totonilco was not on our direct road, we here took another, leading to the village of $L a Z a$ pata (The Shoe), eighteen miles distant, which we reached before sunset, and encamped.

November 12th. Our next stopping place was the Hacienda del Rio Florido, about fifteen miles distant; but having heard of a remarkable meteorite at the Hacienda de Concepcion, about six miles from the direct route, I determined to let the train pass on, while I with a small party took the Concepcion road. Dr. Webb, Messrs. Radziminski, Seaton, Jacobs, and Force, with myself, made the party. Ten miles from Zapata, across the table-land, brought us to a small stream, where, encompassed in a grove of cottonwoods, lay the pretty village to which we were destined.

On our arrival, we stopped under the shade of some large trees, and dismounting at once discovered the object of our search about fifty yards distant, at the corner of a large building. This was the residence of Don Juan Urquida, the proprietor of the hacienda and large estates adjoining, and formerly governor of the State. That no time might be lost, Dr. Webb immediately set to work with his hammers and cold chisels to cut off some pieces from the huge mass of iron before us. This he found to be an undertaking 
of great labor, in consequence of the extreme tenacity and hardness of the mass. After an hour's work, with a man to assist him, he succeeded in cutting off three or four small pieces, which did not altogether weigh an ounce, and were barely sufficient for an analysis. Five chisels having been broken, the Doctor had to desist from his labors, much to our regret, as we were desirous to obtain some specimens for cabinets.

While this was going on, I took a couple of sketches of the mass, showing opposite sides, and also took measurements; but the form was so irregular that these measurements can only aid in conveying an idea approximately of its bulk. Its greatest height is fortysix inches; greatest breadth thirty-seven inches; circumference in thickest part eight feet three inches. Its weight, as given me by Señor Urquida, is thirtyeight quintals, two arrobas, three libras, which, at one hundred pounds to the arroba, would be equivalent to three thousand eight hundred and fifty-three pounds.

This meteorite is very irregular in form, as the drawing shows; and one side is filled with deep cavities, generally round, and of various dimensions. These cavities were doubtless formed when the mass was cooling. At its lower part, as it now stands, is a projecting leg, quite similar to the one on the meteorite we saw at Tucson, and which I have described. The back or broadest part is less jagged than the other portions, and contains fewer cavities, yet, like the rest, is very irregular.*

* From, the various inquiries made at Guajuquilla and at the Haci- 
While we were at work, Señor Urquida, the younger, the brother of Don Juan, came out. Having no letters of introduction to him, I showed him a gene-

enda de Concepcion, I learned of the existence of meteorites, or masses of native iron, in several places. Of those near the former place, of which Dr. Webb went in search, there is no doubt. Some of them are very large masses, partially buried in the earth; while others are less than the one described. There is one at San Gregorio, about fifteen leagues distant; and it is reasonable to suppose from their proximity, that these several masses fell to the earth on the bursting of one and the same meteor.

For the information of such of my readers as are not fanfiliar with the history of these phenomena, I will observe, in the words of a distinguished philosopher, that "Shooting stars, fire-balls, and meteoric stones, are regarded with great probability, as small masses moving with planetary velocity, and revolving in obedience to the laws of general gravity in conic sections around the sun. When these masses meet the earth in their course, and are attracted by it, they enter within the limits of our atmosphere in a luminous condition, and frequently let fall more or less strongly heated stony fragments, covered with a shining black crust." * Another distinguished writer, Kaemtz, fafter examining the several hypotheses, for the origin of these igneous meteors, arrives at similar, conclusions to those of Baron Humboldt. "A great number of observations," he says, "prove that, besides the large celestial bodies, there are small ones that move in space, such as points and luminous trains, which astronomers have often seen traversing the field of their telescopes. These millions of asteroids moving round the sun, become visible when they are ignited by entering the terrestrial atmosphere."

With regard to the masses of meteoric iron, many instances are recorded where they have been known to fall to the earth on the bursting of meteors, and have been carefully examined and analyzed by philosophers. They present the same character, both in form and in their chemical composition; metallic iron predominating, with a few parts of nickel. "The connection of meteoric stones," says Humboldt, ; " with

* Humboldt's Cosmos. Vol, i. p. 98. Otto's translation. London ed.

+ Meteorology. pp. 478-79.

¥ Ibid. p. 101. 
ral letter which General Trias had given me to all officials on my route, directing them to extend to me and my party every facility in the prosecution of our

the grander phenomenon of fire-balls-the former being known to be projected from the latter with such force as to penetrate from ten to fifteen feet into the earth-has been proved, among many other instances, in the fall of aerolites at Barbatan, in the Department of Landes (24th of July, 1790), at Siena (16th of June, 1794), at Weston, in Connecticut (14th of December, 1807), and at Juvenas, in the Department of Ardeche (15th June, 1821). Meteoric stones are sometimes thrown from dark clouds suddenly formed in a clear sky, and fall with a noise resembling thender. Whole districts have occasionally been covered with thousands of fragmentary masses, of uniform character but unequal magnitude, that have been hurled from one of those moving clouds. The great meteoric mass which fell in Siberia in 1771 , described by Pallas, was regarded by the Tartars as a sacred object fallen from heaven. Analogous masses have been found in Bohemia, Hungary, the Cape of Good Hope, Mexico, Peru,'Senegal, Baffin's Bay, etc. The iron is full of cavities, filled with more or less perfect crystals of olivine; when these crystals are removed, the residue still contains 90 per cent. of iron, a certain percentage of nickel, and the rest needs scarcely to be taken into account."*

Of the meteoric masses found in Mexico, Baron Humboldt gives the following account. "In the environs of Durango, is found the enormous mass of malleable iron and nickel, which is of the identical composition of the aerolites which fell in Hungary, in 1751. This mass is affirmed to weigh upwards of 1900 myriogrammes ( 41,933 pounds). Another mass was discovered in Zacatecas, of the weight of 97 myriogrammes (2140 pounds)." The exterior character of this was found by him to be entirely analogous to the malleable iron described by Pallas. ${ }^{\dagger}$

A collection of meteorites has been made by Professor Shepard, of Amherst College, which is already said to embrace two hundred specimens from more than a hundred different localities. Among them is one from Newberry, South Carolina, weighing 58 pounds. Another mass

* Kaemtz. Meteorology, p, 476.

† Politiesl Esssy on New Spain. Vol. ii. p. 293. London ed 
journey to Matamoras. This gentleman was very polite to us, and readily answered our numerous inquiries about the mass of iron. He said it was originally

of malleable iron weighing nine pounds, was found in November, 1852, in digging a ditch near Cayuga Bridge, on Seneca River, N. Y. It measured four inches in diameter and seven inches in length: and what adds to the interest of this, is the fact that but a few miles from where it was found, a meteorite fell in $1827 .^{*}$

There is another interesting account of the discovery of a meteorite in the town of Charlotte, North Carolina. In this case a whizzing noise was heard in the air by several persons, accompanied by a commotion in the atmosphere, and the next moment a stone struck near them, "with a dull heavy jar of the ground." On examination, the meteoric mass referred to was discovered. The people of the town were alarmed by "a sudden explosion, followed at short intervals by two other reports, and by a rumbling in the air. The sounds were distinct, and continued for more than half a minute." This meteor was seen through 250 miles. $\dagger$

It is to be hoped that Professor Shepard, into whose hands this meteorite has been placed, will give the scientific world the results of his extensive study of these most interesting phenomena.

Before closing this note, I will remark, that early in the evening of the 1st of June, the day we left San Isabel in California, a brilliant meteor was seen by us all, passing from west to east. Another which surpassed in brilliancy, in the size of its mass, the length of its fiery train, and the time of its duration any that I ever witnessed, was seen about 8 o'clock in the morning, between the 15th and 20th October, 1852. This occurred a few days before we reached Chihuahua, and passed from west to east over two thirds of the horizon, at the south. On reaching Ringgold Barracks, near Camargo, a few weeks after, Major Paul, the commanding officer at that post, informed me that he saw the same meteor, which passed to the north of them, and heard it explode. As it doubtless dropped on the open, woodless plains of Texas, which are now so muich traversed, it is to be hoped that the masses which then fell may be discovered. 
found about three hundred varas (two hundred and seventy yards) from its present location, and had been moved at different periods by the people of the hacienda to the place where it now stands. It was brought hither with the design of putting it in a blacksmith's shop, to be used as an anvil, although it had never been so employed. An attempt was made to reảuce it, by building a large fire around it, and heating it to a white heat. But so intense was the heat from so large a mass, that the workmen could not approach it, and all their labor was lost. The expense of this operation was more than one hundred dollars, and resulted in obtaining a piece of the metal large enough to work into a pair of spurs.

On the top, which is quite smooth, is an inscription bearing the date 1600 ; but I was unable to make out a single word of it, so much has it been defaced by hammering and the addition of many crosses. It is said that the inscription gave some account of its removal.

Señor Urquida invited us into his house, to give us the particulars of the weight of the mass as estimated by his brother. We accepted his invitation, and were conducted into a very handsome suite of apartments. Here we met several gentlemen, all of whom were of the higher class, extremely affable in their manners, and in their conversation showing much intelligence. Every thing within and around indicated an air of comfort such as I had seen in no part of the country, save in two or three houses in the capital. A library of well-selected books in Spanish, French, and English, some fine pictures, a piano, etc., showed 
the occupants to possess cultivated minds, as well as taste. Our gentlemanly host very politely invited us to remain to breakfast; * but we were obliged to excuse ourselves, on the ground that we had breakfasted before leaving, and that it was necessary to rejoin our party on the Rio Florido without delay.

Taking leave of our polite friends, we pursued our journey across the plateau, and reached the Hacienda del,Rio Florido, nine miles distant, at three o'clock, where we found the party already encamped.

Several mules were taken sick to-day in consequence of the greenness of the corn (maize) they had eaten; and one of them died, notwithstanding every effort to save him.

This place consists of a large hacienda with a colonnade of stone, the capitals of the columns being in the Moorish style. It stands on the margin of the plateau, overlooking the valley of the river, and has a very picturesque appearance. Adjoining this building is a church, well constructed of stone, and of a better description than any we had seen since leaving Chihuahua. These buildings were erected by Juan Ceréra, a Spanish priest, at which time it was considered one of the richest haciendas in Mexico. At his death it was divided among three of his nephews. A considerable village, with about a thousand inhabitants, now surrounds the hacienda. Twenty-six tolerably

* The usual hour for breakfast among the higher classes in Mexico is twelve o'clock. On rising in the morning a cup of coffee or chocolate only is taken, sometimes with the addition of a cracker. Dinner is taken about five, and supper at ten. Many take but two meals, the second one, answering for dinner and supper, at seven in the evening. 
464 CHTHUAHUA TO THE RIO FLORIDO.

good paintings decorate the walls of the church; and around the altar are full length portraits of the Saints, inclosed in a large and massive gilt frame, extending from the floor to the ceiling. In the centre is a statue of "Our Lady of Guadalupe," inclosed in glass. 


\section{CHAPTER XLI.}

\section{RIO FLORIDO TO PARRAS.}

A mule kidnapped-La Noria-Cerro Gordo-Enter the State of Durango -Another escort-Miserable condition of the Mexican soldiers-Recent battle here with the Comanches-La Zarea-Vast herds of cattle and horses-Searcity of wood-Droves of horses-San Pedro del GalloRio Nasas-Fertile valley-Culture of cotton-Corn-fields withont irrigation-La Noria de Pedrecina-Silver mines-Cuencame-Another escort of eivilians-La Noria' Cureña-Rio Buenaval-Pozo CalvoDepredations of the Comanches-Alamo de Parras-Viesca mines-La Peña-Break down-Cold weather-El Pozo-Recent incursion of Indians-Reach Parras.

November 13th. When all was in readiness to start, one of our mules was missing. After hunting about for him for an hour or more, we set off, leaving an arriero to continue the search. A few hours after, the arriero overtook us with the missing animal, which he found concealed in the inner apartment of a house. A woman had fortunately witnessed the roguery of one of her countrymen as he slyly secreted the mule, and she informed the man who was searching for it.

We made fourteen miles to-day, reaching La Noria (The Draw-well) * at 2 o'clock; but it was necessary

* Noria is properly a wheel or engine for drawing water from a VoL, II, -30 
to stop here, as we could not reach La Partida till after dark. I had determined to avoid night travel when it could possibly be avoided, as we had gained nothing by it. The roads are excellent, and we might go on for twenty miles without meeting a rock or gully; but the next moment we might disable the train by plunging into one of these places worn by the rain, or by upsetting in some shelving place. There are no bridges in the country, except over the acequias; and repairs are never made on the roads. If a flood washes a portion away, or it is otherwise rendered unsafe to travel, the place is simply avoided and a new route taken.

La Noria is merely a well with a large hacienda for the raising of cattle, but with no ground for tillage. As it is the only place between the Rio Florido and Cerro Gordo where there is a certainty of finding water, it is the general stopping-place for all passing trains. The table-land here consists of alternate patches of grass and chapporal, but enough of the former for many thousands of cattle.

November 14th. Having a long march before us, the camp was called at an early hour; and before the sun had shed his first rays upon us, we had breakfasted and were moving forwards. Our course lay over a broad plain with a superb road, not surpassed by the best wrought turnpike. To the east, the view was limited by a low range of hills about ten miles distant; while in other directions, neither hills nor mountains were visible. The plain was slightly undulating, with

well; the term is also applied to wells where wheels are so employed, to distinguish them from pozos, or common wells. 
grass and mezquit bushes at intervals. In the lowest depressions where a little moisture had accumulated, the mezquit appeared in thick groves to the height of fifteen feet. At 4 р. м., we reached Cerro Gordo, twenty-six miles from our last camp.

This is a miserable old decaying town, containing less than six hundred souls; although when Lieut. Hardy passed here in 1828 , he says there was a population of three thousand. From the present extent of the town, including its crumbling and unoccupied houses, it is evident that it has been much more populous than at present. It contains a modern built church without any pictures; there is no other object in the place worthy of notice. A small stream passes through it, and there is a very little arable land near. It was originally established as a military post, and is still maintained as such.

As we had now entered the State of Durango, it was necessary to surrender the escort given me at Chihuahua. I accordingly presented my letter from General Trias to the Comandante, and requested him to furnish me another escort through this State. He told me that the soldiers were at my service, but expressed his regrets that he had not the means of furnishing them with their subsistence even for the short march required, and that for nearly a month he had not been able to give them money enough to purchase their daily food. As their pay was but two and a half reals ( 31 cents) a day, and as this was the only difficulty, I at once offered to allow them this amount each, while they were with us, and the same for returning. The Comandante, a very polite and gentlemanly man; made 
many apologies for his straitened eircumstances; and he requested me to send him word, when the escort returned, how much I had paid them, together with my address, in order that he might refund me the money as soon as he should have it in his power.

About three months before our arrival, this place was attacked by a band of a hundred and fifty Comanches, and a large number of mules and cattle stolen. The soldiers turned out to rescue the animals; and a severe fight took place within a quarter of a mile of the town, resulting in the entire defeat of the Mexicans, with the loss of a Lieutenant Colonel and six other commissioned officers, together with thirty soldiers and a number of citizens.

November 15th. Our journey was continued over similar plains to those passed yesterday. Mountains were dimly seen at a great distance to the east. There was more grass and less chapporal. The road was very smooth. In an arroyo, fifteen miles distant, we found water, which enabled us to refresh our animals and push on, reaching the hacienda of La Zarca * after sunset, and making thirty-two miles.

This is now, as it ever has been, one of the largest cattle ranges in the State. The estate includes several villages, and has an extent of nearly a hundred miles. An hour or two before we reached it, we saw immense herds of cattle dotting the plain in every direction, luxuriating on the rich grass which here covers every portion of it. When Dr. Gregg was here, about twenty years ago, so great was the number of cattle on this

* Zarca is a term applied to water, and means clear and pure. 
estate, that it was said, the proprietor had once offered to sell the whole establishment, simply for the consideration of fifty cents for each head of cattle found on it; but that no one could muster sufficient capital to take up the offer. Mr. Kendall, * who stopped here on his way to Mexico with the prisoners from the Santa Fe expedition, says, that when this estate was at the zenith of its prosperity, a regiment of dragoons arrived from Spain and landed at Tampico. This regiment was one thousand strong, and of course the men did not bring their horses with them. The Colonel happening to be a friend of the family of the proprietress, then a widow, she immediately sent him a thousand white horses as a present, for the use of his regiment. There was hardly a month's difference in the ages of these horses, and every one of them had been raised on her estate.

November $16 t h$. The same open table-land continued to-day. On leaving, we descended gradually for about six miles, when we found good water in a laguna by the road side. We then ascended again to a higher level for about twelve miles, by an easy slope. The whole plain was here covered with grass, but entirely destitute even of the smallest bushes. An occasional cactus or yucca rose now and then, to break the monotony of the broad plains. Sometimes they appeared in groups, and at a distance resembled men on horseback or on foot. Often were scouts sent ahead to inspect these mysterious-looking objects.

Passed several large droves of horses, which rushed

* Narrative of the Texan Santa Fe Expedition. Vol, ii. p. 111. 
across our path and galloped away at full speed as we drew near them. There were no herdsmen with them; and it was a matter of surprise to see such herds ten or fifteen miles from any habitation. The best of these horses may be purchased for fifty dollars each, and ordinary ones for from eighteen to twenty dollars. We filled our water kegs at the laguna, and, after making altogether about twenty-one miles, encamped in the open plain near some mezquit bushes, for the sake of the fuel they afforded. Wood had been the most difficult of all things to procure on our journey from El Paso. We gathered it from bushes as we came along; and we often, as was the case this day, were governed in fixing our camp by proximity to it.

November $17 t h$. Our route to-day lay over and among low hills with a stony road, but kept gradually descending towards the valley where we expected to encamp. Towards noon, herds of cattle and milpas (corn-fields) indicated our approach to a settlement; and soon after, we rode into a town that glories in the extraordinary name of San Pedro del Gallo (St. Peter of the (ock). Miserable and filthy as were many of the towns we had visited, this surpassed them all. The plaza seemed to be used as a great cattle-pen, and the streets as avenues to it. There was a general staring at us as we entered the place. Driving through it, we encamped on a level piece of ground just beyond, where we were soon surrounded by a number of anxious inquirers. As an evidence of the poverty of the place, we could buy neither eggs, fowls, nor vegetables -nothing but frijoles, and corn for the animals.

The town is supplied with water from a natural 
well, whence it is conducted into a long trough built of stone. Here the mules and cattle drank, the women did their washing, the people in general performed their ablutions, and got their supply of water to drink. By tapping the fountain near its source, we got pure water.*

November 18th. On leaving El Gallo (as it is often called for shortness) we entered some low hills, and soon after crossed a plain about twelve miles wide, when we reached a range of rocky hills with fantastic summits. Through defiles in these we passed, and entered a broad valley beyond, such as we had not

* Much as the people of the United States have been ridiculed on account of the singular names applied by them to places, those of Mexico are at least equally guilty in this respect. Every State has all the saints in the calendar applied to something; either a village, hacienda, or a rancho; and the Guadalupes and Concepcions are as common as our Washingtons and Franklins. The aboriginal names are, many of them, very pretty and sonorous, and these are often retained, but not without some holy prefix, generally the name of a saint, as though we were to say, Saint Nicholas of Manhattan, Saint Peter of Passama$q u o d d y$, etc. In looking over a geographical dictionary I find the following, some of which occur as often as our Adamses and Jeffersons.

Nombre de Dios,
Madre de Dios,
Todos Santos,
Corpus Christi,
Trinidad,
Valgame Dios,
Sacramento,
La Purissima Concepcion,
Dolores,
Lus Cinco Señores,
San Pedro del Boca Leones,
Santa Cruz del Rosaria,
Cieneguita de Jesus Maria,
La Santa Magdalena,

The name of God.

The Mother of God.

All Saints.

Christ's Body.

Trinity.

God save me.

Sacrament.

The most pure Conception.

Grief.

The five lords.

Saint Peter of the Lion's mouth. The Holy Cross of the Rosary. Jesus Mary's Little Swamp. The Holy Magdalen. 
seen sinee entering the country. For miles it was lined with villages and haciendas, while large cottonwood trees, the usual accompaniments of water-courses, extended in a line as far as the eye could reach. Large fields of corn covered the bottom-lands, and every thing indicated a high state of cultivation. This was the Valley of the Rio Nasas, a beautiful stream about sixty yards in width that discharges itself into the Lake Cayman of the maps, but which is here known as the Laguna de Tlagualila, in the Bolson de Mapimi. Finding a rancho on its banks, where corn and a corral could be obtained, we encamped. Distance from El Gallo, twenty-five miles.

The valley here is from a mile to a mile and a half in width, and has long been noted for the excellent quality of the cotton raised in it. The climate is said to be very mild, and admirably adapted for its cultivation.

In our journey to-day, I noticed for the first time several large fields of maize on the high grounds, with no water near. The soil is excellent on these plains; and by planting the seed just before the rainy season, it comes to maturity rapidly; although the yield is less than when irrigation is employed, and the grain is of an inferior quality. The mezquit trees in this valley are larger than any seen on our route, being full twenty feet in height.

November 19th. Following the bank of the Rio Nasas for five or six miles, we kept on through several small villages and cultivated grounds, then turned suddenly to the east, and passed between two high hills with flat tops. After continuing about three 
miles through a defile, we emerged into a broad plain, bounded on the east by a high range of mountains. This plain was about ten miles across; after it we passed a second range, and beyond this another plain of six or eight miles more, which brought us to La Noria de Pedreceña, a well with a wheel, distant twenty-seven miles from our starting place. Here is a church, apparently modern, with several furnaces for smelting silver ore. The town is surrounded by an adobe wall twelve feet high, outside of which are many houses in a state of decay. It has evidently been more populous than it is at present; for not half the houses seem to be occupied. All the water used by the inhabitants is taken from the well.

November $20 t h$. While the teamsters were hitching up the mules, I rode to the town, and made a call on Don Tomas Pedreceña, the proprietor of the place. I found him an intelligent and gentlemanly man; and at my request he furnished us a series of specimens of the ore from his silver mines in the vicinity. The place was originally founded by his grandfather, and had descended to the gentleman we now saw, who, on coming into possession, had leased the estate. The lessees had for several years abandoned the working of the mines, and devoted themselves to working over the scoria and cinders which lay in the hillocks near the town, and from which they were able by some improved process to extract a considerable amount of the precious metal. Señor Pedreceña took possession himself about six months before our visit, finding the place was fast running down. With this revival it has quite an air of business. Don Tomas took us into the 
church, which is in good condition, and is hung with pretty good pictures of a large size. An advantage in these pictures was, that the name of the subject was painted beneath each of them, a piece of information that would have been acceptable in the case of many others we had seen.

$\mathrm{By}$ the advice of our friend, we here left the direct road, which he informed us was rough and hilly, with some bad arroyos to cross, where wagons were often disabled, and took that to Cuencamé, about twenty miles distant, which we reached early in the afternoon.

Cuencamé, or Quincamé, was once a place of some importance, judging from its many well-built houses and churches. It has three of the latter, one of which, on the plaza, is quite an imposing edifice. The houses on the plaza are large, and plastered outside. The shops, of which there are many, are well filled with goods, and have a show of business.

As the escort furnished us at Cerro Gordo left us at La Noria, I called on the Prefect of Cuencamé with the letter of General Trias, and requested him to furnish me another to El Alamo de Parras, or the first military post in the State of Coahuila. He received me politely, and expressed a willingness to further my views as far as lay in his power. There were no soldiers in the place; but he agreed to procure for us seven reliable men, if I would allow them the usual pay of privates, and something extra for the corporal; an offer which I readily accepted. He could not furnish them animals to ride, as there were but few in the place.

Between here and Parras is the most dangerous 
part of our whole route by reason of the Comanches. The great pass leading to the Bolson de Mapimi is here, through which the Indians enter that portion of Mexico. The little heaps of stones surmounted by crosses, where murders have been committed by the Indians, are met with at every mile; and having got along safe thus far, I did not feel disposed to risk the party and train, if an escort could be had.

The present population of Cuencamé is three thousand souls, as stated to me by the Prefect. It is a very. old place, and the Franciscans formerly had a convent herę. It stands on a small stream, barely sufficient to. supply the wants of the people. There is no bottom-land near, which gives it a most dreary appearance. It is strictly a mining town, and has three smelting works in operation. We went into them, and procured specimens of the ores.

November 21st. We were detained several hours waiting for our escort, so that we did not get off until eleven o'clock. Our course was now east over a bad road. After going about ten miles, we stopped at a well called La Noria Cureña, an abandoned cattle hacienda, near which was good grass, but no arable land. The well is covered with a handsome octagonal building, having wheel-work inside for raising the water by mule power. In an adjoining building we found the leathern buckets, which we rigged with some difficulty by attaching them to a broad leather band which passed over a horizontal wheel, and thence down into the well. On one side these buckets went down empty, and on the other came up filled. The water then fell into a reservoir, whence it was led to the out- 
side into a trough of stone about four feet wide and a hundred in length. Here the animals were watered, though it was with some difficulty we could get the timid mules to drink from such a respectable-looking affair. The Indians attacked this place shortly before our arrival, took every mule and head of cattle, and drove off the inhabitants; since which time it has been abandoned.

November $22 d$. The country had now become .very hilly and rough, with bad roads. On descending a hill, a linch-pin was thrown from one of the wagons, letting the axle down with so much force, that the end of it was broken off and spoiled. Having some pieces of hard wood in the train, the end was cut off and a piece spliced on, a very difficult job, causing a detention of four hours. To ease this axle as much as possible, a portion of the load of this wagon was transferred to the others. We now proceeded cautiously, the road still winding among mountains, and at eight o'clock P. M. reached the river Buenaval, having made twenty-five miles. This is a small stream which rises in the State of Zacatecas, and, running north, empties into the Laguna de Parras, in the Bolson de.Mapimi. It has no bottom-land where we crossed it; and hence is destitute of the cotton-wood trees which are so gratifying to the eye amid the general barrenness.

November $23 d$. My intention on leaving this morning was to go to the Alamo de Parras, about thirtyfive miles distant; but an hour or two after we had started, our spliced axle-tree gave out, which compelled us to stop at the Noria de Pozo Calvo, a well similar to that of Cureña. On examination we found it necessary 
to have a new axle, a want not readily supplied with our limited materials. It was, nevertheless, effected by making a false axle extending two thirds the length of the old one, to which it was fastened with pegs and raw hide. One wheel was consequently six inches further back than the other.

Near by were some fields of corn cultivated without irrigation, which looked very well. About a month before our visit, the Comanches made a descent here, took all the cattle (about forty head) and a number of mules, and killed three men who had them in charge. Only three men now remained at the hacienda, which they intended to abandon in a few days.

November 24th. Our march to-day was all the way over the hills, and through long narrow valleys separating high ridges of mountains. The road was stony and rough most of the way ; the remainder, a deep sandy loam. The dust raised by a strong wind, which blew directly behind us, so filled the air, that objects could not be seen twenty feet ahead. The wind drew through these defiles with great force, raising clouds of dust independent of that caused by the mules and

- wagons. This was the most disagreeable day's journey we had had, and the most tedious; for we did not reach the Alamo de Parras till two hours after sunset, having made thirty miles.

Soon after our arrival, I called on the Alcalde of the town with the letter of General Trias, and made a request for an escort, as the men from Cuencamé had not engaged to go any further. He expressed a desire to serve us; but having no troops, he said he could only 
give us a guard of citizens, on my paying the customary charge. This I readily consented to, and requested that seven mounted men might be placed at my disposal. The Alcalde said it would not be possible for him to find men who would be ready to start in the morning, as it was then late. We were, therefore, obliged to remain over a day.

November 25th. This town consists of a street a mile or more in length, well lined on both sides with neat adobe buildings, most of which are colored or whitewashed. Some streets running at right angles contain a few houses. The plaza and church are quite ordinary and not in keeping with the rest of the town, which is altogether more cleanly and business-like than any we had seen since leaving Chihuahua. Ten leagues distant are the Viesca silver mines, the ore from which is smelted here. In my walks about the town and its vicinity, I observed more cultivated grounds than I had seen elsewhere. To the east is a level plain full ten miles wide, intersected with irrigating eanals in every direction. Cotton is cultivated on this plain to a considerable extent, and is found to do well. I procured some samples of the product, a ready market for which is found at Saltillo.

November 26th. On the arrival of the citizen guard this morning, we again set out. Our course lay east over the plain mentioned yesterday, which did not contain a tree or a bush. On passing this we entered a mountain defile, and soon after reached the hacienda called La Peña (The Rock). This is simply a well with one large building and a cattle-pen, without any arable land. It formerly possessed large numbers of 
cattle, which grazed on the plain; but no animals can now be kept there, on account of the Indians, who are complete masters of the country, notwithstanding the populous towns in every direction. We did not stop here, intending to reach El Pozo, three leagues further: but in passing the rocky defile, one of the wagons broke down, which made it impossible to proceed as it was. There was no alternative but to empty it of its contents, distribute them among the other wagons, and lock the disabled wheel. In this manner we reached El Pozo late in the evening. As we approached, our horsemen in advance were hailed from the walls; and by the time they came up, twenty armed men were at the gate to receive them.

We by this time found the nights very cold, which rendered it necessary to have fires to warm ourselves when fuel could be obtained. This night in particular was exceedingly cold.

El Pozo (The Deep Well) is a large hacienda inclosed with a wall full twenty feet high, resembling a castle or a prison; and is a noted resort for the Comanches and the Lipans, in passing to and from the Bolson de Mapimi, where they dwell. They pass every few days, and we were told that a large band stopped here but two days before. On that day they attacked a train of pack-mules and donkeys, and completely cut it up. The men with it were missing, and it was not known whether they had been killed, or had made their escape to the mountains. It was at this well that a band of Indians received a chastisement from a detachment from Colonel Doniphan's command, when 
passing through here in 1847.* It is probable the Indians did not know who their antagonists were, but believed them to be Mexicans. I have been often told that they will not attack a party of Americans, when they know them to be such; as in their contests with them, they usually get the worst of it. .

November 27 th. On starting this morning, we found an addition of six or eight Mexicans, men and women, to our party, who were going to Parras. Our road wound around hills and across deep arroyos. Numer-

* "Two days before our arrival, a party of Lipan Indians, upon one of their predatory excursions, had stolen from a hacienda, near Parras, several hundred mules and horses, and killed several men. The proprietor, Don Manuel de Ibarra, applied to Captain Reid of our regiment (who was then ahead of us with Lieut. Col. Mitchell's party) for aid against these Indians. The Captain, one of the most gallant officers, took but eight men along, and, accompanied by the Don himself, went back to El Pozo, where the Indians, on their march to the mountains, had to pass. They had hid themselves in a corral, to await the arrival of the Indians. Quite unexpectedly, about twenty of our vanguard came very early this morning to El Pozo, and increased their party to thirty men. Soon afterwards the Indians appeared, from forty to fifty warriors. When our men rushed from the corral on horseback to attack them, the Indians (supposing them to be Mexicans) received them with sneering and very contemptuous provocations; and their confidence in their bows and arrows was increased, when the Americans, firing their rifles from horseback, killed none at the first charge. But as soon as our men alighted, and took good aim with their rifles, the Indians fell on all sides. Nevertheless, they fought most desperately, and did not retire till half of them were dead or wounded. But at last they had to run for their lives, and leave all their dead and all their booty behind. Besides their stolen stock, thirteen prisoners, Mexican women and children, whom they had carried along, were retaken, and released from the brutality of their savage masters. Fifteen Indians were lying dead on the field."-Dr. Wislizenus's Memoir, p. 71. 
ous heaps of stones with crosses, together with many fresh graves by the road side, reminded us of the proximity of the savage and of the murders he had committed. On both sides of the road, three or four miles distant, ran chains of mountains. After a gradual ascent of ten miles, we saw beneath us a broad valley; and upon the right of this, at the base of the mountains, lay the town of Parras. The whitened walls of its houses, its steeples, and the long rows and clusters of cotton-wood trees, presented an agreeable contrast to the bold rugged mountains in the back-ground. Until quite near the town, the plain is barren and not susceptible of cultivation.

It was after sunset when we entered the place, and we at once drove to a sort of caravanserai, which we entered with the whole train. The mules were placed in a corral adjoining. Four of us quartered ourselves in a small apartment in the court, the rest remained in tents. 


\title{
CHAPTER XLII.
}

\author{
PARRAS TO SALTILLO.
}

Parras-Its vineyards-Numerous springs-Orchards-Plantations of the Agave-Extent of its cultivation-Pulque-Hacienda Arriba-Its extensive wine vaults and granaries--Visit to the churches-The Alameda-Departure from Parras-The Hacienda Abajo-Don Manuel de Ibarra and General Wool-Cienega Grande-Ceguin-Vequeria-Gigantic Yuccas-Hacienda de Patos-Don Jacobo Sanchez-His large estates - Claims for indemnification on the United States-Village of PeonsEncantada-Arrival of a courier with despatches from WashingtonBuena Vista-The Barrancas-Ramble over the battlefield-Relics found-Reach Saltillo-No work on a feast day-Fine church-Cotton factories-Dr. Hewison-Economical use of water.

November 28 th to December 1 st. We remained at Parras five days, to repair our wagons. One wheel and an axle had to be made new throughout. The delay was longer than was needed for the work, in consequence of the loss of two days by the drunkenness of our most important mechanics. We had to submit quietly to this imposition, as no others could be found. The time passed heavily, as there was but little of interest in or about the town, and the sight-seeing was soon accomplished.

Parras is the best built town we had yet seen in the country. Many of the houses are of two stories, being quite spacious, with courts in the centre, and 
built with much taste. They possess, too, a degree of comfort, and even luxury, not found in the modern houses of the country. It is an old settled place, and has always been noted for the excellence of its wine and brandy. A species of wild vine was found here by the first settlers, whence its name; ${ }^{*}$ they also brought with them the vites vinifera of Asia, which flourished well. The extensive cultivation of the grape, for which the position of the town is admirably adapted, as well as the extent of arable land near, drew together a large and highly respectable population. Although now much reduced in their worldly means, there are many old families remaining, who possess all the dignity and elegance of manner which always characterized the native Spaniard.

The town extends for a couple of miles along the side of a hill. The smaller vineyards run along the declivity, the larger ones beyond the town, on the plain. The hill, which consists of a porous limestone, abounds in water, which is collected in tanks, and conducted by acequias through the vineyards and the principal streets of the town. Besides these acequias there are numerous wells; in fact, every house of any extent has its own well within its court. When the town has supplied itself, the remainder is conducted by aqueducts or ditches off to the plains, where it is all absorbed in irrigating, first, the gardens and vineyards, and beyond these the fields of wheat and maize. So admirable and economical a use of water I have never before seen.

* Parra, a vine trained on sticks, or nailed to a wall. 
The town on the lower side is encompassed with gardens and orchards, in which we saw pomegranate, fig, pear, and other trees growing with great luxuriance. On the hill back of the town, I saw for the first time plantations of the maguey (agavé Americana), the leaves of which were from six to seven feet in length. They are planted in rows, and surrounded by a hedge of the same, making a most formidable breastwork against both man and beast. It is from these plants that the pulque is made.* We had seen the

* The sap of the maguey is obtained by making an ineision in the central leaves or heart of the plant, which incision is converted into a kind of reservoir for the collection of the juice, by drawing the lateral leaves close together and tying their extremities.

"This is the true vegetable spring, which keeps running for two or three months, and from which the Indian draws three or four times a day. We may judge of the quickness or slowness of the motion of the juice by the quantity of honey extracted from the maguey at different times of the day. A foot commonly yields, in twenty-four hours, four cubic decimetres (or two hundred and forty-two cubic inches, English), equal to eight quartillos. Of this total quantity they obtain three quartillos at sunrise, two at mid-day, and three at six in the evening. A very vigorous plant sometimes yields fifteen quartillos, or four hundred and fifty-four cubic inches, English, per day, for from four to five months, which amounts to the enormous volume of more than eleven hundred cubic decimetres, or sixty-seven thousand one hundred and thirty cubic inches. This abundance of juice, produced by a single maguey of scarcely a metre and a half in height, or four and nine tenths feet, is so much more astonishing, as the agave plantations are in the most arid grounds, and frequently on banks of rocks hardly covered with vegetable earth. In a barren soil, the Indian calculates the product of each maguey at one hundred and fifty bottles, and the value of the pulque furnished in a day at from ten to twelve sols. The produce is unequal, like that of he vine, which varies very much in its quantity of grapes. 
maguey growing wild throughout the desert plains of Chihuahua, Sonora, and California; but nowhere does it attain the size which it reaches in these plantations.

"The cultivation of the maguey has real advantages over the cultivation of maize, grain, and potatoes. This plant, with firm and vigorous leaves, is neither affected by drought nor hail, nor the excessive cold which prevails in winter on the higher Cordilleras of Mexico. The stalk perishes after efflorescence. If we deprive it of the central leaves it withers, after the juice, which nature appears to have destined to the increase of the hampe, is entirely exhausted. An infinity of shoots then spring from the root of the decayed plant; for no plant multiplies. with greater facility. An arpent of ground contains from twelve hundred to thirteen hundred maguey plants. If the field is of old eultivation, we may calculate that a twelfth or fourteenth of these plants yields honey annually. A proprietor who plants from thirty thousand to forty thousand maguey is sure to establish the fortune of his children; but it requires patience and courage to follow a species of cultivation which only begins to grow lucrative at the end of fifteen years. In a good soil, the agave enters on its efflorescence at the end of five years; and in a poor soil no harvest can be expected in less than eighteen years. Although the rapidity of the vegetation is of the utmost consequence for the Mexican cultivators, they never attempt artificially to accelerate the development of the hampe, by mutilating the roots or watering them with warm water. It is discovered that by these means, which weaken the plant, the confluence of juice towards the centre is sensibly diminisher. A maguey plant is destroyed if, misled by false appearances, the Indian makes the incision long before the flowers would have maturely developed themselves."-Thompson's Alcedo.

"The juice of the agave has a very agreeable sour taste. It easily lerments on account of the mucilage and sugar which it contains. To accelerate the fermentation they add a little old and acid pulque. The operation is terminated in three or four days. The vinous beverage, which resembles cider, has an odor of putrid meat extremely disagreeable; but the Europeans who have been able to get over the aversion which this foetid odor inspires, prefer the pulque to every other liquor. They consider it as a stomachic, strengthening, and especially very nutritive; and it is recommended to lean persons. Whites, also, have 
At the southern extremity of the town, is a large estate belonging at present to Don — Arguire, called the "Hacienda Arriba," or the upper hacienda, to "distinguish it from the "Haciendo Abajo," or lower hacienda, of Don Manuel de Ibarra, four miles distant. This is one of the most extensive and valuable estates in Coahuila. Its chief products are wine and wheat. The vineyards which surround it, extend twelve hundred varas (3240 feet) into the plain, while beyond these are extensive fields of wheat and maize. As it seldom rains here, the cultivation of the grape as well as of the cereals, depends wholly upon irrigation; yet there is no river to supply it. In the rear of this hacienda, about half a mile distant, the water oozes from numerous springs in the side of a hill; which unite at the base and form a small stream. This stream as it passes over the porous rocks, receives constant additions. As the descent is considerable, the whole of this water is controlled, and conveyed through a stone aqueduct, first to a flouring mill, and then to the vineyards, gardens, and fields of the hacienda arriba, furnishing an

been known, like the Mexican Indians, totally to have abstained from water, beer, and wine, and to have drank no other liquor than the juice of the agave. Connoisseurs speak with enthusiasm of the pulque prepared in the village of Hocotitlan, to the north of Toluca, at the foot of a mountain almost as elevated as the Nevada of this name. They affirm that the excellent quality of this pulque does not alogether depend on the art with which the liquor is prepared, but also on a taste of the soil communicated to the juice, according to the fields in which the plant is cultivated. There are plantations of maguey near Hocotitlan (haciendas de pulque) which bring in annually more than forty thousand livres, or one thousand six hundred and sixty-six pounds sterling (about eight thousand dollars).-Alcedo. Humboldt's New Spain. 
abundance for all. In fact, with the fall, there is suffcient power to carry other mills, before it reaches the plain where it is to be absorbed by the soil. A portion of this prolific supply, is led by an acequia through the town.

I made a visit to this hacienda, with several gentlemen of my party; where we were politely received by the superintendent, who conducted us through the establishment. The wine vaults are built of adobe, with walls about twenty-five feet in height. By an inscription on the rafters, it appears to have been roofed over in the year 1775 ; yet the timber did not appear to be more than ten years old. The building is said, however, to be much older, the rafters being a portion of the renewed edifice. The several kinds of wine and brandy were arranged in very large casks on both sides of the vault, the whole exhibiting great cleanliness and order. The wine, both white and red, that I tasted, was far superior to that made at $\mathrm{El}^{\prime}$ Paso. About ten thousand gallons are made here annually, for which there is a good market in Coahuila and the adjoining States. The amount of wheat raised on the estate, is about two thousand fanegas, or 5250 bushels; all of which is converted into flour at the hacienda. The granairies are spacious buildings, about one hundred and fifty feet long, from forty to fifty wide, and twenty-five feet high. These, as well as all the buildings belonging to the establishment, are but one story in height. Extensive improvements are now going on, with the addition of new buildings; these are of adobe, plastered over with mortar, and hard finished, and havie a very beautiful appearance. This hacienda was 
purchased by its present owner about four years before for $\$ 130,000$, and now yields an annual income of from twenty-five to thirty thousand dollars.

There is another large wine manufacturer in Parras, Don Jesus Campus, whose establishment we also visited, and which like the former, was kept in fine order. I bought a keg of wine of him, which was said to be ten years old, and a superior article. It was put up with great care; yet, on arriving at New-York, it was found to be sour. All others who have attempted to transport this wine to the United States, have been equally unsuccessful.

Parras contains three churches, which were shown to us by the cura, Juan B. Bobadilla, a courteous and intelligent gentleman. Two of them abound in pictures of a higher standard than any we had seen. More care, too, was taken of them, as well as of the churches, which were in good condition, and exhibited none of those symptoms of decay prevalent every where, except in Chihuahua.

The cura manifested much interest in scientific pursuits, and was quite desirous to know what we had collected. He presented us with some specimens of minerals, reptiles, and insects, and promised to send me a larger collection as soon as he could procure them.

I have omitted to speak of two fine Alamedas, the fashionable promenades of the town. These are beautifully shaded with long rows of large cotton-wood trees, while flowers and lesser plants ornament the walks.

We made several pleasant acquaintances here, and found that Americans were much respected. Many 
inquiries were made about General Wool and his officers, who were here during the war, and who seem to have made a favorable impression on the people.

December $2 d$. Our repairs being completed, we left in the afternoon, and proceeded as far as the Hacienda abajo or San Lorenzo, a large and elegant establishment surrounded by lines and clusters of old cottonwoods. Vineyards and corn-fields extended far and wide over the plain. The owner, Don Manuel de Ibarra, being absent, we did not visit the interior. The whole constitutes a large village. It derives its supply of water from springs in the hills. Don Manuel treated General Wool and the officers of the American army with great respect when here; in return for which, they sent parties against the Indians who had committed depredations on his herds. To this gentleman also belongs the hacienda at El Pozo, where the fight took place between Captain Reid and the Lipans, before mentioned.

December $3 d$. Our route to-day was hilly and tortuous. We made twenty miles; which brought us to a cluster of houses known as the Cienega Grande (Great Marsh), belonging to Don Rey de Guerrero. Fields of wheat were near, with acequias from springs in the mountains.

December $4 t h$. We travelled to-day eighteen miles over a rough and hilly country, the road much cut up with ravines and deep with dust. Saw no cultivation or arable land until we reached Ceguin, where there was a cluster of houses, with fields of maize and wheat; but the people were too lazy to bring us corn-stalks for our animals. They said it was too much trouble. 
Fortunately we brought a little from Cienega Grande, or we should have been badly off for fodder.

December $5 t h$. The country was much the same today as yesterday, with low hills and valleys alternating, and intersected with arroyos which required much care in crossing. Passed several cornfields, with which exception all was barren and desert-like. At sunset reached Vequeria, a hacienda near a spring, twentyfive miles from our starting place. As we passed along, I noticed many gigantic yuccas growing in the form of trees with trunks and branches.

The different species of yucca, of which frequent mention has been made, form a conspicuous feature in the vegetation. They present a great variety of foliage, some narrow and grass-like, and others rigid and firm enough to serve for a "Spanish bayonet," a popular name given to the larger kinds. All are furnished with a sharp hard point at the end of the leaf, which is capable of inflicting a severe wound, and which soon teaches the incautious traveller to give them a wide berth. While some have no stem at all, others have a trunk twenty-five or thirty feet high and from two to three feet in diameter. The largest specimens we saw were near Parras, where the table-lands are covered with them. This species throws out at the top ten or a dozen branches which are bent in all possible directions. A plain covered with yuccas presents a beautiful appearance when in flower with their pure white blossoms arranged in pyramidal spikes several feet in length. The Mexicans and Indians put the different species to various domestic uses. The leaves of the narrower kinds are made into baskets, and the 
fibres of the leaves are twisted into coarse ropes. The trunks of the large species are used in the absence of other timber as palings for making inclosures, or are split into slabs to serve for covering the rude houses of the rancheros.

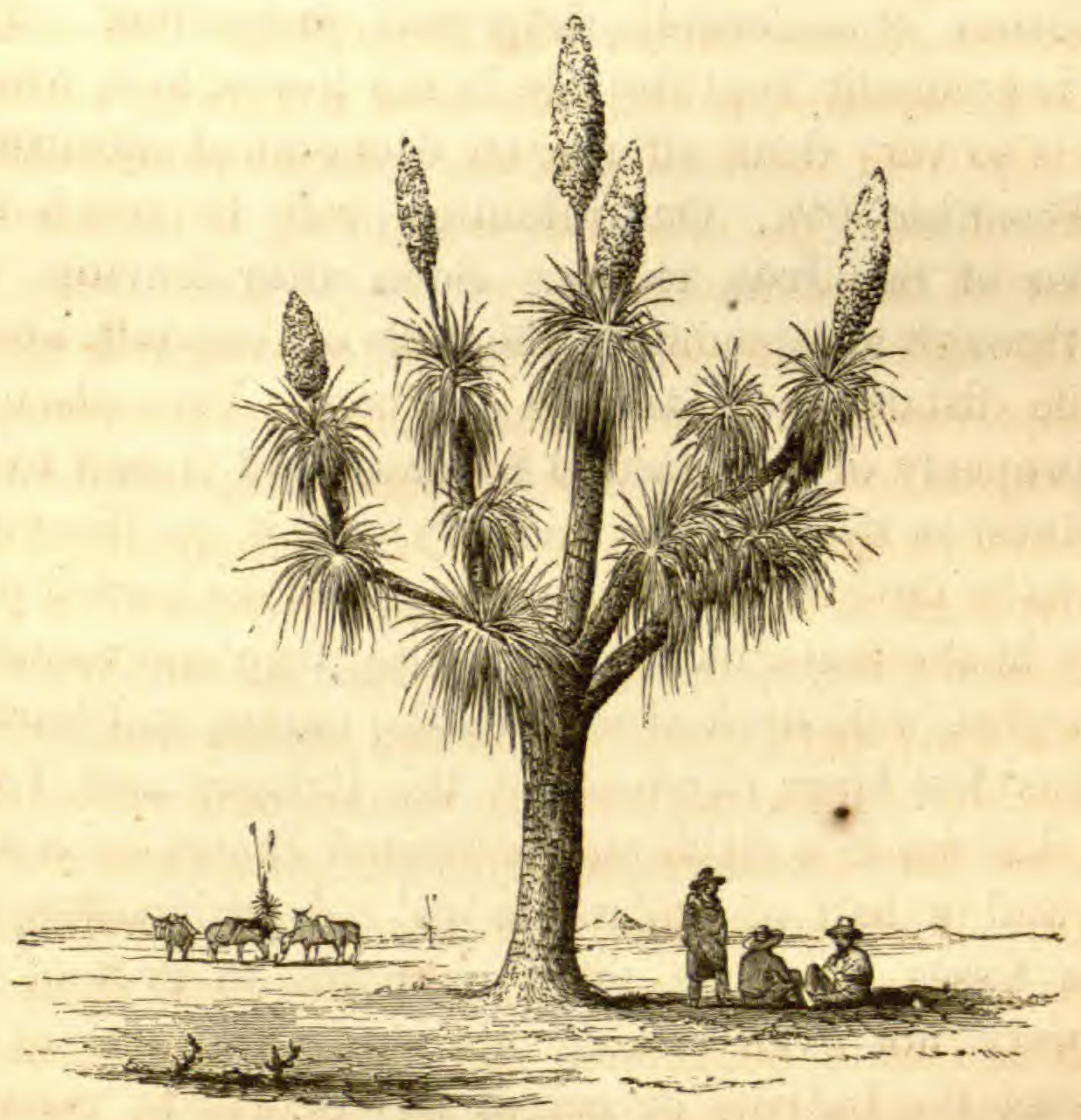

Tucea Tree.

Some species bear an edible fruit called by the Mexicans latiros. These are about the size and shape of the banana, and when fully ripe are very sweet and palatable. The tender portion of the stem near where the leaves are produced is roasted and eaten under the name of quiote; but it is rather stringy and insipid. One of our party saw at an Apache camp a pot-full of 
the flowers boiling for food. The uncooked flowers have quite a bitter taste; but this may probably be removed by boiling. The roots of a narrow-leaved species called amole are used, instead of soap, for washing clothes; bruised between stones, they afford a mucilage when rubbed upon the clothes, which seems to possess considerable detergent properties. The root is generally kept for sale in the towns, and, where soap is so very dear, affords an economical substitute. December 6th. Our intention was to reach the rancho of San Juan to-day. Soon after leaving, we saw through an opening in the hills on our left, about a mile distant, the Hacienda de Patos. This place is the property of Don Jacobo Sanchez, and is said to be the finest in the State of Coahuila. This gentleman is said to be the owner of three quarters of the landed property in the State, including several large and valuable haciendas, well stocked with cattle, mules, and horses. He has lost large numbers by the Indians, and, I am told, has made a claim on the United States for a million and a half of dollars as an indemnification for these losses. Yet he takes no pains to protect his property, not even arming his herdsmen, and never pursues the Indians or makes any efforts to recover what he has lost. In entering into a compact with Mexico for the protection of her frontier, the United States certainly expected either the Mexican government or the proprietors to do something for their own protection. The lands of Don Jacobo extend in a continuous line more than a hundred miles. Such a landholder could well afford to support a body of expert riflemen or rangers, who should be always on the alert 
and pursue the Indians whenever found on his domain. Mules are extremely plentiful here, and are valued at twenty dollars a head on an average. I presume Don Jacobo estimates his mules in his claim on the United States at from fifty to sixty dollars a head. This is about the advance that Americans put upon their property, of whatever nature, when the government is to pay for it; and we can hardly expect the Mexicans to be more moderate than our own citizens.

One of our wagons broke down to-day and so injured the axle-tree that it would not retain its wheel. It was, therefore, taken off and the axle sustained by a long pole.

Our road ascended gradually until we reached an elevated plain with high mountains around us. Passed several ranchos, with large fields of maize. These fields were in the depressions of the plain, and derived sustênance from the drainage of the mountains. The corn looked as well as when artificially irrigated. Among the villages passed was one exclusively of Peons. It consisted of a cluster of extremely rude dwellings or huts around a square, mạny of which were built entirely of the yucca tree. Its trunk set upright formed the walls and doors, while its leaves, placed on poles, after the manner of thatching, made the roof. Want and wretchedness were stamped upon these rude hovels, as well as on the poor cretures who occupied them.

We tried to buy corn-stalks here, but they had none for sale, which obliged us to move on. When opposite San Juan, a cluster of miserable huts a quarter of a mile from the road, I sent to see if fodder 
could be procured; but, much to our surprise, the people would sell none, although there were large cornfields near. It was, therefore, necessary for us to push on and endeavor to reach Encantada, ten miles further. The road proving very good, we got along very well after dark by driving cautiously, and arrived at our place of destination in safety - a place rendered famous from its connection with the campaigns of General Taylor and the battle of Buena Vista. Distance travelled to-day, thirty-two miles.

December 7 th. Before I had risen this morning, I was aroused by the arrival of a courier bringing me dispatches from Washington, and letters announcing the arrival of Major Emory and his corps of engineers at Ringgold Barracks, Texas.

Encantada (Enchanted) is a small village, where the American army under General Taylor was encamped at the time of the approach of Santa Aña with his army of twenty-five thousand men, previous to the battle of Buena Vista. Not finding the position an advantageous one, he fell back and took position at Angostura, the narrowest portion of the valley leading to and beyond Saltillo, which is six miles distant. This valley or pass lies between two ridges of mountain five or six miles apart, which approach towards the north-east, until at Angostura the space is not more than two miles. The eastern range is much the highest, rising ten or twelve hundred feet above the plateau; the western is about half that height. The plateau from the eastern ridge extends about a mile, or half way across the valley, when it drops off abruptly to the flat or alluvial bottom. In 
this bottom runs a small rivulet, which takes its rise at Encantada; but at times, after heavy rains, it is so much swollen that it has cut for itself a deep bed, with perpendicular banks, from twenty to thirty feet deep. This bed is quite inaccessible from above, except in a few places. These deep gullies or ravines are called barrancas, and are peculiar to the country. The tenacity of the soil prevents it from crumbling, except at the base, where the water washes it away. The upper portion then projects, until it has become so much undermined that it cannot sustain itself, when it breaks off, leaving perpendicular walls. These barrancas extend for more than a mile above and below the narrow pass. They also intersect various parts of the bottom, rendering it impossible for a body of troops to traverse it. Hence all the operations were confined to the plateau above, which extends to the eastern range of mountains. The battery of Colonel Washington was stationed between the barrancas and a spur of the plateau, a narrow pass some sixty or eighty feet in width.

The road leads directly through this pass; and on reaching it, we stopped within the redoubt thrown up by Colonel W. I told the men to fasten their teams, and all that felt disposed to visit the battle field to do so. We walked up one of the steep hills or spurs, and reached the plateau, where the party strolled about in all directions as far as the mountains. I had a plan of the battle with me, which enabled us to find the positions occupied by our several bodies of troops. Many relies were found, such as grape shot, bullets of lead and copper, gun-flints, fragments of 
gun-locks, cap trimmings, etc., also a few fragments of human bones. I took two sketches of the battle field, one looking south, the other towards Saltillo. About two miles distant is the small village of Buena Vista. The Mexicans call the place where the battle was fought Angostura, which means a narrow pass.

Leaving this ever-memorable spot, we pushed forward, and at two o'clock reached Saltillo. The town is completely hidden from view until one reaches the brink of the hill in front of it. We drove at once to a court-yard on one of the main streets, where we found accommodations for the whole party. The animals were placed in a corral near by.

We had been in town but a short time when our arrival became known; for our train of six large wagons, five ambulances and carriages, and about forty long-bearded men, armed to the teeth, always produced a sensation when we entered these quiet towns and villages. Several Americans residing in the place made their appearance before we had got stowed away in our quarters, and brought us the news of the result of the Presidental election.

December 8 th. Having some repairs to make on a wagon, we applied to a blacksmith, but he declined working, as it was " $\mathrm{El}$ dia de la Purissima Concepcion," when a great celebration was to take place in the church. Before this man could work or allow his shop to be used, we were obliged to ask permission from the gefe politico - a privilege that was readily granted. This being done, we spent the remainder of the day in looking at the town and its fine churches. The principal church, which occupies one side of the 
plaza, is a noble edifice, though its exterior is yet unfinished. Its interior surpassed any thing we had yet seen, not excepting the cathedral at Chihuahua. It abounds in pictures, some of which are very fine, and are doubtless the work of the old masters. The architectural ornaments, sculptures, gilding, etc., exhibit much taste, and are in fine preservation. We went to the roof and towers, which enabled us to see the thorough manner of its construction. Our New York builders might obtain some useful hints by examining this edifice, the walls of which are double in thickness that of any similar building in New York city.

December 9 th. I rode this morning with Dr. Hewison, an Irish gentleman long resident in Mexico, to visit his cotton factory about three miles distant. It is a neat building of adobe and stone, two stories high. Its power is obtained from a spring of water about a mile distant, in the direction of the hills. This water is first collected in a reservoir, and propels a grist-mill; from this it is carried through an aqueduct, and furnishes the power for three small cotton mills, of which that of Dr. Hewison is one. When these have used it, it is conducted to other small grist-mills; and when it has been made to do all this work, and has reached the level plain, it is led by acequias to irrigate the gardens and fields of maize and wheat. So careful are the mill owners of this water, that it is not allowed to escape and run off at night, or when the mills are not in operation. At such times the gates are closed, and the water collected in a stone reservoir above.

I was enabled to ascertain the exact quantity of water from which all this power is obtained. The VOL. II. -32 
stone aqueduct through which it ran was eighteen inches broad, and the water between ten and twelve inches deep. One of the mills was carried by an overshot wheel forty feet in diameter; the others by wheels somewhat less. The superintendent of Dr. Hewison's mill is from Rhode Island. The operatives are all Mexicans, and, I was told are very quick at learning the art of weaving, and much easier to manage than American operatives. The cotton used is raised in the valleys near, and a ready market is found for the goods as fast as they are produced.

This factory was the favorite ride of General Taylor while in Saltillo; and it was a source of gratification to find that the officers of the American army were still held in high respect by the citizens of the place.

Saltillo, the capital of Coahuila, is a well-built city, with paved streets. Many of its houses are of two stories, and all of them painted in warm colors. The population is about fifteen thousand. Besides the churches mentioned, there is an unfinished edifice, which was commenced by the Jesuits. The Alameda is the finest place of the kind we had yet seen. It is filled with large trees, and its walks are lined with agaves and rose-bushes. In the evening I called, accompanied by the gentlemen of the Commission, to pay our respects to Dr. Hewison and his lady. 


\section{CHAPTER XLIII.}

\section{SALTILLO TO RINGGOLD BARRACKS.}

Leave Saltillo-Accident at the start-Enter the Rinconada Pass-A night in the defile-Los Muertos-Ampudia's redoubt-Magnificent scenery -Hacienda of the Rinconada-Sierra Mitra-Santa Catarina-Subarbs of Monterey-Loma de Independencia-Arrival at Monterey-Pronunciamentos-Visit the Bishop's palace-Beautiful valley-The citadelProsperity of the city-Its climate-Elevation-Departure-MarinRamos-Carrizitos-Dense chapporal-Miss the road-Cerralvo-Puntiagudo-Bad road-Mier-Trade for serapes-Texan Mier Expedition - Character of the Rio Grande above Mier-Ascent of a steamboat to Loredo-Ancient oyster beds-Rio San Juan-Mexican brigade-Camargo-Cross the Rio Grande-Arrival at Ringgold Barracks.

December 10th. As we were not yet out of the reach of the Indians, I applied to, and was furnished with an escort of ten mounted men by the authorities here, who were promptly on the ground at the hour named for starting. Our repairs being completed, we left Saltillo this morning, but had not proceeded more than three or four miles, slowly over a smooth and level road, when the wheel of another wagon gave way, without any apparent cause. On examination it. was found that most of the spokes and the rim were broken, so that the wheel was utterly ruined. Fortunately, we were near Dr. Hewison's factory, to which I rode 
immediately, and was promptly furnished by the superintendent with a beam, which we rigged to the end of the axle as a drag. After the delay of an hour or two, we again moved forward. We passed many haciendas and ranchos, and after proceeding about twelve miles entered the famous Rinconada pass. * The road now became very uneven with a continuation of hills and valleys, while mountains rugged and lofty rose on either side; the defile averaging about two miles in width. Passed a monument erected by the ladies of Saltillo on the spot where some Americans had been murdered by robbers. After making about twenty-five miles, we reached a rancho in the pass called Los Muertos (The Dead), where, just at sunset, we encamped. A small stream flowed by, lined with large cotton-wood trees.

December 11th. It was very cold when we left camp this morning, our elevation now being 6104 feet above the level of the sea, so that all wrapped themselves in blankets or overcoats. Our escort, who put on their gaudy serapes, made a very picturesque appearance. Soon after leaving we reached a narrow and steep descent, where we were obliged to wait for a train that was coming up, before we could descend. Here the pass did not exceed five hundred yards in width. Near this, on the left, is a spur of the mountain which overlooks and commands the defile, where General Ampudia erected a battery or breastwork, for the purpose of checking the advance of the American army. While the train was waiting, I went out to

* Rinconada, a corner or lurking place. 
examine this work, which was but a few rods off, and took a sketch of the magnificent defile. Far ahead, we could just perceive the picturesque summit of the Sierra Mitra (Mitre Mountain), so named from the striking resemblance of one of the summits in the range to a bishop's mitre. The place selected for the Mexican battery would have greatly embarrassed our army had it been maintained; but after the fall of Monterey, it was abandoned.

Soon after descending this hill, we reached the rancho of Rinconada in a curious little nook in the mountain resembling a horseshoe, which gives its name to the pass. From the number of fruit trees and cultivated grounds it had doubtless been once a thriving place. Every thing now seemed to be fast going to ruin.

We continued to descend the whole day; yet, owing to the roughness of the road, and our three-wheeled wagon, we were obliged to drive with great caution, that we might not further disable ourselves. Our escort pointed out to us as we progressed another rancho, which was attacked by a band of Indians a few months before, and all the inmates murdered.

We were unable to reach Monterey as we had hoped to do, and it was long after dark when we reached the village of Santa Catarina, at the base of the Sierra Mitra and about twenty miles from the Rinconada, where we encamped.

December $12 t h$. Soon after leaving, we passed the Molino de Jesus Maria, a large flouring mill, and shortly after reached the Loma de Independencia upon which stands the Bishop's palace, so celebrated in the opera- 
tions of the American army during the investment of Monterey. Having now reached the valley in which stands the city, we passed by walled inclosures where, among a variety of fruit and ornamental trees, we saw some loaded with oranges and lemons. Stone houses with high thatched roofs, surrounded by pretty gardens with more of an air of comfort than any we had seen, lined the approach to the city. On entering, we drove to a corral; and after putting up the wagons and animals, we. took up our quarters at Coindreau's Hotel; a spacious building with a large court, in the style of the country. One might have imagined that another bombardment was going on from the roar of cannon, as we entered the town; but it proved to be nothing more formidable than the celebration of the day of the "Holy Lady of Guadalupe," one of the greatest festivals of the country.

December 13 th. Lost no time in setting the blacksmith and carpenter at work, and in the mean time sallied forth to see what was remarkable in and about the city. We found several Americans in the place, although the number had greatly diminished within a year. There are a great many shops, and every description of goods to be found in them. In many of them the clerks speak English, acquired during the occupation of the city by the Americans. A large commerce has now grown up between Monterey and the United States, which will tend to Americanize the place. At the time of our visit, the singular state of the frontier had greatly contributed to increase this commerce. Pronunciamentos, another name for révolutions, were then in vogue at Matamoras, Camargo, 
Monterey, and other towns, under varions political pretexts; while the real object was to destroy the custom-houses, for the purpose of introducing merchandise without duty. Large quantities had thus been brought in, and sent into the interior of the country.

Rode out to the Bishop's palace; from which, as well as from the Loma de Independencia in the rear, one obtains a fine view of the city. This is a fine old building of stone, and in its day was no doubt an elegant structure; it was in ruins, however, long before General Worth took it. The hill on which it stands is ăbout one hundred and twenty-five feet high; but the portion where the American forces made their charge, is some fifty feet higher. On reaching that, they commanded the palace, where the Mexicans had entrenched themselves behind a strong battery, but which they were soon compelled to evacuate.

The city stands on a plain about a mile distant, and is embosomed among beautiful gardens and orchards, its white houses presenting a striking contrast with the deep green of the foliage. To the south, runs a small stream, a branch of the San Juan River, in the midst of a broad arroyo; beyond which a chapporal plain interspersed with a few cornfields, extends about seven miles to the Saddleback Mountain, one of the most singularly shaped eminences in the country. This mountain is isolated, and forms the last link of the great chain which so abruptly terminates here. To the north and east of the city, a broad plain extends as far as the eye can reach, with here and there fields of corn and sugar cane, among wider fields of chappo- 
ral. About half a mile from the c1ty on this plain, stands the "Black Fort," or citadel, a prominent feature in its fortifications. I went to this fort, but although I sent my card to the commanding officer, was refused admission.* It covers an area of about three acres. Its walls are of solid masonry, with bastions commanding the approaches from the northward. On the eastern side of the city, are several redoubts, as well as along the margin of the arroyo. It was in the taking of these that our army suffered most. The old tannery, where there was a sharp contest, remains just as it was left by our troops. An American gentleman familiar with the history of the affair, accompanied me in a visit to this quarter, and pointed out the several localities.

Monterey is the capital of the State of Nueva Leon, and has a population of from fifteen to eighteen thousand souls. $\dagger$ It is the only city I visited in Mexico (Hermosillo in Sonora, alone, excepted) which is increasing. Here improvements were in progress. Many fine houses were in the course of erection; others were undergoing repairs, and every thing had the appearance of a thriving, active place. The streets are paved and kept clean. Much as has been said of the filth of Mexican towns, I can testify that our New York street inspectors might profit by the example of Monterey.

* In my various journeys through Mexico, this was the only instance of the kind that I met with.

+ My estimates of the population of this and other towns, are from Mexican authority, and are not always reliable. People are too apt to over estimate the population of their towns, and are reluctant to confess their decline. 
We visited the church on the plaza, which had been the hospital for our troops. It contains some bad pictures, and a large quantity of massive silver plate. Into this plaza the Mexican troops were driven before they capitulated.

The city has an elevation of 1626 feet above the level of the sea. We had therefore descended, since leaving Encantada, in a distance of seventy-six miles, 4478 feet.* With this sudden descent, we noticed a striking change in the temperature. As long as we were on the high table land, the mornings and evenings were invariably cool, so as to render an overcoat necessary. We were all glad to get around fires, whenever there was fuel enough to make one; and at night, three or four blankets were necessary. Now, on the contrary, we experienced the genial warmth of June, with roses in bloom in the open air ; thin clothing felt comfortable, and the nights were mild.

December 15 th. Resuming our journey this morning, we passed near the citadel, where our escort of ten dragoons, kindly sent by the Governor, joined us. Our route was now across a broad plain unobstructed by hill or mountain. Passed several ranchos, where the people were engaged in boiling sugar. This region produces fine cane, though its cultivation is not so extensive as would be supposed. Passed, also, the small towns of San Domingo and San Francisco; and three miles beyond stopped at Aqua Fria, a straggling town built upon two sides of a deep arroyo.

* Encantada, according to Dr. Wislizenus, is 6104 feet above the sea. 
December 16 th. The road descended as it did yesterday, and was lined on both sides with dense chapporal. Made a noon halt at a fine stream, the Rio Meteros, just beyond the town of Marin. Passed Aqua Negra, where, during the war, General Canales, with a guerilla band, burned a train of United States wagons, and murdered the unarmed teamsters. At 3 o'clock, reached Ramos, a small agricultural town, eighteen miles from our last camp, where we stopped. The people collected around us soon after our arrival; and from them we learned that it was exceedingly sickly in the place; many of them were suffering from fevers.

December 17 th. Our road to-day was very hilly and stony. Chapporal and low trees closely hemmed in the road, rendering the march dull and monotonous. At 4 P. M., we encamped at a rancho near the town of Carrizitos, where we obtained corn and water.

December 18th. Between Monterey and the Rio Grande, the chapporal is crossed by frequent roads, some running to Reynosa, others connecting villages and ranchos. We were told of this difficulty; but as the courier who brought my letters from Camargo to Encantada, said he knew all the roads, I was induced to let him act as our guide. To-day, however, he mistook his way, and led us into an almost impassable wood. We could not turn around, and were compelled to cut our way for some distance before we struck the road again. Fortunately we extricated ourselves without accident, after the delay of an hour or two.

Soon after, we met with an accident that might have proved more serious. This was the loss of one of the iron boxes to a wheel hub. The train was stopped 
and men sent in search of it, who found it four miles back.

Reached Cerralvo at noon. This is a better looking town than any passed since leaving Monterey. Many of its houses are of stone, and built with some taste. Pushing forward, we encamped at Puntiagudo, about twenty-four miles from our last camp. This is a small village, which still exhibits the effects of the late war in the bare walls of its ruined houses. A small stream passes here, one of the tributaries of the Alcantra.

December 19th. Our road continued over low hills with deep and narrow arroyos at the bottom, one of which cost us a wheel and a tongue. An occasional ravine to pass with abrupt banks, is bad enough; but to-day the whole country seemed to be cut up with them, requiring the utmost care to prevent accidents. After thirty miles of continuous chapporal and a bad road, we reached the town of Mier, on the Rio Grande at 8 o'clock, though it was midnight before we could get corn for our animals, and reduce our camp to quietness.

Mier is an old town on the banks of the Alcantra, a small stream which empties into the Rio Grande three or four miles beyond, and appears, like most other Mexican towns, to be on the decline. In 1828 its population was two thousand eight hundred and twenty-one. It is now much less. Many of its houses are of stone, and well built. It has no lands capable of irrigation; the people, consequently, are obliged to depend upon other occupations than agriculture for support; and this, doubtless, is the reason of their indus- 
trious character. Mier is celebrated for its fine manufactures of serapes and blankets ; and there was scarcely a house in which we did not see the women occupied in weaving them. These serapes, which are worn by all elasses, are made of wool, ornamented with a variety of figures and of various colors. They bring from six to one hundred dollars each, according to their quality and ornaments.

This town fills an important place in the annals of the Texan revolution, on account of its capture by the Texans, under the command of Colonel Fisher, their surrender afterwards to the Mexicans, and their subsequent history.*

Proceeding up the Rio Grande above Mier, the character of the country changes for the better, the bottoms becoming more fertile. The shores are for the greater part, a narrow strip of sand or gravel, surmounted by river bluffs of various heights. The willow, and occasionally the white cypress, occur near the river, while further back the mezquit, ebony, etc., abound.

* This party, which consisted of 261 men, crossed the Rio Grande, where they encountered a Mexican force of 2340 men, with whom they had a severe battle, and took possession of Mier. In this contest, according to the statement of General Green, an officer at the time, the Texan loss was, ten killed and twenty-three wounded-that of the Mexicans, between seven and eight hundred killed and wo nded. The Texans were afterwards induced to surrender to General Mejia, on certain pledges being given them by General Ampudia. They were placed under a guard of three hundred men, and marched off to the City of Mexico. After they had passed Saltillo and were crossing the desert to San Luis Potosi, they rose on their Mexican guard at a place called Salado, overpowered them, and made their escape. Had they kept together and followed the roads, they would have found water and food, and 
In October, 1846, a successful attempt was made to ascend the Rio Grande in the United States steamer Major Brown, by order of General Patterson, with a view to ascertain whether or not it were possible to open a communication between Camargo and the Presidio del Norte. This vessel drew but two feet of water. She experienced few obstacles in reaching the river Salado, nearly a hundred miles by water above Mier. Above this, there was a series of continued shoals, rocks, and rapids, among which the boat repeatedly grounded. She at length reached Laredo, a town about six hundred miles by water from the mouth of the river. Up to this point it was believed that, with the expenditure of one hundred thousand dollars, in removing obstructions, the river might be naade navigable for boats drawing four feet of water.*

December 20th. The bad road of yesterday gave us considerable patching up to do, and caused several hours detention. The good people of the town availed themselves of this delay, and soon thronged the camp,

would doubtless have gained the Texan frontier. They, however, scattered and sought the mountains, where they suffered extremely for the want of water and food. The whole population was roused in pursuit of them ; the small parties were picked up, and the main body reduced by starvation, finally surrendered. They were again marched back to Salado, where, by order of General Santa Aña, they were decimated. Out of 176 prisoners, 17 were shot, the remainder were sent to the city of Mexico. Of these, 35 died from suffering and starvation. Seven were released through the intercession of the American Minister, and four through the intercession of the British minister, dc.-Green's History of the Texan Mier Expedition.

* "Tilden's Notes on the Upper Rio Grande," of an exploration made by order of Major General Patterson. 
each bearing on his or her arm a serape for sale; and I doubt whether, since the occupation of the country by the Americans, they have found so good a market for their productions. Many gentlemen of the party had been desirous to take home with them one of these articles; and the opportunity now presented of buying them fresh from the loom, and at prices much lower than we had seen them in the shops of Monterey and Saltillo, induced many to secure specimens.

In walking round the camp, my attention was attracted to some large oyster shells, which protruded above the clay bank; and, on extending my examination about seventy yards to the south, to a deep arroyo, I noticed thick beds of shells of the genus Ostrea, in its sides and on its bottom. According to Dr. Tilden. these beds extend up to near Loredo; and Dr. Wislizenus found them two miles below Mier on the immediate banks of the river. Our camp was near the town, and the surface of the clay bank where we found them, was at least fifty feet above the river.

We now set out for Camargo, twenty-five miles distant, keeping the western bank of the river, through a forest of chapporal. About several miles distant on the opposite bank, we saw the town of Roma, and soon after were cheered with the sight of a small steamboat, which occasionally works its way as far as this. It is evident that the navigation is attended with difficulties, as we saw her more than once fast on sandbars, which here begin to obstruct the navigation.

Finding that the train would not reach Camargo before dark, and being anxious to get to Ringgold Barracks as soon as possible, I set off in advance, ac- 
companied by Mr. Radziminski and our guide. On reaching the river San Juan, a large stream which enters the Rio Grande, three miles from Camargo, and on which that town stands, we found a body of three or four hundred Mexican troops, cavalry and infantry, waiting to cross. This stream is quite deep, and is crossed by a ferry boat attached to a rope extending from one bank to the other. As the boat would hold but a few horses, it was evident that, if I waited for the whole to cross, I should not get over for hours. I sent my guide (who it appeared was a soldier belonging to the command at Camargo), with my compliments to the commanding officer, Colonel Cruz, to permit me to cross at once. This gentleman very politely acceded to my request, and directed the boat to take over me and my party immediately. On reaching the opposite side, I rode to the quarters of Colonel Cruz, to pay my respects to him, and request permission of him to allow the train of the Boundary Commission to pass unmolested. He assured me that every facility should be afforded the train to cross the San Juan, and thence to the American line. There was some danger here; for this officer was in arms against the Mexican government; and but for the character of my party, it would not have been suffered to pass so quietly. We had had, too, a narrow escape from the rebel chief Caravajal, who, with a band of some two hundred desperate characters, had been devastating the frontier. We had heard of them at various places after leaving Monterey; and at one village, we learnt that they had passed but the day before.

The population of Camargo is about the same as 
that of Mier. Its houses are built of stone or adobe. There is more arable land here, and the same manufactures are carried on as at Mier. Before the Indian wars and the wars of Texas, there were numerous ranchos on both sides of the Rio Grande. Their occupants were chiefly employed in raising of cattle, of which at one time, they possessed not less than forty thousand head. These establishments have now been destroyed, or abandoned. During the late war, the American army had a large depot at this place. The steamboat which . navigate the Rio Grande, finds no difficulty in coming up as far as Camargo. At high water, boats drawing five feet, ascend it with safety.

A ride of three miles, after leaving Camargo, brought us to the Rio Grande, which we crossed in a scow. Its width here is from one hundred and twentyfive to one hundred and fifty yards, with steep banks. On the American side is a considerable settlement, known as Davis' rancho; and about half a mile below is the military post, known as Ringgold Barracks. Hither I drove at once, and was met by Major Paul, the commanding 'officer, and the members of the Commission, who with Major Emory, the United States Surveyor, had been awaiting my arrival.

December 21st. Our train reached the opposite banks of the San Juan last evening, and was occupied the whole of to-day in getting across the two rivers, when the party encamped near the barracks. 


\section{CHAPTER XLIV.}

\section{RINGGOLD BARRACKS TO CORPUS CHRISTI.}

Rio Grande surveying parties-State of the Survey-Despatches from Washington-Proviso affixed by Congress to the appropriation for the Commission-Letter of the Hon. Alex. H. H. Stuart, Secretary of the Interior-Money withheld-Compelled to disband the Commission and return home-Unfortunate situation of the party-Send the train and government property to San Antonio-Leave for the coast-The grassy prairies of Texas-Sal Colorado-Wells at Santa TeresaRavages of the Comanches-Night alarm from mustangs-Abundance of deer and antelope-Los Olmos-Immense drove of mustangsExciting race over the prairie-Horse lost-The prairie on fire-Rio San Francisco-Agua Dulce-Arrival at Corpus Christi.

December 22d. At Ringgold Barracks. When I left El Paso, it was for the purpose of joining Major Emory at this place, in order to complete the survey of the Rio Grande. I now learned from this officer that the survey had been carried as far down the river as Loredo, with the exception of a small space still to be covered between the great Chizo Cañon and the Rio San Pedro, on which two parties were then operating. It was believed that the small portion extending from Loredo to the mouth of the river might be finished in three or four months. The season was the most favorable for engineering operations, and the parties were voL. II. -33 
all on the spot with their instruments, camp-equipage, wagons, animals, provisions, etc. In fact every thing required to ensure the speedy completion of the work was at hand, except boats, which would be necessary when near the Gulf. But all my plans were frustrated by the despatches from Washington.

The despatch of the 15 th October, 1852 , received ${ }^{\circ}$ by me at Encantada, advised me that to the appropriation of one hundred and twenty thousand dollars made by Congress for defraying the expenses of the Boundary Commission, a proviso was added that it should not be used "until it should be made satisfactorily to appear to the President of the United States that the southern boundary of New Mexico is not established by the Commissioner and the Surveyor of the United States further north of the town called Paso than the same is laid down in Disturnell's map, which is added to the treaty."

In communicating to me this act of Congress, the Secretary of the Interior says, that the President and himself "have been forced to the conclusion that, in view of this restriction, the money cannot legally be drawn from the treasury." The Honorable Secretary expressed a strong desire that the work shall go on if I already have the means of maintaining the parties long enough to complete the survey of the river; but if otherwise, the Commission must retire from the field.*

* Here follows the despatch itself :

Department of the INTERIor, WAshington, Oet. 15, 1852.

Sir :- In the Deficiency Bill of the last session, which was approved 21st July, Congress appropriated for the Mexican Boundary Survey the 
The course I had to pursue was plain. Congress nad said that if the southern boundary of New Mexico had been established further north of the town of El Paso than it is laid down in Disturnell's map, the money appropriated to carry on the survey could not be used. This was a new interpretation of the treaty, and one not required either by my instructions or by the words of the treaty itself. The boundary line was

sum of eighty thousand dollars. This was immediately absorbed by the drafts and liabilities which were then outstanding, and the additional sum of twenty-five thousand dollars for like demands was obtained by the act approved 31st August, which has also been nearly exhausted, and other debts still remain unpaid. In this latter the sum of one hundred and twenty thousand dollars was appropriated for the present fiscal year, with a proviso that it should not be used "until it shall be made satisfactorily to appear to the President of the United States that the southern boundary of New Mexico is not established by the Commissioner and Surveyor of the United States further north of the town called 'Paso' than the same is laid down in Disturnell's map, which is added to the treaty." Inclosed I send you a printed copy of my report to the President in regard to this proviso, and of his indorsement thereon. You will perceive that the President and myself have been forced to the conclusion that, in view of this restriction, the money cannot legally be drawn from the treasury. It will not be proper, therefore, for you to make any further drafts upon the department. * * * No exception has been, or could possibly be, taken to the river portion of the boundary; and it is much to be regretted that the department has not authority to use the appropriation for that portion of the survey. * * * You may, possibly, already have the means of maintaining your respective parties long enough to complete the survey of the river, or until you shall have been advised of further action by Congress on the subject. The withdrawal of the Commission is not imperatively called for by the action of Congress, except in so far as the withholding of funds may render it necessary. It would be very desirable to avoid it, if possible; as Congress will again be in session in the course of about six weeks, and possibly as soon as you will receive this communication. 
established at $32^{\circ} 22^{\prime}$ north latitude, where it stands on the treaty map. El Paso is placed on that map about seven minutes of latitude south of the boundary; but when this town is removed to its true position at $31^{\circ} 45^{\prime}$, the distance between the town and the boundary is of course increased to the extent of the error of the map.

I had not money sufficient to continue the work, or

Such a movement would also be attended with much delay in the completion of the survey, and greatly increased expenses to the United States and to the government of Mexico, besides embarrassment and hardship to the employés of the Commission, whose sole dependence is upon their individual labors. It would likewise be a cause of further dissatisfaction on the part of the Mexican government. It will not be proper for you in any event to continue operations on the disputed portion of the boundary (the southern and western limits of New Mexico), nor to make any further drafts upon the department; and if you have not the means already acquired in the manner indicated for completing the survey of the Rio Grande, you will of course cease operations altogether, and return to the United States with your surveying parties. But not knowing precisely your situation in these respects, your return or continuation in the field rnust, with these views of the department before you, be left to your own sound discretion.
*
*
*
*
* $\quad *$

In the event of your being obliged to return from the field, you will make the best possible disposition of the government property in the service of the Commission. * * * But in all these matters you will be governed by considerations of economy to the United States, and convenience and expedition in the future resumption of the work.

I am, Sir, very respectfully,

Your obedient servant,

ALEXANDER H. H. STUART,

John R. Bartlett, EsQ.,

Secretary.

U.S. Commissioner,

Mexican Boundary Survey. 
even to defray the expenses of the officers and men to their homes. The money was tendered to me on my drafts by several houses to the amount of seventy-five thousand dollars, if I decided to go on with the survey; but the instructions sent me on this point were clear, and however desirous I was to complete the work, the will of my government must be obeyed, no matter at how great a sacrifice. The Honorable Secretary directed me, if I already had the means, to continue operations on the Rio Grande, if not, to cease altogether and return home. The intention of Congress was doubtless to break up the survey, and my duty was to submit.

The next step was to disband the Commission as suon as possible, to get the officers and men to their homes, and to place the valuable property of the government where it could be taken care of at the least expense, and where it would be convenient, should Congress, on further reflection, remove the proviso and order the survey to be resumed.

To reach Washington or New York from this distant place would cost a considerable sum; and I found my means quite insufficient to defray the expenses of more than one half of those whom the government was bound to transport back to the places from which they came. Here was a sad dilemma for a large body of men to be placed in by an act of Congress, without any fault on their part-men who had been most arduously engaged on a toilsome and dangerous service for two years and a half, risking life and health in the faithful performance of their duties. I would have been justified in selling off at once, at public auction, 
all the government property, and appropriating the proceeds to the pay of the men, and to enabling the officers to reach their homes. Such a course would have been adopted by most officers placed in my position; but I was willing to submit to inconveniences if the laboring men could be relieved.

I determined, therefore, to divide the money in my possession among the officers, as far as it would go, to meet the expense of reaching their homes. It was enough for about one half. I then directed the quarter-master and commissary, Mr. George Thurber, to take the entire train of animals and wagons (including those used by Major Emory and his parties), together with all the public property, except the instruments, and proceed with the same to San Antonio. That place was a convenient point from which the survey could again be resumed whenever it would be the pleasure of Congress to order it; and it was a place where the animals could be kept at the least expense. I also desired $\mathrm{Mr}$. Thurber to reserve twelve of the best wagons, one hundred mules, and a portion of the equipments and camp equipage, and to sell the remainder at public auction, and apply the proceeds to the payment of the men. And I further directed him to make arrangements with some mercantile house in San Antonio to advance the sum necessary to pay off the laboring men and teamsters, as well as to enable the remaining officers to return to their homes, and to draw on me at Washington for the same." The instru-

* The train continued to Corpus Christi; after which Mr. Thurber proceeded to San Antonio, as directed. He there raised the 
ments, both astronomical and surveying, were in eharge of the principal surveyor, Major W. H. Emory. Having made these arrangements, we prepared to continue our journey to the coast. A steamer ran to Matamoras; but as there was no communication between that place and New Orleans, I thought it the surer way to proceed by land to Corpus Christi, on the Gulf of Mexico, about one hundred and fifty miles distant, and thence by land or water to Indianola, where a line of steamers connected with New Orleans.

December 27th. Left Ringgold Barracks at one, P. M., with a portion of the train, accompanied by Major Emory with his officers and several wagons. Mr. Thurber remained, intending to follow the next day with the rest of the train. The country for five or six miles is undulating, with low hills and a gentle ascent from the river until the plain is reached. For this distance it is covered with the same dense chapporal as on the opposite side of the river, and is equally destitute of grass. Passing this belt, a higher level is reached, where there is better soil. Here grass begins to appear, with larger shrubbery; the mezquit reaching a height of from fifteen to twenty feet, and

necessary funds, through the kindness of Messrs. Vance \& Brother, merchants at that place; which enabled him to discharge and pay off all the teamsters, laboring men, and mechanies, some sixty or seventy in number, as well as to furnish the means to the rest of the officers of returning to their homes. He then remained with three or four men, barely sufficient to take care of the hundred animals he had reserved and the other property, until the following June, when he was released by the parties sent out to resume the work. The interruption of the survey delayed its completion about eight months, at an additional expense of fifty thousand dollars. 
forming thick woods. In passing a gully where the road was much washed away, the tongue of one of the wagons was broken and had to be repaired with ropes. Encamped after dark on the open plain, amid an abundance of grass.

December 28th. The prairie continued grassy, interspersed with the prickly pear and low mezquit, opening occasionally for a few miles without shrubbery. The road became quite sandy and heary for the animals. In the afternoon, stopped at Sal Colorado, a miserable cattle rancho with a well, where we stopped to water our animals. This place is called forty miles from Ringgold, which is a large estimate. There are pens and corrals here, used for catching and securing mustangs, in which this portion of Texas abounds. Continued our journey to Santa Teresa, five miles further, where we encamped. Here was a deserted rancho in ruins, with three wells near. It had been used, like that at Sal Colorado, for ensnaring wild horses. Last year the Comanches attacked it, murdered the occupants, burned the houses, and took away all the cattle, mules, and horses. It has not since been occupied. In two of the wells, which were about fifteen feet deep, the water was brackish; but from the third we procured good water with some difficulty.

December 29th. The mustangs came around our camp in great numbers last night. They so alarmed the mules that, fearing a general stampede, the guard was obliged to fire upon them, which drove them off. The road to-day was heavy; the country an open rolling prairie, covered with luxuriant grass, and dotted with clusters of mezquit and oak. Now and then would 
appear a long line or belt of these trees, extending a mile or more. At noon, stopped in a grove of mezquit, and sent our animals to a lagoon half a mile to our left for water. After letting them graze an hour, we resumed our march. We reached a pond four miles further, and a little beyond a second and larger one. This water was covered with wild ducks and geese; but they took the alarm at the first appearance of the train, and were off before we could get a shot at them. Keeping on a few miles, we encamped on the open prairie. Large numbers of deer, antelope, and wild horses were seen during the day; but the latter kept at a respectful distance. Two deer were killed.

December 30th. Off by break of day. The rolling prairie continued without trees or shrubbery, save here and there a little mot or group. As we approached Loma,Blanca (White Hill), some low hills appeared, whose sides showed banks of white sand. Herds of mustangs, going at full speed, crossed and recrossed the broad prairie, presenting a beautiful spectacle as they stretched for a mile or more, with their long bushy tails streaming in the wind. They did not venture within a quarter of a mile of us. Deer and antelope were also seen in great numbers bounding over the broad plain or feeding in herds. They too were shy, and had evidently come in contact with man before. As there was neither tree nor bush to be seen, and no cover of any sort, all our efforts to get within rifle-shot were unavailing.

Near Loma Blanca is the bed of a laguna, which extends for more than a mile on both sides of the road. 
There was every indication that it had recently been filled with water; but we sought for some in vain. Deeply worn paths made by the mustangs were seen in every direction, showing that it was a place of resort for these animals. After travelling eight hours we reached a chain of lagunas called Los Olmos, which crossed our path. Having travelled more than twenty miles over a sandy road, and our animals showing signs of great fatigue, we encamped. The water was sweet and the grass abundant.

December 31st. A portion of our journey yesterday was over the prairie, where there was no trace of a road. To-day continued the same; "yet the man who pretended to guide us seemed familiarly acquainted with it. A few hours after leaving, the prairie near the horizon seemed to be moving, with long undulations, like the waves of the ocean. Unable to account for this singular appearance, I looked with my telescope, when, to my surprise, I discovered the whole prairie towards the horizon alive with mustangs. Soon after they could be seen coming towards the train.

Major Emory at this time was in advance of me about half a mile with his portion of the wagons. We saw the long line of mustangs approach him, and soon after pass before, the whole herd following after, and extending as far as the eye could reach across the prairie. The mules became restive, and we could see the teamsters hurrying forward the wagons for protection behind each other. On went the great stream, and the next moment one of the mule teams in advance sprang from the train and dashed off at full speed after and among the wild horses. The teamster 


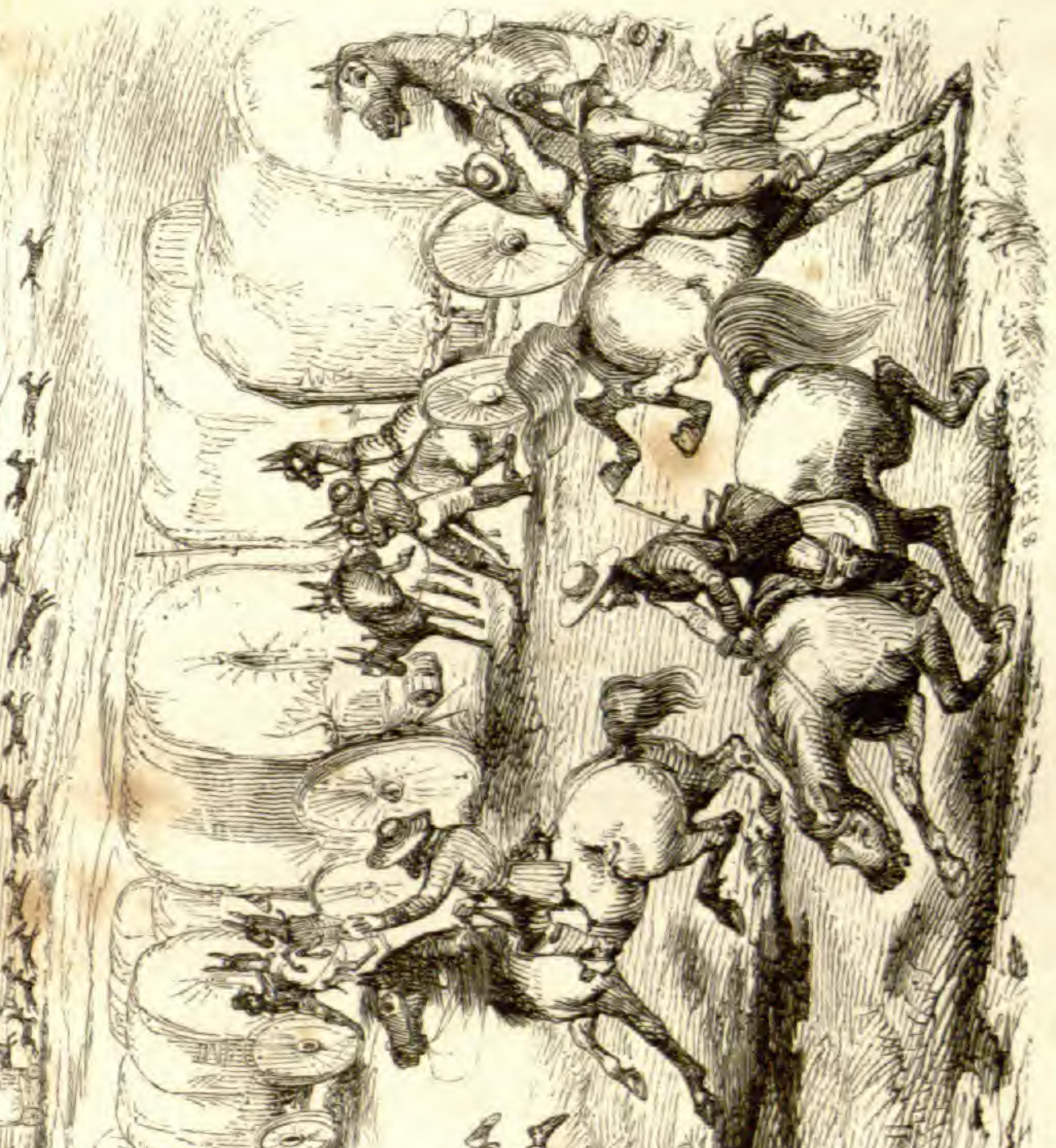

空

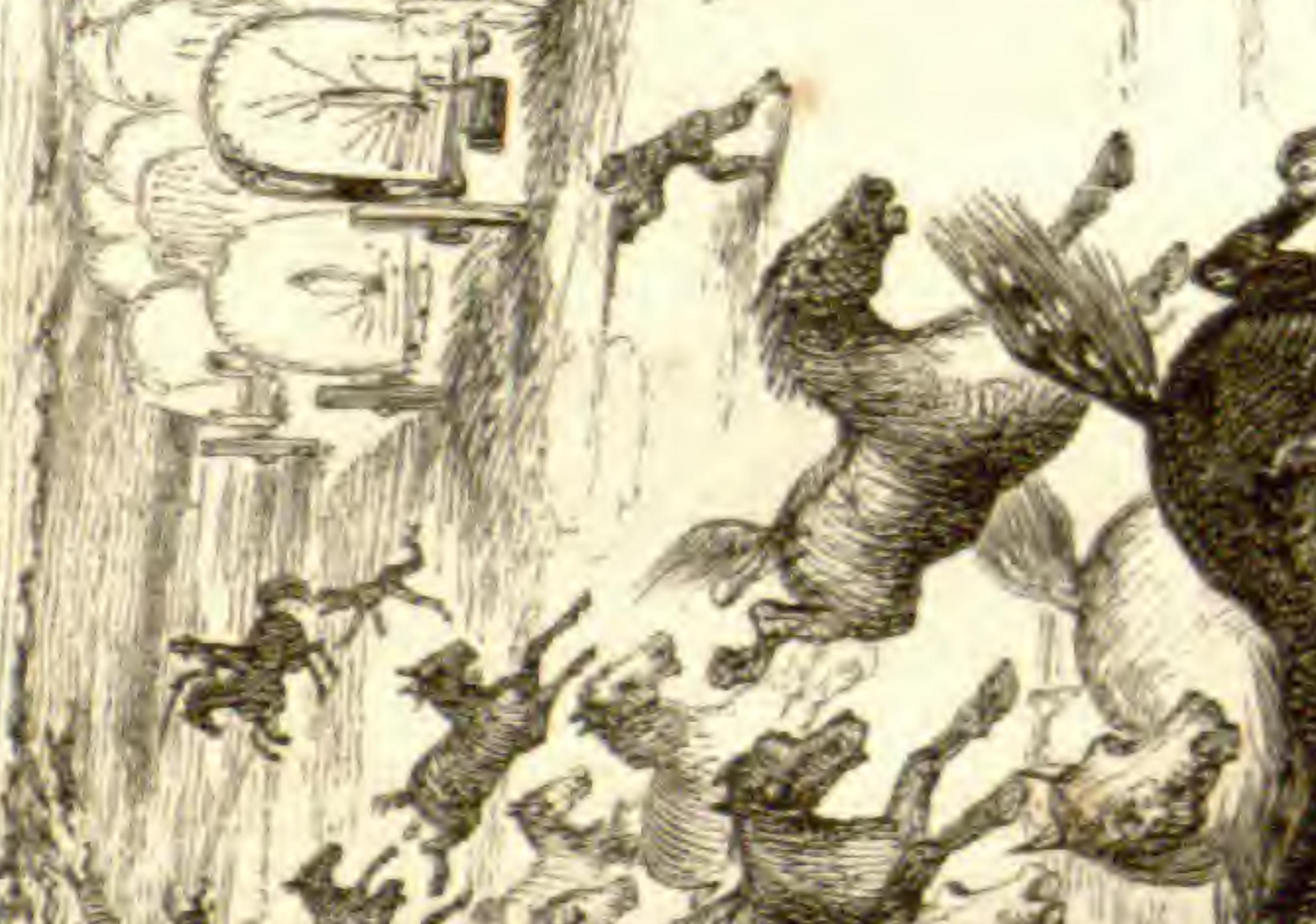

औ 4 (4)

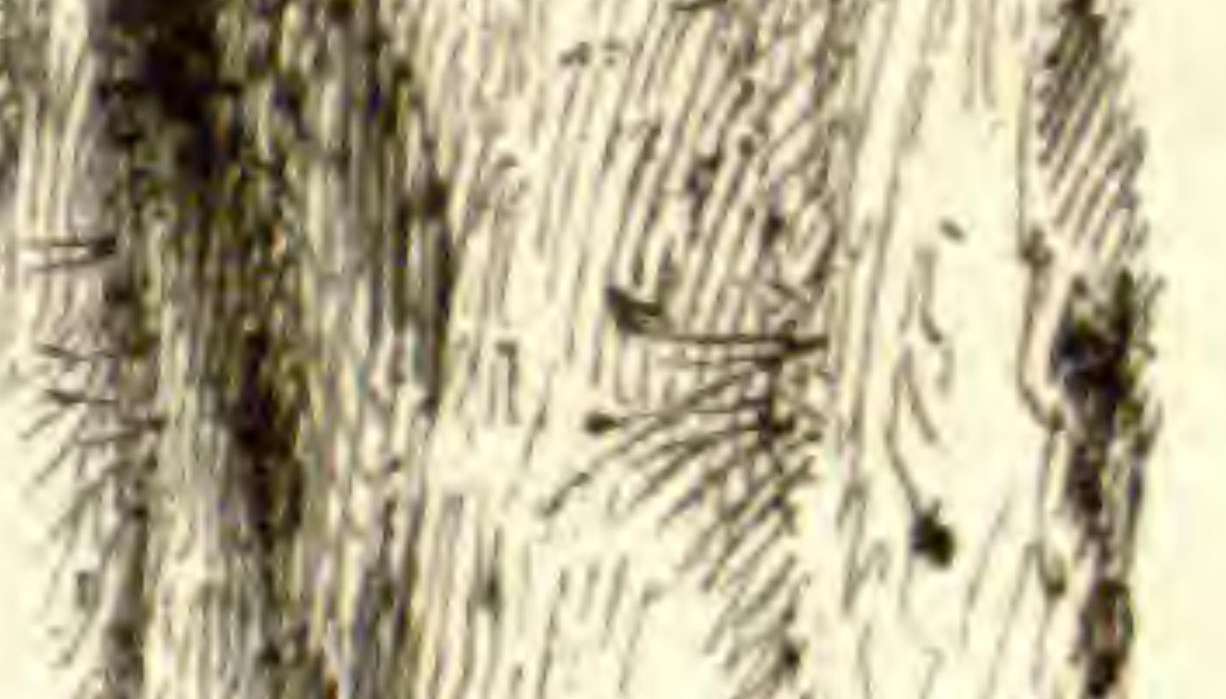

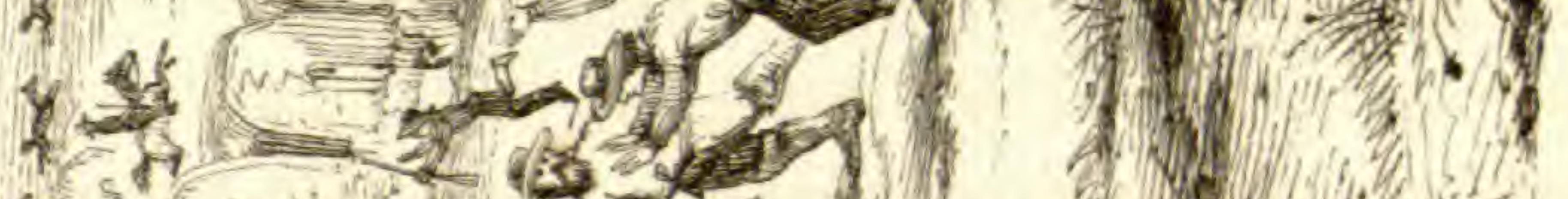

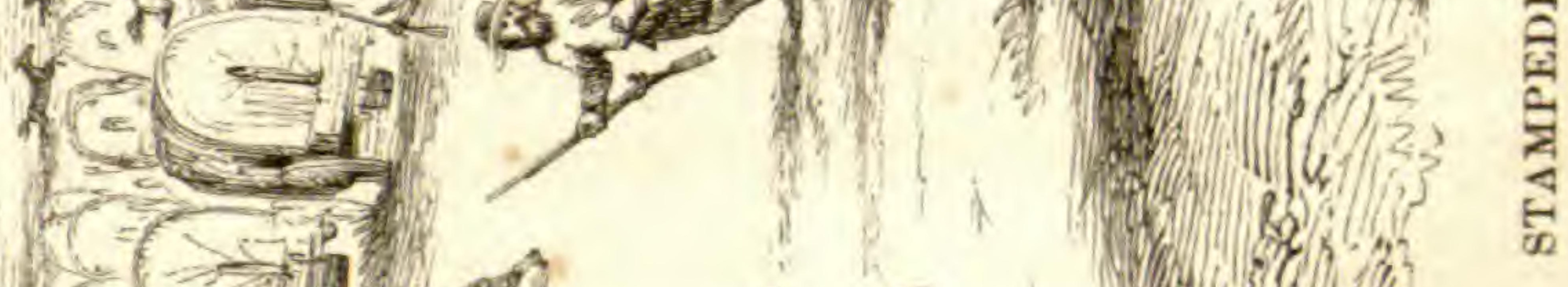

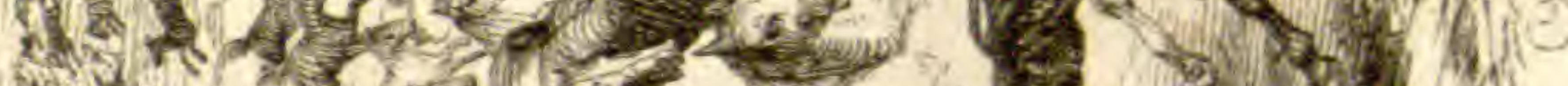

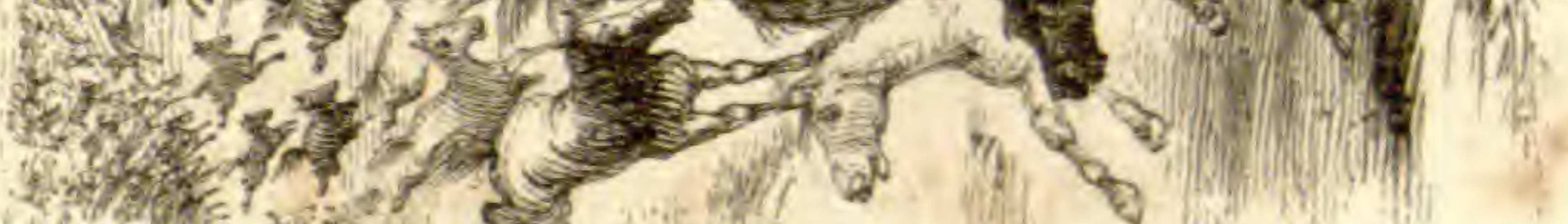
ing 
a

a
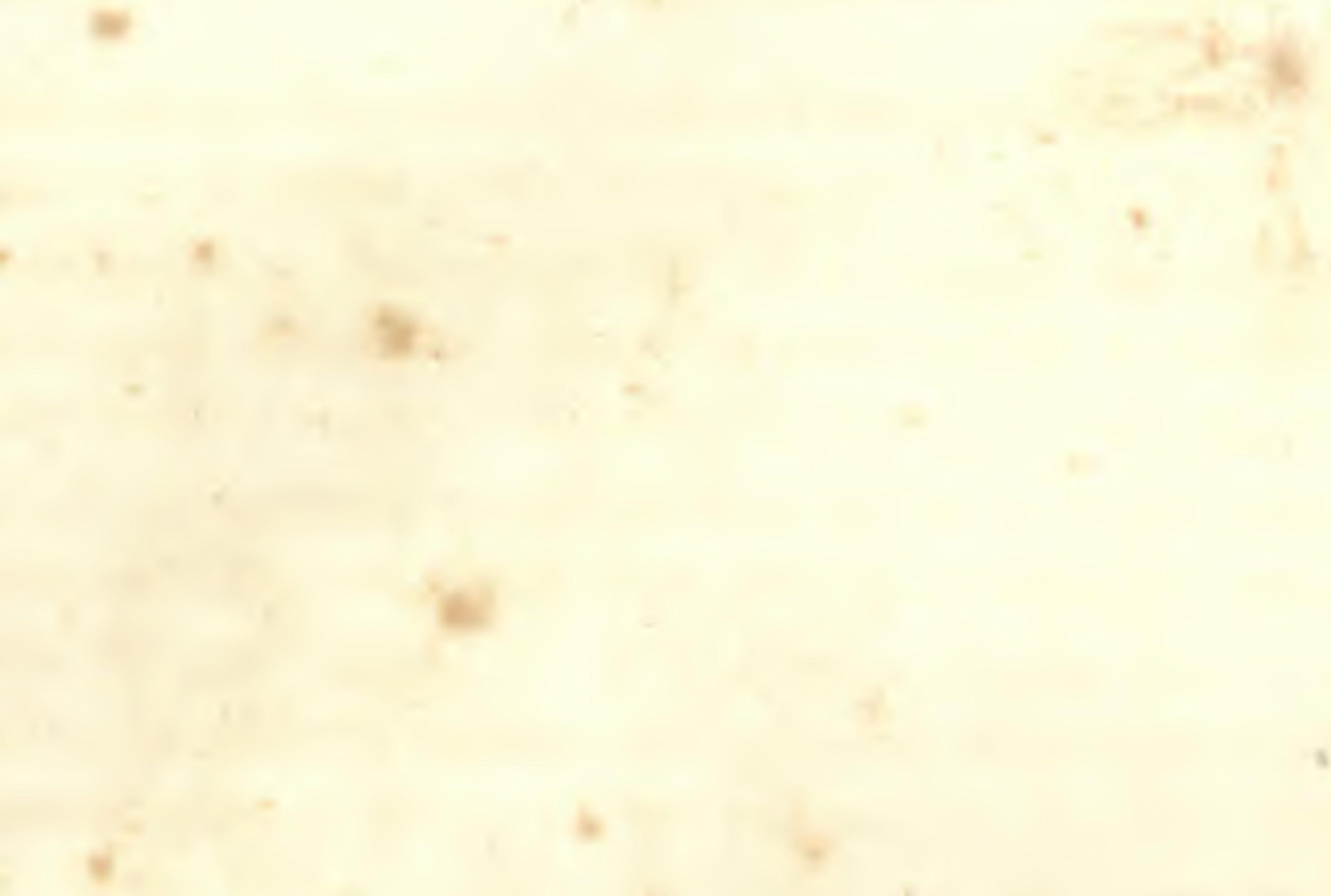

e
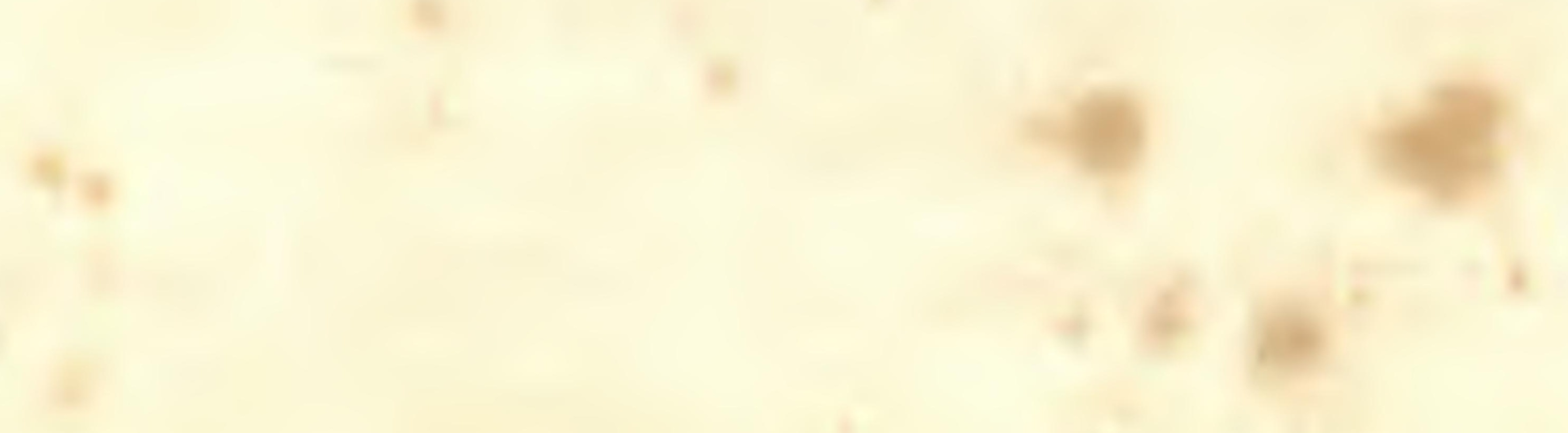

$+$

4

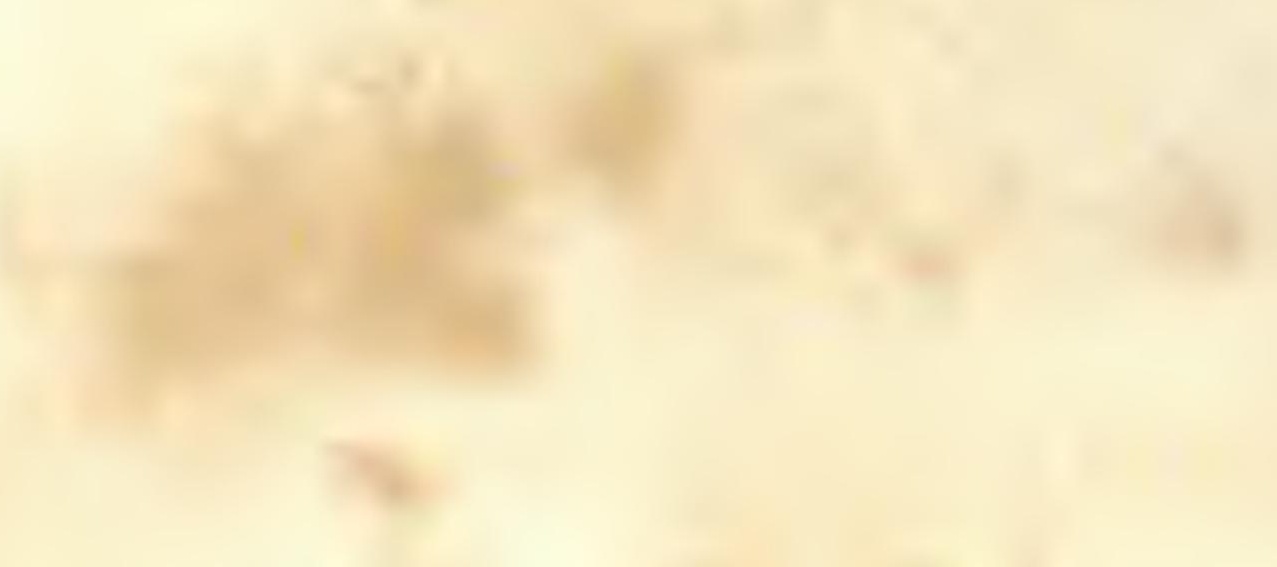

and

4

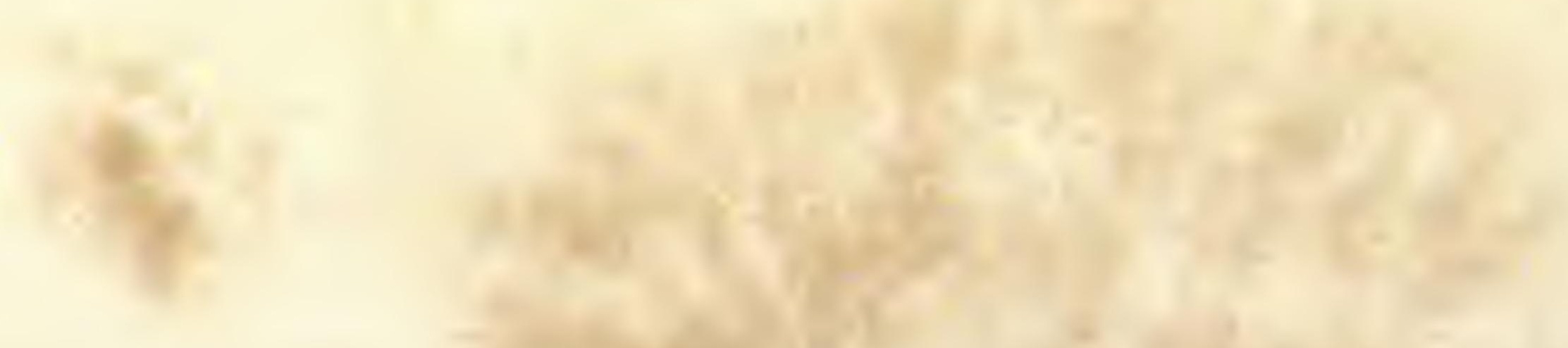

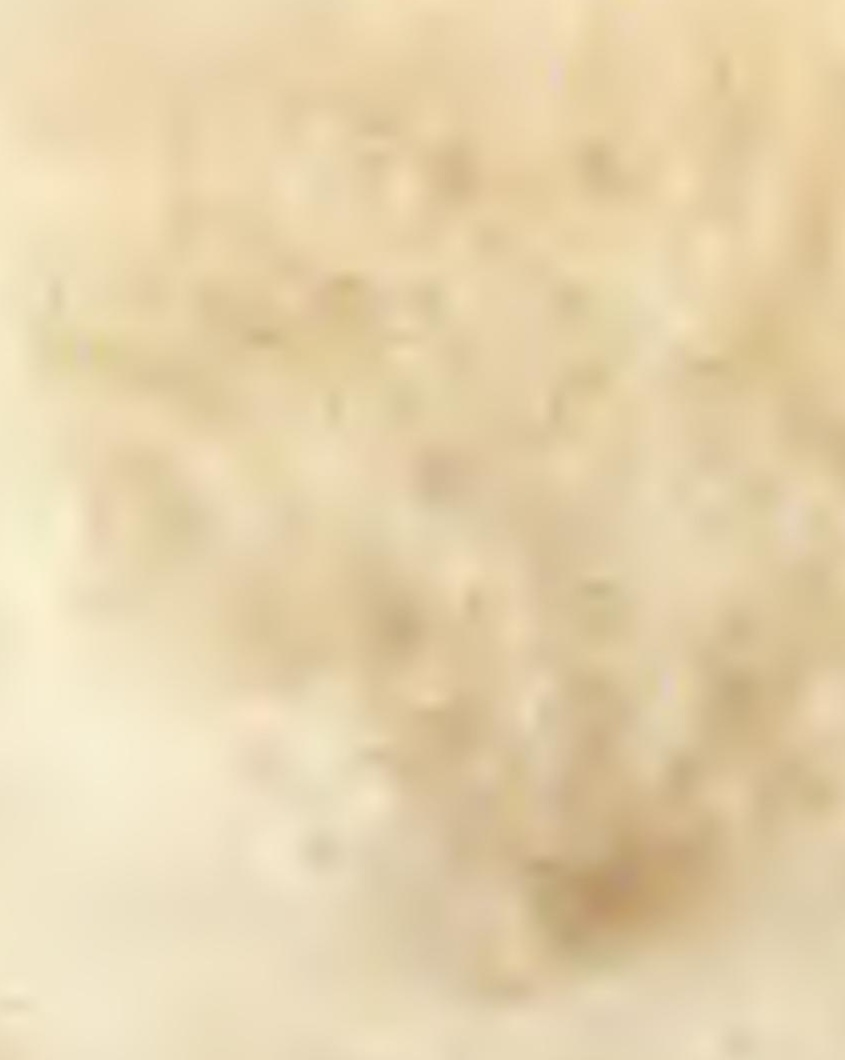

tex

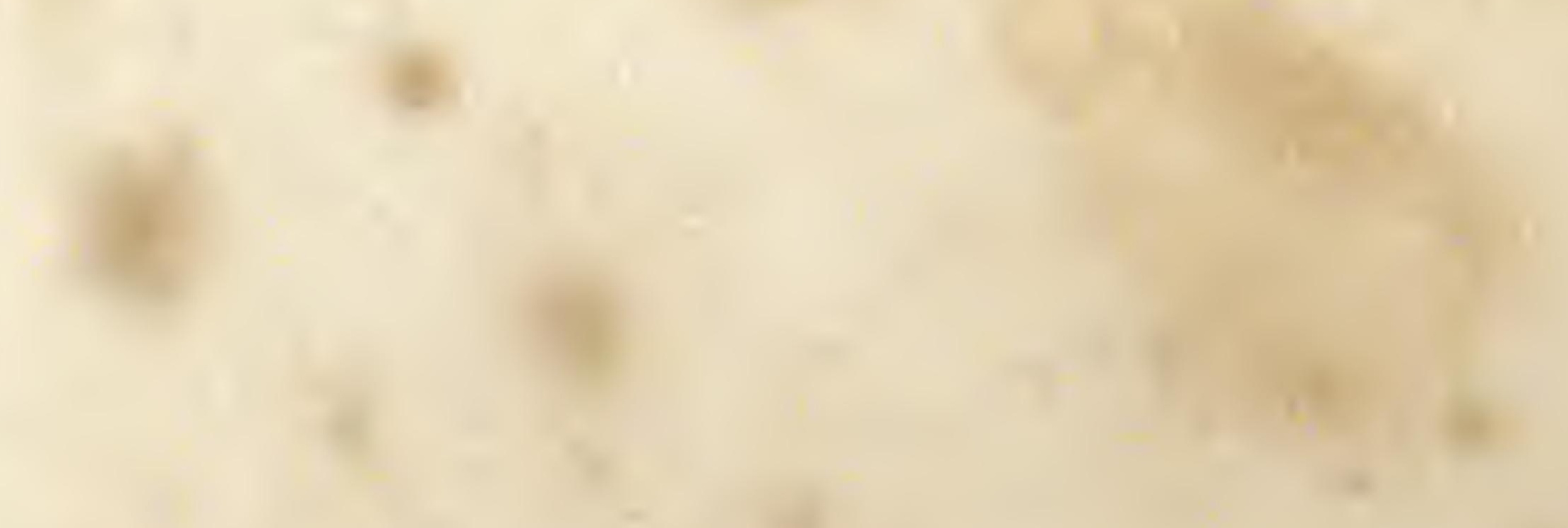


in vain tried to restrain them. It was all to no purpose. Away they went, John Gilpin like, the wagon with six mules, followed by all the loose animals that were driven with the train, which had also partaken of the stampede. The herdsmen, in order to check the runaways, left the train and went in pursuit, making altogether the most exciting spectacle we had yet witnessed. The chase continued for a mile; for the mules in the wagon had become perfectly frantic with fear, surrounded as they were by equally frightened mustangs, and all bounded over the prairie at their utmost speed. Seeing the danger, our men put on the lash, and we hurried forward to render such aid as lay in our power. The men of the other party fired at the herd, which had the effect of breaking the line, and turning it in another direction.

The frightened herd made directly for us, in the same long line, the termination of which we could not see, as it lost itself far in the distance. I now became alarmed, fearing a general stampede among - our mules; for nothing can restrain these timid creatures when frightened. If they cannot take their wagon with them, they become so frantic that they will tear themselves from their harness and flee away. Our first precaution was to close up the wagons, so that only those in the first one would see the mustangs. The mules of the second were placed alongside of the foremost wagon, the next by the side of the second, and so on to the last, each wagon thus protecting the team that followed it. We now locked the wheels of all, and men stood by the leaders to restrain and quiet them. As I had no inclination to be carried off against 
my will among a herd of frantic wild horses after the fashion of Mazeppa, I dismounted and hitched my mule to a wagon, and with several others ran with my fire-arms to meet the advancing steeds, which were now nearly upon us, led off by a fearless stallion. We discharged our arms at them as they approached, and fortunately with good effect. The leader was turned, and the avalanche of wild animals swept by us like a tornado, much to our relief. We held in for a few minutes until the herd had passed, when we unlocked our wheels and hastened forward to the first of the train, which had halted.

By the time we reached it, the runaway wagon and mules, with those who had been in pursuit, were just coming up after a most exciting chase. Fortunately no one was injured, and our animals were all captured and brought back, except one, and that one of the most valuable horses belonging to the party. This animal was ridden by the wagon-master, and when in full pursuit of the runaways, he stepped into one of the burrowing places which abound on the prairies, fell, and threw his rider over his head. Thus freed from restraint, he joined his wild brethren and disappeared on the prairie, with his saddle, bridle, and trappings.

As we continued our journey other herds of mustangs were seen coming from the east, but none approached us. Large numbers of deer and antelope were also perceived as we jogged along. In the afternoon we crossed a deep ravine, the dry ber of the Escondida, which bore the traces of recent water; and just beyond this the great prairie was on fire. 
We had for hours noticed the huge volumes of smoke as they ascended from the plain, and attributed the flight of animals towards us, which we had seen during the day, to this fire. It stretched for miles in both directions, and was sweeping directly towards us. Whenever it reached a patch of high grass, volumes of dense smoke rose up, while the vivid flames leaped with greater rapidity over the plain. We rode up and down for some distance, but could find no opening through. At length a place was seen where the fire raged with less fury. Here the horsemen led the way; whereupon the teamsters put the whips to their animals, and uttering a loud whoop dashed through the flames.

A short distance beyond we passed another chain of lagunas, or small ponds, known as Santa Gertrude. The water was good here; but finding that we could make a few more miles, I hurried forward. Five miles further, over an excellent road, brought us to San Francisco River, which unfortunately had no water in it.

The prairie had been more level to-day, and, except where burned, was covered with excellent grass. The bed and banks of the San Francisco were lined with large trees overhung with moss. We made thirty miles to-day, for about half of which distance the road was excellent.

January 1st, 1853. At an early hour breakfast was despatched; and the tents were struck, and the party was in motion at the break of day. The prairie was now a dead level, the grass short, and the road very good. Not a bush or a tree was to be seen; yet there 
was no lack of prominent objects; for thousands of deer and antelope were scattered over it. Never before had we seen such numbers. Droves of mustangs also appeared. The deer and antelope were usually grazing in herds of from ten to fifty; and as we approached they leisurely trotted off to a short distance, and again stopped. We shot none; for as I was desirous to reach Corpus Christi before night, we were pushing forward on the run, and could not be delayed for the sake of game, tempting as it was. Among the antelope I noticed several of a pure white.

Ten miles brought us to Agua Dulce (Sweet Water), where there were some filthy pools of water and several ranchos; and twelve miles further to the Oso, a small pond, or rather mud-hole, the water in which was so bad that the animals would not drink it. The road being good and the weather cool, we again dashed off on a run, when an additional nine miles gladdened our sight with the blue waters of the Gulf of Mexico, which stretched out before us in a long line, bounding the horizon for many miles. This was a delightful spectacle to us after an absence of two years and a half, and especially as it was the termination of a land journey of nearly two thousand three hundred miles. At three o'clock, P. M., we reached Corpus Christi, and drove to the excellent hotel of Mr. Noesler. Here we met Captains Gibbs and Rhett, Dr. Jarvis, and other officers of the United States army, from whom we were gratified with late news from home.

My first inquiry was for the means of reaching New Orleans; and finding there was no steamer running, and no means of reaching there except by tak- 
ing an open boat through the lagunas to Indianola, a distance of about one hundred and forty miles, or making a land journey around the shore to the same place, I chose the former. I had had quite enough of land journeys for the present; and hearing there was a small boat at the wharf, I lost no time in chartering her to transport me and such others as chose to accompany me. She could stow away four persons beneath a piece of deck over the bow, by crawling in on the hands and feet; but there was not sufficient height to sit up. However, it was a change, and I determined to try it. The Captain agreed to leave in the morning. 


\section{CHAPTER XLV.}

\section{CORPUS CHRISTI TO WASHINGTON.}

Corpus Christi-Its fine position-Geographical features of the countryNueces Bay and River-A norther-Its effects on the fish in the lagunas-Leave Corpus Christi in an open boat-Shallow bays and lagunas of the Gulf-Vast numbers of water-fowl-Bays of Aransas and Espiritu Santo-Reach Decrow's Point-Matagorda Bay and its commerceEmbark for New Orleans-Galveston-Arrival at New Orleans-Voyage up the Mississippi, and by way of Louisville, Cincinnati, Cleveland, Buffalo, and Albany to Providence-Arrival at home-Proceed to Washington.

THe town of Corpus Christi is more pleasantly situated than any place I had yet seen on the Gulf of Mexico, having the advantage of a bluff from eighty to one hundred feet high above the shores of the Gulf. The business portion of the town stands chiefly on the beach below; but the bluff is now being covered with dwelling houses, and is by far the most pleasant situation. Like other places on the northern shores of the Gulf, it is separated from the sea by a broad bay. Here there is plenty of water; but on the bar which connects it with the Gulf there is only about six feet.

Corpus Christi Bay is about forty miles from north to south, and twenty from east to west. Connected with 
it, and making far up into the land, is Nueces Bay, about ten miles long and five wide, which receives at its head the Nueces River. This river has its rise in the Guadalupe Mountains about three hundred miles distant. The stream, which is deep, narrow, and rapid, with very steep banks, is navigable for small boats, about forty miles from its mouth; and with some improvement the navigation might be extended to the point of confluence with the Rio Frio, its principal tributary. The latter has a course of about one hundred and fifty miles, and has for its tributaries the San Miguel, Atascoco, La Parida, and Tordillo rivers. The San Miguel is about one hundred and twenty miles in length, and runs nearly parallel with the Rio Frio. The Laguna, the Leona, the Arroyo Saco, and the Arroyo de Uvalde, are also branches of this stream-the last named "being formed of nearly a hundred springs of crystal water, that gush from the munificent soil of the valley, which is headed by a singularly difficult defile, named the Cañon de Uvalde." West of Corpus Christi Bay, several small streams enter the Laguna del Madre, among them the Agua Dulce, Las Pintas, San Fernando, Santa Gertrude, Los Olmos, and Escondida. Most of these we passed in crossing from the Rio Grande; but the water in them was so low that we hardly recognised them as running streams, and some were entirely dry.

The land near Corpus Christi is very fertile. Groups and belts of timber are found near the coast; but after leaving this, a vast undulating prairie extends from the Nueces to within three or four miles of the Rio Grande. This plain is covered with the richest grass, and abounds voL. II. -34 
in mustangs, deer, antelope, and large herds of beefcattle.

Opposite Corpus Christi Bay, separating it from the Gulf, is Mustang Island, about thirty-five miles long and from two to four in width. Further south, another long and narrow sound opens, called the Laguna del Madre, about ninety miles in length and from three to six in width; an island about the same length, and from two to four miles in width, separates it from the Gulf. This laguna is so shallow as to be unavailable for navigation, even for vessels of light draft.

The position of Corpus Christi renders it very healthy; and when many other places on the coast suffer from fevers, this, owing to its elevation, is exempt. It is at present the Head Quarters of the Military Division in Texas; and from the facility of entering the harbor, it is destined to be one of the most important places on the coast.

January $2 d$. There was a dead calm to-day, which prevented us from leaving.

January $3 d$. A violent norther arose during the night, and we had it piercing cold to-day. When in the house, we were seated by fires, and when outside the door, wrapped in our overcoats. Yet in spite of all our efforts, it seemed almost impossible to keep warm, so penetrating are these winds to systems which have become relaxed.

When these winds blow so violently, they drive the water from the shallow lagunas into the Gulf, and increase the difficulty of navigating them. Many of the bars are then nearly dry. There is one in particular, across the mouth of the Nueces Bay, which de- 
serves to be noticed. When the tide comes into this bay, as well as in all others, it is resorted to by large numbers of fish from the Gulf, to feed. The water may then be from five to ten feet deep, and is of the same temperature as that of the Gulf. But after a norther has blown for twelve or twenty-four hours, its temperature is so much reduced, that the fish become chilled, and not having strength enough to make their way over the bar, now more shallow than ever, they often lie there in heaps. At these times the people go to the bar with their wagons, and with a spear or fork pick up the finest fish, weighing from ten to a hundred pounds, and thus carry away loads. Many were brought in to-day, and they proved a great luxury to us. *

To-day, again, it was impossible to sail, for we

* In the remarkable journey of Alvar Nuñes Cabeça de Vaca from Florida to Cinaloa, on the Pacific coast, between the years 1527 and 1535, he remained for eight months among a tribe of Indians on the Gulf of Mexico, whom he calls the Avavares. "They were all," he says, "ignorant of time, either by the sun or moon, nor do they reckon by the month or year; but they better know and understand the differences of the seasons, when the fruits come to ripen, the fish to die, and the. position of the stars, in which they are ready and practised."

The season when the fish come to die, has never been understood. When Mr. Buckingham Smith, the learned translator and commentator of the "Narrative of Cabeça de Vaca," asked me, on my return from Mexico, whether in my journeys along the northern shores of the Gulf, I had seen or heard any thing that would enable me to elucidate the passage in question, the incident I have named as happening annually on the bars of the lagoons, when the northers blow, at once occurred to me; and on explaining what I had witnessed, Mr. Smith at once agreed with me that this was the true solution of the passage. 
should have perished in an open boat; so we kept as close as possible.

January 4 th. The wind blew violently during the whole night, and the morning opened upon us as cold as ever. The buckets of water that stood outside the door were covered with ice an inch thick. During the forenoon, the wind began to subside, so that I was enabled to take a ride to some of the beautiful places in the vicinity. Several of the party, including Dr. Webb, Major Emory, and Mr. Radziminski, set out in wagons for Indianola, preferring that mode of conveyance. Mr. Henry Jacobs and two of the servants were all that would undertake the boat voyage with me.

About noon a light breeze sprung up from the land, when we embarked in our little craft for Saluria, a small port on the Gulf, at the entrance to Matagorda Bay, about one hundred and forty miles distant. We had not proceeded more than ten or twelve miles, before the wind died away and left us becalmed. Creeping beneath the deck that covered the forward part of the boat, we stretched ourselves on our blankets in a space about three feet wide, where we contrived to get a little sleep.

January 5 th. The morning found us on the opposite side of Corpus Christi Bay, a light breeze wafting us eastward towards Aransas Pass. The navigation here is carried on with boats of light burden through the shallow bays or lagunas, which line the west and north-west shores of the Gulf of Mexico. These bays are exceedingly shallow, sometimes presenting a breadth of ten or fifteen miles, by a hundred or more in length. Yet these broad spaces of water are often 
not more than three or four feet deep, even in the middle. This depth would admit flat-bottomed vessels of large capacity, were it not for the numerous bars which intersect them, sometimes leaving but a few inches of water; hence, none but flat-bottomed boats can navigate these waters, and even these may be suddenly arrested in their progress, should a norther occur and drive the water out of the bays.

Our course lay through a channel less than twenty yards wide for miles, with bars of sand on both sides but an inch or two above the water. These were covered with myriads of water-fowl, including cranes, swans, herons, ibises, geese, ducks, curlews, plover, sand-pipers, etc. The large cranes and swans stood in lines extending for miles, appearing like a light sandy beach or white cliff; and it was impossible to dispel the delusion, until the vast flock, with a simultaneous scream that could be heard for miles, rose from their resting place. Occasionally, we would round a point which concealed a bay the surface of which was filled with ducks and geese; these, taking the alarm, would rise in one continuous flock, making a noise like thunder, as they flapped their wings on emerging from the water. Notwithstanding the vast numbers of these birds, I shot but few; for the water was so shallow that we could not get within gun shot of them with our boat. With a light skiff, and a few bushes or a bunch of grass, a gunner would have such sport as no other portion of the world can surpass.

We ran ashore on a beach of shells, knocked up a fire of drift-wood, and got breakfast; after which we entered Aransas Bay, separated from the Gulf by St. 
Joseph's Island. This island is less than two miles wide, and about twenty-five in length. South-west of this, between Aransas Pass and Corpus Christi Inlet, is Mustang Island, already spoken of.

Aransas Bay extends about twenty-five miles from north-east to south-west, and is about twelve miles wide. It has a general depth of from eight to twelve feet, but is obstructed by a shoal and range of islands extending across it, over which there is less than three feet of water. Connected with Aransas is Copano Bay, twenty miles in length by three in width. The shores of these bays are extremely low and flat.

We made but little progress to-day, the wind having died away; and finding ourselves fast on a bar, there was no occasion to anchor. So we again turned in, and lay by till morning.

Tanuary 6th. One of the sailors carried me on shore on his back, that I might have a shot or two at the shoals of ducks near by; but as there was no shelter behind which they could be approached, the few that I shot hardly repaid the trouble. We lay here several hours, when at length a light breeze sprung up from the west which wafted us onward, and across Espiritu Santo Bay, about twenty miles in length and ten in width. At its head, it receives the waters of two considerable rivers, the San Antonio and Guadalupe. It is separated from the Gulf by Matagorda Island, about thirty miles in length.

An amusing incident occurred when we were about midway across the bay. We had left Corpus Christi with but a single keg of water, expecting to make our voyage in twenty-four hours. But we had now been 
out forty-eight hours; and unless a good breeze should favor us, we could not expect to reach our place of destination before the next day. Our water was gone; and there was none to be found on the beach. Seeing a small craft approaching from an opposite direction, we stood for her; and when within two hundred yards, our captain hailed her, and asked if they could spare us any water. The reply was in the affirmative; but when I expected we should pull for her, to my utter surprise, a sailor composedly stepped into the water, and, with a bucket on his arm, walked to the other boat, where he got it filled. The bay was less than three feet deep, although we were many miles from the shore, which was barely visible. Did one not know where he was, he might imagine himself at sea.

At the eastern end of the bay, the water was so shallow that the passengers were carried on the backs of the men to a small island near by, while the captain and sailors jumped into the water, and lifted and pushed the boat over. A little further we came to a "dug out" - that is, a passage cut or dug across a bar, about twenty yards through. Here the men got into the water again; and each of the passengers taking an oar, we managed to force the boat through. The shallowness of the water and the consequent difficulties of navigating these lagoons after a norther, may be judg. ed of, when I state that our little craft drew less than fifteen inches.

January $7 t h$. After a third night passed in the open boat, we emerged from these shallow waters soon after day-light; and crossing Paso Cavallo, with the town of that name on our right, we landed at 8 o'clock 
at Decrow's Point. We breakfasted at a hotel, where we learned that the steamer Louisiana, from Indianola for New Orleans, would pass here to-morrow.

Decrow's Point forms the western termination of Màtagorda Peninsula, a neck of land about sixty miles in length, and from one to two in width. Within this is Matagorda Bay, another shallow body of water, from six to ten miles wide. Paso Cavallo (Horse Pass) is the entrance to this bay from the Gulf of Mexico, and is always considered safe for vessels drawing from eight to nine feet of water. The principal and most accessible port within Matagorda Bay is Indianola, where steamers drawing eight feet of water enter. Many rivers empty into the bay; the largest of which, the Colorado, rises in the Guadalupe Mountains, and has a course of about eight hundred miles before it reaches the Gulf. Among the other streams, are the La Vaca and Navidad rivers. Within this bay is La Vaca, which is reached by small vessels. A railway is now in the course of construction from Saluria to San Antonio, which will render this the most important port on the Gulf, it being accessible for large vessels, and affording a safe harbor. An extensive commerce is now carried on between Indianola and New Orleans, with steamers of a large class; besides which, vessels run direct to New York and Boston. The number of passengers and the quantity of merchandise coming hither, are evidences of the thriving condition of this portion of the State.

January 8 th. The steamer Louisiana came to, this morning, off the Point, when I took passage in her for New Orleans. Major Emory, Dr. Webb, Mr. Radzi- 
minski, and the other gentlemen who had taken the land route from Corpus Christi, were on board. We stood out to sea with a light wind, and soon after headed to the north-east for Galveston.

January 9 th. Entered the port of Galveston this morning, where we remained until 4 o'clock, P. .. This city had greatly increased since August, 1850, when we stopped here. Its commerce, too, judging from the number of ships and steamers, must have augmented in proportion.

January 10th. Late in the afternoon we reached New Orleans, where I took up my quarters at the St. Louis Hotel.

January 11 th. On my journey from Texas, I learned by a newspaper that the United States Senate had, on the assembling of Congress, removed the restriction which prevented the use of the appropriation under certain conditions; so that the survey might now be permitted to go on again. But the commission had been broken up ; the injury had already been inflicted upon its members, who were now scattered and on their way to their homes; and it was too late to return to the field of operations. I, therefore, sent a telegraphic despatch to the Hon. Alex. H. H. Stuart, Secretary of the Interior, advising him of my arrival at New Orleans, with a portion of the officers of the Commission, and requesting information respecting the funds at my disposal, as well as instructions as to further proceedings.

January 14th. After waiting four days for an answer to my despatch, the necessity of my being in Washington as soon as possible required that I should delay no longer; particularly as I now learned that 
the telegraph wires were broken, and the communication consequently interrupted. I therefore took passage on the steamer Chancellor, to sail this evening for Louisville, accompanied by Dr. Webb and Messrs. Jacobs and Force. Major Emory and the other officers of the Commission were to take the land route; but having caught a cold in my boat voyage along the Texan coast, from which I was suffering severely, I deemed it most prudent to take a more easy though longer route by the Mississippi River.

Our boat was deep and consequently slow, so that it was ten days before we reached Louisville: the day after, we took another steamer for Cincinnati, which we reached the following morning, and immediately took the railway cars for Cleveland, on Lake Erie, where we arrived the same evening. I felt keenly the change of temperature to-day, as the ground was covered with snow, and we found ourselves in the midst of a northern winter. After an hour's delay at Cleveland, we took the shore railroad for. Buffalo, which should have arrived at that place the following morning in time to connect with the eastern train for Albany; but we got fast in a snow bank, which detained us for six hours. Our fire went out, and there was no wood to supply it. At length the train from Buffalo opened the track, which enabled us to push our way through, so that we arrived in that city at noon. Having missed all the morning trains, we were obliged to wait until five o'clock before we could start for Albany, when the ice and snow on the rails so retarded us that we arrived there too late for the morning cars. We had, therefore, to lie over a day; but 
this was not unacceptable, as we had been out the two previous nights. The next morning we took the railway for Providence, (Dr. Webb leaving us at Worcester,) where we arrived the same evening, and where I had the happiness of again meeting my family and friends, from whom I had been separated two years and a half.

I remained with my family two days, and then left for Washington, and presented myself at the Department of the Interior.

\section{RESULTS OF THE LABORS OF THE BOUNDARY COMMISSION.}

BEFORE closing this narrative, it seems proper that I should speak of the work acomplished while the Boundary Commission was under my charge. This I do, not so much to lay elaim to any merit for the same on my own account, as that the labors of the officers who performed these duties may be made known, and proper credit be given to them.

1. A reconnaissance and survey from Indianola, on the Gulf of Mexico, to El Paso del Norte.

The plan of this operation was based upon astronomical observations, for the latitude and longitude of points, by means of a sextant, chronometers, and a four-feet telescope for observing occultations of stars 
by the moon. These points were connected by a chain and compass survey, accompanied by a line of levels, as fur as San Antonio. From El Paso the survey was continued to the Initial Point of the southern boundary of New Mexico on the Rio Grande, making altogether a distance of between nine hundred and a thousand miles surveyed.

At nearly all the astronomical stations on this line, upwards of fifty in number, observations were made by a Fox dip circle for magnetic inclination, declination, and intensity.

An accurate meteorological register was kept through the whole line of march. An.interesting comparison of the aneroid and ordinary barometer was made, extending over elevations varying from the level of the sea to an altitude of six thousand feet. A complete set of barometrical and aneroid observations were taken for the construction of a profile, which shows the contour of the whole country from San Antonio to San Eleazario, on the Rio Grande, exhibiting not only the most prominent points, but likewise the elevations and depressions in each day's march.

The astronomical and magnetic observations were made by Lieutenant A. W. Whipple, of the corps of topographical engineers, acting chief astronomer in charge of the party, and under whose direction the whole work was carried on.

The survey was performed by John Bull, Esq., first assistant surveyor.

The map of this survey was plotted on a scale of one inch to the mile, and the topography accurately laid down by M. Von Hippe]. 
The meteorological observations, including the barometrical profile of the comparison of the aneroid and barometer, and the temperatures of the different springs, etc., etc., met with on the route, were by Marine T. W. Chandler, Esq.

The sketches exhibiting the characteristic features of the country, were made by Henry C. Pratt, and A. de Vaudricourt, Esqs.*

2. At the Presidio of San Eleazario, El Paso, Fronteras, Doña Ana, and the Initial Point on the Rio Grande, a more extensive series of astronomical and magnetic observations were made, and the latitude and longitude of these several places determined by Lieutenant Whipple personally. Lieutenant W. also erected an astronomical observatory at Fronteras, where a most interesting and elaborate series of astronomical, magnetic, and meteorological observations were made, the latter by $\mathrm{Mr}$. Chandler, who continued them after Lieutenant Whipple had taken the field to conduct the survey westward.

3. At the Copper Mines, in the Rocky Mountains (afterwards Fort Webster), at an elevation of six thousand two hundred feet above the level of the sea, the latitude and longitude were determined by Lieutenant Whipple, and the meteorological observations continued by Mr. Henry C. Force, assisted by Mr. James H. Houston.

While the Commission was waiting for Colonel

* The latter accompanied the parties, and soon after his arrival at El Paso left the Commission. Mr. Pratt came up with a train a few months later, and took a large number of sketches. 
Graham, a party under the charge of John Bull, Esq. first assistant surveyor, made a reconnaisance of the country between the Rio Grande and the Gila, in which a more direct road was opened from Doña Ana to the Copper Mines. This reconnaisance was extended to the Presidio of Janos, in the State of Chihuahua.

5. The southern boundary of New Mexico, extending west three degrees from the Initial Point on the Rio Grande at $32^{\circ} 22^{\prime \prime}$ north latitude, and from the western termination of the line due north to the Gila, was surveyed exclusively by Lieutenant A. W. Whipple and his assistants. This officer also surveyed the river Gila, from the point where it is intersected by the before-mentioned line to its junction with the Colorado, a distance, including the sinuosities of the river, of about four hundred and fifty miles, making together between six and seven hundred miles from the Rio Grande to the Colorado. The boundary along this parallel was the most difficult part of the whole survey.

Astronomical observations were made during the survey of the Gila every night but two, which were cloudy. The whole number of astronomical and meteorological stations was about sixty; nearly all of which were also magnetic stations. To these it is proper to add that there were three astronomical and magnetic stations, besides several made by Lieutenant Whipple on his trip from San Diego to the Colorado, in September, 1849, thus completing a consecutive chain of points of observation by this officer extending from the Atlantic coast, via San Antonio, El Paso del Norte, and the mouth of the Gila, to the Pacific Ocean. 
At most of these stations the three elements of inclination, declination, and intensity were observed.

6. A chain and compass survey was made by A. B. Gray, Esq., Principal Surveyor, his first assistants being John Bull and J. H. Prioleau, Esqs., from the point where the southern boundary of New Mexico strikes the river Gila to a point about seventy miles above its junction with the Colorado, about four hundred miles. This survey was independent of that made by Lieut. Whipple.*

7. In returning from San Diego, California, the unfinished portion of the survey of the Gila was completed by Lieut. Whipple; after which our parties again united at the Pimo Villages, on the Gila. We then returned together to El Paso by a different route from that taken on our journey out, thereby enabling us to collect much valuable information in the northern portions of Sonora and Chihuahua not previously explored by a scientific party. On this journey or reconnoissance (to use a military term), of which a detailed account is given in this work, an elaborate series of astronomical and meteorological observations were made by Lieut. Whipple in the same manner as those before mentioned. The true position in latitude and longitude of Tucson, Tubac, Santa Cruz, Guadalupe Pass, Janos, and Correlitos, besides intermediate points, was then first determined by this officer; and the mountains, streams, and other geographical features

* I regret that I am unable to speak more fully of this survey, as Mr. Gray has never furnished me the details or made any official report to me. 
of this hitherto unknown region, were accurately delineated upon the maps.

The barometrical profiles constructed by Lieut. Whipple, and the minute topography of the maps laid down in the two extensive journeys in which this officer accompanied me between the Rio Grande and the Pacific, are of the highest importance as showing the practicability of a route for a railroad or other public highway south of the Gila. In order to render this information immediately available, a reduction of the astronomical and meteorological observations has already been made, as well as barometrical profiles of these several reconnoissances.

The surveys of Mr. Gray and Lieutenant Whipple, and the astronomical observations made by the latter in the journeys to and from California, have enabled the Commission to lay down with accuracy for the first time the geography of the Gila and of the vast region between the Rio Grande and the shores of the Pacific.

The plot and topographical sketches of the survey between the Rio Grande and the Colorado were mostly completed in California and transmitted to Washington. At the same time reports of various reconnoissances made along the line, with tables of astronomical, magnetic, and meteorological observations by Lieut. Whipple were forwarded. These plottings, reports, and tables were placed by me in the hands of Major Emory, Principal Surveyor, on my return to Washington; and engineers and draughtsmen have since been engaged in completing the maps, and reducing the observations, under his direction.

8. Along this line an extensive series of sketches 
and drawings were made by Henry C. Pratt, Esq., draughtsman and artist to the Commission, which exhibit the characteristic features of the regions visited, including the mountain passes, outlines of the mountain chains as they presented themselves to us from different points, etc., etc. ; and convey a far more comprehensive idea of the physical geography of the zone of country traversed than can be given in any written description. To this department of our work I devoted some of my leisure moments, particularly in journeys on which I was not accompanied by Mr. Pratt.

Of the labors of the parties on the Rio Grande or Bravo Del Norte, I have now to speak. These parties were all placed by me under charge of Brevet Lieut. Col. J. D. Graham, of the Topographical Engineers, Principal Astronomer and Head of the Topographical Scientific Corps, a programme of which will be found in Appendix F. This officer was detailed for service on the Boundary Survey, on the 23d October, 1850 , and reached the Head Quarters of the Commission at the Copper Mines, New Mexico, the nearest point to our field of operations, on the $2 d$ of August, 1851. He was recalled by the Hon. Alex. H. H. Stuart, Secretary of the Interior, on the 13th of September of the same year; and on the same day, Brevet Major W. H. Emory was appointed to his place. The latter reached El Paso on the 25th of November, and delivered the order of recall to his predecessor.

Major Emory, in his letter to me under date of June 1st, 1852, ${ }^{*}$ informing me of the work performed

* Senate Document, No. 6, Special Session, 1853, p. 42.

voL. II. -35 
by his predecessor, says, "A survey of the river had been commenced by Colonel Graham, at the Initial Point, and prosecuted as far as the Paso del Norte, and an observatory partially erected at Frontera, and information given me by Colonel Graham that Frontera, a cardinal point in the survey, had not yet been determined. I also found it necessary to resurvey the river down to Frontera." *

Deducting, therefore, the re-survey which Major Emory deemed necessary, there remain the eight miles from Frontera to El Paso, to be placed to the credit of Colonel Graham. The results of the labors of Major W. H. Emory, after taking charge of the Survey of the Rio Grande, were reported to me by that officer as follows. $\dagger$

The determination of the latitude and longitude of San Eleazario and Frontera, which had previously been determined by one of his predecessors, Lieutenant Whipple, while acting as Chief Astronomer.

The determination of the latitude and longitude of the cañon one hundred miles below San Eleazario, the

* I should do injustice to Mr. Prioleau, a meritorious officer, did I not state, that when directed to make a survey of the Rio Grande from El Paso to the Initial Point, he declared it would be impossible to perform the work correctly with the instruments at his command. Another undertook it; the Survey was made and set aside. On Colonel Graham's arrival, another survey was made under his immediate direction, and afterwards rejected by his successor Major Emory. The latter placed the work in the hands of Mr. Radziminski, Principal Assistant Surveyor, by whom it was executed in a highly satisfactory manner, and accepted as the official Survey.

† See Letter from Major Emory to J.R. Bartlett. Senate Doc. Special Session, 1853 , No. 6 , p. 58. 
Presidio del Norte, Eagle Pass, and Loredo ; the latitude of various intermediate points was determined by the sextant, and the approximate longitude by the passage of chronometers.

"The survey of the river from El Paso to the Presidio del Norte, was completed by Assistant Von Hippel.

"The survey of the river from Eagle Pass to Loredo, under the orders of Lieutenant Michler.

"The survey of the river from Eagle Pass to the mouth of the Pecos, by Assistant Schott.

"The survey of the river from Presidio del Norte to Fort Vicente by Assistant M. T. W. Chandler.

"The re-survey of the river from Frontera to $32^{\circ}$ 22', by Principal Assistant Charles Radziminski."

The length of these several surveys, may be stated approximately at one thousand miles.

The following recapitulation will show the extent of the surveys, and by whom performed, during the period the Commission was under my charge.

By Lieutenant A. W. Whipple.

Indianola to El Paso and the Initial Point, - - 850 miles. The Southern Boundary of New Mexico, connecting the Rio Grande with the Gila, - - 200 do.

The River Gila to the Colorado, _ . . 450 do.

1500

By Lieut. Colonel J. D. Graham.

On the Rio Grande, near El Paso, - _ - - 8 do.

By Major W. H. EMory.

On the Rio Grande, - - - . - 1000 do.

2,508 . 
My successor, General Robert B. Campbell, took the field in May, 1853; and under his orders, the survey of the Rio Grande from Loredo to its mouth, and a portion in the cañon of that river, was completed before the close of the year.

In the department of Zoology, much has been accomplished by officers of the Commission. The collectors were Mr. J. H. Clark, Dr. Thomas H. Webb, and Mr. Arthur Schott.

A large collection of fishes was made in the waters of the Rio Grande, and in the tributaries of the Gila and the streams to the south of it, by Mr. Clark, a large portion of which have proved new to science. Many of these have already received a sort of publicity through the proceedings of the Academy of Natural Sciences. Among them are some new genera. Representatives of the families Labridae and Characini, were detected, in the waters of the Rio Grande.

A considerable number of reptiles were collected by Messrs. Clark and Schott, embracing new genera and species, which have already been described by Professors S. F. Baird and Charles Girard, in the Proceedings of the Academy, and their "Catalogue of North American Serpents," published by the Smithsonian Institution. In speaking of the collection sent home by Mr. Clark in the spring of 1852 , these distinguished naturalists remark, that "It will be perfectly safe to say, that one hundred undescribed species of North American vertebrate animals have been added to our fauna. The entire annals of zoological history scarcely present a parallel to this case."

Dr. Webb made an interesting collection of fishes, 
reptiles, and insects, the particulars of which are unknown to me. Mr. Schott, also, collected many interesting insects of the orders orthoptera and coleoptera, part of which have been described by Dr. John L. Leconte. In birds, and the smaller mammalia, some interesting specimens were collected by each of the gentlemen named.

When fully studied and described, these collections, it is expected, will furnish new and interesting facts respecting the distribution of animal life in the country explored; and if properly illustrated by figures, they will constitute a most valuable contribution to our knowledge of the animals of that portion of the United States.

Botanical collections were made by Dr. J. M. Bigelow, Mr. Charles Wright, Mr. George Thurber, and Dr. C. C. Parry. Dr. Bigelow's collections were made upon the road between Indianola and El Paso, in the vicinity of the Copper Mines, and upon the Rio Grande. He also made an excursion to Lake Guzman and other points in pursuit of specimens in his branch of natural science. His collection has not, to my knowledge, been reported upon; but from the zeal and enthusiasm with which that gentleman prosecuted his researches, there is no doubt that it contains much that is valuable. Mr. Wright accompanied Colonel Graham in his travels; and his connection with the Commission ceased soon after the removal of that officer. A portion of Mr. Wright's collection has been published by Dr. Gray among the Memoirs of the Smithsonian Institution, and contains many new genera and species. Mr. W., whose name is identified with the botany of Texas and 
Northern Mexico, is now engaged in the Ringgold Exploring Expedition, and, by his devotion to the botany of the regions visited, will doubtless contribute largely to the value of the scientific results of that enterprise.

Mr. Thurber, though for the greater part of the time acting as quarter-master, made a large collection, the examination of which has not yet been completed. Some six or seven unpublished genera have been determined, and a corresponding number of new species. As he collected in localities afterwards passed over by Mr. Wright, and a portion of the time in company with that gentleman, many of the novelties in his collection have been anticipated in the memoir alluded to. As Dr. Parry was engaged with a portion of the Commission under Major Emory, I had no opportunity of acquiring a personal knowledge of his labors; but from his reputation as a botanical observer, I have no doubt that he improved successfully the opportunities his field presented.

The geological collection was made by Dr. Thomas H. Webb, Secretary of the Joint Commission. This officer was indefatigable in his labors to collect a series of specimens that should illustrate the structure and mineral resources of the vast region traversed by the Commission; but the collection made on the journey from the Copper Mines of New Mexico to California was mostly lost, in consequence of the abandonment of the wagons and the perishing of the animals. A few boxes of minerals, were, however, collected in California and sent home in safety by water. On the journey from the Pacific coast, by the Gila and El 
Paso, and thence through Chihuahua and the Mexican States to the south, Dr. Webb was enabled to make a collection of fossils and minerals, including some choice specimens of gold and silver ores, which were brought home in safety A collection of fossils and minerals in the valley of the Rio Grande was also made by $\mathrm{Mr}$. Arthur Schott.

In ethnology the collection was made almost exclusively by myself. This consists of vocabularies, each embracing two hundred words, in upwards of twenty Indian languages. Many of these had never been taken down before, and few as fully as by me.

Further to illustrate the aboriginal tribes, I have obtained accurate and characteristic portraits of many individuals seen, both male and female, with sketches exhibiting their manners and customs, their arts, husbandry, etc.

I had prepared an extended disquisition on the semi-civilized tribes occupying the vast basin between the Rocky Mountains, or rather the Rio Grande, and the Colorado of California; but the subject was found to be so extensive and so deeply interesting, that I determined to reserve it for a special report, which I intend to prepare on the ethnology of the Indian tribes of the extensive region explored by the Boundary Commission, in which also my Indian vocabularies will be embraced.

By the preceding statement it will be seen that no exertions were spared, and no suitable opportunities omitted, to do all in my power to advance the cause of science. It now remains for the government to take such measures as it may deem proper to lay the results 
of the Commission, obtained with so much labor, with so much expense, and with so much personal suffering and privation, before the American people and the scientific world. 
NOTES. 


\section{NATURAL HISTORY.}

The Natural history of the regions traversed-Animal life on the deserts -Quadrupeds-Reptiles, their great variety and numbers-Peculiar vegetation of the deserts-The "Prairie Dog" and its habits-The antelope, etc.

HAVING but incidentally spoken of the Natural History of the countries I passed through, I now propose to give some brief notices of the most remarkable animals that were seen from time to time.

In a region as barren as the greater portion of that traversed, animal life would hardly be expected to abound. Nevertheless, there was no spot, however barren, or however distant from water, where rabbits and wolves were not seen. On these plains, whether desert or grassy, there are fewer birds. Often, for days together, nothing of the feathered tribe was seen except the omnipresent crow. Living equally well on animal food, seeds, or roots, there is no place where he may not thrive.

In the mountains and along the water-courses, where there are more or less forest trees and shrubbery, both quadrupeds and birds are found in greater variety. Among the former may be mentioned the leopard, cougar, ocelot, lynx, panther ; the brown, black, and grizzly bear; the fox, antelope, and various kinds of deer ; the large wolf (lobo), and the coyote, raccoon, skunk, marmot, weasel; a great variety of moles, rats, and mice, 
which harbor in the ground; hares, rabbits, squirrels, Rocky Mountain sheep, etc. These several animals, of course, have their particular localities. The elk is not found south of the Gila. The beaver is still met with on the Pecos, the Rio Grande, the Gila and its northern tributaries; and within a mile of El Paso I saw evidences of his labors. In the Copper Mine region, which is in the Rocky Mountains, almost every animal that $I$ have named may be found ; bears in particular are extremely abundant.

But while the parched and desert plains are so destitute of quadrupeds and birds, they abound in reptiles and insects in the greatest variety. Lizards of every size and color, from one and a half to eighteen inches in length, are found here; all of which are harmless. Then comes the family of "horned frogs," which are allied to the chameleon and lizard. Of these harmless little creatures, all covered, as a means of defence, with sharp horny projections, there is also a great variety. Next to these, come the poisonous reptiles. First is the horrid tarantula, with his hairy body as large as a pigeon's egg, and with legs as long as one's finger, striding over the ground and nestling under one's blankets at night. His sting, or bite, sometimes causes death. His habitation is in the ground, the opening to which he covers over with a trap-door. There are other large spiders that also harbor in the earth, and protect the entrance to their abodes in the same manner. Next are the white and the black scorpions, the former of which are very abundant. These are from one and a half to two inches in length. The sting of the black variety is sometimes fatal. The white ones were often found in the boots of the men, into which they crept at night, and were not discovered until they stung the foot. A sharp pain was the consequence for a few hours, or perhaps a day, when it passed off. These creatures were sometimes found in our beds in the morning.

But perhaps there is no more hideous-looking reptile infesting the plains than the centipede. These are from three to ten 
inches in length, and are exceedingly poisonous, sometimes fatal. Then there is the venagron, as the Mexicans call it, a black insect about two inches in length, also very poisonous ; and lastly, the alacran, a species of scorpion, the most venomous of all. These last, fortunately, are chiefly confined to the city of Durango ; where, owing to their numbers, and the fatality which attends their sting, a bounty of six cents is given by the government for every one killed. We close this catalogue with the rattlesnake, which needs no deseription. This creature is found every where, from the Gulf of Mexico to the Pacific, alike in grassy, rocky, and desert regions. Hundreds of them were killed by our party ; yet I am not aware that any of us were bitten. Two horses that were bitten died. All the other reptiles and insects of ' which I have spoken are found throughout the countries contiguous to the Boundary, and were seen almost daily. Thus has nature adapted a numerous class of animals for the otherwise solitary desert, where they enjoy undisputed sway. These plains also abound in moles, rats, mice, rabbits, and other burrowing animals ; sometimes to such an extent, that it is dangerous to pass over them with horses and mules. Many specimens of the lesser mammalia were brought home by the Commission, as well as a collection of reptiles and insects. Of reptiles, a very large number was discovered which are entirely new. This collection is now in the cabinet of the Smithsonian Institution at Washington.

One of the most interesting animals met with on the prairies and high table-lands, is the "prairie dog," which is in fact no other than a marmot, having no character in common with dogs. Its look and habits are totally different. The Canadian trappers used to call it a "petit chien ;" and this, together with the noise it makes, which however, is more of a ehirp or yelp than a bark, has caused it to receive the name of 'prairie dog.'

The first community of these little creatures we met with was in Texas, near Brady's Creek, a branch of the Colorado 
of the east. This was the largest we ever saw, nor have I ever heard of one as extensive. For three days we travelled through this colony, during which time we did not lose sight of them. On either side, as far as we could see over the plain, their habitations extended, standing out in bold relief in the little hillocks they had raised with the earth brought from their subterranean abodes. Their habitations are usually about ten yards apart, and the hillocks contain from one to two cartloads of earth each. Some have one entrance, others two, which incline at an angle of about forty-five degrees. To what depth they extend I could never learn, and only know that the frequent attempts to drown the animals out by pouring large quantities of water in them, have rarely succeeded.*

A well-beaten track extends from one to the other of these hillocks, showing that a close intimacy exists between their occupants, or perhaps family connection. We supposed this community or "dog-town," as it is called, extended at least sixty miles, as we travelled at that time twenty miles a day. As to its width, we could not form a decided opinion; but presuming it to have been only half as wide as it was long, an idea may be formed of the vast number of animals it contains. $\dagger$

For the greater part of this distance the country was flat, and covered with short grass, kept so probably by these ani-

* Lieutenant Abert mentions an instance where several were obtained by pouring water into their burrows. They afterwards became quite tame.Report, p. 421.

fIf we suppose that this community extended fifty miles in one direction and but ten in another, we have a superficies of five hundred square miles; and allowing them to be thirty feet apart, or nine hundred square feet for each (a large allowance), it would give about thirty thousand habitations to the square mile, or $15,000,000$ in the five hundred miles. Estimating but two of these little creatures, which is the smallest supposable number to a habitation, we have a total of thirty millions in this community. I think it would be quite safe to reckon three or perhaps four animals to each hillock. 
mals feeding on it. A few scattered mezquit trees also grew among them. Rivers did not limit the colony ; for they were found on both sides of several streams. In several places I noticed a colony on the summit of elevated plateaus or hills, where the country was exceedingly barren, and the herbage so scant as to appear entirely inadequate to their subsistence. In this case it was evident that the colony was not in a flourishing condition, as many of the habitations were deserted.

Of the habits of these animals I can say little from observation, although I saw thousands of them. I would gladly have taken a day to conceal myself near them for the purpose of watching their actions, but when in the most interesting places we were moving forward. Major Long, in his Expedition to the Rocky Mountains, says they pass the winter in a lethargic state. Other travellers deny this, and say that they come from their holes during the winter whenever the weather is mild. I saw them out on some pretty cold days in November. Even in the plains further to the north, where snow lies on the ground for weeks, and where the cold is severe, they are seen out during the winter.

Where they obtain water has puzzled naturalists. Some travellers say that they dig down until they find it. This cannot be the case ; for I have seen them on dry elevated plains, twenty miles from water, and where there was no dew.

The color of the prairie dog is light brown. The lower part of its body, with the face and neck, are of a whitish yellow. Its size varies from that of a gray squirrel to that of a northern woodchuck, which it resembles in form more than any other animal. The body of a full-grown specimen is about twelve inches in length ; its tail, which is bushy, between three and four. It stands erect like a squirrel, with its tail in constant motion, particularly when seated upon the top of its hillock chirping to its companions. As we drew near their villages, an alarm seemed to be given by one placed as a sentinel on a hillock in the outskirts. As soon as the signal 
was made, a general scampering to get home took place among them, some running in one direction, some in another. When they reached their habitations, they would stand erect at their entrances, with their heads just peeping above, and keep up an incessant chirping and frisking of their tails until we passed. As we drew quite near, some of them would turn a somerset into their holes and disappear.

We found it difficult to secure them; for they always stood at the entrance of their burrows, so that, if shot, they fell within. I do not think that out of twenty shots sometimes fired at these creatures, more than one specimen was obtained.

This marmot is said to be good food; but at the time we killed those referred to, our provisions were abundant, and no one could be induced to try them. Subsequently, when we got on short allowance, I do not think any one would have hesitated to eat them.

Rabbits often burrow with these animals, or, what is more probable, they occupy habitations made by the latter. The habits of a rabbit lead him to places where there are more shrubs, and not a bare plain. It is probable, therefore, that the rabbits seen among the prairie dogs are merely wanderers, who have strayed away from their proper abodes, and finding comfortable quarters already provided, without the labor of burrowing themselves, have driven away the weaker animals and taken possession of their dwellings.

A small brown owl also resides with the prairie dogs, and is almost always found standing on their hillocks, acting perhaps as a sentinel, for which the community has to pay dear. He is undoubtedly an interloper; as, from the known habits of this bird, one of which is its fondness for ground mice, moles, and other small quadrupeds, it doubtless seeks the habitations of the prairie dogs to feed on their young. The parent dogs can have little courage to permit a diminutive bird like this to prey upon their offspring.

But the most serious interloper in the dog-towns is the 
rattlesnake. I had often heard that this reptile was found among them, and thought it must be accidental, until I witnessed how frequently it occurs. On one occasion I saw several of those revolting creatures enter a single hole in the very midst of a dog-town. No one can believe that any friendship exists between animals of such opposite natures; and it cannot be doubted that the rattlesnake takes up his abode among them for sinister purposes. They cannot drive him away, and are therefore compelled to give him quiet possession of any habitation he may enter, and allow him occasionally to feed upon the junior members of the fraternity.

I have seen the prairie dogs in Texas, New Mexico, Chihuahua, Sonora, and California.

During our various journeys we encountered numerous herds of antelopes on the plains. Several were shot and found to be excellent eating. They are more timid than the deer, and a good deal of stratagem is necessary to secure one.

The antelope is considered a more beautiful animal than the deer. Its legs are more slender, and its body of different colors, light and dark brown, red with a white belly, spotted, and sometimes pure white. Their horns are quite short and consist of a simple curved stem without branches. Catlin, I think, in his Wild Sports of the West, speaks of the curiosity of the antelope's disposition, and of a method resorted to by hunters to entrap or shoot it. This is to affix a piece of red cloth to a pole and insert it in the earth. The animals see it as they bound over the prairie, turn from their course, and timidly approach it, some venturous buck leading the way. The rest of the herd follow him in single file, after the old established custom of the prairies. In the mean time the hunter has concealed himself in the grass, so that, when the herd approaches, he selects the fattest for his mark. It sometimes happens that several are thus killed from a single herd. One of the members of the Commission tried the experiment of lying in wait for a passing herd. As they approached he shot voL. II. -36 
one. The frightened animals ran a short distance, and then stopped and turned round to see what the mysterious noise was that had so alarmed them. They even returned to the spot where their dead comrade lay. A second shot brought another to the ground. The herd, again startled at the report of the rifle, loped slowly away a short distance, and once more returned to the fatal spot, when another was brought down. The sportsman now rose from his place of concealment and secured his three animals. How long they would have continued to return, I know not. He had but three bullets with him.

In some parts of Texas deer are so abundant that it ceases to be a sport to kill them. Neither skill nor ingenuity is required, and even the usual caution of the practised sportsman is unnecessary. Such is the case on the lower road from San Antonio to El Paso, at a stream called Turkey Creek. Here the train stopped one day to rest, when twenty deer were killed and brought to camp. After leaving the Rio Grande we found none until we reached the Rio Mimbres, where again they became numerous. Beyond that we found them in the mountains and along the bottom-lands of the Gila, but not in large numbers.

On the whole, game, both animals and birds, was scarce throughout the broad regions traversed by us, except in the mountain districts, where it was abundant. In California, however, after reaching the rich valleys and timbered country, it is found in still greater quantity and variety; but my stay was so short there, and my journeys confined to so limited a district, that I am unprepared to testify except to the general fact.

In noticing the distribution of animals over the desert regions which occupy so large a space of the interior of our continent, it will have been observed how beautifully nature has adapted them for these districts. Here man, the terror of all animals, cannot live; for there is no soil that he can cul- 
tivate," no water to slake his thirst, no wood to supply him with fuel; nor can the domestic animals so necessary to him exist. But while these inferior animals have such undisputed sway unmolested by man, their lives are, nevertheless, attended with other dangers. It might be supposed that the venom of the tarantula, the centipede, the scorpion, and the rattlesnake would effectually preserve them from all enemies. But such is not the case. A most voracious bird is found here, called by the Mexicans the "paysano," and by the Americans the "chapporal cock," which feeds on these hideous creatures. He even ventures to attack the rattlesnake, and, as if aware of the latter's venom, protects himself from its fangs by using his wing as a shield. Many instances have been related to me by eye-witnesses of contests between the rattlesnake and this bird, in which the latter always came off conqueror. His aim is to seize the reptile by the back of his neck, when he may be considered as vanquished. With the exception of this bird and the hog, every animal has an instinctive dread of rattlesnakes, and will fly at their approach. The hog eats them with impunity. Other dangers attend these reptiles from crows, buzzards, and hawks; while the serpent tribe get their living on the lizards and frogs.

Another peculiarity of the desert is its remarkable vegetation; every thing being armed with thorns. First comes the endless variety of cacti, to look at some of which will make one shudder. These are seen from the tiny plant not larger than the finger to the giant petahaya raising its tall stem to the height of fifty feet. Then come the mezquit or acacia, the tornilla, the fouquiera, the agaves, and yuccas, all armed with the most terrific spikes or thorns. Even among the tender grasses, the mezquit has its minute thorns. But these thorny and angular forms are not confined to animal and regetable life : they seem to be extended to nature even in the grandest aspect in which she here appears. The mountain ridges, as I have before observed, present the most singular summits, 
terminating in pyramidal points, or resembling towers, minarets, etc. Thus is every thing in these regions peculiar. To indemnify man for the inhospitable deserts and barren soil which occupies so large a space, nature furnishes, embowelled in her innumerable mountains, the greatest variety and abundance of precious metals. The vast riches embedded in the great "Sierra Madre" are as yet little dreamt of; but I do not hesitate to say that for wealth of this description even California will yet have to yield the palm to these mountains.

Without entering into particulars about the variety of fishes brought home, I will merely observe, that while at San Diego, California, in May, 1852, Dr. Webb caused a seine to be drawn in the bay, which brought to light some exceedingly interesting specimens, and among them several which, on being opened for the purpose of better preserving them in alcohol, were found, to our great surprise, to contain each ten or twelve living young. They excited much attention at the time, being the first evidence brought to light, as far as we were aware, of the existence of viviparous fishes.

The public has been informed of the subsequent discovery of similar fishes in the Bay of San Francisco ; but of those found by us in the Bay of San Diego no description has yet been given. Our specimens, after being kept alive in water several days, were sent with other objects of natural history to Boston, where they safely arrived. 
ADAPTATION OF THE COUNTRY FOR A RAILWAY. 565

\section{ADAPTATION OF THE COUNTRY FOR A RAILWAY.}

Brief remarks on the Geography of the countries traversed by the Boundary Commission, and upon their adaptation for a Railroad connecting the Atlantic with the Pacific.

F Rox the Rio Grande eastward, between the parallels of 30 and 34 north latitude, lies the great plateau of Texas, " extending more than three hundred miles. Further north it is known as the Llano Estacado, or Staked Plain. This broad district is destitute of forest trees and shrubbery, except along the immediate margin of the water-courses. The belt of forest even here is exceedingly limited, being often confined to the very banks, and never extending a hundred yards from the stream. In this region the Red River, the Brazos, and the Colorado have their rise ; but it is not until they have coursed for some hundreds of miles that their banks present any considerable extent of bottom land with its accompanying forests. As they descend from the high table, the valleys expand, the land becomes more fertile, luxuriant valleys appear, and forests of oaks extend for miles.

The plateau bears but little grass, and this a short stunted variety, which, after rains, shoots rapidly up, and as speedily becomes dry, affording but little sustenance. Without water and grass this arid belt is an effectual barrier to the progress of the buffalo, which otherwise would cover in myriads the plains of Lower Texas.

* A large portion of this desert plateau is now included within the territory of New Mexico, having been transferred to the United States by purchase. 
About the parallel of $29^{\circ} 30^{\prime}$ the table-land breaks off into numerous spurs, descending to the great plains or prairies, which extend to the shores of the Gulf of Mexico in a broad belt from one hundred and fifty to two hundred miles in width. The whole of this district consists of gently undulating plains without timber, save along the margins of the streams, and is covered with the most luxuriant grass. The eastern portion of this plain is watered by numerous streams, and in fertility is unsurpassed by any portion of the globe. The western and south-western portion is deficient in water-courses. The Rio Grande possesses few tributaries here worth notice; and south of the Nueces, the streams entering into the Gulf are quite diminutive. But for grazing and rearing large herds of cattle, the land is unsurpassed ; and it is evident, from what we saw of wells sunk in the midst of these plains, that water can be found any where within a hundred feet of the surface.

"The indigenous prairie grass is tall, coarse, full of seed at the top, and when young resembles wheat in the spring. But in grasses the glory of the State is the merquit, found only in Western Texas. It yields a fine soft sward, preserves its verdure in the winter, and beyond all comparison affords the best wild pasture in the world. It has also the peculiar property of retaining its nutritive quality after it has become hard and dry."

West of the Rio Grande, from about the thirty-fourth parallel to the Gulf of California, and, I may add, to the shores of the Pacific, and thence south for eight hundred or a thousand miles, this vast region is but poorly adapted to agriculture. It is destitute of forests, except in the higher regions of the Sierra Madre, or great chain of the Cordilleras, or in the defiles leading to them. Timbered land is also found in narrow strips along the water-courses; but these cannot with propriety be termed forests. There are also valleys between parallel ranges of mountains, sometimes two or three miles in width, which derive some moisture from the mountains, where 
the mezquit and live-oak attain a considerable size. Grass appears only at intervals. The high table-land of Chihuahua exhibits it in the greatest quantity; but even there it is not continuous. Sometimes it is found spreading over districts fifty or more miles in extent, when a barren interval of thorny chapporal appears, and for miles a blade of grass is not to be seen. Upon the whole I feel safe in saying that of the elevated plateau not more than two thirds can be called a grazing country. But even this presents a vast surface, extending from about the parallel of $32^{\circ} 40^{\prime}$, where the Rocky Mountains suddenly drop off near the Copper Mines of New Mexico (now Fort Webster), to the twenty-sixth parallel. The watercourses here run towards the north, and discharge themselves into lakes which have no outlets. The Conchos alone, a stream which is as large as the Rio Grande, and has many tributaries, discharges itself into that river. It is in that portion of Chihuahua which forms the eastern slope of the Sierra Madre, as I have before said, that the best arable and timbered land is to be found. This, for a mountainous district, is well watered.

The district south of the river Gila, between the Rio Grande and the Pacific, for about one hundred and fifty miles in width, is of the most barren character. The summit of the great ridge or plateau is covered with a short grass. On leaving this and proceeding westward come broad plains, with but little vegetation, save the stunted mezquit and other plants common to these arid regions. This broad belt extends to the Pacific, and is crossed at intervals of from fifteen to thirty miles with short and isolated ridges of mountains from one thousand to two thousand feet above the plain, running from north-west to south-east. These at a distance appear like a continuous chain; but on approaching them, they are found to be in short ridges from five to ten miles in length, overlapping each other and affording easy passages across. In this respect these chains differ from the mountain ranges both at 
the north and at the south. Coming from the north, they present but few openings until they reach the parallel of about $32^{\circ} 40^{\prime}$, where they suddenly fall off eight miles south of Fort Webster and disappear entirely. At Fort Webster," between the Gila and the Rio Grande, these mountains attain a height of more than eight thousand feet above the level of the sea. $\uparrow$ They rise in peaks, separated by narrow and intricate valleys, and maintain this character until they terminate on the plateau, as stated. This plateau extends southwardly through the greater portion of Mexico.

In about the latitude of $31^{\circ} 15^{\prime}$ north, the great Cordillera range again begins to appear on the western border of the table-land, and is as it were the concentration of many lesser ridges into one vast chain, elevated, compact, and impassable, extending through the entire length of New Mexico to the Cordillera of the Andes in South America. The wagon road of Colonel Cooke, followed by the Commission, crosses a spur of the Sierra Madre here. A second pass, for mules only, exists a short distance further south, connecting Correlitos with Babispe ; after which there is no passage through, nor can these mountains be crossed again with mules for several hundred miles.

The river Gila, from its source to a point about fifty miles below where the San Pedro enters, is closely hemmed in by lofty and impassable mountains. After this they appear only at intervals, and not in continuous chains. The rest of the valley of the Gila is quite open to its junction with the Colorado. The mountains in a few instances reach the banks of the

* Fort Webster was established at the Copper Mines, or Santa Rita del Cobre, after they were abandoned by the Boundary Commission in Oetober, 1851.

$+\mathrm{Mr}$. Henry C. Force, the indefatigable officer in charge of the meteorological department attached to the astronomical party of Lientenant Whipple, ascended to the highest summit of the Bufa del Cobre, near our encampment, with a barometer, and ascertained its height to be seven thousand nine hundred and ninety seven feet above the level of the sea, and one thousand eight hundred and one feet above the valley where we were encamped. 
river; but they are passed by following the valley of the river or other openings through them.

No stream enters the Gila on the south side after the San Pedro is passed. There is a small water-course known as the Santa Cruz River, which rises in some springs near the sources of the San Pedro, and which, after a course of less than a hundred miles, is lost in the desert near Tucson. Near this are good lands, which by irrigation are rendered fertile. We have, therefore, a space of about two hundred and fifty miles without a water-course or arable valley except the Santa Cruz, and nearly one hundred and sixty miles before any considerable stream is reached at the south, in the State of Sonora. This wide region is of the most barren and desert-like character, consisting of arid plains, with short and detached ridges of mountains at long intervals.

The water-courses of Sonora take their rise in the Sierra Madre and in the mountains at the north. Those which rise in the former, receiving a more copious and constant supply of water, reach the ocean ; while the streams in the northern portion of the State, after traversing arid deserts, and forcing their way through lofty mountains for three or four hundred miles, lose so much by evaporation that they do not reach the sea, but are swallowed up in the sands of the desert or cienegas (marshes). These streams lose much, too, by irrigating the cultivated valleys through which they run.

Except along the bottom-lands of these streams, there is no arable land in Sonora. What there is, however, is exceedingly fertile, and yields enormous crops. Owing to the rapid descent of the streams, the water is easily controlled and conducted by irrigating canals over: the arable lands; so that every considerable land-owner may have his own canals. In the northern portion of the State, near the Gila, there is but little tillable land. The best portion of it is that occupied by the Pimo and Coco-Maricopa Indians. In portions of the Santa Cruz and San Pedro valleys are good lands, but the 
quantity is small; and the latter is rather a grazing than an agricultural district.

In about the latitude of $31^{\circ}$ the water-courses of northern Sonora begin to appear, and with them the luxuriant valleys, through several of which I found my way across the country to the Gulf. Those streams, though denominated rivers, would scarcely be characterized as such in the United States; the term rivulet would be far more appropriate.

As regards the construction of a railway through Texas, the country is entirely open and generally level. The first elevation to be passed, following the parallel of 32 degrees, is Castle Mountain, about ten miles east of the river Pecos, which may be avoided by diverging either to the north or south. After crossing the Pecos, the route should be south of the Guadalupe range of mountains, a lofty and continuous chain, which, coming from the north, where it is united by the Sacramento range, terminates abruptly in about $31^{\circ} 50^{\prime}$ north latitude. South of these mountains, the country is quite open and apparently level, with isolated mountains at long intervals, but no connected chains. For the hundred miles which we followed the Pecos, there were neither hills nor mountains, and this character of country extends to the Rio Grande. A mountain chain, called the "Sierra de los Organos," crosses this river near El Paso, and extends north for some eighty miles. These mountains may easily be passed through where the river has opened a way for itself near El Paso, and again about forty miles to the north. But surveys must determine whether, in coming from the Mississippi, a route near the parallel of 32 degrees, or along the Colorado or Canadian rivers, will be more practicable.

After crossing the Rio Grande, should a point north of El Paso, between the latitude of $31^{\circ} 53^{\prime}$ and $32^{\circ} 20^{\prime}$ be selected, there is an open country for more than one hundred miles. Some mountain ranges are then to be passed, through easy slopes or defiles, and in no case by surmounting them. In fact, 
so gradual are the ascents and descents, that they are scarcely perceived. After they are passed, broad, open, and level plains occur, where for miles very slight embankments or excavations will be required for the construction of a road.

If, on examination, it is not deemed advisable to cross the Rio Grande within the district named, we nust then strike it about twenty-five miles further south, near San Eleazario, thence across the basin of that river to the table-land beyond and south of the mountains which lie west of El Paso. Broad level plains again occur here without any continuous mountain chain.

An idea has arisen that the line of Colonel Cooke's road is a practicable one for a railway. This is a great mistake. That road crosses a spur of the Sierra Madre with a descent of from twelve to fifteen hundred feet in ten miles, all of which is avoided by keeping some ten or twenty miles to the north. In fact, my route with the engineering parties across this district, as detailed in this narrative, diverging occasionally a few miles, will be found a practicable one.

The first barrier of consequence, of which I cannot speak with certainty, is a range of mountains beyond the San Pedro river, bounding the Santa Cruz valley on the east. They terminate in latitude $31^{\circ} 15^{\prime}$ where our parties passed them. Between $32^{\circ}$ and $32^{\circ} 22^{\prime}$ they are passed by wagons, but I cannot state with what facility. If an opening exists any where between the $32 \mathrm{~d}$ parallel and the Gila, the last obstacle to reaching the plateau near that river is overcome. Here is an open level plain, from one hundred to one hundred and twenty miles aeross, to the river.mentioned. In fact, it may be said that when the San Pedro Mountains are passed, we shall have an uninterrupted plain of about two hundred and fifty miles to the Colorado.

It will thus appear, that the entire district from the Rio Grande to the Colorado, which may be put in round numbers at five hundred miles, consists of broad, open, gravelly plains, from fifteen to twenty-five miles in width, with scarcely an un- 
dulation, and for long distances requiring but slight excavations and embankments. The mountains may be passed through open defiles of easy ascent and descent. When the Gila is reached, either the bottom or the table land may be followed; though the latter will doubtless have the preference, as it presents a perfectly hard and level surface. In a few instances, ranges of mountains approach the bottom-land of the Gila. Openings may doubtless be found through these, or they may be passed by cutting away near the river.

The Colorado River presents no difficulties for bridging. At Fort Yuma, where the Gila joins it, it is about six hundred feet wide, but above and below the junction, it expands to eight hundred and twelve hundred feet. In dry seasons there is between four and five feet of water at Fort Yuma.

After this river is passed, we reach the great California Desert, about one hundred miles across, which increases in width towards the north. This desert is destitute of wood, water, and grass ; it presents a hard level surface with slight undulations, and seems almost graded by nature for a railway. After leaving the bottom or valley. of the Colorado, and before the table-land or desert is reached, there is a belt of moving sand. Its southern extremity is now about twelve miles below Fort Yuma, where I passed it with my parties without crossing it. Its breadth is about four, and its entire length, less than twenty miles. This is the only belt of moving sand that I know or within the district referred to, west of the Rio Grande.

On passing this desert, we reach the Sierra Nevada, where a pass must be sought, and for this purpose engineers are now in the field. To reach San Diego, it will be necessary to tunnel the coast range of mountains ; and it is probable that either a tunnel or an inclined plain with stationary engines will be indispensable to cross the Sierra Nevada, in order to strike the valleys leading to San Francisco.

On the broad desert last mentioned, we found water in its very centre in two places by digging. Sluices or basins are 
known to exist in several places, which are filled with water at times, by the overflows of the Colorado. In these, by sinking wells, a plentiful supply of water can doubtless be procured.

Should the route of which I am speaking be selected for a railway, supplies could be furnished at several places on the line after leaving the settled portions of Texas. New Mexico and the valley of the Rio Grande would furnish cattle, sheep, mules, flour, and corn. The valley of the Casas Grandes in Chihuahua, is one of the finest wheat and corn districts in the country, and Sonora could furnish an abundance of cattle, wheat, corn, and beans. Supplies may also be taken to the line of the road by the Gulf of California and the Colorado River. The latter, although it has from four to five feet of water near the junction when lowest, is somewhat obstructed by sand-bars towards its mouth; but I have no doubt that steamers, with a light draught of water, may ascend, the greater portion of the year, even for a distance a hundred miles above Fort Yuma. The Gila can never bẻ navigated except in time of floods or high water, when flat-bottomed boats might possibly pass up to the Salinas, one hundred and eighty miles above its mouth. Supplies might be sent, as is now proposed, to Fort Yuma, by sailing vessels to the head of the Gulf of California, and thence by a small steamer up the Colorado.

I have spoken of desert, woodless plains on the line near the parallel of $32^{\circ}$. It is proper to remark that any route south of the parallel of $35^{\circ}$, must cross the great Llano Estacado, east of the Rocky Mountains, which increases much in width above the $32 \mathrm{~d}$ parallel. I crossed it about $31^{\circ} 30^{\prime}$ or from the head waters of the Concho to the Horse Head Crossing on the Pecos, a distance of seventy miles, without water; but a degree further north, its width is more than doubled. Then the region between the Pecos and the Rio Grande is equally barren (so far as known), and must also be crossed by any route south of the 35 th parallel. 
So with the great California desert west of the Colorado; all routes south of the 36 th parallel must cross this, even though the Mohavi River be followed, unless the explorations now being made should discover some valley or stream not yet known.

Some observations are necessary respecting timber and other materials requisite for the construction of a railway. Forests and timbered lands extend from the basin of the Mississippi through eastern Texas, and on the slopes leading to the table-land, where they are limited to the margin of the streams. The next are found in the Guadalupe range of mountains, as well as in defiles leading to it, or following a more northerly line, in the Sacramento range. Both pine and oak exist here in abundance. Next, we have the open plains to the Organ Mountains, a chain running north and south about fifteen miles east of the Rio Grande. Here both oak and pine timber are found. Proceeding west across the Rio Grande, the supply of timber must be obtained from the Rocky Mountains in the vicinity of the Copper Mines (FortWebster). Beyond this, north of the $32 \mathrm{~d}$ parallel, there are no elevated mountains, and hence no pines. The mountain defiles are filled with oaks of a small size, and the margin of arroyos and streams with cottonwoods. In the valley of the Santa Cruz, between Tubac and Santa Cruz, are very considerable forests of mezquit, the best material for rail-ties that can be found. Next to this is the valley of the Gila, which is only wooded at intervals with cottonwoods and mezquit. For portions of the distance, the use of stone for sleepers or ties, would no doubt be advisable. This material exists in most of the mountains ; and occasionally isolated rocky masses, or "buttes," rise up suddenly from the plain.

I have suggested to civil engineers the use of the roots of the mezquit for sleepers. These roots, even when mere shrubs, are as solid and compact as lignum vitæ, and sometimes contain as much wood as a tree of twenty-five feet in height. If 
these could be smoothed at the surface and inserted firmly in the ground, they would endure longer than any material ever used for the purpose, except stone ; and the desert regions where there is no timber, would furnish an abundant supply of these roots. The experiment is worth trying.

With regard to water, there are certain indications, even in the most desert regions, by which experienced travellers generally find it by digging. It may be found, too, in every mountain range, and in great depressions on the plains by digging or boring. An examination of the map, or of this narrative, will show what running streams or springs exist, from which to obtain a supply.

From these brief remarks, it will be seen that the advantages of the southern route for a railway, are an open and remarkably level country from the Mississippi to the Sierra Nevada of California-a summit level a thousand feet less than that of the other routes (so far as known) - entire freedom from snows-and convenience in obtaining supplies. The disadvantages are a deficiency of timber, water, and food for animals; and the want of tillable lands for settlements and farms. 


\section{INTRODUCTION OF CAMELS.}

Remarks on the Introduction of Camels as a means of Transportation on the Prairies and Deserts of the Interior.

In traversing the broad plains and deserts of the interior of the continent, the subject of using camels as a means of transportation oftened occurred to me; and on my return, I learned that the subject of introducing them had been discussed in the newspapers, and that a resolution had been offered in Congress, asking for an appropriation to test the experiment.

A memoir on the subject, at considerable length, written with much ability, and embracing a vast number of curious, interesting, and important facts, by George R. Gliddon, Esq., was laid before the Committee on Military Affairs of the Senate. This committee asked for an appropriation to enable the Secretary of War to import thirty camels and twenty dromedaries of various breeds, together with ten Arabs, familiar with their habits, whose services might be retained for two years. The plan proposed was to send an efficient agent to Egypt, who was to proceed to the interior of the country, as far as Nubia, and there procure the finest specimens of the best breeds; for the camel, like the horse and the ox, presents many varieties. On the African coast these animals are found in great numbers; but they are said to be inferior to those of the interior. If the experiment is to be fairly tested, and made a Government undertaking, of course the very best breeds, both from Africa and Asia, should be obtained 
There is, perhaps, no gentleman in the United States whose opinion on this subject is entitled to so much weight as that of Mr. Gliddon, who was a resident in the Levant for twenty-three years, eight of them as United States Consul at Cairo, and who grew up with the camel and the Arab. His early days were connected with Oriental life, traversing at various times the deserts of Arabia and northern Africa. Mr. Gliddon, knowing the interest I felt in this subject, and that I had had some experience in my various journeys across the deserts and plains of the interior of our continent, has kindly placed in my hands the results of his inquiries into the history of the camel, and of its introduction into various parts of Asia and Africa, from which he has permitted me to make such extracts I I deemed suitable, for a brief paper like the present.

From my experience of nearly three years with horses, mules, asses, and oxen, and with wagons, carts, and packs, I do not hesitate to hazard the opinion, that the introduction of camels and dromedaries would prove an immense benefit to our present means of transportation, that they would be a great saving to animal life, and would present facilities for crossing our broad deserts and prairies not possessed by any other domestic animals now in use.

Many have imagined that the camel, being indigenous to certain parts of Africa and Asia, would not thrive in America; but from the climate, and the food upon which he would be compelled to live in the districts where he would be required to labor, I doubt not his habits will be found to be as well adapted to them, as to one half, or two thirds, of the region where he now thrives. Less than four centuries have passed since the introduction of the horse, ox, ass, mule, goat, sheep, pig, dog, etc., into America, and they now exist in myriads from the shores of the Arctic Sea to Cape Horn. Like man, they seem to adapt themselves to every clime ; nature modifying them to the heat or cold, to the arid plains or the marshy lands, where they become domiciled. The camel is as strictvoL. II. -37 
ly a domestic animal as the horse, his existence in a wild state being now doubtful; ; and there is no reason why hemay not as well adapt himself to our deserts and prairies as to the steppes of Tartary or the Sahara of Africa.

On the forty species of animals reduced at this day to a state of domestication, Geoffroy Saint Hilaire, a distinguished French naturalist, remarks that " of these thirty-five are now cosmopolitan, as the horse, dog, ox, pig, sheep, and goat. The others have remained in the region of their origin, as the lama and the alpaca on the plateau of Bolivia and Peru, or have been transplanted only to those countries which most approximate to their birth-place in climatic conditions, as the Tongusian reindeer at St. Petersburg. Out of the thirty-five domestic species possessed by Europe, thirty-one originated in Central Asia, Europe, and Northern Africa. 'Only four species have been contributed by the two Americas, Central and Southern Africa, Australia, and Polynesia; although these portions of our globe contain the greater number of zoölogical types. In consequence, the great majority of domestic animals in Europe are of exotic origin, and hardly any are derived from countries colder than France; on the contrary almost all were primitively inhabitants of warmer climates." $\dagger$

Widely as the camel, or "ship of the desert," as it is called in the poetic language of the East, is now dispersed over all parts of Asia and of Central and Northern Africa, there is historical evidence to show that there was a period when he was a

* Humboldt quotes Chinese and Turkish authors who affirm that the wild eamel, as well as wild horses and asses, is still to be found in Eastern Turkis$\tan$ and in the countries north of China. Cuvier believes that, if such is the ease, they have merely become wild after their owners had given them their liberty. In the interior of Sonora are thousands of wild cattle which are fiercer than the buffalo. The wild horses, or mustangs, of Texas and Northern Mexico are also known. But all these are the offspring of domesticated animals.

† La domestication du Llama, etc. Projet d'une Ménagerie Nationale d'Acclimation. 


\section{stranger, even in Africa, and when his sphere in Asia was com- paratively limited." Now, his geographical diffusion is equal to}

* "The camel," says Humboldt, "was entirely unknown to the cultivated people of Carthage, through all the centuries of their flourishing existence, until the destruction of the city. It was first brought into use for the armies by the Marusians, in Western Lybia, in the time of the Cæsars; perhaps in consequence of its employment in commereial undertakings by the Ptolemies, in the valley of the Nile. The Guanches inhabiting the Canary Islands, who were probably related to the Berber race, were not acquainted with the eamel before the fifteenth century, when it.was introduced by Norman conquerors and settlers. In the probably very limited communication of the Guanches with the coast of Africa, the smallness of their boats must necessarily have impeded the transport of large animals. The true Berber race, which was diffused throughout the interior of Northern Africa, is probably indebted to the use of the camel, throughout the Lybian desert and its oases, not only for the advantages of internal communication, but also for its escape from complete annihilation and for the maintenance of its national existence to this day. The use of the camel continued, on the other hand, to be unknown to the negro races; and it was only in company with the conquering expeditions and proselyting missions of the Bedouins through the whole of Northern Africa, that the useful animal of the Nedschd, of the Nabatheans, and of all the districts occupied by the Aramean races, spread here, as elsewhere, to the westward. The Goths brought the camels as early as the fourth century to the Lower Istros (the Danube), and the Ghaznevides transported them in much larger numbers to India as far as the banks of the Ganges,*

Other authorities agree as to the comparatively recent introduction of the eamel and dromedary into Northern Africa. Baron Humboldt distinguishes two epochs in their distribution there, "the first under the Ptolemies, which operated, through Cyrene, on the whole of the north-west coast, and the second under the Mohammedan epoch of the conquering Arabs;" + while the dromedary, now so much in use, was only propagated in the region of Algiers as late as the middle of the sixteenth century. $f$

A number of eurious facts have been brought together by Mr. Gliddon, to show that the camel was not used in the earliest Egyptian times; the most satisfactory evidence of which is, that it does not appear on any of the Pharaonic monuments: a conclusion to which Champollion-Figeac had arrived. "But one thing worthy of remark," says that distinguished archæologist, "is that there is not found on any monument the figure or mention of the camel; a native of Arabia. This valuable animal appears to have been unknown to the ancient Egyptians for service." § 


\section{that of most other domesticated animals. "He has followed," says Mr. Gliddon, "the radiations of war, commerce, and emi-}

In the journeys made by the patriarchs of the Seriptures into Egypt they were accompanied by camels; these animals were also employed in bearing the productions of Arabia to that country, but they were always the property of aliens, and their residence there was but temporary. So "during the stay of the Hebrews in the land of Goshen, no allusion is made to eamels, save in Exodus, ix. 3, whether owned by themselves or by their Egyptian rulers. On the contrary, the especial mention of asses as the animals on which Jacob's sons carried their sacks of corn over the desert of the Isthmus of Suez * - of wagons furnished by the Egyptians to bring up Jacob from Canaan $\nmid$ - of cattle, horses, flocks, and asses, as the only zoölogical property the famishing Egyptians could give in exchange for bread, $\neq$-combined with the notable fact that, in the account of the Mosaic exodus, horses attached to chariots and cattle are the only quadrupeds enumerated;-ail these accumulated evidences, I repeat, amply confirm hieroglyphical and historical negatives of the naturalization of eamels in Egypt, at any time prior to the Persian invasion, B. C. 525." (Gliddon's Memoir, MS.)

One of the most elaborate treatises on the geographical distribution of the eamel in the Old World, is that of the distinguished geographer and ethnologist Karl Ritter, who in his great work has devoted 150 pages to the history of this quadruped. I shall merely quote the results of his investigations to show the wide extent of the present diffusion of the camel. These natural limits are established as follows:- "Towards eastern and south-eastern Asia, by the tropical, sultry, maritime, Indian, and Farther Indian climate of the Elephant-land and fluvial zone of the Cocoa-forests; -towards the north on the Upper Jenesei, Baikal, and Irtysh, by the Reindeer-zone of the sub-polar climate of $58^{\circ}$ to $56^{\circ}$ North Latitude;-beyond the flat steppe-lands of the nomadic tribes, by agriculture upon the European culture-ground, with the fixed dwellings of its inhabitants. In the Maghreb, or northern half of the African continent, the Lybian camelzone, towards the north (from the Erythræan East to the Atlantic West), is exhibited without limit, as far as the Berber races, as well as Moors and Bedouins, inhabit the Sahara and the Oases. But south of that it is limited by the zone of tropical rains, or the wet season, along the valleys of the Senegal, the Niger system, and the Bahr el-Abiad. Here the expanse of sand and gravel changes into a luxuriant, thiekly-wooded, fruit-bearing soil, subject to inundation, before which the organization of this desert-animal shrinks back, and where begins the belt of the central Negro States of Soudan, or the Land of the Blacks, with whom asses and bullocks, as universal beasts of transport, thrive, being better suited to the elimate, or where the negro has become his own bearer of burdens." $\S$ 
gration over a stupendous segment of the earth's superficies," stretching across the whole of Asia, and extending as far north as the 56th paralle] of latitude. Amid the defiles of the Caucasus, the Himalaya, and the Kuenleen ; over the black plateau of Upper Asia, and the scorching plains of Hindostan ; skirting the shores of the Indian Ocean, the Yellow, the Caspian, and the Black seas, "winter or summer, he resignedly plods his weary way," burdened with whatever load his master places on his back. He is much used in eastern Europe ; and in Africa, across its entire breadth, from the shores of the Mediterranean to the region of the tropical rains.

Taking a portion of the North American Continent corresponding with the camel zone of the old world, the most extreme northern limits of the United States would be congenial to him. But we should not require his services north of Missouri, or about the 40th parallel. From thence, southward to the Gulf of Mexico, but particularly in Texas, the climate would be most congenial to him. The high table-lands of Texas, New Mexico, Utah, Sonora, Chihuahua, Durango, and portions of Central Mexico, are equally adapted to him. The entire route from the Mississippi to California, particularly that south of Santa Fe by the Gila, where there are no mountains to cross ; and also, the great highway over the table-lands of Mexico, are well adapted to his habits. But he would be most useful on those long jornadas and deserts where there is either no water, or where it is so brackish that mules and horses will not drink it.

There are peculiarities in the arid plains and deserts of North America which seem to fit them for the habits of the camel. His favorite food in Africa is beans and chopped straw. Now, it is a well known fact, that however barren our deserts, they abound in mezquit bushes or chapporal, which shrub bears a most nutricious bean. Whether this plant attains a height of three feet on the desert or twenty in the bottom-lands, it is equally prolific. Mules and cattle feed on 
them when they cannot get grass or corn; yet they never thrive on them, but, on the contrary, lose flesh. Other peculiarities are the salines and salt lakes, which abound on the arid plains throughout the table-lands, as well as on the slopes towards both oceans. When driven to great extremities, mules will sometimes drink this salt or brackish water ; but I have driven them fifty or sixty miles without water, yet on reaching a saline not one in ten would touch it. To camels brackish water is as acceptable as if from the purest fountains.

"Frugal in appetite," says Mr. Gliddon, "the camel's epicurism never rises above a sufficiency of split beans and chopped straw ; but while in the vernal season he relishes clover and grasses, his massive grinders, cutting like cold chisels, masticate alike the dryest stalks or the toughest thorns; and his ' cast-iron' stomach digests and converts into nutriment stems otherwise so devoid of succulence, that the camel subsists where every other gramnivore must starve. When necessary, he can go five days without water."

With us, the food we shall have to give them will be various kinds of grasses, in particular those popularly known as mezquit, the grama, and the buffalo grass, which grow on the prairies, the elevated table-lands, and the mountains. For more solid food we have the Mexican frijoles and maize, with other cereals. On the deserts there are plants which mules will not touch, which the camel would doubtless feed upon.

With regard to the capacities of camels for carrying burdens all depends upon the breed. "Six hundred pounds," says Mr. Gliddon, "is a fair estimate for the best Arabian well fed animal, with which he will travel twenty miles a day. The Bactrian camel, which is less capable of enduring heat, will carry ordinarily eight hundred pounds. Dromedaries, which are not employed for carrying burdens, but for riding, can travel freely fifty or sixty miles every twenty-four hours (including eight to twelve hours for rest and stoppage), and 
this too with a rider estimated to weigh one hundred and seventy-five pounds and one hundred pounds weight of saddle, baggage, etc. His average gait is five miles an hour, at which he will continue for weeks. On an emergency he may be pushed, with this same weight, double the distance; but then the jolting is increased with the speed of the animal, and could only be borne by experienced riders." Colonel Shiel, an experienced British officer, long versed in military service in Hindostan, says, the dromedary "is able to travel in all situations: mountains and plains, blazing sun, frost and snow, seem alike to him."

It is proper to state that in hot countries the camel's hair is clipped close, while in the cold it is permitted to grow, according to the temperature he is exposed to, when it attains a length of six inches. Hence he can live in the region of the reindeer as well as in that of the lion.

This animal is therefore used exclusively, from the Nile to the Ganges, for the purpose of war and expresses, or duties requiring expedition; and instances are on record where war parties of Bedouin Arabs, lightly equipped, with a small supply of provisions, have been known to traverse a space of three hüured miles in four days. $\dagger$

I have devoted more space to this subject than I intended;

* Journey through Kurdistan,-Jour. Royal Geog. Soc., vol. viii. p. 97.

† "The female camel yields an abundance of excellent milk, which, mixed with meal, is the standard dish of Bedouin economy; when acidulated, it constitutes the favorite dish of the Turkoman; when fermented, an intoxieating drink called 'kermis' by the Tartars.

"The hair is a well known article of commerce, out of which nomadic tribes manufacture clothing and tents, as well as all the halters, cords, saddle-bags, and ornamental trappings for the camel himself. The flesh of a young camel is esteemed a luxury, and at every age a wholesome diet. It is cut into strips and dried in the same manner as beef is preserved in Mexico. The dung is used for fuel, in the same manner as the buffalo dung by our prairie travellers. The entrails and minor sinews are adapted to thongs, bow-strings, fastenings, etc., while the hide is sold for the same purpose as we use the hide of beef-eattle and buffaloes, such as shoes, sandals, belts, harness, saddles, etc." - Gliddon's Mem. MS. 
but as it is little known, and is now being brought before the country, I have felt justified in extending these remarks. In conclusion, to give an idea of the number of animals used by the government for transportation, I quote from the official report of the Quarter-master General made in 1851. By this it appears that more than ten thousand horses, mules, and oxen were constantly required for transportation, and for mounting guides, spies, escorts, and troops. At the same time, when the army was increased about fifty per cent., the cost of transportation reached two million dollars, an increase of one thousand five hundred per cent. If we go back to the year 1844, the cost of transportation was about one hundred and twenty thousand dollars, and in seven years had increased to two millions 
APPENDICES. 



\section{APPENDICES.}

A.

Article V. of the Treaty of Guadalupe Hidalgo, relating to the Boundary between the United States and Mexico.

"The boundary line between the two Republics shall commence in the Gulf of Mexico, three leagues from land, opposite the mouth of the Rio Grande, otherwise called Rio Bravo del Norte, or opposite the mouth of its deepest branch, if it should have more than one branch emptying directly into the sea; from thence up the middle of that river, following the deepest channel, where it has more than one, to the point where it strikes the southern boundary of New Mexico; thence westwardly along the whole southern boundary of New Mexico (which runs north of the town called Paso) to its western termination; thence northward, along the western line of New Mexico, until it intersects the first branch of the river Gila (or if it should not intersect any branch of that river, then to the point on the said line nearest to such branch, and thence in a direct line to the same); thence down the middle of the said branch and of the said river, until it empties into the Rio Colorado, thence across the Rio Colorado, following the division line between Upper and Lower California, to the Pacific Ocean.

"The southern and western limits of New Mexico, mentioned in this article, are those laid down in the map entitled, 'Map of the United Mexican States, as organized and defined by various Acts of the Congress of said Republic, and constructed according to the best Authorities. Revised edition. Published in New York, in 1847, by J. Disturnell.'Of which map a copy is added to this treaty, bearing the signatures and seals of the undersigned plenipotentiaries. And in order to preclude all difficulty in tracing upon the ground the limit separating Upper from Lower California, it is agreed that the said limit shall consist of a 
straight line drawn from the middle of the Rio Gila, where it unites with the Colorado, to a point on the coast of the Pacific Ocean, distant one marine league due south of the southernmost point of the port of San Diego, according to the plan of said port made in the year 1782 by Don Juan Pantoja, second sailing-master of the Spanish fleet, and published at Madrid in the year 1802, in the Atlas to the Voyage of the schooners Sutil and Mexicana, of which plan a copy is hereunto added, signed and sealed by the respective plenipotentiaries.

"In order to designate the boundary line with due precision, upon authoritative maps, and to establish upon the ground land-marks which shall show the limits of both Republics, as described in the present article, the two governments shall each appoint a commissioner and a surveyor, who, before the expiration of one year from the date of the exchange of ratifications of this treaty, shall meet at the port of San Diego, and proceed to run and mark the said boundary in its whole course to the mouth of the Rio Bravo del Norte. They shall keep journals, and make out plans of their operations; and the result agreed upon by them shall be deemed a part of this treaty, and shall have the same force as if it were inserted therein. The governments will amicably agree regarding what may be necessary to these persons, and also as to their respective escorts, should such be necessary.

"The boundary line established by this article shall be religiously respected by each of the two Republics; and no change shall ever be made therein, except by the express and free consent of both nations, lawfully given by the general government of each, in conformity with its own constitution.

\section{B.}

Official Instructions from the Department of the Interior to John R. Bartlett, Commissioner on the part of the United States, for running and marking the Boundary line between the United States and the Republic of Mexico.

Department of the InTerior, August 1, 1850.

Sir : In a letter from the Department, bearing date of June 19, 1850 , you were informed thạt you had been appointed Commissioner 
on the part of the United States for running and marking the boundary line between the United States and the Republic of Mexico, under the fith article of the treaty of Guadalupe Hidalgo.

By the documents in this department, copies of which have been placed in your possession, or to which you have had access, you will perceive that that portion of the boundary between the junction of the Gila with the Colorado and the Pacific Ocean has already been run by your predecessor. By the same documents it also appears that the Joint Commission in February last mutually agreed to suspend their operations, and meet on the first day of Nevember next, at El Paso, on the Rio Grande, and resume their operations westward from that point.

You will, therefore, in conformity with that agreement, proceed, with the Commission appointed to perform the duties of running the boundary mentioned, to El Paso, by the nearest and most convenient route, so as to reach there by the first of November.

As the organization of the Commission on the part of the United States has been made with a view to other objects beyond that of running the boundary, it becomes necessary to call your attention to the duties required.

By the sixth article of the Treaty of Guadalupe Hidalgo, provision is made for the collection of information relative to the construction of a "road, canal, or railway, which shall, in whole or in part, run upon the river Gila, or upon its right or left bank, within the space of a marine league from either margin of that river." And that "should it be found practicable and advantageous to construct such a road, the governments of both Republics will form an agreement regarding its construction, in order that it may serve equally for the use and advantage of both countries."

As the examinations to be made, and the information to be collected, agreeably to this article, are of very great importance, you will make such an organization of parties, and assign to them such duties, as will be productive of the desired result.

The boundary line where you will commence your labors begins at the "point where the Rio Grande strikes the southern boundary of New Mexico; then westward, along the whole southern boundary of New Mexico (which runs north of the town called Paso) to its western termination; thence northward, along the western line of New Mexico, until it intersects the first branch of the river Gila (or if it should not intersect 
any branch of that river, then to the point on the said line nearest to such branch, and then in a direct line to the same").

This portion of the line can only be ascertained by examinations and surveys upon the ground. You will, however, receive important aid in the determination of this line, as the treaty expressly declares that "the southern and western limits of New Mexico, mentioned in this article, are those laid down on the maps of the United Mexican States, published at New York in 1847, by J. Disturnell," a certified copy of which was appended to the treaty, bearing the signatures and seals of the plenipotentiaries. You are furnished with a certified copy of this map.

The remainder of the boundary runs along the middle of the River Gila and the Rio Grande; of the former, from the point where the western line of New. Mexico intersects it to its junction with the Colorado; and the latter, from the point intersected by the southern line of New Mexico near El Paso, to its mouth.

As the organization of the Commission under your charge has been made for the purpose of collecting information relative to the country contiguous to the boundary line, in addition to the running of that line, it is desirable that you should avail yourself of every opportunity afforded by your passage through the unexplored regions of Texas, New Mexi$c o$, and California, to aequire information as to its geography, national history, \&c., when it can be obtained without retarding the progress of the boundary survey. You are, therefore, at liberty to send out exploring parties, when not otherwise employed on the survey of the line, to examine the country north of the Gila, as well as on either side of the Rio Grande, for the above and kindred purposes.

It is stated, on the authority of persons who have traversed the country near the river Gila, that during a considerable portion of the summer there is neither grass nor water to be obtained. Should the Commission be in this region at this season, it may be compelled to suspend its operations. In such an event, your party may be usefully employed in geographical and scientific explorations in the regions before alluded to.

The collection of information relative to the precious metals, quicksilver, and the various minerals, ores, and other substances, useful in the arts, is very desirable. In reference to the existence and localities of these, as well as the locations of mines formerly worked by the early settlers in California and New Mexico, and since abandoned, owing to the incursions of the Indians, or other causes, you will do all in your power 
to acquire information as far as you may be able, without impeding the main objects of the Commission.

After you have traced the boundary to the junction of the Gila with the Colorado, you will be compelled to retrace your steps to El Paso, Before doing this, as you will possess many facilities for the purpose, you are at liberty to proceed up the Colorado River, and make such explorations as your time and facilities will permit, provided the boundary survey is not arrested in so doing.

The discovery of more practicable routes through California for emigrants, is desirable. The present routes, by way of the Great Salt Lake and the River Gila, are attended with many difficulties. If a portion of the Commission can be spared, with an adequate escort, to seek such routes, while it is in their vicinity, you are at liberty to employ them.

As it is indispensable that each government should be furnished with a full and circumstantial record of the proceedings of the Commissioners, they will doubtless order such to be kept in duplicate. This duty will devolve upon the clerks or secretaries appointed on both sides, who will be responsible for the accuracy of such records, and for their safe delivery, properly certified, to the respective governments, at the expiration of the Commission.

As soon as the boundary shall have been ascertained and marked, you will cause a true and accurate map to be made of the country through which it passes, in its entire extent. A duplicate copy of said map, certified by the commissioners and surveyors on both sides, should accompany the records of the proceedings of the Commission.

The joint report of declaration by the commissioners "of the final result agreed upon by them," under the fifth article of the treaty, will also be transmitted to the department, to be filed with the journal or record of their proceedings and the maps.

Your salary as commissioner, which has been fixed by Congress, at three thousand dollars, will commence on the fourteenth day of June 1850 , the day of your appointment by the President, when you were ordered to report yourself for duty to this department. Under the head of contingent expenses of the Commission, will be embraced your reasonable personal and travelling expenses while in service, and those of the principal surveyor, chief astronomer, and other officers of the topographical engineers and navy who may be detailed to assist you in the field, or otherwise; the pay and subsistence of assistant surveyors and 
draughtsmen, chain-carriers, mechanics, laborers, cooks, servants, and guides, and the incidental and necessary expenses of exploring parties ; the pay and subsistence of secretaries, surgeon, quarter-master, commissary, assistants, and clerks; the purchase of an outfit, including horses, mules, tents, and camp-equipage, arms and ammunition, books and stationery, instruments, medical stores, boats, mechanics' tools, wagons, and vehicles for the transportation of the Commission, and its stores by sea or otherwise; the purchase of articles for presents to, or traffic with, the Indians, clothing for the men (to be repaid by them); and the purchase and fixing of monuments to mark the boundary line. Of all these expenses you will keep a regular account, which, together with the necessary vouchers, you will render and transmit quarterly to the Fifth Auditor of the Treasury, for settlement. And to meet the same, as likewise the payment of the salaries, you will from time to time, as occasion may require, draw upon the Department, taking care not to exceed in the amount drawn at any one time the sum which will be required to meet the necessary and actual expenses of the Commission. You will be charged exclusively with the disbursement of the money appropriated to pay the expense of the Commission.

As soon as the Commission is filled, you will transmit to this Department a list containing the names of the several persons composing it, the nature of the duties assigned to each individual, and the compensation allowed to them respectively; and will also, from time to time, inform the Secretary of the Interior of any change which you may by circumstances be induced to make in its organization.

In organizing for duty, you are referred, for any information which you may deem necessary, to Andrew B. Gray, Esq. who has been appointed Surveyor under the treaty, and to Brevet Lieut. Colonel John McClellan, of the Topographical Engineers, whom the President has designated as "Chief Astronomer and Head of the Topographical Scientific Corps of the Commission."

Very respectfully, your obedient servant,

D. C. GODDARD, Secretary ad Interim.

John R. Bartlett, Esq.,

Commissioner on the part of the United States, to run and mark the Boundary between the United States and Mexico. 
Additional Instructions from the Hon. Alex. H. H. Stuart, Secretary of the Interior, explanatory of the foregoing.

Department of the Interior, November 4, 1851.

SIR : As some misunderstanding has arisen with regard to the instructions communicated in my letter of the $23 \mathrm{~d}$ of October, 1850 , I deem it proper to add such explanations and modifications as the circumstances seem to demand; and as Brevet Major Wm. H. Emory, the Chief Astronomer, has been appointed by the President the Surveyor, under the treaty, to run and mark the boundary line between the United States and Mexico, in place of A. B. Gray, Esq., some further explanations respecting his position and duties are necessary. The officers and members of the scientific corps immediately connected with the survey of the boundary line shall be placed under the immediate orders of the surveyor. Any lines agreed upon by the Joint Commission as the lines of boundary, shall be run and astronomically determined by the surveyor. He will have charge and direction of all the surveys of the boundary line, and shall determine the Initial and intermediate points of the survey by astronomical means, acting under your direetion. This corps shall consist of such number of assistants as you, upon advising with him, may deem absolutely necessary. He shall issue his instructions in writing, and shall preserve a copy of them in a book kept for that purpose. He shall require monthly reports from the heads of parties, and shall place them before you in a condensed form. He shall have charge of the surveying and astronomical instruments; and for their safe keeping, will be responsible to you. He shall be allowed a clerk, whose salary shall not exceed that of a sub-assistant. He shall be responsible to you, and through you to this department, for as rapid a prosecution of the surveys, and for all the astronomy conneeted with them, as may be consistent with their accuracy; and will be held accountable for all the quarter-master's stores, camp and garrison equipage, placed at his disposal.

Should any doubts arise between yourself and the Mexican Commission, the surveyor shall be required to make such surveys and maps as may tend to elucidate the point or line in dispute.

Should the surveyor at any time differ with your views on any VoL. II. - 38 
question connected with the survey, \&c., he will defer to your opinion until the case is submitted to, and decided by the department.

After the work in the field shall have been completed, the maps shall be drawn, under the immediate supervision of the surveyor under your control, on the scale suggested in the instructions to you under the date of October 23, 1850. In the mean time, during an inclement season, when the field-work may necessarily be arrested, the first plotting (or rough sheets) should be prosecuted. On the completion of the maps, they shall be signed by the surveyor, previous to their being authenticated by the commissioners.

No officer but yourself is allowed to draw for any moneys appropriated for the Mexican Boundary service. The surveyor may draw his salary from this department or from you. All the scientific DeParTMENTS not - directly connected with the surveys of the boundary line, are placed under your immediate direction. The means appropriated by Congress being very limited, it is incumbent upon this department to order such reductions in the number of persons devoted to the purposes of science as your discretion may deem least advantageous. You, as the first officer of the Commission, will be held responsible to this department for the proper administration of the great work confided to your charge.

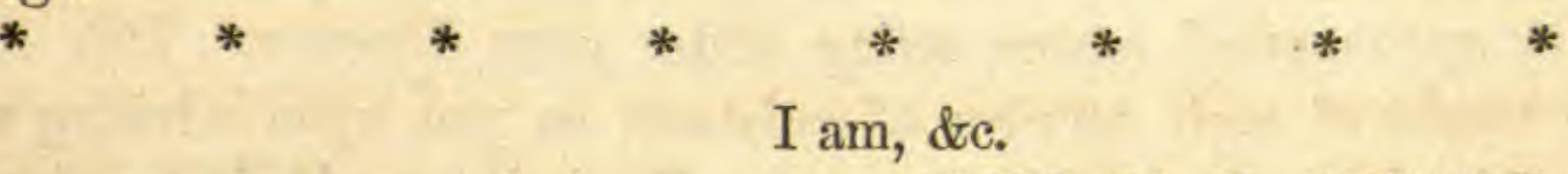

ALEX. H. H. STUART,

To John R. Bartlett, Esq.

Secretary.

Commissioner, etc. etc.

List of Members of the United States and Mexican Boundary Commission, as organized in Washington, August, 1850.

John R. Bartlett, Commissioner.

Andrew B. Gray, Principal Surveyor.

Thomas H. Webв, M. D., Secretary. 
Robert C. Murphy, Clerk and Assistant Secretary.

JAMES MyeR, Quarter-master.

J. C. Sheldon, Assistant Quarter-master.

George F. Bartlett, Commissary.

Henry Jacobs, Assistant Commissary.

John M. Bigelow, M.D., Surgeon.

John C. Cremony, Interpreter.

George Thurber, Botanist.

Theodore F. Moss, Geologist and Mining Engineer.

Јонм Bull, First Assistant Surveyor.

J. H. Prioleau, do. do.

Joseph Moorehead, do. do.

M. T. W. Chandler, in charge of Magnetic and Meteorological Department.

A. de Vaudricourt, Principal Draughtsman.

S. H. Kettlewell, Assistant, Astronomical Department.

Henry C. Foree, do. do.

James Henning, Computer and do.

John O'Donoghue, do. do.

Hugh Campbell, do. do.

P. CRenion, do. do.

Assistants in the surveying, astronomical, and topographical division, whose positions were fixed at El Paso, when the parties were organized for field duty :

Thomas Thompson,

A. Von Steinwehr,

Eugene Hesse,

Edward Barry,

Alex. A. Camp,

Geo. G. Garner,

R A. Matthews,

James Steel,

William Bausman,

Geo. M. Gordon,

R. L. GRIFFIN,

J. E. WEEMS,

Joseph Hoban,

C. N. Simms,
Malcolm Seaton, William White, JR., Frank Wheatos, Henry C. Cranston,

S. P. SANFord, Thomas Walter Jones, Charles A. Snowden, George L. Peirce, E. A. Phillips, J. T. MCDUfFie, John B. Steuart, J. P. Espy, Jr., George P. Ihrie, Clement Young, 
Thomas Dunn,

James H. Houston,

Raymond Nias,

T. W. TANSILL,

JAMES T. Scotr,
F. D. Keller,

L. C. Houghton,

P. B. Mowry,

W. B. YERBY,

A. P. Willbar.

From the corps of Topographical Engineers :

Brev. Lieutr. Col. John McClellan, Chief Astronomer, and Head of the Topographical Scientific Corps.
Capt. E, L. F. HaRdcastle,
Lieut. A. W. Whipple,
Assistant
do.
do.
do.

Colonel McClellan was recalled in October following, and Brevet Lieutenant Colonel J. D. Graham appointed in his place. The latter was recalled in October, 1851, and Brevet Major W. H. Emory appointed to his place; and soon after Mr. A.B. Gray, Principal Surveyor, was recalled, when Major Emory was appointed Surveyor, and the office of Chief Astronomer abolished. The Commission was greatly reduced in the summer of 1851 , at which time other changes were made.

The following gentlemen, who accompanied Colonel Graham, reported themselves at the head quarters of the Commission, at the Copper Mines, in July and August, 1851 :

Charles Radziminski, Principal Assistant Surveyor.

Lieut. A. E. Burnside, $3 d$ Artillcry, Quarter-master and Commissary.

Lievt. W. F. Sмiтh, Topographical Engineers, Assistant Astronomer.

Henry C. Pratt, Draughtsman and Artist.

John H. Clark, Zoologist and Assistant Computer.

Charles Wright, Botanist and do.

John Lawson, Clerk to Colonel Graham.

W. A. TAYLoR, Sub-Assistant in the Surveying Corps.

John J. Pratt, do. do.

Major Emory, on joining the Surveying party on the Rio Grande to relieve Colonel Graham, was accompanied by the following officers, to be added to those already detailed for that party :

Lieut. Michler, Topographical Engineers.

Arthur Schotт, First Assistant Surveyor.

Edward Ingraham, Sub-Assistant $d o$.

George C. Gardner, Clerk. 
D.

Official Report of the Survey of the River Gila, by Lieutenant A. W. Whipple, of the Topographical Engineers, dated San Diego, California, January 10th, 1852.

\section{San Diego, California, January 10th, 1852.}

CoL. : I have the honor to report my arrival at San Diego, with the party of the Boundary Commission under my command. Nearly the whole time since you left us upon the San Pedro, until our arrival here, we have been upon a short allowance of provisions.

With fourteen and a half days' rations of flour, and without an escort, we left St. Peter's Springs upon the Rio San Pedro, on the 3d of October, 1851. We arrived at the desired points on the Gila, northeast of Fort Graham, on the evening of the 9th. The transit instrument was mounted the same night, and both limbs of the moon were observed for longitude. The Topographical survey of the Gila, was commenced at this point. My excellent assistants in this portion of the work, Henry C. Force and Frank Wheaton, are worthy of great praise for their industry and skill in the performance of their duties. I should be pleased to have their names brought before the Department at Washington, and their merits appreciated.

The survey was carried on without difficulty below the junction of Rio San Francisco, as far as the entrance to the eañon of the Pinal Lleño mountains. Into this we foreed our way, although Indians told us that neither man nor beast could pass through. In some places by wading, in others by climbing upon the sides of the cañon, which rose perpendicularly from five to fifteen hundred feet in height, the survey progressed for eight or ten miles. The want of men and of provisions prevented us from sending reconnoitering parties in advance. The train passed over mountains rough and steep upon the north side of the river. Having succeeded in reaching a gorge by which a mountain stream leaps into the river, we were here compelled to abandon our wagon and lead the pack-mules over steep mountains. The following extract from the Meteorological Notes, will give an idea of our route. 


\begin{tabular}{|c|c|c|c|c|}
\hline $\mathrm{D}^{\circ} \quad \mathrm{C}$ & hor ? & & Bar. & \\
\hline Cañon Springs, & 27 , & S. Rise, & " & 27,470 \\
\hline Iron Hill, & 28 , & 6 A. M. & 6 & \\
\hline nit Pass, & "6 & $8 \frac{1}{2}$ A. M. & " & 26,073 \\
\hline Cascade Gr & $"$ & $9 \frac{1}{2}$ A. M. & " & 27,194 \\
\hline$" 6$ & " & $7 \frac{1}{2} \quad$ A. M. & " & 27,229 \\
\hline is Gila & $"$ & $1 \frac{1}{2}$ P. M. & " & 25,790 \\
\hline
\end{tabular}

The Cascade Grotto is too wildly beautitul to pass unnoticed. Descending over twelve hundred feet in an hour, we plunged into an Indian garden, where were melons, maize, and beans, and to our surprise a field of cotton. This fertile spot is an inclined plain, evidently formed by deposit from a mineral spring, which gushes from the mountain, irrigates the fields, and then follows a ravine, leaping from cliff to cliff, in beautiful cascades, until it joins the Gila, which appears in view a thousand feet below the garden. Passing beneath the first water-fall, one enters a charming stalactite cave, consisting of two apartments, richly decorated. At the foot of the precipice are flowering shrubs and matted vines, whose red flowers gaily contrast with the surrounding verdure.

This singular formation is filled with petrifactions. In one place was seen the trunk of a large cotton-wood tree completely petrified, and cropping out from a bed of coarse lime-stone. A chip showed distinctly bark and fibre.

From this point the Gila was inaccessible; and having hired an Indian from the hills, we followed his guidance, and reluctantly turned our backs to the river. Surrounded by a great body of Pinal Lleños, we passed through their strongholds, and on the 1st of November again struck the Gila, probably not more than ten miles below the point at which we left it.

Having surveyed up as far as possible from this place, we then followed the course of the Gila to the mouth of the Rio San Pedro. Here, while observing moon culminations for longitude, we sent a party eighty miles to the Pimo village, where flour was purchased. December 9th, I met this party on its return. When we arrived at the Pimo village, Colonel Craig, with our escort of twenty-three men, and Captain Barry, with about twenty-five days' rations, were awaiting us. The banks of the 
river from the Pimo settlement to the junction of the Rio Salinas, are fertile, producing crops of cotton of the first quality. The Maricopas have been driven by the Yumas from their settlement near the Salinas into closer proximity to the Pimos. Within the last year many have been killed, including Juan Antonio Llunas, a Maricopa by birth, but commander-in-chief of the confederate tribes. If protected from incursions of Apaches, Cuchans, and Yumas, the Maricopas would gladly return to their fertile fields upon the American bank of the Gila; and, in case of an Indian war, they would prove a valuable auxiliary to our troops. The Salinas, at its junction, is a beautiful stream, clear as crystal, large as the Gila, and, to our surprise, not salt. Having progressed with the topographical survey to within about eighty miles of the junction of the Gila with the Colorado, and our supplies of provisions failing, we were obliged on the 14th of December to postpone its conclusion until provisions could be procured at the army depot at "Camp Yuma." In four days we reached the junction. Here, meeting Captain Jimenes and party of the Mexican Commission, who had arrived the day previous, to our consternation we learned that the military post had been abandoned. There was no alternative but to follow the soldiers. Crossing the Colorado, we arrived on the 1st of January, 1852, at Santa Isabel, where Captain Davidson kindly saved us from suffering by hunger. On the 8th of January we encamped at San Diego. The agricultural resources of the Gila are of little value to the United States, more than nine tenths of the soil susceptible of cultivation being upon the Mexican bank. Settlements could, however, be supported at the mouth of the San Francisco, opposite the mouth of the Rio San Pedro, upon the Salinas, and at the junction of the Gila with the Colorado. From what precedes it may be inferred that it would hardly be practicable to construct "a road, canal, or railway" to run wholly upon the river Gila. The Cañon of the Pinal Lleño Mountains is a complete barrier. The Pass below the junction of the Rio San Pedro, is equally impracticable. Between the Pimo settlements and the junction of the Gila with the Colorado, nature interposes no serious obstacle to the construction of a way of communication, such as the travelling public may demand. But from the Pimo village to the Rio Del Norte, I know of no practicable route even for a wagon road, except by entering the State of Sonora to avoid the Pinal Lleño Mountains. Possibly a route may be found following the course of the Salinas towards Santa Fé. Otherwise, a jor- 
nada must be traversed to Tucson in Mexico; thence crossing the Rio San Pedro, a road may pass from spring to spring-leaving the Guadalupe Pass to the south-and may proceed in the vicinity of the southern boundary of New Mexico to Doña Ana. Four permanent military posts should at the same time be established near this route; one at Col. Craig's "Cantonment Dawson" among the Copper Mines of New Mexico, where a well-watered and fertile valley, rich in precious metals, would soon support a flourishing settlement; one at the mouth of the Rio San Pedro, where the Pinal Lleño Indians would be intercepted in their marauding expeditions to Sonora ; and the third upon the excellent cotton-lands at the mouth of the Salinas. The fourth, upon the Colorado, has already been established by order of the War Department. By treaty stipulations with Mexico, it is solemnly agreed, that all incursions into her territory of our savage tribes shall be forcibly restrained by the government of the United States. At present, Indian depredations in Sonora are notorious. Seores of our own citizens also have been slaughtered by these roving robbers, and we have seen their bones bleaching by the road-side. The government is, therefore, bound to station a strong military force upon the frontier. Protection to the settlers will enable the resourees of the country to be developed; emigrants, assured of safety and supplies at these depots, will avoid the perils and expense of a sea royage; and it will soon be seen whether the wants of the people require, so as to render advantageous, the construction of a canal or railway which may in part run upon the river Gila.

The construction of a wagon road by the route proposed through Sonora for the use of both countries, would be of no less advantage to Mexico than to the United States. An agreement to this effect is, in fact, necessary to the fulfilment of the treaty stipulations with reference to the protection of the frontier. This done, and some slight encouragement given to trade, and the now half-depopulated province of Sonora will soon become one of the most flourishing States of Mexico.

From the day of first striking the Gila to the time of reaching its mouth, seventy days, astronomical observations were made every night except two, which were cloudy. The whole number of astronomical and meteorological stations upon the Gila were forty-six. Nearly all of these were also magnetic stations. Between the mouth of the Gila and this place are three intermediate astronomical and magnetic stations, besides those made on my trip from San Diego to the Colorado in Sep- 
tember, 1849. Thus is completed a consecutive chain of magnetic sta- . tions extending from the observatory at Cambridge, Massachusetts, by way of Galveston, San Antonio, and El Paso del Norte, to the Pacific Ocean. At most of the stations, the three elements, inclination, declination, and intensity have been observed. Th the astronomical and magnetic department, John O'Donoghue and Hugh Campbell have been my invaluable assistants.

The magnetic instrument used was made by Mr. George, of Falmouth, under the direction of the celebrated Mr. Fox, the inventor. It is the same that was turned over for this service by yourself at the close of the North-eastern Boundary survey. With it I observed at Chagres, Gorgona, and Panama, in 1849.

It is believed that a map exhibiting the results obtained will prove of much interest, and when published will add credit to the department under which the operation has been conducted. I regret that we have not the power of embracing the present opportunity-by returning to the United States by way of China and the Mediterranean-to surround the globe with a series of magnetic observations. Not only would the value of the results upon the boundary be greatly enhanced by such direct comparison at European observatories, but passing through or near the maxima of horizontal intensity, the lines of no variation would be crossed, and an exceedingly interesting belt of observations might be completed around that part of the world, at present, with reference to magnetism, so little known.

Notwithstanding the recent hostility of the whole tribe of Apaches, Colloteros, Pinal Lleños, and Tontos, through which we passed without an escort, nothing but kindness was received from them. The Yumas and Cocopas, though glorying in the belief that they had driven away the small detachment of United States troops stationed among them, still treated us with respect and favor. The vigilance of Colonel Craig gave them no opportunity of showing hostility.

One sad accident $I$ have to record : the death of Thomas Harper, an excellent young man from Kentucky, and a member of my party. While bathing in the Colorado, he was seized with cramp, sank, and, although a dozen leaped into the water to afford assistance, the rapid current bore him beyond reach, and search was fruitless.

Major Heintzelman is now preparing to establish the military post at the Colorado River. Soon as this is done, I hope to be able to ob- 
tain supplies of provisions; and in ten days after the recommencement of the work, the survey of the Gila will be completed. In the mean time, until the arrival of Mr. Bartlett, who is supposed to be at Guaymas, or, while awaiting other means of procuring supplies for our return, myself and assistants åre actively employed in completing our observations and plotting the notes of the survey.

I remain, Sir, very respectfully,

Your obedient servant,

A. W. WHIPPLE,

Lt. U. S. Topographical Engrs.

To Brev. Lt. Col. J. D. Graham, U. S. T. E.

Principal Astronomer, etc.,

U.S. B. Commission

E.

Colonel J. D. Graham to the Hon. Alex. H. H. Stuart, Secretary of the Interior, in reference to the Survey of the Head Waters of the Gulf of California and the River Colorado, by Lieutenant I. G. Strain, U. S. Navy.

Washington, December 31, 1850.

The Honorable the Secretary of the Department of the Interior having referred to me (for my views of the measures therein suggested) the letter of Lieutenant I. G. Strain, of the navy, of the 31st of October last, and the papers accompanying it, I have the honor to state that I have perused them all with attention, and that I feel obliged to give it as my opinion (which I do with all deference), that the measures sug. gested by Lieutenant Strain have no relation whatever to the survey and demarkation of the boundary under the Treaty of Guadalupe Hidalgo; and that they ought not in any way to be connected therewith. I have made a careful calculation of the length of boundary line to be surveyed and marked by suitable monuments, and find it to be about one thousand six hundred miles, independent of the lateral surveys that will be requisite, in order to determine the true line of boundary, should 
doubts on this point arise, on any portion of the line, in the minds of the Commissioners. The aggregate extent of survey necessary to fix the line, will scarcely fall short of two thousand or two thousand five hundred miles. Every one connected with this survey will then have as much as they can possibly attend to in performing the duties immediately connected with the boundary line, which should be completed at as early a period as possible.

Besides these considerations of expediency, I cannot pereeive how the expenses which would attend the accomplishment of Lieutenant Strain's project, could be legitimately drawn from the appropriations granted by Congress for the boundary survey.

The Gulf of California lies far from the line of boundary, and in territory belonging exclusively to Mexico, and not within the jurisdiction, therefore, of the United States. To attempt a minute survey of this gulf, under the pretence of its being an adjunct operation to the boundary survey; would undoubtedly arouse the suspicions of Mexico, and give offence to that Republic.

It is true, that by the provisions of the late treaty our citizens have the right of ingress and egress through the Gulf of California; and it is not improbable, that if the proposition were made to the Mexican government through the proper channel, she might be disposed to enter into a joint arrangement with our government for an accurate hydrographic survey of the gulf; an undertaking that would be equally honorable to both governments, and highly advantageous to the commerce of both people. But in such an event, I should think it highly expedient that so important an operation should, on our side, be placed under the direction of one of the organized corps of the government, maintained for such purposes, and provided with all the necessary apparatus and scientific experience which are necessary to success.

I find by the latest maps we have of California, that the area of this gulf is not less than sixty-two thousand square miles. To acomplish a survey of it in a manner to satisfy the requirements of commerce would, to say the least, occupy several years; and it would probably cost very nearly as much as has been appropriated for the whole boundary survey, perhaps even more.

If a mere reconnoissance of the gulf is proposed, I will remark that Mr. Gray, the United States Surveyor, informed me, on his arrival here, that General Persifer Smith had already detailed an officer and supplied 
a vessel for that object. I presume he had proper authority for so doing.

In regard to the "flotilla," which Lieut. Strain alluded to as being in command of, I must again most respectfully remark, that I consider this an injudicious arrangement, and that it ought to be dispensed with. I have been frequently engaged on surveys, for the last thirty years, of rivers, harbors, and portions of the sea coast, and always found the best persons to manage the boats employed on such service were the engineers and surveyors charged with, and responsible for, the execution of the duty. Landsmen born and reared near the sea coast, or near our great rivers, generally possess all the skill requisite for the management of such boats; and I would much prefer on this boundary service the system, in this respect, which I have always heretofore practised, and therefore I recommend it to your favorable consideration.

The letter of Lieut. Strain to the department, of October, 31, and the papers therein alluded to as accompanying the same, are herewith handed back to the department.

"All which is respectfully submitted.

$$
\begin{aligned}
& \text { J. D. GRAHAM, } \\
& \text { Lt. Col. and Head of Scientific Corps, } \\
& \text { \&c., \&c., de. }
\end{aligned}
$$

Hon. Alex. H. H. Stuart,

Sec. of the Departinent of the Interior.

\section{F.}

Programme of the Party detailed for the Survey of the Rio - Grande, August 27, 1851.

Lr. Col. J. D. Graham, Principal Astronomer in charge of the party. Lr. W. F. Sмттн, Topographical Engineers, Assistant Astronomer. Lr. A. E. Burnside, $3 d$ Artillery, Quarter-master and Commissary. M. Von Hippel, Draughtsman.

M. T. W. Chanduer, 1st Assistant in charge of Meteorological Department. 
Lieut. O. H. Tillinghast (soon after removed by Major Emory), Quarter-master and Commissary.

Thomas W. Jones, Assistant. J Jumes Henning, Assistant. J. H. Clark, do. P. Crenion, do.

Charles Wright, do. James P. Espy, do. Wm. White, Jr., do. Geo. G. Garner, do.

Charles A. Snowden, do. $\quad$ E. A. Phillits, do.

Thomas Thompson, do. A. P. Wilbar, do.

James H. Houston, do.

T. W. TAnsiLi, > Clerks in the Commissary and Quarter-master's George S. Peirce, $\}$ Departments.

Thirteen chainmen, flag-bearers, station-markers, and mechanics; nineteen cooks, servants, and laborers; with teamsters and herdsmen in addition. .

Many additions, and some changes, were made by Major Emory when he relieved Colonel Graham, in November following. 


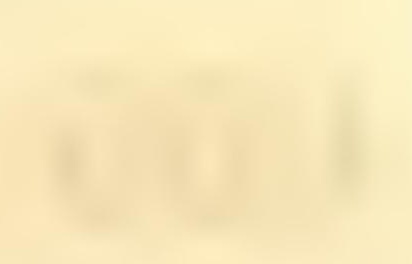

- n

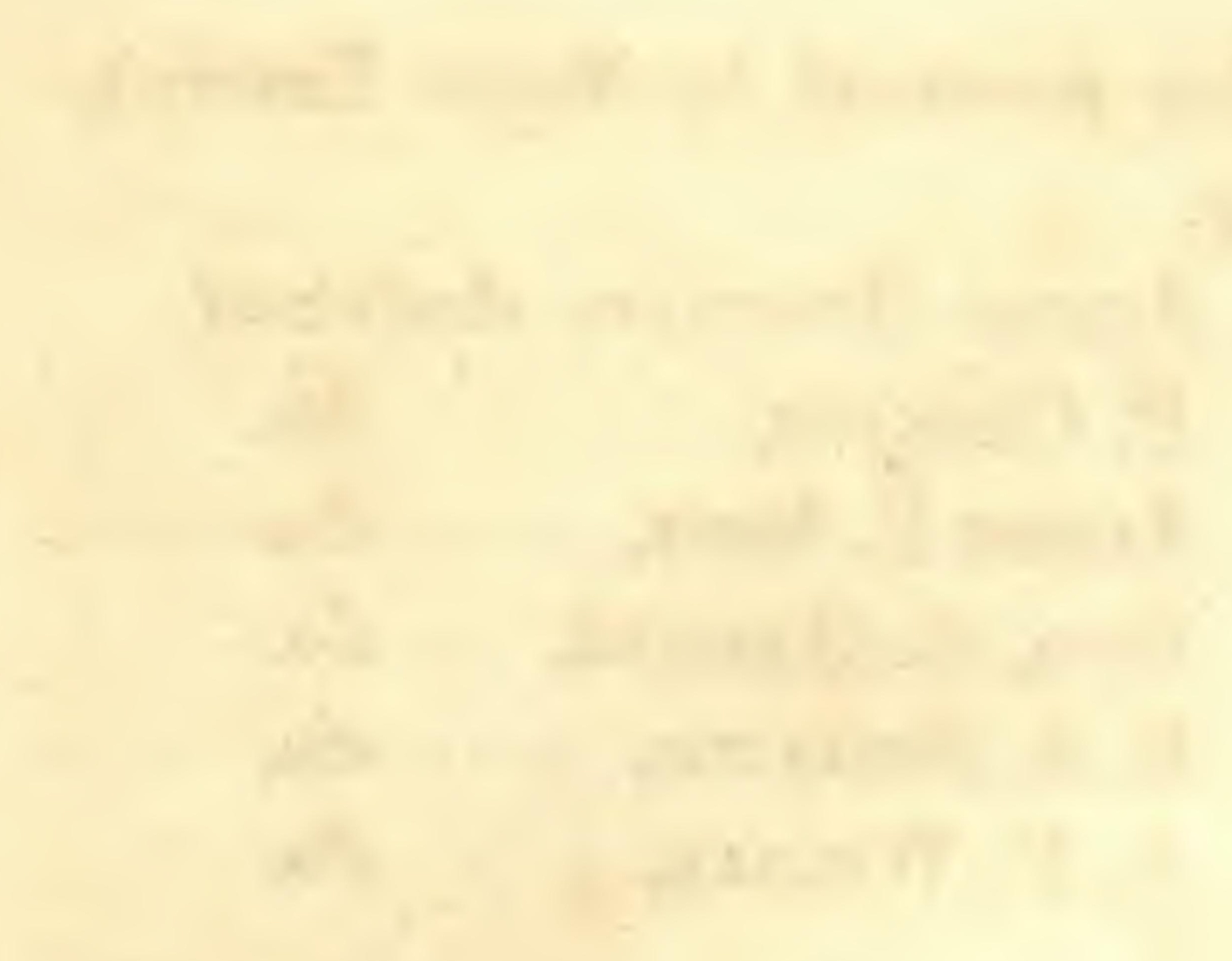




\section{N D E X.}

\section{A.}

AcapUlCo, arrival at, i. 499. description of, i. 500 . its ancient commerce, i. 503.

Agave Mexicana and its uses, i. 291; ii. 484 .

where seen, i. 198, 254; ii. 105, $124,126,296,370$.

Agua Dulce, Texas, ii. 526.

Aguardiente, how made, i. 290.

Agua Prieta, Sonora, i. 257, 294; ii. 290.

Agutar, Gov., of Sonora, i. 435.

- journey with, to Guaymas, i. 463.

Alacran, The, of Durango, ii. 557.

Alamo, The, at San Antonio, i. 41.

Alamo Месно, well at, ii. 132, 140.

desert at, ii. 135 .

Alamo de Parras, arrival at, ii. 478.

- extensive eultivation near, ii. 478.

Atarcon, his voyage up the Colorado in 1540 , ii. $168,170,181$.

Evsign, voyage to California in 1594 , ii. 98.

AlBuquerque, its elevation above the sea, i. 196.

character of the country between it and the Gila, ii. 144.

Atcedo, notices the petahaya, ii. 192.

Alden, Capt., trip with, to the Faralones, ii. 53.

Alegro. History of the Jesuits referred to, ii. 183, 212.

his notices of the Pimos, ii. 266, $282,299$.

Alfalfa and its cultivation, ii. 437. Algodones on the Colorado, ii. 150. Alkaline salt in Chihuahua, ii. 417.
Almaden, Spain, notices of the quicksilver mines at, ii. 59.

Almaden, New, deseription of, ii. 57. the quicksilver furnaces at, ii. 58,67 .

Altar, Presidio of, Sonora, i. 407.

Ampudia, Gen., his battery in the Rinconada pass, ii. 510.

ANDrews, Maj., at Fort Yuma, ii. 152. acknowledgments to, ii. 158.

Angeles, Los, California, journey to and deseription of, ii. 80,82 .

Star, newspaper, ii. 81.

Angostura, eneampment at, ii. 494.

Animals, losses of, by the cold, i. 144.

ANKRIM, Hon. J. L., i. 61.

ANTELOPE, great numbers of, in Western Texas, ii. 521-526.

Antelope Creek, Texas, i. 74, 75.

Apaches, first visit from, i. 300 .

- captives taken from, i. 310 .

friendly relations with, i. 320 .

Americans attacked by them in Chihuahua, i. 295.

dialogue with, i. $312,334$.

their range and numbers, i. 323 ; ii. 386 .

ethnological position, habits and physical character, i. 326.

one killed by a Mexican, i. 331.

Deseent by them on the animals at the Copper Mines, i. $343,346,349,351,353$.

their ravages in Sonora, i. 408, 447,450 ; ii. $292,317$.

defeated by the Opates, i. 454 .

their ravages in Chihuahua, ii. $293,345,369,377,415,427$.

their depredations near El Paso, ii. $384,388$. 
Apaches, their treachery and hostile. character, ii. 387 .

encounter with, in Chihuahua, ii. 411.

their plunder of Armijo's train, ii. 415 .

Aranama Mission, Texas, i. 30.

Aransas Bay, Texas, ii. 533.

ArIspe, Sonora, visit to, i. 282.

ArmiJo's train robbed by the Indians, ii. 415 .

Arroyo de Uvalde River, Texas, ii. 529. Ash Creek, Sonora, ii, 326.

Assumption River, N. Mexico, ii. 269.

Astronomical Observatory established at San Eleazario and Frontera, i. 176 .

Atascoco River, Texas, ii. 529.

Atmosphere, its clearness in Texas, $i$. 118.

Aztecs, the notion of their migration from the north not well founded, ii. 283 .

B.

Babasaqut, Sonora, i. 417.

Babispe, Presidio of, Sonora, i. 407.

— pass in the Sierra Madre near, ii. 568.

Babooomori River, Sonora, i. 393.

Bachimba, Chihuahua, ii. 444.

Bacuach, Sonora, visit to, i. 275.

BaHIA del Espiritu Santo, i, 26.

BAIRD, Prof. S. F., his notice of the zoology of the commission, ii. 548.

Ba Tropa Indians, California, ii. 178.

BALE, Señora, of Napa valley, ii. 22.

- Sergeant, and the deserters, ii. 136.

BaLl given to the people of El Paso, i. 167.

Balleza River, Chihuahua, ii. 450.

Barbabi valley, Sonora, i. 273.

Barlex, its cultivation in California, ii. 15 .

BAROMETERs broken, ii. 184.

Barragan, Capt., Mexican Army, i. 406 ; ii. 292.

Barrancas near Buena Vista, ii, 495.

Barrox \& Forbes, their quicksilver mine, ii. 67.

Barry, Capt., organizes a rifle corps, i. 19.

Barry \& Sheldox reach El Paso, i. 149.
Bears, their numbers in the Rocky Mountains, i. 236. in California, ii. 36, 48 . emigrants encounter one near the Guadalupe Pass, ii. 335.

Beaver, where found, ii. 566.

BeEr cattle found, i. 101, 103.

BeLLs, old, in Sonora, i. 276, 419.

Benicia, California, ii. 12.

Berne, Mr., of Guadalupe, Texas, i, 55.

Berthold, Justice, of Socorro, i. 159.

Bester, Norman, New Almaden, ii. 63.

Bigelow, Dr. J. M., his botanical collection, ii. 549.

Big Horn Mountain, Gila, ii. 197.

Black-tailed deer, ii. 197.

Black Water Creek, i. 263.

Blanco, General, visit to and from, ii. 292, 293.

Bobadilla, Juan B., of Parras, ii. 488.

BoDEga Bay, California, ii. 28.

Boming Spring, Texas, i. 118.

Bolson de Mapimt oceupied by the Indians, ii. 455.

Bond, Lieut., at Fort Yuma, ii. 152.

Botanical Collections of the Commission, notice of, ii. 549,550 .

Botrom Lands on the Rio Grande, i. 196. their great extent, i. 188.

of Sonora, ii. 569 .

Boturini's theory of the Aztec migration, ii. 283.

Boulders at Waco M't'n, i. 134, 170.

- near the Gila, ii. 195, 206.

Boundary Commission, its outfit proeured, i. 4.

- its organization and objects, i. 5 . list of the members of, ii. 594 .

Boundary LINE between the United States and Mexico.-Vth article of the treaty relating to, ii. 587.

see Initial Point.

Bracrto, eneamp near, ii. 395.

- note on Col. Doniphan's battle at, ii. 395 .

Brady's Creek, Texas, i. 70, 71.

Brandy of El Paso, i. 186.

production of, in Sonora, i. 469.

Brazos River, its source, ii. 565 .

Brodie, J. P., of Sonora, i. 463, 471.

BryAx, Major, his route and itinerary through Texas, i. 83, 136.

Bunna Vista, encampment near, and visit to the battle-field of, ii. 494. 
Buenaval Rio, Zaeateens, ii. 476.

Buena Vista Rio, Chihuahua, ii. 450.

Buford, Capt. A., i. 200, 205, 207.

comes to the aid of the Commission with his dragoons, i. 350.

his expedition against the Indians, i. 351 .

Bnul, John, Reconnaissance by, and new route opened to the Copper Mines, i. 177 ; ii, 542.

his survey from Indianola to $\mathrm{El}$ Paso, i. 14 ; ii. 542.

his connection with the Gila survey, ii. 543.

Burro Mountains, New Mexico, i. 361. Burrowing animals in Texas, i. 99.

\section{C.}

Cabeca River, Texas, Encampment on, i. 31 .

Cabeca de VACA, reference to, ii. 531.

Cache on the Gila opened, ii. 199.

— used by the Hudson's Bay trader's, ii. 199.

- mode of eonstructing them,ii. 200.

- indieations of one seen, ii. 202.

CACT, travelling among, ii. 301.

Caddo Indians of Texas, i. 66.

Calabasa, Sonora, ii. 307.

Calr killed for a deer, i. 23.

Califorsia, eharacter of the natives of, ii. 73 .

its advantages independent of gold, ii. 98.

the ladies of, ii. 104.

its agricultural resourees, i. 106. the fertility of its soil, ii. 119.

Gulf of, exploration and survey of its head-waters recommended, ii. 162.

- Lieut. Strain's plan for this survey in his letter to the Secretary of the Interior, ii. 163165.

survey of, defeated by Lieut. Col. Graham, ii. 165, 166.

examination of, authorized by instructions, ii. 167 .

explored by Alarẹon in 1540, ii. 168.

Gulf of, explored by Consag in 1746 , ii. 170 .

voyage of Lieut. Hardy in 1828, ii. 170 .

- aspect of its shores, i. 483.

- desert, its barrenness, ii. 126-130.
Camargo, arrival at and description of, ii. 511.

Camels, note on their introduction on the deserts and plains, ii. 576 -584 .

Campbell, Dr. J. W., of Ures, Sonora, i. 455,436 .

his kindness to the author, i. 438 .

Camp Creek, Texas, i. 69.

Campus, Don Jesus, of Parras, his wine vaults, ii. 488 .

Canales, Gen, his destruction of U. S. wagons, ii. 506 .

Cantarecio, Chihuahua, ii. 406.

Captives (Mexican) rescued from the Apaches, i. 310.

Captrve girl rescued (see Inez Gonzales), i. 303.

Caravajal, General, ii. 511.

Carmel River, California, ii. 76.

Carmer Mission, California, ii. 77.

Carmen, Island of, California, i. 483.

Carmen River, Chihuahua, ii. 407-411.

Carrasco General, meeting with, in Sonora, i. 263.

makes a descent on the Apaches, at Janos, i. 267.

his opinion of Gen. Seott and the American officers, i. 270.

meet his brigade in Guadalupe Pass, i. 295.

Carrizal, Chihuahua, ii. 409.

Carriziros, Tamaulipas, ii. 506.

Carrizo Creek, California, its character, ii. 126-128.

vegetation near, ii. 127.

Castello, Domenieo de, voyage up the Colorado in 1540 , ii. 168.

Castiltan language, its purity in California, ii. 74.

Castrllero, Señor, proprietor of the New Almaden mine, ii. 67 .

Castre Mountain, Texas, i. 91 ; ii. 570.

Casas Grandes, on the Rio Salinas, ii. 244-248.

- on the Gila, account of, ii. 271285.

noticed by Father Kino in 1697 , ii. 265 .

deseribed by Futher Font in 1776 , ii. 278 .

mistakes of authors in reference to, ii. 280 .

Chihuahua, visit to, and description of, ii. $345-365$.

their general character the same 
as the ruins on the Gila and the Salinas, ji. 354.

Casas Grandes of Chihuahua, their resemblance to edifices of the Pueblo Indians of New Mexico, ii. 357-368.

Casas Grandes River, Chihuahua, ii. $237,342,347,363$.

its bottom-lands, ii. 347,360 , 363.

- its agricultural produets, ii. 363 .

Catalina Island, Gulf of Cal, i.483.

- on the Pacific coast, ii. 79.

Cawenas Indians, small remnant of, on the Gila, ii. 251.

Carman Lake, ii. 472.

Cegurn, near Parras, ii. 489.

Cereus Giganteus, first seen in Sonora, i. 416 .

for further notices of this plant see Petahaya.

Centipedes, their numbers, ii. 556 .

Ceralyo, town of, ii. 507.

Cerreals of California, ii. 106.

Ceris Indians of Sonora, i. 463.

- langtiage, history, and characteristics of, i. 464.

poisoned arrows of, i. 465 .

Cerro Gordo, Durango, ii. 467.

escort furnished at, ii. 467 .

attack of Comanches on, ii. 468.

Cervis Lewisir, i. 236.

Chandler, M. T. W., his meteorological observations, ii. 541.

Chapporal in Texas, its eharacter, i. 93 .

Chapporal Cock, ii. 563.

Charco de Grado, Chihuahua, ii. 406.

Chemeguaba Indians of the Colorado, ii. 178.

Chrmuanua, its trade with San Antonio, i. 40.

- approach to, ii. 421.

- map and statistical report on, made in 1834 , ii. 429 .

- deseription of the eity, ii. 431440.

its arable and timber lands, ii. 567.

Chinuahua dogs, diminutive breed of, ii. 440.

Chili Colorado of Sonora, i. 408.

Chimney Rock near Fort Yuma, ii. 159.

Curnapi, Sonora, i. 279.

Chinese in California, ii. 12.
Chipota, the Lipan Chief, i. 76-79.

CHiqueta, the Lipan Chief, i. 79.

Cholera among the Gila Indians, ii. 241.

Crвolo River, encampment on, i. 33.

Cienega Grande, near Parras, ii. 489.

Cinnabar of New Almaden, ii. 57.

Clarke, Edw. C., the murder of, i.158.

J. H., his zoologieal collections, preface viii.; ii. 548 .

Clayigero, his theory of Aztec emigration not well founded, ii. 283.

his reference to the Casas Grandes, ii. 358-362.

Clear Lake, California, ii. 36.

ConNpa Indians of the Colorado, ii. 178.

Cocopa Indians of the Colorado, ii. 179.

Coco-Maricopa Indians, visit from at Ures, i. 451.

on the Gila, ii. 211, 213.

their religious notions, ii. 221 , 222.

their former range, ii. $22 i$.

their courtship and marriage, ij. 222.

their cotton manufactures, ii. 224 -226 .

their pottery and basket-work, ii. 226 .

their dress, ii. 228-230.

their villages and mode of irrigation, ii. 234.

their granaries, ii. 235, 236.

their wars with the Yumas, ii. 252.

their alliance with the Pimos, ii. 262.

their numbers, ii. 263.

visited by Kino in 1698, ii. 267 .

where found by Font in 1775 , and by Sedelmayer in 1744, ii. 268.

Cocospera, Sonora, Mission at, i. 413.

meet French emigrants journeying to, i. 472 ,

Cocurarachi, Sonora, i. 272.

Coletre River, Texas, eamp on, i. 19.

- its charater, i. 21.

Colima, Mexico, its position, i. 494.

- its history and population, i. 498.

the voleanos of, i. 493 .

Colonizatios of the English and Spanish compared, ii. 299. 
Comanche Spring, Texas, i. 53.

Comanche Indians, ii. 385.

- their depredations, ii. 476,417 , $479,480,497,520$

their range and numbers, ii. 386 , 424.

- their attack on the town of Saueillo, ii. 447.

their robbery of 120 mules from a train, ii. 448.

in the Bolson de Mapimi ii. 455. defeat the Mexicans at Cerro Gordo, ii. 468.

Cola Azul, the Pimo chief, ii. 254.

Colorado River of Texas, ii. 536.

Colorado River, California, arrival at, ii. 150.

bottom lands on, ii. 149, 151, 159-161.

hills of moving sand near, ii. $149,150$.

its junction with the Gila, ii. 158.

its character, ii. $15 \%, 160,173$, $174,168,170,172,572$.

nature of its bend, which gives the U. S. both its banks at Fort Yuma, ii. 160.

traces of old Spanish missions on, ii. 161.

difficulties in navigating, ii. 162 , $168,170,171,172$.

survey of, recommended, ii. $\mathbf{1 6 2}$.

Lt. Strain's plan for such survey, 163-165.

Col. Graham defeats the plan, ii. 165 ,

Alarcon's voyage up in 1540, ii. $168,169,181$.

Consag's attempt to ascend it in 1746, ii, 170.

Hardy's attempt in 1828 , ii. 170 .

Turnbull's voyage up in 1852 , ii. 172.

Major Heintzelman's reconnaissance of, ii. 168.

height of and greatest rise, ii. 174.

particulars of the ferry established on, by Dr. Langdon, ii. 174.

Comera, another name for the Diegenos; ii. 179.

Comera Indians of California, ii. 7.

Coscepcion, Texas, Mission of, i. 44.

Concepcion Point, California, ii. 79.
Concho River, Texas, i. $85,86$.

do. South Fork, i. 79.

Conchos River, Chihuahua, ii. 450, 567.

its bottom lands, ii. 451 .

Conde, Gen'l Pedro, see Gareia Conde.

Cooke's Spring, New Mexico, i. 219,

Cooke, Colonel St. George, his California road, i. 244 ; ii. 332.

his opening of Guadalupe Pass, i. 251 ; ii. 332 .

traces of his camps, ii. 197, 330 .

opens the defile at San Felipe, California, ii. 123.

Cooke's Welt, California desert,ii. 148.

Coos's, Mr, Wagons, eneampment of, near the Guadalupe Mountain, Texas, i. 121.

rancho, El Paso, i. 192.

- party, losses of animals by, i. 192.

meeting with in Sonora with large herd of sheep, ii. 293.

Copper Mines near the Gila. Dr. Webb's report on, i. 178 .

history and deseription of, i. 228 .

Cordero, Gov. of Chihuahua, ii. 428.

- his certificate relating to the boundary, ii. 437.

Cons, its price at El Paso, i. 150.

- its price at Arispe, i. 284,

Cornudos del Alamo, Texas, i. 121, 128.

Coronado's Islands, description of, ii. 86-88.

Corpus Christr, Texas, arrival at, ii. 526.

- its bay and vicinity, ii. 528 .

Corral, mode of forming one, i. 49.

Correlitos, Chihuahua, visit to, ii. $342,344$.

__ furnaces for smelting silver ore at, ii. 343.

Cosnrna Indians of New Mexieo, ii. 178.

Corton, its cultivation in Sonora, i. $441,469$.

- its eultivation in Texas, i. 28.

_ its cultivation in Parras, ii. 486.

- seen growing on the banks of the Colorado, Cal, in 1542, ii. 182. its cultivation by the Indians on the Gila, ii. 224, 598.

on the Rio Nasas, ii. 472.

at Alamo de Parras, ii. 478.

Cotron lands in California, ii. 106. 
Comton mrlts, near Saltillo, ii. 497 .

Covayan Mountain, Sonora, i. 264.

Cows, how milked in Sonora, i. 475.

Craig, Colonel, appointed to eommand escort, i. 6.

loses seven men by desertion, $i$. 169.

visits Sonora with the author, $i$. 239.

loses mules by the Indians at the Copper Mines, i. 343, 346, 351.

pursues the Apaches, i. 346, 350, 351.

meeting with, at San Diego, i. 505.

at Santa Isabel, Cal., ii. 118,121.

his vigilance on the mareh, ii. 131.

departure from camp on the California desert, and last interview with him, ii. 131.

meets U.S. deserters, ii. 136 .

is shot by the deserter's, ii. 138.

- particulars of his death as related by Dr. Webb, ii. 141.

his burial on the desert, ii. 145.

his character and military services, ii. 146.

Crawfish in California, ii. 84.

Creosote plant, i. 94.

Crows seen everywhere, ii. 555.

Cruces, New Mexico, ii. 392.

Crez, Colonel, of Camargo, ii. 511.

Cruz, LA, town of, Chihuahua, ii. 450 .

D.

DAMAs' notice of quieksilver mines in Spain, ii. 60.

Dana's notice of San Diego, ii. 96.

Date tree at Ures, i. 441.

Davidson, Capt., at Fort Yuma, ii. 152.

Decrow's Point, Texas, ii. 536.

DeEr, abundance of in Texas, ii. 562.

Delaware Creek, Texas, i. 110-116.

Delaware Indians in Texas, visit to, i. 59.

Desert of California, great loss of animals on, ii. $126-147$.

- pools of brackish water on, ii. 135.

- intense heat on, ii. $139,140$.

— wagons and property abandoned on, ii. 140.

- account of, ii. $4,129,130,572$.

- desert south of the Gila, ii. 187, $196,208,209,259,286,290,567$.
Desert from Texas to the Pacifie, i. 139.

Desert regions in Texas, i. 87.

Desert plants, vivifying influences that nourish them, ii. 126. character of, ii. 563.

Diary interrupted by illness, i. 434.

Dravolo Mountain, Texas, i. 104.

Dregeno Indians, visit from at San Diego, ii. 7 .

at Santa Isabel, California, ii. 119.

at San Felipe, California, ii. 122.

— at Vallecito " ii. 125.

Digger Indians, “ “ ii. 29.

Disturxell's Map of Mexico, errors in, i. 152-201.

Ditching land in California, ii. 18.

Doввiss, Captain, kills Mr. Wakeman, i. 154 .

Dogs, diminutive breed of, in Chihuahua, ii, 440.

Dona Ana, visit to, i. 154.

- its elevation above the sea, i. 196.

- description of, i. 211 ; ii. 892.

Doniphan, Coloner, his affair at Bracito, ii. 395 .

- his taking of Santa Rosalia, ii. 451.

- at the battle of Sacramento ii. 420.

Dote Creek, Texas, i. 79.

Deвos, Dr., Chihuahua, ii. 425.

Ducks, wild, in Texas, i. 85.

Dukey, Francisco, the Maricopa Chief; ii. 213-219.

E.

EDDY, Lt. aeknowledgments to, ii. 106.

ELK, their abundance in California, ii. 48 .

Er Paso Del Norte, arrival at in 1850 , i. 36 .

- the mountain pass at, i. 145 .
dinner given the authorities at, i. 146 .

entertainment given the people of, i. 166.

its description, i. 184.

Oriental style of its houses, i. 189.

geographical position of, i. 193.

its beight above the sea, i. 196.

departure from, for the Pacific, i. 149. 
El Paso del Norte, error in position of, on Treaty map, i. 201.

latitude and longitude of, determined by Lieut. Whipple, ii. 383.

return to, from California, ii. 378 . final departure from, ii. 401.

Emigrants, trespasses of, in Sonora, i. 423.

to California met with, ii. 287, $305,339,310,311,320,321$, $323,327,329,331,335,341$.

EMory, Major, appointed surveyor in place of A. B. Gray, ii. 85.

letter to Secretary Stuart on the Initial Point, i. 344.

his opinion of the value of the disputed territory, i. 346 .

his report of the survey of the Rio Grande, ii. 513.

results of his labors as surveyor, ii. $546,547$.

Encantada, encampment at, ii. 494.

Excinillas, Lake of, ii. 416.

- town of, Chihuahua, ii. 418.

Evglish, an Ameriean named, in eap tivity, i. 456.

Escondida, Texas, ii. 524.

Espiritu Santo Bay, Texas, i. 21 ; ii. 534.

Ethnologteal collections made, ii. 551.

Euphorbia, i. 53.

ExECurion of murderers at Socorro, $i$. 62.

\section{F.}

Falcon Steamer, embark in, at Havana, i. 7.

False Bay, California, ii. 96.

Fandango in Magdalena, i. 429.

Fanniv, Col., massacre of, in Texas, i. 28.

Fillmore, Fort, visit to, i. 195 ; ii. 390.

silver mine near, ii. 392 .

Fishes taken in the Salinas, ii. 240244.

— of the Gila, ii. $195-207$. the Gulf of Mexico, ii. 531.

Flat Rock Ponds, Texas, i. 89-90.

Flores, Gen. interview with, i, 456.

Flour, prices of at El Paso, i. 191.

Flotte, Lewis, his smelting works at Barraneos, ii. 346.

his loss by the Indians, ii. 345 .
Flotte, Lewis, his silver mines near Correlitos,ii. 366 .

his persecutions and sacrifices, ii. 425 .

accompanies the Commission with his family, ii. 442 .

Font, Pedro, visits the Colorado, in 1776 , ii. 183 .

his MS. journal and map, ii. 183.

his account of the Pimos, ii. 267.

his account of Casas Grande, ii. 278.

Forbes, Alex, his notice of Father Peyri, ii. 93.

Force, H. C., his meteoric observations, ii. 541-568.

Forests and timber lands, where found, ii. 574 .

Fosstr Shells, Texas, i. 92.

near Mier, ii. 511.

Fossils on the Gila, ii. 598.

Fovquiera, i. 121 ; ii. $255,257,296$, $430,445$.

Fredericksrurg, Texas, i. 59.

Fremont, Col. J. C., appointed U.S. Commissioner, i. 3.

his journeys in the California basin, ii. 107.

Frontera, Texas, astronomical observatory at, i. 194.

Frosteras, Sonora, send party in search for, i, 261.

visit to, i. 264, 292.

G.

Gallantin, his ferry, on the Colorado, ii. 174 ,

with his party, murdered by the Yumas, ii. 175 .

Gallatin, Albert, his notice of the Casa Grande, ii. 281.

Galveston, Texas, arrival at, i. 9. second visit to, in 1853 , ii. 537 .

Gambuciso miners, ii. 448.

GAME and its seareity, ii. 562 .

GAME DINNER, mode of cooking without utensils, ii. 37 .

Gandera, Don Manuel, Governor of Sonora, i. 459.

his estates at Tapahui, i. 459.

his silver mine and its products, i. 462 .

Garcia-Conde, General, arrival of, at El Paso, i. 150.

reaches the Copper Mines, i. 227.

visit to, on the Mimbres, i. 298. 
Garcia Conde, Gen., visit from, connected with the captives, i. 309.

leaves the camp on the San Pedro for Santa Cruz, i. 380.

his death and character, i. 455.

his survey of Chihuahua, ii. 429 .

his statistical report on Chihuahua, ii. 429 .

Garcia, Col., meet his command at San Bernardino in search of the Apaches, ii. 328.

Garcia, Don Ilarion, i. 399-432.

Garces, Father, his journey to California in 1776 , ii. 183 .

his visit to the Gila, ii. 267.

Gardner, Lieut., at Fort Yuma, ii. 156.

Gar Pike in Texas, i. 65.

Gatron, Mr., U.S. Consul at Mazatlan, i. 487 .

Genegueh Indians of the Colorado, ii. 178.

GeOFFroy, St. Hiliare, on domesticated animals, ii. 578 .

Gersers of California, set out for, ii. 12.

deseription of them, ii. 39.

Gila River, departure from the Copper Mines for the survey of, i. 358.

- its junction with the Colorado, ii. 158 .

- its delta, ii. 159.

- its bottom-lands, ii. 159, 186, 188, $232,260,271,568$.

- a small portion only susceptible of eultivation, ii. $205,599$.

- a small stream until it receives the Salinus, ii. 244.

tound to be dry, ii. $215,249$.

searcity of grass on, ii. 211-215.

errors in its geography, noticed by Kino in 1700 , ii. 212.

corrections in its geography, ibid.

former population near, ii. 277 .

- Lieut. Whipple's report of his survey of, ii. 597.

capabilities of navigation, ii. 160 , 573.

Grrard, Prof. Charles, his estimate of the zoology of the Commission, ii. 548.

Gliddon, G. R., his essay on camele, and their introduction into the U.S. ii. 576.

Goud Mrves in Sonorn, i. 275 ; ii. 304.
Goliad, Texas, notice of, i. 25.

- massacre of Col. Fannin at, i. 28.

Gonzales, Señor, of Magdalena, i. 427.

Good Spring Creek, Texas, i. 79.

Graham, Col. J. D., appointed Chief Astronomer, i. 150.

delays of, and arrival at El Paso, i. $180,303,340$.

joins the Commission at the Copper Mines, i. 346.

his assumptions and recall, i. 348.

prevents the reconnoissance of the Gulf of Califorvia and the Colorado, ii. 165--167.

his letter on the subject to the Hon. A. H. H. Stuart, Sec'y of the Interior, Appendix E.

- result of his labors, ii. 546,547 .

Grama Grass, i. 87, 243.

Granite Boulders, i. 129-133.

Grasses indigenous to Texas, ii. 566.

GraPe, its culture at El Paso, i. 185.

" in California, ii. 119.

" at Parras, ii. 483-

487.

Gray, A. B., appointed Surveyor, i. 2.

— reaches the Copper Mines, i. 340.

organizes a party for the survey of the Gila, i. 341-356.

objects to the Initial Point, i. 341.

- ordered to affix his signature to the papers establishing the Initial Point, i. 342.

his removal, ii. 85 .

his survey of the Gila, ii. 543 .

Green Mounds, Texas, i. 79, 80.

Green, Lr. D. C., his expedition to Socorro, i. 346.

GregG, Dr., his notice of La Zarea, ii. 468.

Grizzly Bear, chase after, i. 363.

Guadalupe Rrver, Texas, i. 21, 54.

Guadalupe Mountain, Texas, i. 117; ii. 570 .

Pase, Texas, i. 120.

Pass, Sonora, i. 251, 294 ; ii. 329.

old road across it, i. 244.

town on the Rio Grande, ii. 405.

Guadalupe Hidalgo, treaty of ; its requirements in reference to the boundary, i. 1 ; ii. 587.

GUAJUQUiLA, town of, ii. 453.

GUaymas, its position and harbor, i. 476,477 .

its trade and eommerce, i. 478. 
$\mathrm{H}$.

Hacienda Arriba, near Parras, ii. 486.

- Abajo, near Parras, ii. 489.

Blanca, accident at, ii. 456 .

de Concepeion, Chihuahua, ii. 457.

del Rio Florida, do. ii. 463.

H'Hava Indians of California, ii. 7.

HaLE's Ethnology of the Indians, ii. 278.

Hardoastre, Capt., in charge of the survey in California, i. 6.

$\mathrm{H}_{\text {ARDY, }}$ Lieut., his voyage up the Gulf of California, ii. 170.

notices the petahaya, ii. 193 .

notices Casas Grandes, ii. 361.

on the Chihuahua dogs, ii. 450 .

Harper, T. drowned in the Colorado, ii. 6 .

Havana, visit to, i. 7 .

Hawalco Indians of the Colorado, ii. 179.

Heintzelman, Major S. P., arrival of - messenger from, ii. 152.

details Lieut. Paige with escort for the Commission, ii. 156.

facilities furnished by, to the Commission, ii. 158.

his command at Fort Yuma, ii. 162.

reduces the Yumas, ii. 173 .

- experiments on the velocity of the Colorado, ii. 173.

sends relief to emigrants, ii. 204.

Hendershotr, Lieut., at Fort Yuma, ii. 152.

sent against the Yumas, ii. 185.

Hermosillo, Sonora, description of, i. $466,467$.

trade and commerce of, i. 470 .

Hernandez notices the petahaya, ii. 192.

Hervas, Catalogo de los lenguas, ii. $178,270$.

Hewison, Dr., of Saltillo, ii. 497.

Hrokory Creek, Texas, i. 64.

Hrppes, M. Von, his labors, ii. 540.

Нгтснсоск, Gen, visit to, ii. 13.

- furnishes an escort and other facilities to the Commission, ii. 14,107 .

Horned Frogs and their numbers, ii. 556.

Hors, Capt., of San Blas, i. 490.

Horses seen in great numbers at $\mathrm{La}$ Zarea, ii. 470.
Horsanead Crossing, Peeos River, i. 93,94 .

Hot Spring, New Mexico, i. 225.

Human Bodies found, ii. 337.

Humboldt, Baron, on the elimate of Acapulco, i. 501.

notice of cylindrical eacti, ii 193.

his reference to Casa Grande, ii. 280.

on the cultivation of the agave, ii. 485 .

on meteorites, ii, 459 .

on the camel, ii. 578,579 .

\section{I.}

Ibarra, Don Manuel de, his estate near Parras, ii 489.

Imuriz, Sonora, town of, i. 418.

INDIAN TRIBEs referred to. For fuller notices see the names of the separate tribes.

Apaches, i. $300-334$; ii. 386.

BajIopas of California, ii. 178 .

Cadpoes of Texas, i, 66.

CERIS of Sonora, i. 463.

Cawenas of the Gila, ii. 251.

- Chemeguabas of the Colorado, ii. 178.

Connpas of the Colorado, ii. 178.

Coco-Maricopas of the Gila, ii. 220-237, 268.

- Cocopas of the Colorado, ii. 179.

- Comeyas of California, ii. 7, 270.

- Comanches of Texas, ii. 386.

- Cosninas of New Mexico, ii. 178.

Cuchans of the Colorado, ii. 179.

Cutganes of the Colorado, ii. 172.

Delawares of Texas, i. 59.

Diegexos of California, ii. 7.

Diggers of California, ii. 29-34.

Geniguen of " ii. 178.

H'HANA of " ii. 7 .

JUMBUICRARI of " ii. 178.

KECHI of " ii. 92.

Lipans of Texas, i. 76 ; ii. 455.

Mohavis of California, ii. 178.

Moquis of New Mexico, ii. 178.

NAvajos of " i. 329.

Opates of Sonora, i. 444.

Opas of the Gila, in 1775 , ii. 268.

PAPAgos of Sonota, i. 382; ii. 298.

Prmos of the Gila, ii. 220-258.

Prros of the Rio Grande, i. 184.

Qurquimas of California ii. 178.

SAN FeLIPE, " ii. 122.

SANTA Isaber, ", ii. 117 . 
Indian Tribes, San Luis Obispo, Cal., ii. 56.

San Pasqual, "

Sinecu of Chihuahua, i. 148.

Tarahumaras of "

Teauas of New Mexico, ii. 178.

Trmbabachi of the Col., ii. 178.

Tonto Apaches of New Mexico, ii. 258.

- YAQUI of Sonora, i. 142.

Yumas of the Colorado, ii. 149.

YAMPAOS of " ii. 179 .

INDIANs, miscellaneous notices of.

California tribes, their present degraded condition, ii. 84 .

their love for the missionaries, ii. 94 .

notices of, by Viscaino, in 1594, ii. 99.

diversity of their names, how accounted for, ii. 30 .

those mentioned by the early missionaries disappeared, ii. 179.

sagacity shown in eapturing the murderers of Colonel Craig, ii. 144.

beard peculiar to the California tribes, ii. 34.

condition of the mission tribes at Los Angeles, California, ii. 82.

suggestions for ameliorating the condition, and for the governing of the tribes on the Mexican frontier, ii. 384-390.

depredations, the great extent of, in New Mexico, from official records, ii. 385 .

attack the train when on the mareh, ii. 412.

their great destruetion of animal life, ii. 447.

Indian SigN, i. $72,95,105$.

- Mortars, for pounding corn, ii. $370,411$.

Indanola, Texas, arrival at, i. 9.

- its commercial advantages, i. 13; ii. 536 .

INez Gonzales, the Mexican eaptive girl, i. 303.

leaves the Copper Mines with the commission, i. 357.

- meets her father on the Babocomori, i. 398.

is restored to her mother, i. 402.

pass the eañon where she was captured, i. 415.
InEz Gonzales, meeting with again at Tubac, and her sad fate, ii. $303,316$.

Initual Point on Rio Grande, at $32^{\circ}$ $22^{\prime}$, visited cfficially, i. 200.

history of the agreement in reference to, i. 201.

particulars of its establishment, i. 204.

document deposited at, i. 206.

- letter from the commissioner to the secretary of the interior, in relation to, i. 208.

objeeted to by A. B. Gray, i. 341.

approved by the U. S., and Mr. Gray ordered to affix his signature, establishing it at $32^{\circ}$ $22^{\prime}$, i. 342 .

order from the secretary of the interior to Major Emory, to sign the doeuments establishing it, i. 343.

Major Emory's letter in reply, stating that he had obeyed instructions, i 344 .

official MS. map found in Chihuahua, defining the boundary, ii. 429 .

as laid down in the constitution of Chihuahua, ii. 430.

on the Pacifie, ii. 104.

Instructions (official), ii. 588.

Irrigation, uncertainty of, on the Rio Grande, i. 187.

Isleta, Texas, town of, i. 193.

ITURBIDE, the emperor-his monument, ii. 435 .

Don Felipe de, i. 151.

\section{J.}

JACKASS RABBIT, i. 76.

JANOS ROAD to Sonora, ii. 332.

- presidio of, ii. 338.

JENKINS, J. joins the commission on the desert with despatehes, ii. 131.

Jesurts, their usefulness in Mex. ii. 431.

- their suceess as missionaries, ii. 432.

JiMENEs, or Guajuquilla, ii. 453 .

Jornt Com, first meeting of, i. 151.

Jornada del Muerto, N. Mexico, i. 215.

Jambuicrariri Indians, ii. 178.

Juniper Serro, Father, names San Francisco, ii. 10.

his letter from Monterey, Cal, in 1770 , ii. 752 . 
Juniper Serro, Father, his letter from San Diego, in 1769, ii. 100-103.

\section{K.}

KAEMTZ on meteorites, ii. 459.

KAPP, Dr. E. Texas, visit to, i. 56 .

Kearney, General, traces of his eamps, ii. $197,271$.

- his aetion at San Pasqual, ii. 113. Keller's farm, Napa valley, ii. 24.

KICKAPOo ereek, Texas, i. 73.

KitBurs's farm, in Napa valley, ii. 24. - great yield of vegetables on, ii. 25-49.

Kino, Father, on the Colorado, in 1700 , ii. 178 .

proves Lower California to be a peninsula, ii. 183 .

his journeys to the Gila, ii. 183.

corrects the geography of the Gila in 1700 , ii. 212 .

visits the Pimo Indians, ii. 267 .

visits the Casa Grande, on the Gila, in 1694, ii. 281.

church at San Xavier, built by him in 1700, ii. 299.

KNIGHT's farm, Napa valley, ii. 28.

Koeblerina, plant, i. 94.

\section{L.}

Labor, prices of, at El Paso, i. 191.

Laguna, near the Gila, ii. 199.

— de Encinillas, ii. 416.

de Patos, Chihuahua, ii. 406.

de Santa Maria, ditto, ii. 371 .

del Madre, Texas, ii. 530.

Lagunas, on the Gulf of Mexico, ii. 530-5 32.

LAKES on the Mexican table-land have no outlets, ii. 416.

Langberg, Col. Emilio, i. 151; ii. 398. accompanies the author to Fort Fillmore, ii. 390 .

furnishes escort to Chihuahua, ii. 397.

Langdon, Dr. establishes the ferry on the Colorado, ii. 174.

— his party killed by the Yumas, ii. $17 \overline{5}$.

LA Parida, river, Texas, ii. 529.

Larrea Mexicana, i. 87 ; ii. 130,136 , $210,290$.

Las Garzas, Chihuahua, ii. 450.

Lasso thrown by the Lipans, i. 82 .

Las Playas, Chihuahua, i. 246.

La Playa, California, ii. 96.
LA SAlLe, town of, Texas, i. 12. and his explorations, i. 12.

LA VACA, town of, Texas, ii. 536.

LEA, Judge, of Goliad, i. 27.

Leroux, Antoine, engaged with his pack mules and men, ii. 85 . sent to San Bernardino, ii. 118.

Limestone Sinks, Texas, i. 110.

Lipan Indians, Texas, i. 76.

extent of the tribe, i. 81.

of the Bolson of Mapimi, ii. 455.

Lipan Camp creek, Texas, i. 82.

Lizards and their variety, ii. 556.

Llano River, Texas, i. 64-66.

settlement on, destroyed by the Comanches, i. 64.

Lobelia Cardinalis, i. 53.

Loma Blanca, Texas, ii. 521.

Loma Ponvt, California, ii. 94.

- DE IndePENDENCIA, ii. 503.

Long, Major, notice of prairie-dogs, ii. 559.

Los Olmos, Texas, ii. 522.

LoRETo, Lower California, account of, i. 483-484.

Los Angeles, Cal, visit to, ii. 81.

grassy plains near, ii. 106 .

Lower Califorsia supposed to be an island until 1698, ii. 183.

\section{M.}

MoClellan, Col. J., notice of his removal, i. 150.

Magdalena, Sonora, arrival at, i. 422. ordered before the alcalde at, $i$. 422.

festival of San Franciseo at, i. 425.

- grand procession of do., i. 431.

- description of the town, i. 432.

Magorfin, J. W., of El Paso, facilities furnished by, i. 143.

Magoffinsville, Texas, i. 193 ; ii. 393.

Magruder, Col. J. B., San Diego, ii. 104.

acknowledgments to, ii. 107.

his successful efforts in taking the murderer of Col. Craig, ii. 144.

Maguey and its uses, i. 290 ; ii. 484.

- plantations at Parras, ii. 484.

Marze cultivated on the Colorado in 1542. ii. 182.

Mammalia of the regions traversed, ii. 555.

Manacita tree, California, ii, 43.

Manahuila, eamp at, i. 24. 
Mange, Capt, his explorations in the Gulf of California in 1698, ii. 183.

— his visit to Casa Grande, ii. 265, 281.

Mangus Colorado, chief of the Apaches, i. $300,311,319$.

McCalt, Gen., arrives at Ft. Yuma, ii. 156.

Manzanilla Bay, entrance to, i. 494.

- deseription of, i. $495,496$.

Marin, town of, ii. 506.

Matagorda Bay, and its ports, i. 13; ii. 536 .

Mazatlan, description of, i. $485-487$.

Medanos, Los, of Chihuahua, ii. 372376.

Medina, Col., of Janos, ii. 340.

Mercury, its effects on miners, ii. 66 .

Mesilla Valley, its value, i. 188, 346.

— its history, i. 212 ; ii. 391.

Metates, where found, ii. 245, 276, 361.

Meteorite, found at Tueson, ii. 297.

at the Hacienda de Concepcion, ji. 457 .

—— near Guajuquilla, ii. 455.

- notes on, from Kaemtz, Humboldt, and others, ii. 459,460 .

Meteors seen to fall, ii. 461.

Meteros River, Monterey, ii. 506.

Mexican Women, their dress, i. 147.

Mezcal, how made, i. 290.

Mezqurr tree and its uses, i. 76.

- bean, ground and used as food, ii. $218,232$.

roots, used for smelting, ii. 344.

- for rail ties, ii, 574 .

Mezquiquite, loaves of, ii. 182.

Mrer, arrival at, ii. 507.

—_ serapes of, ibid.

- expedition from Texas, ii. 508.

Miles, Col., Fort Fillmore, ii. 390.

Mrlaad, Dr., at Fort Yuma, ii. 152, 184.

Mrumary posts on the frontier, sug. gestions for more active operations at, ii. 388 .

Mimbres River, N. Mexico, i. 221.

Mrrage seen at Las Playas, i. 246.

- note or, by Humboldt, i. 247 .

Mrssouri Currant, i, 223, 288.

Monavi River, California, ii. 178.

Monavı Indians, ibid.

Molasses made from the petahaya, ii. 218.
Monterey, California, first expedition of Juniper Serro to in 1769, ii. 10,75 .

visit to and description of, ii. 72 -78 .

Monterey, Mexico, arrival at, ii. 502. description of, ii. 502-505.

Monumext at the Initial point, on the Pacific, ii. 104.

Mormon settlement, Texas, i. 58.

Moqu Indians, N. Mexico, ii. 178.

- their eultivation of wheat, ii. 263.

Mount Helexä, Cal., Russian inseription on, ii. 28.

Mules, how shod in stocks, i. 16.

- lost in Texas, i. 71, 100.

lost at the Copper Mines, i. 343, 346,349 .

lost at Frontera, i. 346.

lost on California desert, ii. 2-3.

their value in Coahuila, ii. 493.

stampeded by the Apaches, ii. 412.

by mustangs, ii. 522 .

Mule Spring, New Mexico, i. 218.

Muspangs seen in Sonora, i. 383. mode of catching in Texas, ii. 521.

their numbers in Texas, ii. 521525.

stampede of mules by, ii. 522524.

Ponds, Texas, i. $87,90$.

Island, do. ii. 530 .

\section{N.}

NaPA Valley, Cal., journey through, ii. 14-19.

Indians of, ii. 30-34.

Nasas River and Valley, ii, 472.

Navajo Indians, visit from, i. 329.

- BLANKETS, i. 330.

New Mexico, its early history, i. 182

New Mexionan Traders, i 303.

New River, Cal., sudden appearance of water in it, ii. 135.

Norther and snow storm in Texas, i. 411.

at Corpus Christi, ii. 520.

Nomenclature of Mexican towns, ii. 371.

Noria, LA, Durango, ii. 465.

- Curena, ii. 475.

de Pedrecena, ii. 473.

de Pozo Calvo, ii. 476. 
Novato Valley, Cal., i. 51.

Nuecrs Bay and River, Texas, ii. 529.

O.

Oatman family, remains of, murdered by the Indians near the Gila, ii. 203 .

- particulars of the event, $i b$.

- statement of the Indians on the event, ji. $218,257,258$.

OATs, wild, of California, ii. 14.

Obsidian hills, California, ii, 49.

- - use of by the Indians, ii. 50.

Ojo del Alamo, Texas, i. 130.

- Caliente, Neiv Mexico, i. 225.

—— Chihuahua, ii. 410.

- DE GALLEGo, do., ii. 415.

- de Inez, N. Mexico, i. 362. de Lucero, Chihuahua, ii. 406. de Vaca, N. Mexico, i. 243, 361.

Onsons, great erop of in California, ii. $24,49$.

Opa Indians, R. Gila, in 1775 , ii. 268.

Opate Indians of Sonora, i. 444, 445. battle with the Apaches, i. 454.

Opodepe, Sonora, i. 434.

Opuntia arborescens, i. 128.

Organ Mountains, N. Mex., i. 134, 195. visit to, ii. 392.

Osborne, J. W., of Napa, ii. 14.

Ostrea shells found at Mier, ii. 511.

Otringer, Capt., voyage with from Monterey to San Diego, ii. 71. to the Coronados, ii. 86 ,

\section{P.}

Pacheco, Padre of Santa Cruz, ii. 312.

Paohetehu, spring at, i. 242.

Pack-mules, mode of fitting out, i. 358.

Patge, Lt. G. W., commands escort to the Pimo villages, ii. 157. 186.

his return to Fort Yuma, ii. 259.

Palmetto, last seen in Texas, i. 53.

Palo Verde, ii. 194, 210, 290.

Palov, Father, ii. 78.

Papago Indians, i. 382 ; ii. 298.

Parras, description, of, ii. 482, 489. its vineyards, ii, 483,487 .

Paso Cavallo, Texas, ii. 536.

Patos, Hacienda de, ii. 492.

Pavi, Maj., Ringgold Barracks, ii. 512.

Paysano, and its habits, ii. 563.

Peach Trees, in California, i. 24.

Pecan nuts in Texas, i. $75,84$.
Peccari, a tame one seen, i. 55.

Pecos River, its character, i. 93, 101.

narrow escape in crossing, $i$. 97.

Peons, village of in Coahuila, ii. 493.

Pena, La, Coahuila, ii. 478.

Penol, El. Chihuahua, ii. 417.

Pepper-tree, in California, ii. 90.

Petahaya, deseription of, ii. 188, 190. 209.

where found, i. 497 ; ii. 416 , vol. ii. $189,209,248,272,290$, 296.

early notices of by Venegas, Salvatierra, Alcedo, and Hernandez, ii. 191, 192.

recent notices by Humboldt, Pattie, Hardy, etc. ii. 192, 193.

Indians shooting at, ii. 237.

Peyri, Father, founds the Mission of San Luis Rey, ii. 93.

Predernales River, Texas, i. 58.

Prmo Indians, their manners and customs, ii, 220, 237.

their spinning and weaving, ii. $225,226$.

conference with, ii, 255, 258.

their arts and agriculture, ii. $262,264$.

their physical type, ii. 263.

early accounts of them, ii. 268 .

Pinaleno Indians, i. 308.

Pinos Point, California, i. 73.

Pinus Edulis, i. 234.

Piro Indians of the R. Grande, i. 184.

Pitic, Sonora, i. 466.

Plateau of Texas, i. $72,87,138$; ii. 565.

of Mexico, ii. 567, 568 .

Pluton River, California, visit to, ii. 36,42 .

Pomegranates, where seen, i. 284, 414,420 ; ii. 484.

distillation from, i. 421.

Portulacca, used as food, i. 390 ,

Poziro, Sonora, marsh of, i. 474.

Pozo, Ex, Coahuila, arrival at, ii. 479. fight between the Lipans, and Col. Doniphan's troops at, ii. 480 .

Pottery, of the Indians, ii. 226.

- ancient found, ii. 243, 247, 360.

PraIrIE-DoGs, where seen, i. 99, 72, $76,87,110,128,249$.

their natural history, ii. 557 , 561. 
Pratrie Fowls, i, 15.

- on fire, i. $15,16,88$.

passed by the train, ii. 525 .

Pratr, H. C., his collection of sketehes, ii. 545 .

Presidios, of Sonora, i. 407.

Prioleav, J. H, his surveys, i. 117; ii. 543.

Pronunciamentos in Mexico, ii. 502.

Pulque, how obtained from the maguey, ii. 484.

Puntragudo, village of, ii. 507.

Q.

Quicksilver Mine, of New Almaden, California, visit to, ii. 57 .

its produce in 1853 , ii. 62 .

Mines of the world, ii. 59.

Qurnces, abundance of in Sonora, i. 284.

Qurneurma Indians, Cal., ii. 178.

R.

RABBIT3, their extent, i. 76 ; ii. 555.

RAdziminski, C., arrival of at the Cop. per Mines, i. 341.

goes to Washington with despatches, i. 248.

his surveys, ii. 546, 547 .

RaILway from Indianola to El Paso, survey for, i. 14.

- practicable route for, i. $139,140$. report on said route, and thence to the Pacific, ii, 570, 575.

RaMos, town of, ii. 506.

RAMADA, Chihuahua, ii, 452.

Randalt, D. A., journey with to New Almaden, ii. 54.

RATtLesNake, its numbers, ii. 557.

- its connection with the prairiedogs, ii. 561 .

horses bitten by, i. 84 ; ii. 342 .

Rayon, Sonora, i. 4:34.

REDWOOD, of California, notice of, ii. $16,21,57$.

Red Rrver, its souree, ii. 665.

Ridpelis, B., U.S. Consul, Chihuahua, ii. 426 .

Rinconada Pass, encampment in, ii. 500.

Ringgold Barracks, Texas, ii. 512, 519.

Rio Grande, obstructed by iee, i. 158. difficulties in fording, i. 167, 187. its survey commenced, i. 177.

productions of its valley, i. 185.
Rio Grande, its bottom-lands, i. 188 , 200 ; ii. 392.

— its valley near Mier, ii. 508.

- its ascent by a steamer, ii. 509.

its crossing at Camargo, ii. 512.

- upsetting of a wagon in, ii. 404.

Rio Florido, its valley, ii. 450, 452, 454.

hacienda at, ii. 457,463 .

meteorite at, ii. 458.

Ritter, KarL, on the camel, ii. 580.

Robinson, J. A., U. S. Consul, Guaymas, i. 476.

Rocky Mountains, abrupt termination of,, ii. 567.

Russian River, California, ii. 36.

$\mathrm{S}$.

Sabine Creek, Texas, camp on, i. 53, 54.

Sacket's Welt, California desert, ii. 129.

Sacramento Mrs. Texas, i. 121.

- battle of, ii. 420 .

- valley, Cal. ii. 106.

Salado, Chihuahua, ii. 371.

Satazar, Don José, his report on the Initial Point, i. 202.

Sal Colorado, Texas, ii. 520.

SALINE efflorescence, Texas, i. 100, 103. Chihuahua, ii. 417.

- lakes, Texas, i. $122,125$.

Salinas River, its bottom-lands, ii. $240,244$.

ancient eultivation on, ii. 242.

ancient remains on, ii. $242,245$.

Samalayuda, Chihuahua, i. 377.

Sanchez, Don Jacobo of Coahuila, his immense estate, ii. 492.

SAND-Drifts, near the Colorado, ii. $149,150$.

in Chihuahua, ii. 372.

difficult passage of, ii. 371,376 .

Sanford, S. P., arrives with despatehes, i. 303.

Sandstone Columins, near Arispe, i. 280.

near the Mimbres, i 224.

SAn Antonio, Texas, arrival at, i. 33.

- departure from, i. 48.

description of, i. 39.

San Bernardino, Sonora, i. 255; ii. 328.

Cal. purchased by the Mormons; ii. 120.

San Blas, visit to, i. 490. 
San Carlos, Sonora, presidio of, i. 407. Mission, California, ii. 76.

San Diego, N. Mexico, ford at, i. 215. California, arrival at, i. 505 .

Conmission meets at, i. 2.

description of its harbor, ii. 94 .

its agricultural productions, ii.88.

fertile lands near, ii. 97.

discovered by Viscaino, ii. 98.

visited by Juniper Serro in 1769 , ii. 100 .

mission at, ii. 103.

San Eleazario, Texas, town of, i. 193.

San Felipe, Cal. and its Indians, ii. 122.

San Fraxcisco, Sonora, annual feast of, i. 411,424 .

legend of its origin, i. 424.

account of the festival of, i. 428.

enre of diseases by, i. 427 .

California, its growth and prosperity, ii. 8.

its' commerce and business, ii. 9 .

- origin of its name, ii. 10.

San Francisco River, or Verde, ii. 243. Texas, ii. 525 .

San Gabriel Mission, Cal, ii. 83.

San Ignacio, Sonora, town of, i. 419. River of, i. 416.

San Joachin, Cal., its valley, ii. 106.

San Jose, Cal., its fertile valley, ii. 54. visit to the town of, ii. 56 .

- mission of, Texas, i, 44.

San Juan Rrver, at Camargo, ii. 511.

San Lazaro, Sonorn, visit to i. 412 ; ii. 211.

San Lucas, Cape, change of elimate at, i. 504 .

San Luts Obtspo, Cal., Indians of, ii. 56.

San Luis Rey, Cal,, Mission of, ii. 89.

San Miguel River, Sonora, i. 413.

Chihuahua, ii. 337.

bottom-land of, ii. 342 .

- River, Texas, ii. 529.

San Pablo, Chihuahua, ii. 445.

San Pasqual, Cal., mountain at, ii. 113, 116 ,

action at, during the war, ii. 113. its Indians, ii. 115.

San Pedro, California, arrival at and description of, ii. 79 .

Springs, Texas, camp at, i. 38.

- Rrver, Sonora, i. 377.

- its valley, i. 379 .

— DFL GaLLo, ii. 470.

- CreEk, Chihuahua, ii. 445.

San Saba River, Texas, i. 68.
San Rafael Valley, California, ii. 51.

SaN Xavier del Bac, Sonora, ii. 298.

SANTA AnA, General, his position at Angostura, ii. 494.

Santa Barbara, N. Mexico, i. 217.

Santa Catarina, near Monterey, i. 501.

Santa Clara, Cal., Mission of, ii. 55.

Santa Cruz, Sonora, description of, i. 407.

— second visit to, ii. $314,320$.

- River, i. 412 ; ii. $293,295,305$.

— Valley, ii. 297, 300, 307.

- Chihuahua, ii. 445.

Santa Eulalia, Chihuahua, ii. 434.

Santa Gertrude River, Texas, ii. 525.

Santa Isaber, California, ii. 115. ancient mission at, ii. 117.

Santa Marta River, Chihuahua, ii. 378.

- laguna de, ii. 371 .

Santa Rita del Cobre, hist. of, i. 227.

mount in, Sonora, i. 407 ; ii. 308.

Santa Rosa Island, California, ii. 79.

Santa Rosalia, Chihuahua, ii. 450.

Santa Teresa, Texas, ii. 520.

SALTILLO, account of the city, ii. 496 , 498.

Saucillo, Chihuahua, ii. 446.

SaUz, Er, Chihuahua, ii. 419.

Sснотт, A., his zoologieal collection, ii. 550.

Scorpions, their numbers, ii. 556.

Sculptured rocks on the Gila, ii. 195, 206.

Scunvy, its appearance, i. 237 ; ii. 379.

Sea Lrons, in California, ii. 88.

Sebilla River, Texas, i, 31.

Sedelmayer, his exploration of the Colorado, ii. 183.

- notices the Cocomaricopas in 1744, ii. 269.

Shells, Sea, among the ruins on the Salinas, ii. 245 .

oyster, found on the Rio Grande, ii. 510.

Shepard, Major, sends troops to our aid, i. 350 .

Sterra Madre, its mineral wealth, ii, 564.

impassable south of Cooke's road, ii. 332.

de los Ánimas, i. 249.

Mitre, Monterey, ii. 501.

Signs on the plains, j. 106.

Silver mines, Correlitos, ii. 344, 366.

Organ mountaius, ii. 392. 
Silver mines of Governor Gandera, Sonora, i. 462.

near Cuencame, ii. 475.

— La Noria Pedrecena, ii. 473.

Viesea, Coahuila, ii. 478.

Santa Eulalia, ii. 434.

Chihuahua, ii $431,438$.

Guajuquilla, ii. 453.

Santa Cruz, ii. 446.

Saucillo, ii. $447,448$.

Sinecu, Pueblo of, i. 183.

SNook's rancho, California, ii. 112.

Snow Storm at Delaware Creek, i. 111.

SMokivg, practised by the ladies in Mexico, ii. 429.

Socorro, Texas, town of i. 193. - murderers executed at, i. 163.

Solidad Mountain, Texas, i. 135

- HILL, near San Diego, i. 112

Sonoma Valley, California, ii. 51 .

SoNora, its agricultural productions, i. $440,469$.

its exports, i. 447 .

_- deficiency of wagon roads, i. 457 . its Indian tribes, i. 446.

- its streams and arable lands, $i$. 459,462 ; ii. 569 .

RIVER and its sourees, i. 267, 285, $440,468$.

- its various names, i. 416.

Spanish hist. documents at San Antonio, i. 41.

Staked Plain of New Mexico, ii. 565. St. Josepu's Island, Texas, ii. 534.

Storm on the Gila Desert, ii. 286.

Stockmon, Commodore, relieves the Ameriean army at San Pasqual, ii. 113.

his eminent services in California, ibid.

Stratn, Lieut. I. G. his plan for a survey of the Gulf of California and the Colorado River, ii. 163,165 .

Stuart, Hon. A. H. H, his letter to Daniel Webster relating to the boundary, i. 210.

his letter to A. B. Gray requesting him to sign the agreement fixing the Initial Point, i. 343.

— his letter to Maj. Emory on the same subject, i. 343.

his making known the act of Congress, which caused the suspension of the Survey, ii. 514.
Sugar Cane, its cultivation in Sonor, i. 469 .

- at Monterey, ii. 505.

Sutter, Capt., his early history, and settlement in California, ii. 68 , 70.

Sweeny, Lieut., meeting with, on the California Desert, ii. 130.

- at Fort Yuma, ii. 152.

Sycamore Tree, i. 53 ; ii. 53.

T.

Tamaules, how made, i. 207.

TAnori, Chief of the Opates, i. 444.

defeats the Apaches, i. 453.

Tapahur, Sonora, visit to, i. 459 .

Tarahumaras of Sonora, i. 416.

TARANTulas, their numbers, ii. 556.

Tardillo River, Texas, 529.

Tehua Indians of N. Mex., ii. 178.

Temperature on the Gila, ii. 198, 283, 285.

—at Fort Yuma, ii. 184.

ehanges of, in the winter, ii. 3 .

Tennant, John, murder of, i. 34.

Terraced Hills, Texas, i. 57, 133.

Teras de Cabre, Sonora, i. 476.

Texas, its advantages for inland trade with Mexico, i. 40.

fertility of its prairies, ii. 519, 566.

extent of its table-land, ii. 565 .

Thorne's Well, Texas, i. 130.

Thurber, Geokge, his journey to $\mathrm{El}$ Paso for relief, i. 125.

his visit to the Germans on the Llano, i. 64.

his botanical collection, ii. 550 .

takes the train to San Antonio, ii. 518.

Trmbabachi Indians, ii. 178.

Tlagualila, laguna de, ii. 472 .

Tonto Indians of N. Mexico, ii. 179.

Toтonico, Chihuahua, ii. 456.

Tortillas, how made, i, 107.

Toyah Creek, Texas, i. 103.

Trains, for transportation, their cost, ii. 436 .

Trias, Gen. his estates at Peñol, ii. 418, his character and influence, ii. 426.

official dinner and ball given by him to the Commission, ii. 427.

dinner to him and his officers, ii. 429.

furnishes an escort, ii. 442 . 
Trour of the Gila and Salinas, ii. 192, $107,244$.

of the San Miguel, ii. 337.

Tuape, Sonora, i. 434.

Tubac, Sonora, ii, 302, 304.

Tuoson Desert, Sonora, ii. 286, 290.

- visit to, ii. 292, 195.

Tulare Platns, California, ii. 106.

Tumadacori, Sonora, ii. 308.

Turnbul., Mr., his ascent of the $\mathrm{R}$. Colorado, ii. 172.

\section{V.}

Vallecita, Cal, eamp at, i. 124, 125.

VALLEJO, Cal, notice of, ii. 14.

VANCOUVER's account of the valleys of California, ii. 55.

Van Horne, Maj., El Paso, i. 113, 162.

VEGerables, great want of, ii. 194.

Vegetation of the deserts and plains, ii. 563 .

Velasco, Don. F. of Hermosillo, i. 466.

Venagron, a poisonous insect, ii. 557 .

Venegas, Notices of the Assumption River and the Coco Maricopas, ii. 269.

his notice of the petahaya, ii. 191.

Vequeria, near Parras, ii. 490.

Verde RIVER, its junction with the Salinas, ii. 243.

Viotoria, Texas, i. 16, 20.

Viscayso, his voyages to California in 1594, ii. 88, 98, 101.

Vitis CEstrvalis, i: 56.

Viviparous Fishes discovered at San Diego, Cal., ii. 564.

Volonino Action, evidences of ii. 39, 50.

\section{W.}

Waco Mountain, Texas, i. 131, 133.

-excursion to, i. 168.

i. 286, 293, 297.

WAGons broken, ii. $117,139,292,305$, $476,479,493,499$.

-numbers of, found on California Desert, ii. 139.

bought of enigrants at Tubae, ii. 306.

found abandoned on the Gila, ii. 197.

upset, ii. $128,330,456$.

WaKeMan, U. B. killed, i. 153.

WALLACE, Dr. of Sonora, i..436.

Walnut Crefk, Chihuahua, ii. 367.
Water Fowi, immense numbers of, seen on the Gulf of Mexico, ii. 533.

WATER Spouts seen off Cape Hatteras, i. 7 .

WebB, Dr. T. H., his report on the Copper Mine region, i. 178.

his visit to Guaymas, i. 436 , 437.

leaves Ures for the Gila, i, 450.

his arrival at San Diego and report of his journey, ii. 1,-5.

his report relating to the death of Colonel Craig, ii. 141,-143.

his zoologienl collection, ii. 548 .

his mineralogical do., ii. 550.

WeBster, ForT, ii. 568 .

Whipple, Lieut. A. W. appointed chief Astronomer, i. 177.

determines the position of $\mathrm{El}$ Paso, i. 193.

his official report on the Initial Point, i. 202.

appointed Surveyor, i. 204.

recognized as Surveyor by the United States, i. 211.

organizes party for the Gila survey, i. 356.

his official report on the survey of the Gila, ii, 597, and appendix $D$.

account of his survey from Indianola to El Paso, i. 14 ; ii. 539.

results of his labors, ii. 541-543, 547.

Wild Cattle in Sonora, i. 258, 294, 417.

Wrid China Ponds, Texas, i. 90.

Wine of El Paso, i. 186.

of Parras, ii. 483, 486, 488.

Wisctzenus, Dr. excellence of his memoir on New Mexico, ii. 455.

WoLves, their numbers, ii. 555 .

Woot, General, favorable impression left by him in Mexico, ii. 489.

Woon, its scarcity, ii, $325,344,446$.

Wright, Charles, his zoological eollection, ii. 550 .

\section{Y.}

Yampa Indians, Colorado R. ii. 179.

YAQUI INDIANS of Sonora, their position and character, i. 442, 444.

Yaunt, Mr. of Napa Valley, ii. 19.

Young, Alex. trial and execution of, i. 165 . 
Yuccs, The, and its uses, i. 196, 254; ii. $445,490,493$.

Yuma Indians, reach the country of, ii. 149.

they plunder the Commission, ii. 153.

incidents eonnected with, ii. 150 , $172,173,177$.

they destroy a fort, and massacre Gallantin and his party, ii. 174, 175.

massacre of emigrants by, ii. 176.
Yuma Fort, Col., arrival at, ii. 152. position of, ii. 158.

—old Spanish mission at, ii. 161.

\section{Z}

Zapata, Chihuahua, ii. 457.

Zarca, LA, Chíhuahua, ii. 457.

a great cattle range, Durango, ii. 468.

Zodiac, Texas, 158.

Zoological COLLEOTIONS, extent of, made by the Commission, Pref. VIII. and ii. 548, 550. 